\title{
ERRATA SHEET
}

\author{
Issue Date: September 2008
}

The following corrections apply to Nevada Test Site Environmental Report 2006, DOE/NV/25946--259, National

Security Technologies, LLC, dated September 2007.

Tables 3-10 and 3-11 contained errors. The column totals for the "All Environmental Samplers" row, near the bottom of each table, contained totals that were offset by one column to the right. The corrected tables are provided below.

Page 3-16, Table 3-10, Gross alpha radioactivity in air samples collected in 2006

Table 3-10. Gross alpha radioactivity in air samples collected in 2006

\begin{tabular}{|c|c|c|c|c|c|c|c|c|c|}
\hline \multirow[b]{2}{*}{$\begin{array}{l}\text { NTS } \\
\text { Area }\end{array}$} & \multirow[b]{2}{*}{ Location } & \multirow{2}{*}{$\begin{array}{c}\text { Number } \\
\text { of } \\
\text { Samples }\end{array}$} & \multicolumn{7}{|c|}{ "Gross Alpha (x 10-16 $\mu \mathrm{Ci} / \mathrm{mL})$} \\
\hline & & & Mean & Median & $\mathrm{SD}^{(\mathrm{a})}$ & $\operatorname{Min}^{(b)}$ & $\operatorname{Max}(c)$ & $\begin{array}{l}\text { Mean } \\
\text { MDC }\end{array}$ & $\begin{array}{c}\%> \\
\text { MDC }\end{array}$ \\
\hline 1 & BJY & 52 & 24.64 & 21.73 & 14.91 & -2.23 & 80.10 & 27.66 & 38.5 \\
\hline 3 & U-3ah/at N & 52 & 28.61 & 26.73 & 19.30 & 4.54 & 116.00 & 27.41 & 51.9 \\
\hline 3 & U-3ah/at S & 50 & 34.17 & 28.80 & 21.89 & 0.00 & 87.50 & 27.28 & 52.0 \\
\hline 3 & U-3bh N & 52 & 25.84 & 25.88 & 17.21 & 0.00 & 105.70 & 27.36 & 44.2 \\
\hline 3 & U-3bh S & 52 & 24.27 & 24.67 & 11.22 & 0.00 & 45.00 & 27.54 & 42.3 \\
\hline 5 & DoD & 52 & 20.05 & 18.81 & 9.92 & -4.48 & 47.30 & 27.45 & 24.0 \\
\hline 5 & Sugar Bunker N & 45 & 34.60 & 33.86 & 16.98 & 3.40 & 91.80 & 28.56 & 64.4 \\
\hline 6 & Yucca & 51 & 26.78 & 25.63 & 15.71 & 2.71 & 102.60 & 27.50 & 38.2 \\
\hline 9 & Bunker 9-300 & 52 & 60.26 & 58.93 & 34.82 & 7.99 & 157.60 & 27.61 & 78.8 \\
\hline 10 & Gate 700 S & 51 & 23.78 & 24.90 & 11.75 & 1.16 & 56.00 & 28.18 & 41.2 \\
\hline 10 & Sedan N & 49 & 22.25 & 21.90 & 13.78 & -3.45 & 55.40 & 28.42 & 26.5 \\
\hline 16 & 3545 Substation & 50 & 18.50 & 16.10 & 10.40 & 1.10 & 54.30 & 27.52 & 23.0 \\
\hline 18 & Little Feller 2 N & 52 & 19.73 & 20.86 & 11.84 & -3.31 & 42.60 & 27.56 & 26.9 \\
\hline 20 & Gate $20-2 P$ & 51 & 18.59 & 19.44 & 11.39 & -11.65 & 45.00 & 27.97 & 23.5 \\
\hline 20 & Schooner & 51 & 18.58 & 16.58 & 12.25 & -2.28 & 46.80 & 27.20 & 27.5 \\
\hline 23 & Mercury Track & 51 & 18.02 & 18.12 & 9.88 & -3.39 & 43.40 & 27.47 & 23.5 \\
\hline 25 & Gate 510 & 52 & 20.74 & 20.37 & 12.33 & -5.60 & 49.50 & 27.57 & 35.6 \\
\hline 27 & ABLE Site & 50 & 17.72 & 18.69 & 7.60 & -1.16 & 30.80 & 27.33 & 17.0 \\
\hline \multicolumn{2}{|c|}{ All Environmental Samplers } & 915 & 25.37 & 22.31 & 18.55 & -11.65 & 157.55 & 27.64 & 37.7 \\
\hline 27 & JASPER Stack & 50 & 269.73 & 9.87 & 1753.81 & -686.16 & 12339.40 & 1160.66 & 3.0 \\
\hline
\end{tabular}

Blue-shaded locations are EPA-approved critical receptor sampler stations.

The orange-shaded location is a point-source sampler station.

Non-shaded locations are environmental sampler stations.

Green shading indicates that some percentage of samples had concentrations above the sample-specific MDC.
(a) Standard deviation
(b) Minimum
(c) Maximum 
Page 3-17, Table 3-11, Gross beta radioactivity in air samples collected in 2006

Table 3-11. Gross beta radioactivity in air samples collected in 2006

\begin{tabular}{|c|c|c|c|c|c|c|c|c|c|}
\hline \multirow[b]{2}{*}{$\begin{array}{l}\text { NTS } \\
\text { Area }\end{array}$} & \multirow[b]{2}{*}{ Location } & \multirow{2}{*}{$\begin{array}{c}\text { Number } \\
\text { of } \\
\text { Samples }\end{array}$} & \multicolumn{7}{|c|}{ Gross Beta $\left(\times 10^{-15} \mu \mathrm{Ci} / \mathrm{mL}\right)$} \\
\hline & & & Mean & Median & $\mathrm{SD}^{(\mathrm{a})}$ & $\operatorname{Min}^{(b)}$ & $\operatorname{Max}^{(c)}$ & $\begin{array}{l}\text { Mean } \\
\text { MDC }\end{array}$ & $\begin{array}{c}\%> \\
\text { MDC }\end{array}$ \\
\hline 1 & BJY & 52 & 19.03 & 18.57 & 5.07 & 8.00 & 30.98 & 4.13 & 100.0 \\
\hline 3 & U-3ah/at N & 52 & 19.13 & 19.10 & 4.72 & 7.67 & 30.51 & 4.10 & 100.0 \\
\hline 3 & U-3ah/at S & 50 & 19.89 & 20.56 & 5.15 & 9.09 & 29.88 & 4.08 & 100.0 \\
\hline 3 & U-3bh N & 52 & 19.28 & 19.57 & 5.50 & 7.91 & 32.32 & 4.09 & 100.0 \\
\hline 3 & U-3bh S & 52 & 19.47 & 19.38 & 4.90 & 9.90 & 29.72 & 4.12 & 100.0 \\
\hline 5 & DoD & 52 & 20.04 & 19.84 & 5.19 & 9.64 & 33.76 & 4.10 & 100.0 \\
\hline 5 & Sugar Bunker N & 45 & 21.33 & 20.92 & 5.06 & 8.69 & 34.07 & 4.32 & 100.0 \\
\hline 6 & Yucca & 51 & 20.41 & 20.81 & 5.41 & 9.13 & 33.51 & 4.12 & 100.0 \\
\hline 9 & Bunker 9-300 & 52 & 19.50 & 20.02 & 5.23 & 9.41 & 29.24 & 4.12 & 100.0 \\
\hline 10 & Gate 700 S & 51 & 18.90 & 19.14 & 5.27 & 5.57 & 32.63 & 4.23 & 100.0 \\
\hline 10 & Sedan N & 49 & 18.20 & 18.59 & 4.86 & 7.69 & 28.63 & 4.24 & 100.0 \\
\hline 16 & 3545 Substation & 50 & 18.27 & 17.38 & 5.31 & 7.57 & 36.30 & 4.13 & 100.0 \\
\hline 18 & Little Feller $2 \mathrm{~N}$ & 52 & 17.76 & 18.20 & 4.78 & 6.88 & 27.62 & 4.12 & 100.0 \\
\hline 20 & Gate $20-2 \mathrm{P}$ & 51 & 18.04 & 18.08 & 5.01 & 5.76 & 29.63 & 4.18 & 100.0 \\
\hline 20 & Schooner & 51 & 18.58 & 18.16 & 4.96 & 7.14 & 28.20 & 4.06 & 100.0 \\
\hline 23 & Mercury Track & 51 & 19.02 & 19.85 & 5.13 & 6.59 & 29.00 & 4.11 & 100.0 \\
\hline 25 & Gate 510 & 52 & 19.86 & 20.52 & 5.18 & 10.99 & 32.42 & 4.12 & 100.0 \\
\hline 27 & ABLE Site & 50 & 18.41 & 18.40 & 5.17 & 7.43 & 30.24 & 4.08 & 100.0 \\
\hline \multicolumn{2}{|c|}{ All Environmental Samplers } & 915 & 19.16 & 19.42 & 5.14 & 5.57 & 36.30 & 4.13 & 100.0 \\
\hline 27 & JASPER Stack & 50 & 66.41 & 1.02 & 471.11 & -41.00 & 3329.63 & 177.50 & 4.0 \\
\hline
\end{tabular}

Blue-shaded locations are EPA-approved critical receptor sampler stations.

The orange-shaded location is a point-source sampler station.

Non-shaded locations are environmental sampler stations.

Green shading indicates that some percentage of samples had concentrations above the sample-specific MDC.
(a) Standard deviation
(b) Minimum
(c) Maximum 


\section{Nevada Test Site \\ Environmental Report 2006}

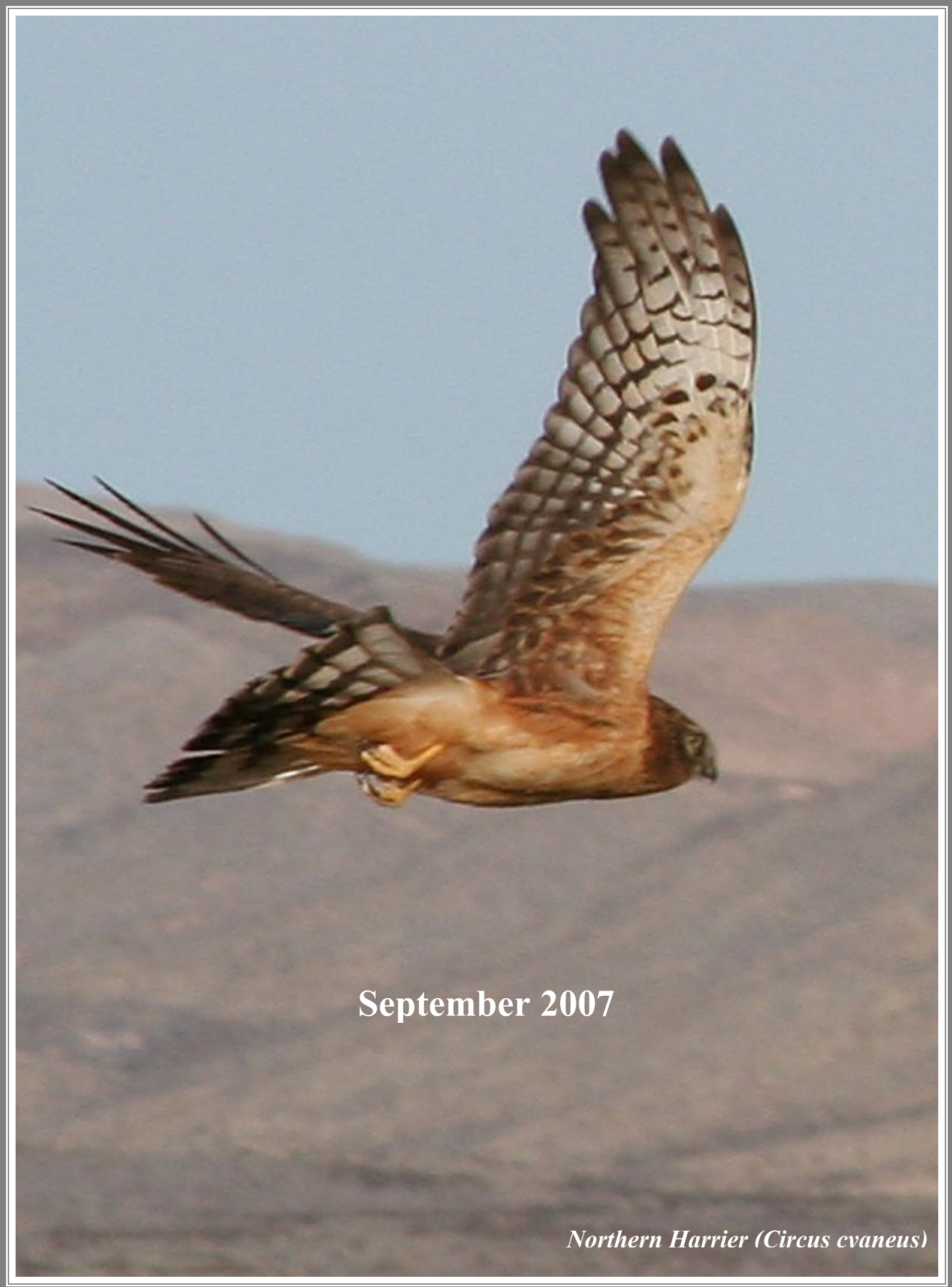




\title{
Disclaimer
}

Reference herein to any specific commercial product, process, or service by trade name, trademark, manufacturer, or otherwise, does not necessarily constitute or imply its endorsement, recommendation, or favoring by the United States Government or any agency thereof or its contractors or subcontractors.

Available for sale to the public from:

\author{
U.S. Department of Commerce \\ National Technical Information Service \\ 5285 Port Royal Road \\ Springfield, VA 22161-0002 \\ Telephone: (800) 553-6847 \\ Fax: (703) 605-6900 \\ E-mail: orders@,ntis.gov \\ Online ordering: http://www.ntis.gov/ordering.htm
}

Available electronically at http://www.osti.gov/bridge

Available for a processing fee to the U.S. Department of Energy and its contractors, in paper, from:

U.S. Department of Energy

Office of Scientific and Technical Information

P.O. Box 62

Oak Ridge, TN 37831-0062

Telephone: (865) 576-8401

Fax: (865) 576-5728

E-mail: reports@adonis.osti.gov 


\title{
Nevada Test Site Environmental Report 2006
}

\author{
Senior Author: Cathy A. Wills \\ Technical Editor: Fina Martinez-Myers \\ Graphics Arts/Desktop Publisher Specialist: Angela McCurdy \\ Geographic Information System Specialist: Ashley Cushman
}

September 2007

Work Performed Under

Contract No. DE-AC52-06NV25946

\author{
Prepared for: \\ U. S. Department of Energy \\ National Nuclear Security Administration \\ Nevada Site Office
}

Prepared by:

National Security Technologies, LLC

P. O. Box 98521

Las Vegas, NV 89193-8521 
THIS PAGE INTENTIONALLY LEFT BLANK 


\section{Executive Summary}

The Nevada Test Site Environmental Report 2006 (NTSER) was prepared to meet the information needs of the public and the requirements and guidelines of the U.S. Department of Energy (DOE) for annual site environmental reports. It was prepared by National Security Technologies, LLC (NSTec). This Executive Summary presents the purpose of the document, the major programs conducted at the Nevada Test Site (NTS), NTS key environmental initiatives, radiological releases and potential doses to the public resulting from site operations, a summary of nonradiological releases, implementation status of the NTS Environmental Management System, a summary of compliance with environmental regulations, pollution prevention and waste minimization accomplishments, and significant environmental accomplishments. Much of the content of this Executive Summary is also presented in a separate stand-alone pamphlet titled Nevada Test Site Environmental Report Summary 2006 produced to be a more cost-effective means of distributing information contained in the NTSER to interested DOE stakeholders.

\section{Purpose of the NTS Environmental Report}

This NTSER was prepared to satisfy DOE Order 231.1A, Environment, Safety and Health Reporting. Its purpose is to (1) report compliance status with environmental standards and requirements, (2) present results of environmental monitoring of radiological and nonradiological effluents, (3) report estimated radiological doses to the public from releases of radioactive material, (4) summarize environmental incidents of noncompliance and actions taken in response to them, (5) describe the NTS Environmental Management System and characterize its performance, and (6) highlight significant environmental programs and efforts. This report meets these objectives for the NTS and its three Nevada satellite sites mentioned below.

\section{Major Site Programs and Facilities}

The U.S. Department of Energy, National Nuclear Security Administration Nevada Site Office (NNSA/NSO) directs the management and operation of the NTS and seven satellite sites across the nation. The NTS is located about 105 kilometers $(\mathrm{km})$ (65 miles [mi]) northwest of Las Vegas. The seven satellite sites include three sites in Nevada (North Las Vegas Facility, Cheyenne Las Vegas Facility, and the Remote Sensing Laboratory (RSL)-Nellis) and four sites in other states (Remote Sensing Laboratory - Andrews in Maryland, Livermore Operations in California, Los Alamos Operations in New Mexico, and Special Technologies Laboratory in California). Los Alamos, Lawrence Livermore, and Sandia National Laboratories are the principal organizations that sponsor and implement the nuclear weapons programs at the NTS. Up until June 30, 2006, Bechtel Nevada (BN) was the Management and Operating $(\mathrm{M} \& \mathrm{O})$ contractor accountable for the successful execution of work and ensuring that work was performed in compliance with environmental regulations. On July 1, 2006, NSTec became the responsible NTS M\&O contractor. The NTS and its seven satellite sites all provide support to enhance the NTS as a site for weapons experimentation and nuclear test readiness. The three major NTS missions include National Security, Environmental Management, and Stewardship of the NTS.

Facilities that support the National Security mission of keeping the U.S. stockpile of nuclear weapons safe and reliable include the U1a Facility, Big Explosives Experimental Facility, Device Assembly Facility, and Joint Actinide Shock Physics Experimental Research (JASPER) Facility. Facilities that support the Homeland Security program include the new Radiological/Nuclear Countermeasures Test and Evaluation Complex, which was expected to be operational in 2006, but is currently on hold.

\section{Other Key Initiatives}

Apart from the major site programs, other NTS activities include demilitarization activities, controlled spills of hazardous material at the Non-Proliferation Test and Evaluation Complex (NPTEC) for research purposes, processing of waste destined for the Waste Isolation Pilot Plant in Carlsbad, New Mexico, or the Idaho National Laboratory in Idaho Falls, Idaho; and environmental research. 


\section{Environmental Performance Measures Programs}

During the conduct of the major programs and other key initiatives mentioned above, NNSA/NSO complies with applicable environmental and public health protection regulations and strives to manage the land and facilities at the NTS as a unique and valuable national resource. For the identification of NTS environmental initiatives, BN, and then later NSTec, relied upon their Integrated Safety Management System (ISMS), contractual Work Smart Standards (WSS), and the Environmental Management System (EMS). The ISMS is designed to ensure the systematic integration of environment, safety, and health concerns into management and work practices so that NTS missions are accomplished safely and in a manner which protects the environment. Implementation of an ISMS at the NTS was verified by NNSA/NSO in July 2001. NNSA/NSO oversees ISMS implementation through the Integrated Safety Management Council.

WSS are an integral part of the ISMS whereby hazards and environmental aspects of work are identified and standards of operation are established that are specific to the work environment, its associated hazards, and its threats to the environment. WSS are developed at the management level with the most expertise in the work. NNSA/NSO approved the initial complete set of BN WSS in September 1996 and approved the set of NSTec WSS in July 2006. The approved WSS identify within each M\&O Contractor's program, the contractual commitment to meet applicable laws, regulations, and policies which protect the public and the environment. Compliance with WSS is tracked through management assessments.

The NSTec EMS is currently integrated with the ISMS. It is designed to incorporate concern for environmental performance throughout the organization, with the ultimate goal being continual reduction of the organization's impact on the environment. Specific objectives and targets to reduce environmental impacts are identified through the EMS process and are tracked annually.

The major event affecting the EMS program during 2006 was a commitment by NSTec to pursue ISO 14001 Certification (ISO stands for the International Organization for Standardization). NSTec committed in their contract proposal to obtain the certification by June 30, 2009. An internal management assessment was performed in December 2006 to evaluate the current environmental program against the requirements of the ISO 14001:2004 Standard. The assessment showed that the current program is mature and effective, but improvements must be made in some of the elements to satisfy all the rigorous ISO 14001 requirements.

\section{Performance Measures}

Performance measures are used to evaluate the achievement of organization or process goals and to identify the need to institute changes in an organization or process. The NTS performance measures, defined from the WSS, relate to protection of the environment and the public from effects of NTS operations. These performance measures apply to several programs and processes. They include: (1) the potential radiological dose received by the public; (2) the identification, notification, and mitigation of spills and releases to the environment; (3) the reduction in the generation of wastes; and (4) compliance with applicable environmental protection regulations. The performance measures tracked by each process or program (e.g., air quality protection) are consolidated and presented in this report in Section 2.0, Compliance Summary. As part of implementing the EMS, objectives and targets to reduce environmental impacts were also identified. The objectives and targets for 2006 were reviewed and approved by the Executive Safety Committee. They are related to the protection of cultural and natural resources, reduction of generated wastes and amounts of petroleum-based fuels used, the protection of groundwater, and the environmentally-sound management of groundwater resources. These additional objectives and targets (Section 17.0) were tracked by BN and then by NSTec in addition to those measures presented in Section 2.0.

\section{Offsite Monitoring for Radiological Releases into Air}

An oversight radiological air monitoring program is run by the Community Environmental Monitoring Program (CEMP) and is coordinated by the Desert Research Institute (DRI) of the Nevada System of Higher Education under contract with NNSA/NSO (Section 6.0). Its purpose is to provide monitoring for radionuclides that might be released from the NTS. A network of 29 CEMP stations, located in selected towns and communities within a 
160,000 square kilometer $\left(\mathrm{km}^{2}\right)\left(61,776\right.$ square mile $\left.\left[\mathrm{mi}^{2}\right]\right)$ area of southern Nevada, southeastern California, and southwestern Utah, was operated during 2006. The CEMP stations monitored gross alpha and beta radioactivity in airborne particulates using low-volume particulate air samplers, penetrating gamma radiation using thermoluminescent dosimeters (TLDs), gamma radiation exposure rates using pressurized ion chamber (PIC) detectors, and meteorological parameters using automated weather instrumentation. Two new stations were established in 2006, one between Shoshone and Tecopa, California, in February and one in Duckwater, Nevada, in November.

No airborne radioactivity related to historic or current NTS operations was detected in any of the samples from the CEMP particulate air samplers during 2006. Gross alpha and gross beta radioactivity was detected at all CEMP stations at levels which were consistent with previous years and which reflect radioactivity from naturally-occurring radioactive materials (Section 6.1.1). The mean annual gross alpha activity across all sample locations was $1.36 \pm 0.48 \times 10^{-15}$ microcuries per milliliter $(\mu \mathrm{Ci} / \mathrm{mL})$. The mean annual gross beta activity across all sample locations was $2.22 \pm 0.21 \times 10^{-14} \mu \mathrm{Ci} / \mathrm{mL}$. No man-made gamma-emitting radionuclides were detected.

TLD and PIC detectors measure gamma radiation from all sources: natural background radiation from cosmic and terrestrial sources and man-made sources. The offsite TLD and PIC results remained consistent with previous years' background levels and are well within background levels observed in other parts of the United States. The highest total annual gamma exposure measured offsite, based on PIC data, was 183.08 milliroentgens per year $(\mathrm{mR} / \mathrm{yr})$ at Milford, Utah. The lowest offsite gamma exposure rate measured was $72.27 \mathrm{mR} / \mathrm{yr}$ at Pahrump, Nevada (Section 6.1.3).

\section{Onsite Monitoring and Estimating of Radiological Releases into Air}

Estimates of radionuclide emissions from the following sources were used to compute total air emissions from source locations on the NTS. Those emissions and locations identified for 2006 included: (1) tritium gas released at Building 650 in Area 23 during equipment calibration (0.0000225 curies per year [Ci/yr]); (2) the evaporation of tritiated water discharged from E Tunnel in Area 12 ( $9.8 \mathrm{Ci} / \mathrm{yr})$; (3) the evaporation of tritiated water removed from the basement of Building A-1 at the North Las Vegas Facility (NLVF) and transported to the NTS for disposal in the Area 5 Sewage Lagoon (0.0003 Ci/yr); (4) the evaporation and transpiration of tritiated water from soil and vegetation, respectively, from the Area 3 Radioactive Waste Management Site (RWMS) (54 Ci/yr), the Area 5 RWMS $(19 \mathrm{Ci} / \mathrm{yr})$, the Schooner crater $(77 \mathrm{Ci} / \mathrm{yr})$, and the Sedan crater $(85 \mathrm{Ci} / \mathrm{yr})$; and (5) the re-suspension of surface soil containing americium-241 $(241 \mathrm{Am})$ and plutonium-239+240 $(239+240 \mathrm{Pu})$ from past nuclear testing over numerous areas of the NTS. Total tritium emissions from all sources was estimated to be 245 curies (Ci) in 2006, and those for americium and plutonium were 0.047 and $0.29 \mathrm{Ci}$, respectively (Section 3.1.9). The methods used to estimate these quantities each year include the use of annual field air and water monitoring data, historical soil inventory data, and accepted soil resuspension and air transport models.

\begin{tabular}{|c|c|c|c|c|c|c|c|c|c|c|}
\hline \multirow[b]{2}{*}{${ }^{3} \mathrm{H}$} & \multicolumn{10}{|c|}{ Total NTS Radiological Atmospheric Releases for 2006 (Ci/yr) } \\
\hline & ${ }^{85} \mathbf{K r}$ & $\begin{array}{c}\text { Noble } \\
\text { Gases } \\
\left(\mathrm{T}_{1 / 2}<40\right. \\
\text { days }) \\
\end{array}$ & $\begin{array}{c}\text { Short-Lived } \\
\text { Fission and } \\
\text { Activation } \\
\text { Products } \\
\left(\mathrm{T}_{1 / 2}<3 \mathrm{hr}\right) \\
\end{array}$ & $\begin{array}{c}\text { Fission } \\
\text { and } \\
\text { Activation } \\
\text { Products } \\
\left(\mathrm{T}_{12}>3 \mathrm{hr}\right) \\
\end{array}$ & $\begin{array}{c}\text { Total } \\
\text { Radio- } \\
\text { iodine } \\
\end{array}$ & $\begin{array}{c}\text { Total } \\
\text { Radio- } \\
\text { strontium }\end{array}$ & $\begin{array}{c}\text { Total } \\
\text { Uranium }\end{array}$ & Plutonium & $\begin{array}{c}\text { Other } \\
\text { Actinides }\end{array}$ & Other \\
\hline 245 & 0 & 0 & 0 & 0 & 0 & 0 & 0.0001 & $\begin{array}{c}0.29 \\
(239+240 \mathrm{Pu})\end{array}$ & $\begin{array}{c}0.047 \\
\left({ }^{241} \mathrm{Am}\right)\end{array}$ & 0 \\
\hline
\end{tabular}

A network of 19 air sampling stations (3 having low-volume particulate air samplers, 1 having a tritium water vapor sampler, and 15 having both) and a network of 109 TLDs were used to monitor diffuse onsite radioactive emissions in 2006. Several human-made radionuclides from legacy contamination were measured in air samples at levels above their minimum detectable concentrations (MDCs) in 2006: ${ }^{241} \mathrm{Am}$, tritium $\left({ }^{3} \mathrm{H}\right)$, plutonium-238 $\left({ }^{238} \mathrm{Pu}\right)$, and ${ }^{239+240} \mathrm{Pu}$ (Section 3.1.4). These were attributed to the resuspension of contamination in surface soils from legacy sites and to the evaporation and transpiration of tritium from the soil, plants, and containment ponds at legacy sites. The highest mean level of ${ }^{241} \mathrm{Am}\left(178.52 \pm 98.57 \times 10^{-18} \mu \mathrm{Ci} / \mathrm{mL}\right]$ was detected at Bunker 9-300 in Area 9, a vacant building 
located within an area of known soil contamination from past nuclear tests (Section 3.1.4.1). The highest mean level of tritium $\left(360.31 \pm 401.58 \times 10^{-6}\right.$ picocuries $\left.[\mathrm{pCi}] / \mathrm{mL}\right)$ was detected at Schooner, site of the second-highest yield Plowshare cratering experiment on the NTS where tritium-infused ejecta surrounds the crater (Section 3.1.4.5). The highest mean levels of plutonium isotopes in air were at Bunker 9-300 (17.61 $\pm 9.51 \times 10^{-18}$ and $1,201.9 \pm 622.14 \times 10^{-18} \mu \mathrm{Ci} / \mathrm{mL}$ for ${ }^{238} \mathrm{Pu}$ and ${ }^{239+240} \mathrm{Pu}$, respectively) (Section 3.1.4.3). The relatively high plutonium values occur most often at the Bunker 9-300 air sampling station due to historical nuclear testing in Area 9 and surrounding Areas 3, 4, and 7. Uranium isotopes are also measured in air samples collected in areas where depleted uranium ordnance have been used or tested. However, the samples' isotopic ratios were close to what one would expect from naturally-occurring uranium in soil with possibly a slight contribution of enriched depleted uranium; the ratios did not resemble those expected from depleted uranium (Section 3.1.4.4).

Gross alpha and gross beta radioactivity was detected at all stations on the NTS (Section 3.1.4.6). The average gross alpha activities ranged from $17.72 \pm 7.60$ to $60.26 \pm 34.82 \times 10^{-16} \mu \mathrm{Ci} / \mathrm{mL}$; the highest seen at Bunker 9-300. The average gross beta activities ranged from $17.76 \pm 4.78$ to $21.33 \pm 5.06 \times 10^{-15} \mu \mathrm{Ci} / \mathrm{mL}$; the highest seen at Sugar Bunker $\mathrm{N}$ in Area 5 where heavy loading of soil on the air filters is typical due to the sampler's proximity to a busy dirt road.

Both ${ }^{239+240} \mathrm{Pu}$ and tritium continue their overall declining trends at the air sampling locations (Sections 3.1.4.3 and 3.1.4.5, respectively). Tritium in air concentrations have decreased since the cessation of testing in 1992. At most locations, the average decline rate of tritium air concentrations is around 19 percent per year across all locations. This ranges from 5.5 percent per year at BJY in Area 1 to an average of 36 percent per year in Areas 23 and 25. The only exception to this trend has been Schooner in Area 20, at which sampling began relatively recently. ${ }^{239+240} \mathrm{Pu}$ concentrations have likewise decreased. The estimated average annual rates of decline in ${ }^{239+240} \mathrm{Pu}$ air concentrations range from 3.4 percent for Areas 1 and 3 to 17.2 percent for Areas 18, 19, and 20. The downward trends in plutonium concentrations are attributed to its dispersal by the wind and weathering in the soil, where it becomes bound to less mobile particles.

The highest estimated mean annual gamma exposure measured at a TLD station on the NTS was $771 \pm 41 \mathrm{mR} / \mathrm{yr}$ at Schooner, one of the legacy Plowshare sites on Pahute Mesa. The lowest was $59 \pm 3 \mathrm{mR} / \mathrm{yr}$ in Mercury at the fitness track (Section 5.3). The mean annual gamma exposure at 17 TLD locations near the Area 3 and Area 5 RWMSs was $143 \pm 60 \mathrm{mR}$. At the $35 \mathrm{TLD}$ locations near known legacy sites (including Schooner), it was $268 \pm 175 \mathrm{mR}$. At 9 TLD locations in uncontaminated sites away from all current operations, it was $125 \pm 29 \mathrm{mR}$.

\section{Offsite Radiological Monitoring of Water}

Offsite water monitoring conducted by the M\&O Contractor and by DRI (through the CEMP) verifies that there has been no offsite migration of man-made radionuclides from NTS underground contamination areas.

In 2006, BN and then NSTec conducted radiological monitoring of 16 offsite wells and 7 offsite springs. The wells included 3 private domestic wells, 3 local community wells, and 10 NNSA/NSO wells drilled for hydrogeologic investigations including groundwater flow modeling. All of the NSTec-sampled wells and springs are in Nevada within $35 \mathrm{mi}$ from the western and southern borders of the NTS. The DRI, through the CEMP, sampled 27 offsite water locations in 2006. They included 4 springs, 20 wells, and 3 surface water bodies located in selected towns and communities within $232 \mathrm{mi}$ from the NTS. One site, the Beatty Water and Sewer well, is sampled by both NSTec and DRI. CEMP and the M\&O Contractor water samples are both analyzed for tritium. The BN and NSTec offsite water samples were also analyzed for man-made gamma-emitting radionuclides that would signify contamination from nuclear testing and for gross alpha and gross beta radioactivity to determine if alpha or beta radioactivity at any well or spring is increasing over time.

CEMP results in 2006, as in past years, continue to verify that no contaminated groundwater has migrated beyond the NTS boundaries into surrounding water supplies used by the public (Section 6.2). Tritium concentrations from the wells ranged from $-12.9 \pm 12.8$ to $12.9 \pm 12.8$ picocuries per liter (pCi/L). For the springs and surface waters, they ranged from $0 \pm 19.2$ to $35.4 \pm 25.8 \mathrm{pCi} / \mathrm{L}$. As in previous years, samples from Boulder City and Henderson municipal water supplies contained tritium at levels barely above detection. These two municipal water systems obtain water from Lake Mead, which has documented levels of residual tritium persisting in the environment that originated from global atmospheric nuclear testing. 
Similarly, the results of BN and NSTec offsite water monitoring verified that there has been no offsite migration of man-made radionuclides from NTS underground contamination areas. None of the offsite springs or the offsite public or domestic water supply wells had levels of tritium above their detection limits, except the School Well in Amargosa Valley. This well had one duplicate sample for tritium of $23 \pm 13 \mathrm{pCi} / \mathrm{L}$, slightly above its sample-specific MDC of $20 \mathrm{pCi} / \mathrm{L}$, but the grab sample collected on the same date had $13 \pm 10 \mathrm{pCi} / \mathrm{L}$ of tritium, below its MDC of $16 \mathrm{pCi} / \mathrm{L}$. Tritium levels among all the sampled drinking water wells ranged from $9.3 \pm 11$ to $23 \pm 13 \mathrm{pCi} / \mathrm{L}$ (Section 4.1.4). Tritium in the seven offsite springs ranged from $-0.54 \pm 1.2$ to $16 \pm 2.1 \mathrm{pCi} / \mathrm{L}$ (Section 4.1.5). Tritium in the ten non-potable NNSA/NSO offsite wells ranged from $1.2 \pm 7.4$ to $23 \pm 14 \mathrm{pCi} / \mathrm{L}$ (Section 4.1.4). The highest tritium levels measured in offsite wells are within the range of concentrations indicative of analytical background levels for tritium (20 to $39 \mathrm{pCi} / \mathrm{L}$ ) (Section 4.1.3). No offsite wells or springs contained any man-made gamma-emitting radionuclides.

Most offsite wells and all offsite spring samples contained detectable gross alpha and gross beta activity (Sections 4.1.4 and 4.1.5). The levels of activity in offsite drinking supply wells and springs were all less than the U.S. Environmental Protection Agency (EPA) limits set for drinking water $(15 \mathrm{pCi} / \mathrm{L})$, except for the spring at Spicer Ranch. This spring's measured gross alpha activity was $16 \pm 2.1 \mathrm{pCi} / \mathrm{L}$. The detectable gross alpha and gross beta radioactivity in all of the offsite spring and well samples is most likely from natural sources.

\section{Onsite Radiological Monitoring of Water}

In 2006, the onsite water monitoring network was comprised of 6 potable and 4 non-potable water supply wells, 15 monitoring wells, 1 tritiated water containment pond system, and 2 sewage lagoons. The 2006 data continue to indicate that underground nuclear testing has not impacted the NTS potable water supply network. None of the six potable wells had detectable concentrations of tritium. However, the duplicate samples from UE-16D and WW C1 (both non-potable wells) collected in October measured 13 and $14 \mathrm{pCi} / \mathrm{L}$, respectively, both slightly above their MDCs. In both cases the tritium results from the grab samples, collected at the same time as the duplicate samples, were below their MDCs. All of the water samples from the ten supply wells had non-detectable concentrations of man-made gamma-emitting radionuclides (Section 4.1.6). The gross alpha and gross beta radioactivity detected in potable water supply wells represent the presence of naturally-occurring radionuclides.

Four of the 15 monitoring wells sampled had detectable levels of tritium ranging from $12 \pm 7.2$ to $484 \pm 35 \mathrm{pCi} / \mathrm{L}$, all well below the MCL of 20,000 pCi/L (Section 4.1.7). Three of these wells (PM-1, UE-7NS, and WW A) are each within $1 \mathrm{~km}(0.6 \mathrm{mi})$ of an historical underground nuclear test; all have consistently had detectable levels of tritium in past years. Their tritium levels are still less than 3 percent of the EPA MCL for drinking water of 20,000 pCi/L, and no trend of rising tritium concentrations in these wells have been observed since 2000 . One other monitoring well (ER-20-2 \#1) had detectable tritium levels just above the sample-specific MDC.

Most groundwater samples on the NTS had measurable gross alpha and/or gross beta levels below the EPA limits for drinking water which are likely from natural sources. One well $(\mathrm{U}-19 \mathrm{BH})$ had gross alpha levels above the EPA drinking water limits which is likely due to contamination due to its proximity (within $1 \mathrm{~km}$ ) to an historical underground nuclear test.

Five constructed basins collect and hold water discharged from E Tunnel in Area 12 where nuclear testing was conducted in the past. Tunnel effluent water and sediment samples are analyzed for tritium, gross alpha, gross beta, and other radionuclides. Most samples had detectable radionuclide concentrations in 2006 (Section 4.1.8). The average tritium concentration in tunnel effluent water was $604,000 \mathrm{pCi} / \mathrm{L}$, lower than the limit allowed under a discharge permit $(1,000,000 \mathrm{pCi} / \mathrm{L})$. Gross alpha and gross beta values in 2006 were also less than their permitted limits.

Neither of the two onsite sewage lagoons had detectable levels of tritium (Section 4.1.9).

The Underground Test Area (UGTA) Project pumps tritiated water into lined sumps during studies conducted at post-shot or near-cavity wells on the NTS. None of these types of contaminated wells were sampled in 2006. The UGTA Project did sample three uncontaminated wells in 2006, and the tritium levels in these wells were all below detection limits (Section 4.1.10). 


\section{Radiation Dose to the Public from the NTS}

Background Gamma Radiation - Mean background gamma radiation exposure rates on the NTS are measured at ten TLD stations located away from radiologically-contaminated sites. These ranged from 82 to $164 \mathrm{mR} / \mathrm{yr}$ during 2006 (Section 5.3). This equates to an annual estimated background external dose of 82 to 164 millirem per year (mrem/yr) to a hypothetical person residing at those locations all year. In comparison, DRI measured background radiation in 2006 at offsite locations using TLDs which ranged from $78 \mathrm{mR} / \mathrm{yr}$ at Pahrump, Nevada, to $154 \mathrm{mR} / \mathrm{yr}$ at Sarcobatus Flats, Nevada. The DRI PIC detectors measured background radiation ranging from $72.27 \mathrm{mR} / \mathrm{hr}$ at Pahrump to $183.08 \mathrm{mR} / \mathrm{yr}$ at Milford, Utah.

Public Dose from Drinking Water - Man-made radionuclides from past nuclear testing have not been detected in offsite groundwater in the past or during 2006 (Section 4.1). The offsite public cannot receive a radiation dose from NTS operations from drinking water.

Public Dose from Inhalation - The radiation dose limit to the general public via just the air transport pathway is established by the National Emission Standards for Hazardous Air Pollutants (NESHAP) under the Clean Air Act to be $10 \mathrm{mrem} / \mathrm{yr}$. The EPA, Region IX, has approved the use of six air sampling stations on the NTS (called "critical receptor" stations) to verify compliance with the NESHAP dose limit. These six stations are part of the 19 stations in the NTS air sampling network and they are located near legacy sites of contamination and along the NTS boundaries. The following human-produced radionuclides were detected at three or more of the critical receptor samplers in 2006: ${ }^{241} \mathrm{Am},{ }^{238} \mathrm{Pu},{ }^{239+240} \mathrm{Pu}$, and ${ }^{3} \mathrm{H}$ (tritium). Concentrations of these radionuclides at each of the stations indicated that the NESHAP dose limit to the public was not exceeded. The Schooner critical receptor station in the far northwest corner of the NTS experienced the highest concentrations of radioactive air emissions (Section 3.1.5), yet an individual residing at this station would experience a dose from air emissions of only $2.5 \mathrm{mrem} / \mathrm{yr}, 25$ percent of the admissible dose limit. No one resides at this location, and the dose at offsite populated locations $20-80 \mathrm{~km}(12-50 \mathrm{mi})$ from the Schooner station would be much lower due to wind dispersion.

Public Dose from Direct Radiation - The radiation dose limit to the general public via all possible transport pathways (over and above background dose) established by DOE Order 5400.5 is $100 \mathrm{mrem} / \mathrm{yr}$. This includes internal and external dose. The external, direct gamma radiation exposure to the public from NTS operations in 2006 was negligible. Areas accessible to the public had exposure rates comparable to natural background rates in 2006 (Section 5.3.1). In 2005, the TLD location on the west side of the parking area at Gate 100, the NTS entrance gate, had an estimated annual exposure of $220 \mathrm{mR}$. In 2006, however, this Gate 100 TLD station measured a mean annual exposure of $105 \mathrm{mR}$, with quarterly values ranging from 68 to $160 \mathrm{mR}$, similar to background doses measured offsite by DRI. It is likely that low-level radioactive waste shipments intermittently parked there prior to entering the NTS are responsible for such year-to-year and quarter-to-quarter variation.

The great majority of the NTS is bounded by the Nevada Test and Training Range (NTTR). Military or other personnel on the NTTR who are not classified as radiation workers would also be subject to the 100 mrem annual dose limit for members of the public. Military personnel could be exposed to direct radiation from legacy sites in Frenchman Lake playa. A TLD location near the NTS boundary with NTTR in the Frenchman Lake playa had an estimated annual exposure during 2006 of $379 \mathrm{mR}$ (down from 391 in 2005 and from $411 \mathrm{mR}$ in 2004). The resulting above-background dose of approximately 215 to $313 \mathrm{mrem} / \mathrm{yr}$, depending on which background radiation value is used, would exceed the $100 \mathrm{mrem} / \mathrm{yr}$ dose limit to a hypothetical person residing year-round at this location. However, there are no living quarters or full-time personnel in this vicinity.

Public Dose from Ingestion of Radionuclides in Game Animals - Game animals from different contaminated NTS sites are trapped each year and analyzed for their radionuclide content. These results are used to construct worst-case scenarios for the dose to hunters who might consume these animals if the animals moved off the NTS. In 2006, jackrabbits were trapped at the T2 site in Area 2 and at a control site in Area 14. Also, one mule deer in Yucca Flat and two pronghorn antelope from Areas 5 and 23, all killed accidentally by vehicles, were sampled. No manmade radionuclides were detected in muscle tissue from the deer or antelope. Based on the jackrabbit samples, the highest annual dose to a member of the public was estimated to be $0.12 \mathrm{mrem}$ ( 0.0012 millisieverts), assuming that this person eats 20 jackrabbits. This hypothetical dose is only 0.12 percent of the annual dose limit for members of the public. To put this dose into perspective, it is 4 times lower than the dose from cosmic radiation received by an individual while on a one-hour airplane flight at 39,000 feet (0.5 mrem). 
Public Dose from All Pathways - Existing 2006 radiological monitoring data from groundwater monitoring wells, air sampling stations, TLD stations, and game animals indicate that the dose to the public living in communities surrounding the NTS are not expected to be higher than the previous 10 years and are expected to be less than 1 percent of the $100 \mathrm{mrem} / \mathrm{yr}$ dose limit.

\section{Nonradiological Releases into Air}

The release of air pollutants is regulated on the NTS under a Class II air quality operating permit. Class II permits are issued for "minor" sources where annual emissions must not exceed 100 tons of any one criteria pollutant, or 10 tons of any one of the 189 hazardous air pollutants (HAPs), or 25 tons of any combination of HAPs. Criteria pollutants include sulfur dioxide $\left(\mathrm{SO}_{2}\right)$, nitrogen oxide $(\mathrm{NO})$, carbon monoxide $(\mathrm{CO})$, particulate matter $(\mathrm{PM})$, and volatile organic compounds (VOCs). The NTS facilities regulated by the permit include: (1) over 15 facilities/185 pieces of equipment in Areas 1, 3, 5, 6, 12, and 23; (2) the NPTEC; (3) Site-Wide Chemical Release Areas; (4) the Big Explosives Experimental Facility (BEEF); and (5) the Explosives Ordnance Disposal Unit.

An estimated 4.57 tons of criteria air pollutants were released on the NTS in 2006 (Section 3.2.1). The majority of the emissions were NOx from diesel generators and VOCs from the bulk storage of gasoline. The estimated quantity of all HAPs released in 2006 was 1.87 tons (Section 3.2.1). Total air emissions of lead, classified as a HAP as well as a criteria pollutant, was 42 pounds (Section 10.3). No emission limits for any criteria air pollutants or HAPS were exceeded. In 2006, performance emission tests were conducted for four NTS generators. One of the generators (the JASPER generator) exceeded its emission limits set by the air permit and was shut down.

In 2006, four tests consisting of a combined total of 49 releases of hazardous chemicals were conducted at the Area 5 NPTEC facility and at the Port Gaston facility in Area 26 (Section 3.2.5). An annual report of the types and amounts of chemicals released and the test plans and final analysis reports for each chemical release were submitted to the state of Nevada. No ecological monitoring was performed since each test posed a very low level of risk to the environment and biota.

There were no discharges of nonradiological hazardous materials off of the NTS or off of any of its satellite facilities in 2006.

\section{Nonradiological Releases into Water}

There are no liquid discharges to navigable waters, offsite surface water drainage systems, or publicly owned treatment works resulting from operations on the NTS. Therefore, no Clean Water Act National Pollution Discharge Elimination System (NPDES) permits are required for NTS operations.

In 2006, industrial discharges on the NTS were limited to two operating sewage lagoon systems, the Area 6 Yucca Lake and Area 23 Mercury systems. Under the conditions of state of Nevada operating permits, liquid discharges to these sewage lagoons are tested quarterly for biochemical oxygen demand, $\mathrm{pH}$, and total suspended solids. Annually, sewage lagoon pond waters are sampled for a suite of toxic chemicals. In 2006, quarterly and annual analyses of sewage influent and pond waters, respectively, both showed that all water measurements were within permit limits (often below detection levels) with one exception. One measure of 5-day Biological Oxygen Demand (BOD 5 ) Mean Daily Load was exceeded at the Area 23 Mercury lagoons in the second quarter. The lagoon waters were resampled in the second quarter, and $\mathrm{BOD}_{5}$ levels were found to be below permit limits and remained so for the remainder of the calendar year (Section 4.2.3).

\section{Onsite Nonradiological Drinking Water Quality}

NNSA/NSO operates a network of six permitted wells that comprise three permitted public water systems on the NTS; these supply the potable water needs of NTS workers and visitors. NNSA/NSO also hauls potable water to work locations at the NTS that are not part of a public water system. Monitoring results indicate that water samples from the three public water systems and from the potable water hauling trucks met the National Primary and Secondary Drinking Water Standards in 2006 with one exception. The Area 12 water system exceeded the action level 
for lead (0.037 milligrams per liter [mg/L]; with action level of $0.015 \mathrm{mg} / \mathrm{L}$ ) (Section 4.2.1). The high level is attributed to the camp's inactivity and resultant lack of flushing within the service lines. In September 2006, this public water system was reclassified to a non-community transient system.

\section{Nonradiological Releases into Air and Water at the NLVF}

Like the NTS, the NLVF is regulated for the emission of criteria air pollutants and HAPs. The regulated sources of emissions include an aluminum sander, an abrasive blaster, emergency generators, and a spray paint booth. The combined quantity of criteria air pollutants and HAPs emitted at the NLVF in 2006 was 0.351 tons, ranging from 0.001 tons for HAPS to 0.237 tons for nitrogen oxides (Appendix A, Section A.1.3).

Water discharges at the NLVF were regulated in 2006 by a permit with the City of North Las Vegas (CNLV) for sewer discharges, two temporary state-issued NPDES discharge permits, and an EPA-issued NPDES discharge permit which replaced the temporary permits. The final EPA NPDES authorizes the discharge of pumped groundwater from dewatering operations to the groundwater of the State via percolation and to the Las Vegas Wash via the CNLV storm drain system. Self-monitoring and reporting of the levels of nonradiological contaminants in sewage and industrial outfalls is conducted. In 2006, contaminant measurements were below established permit limits in all water and sludge samples from NLVF except in water samples from two outfalls where total dissolved solids (TDS) exceeded permit limits (Appendix A, Section A.1.1). In response to these exceedances, a Salinity Control Plan discussing steps taken to reduce the TDS levels was written and submitted to CNLV. CNLV conducted an annual inspection in November 2006 that resulted in no findings or corrective actions.

\section{Nonradiological Releases into Air and Water at RSL-Nellis}

The sources of air pollutants at RSL-Nellis that are regulated for the emission of criteria pollutants and HAPs include boilers, water heaters, emergency generators, a spray paint booth, and a vapor degreaser. The total estimated quantities of criteria air pollutants and HAPs emitted in 2006 is 0.383 tons. Natural gas consumption at RSL-Nellis in 2006 was 3,213,100 cubic feet $\left(\mathrm{ft}^{3}\right)$. Natural gas consumption is reported as a requirement of the RSL-Nellis air permit.

Discharges of wastewater from RSL-Nellis are required to meet permit limits set by the Clark County Water Reclamation District. All wastewater outfall samples in 2006 were below permit limits (Appendix A, Section A.3.1).

\section{Pollution Prevention/Waste Minimization (P2/WM) Activities}

P2/WM activities result in reductions to the volume and/or toxicity of waste actually generated onsite. Overall, a reduction of 149 mtons (164 tons) of hazardous wastes was realized in 2006. The largest volume of hazardous waste reduction came from shipments of bulk used oil (98.2 metric tons (mtons) [108 tons]) and lead acid batteries (34.5 mtons [38 tons]) to offsite vendors for recycling. In 2006, NSTec bought three refrigerant recycling machines and recycled 0.6 mtons ( 0.66 tons) of refrigerant.

Overall, a reduction of 803 mtons (883 tons) of solid wastes was realized in 2006 (Section 11.3). The largest proportion of solid waste reductions came from offsite shipments of 538.7 mtons (593 tons) of scrap ferrous metal and 154.4 mtons (170 tons) of mixed paper and cardboard to offsite vendors for recycling and shipment of $67 \mathrm{mtons}$ (74 tons) of food wastes from the NTS cafeterias to a local pig farm.

\section{Accidental or Unplanned Environmental Releases or Occurrences}

In 2006, there were no reportable accidental or unplanned environmental releases or occurrence on the NTS or at any of the NTS satellite facilities. 


\section{Historic Preservation and Cultural Resources Management}

DRI archeologists examined a total of 140.2 hectares (ha) (346.7 acres [ac]) during cultural resources inventories and historical evaluations in 2006. The inventories were conducted for two proposed projects in Area 18. Three prehistoric sites, two isolated features, and seven isolated artifacts were found and recorded. None of the sites met the criteria for eligibility of the National Register of Historic Places (NRHP) (Section 12.1.1). Evaluations of historic structures were conducted for U12b Tunnel, U12e Tunnel, and the Area 25 BREN Tower Complex, but only the U12b Tunnel complex has been determined eligible to the NRHP; the review and determinations for the other two are pending. The potential adverse effects of the proposed Divine Strake high explosives test on the rock cabin near Tippipah Spring were mitigated through intensive documentation (Section 12.1.2).

The National Historic Preservation Act requires federal agencies to identify and maintain the integrity of historic properties under their jurisdiction. Historic properties are cultural resources that have been determined eligible to the NRHP through consultation between the NNSA/NSO and the Nevada State Historic Preservation Office. Two field projects were conducted in 2006 to meet this requirement. One project focused on 10 sites that were temporary American Indian camps and lithic tool manufacturing areas. The second field project was at Cane Spring (Section 12.1.3). All of the sites were in a very good state of preservation. Additional 2006 field projects focused on obtaining photographic documentation of late twentieth century nuclear testing related structures. One 2006 project required archival research but no fieldwork. This was in support of the proposed small arms range in Area 12 near Area 12 Camp which was later cancelled.

The NTS Archaeological Collection currently contains over 400,000 artifacts (Section 12.2). Any new additions to the NTS collection continue to be inventoried and the inventory list provided to the NTS-affiliated American Indian tribes. All artifacts which the tribes have requested have been repatriated to them. Known locations of American Indian human remains at the NTS continued to be protected from NTS activities in 2006. All consultations between NNSA/NSO and the tribes occurs through the Consolidated Group of Tribes and Organizations (CGTO) comprised of 16 groups of Southern Paiute, Western Shoshone, and Owens Valley Paiute-Shoshone, along with the Las Vegas Indian Center, a Pan-Indian organization.

In 2006, the CGTO tribal groups were consulted regarding the proposed Divine Strake test, and work with the CGTO continued on the American Indian exhibit at the Atomic Testing Museum in Las Vegas (Section 12.3).

\section{Ecological Monitoring}

A cumulative total of $110.25 \mathrm{ha}(272.43 \mathrm{ac})$ of habitat on the NTS within the range of the federally threatened desert tortoise (Gopherus agassizii) has been disturbed since the desert tortoise was listed as threatened in 1992. In 2006, biologists conducted surveys for 21 projects within tortoise habitat. No desert tortoises were accidentally injured or killed, nor were any found, captured, or displaced from project sites. One desert tortoise was accidentally killed along a paved road (Section 13.1).

Numerous field surveys for important plants and animals were conducted on the NTS in 2006. They include species protected or managed under state or federal regulations, those listed on the Nevada Natural Heritage Program's Nevada At-Risk Plant and Lichen Tracking List and the At-Risk Animal Tracking List, and bats listed as being at risk under the Nevada Bat Conservation Plan. In total, they include 44 plants, 1 mollusk, 2 reptiles, over 250 birds, and 26 mammals. One new population of the plant Ivesia arizonica var. saxosa was found (Section 13.3.1.3). The western red-tailed skink (Eumeces gilberti rubricaudatus) was trapped from six new locations (Section 13.3.2.1). Western burrowing owls (Athene cunicularia hypugaea) were also trapped at six new locations (Section 13.3.2.2). A common black-hawk (Buteogallus antbracinus) was observed for the first time on the NTS (Section 13.3.2.3).

In 2006, there were 16 wildland fires and a total of 3,486 ha (8,615 ac) burned. An annual vegetation survey to determine wildland fire hazards was conducted in the spring, and survey findings were submitted to the NTS Fire Marshal. The roadside areas that had the highest risk of wildland fires were in Areas 29 and 30 (Section 13.5).

A West Nile Virus sampling program on the NTS continued in 2006. Biologists conducted 14 trapping sessions at 8 sites on the NTS. A total of 111 individuals representing 6 species was captured and analyzed. One Culiseta inornata mosquito tested positive for the virus, but the test result is suspected to be false. Six injured hawks from the NTS tested negative for the virus (Section 13.3.2.3). 


\section{Compliance with Environmental Laws, Regulations, and Policies}

A summary of NNSA/NSO's compliance with over 100 applicable environmental laws, regulations, and policies is presented in Section 2.0 of this NTSER. The major categories of these drivers are listed below. Where compliance for a category was not 100 percent, all of the noncompliance incidents are noted.

\begin{tabular}{|c|c|}
\hline \multicolumn{2}{|c|}{ Environmental Compliance Summary for the NTS in 2006} \\
\hline Category & Noncompliance Incidents \\
\hline Air Quality & $\begin{array}{l}\text { Three pieces of equipment failed their performance emissions test and } \\
\text { were shut down (Section 3.2.2). }\end{array}$ \\
\hline Water Quality and Protection & $\begin{array}{l}\text { Limits for lead were exceeded in Area } 12 \text { public water system } \\
\text { (Section 4.2.1.1). Limits for total dissolved solids were exceeded in } \\
\text { sewage outfalls at NLVF (Section A.1.1.1). }\end{array}$ \\
\hline Radiation Dose Protection & None \\
\hline $\begin{array}{l}\text { Radioactive and Non-Radioactive Waste } \\
\text { Management and Environmental Restoration }\end{array}$ & None \\
\hline Hazardous Materials Control and Management & None \\
\hline Pollution Prevention and Waste Minimization & $\begin{array}{l}\text { One Executive Order } 13101 \text { goal, to have } 100 \text { percent of purchases of } \\
\text { items from the EPA-designated list contain recycled materials at } \\
\text { the specified minimum content, was not met. The percentage of such } \\
\text { purchases in } 2006 \text { was } 73 \text { percent (Section 11.1). }\end{array}$ \\
\hline $\begin{array}{l}\text { Historic Preservation and Cultural Resource } \\
\text { Protection }\end{array}$ & None \\
\hline $\begin{array}{l}\text { Conservation and Protection of Biota and } \\
\text { Wildlife Habitat }\end{array}$ & $\begin{array}{l}\text { Four accidental bird deaths attributable to NTS activities (e.g., roadkill); } \\
\text { represented } 3 \text { species protected as migratory birds (Section 13.3.2.3). }\end{array}$ \\
\hline
\end{tabular}

\section{Significant Environmental Accomplishments}

Environmental Restoration - The cleanup of sites contaminated by past DOE operations and the hydrogeological investigations supporting characterization of underground nuclear contamination areas are the most significant environmental work performed by NNSA/NSO each year. The DOE, U.S. Department of Defense, and the State of Nevada Division of Environmental Protection identify a work scope and milestone schedule for the cleanup and safe closure of the contaminated above-ground sites and for the field investigations and model development necessary to characterize the underground sites. A total of 339 contaminated above-ground sites was closed safely in 2006 . These above-ground sites consist of facilities and land, such as the Test Cell A Facility, and are referred to as Industrial Sites. In addition to the Industrial Sites closures, extensive progress was made toward the development of hydrologic models describing groundwater flow and possible radionuclide transport from the primary underground sites into the groundwater underlying public lands outside the boundaries of the NTS. This involved the completion of groundwater flow models for CAU 98 (Frenchman Flat) and CAUs 101 and 102 (central and western Pahute Mesa) (Section 14.3).

Pollution Prevention - NNSA/NSO received two NNSA Environmental Stewardship Awards (ESAs) and two NNSA Best-In-Class Awards for pollution prevention activities in 2006. The BEEF, operated by the Lawrence Livermore National Laboratory, won an ESA for incorporating P2/WM practices into the facility design and daily operating procedures. NSTec's Information Services Personal Computer Leasing Group was awarded the second ESA for developing an electronics stewardship program that promotes environmentally responsible management of leased computers (from Dell Corporation) and company-owned computers. Through this program, all company computers are either refurbished, reused, or their parts are recycled, and NSTec orders new leased "green computers" 
from Dell Corporation whenever possible, because they are manufactured with materials that are more easily recycled and less toxic to the environment (Section 11.2.2).

One NNSA Best-In-Class Award recognized the efforts of Stoller-Navarro Joint Venture for fully integrating EMS into their infrastructure and culture. By instituting the EMS, NNSA/NSO enhanced workplace safety, reduced potentially hazardous and potentially radioactive waste streams by an estimated 11,167 cubic feet, and saved an estimated \$1.4 million in disposition costs over the life-cycle of the Environmental Restoration Project. The second NNSA Best-In-Class Award went to the NSTec Advanced Monitoring Systems Initiative Program for developing an automated universal platform for the deployment of analytical sensors in the field for long-term monitoring of environmental contaminants. Use of this system greatly reduces costs associated with sampling, transportation, shipment, and analysis of samples, and decreases the risk of environmental contamination and out-of-compliance violations as well as worker exposure to hazardous chemicals (Section 11.2.2)

Waste Management - In 2006, the secondary sewage lagoon in Area 23 was lined with a geosynthetic clay and high density polyethylene liners. The Area 23 sewage lagoon system is now a fully contained basin, thus preventing any infiltration to the waters of the State. 
THIS PAGE INTENTIONALLY LEFT BLANK 


\section{Acknowledgements}

Environmental Technical Services (ETS) of National Security Technologies, LLC (NSTec), is responsible for production of this document for the U.S. Department of Energy, National Nuclear Security Administration Nevada Site Office (NNSA/NSO). Environmental monitoring and compliance data were gathered through the combined efforts of several NSTec organizations in addition to ETS: Environmental Services, Radioactive Waste Operations, Solid Waste Operations, Environmental Restoration, Ecological Services, Radiological Control, Occupational Safety \& Health, and Contractor Assurance \& Compliance. The Water Resources and Cultural Resources divisions of the Desert Research Institute (DRI) contributed data for offsite water and air monitoring and cultural resource protection. Stoller-Navarro Joint Venture (SNJV) provided schedule and progress data for environmental restoration projects. SNJV also provided radioanalysis data for certain onsite wells sampled under the Underground Test Area Project. The Air Resources Laboratory, Special Operations and Research Division (ARL/SORD) provided summary descriptions of the Nevada Test Site (NTS) climate, and the U.S. Geological Survey (USGS) provided water level and usage data for selected wells. My thanks go to each of the authors and contributors who are listed below from these organizations.

\section{Chapter Authors and Contributors}

\section{Executive Summary}

Cathy A. Wills, NSTec

\subsection{Introduction}

Charles B. Davis, EnviroStat

Cathy A. Wills, NSTec

\subsection{Compliance Summary}

Colleen M. Beck, DRI

Elizabeth C. Calman, NSTec

Andrea L. Gile, NSTec

Robert F. Grossman, NSTec

Dennis L. Gustafson, NSTec

Madelyn A. Hayes, NSTec

Orin L. Haworth, NSTec

David B. Hudson, NSTec

Alfred J. Karnes, NSTec

Coby P. Moke, NSTec

Teresa M. Morgan, NSTec

Steve J. Nacht, NSTec

Paul K. Ortego, NSTec

Phyllis M. Radack, NSTec

Stuart E. Rawlinson, NSTec

Glenn Richardson, NSTec

Gregory T. Schmett, NSTec

Carlton Soong, NSTec

Janene L. VanDeroef, NSTec

Tammy H. Wallace, NSTec

Ronald W. Warren, NSTec $\underline{3.0 \text { Radiological and Nonradiological }}$ Air Monitoring

Elizabeth C. Calman, NSTec

Charles B. Davis, EnviroStat

Robert F. Grossman, NSTec

Teresa M. Morgan, NSTec

Tammy H. Wallace, NSTec

Ronald W. Warren, NSTec

\subsection{Radiological and Nonradiological} Water Monitoring

Charles B. Davis, EnviroStat

David B. Hudson, NSTec

Paul K. Ortego, NSTec

Phyllis M. Radack, NSTec

David D. Rudolph, NSTec

Carlton Soong, NSTec

Janene L. VanDeroef, NSTec

Ronald W. Warren, NSTec

\subsection{Direct Radiation Monitoring}

Charles B. Davis, EnviroStat

Ronald W. Warren, NSTec

\author{
6.0 Oversight Radiological Monitoring \\ of Air and Water \\ William T. Hartwell, DRI \\ Craig Shadel, DRI \\ Charles E. Russell, DRI
}




\subsection{Radiological Biota Monitoring}

Ronald W. Warren, NSTec

8.0 Radiological Dose Assessment

Robert F. Grossman, NSTec

Ronald W. Warren, NSTec

Phillip D. Worley, NSTec

9.0 Waste Management and

Environmental Restoration

Pat Arnold, NSTec

Troy S. Belka, NSTec

Tamiko Y. Brown, SNJV

Carol F. Dinsman, SNJV

David B. Hudson, NSTec

Steve J. Nacht, NSTec

Gregory T. Schmett, NSTec

Carlton Soong, NSTec

Glenn Richardson, NSTec

10.0 Hazardous Materials Control and

Management

Orin L. Haworth, NSTec

Madelyn A. Hayes, NSTec

11.0 Pollution Prevention

Alfred J. Karnes, NSTec

12.0 Historic Preservation and Cultural

Resources Management

Colleen M. Beck, DRI

Barbara A. Holz, DRI

\subsection{Ecological Monitoring}

David C. Anderson, NSTec

Paul D. Greger, NSTec

\subsection{Ecological Monitoring (continued)}

Derek B. Hall, NSTec

Dennis J. Hansen, NSTec

W. Kent Ostler, NSTec

14.0 Underground Test Area Project

Sigmund L. Drellack, NSTec

15.0 Hydrologic Resources Management

Program

Bruce W. Hurley, NNSA/NSO

Robert P. Graves, USGS

16.0 Meteorological Monitoring

Darryl Randerson, ARL-SORD

17.0 Environmental Management System

Orin L. Haworth, NSTec

David Schrock, SNJV

Cathy A. Wills, NSTec

18.0 Compliance Quality Assurance Program

Elizabeth Burns, NSTec

Jerry J. Dugas, NSTec

Theodore J. Redding, NSTec

19.0 Oversight Quality Assurance Program

Craig Shadel, DRI

Appendix A: NTS Satellite Facilities

Elizabeth C. Calman, NSTec

Sigmund L. Drellack, NSTec

Madelyn A. Hayes, NSTec

Ronald W. Warren, NSTec

Appendix B: Glossary

Modified from Lawrence Livermore

National Laboratory 2003

Environmental Report

\section{ETS Support Staff}

The following individuals within ETS are responsible year-in and year-out for the numerous tasks that are integral to the collection, quality assurance, and quality control of much of the environmental data reported in this environmental report. These are the "behind the scenes" folks. Thank you all for your efforts in the following areas.

Administration of the Bechtel Environmental Integrated Data Management System (BEIDMS) for Routine Radiological Environmental Monitoring Program (RREMP), Clean Water Act (CWA) and Safe Drinking Water Act (SDWA) Projects:

Elizabeth Burns

Robert G. Peppard

Coordination of Field Sampling Operations for RREMP, CWA, and SDWA Projects:

Terrence P. Sonnenburg 
Field Sampling for RREMP, CWA, and SDWA Projects:

Melissa A. Cabble

Martin D. Cavanaugh

Paul D. Greger

Matthew O. Weaver

Alan O. Wittig

Laboratory Operations Supporting RREMP Screening and Sample Processing:

Lynn N. Jaussi

Sample Management Supporting the NSTec Subcontracting of Environmental Analytical Services:

Catherine D. Castaneda

Theodore J. Redding

RREMP Data Verification, Validation, and Review:

Elizabeth Burns

David B. Hudson

Ronald W. Warren

Quality Assurance Oversight of the RREMP:

Jerry J. Dugas

\section{Report Production and Distribution Support Personnel}

Lastly, my appreciation goes to the following individuals who were responsible for improving the quality, appearance, and timely production and distribution of this report:

Ashley Cushman of NSTec Geographic Information Systems (GIS) worked with all the authors to produce the highquality GIS-generated maps and figures.

Charles Davis of EnviroStat provided support for the statistical analyses and interpretation of NTS radiological monitoring data collected by ETS.

Tom Fitzmaurice of NSTec Environmental Restoration provided his artistic talents to produce the drawing of possible pathways of radiological exposure to the public presented in the NTSER Summary.

Kurt Jahn and Mark Shaw of Technical Publications and Graphic Services/Office Services (TPGS/OS) produced high-quality hard copies and compact discs of the NTSER and the NTSER Summary under a tight production schedule.

Fina Martinez-Myers of Technical Publications provided a thorough review of this document to ensure spelling, format, grammar, references, tables, figures, acronyms, table of contents, etc., were all in order.

Angela McCurdy of TPGS/OS is the document's graphics specialist and desktop publisher responsible for the final layout and format of the NTSER and the covers. Her skill and dedication applied to this project year after year are greatly appreciated. 
THIS PAGE INTENTIONALLY LEFT BLANK 


\section{Table of Contents}

Executive Summary iii

Acknowledgements $\mathrm{XV}$

List of Figures xxvi

List of Tables xxviii

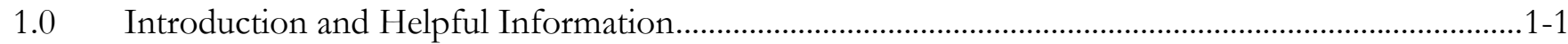

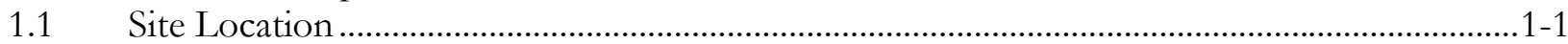

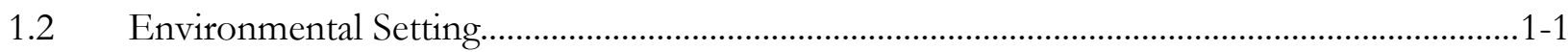

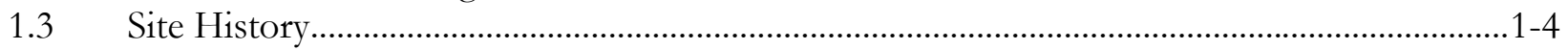

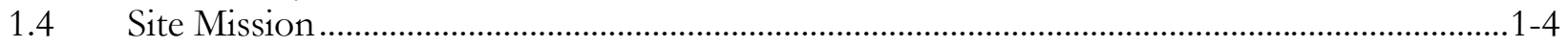

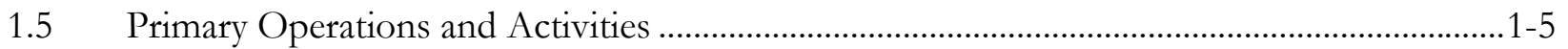

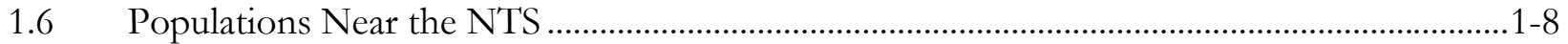

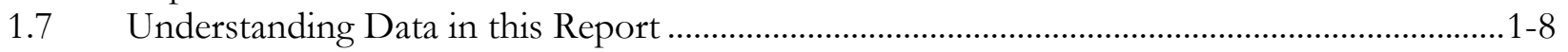

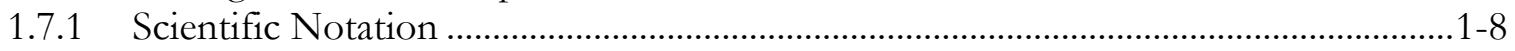

1.7.2 Unit Prefixes.......................................................................................................... 1-8

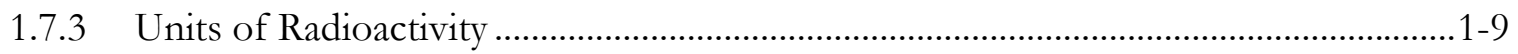

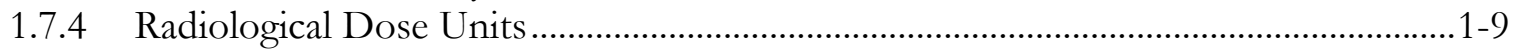

1.7.5 International System of Units for Radioactivity and Dose ........................................1-9

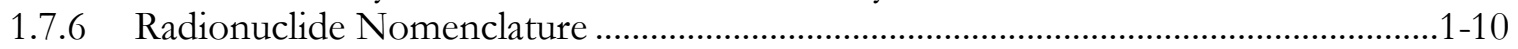

1.7.7 Units of Measurement ..............................................................................................1-10

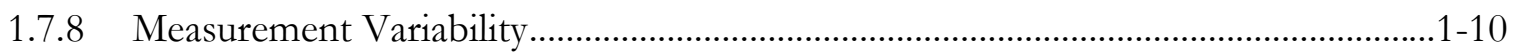

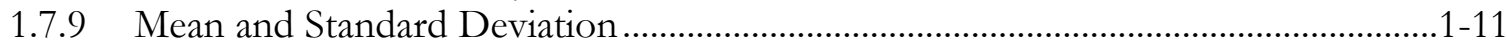

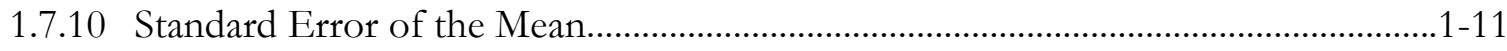

1.7.11 Median, Maximum, and Minimum Values ...............................................................1-11

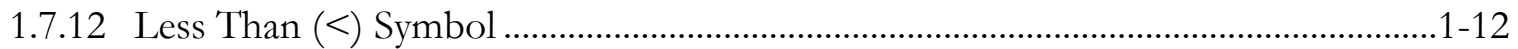

1.7.13 Negative Radionuclide Concentrations ...................................................................1-12

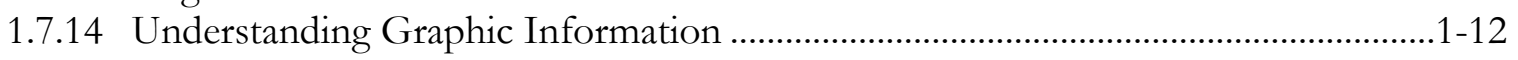

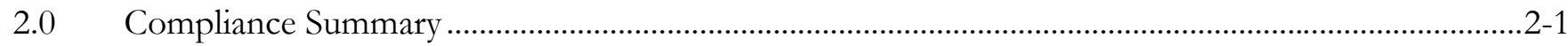

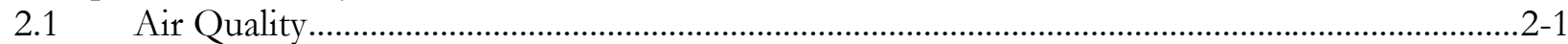

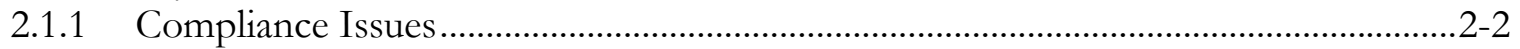

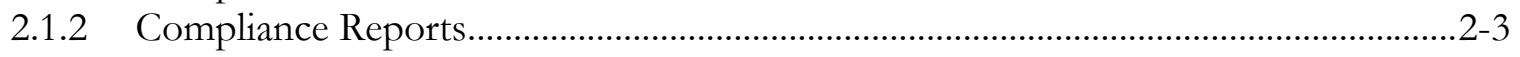

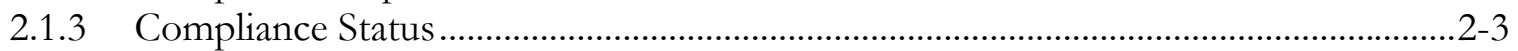

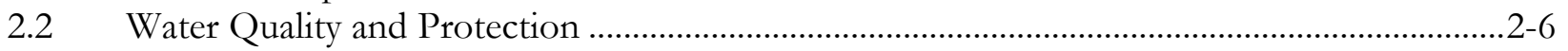

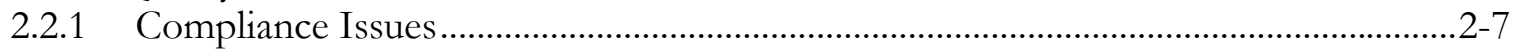

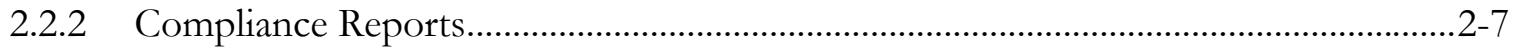

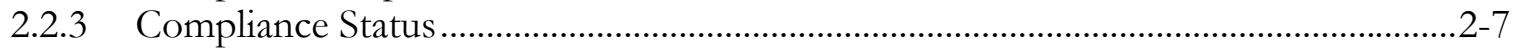

2.3 Radiation Dose Protection ...................................................................................................2-10

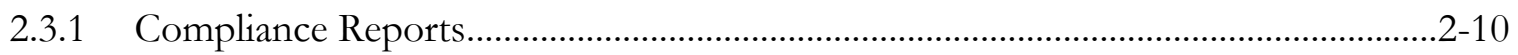

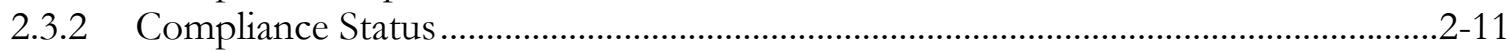

2.4 Radioactive and Nonradioactive Waste Management and Environmental Restoration .......2-12

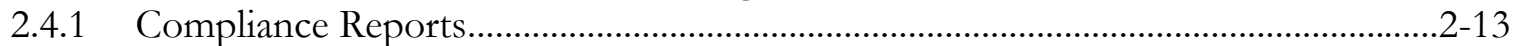

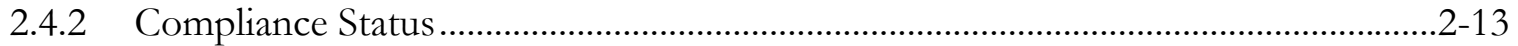

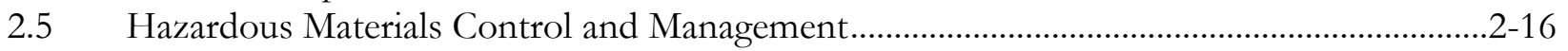

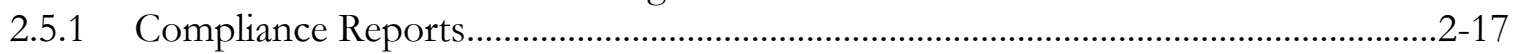

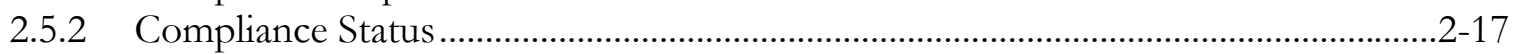

2.6 National Environmental Policy Act............................................................................................ 


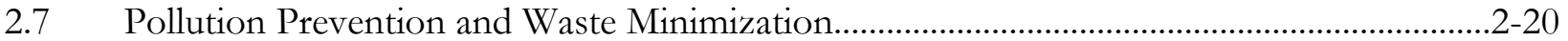

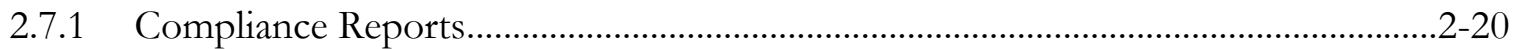

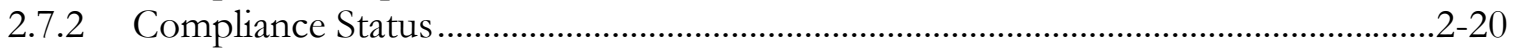

2.8 Historic Preservation and Cultural Resource Protection ..........................................................2-22

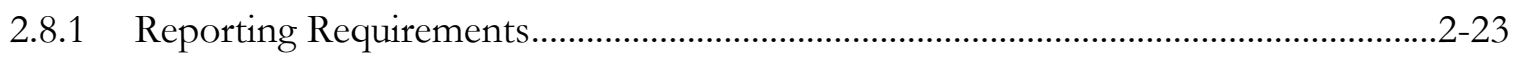

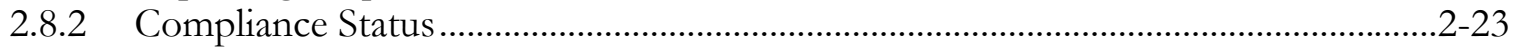

2.9 Conservation and Protection of Biota and Wildlife Habitat ..................................................2-24

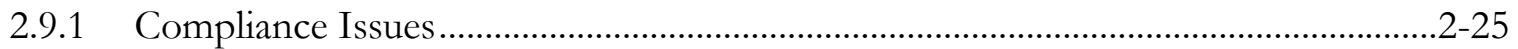

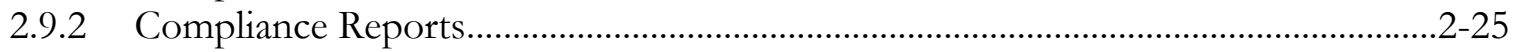

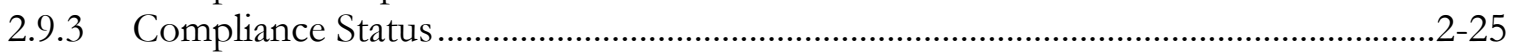

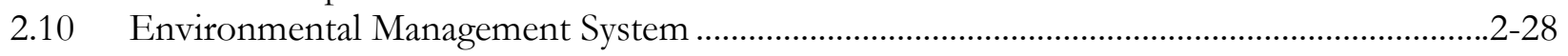

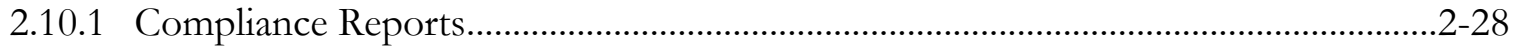

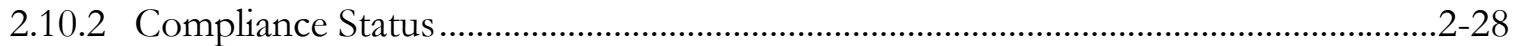

2.11 Occurrences, Unplanned Releases, and Continuous Releases ................................................2-29

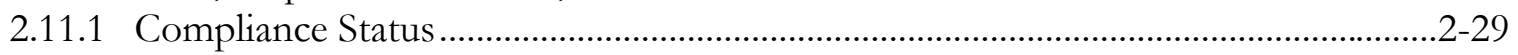

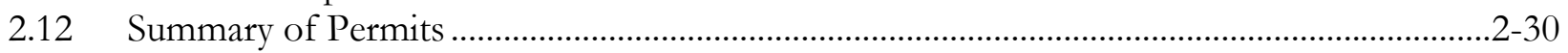

3.0 Radiological and Nonradiological Air Monitoring ......................................................................... 3-1

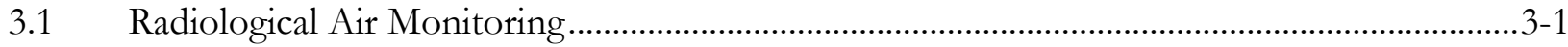

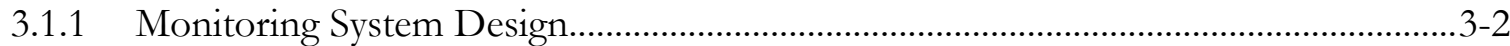

3.1.2 Air Particulate and Tritium Sampling Methods .............................................................

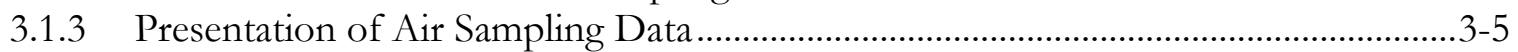

3.1.4 Air Sampling Results from Environmental Samplers ................................................. $3-5$

3.1.4.1 Americium-241 ....................................................................................

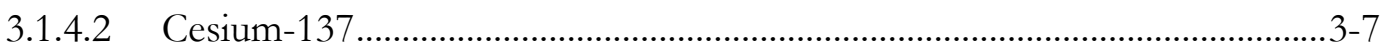

3.1.4.3 Plutonium Isotopes ................................................................................ $3-7$

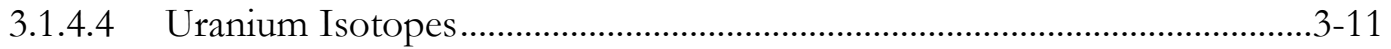

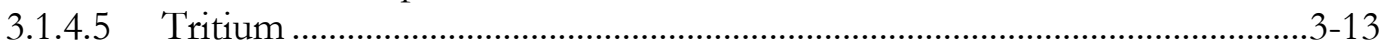

3.1.4.6 Gross Alpha and Gross Beta ................................................................... $3-16$

3.1.5 Air Sampling Results from Critical Receptor Samplers ............................................. 3-18

3.1.6 Air Sampling Results from Point-Source (Stack) Sampler .......................................... 3-19

3.1.7 Emission Evaluations for Planned Projects .................................................................

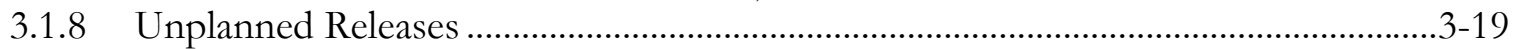

3.1.9 Total NTS Radiological Atmospheric Releases .............................................................19

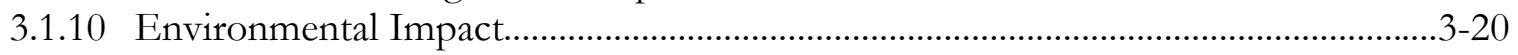

3.2 Nonradiological Air Quality Assessment .....................................................................................21

3.2.1 Emissions of Criteria Air Pollutants and Hazardous Air Pollutants ..........................3-22

3.2.2 Performance Emission Testing and State Inspection................................................. 3-24

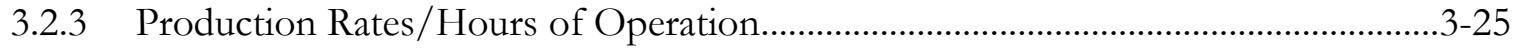

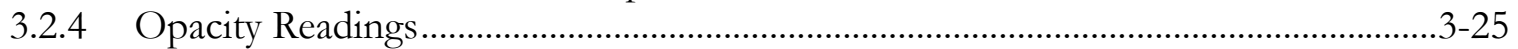

3.2.5 NPTEC and BEEF Reporting ............................................................................. $3-26$

3.2.6 Tactical Demilitarization Development (TaDD) Project Reporting .......................... $3-27$

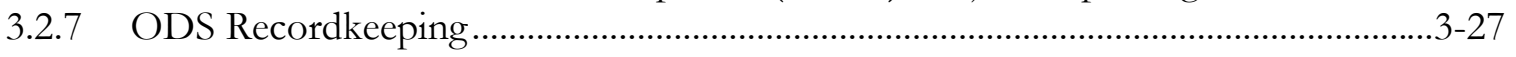

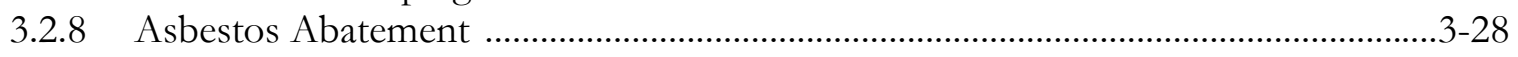

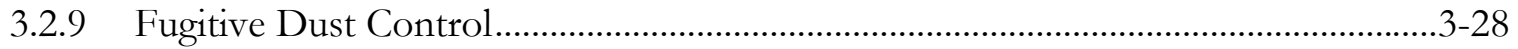

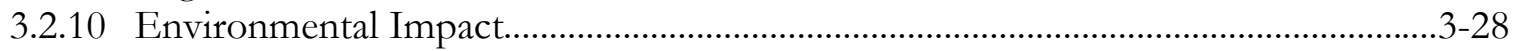

4.0 Radiological and Nonradiological Water Monitoring ......................................................................4-1

4.1 Radiological Surface Water and Groundwater Monitoring …...................................................4-1 


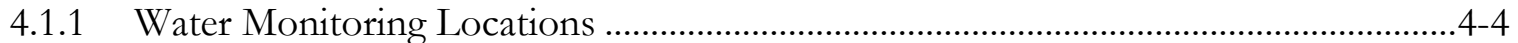

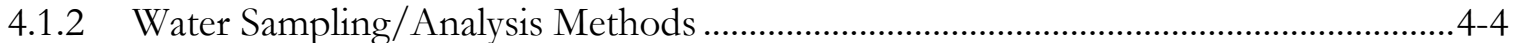

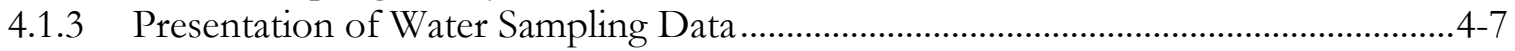

4.1.4 Results from Offsite Wells ........................................................................................

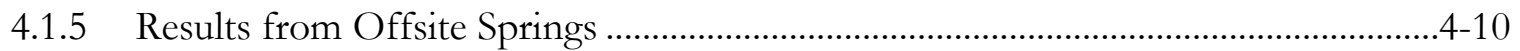

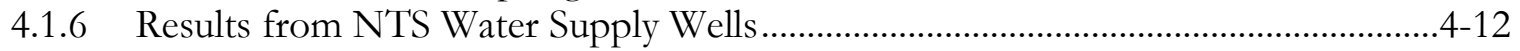

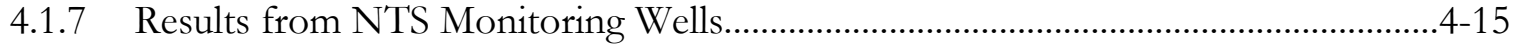

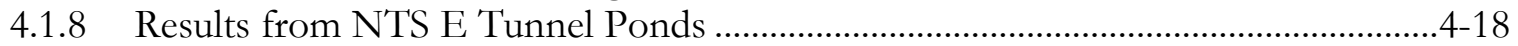

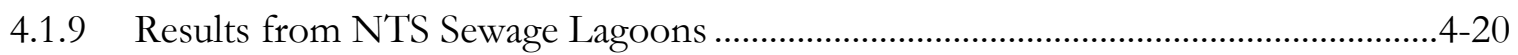

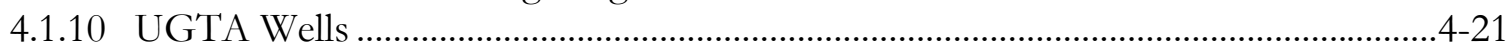

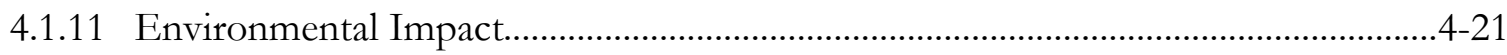

4.2 Nonradiological Drinking Water and Wastewater Monitoring .............................................4-23

4.2.1 Drinking Water Monitoring ............................................................................................. 4 -23

4.2.1.1 Water Quality of PWS and Permitted Water-Hauling Trucks...................4-23

4.2.1.2 Sanitary Survey of PWS and Inspection of Permitted

Water-Hauling Trucks ...................................................................................4-26

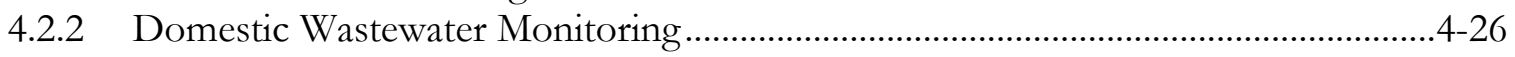

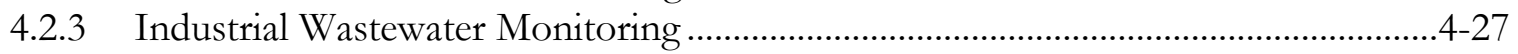

4.2.3.1 Quarterly Analysis of Influent Water Quality ..............................................4-27

4.2.3.2 Annual Analysis of Toxicity of Sewage Lagoon Pond Waters ...................4-29

4.2.3.3 Sewage System Inspections.........................................................................4-30

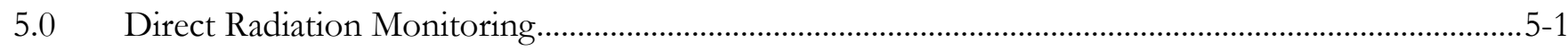

$5.1 \quad$ Measurement of Direct Radiation ....................................................................................... 5-1

5.2 Thermoluminescent Dosimetry (TLD) Surveillance Network Design....................................5-2

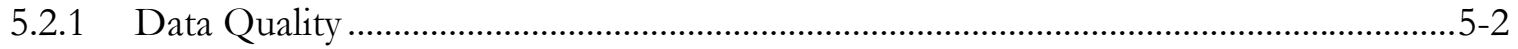

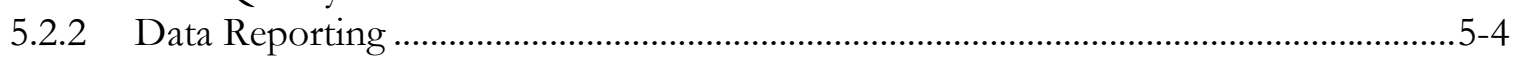

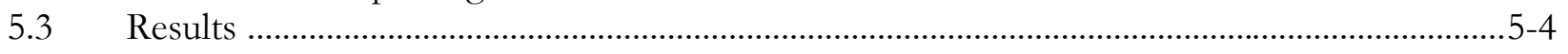

5.3.1 Potential Exposure to the Public along the NTS Boundary ........................................5-7

5.3.2 Exposure Rates at RWMSs ........................................................................................

5.3.3 Exposures from NTS Operational Activities............................................................. $5-9$

5.3.4 Exposure to NTS Plants and Animals ..........................................................................

5.3.5 Exposure Rate Patterns in the Environment over Time................................................5-9

Environmental Impact ........................................................................................................

6.0 Oversight Radiological Monitoring of Air and Water.....................................................................6-1

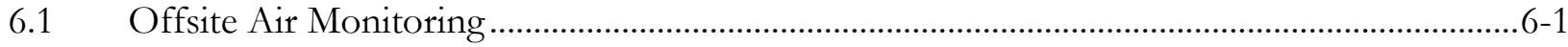

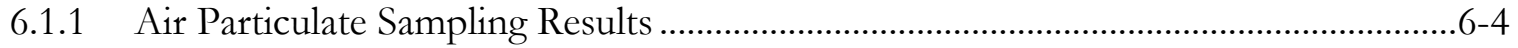

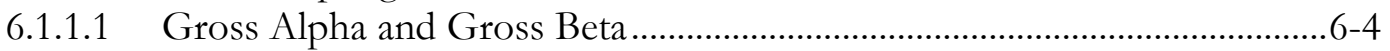

6.1.1.2 Gamma Spectroscopy ............................................................................

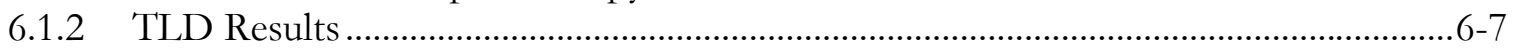

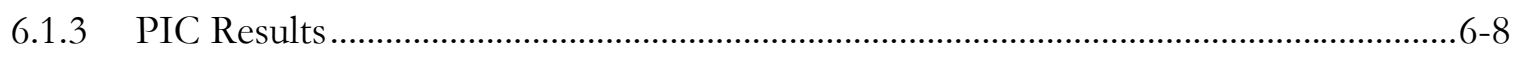

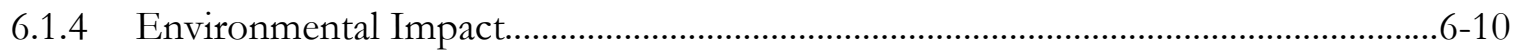

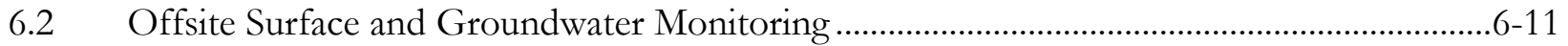

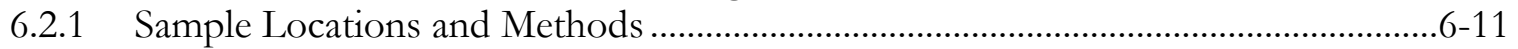

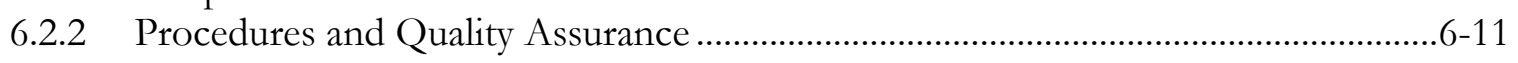

6.2.3 Results of Surface Water and Spring Discharge Monitoring ......................................6-14

6.2.4 Results of Groundwater Monitoring ............................................................................. $6-14$

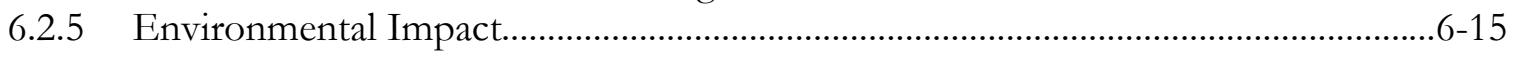




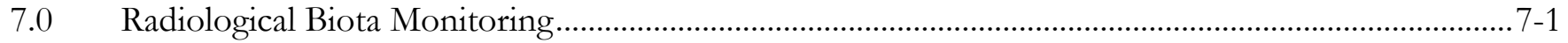

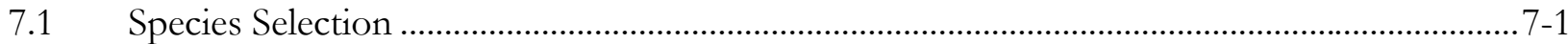

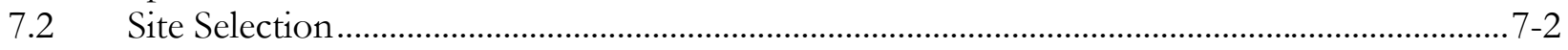

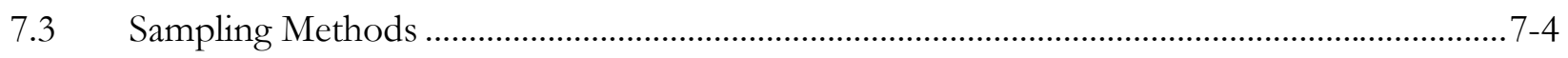

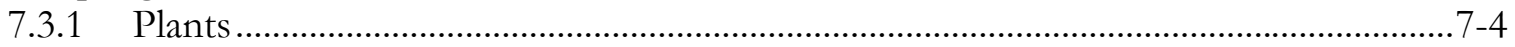

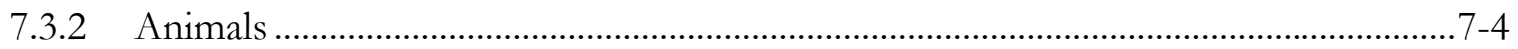

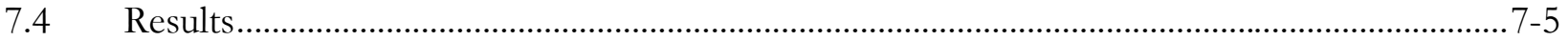

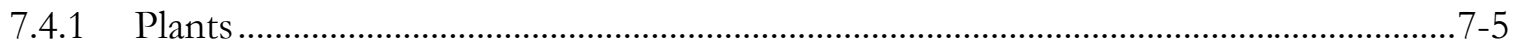

7.4.2 Animals ............................................................................................................

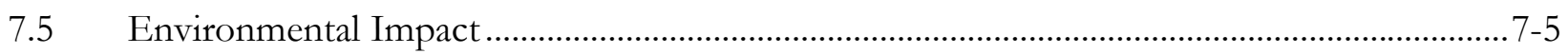

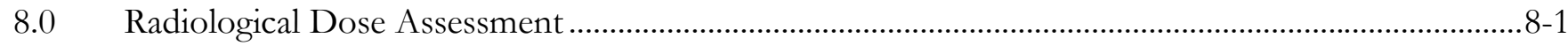

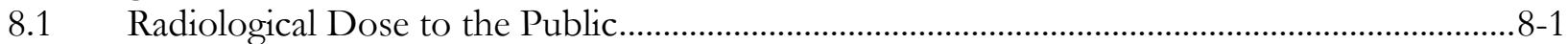

8.1.1 Possible Exposure Pathways to the Public .......................................................................

8.1.2 Dose to the Public from NTS Air Emissions .................................................................

8.1.3 Dose to the Public from Ingestion of Wild Game from the NTS...............................8-3

8.1.4 Dose to the Public from Drinking Contaminated Groundwater...................................8-4

8.1.5 Dose to the Public from Direct Radiation Exposure Along NTS Borders.................8-4

8.1.6 Dose to the Public from Release of Property Containing Residual

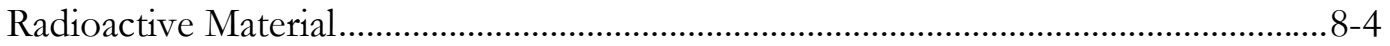

8.1.7 Total Offsite Dose to the Public from all Pathways .....................................................

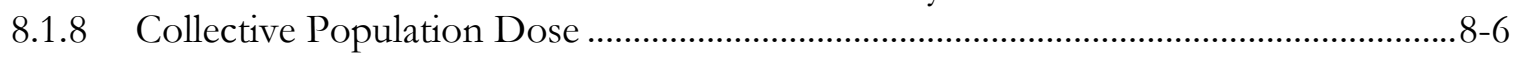

8.2 Dose to Aquatic and Terrestrial Biota ..................................................................................... $8-7$

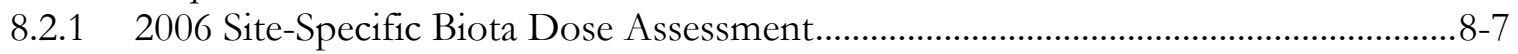

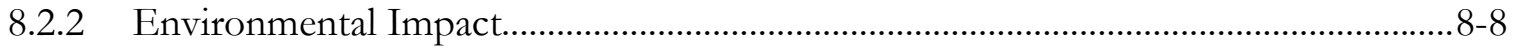

9.0 Waste Management and Environmental Restoration ......................................................................9-1

9.1 Radioactive Waste Management .........................................................................................

9.1.1 Maintenance of Key Documents ..................................................................................

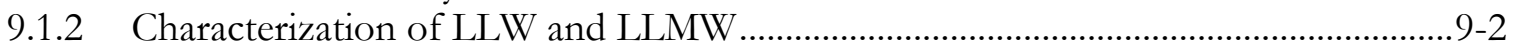

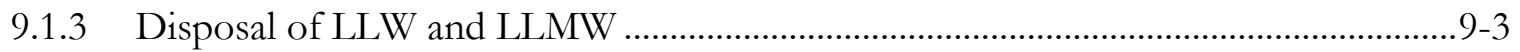

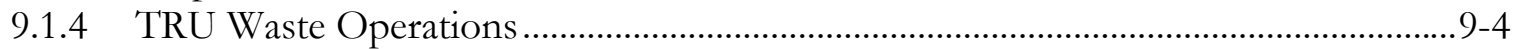

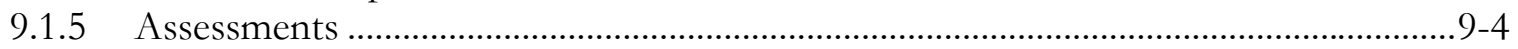

9.1.6 Groundwater Monitoring for Low-level Waste Pit P03U ............................................9-4

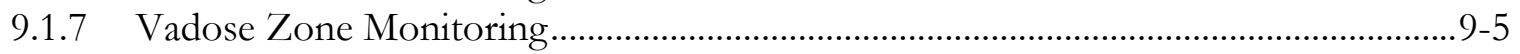

9.1.7.1 Area 3 RWMS Drainage Lysimeter Facility................................................... 9-5

9.1.7.2 Area 5 RWMS Weighing Lysimeter Facility .................................................... 9-5

9.1.7.3 RWMS Waste Cover Automated Monitoring ...............................................9-6

9.1.7.4 RWMS Supplemental Automated Monitoring...............................................9-6

9.1.7.5 Gas-phase Tritium Monitoring ..................................................................... 9-6

9.1.7.6 Radon Flux ............................................................................................ 9-6

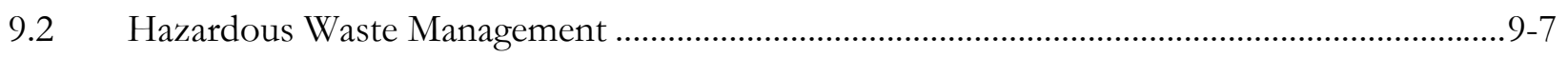

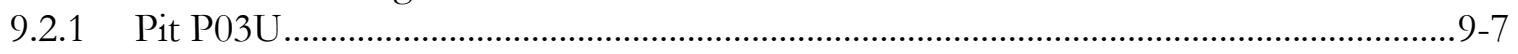

9.2.2 Hazardous Waste Storage Unit and Satellite Accumulation Areas ..............................9-7

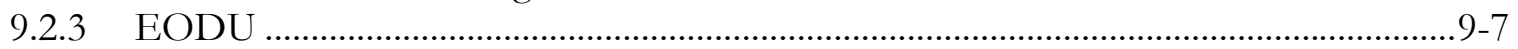

$9.3 \quad$ Underground Storage Tank (UST) Management .................................................................. $9-8$

9.4 Environmental Restoration - Remediation of Historic Contaminated Sites............................9-8

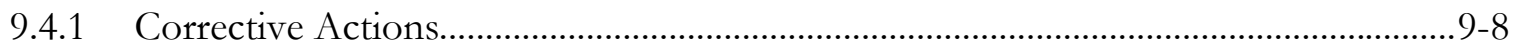

9.4.2 Post-Closure Monitoring and Inspections ......................................................................9-9 


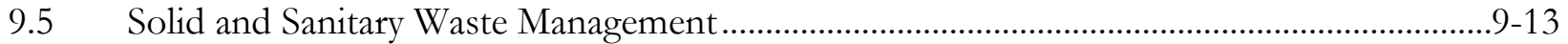

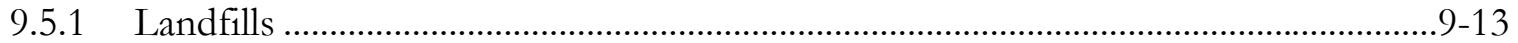

9.5.2 Sewage Lagoons..................................................................................................... 9.13

$10.0 \quad$ Hazardous Materials Control and Management .........................................................................10-1

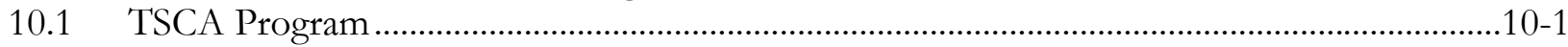

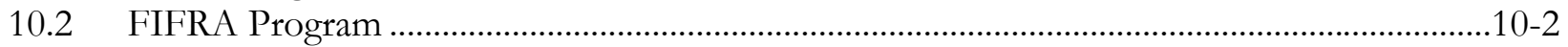

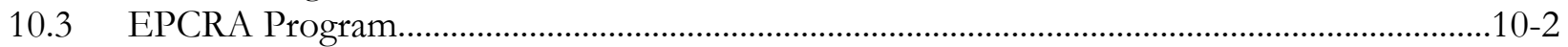

10.4 Nevada Chemical Catastrophe Prevention Act.......................................................................10-3

11.0 Pollution Prevention and Waste Minimization ..............................................................................11-1

$11.1 \quad$ P2/WM Goals and Components .................................................................................11-1

11.2 Major P2/WM Accomplishments and Awards ......................................................................11-2

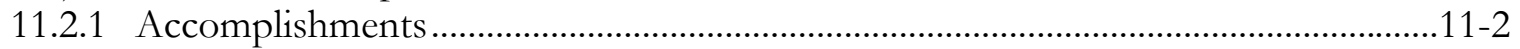

11.2.2 Award-winning Accomplishments.........................................................................11-2

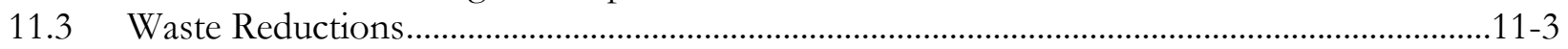

12.0 Historic Preservation and Cultural Resources Management...........................................................12-1

12.1 Cultural Resources Inventories, Historical Evaluations, and Associated Activities...............12-1

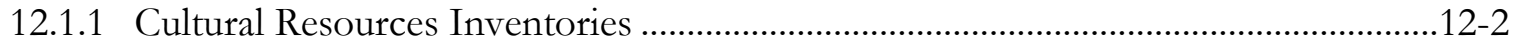

12.1.2 Evaluations of Historic Structures ............................................................................12-2

12.1.3 Associated Cultural Resources Activities................................................................12-3

12.1.3.1 Adverse Effect Assessments and Mitigation Activities ..............................12-3

12.1.3.2 General Reconnaissance/Archival Research............................................12-3

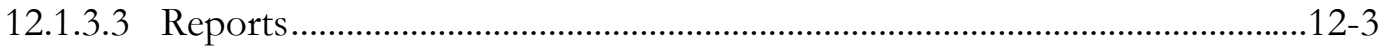

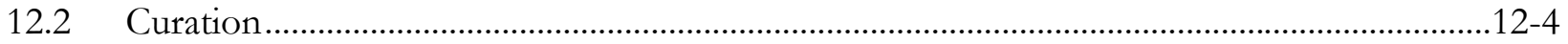

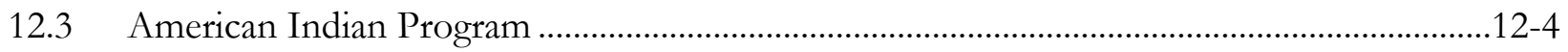

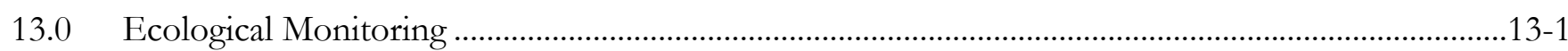

13.1 Desert Tortoise Compliance Program.............................................................................13-1

13.2 Biological Surveys at Proposed Project Sites ..................................................................13-3

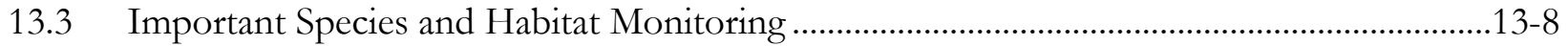

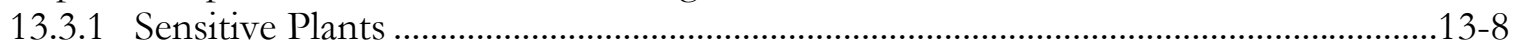

13.3.1.1 Frasera pabutensis ....................................................................................13-8

13.3.1.2 Hulsea vestita spp. inyoensis.................................................................. 13-10

13.3.1.3 Ivesia arizonica var. saxosa ....................................................................... 13-10

13.3.2 Important Animals ......................................................................................... 13-11

13.3.2.1 Western Red-tailed Skink .................................................................. 13-11

13.3.2.2 Western Burrowing Owl .................................................................. 13-11

13.3.2.3 Bird Monitoring and Mortality ................................................................. 13-11

13.3.2.4 State-Protected Small Mammals............................................................... 13-15

13.3.2.5 Sensitive Bats ............................................................................. 13-15

13.3.2.6 Wild Horses......................................................................................... 13-15

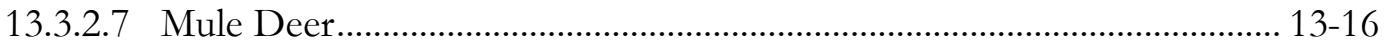

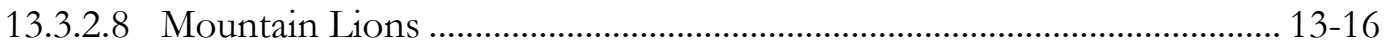

13.3.3 Natural and Man-Made Water Sources ................................................................ 13-16

13.3.4 West Nile Virus...................................................................................................... 13-17

13.4 Habitat Restoration Monitoring Program ................................................................... 13-17

13.4.1 Revegetated Project Sites ...................................................................................... 13-17 
13.4.2 Wildland Fire Sites ...................................................................................... 13-18

$13.5 \quad$ Wildland Fire Hazard Assessment........................................................................................ 13-18

13.6 Biological Monitoring of the NPTEC Complex ………………………………………….... 13-21

14.0 Underground Test Area Subproject.....................................................................................................14-1

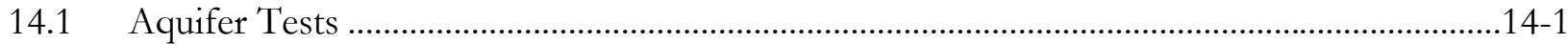

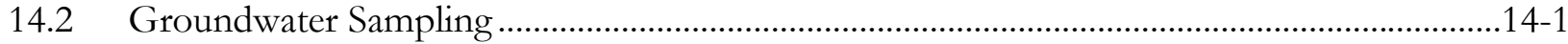

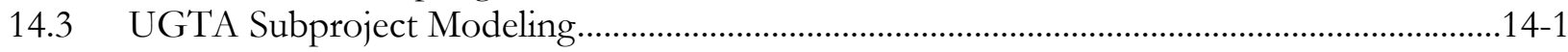

15.0 Hydrologic Resources Management Program.......................................................................................15-1

15.1 Program Goals and Activities ................................................................................................15-1

15.1.1 Hydrology and Radionuclide Investigations for Operations .......................................15-1

15.1.2 Long-Term Groundwater Stewardship....................................................................15-2

$15.2 \quad 2006$ Field Monitoring........................................................................................................15-2

15.2.1 Water Levels and Temperature …………………………………………………....15-2

15.2.2 Water Usage …………………………………………………………………....15-3

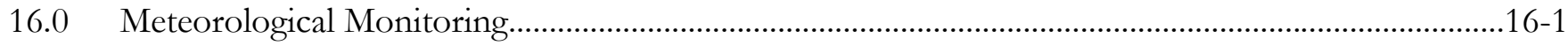

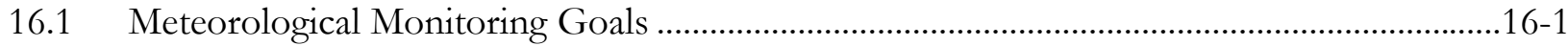

16.2 MEDA Station Locations ……………………………………………………………….....16-1

16.3 MEDA Station Instrumentation..........................................................................................16-1

16.4 Rain Gauge Network .....................................................................................................16-3

16.5 Data Access......................................................................................................................

17.0 Integrated Safety Management System and Environmental Management System .............................17-1

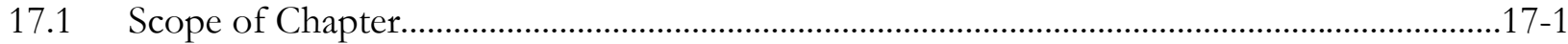

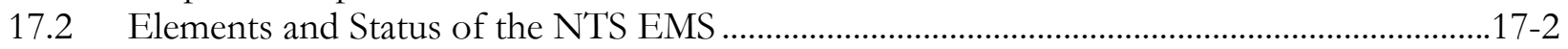

17.2.1 NTS Environmental Policy........................................................................................17-2

17.2.2 Environmental Aspects .............................................................................................17-2

17.2.3 Legal and Other Requirements ...............................................................................17-3

17.2.4 Objectives, Targets, and Programs ………………………………………………....17-3

17.2.5 Resources, Roles, Responsibilities, and Authorities.................................................17-6

17.2.6 Competence, Training, and Awareness...…………………………………………....17-6

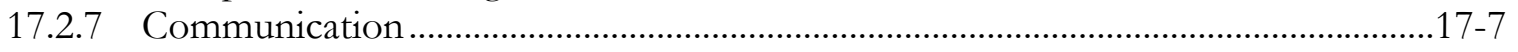

17.2.8 Documentation....................................................................................................17-7

17.2.9 Control of Documents ................................................................................................17-7

17.2.10 Operational Control..................................................................................................17-7

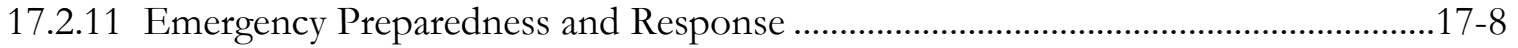

17.2.12 Monitoring and Measurement...............................................................................17-8

17.2.13 Evaluation of Compliance ..........................................................................................17-8

17.2.14 Nonconformity and Corrective and Preventive Actions ..........................................17-8

17.2.15 Control of Records ............................................................................................17-8

17.2.16 Internal Audit ....................................................................................................17-9

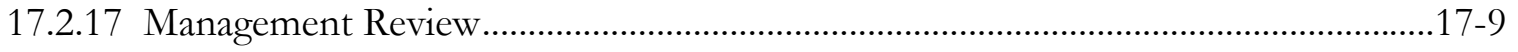

$18.0 \quad$ Compliance Quality Assurance...............................................................................................18-1

$18.1 \quad$ Sampling and Analysis Plan................................................................................................18-2

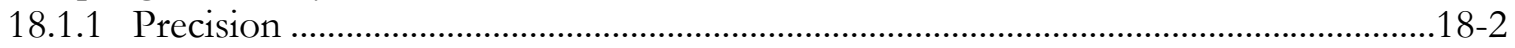

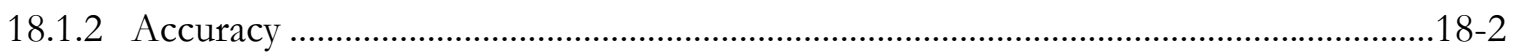




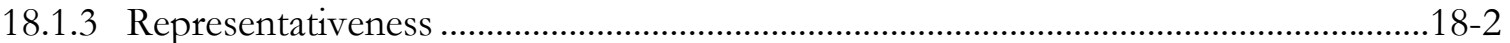

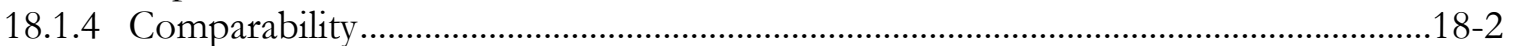

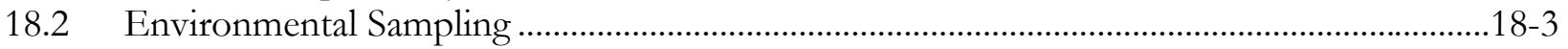

18.2.1 Training and Qualification .....................................................................................18-3

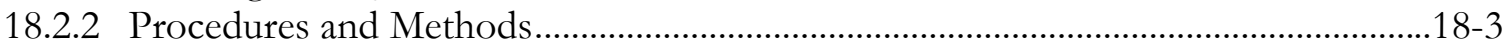

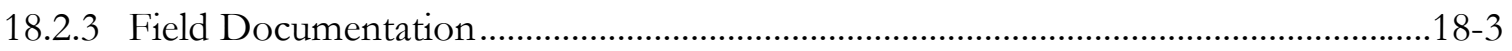

18.2.4 Inspection and Acceptance Testing........................................................................18-3

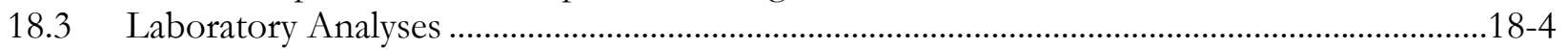

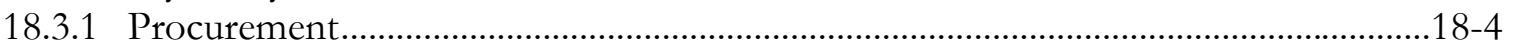

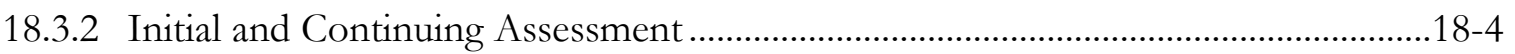

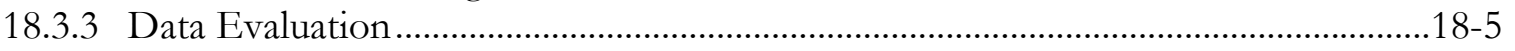

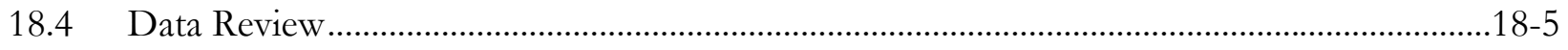

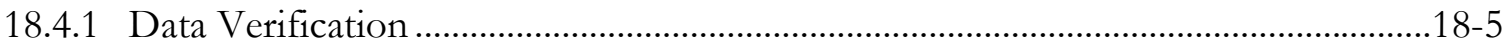

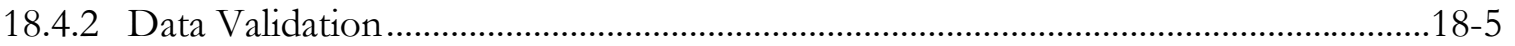

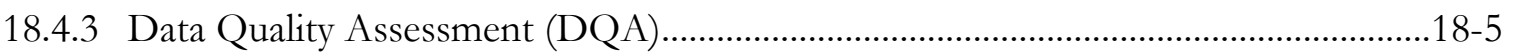

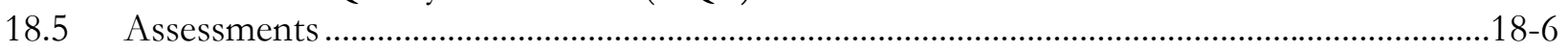

18.5.1 Programmatic ....................................................................................................18-6

18.5.2 Measurement Data ..............................................................................................18-6

18.5.2.1 Field Duplicates ...................................................................................18-6

18.5.2.2 Laboratory Control Samples (LCSs) ............................................................18-8

18.5.2.3 Blank Analysis...................................................................................18-8

18.5.2.4 Proficiency Testing Program Participation..................................................18-9

19.0 Oversight Quality Assurance Program for the Community Environmental

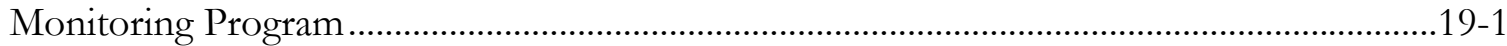

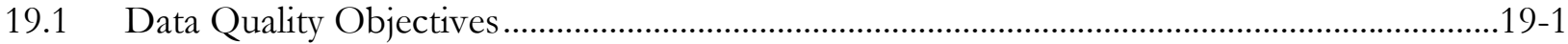

19.2 Measurement Quality Objectives (MQOs) …..........................................................................19-1

19.3 Sampling Quality Assurance Program …............................................................................19-1

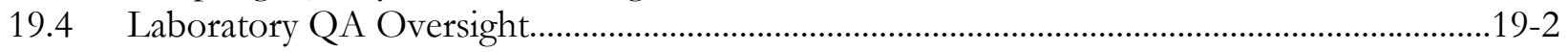

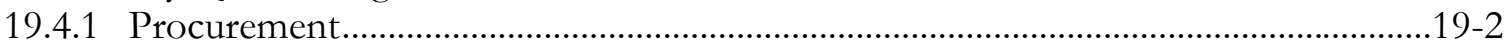

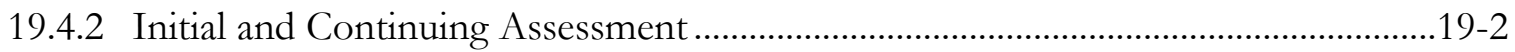

19.4.3 Laboratory QA Program ........................................................................................19-3

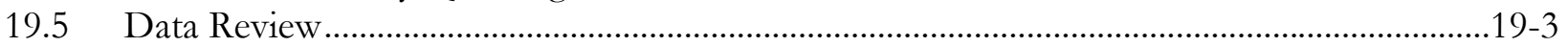

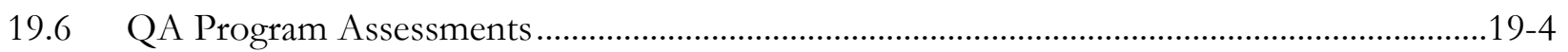

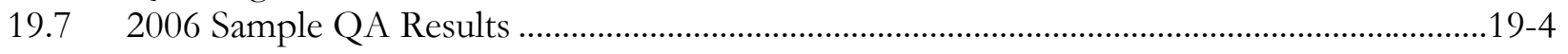

19.7.1 Field Duplicates (Precision) .......................................................................................19-4

19.7.2 Laboratory Control Samples (LCSs) (Accuracy) .........................................................19-5

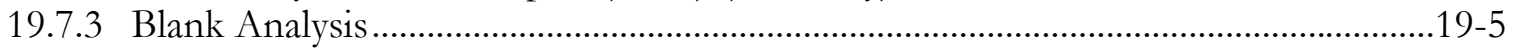

19.7.4 Inter-laboratory Comparison Studies .................................................................19-5

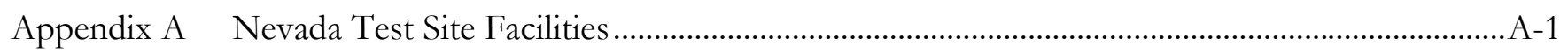

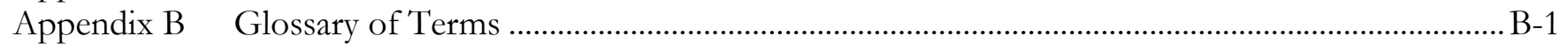

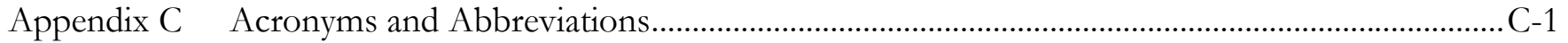

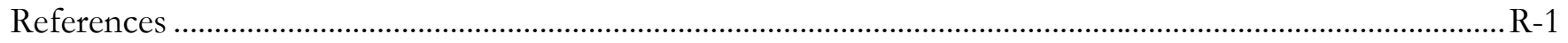

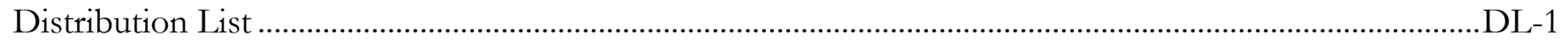




\section{List of Figures}

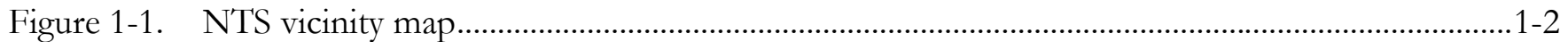

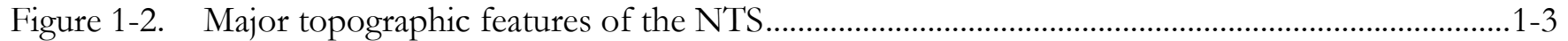

Figure 1-3. NTS operational areas, principal facilities, and past nuclear testing areas ..................................1-6

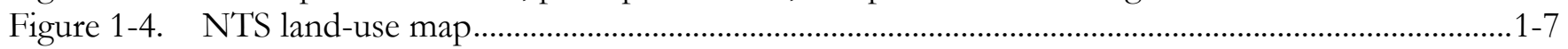

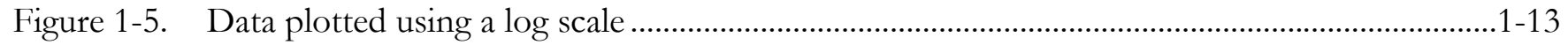

Figure 1-6. Data plotted using a linear scale ..........................................................................................1-13

Figure 3-1. Radiological air sampling network on the NTS in 2006.....................................................3-3

Figure 3-2. Concentrations of ${ }^{241} \mathrm{Am}$ in air samples collected in 2006 ......................................................3-6

Figure 3-3. Concentrations of ${ }^{238} \mathrm{Pu}$ in air samples collected in 2006 ...........................................................3-8

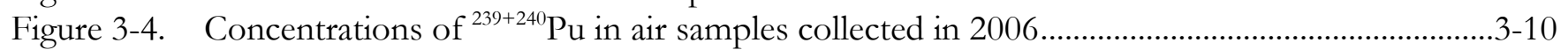

Figure 3-5. Long-term trends in average annual mean ${ }^{239+240} \mathrm{Pu}$ for NTS area groups ...............................3-10

Figure 3-6. Fitted average long-term trends in ${ }^{239+240} \mathrm{Pu}$ mean values by NTS area groups........................3-11

Figure 3-7. Concentrations of tritium in air samples collected in 2006 and Pahute Mesa

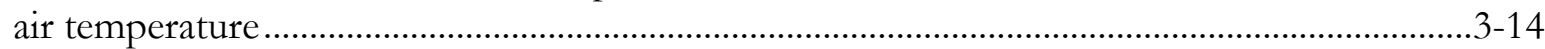

Figure 3-8. Concentrations of tritium in air samples collected in 2006 and Pahute Mesa

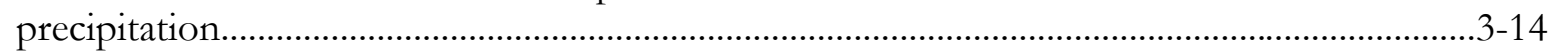

Figure 3-9. Average long-term trends in tritium at locations having at least 7 years of data .....................3-15

Figure 3-10. Tritium emissions at Schooner and June-September average temperatures at

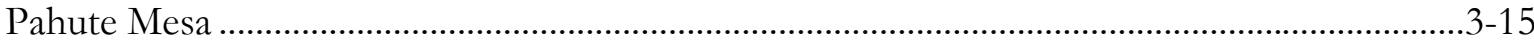

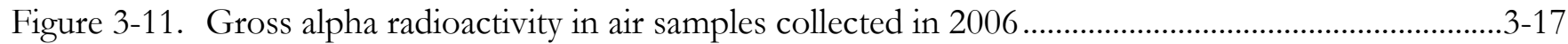

Figure 3-12. Gross beta radioactivity in air samples collected in 2006 ......................................................3-18

Figure 3-13. Criteria air pollutants released on the NTS since 1996 ............................................................3-24

Figure 4-1. Areas of potential groundwater contamination on the NTS .................................................4-2

Figure 4-2. RREMP well monitoring locations sampled on and off the NTS in 2006 ...............................4-5

Figure 4-3. RREMP spring and surface water monitoring locations sampled on and off the

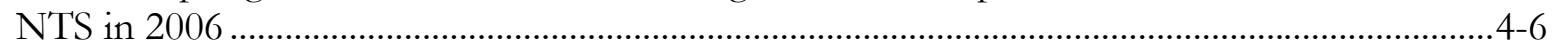

Figure 4-4. Gross alpha and gross beta levels in offsite wells from 2000 to 2006......................................4-9

Figure 4-5. Tritium concentrations in offsite wells from 2000 to 2006 ....................................................... 4-9

Figure 4-6. Gross alpha and gross beta levels in offsite springs from 2000 to 2006 ................................4-11

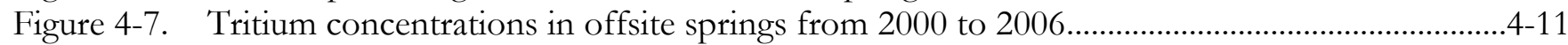

Figure 4-8. Gross alpha and gross beta levels in NTS potable water supply wells from

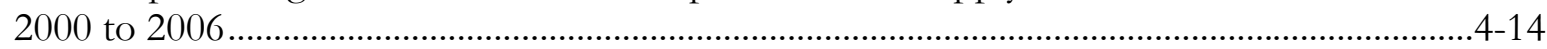

Figure 4-9. Tritium concentrations in NTS potable water supply wells from 2000 to 2006......................4-14

Figure 4-10. Concentrations of tritium in wells with a history of detectable levels ......................................4-17

Figure 4-11. Tritium concentration in E Tunnel Ponds from 1995 to 2006 .................................................4-20

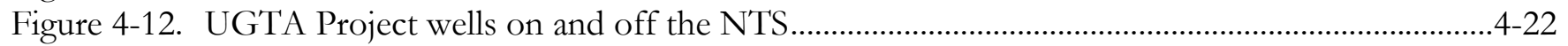

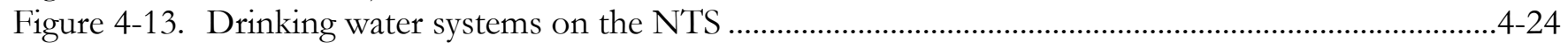

Figure 4-14. Active permitted sewage disposal systems on the NTS ...........................................................4-28

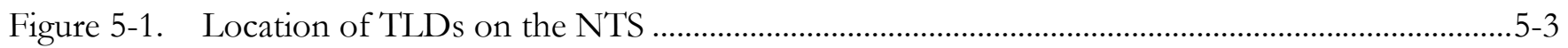

Figure 5-2. 2006 annual exposure rates in and around Area 3 RWMS and at background locations..........5-8

Figure 5-3. 2006 annual exposure rates around Area 5 RWMS and at background locations.....................5-8

Figure 5-4. 2006 annual exposure rates on the NTS by location type and off the NTS

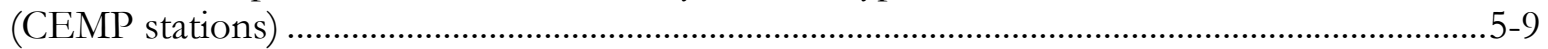

Figure 5-5. Trend in direct radiation exposure measured at TLD locations ..............................................5-10 


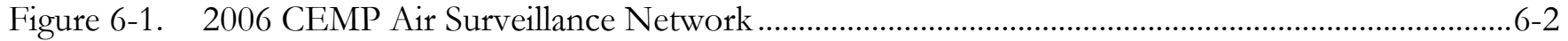

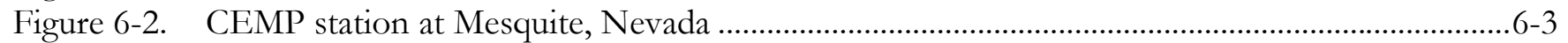

Figure 6-3. Historical trend for gross alpha analysis for all CEMP stations ...............................................6-5

Figure 6-4. Historical trend for gross beta analysis for all CEMP stations ..................................................6-6

Figure 6-5. Historical trend for TLD analysis for all CEMP stations...........................................................6-8

Figure 6-6. The effect of meteorological phenomena on background gamma readings ............................6-10

Figure 6-7. 2006 CEMP water monitoring locations ....................................................................................6-13

Figure 7-1. Radiological biota monitoring sites on the NTS and sites sampled in 2006 ............................7-3

Figure 7-2. Concentrations of man-made radionuclides in plants from T2, 2002 and 2006......................7-8

Figure 7-3. Concentrations of man-made radionuclides in animals from T2, 2002 and 2006....................7-8

Figure 8-1. Estimated radiation dose from NTS air emissions to the offsite MEI from 1992 to 2004.

Figure 8-2. Comparison of radiation dose to the MEI and the natural radiation background

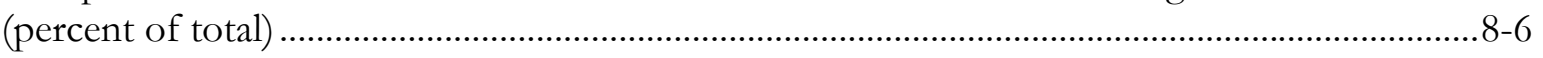

Figure 8-3. Collective population dose within $80 \mathrm{~km}$ of NTS emission sources from 1992 to 2004 ......

Figure 13-1. Desert tortoise distribution and abundance on the NTS .

Figure 13-2. Location of biological surveys conducted on the NTS in 2006 13-7

Figure 13-3. Location of sensitive plant populations monitored on the NTS in 2006

Figure 13-4. H. vestita spp. inyoensis on road cut along Stockade Wash Road...

Figure 13-5. I. arizonica var. saxosa growing on north and west faces of large boulders on Pahute Mesa

Figure 13-6. Western red-tailed skink captured at Twin Spring, Site 9. 13-11

Figure 13-7. Captured western burrowing owl. $13-11$

Figure 13-8. Locations where western red-tailed skinks have been trapped and sites sampled in 2006

Figure 13-9. Known western burrowing owl distribution on the NTS and locations trapped in 2006

Figure 13-10. Number of bird deaths recorded on the NTS by year and cause. $13-14$

Figure 13-11. Mountain lion photographed at Tub Spring 13-16

Figure 13-12. Location of wildland fires on the NTS. 13-19

Figure 13-13. Index of combined fine and woody fuels at 211 survey stations on the NTS during 2006.

Figure 14-1. Location of UGTA Project model areas. 14-3

Figure 16-1. Example of a typical MEDA station with a10-meter tower .....................................................16-1

Figure 16-2. MEDA station locations on and near the NTS .................................................................16-2

Figure 16-3. Climatological rain gauge network on the NTS ....................................................................16-4 


\section{List of Tables}

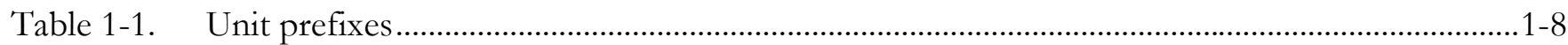

Table 1-2. Units of radioactivity...................................................................................................

Table 1-3. Units of radiological dose...................................................................................................

Table 1-4. Conversion table for SI units.................................................................................................

Table 1-5. Radionuclides and their half-lives .........................................................................................1-10

Table 1-6. Metric and U.S. customary unit equivalents ...........................................................................1-11

Table 2-1. NTS compliance status with applicable air quality regulations......................................................2-4

Table 2-2. NTS compliance status with applicable water quality and protection regulations.......................2-8

Table 2-3. NTS compliance status with regulations for radiation protection of the public and the environment..............................................................................................................2-11

Table 2-4. NTS compliance status with applicable waste management and environmental restoration regulations .......................................................................................................2-14

Table 2-5. NTS compliance status with applicable regulations for hazardous substance control and management.............................................................................................................2-18

Table 2-6. NTS NEPA compliance activities conducted in 2006 ...............................................................2-19

Table 2-7. NTS compliance status with applicable pollution prevention/waste minimization

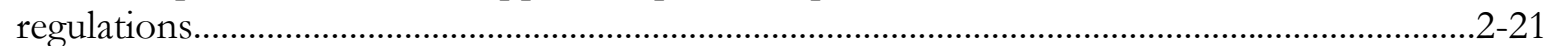

Table 2-8. NTS compliance status with historic preservation regulations ..................................................2-23

Table 2-9. NTS compliance status with applicable biota and wildlife habitat regulations ..........................2-26

Table 2-10. NTS compliance status with Environmental Management System regulations ........................2-28

Table 2-11. Environmental permits required for NTS and NTS site facility operations ............................2-30

Table 3-1. Regulatory concentration limits for radionuclides in air............................................................... 3-4

Table 3-2. Concentrations of ${ }^{241} \mathrm{Am}$ in air samples collected in 2006 ..........................................................3-6

Table 3-3. Concentrations of ${ }^{137} \mathrm{Cs}$ in air samples collected in 2006 ........................................................

Table 3-4. Concentrations of ${ }^{238} \mathrm{Pu}$ in air samples collected in 2006 ............................................................ $3-8$

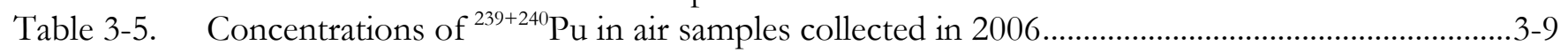

Table 3-6. Concentrations of uranium isotopes in air samples collected in 2006 .....................................3-11

Table 3-7. Observed values of uranium isotope ratios................................................................................ $3-12$

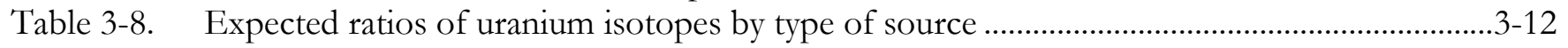

Table 3-9. Concentrations of tritium in air samples collected in 2006......................................................3-13

Table 3-10. Gross alpha radioactivity in air samples collected in 2006 .......................................................3-16

Table 3-11. Gross beta radioactivity in air samples collected in 2006 .........................................................3-17

Table 3-12. Sum of percents of compliance levels for radionuclides detected at critical receptor

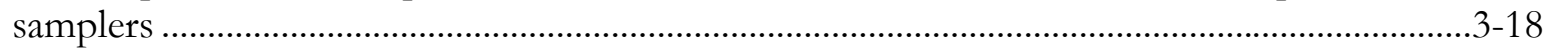

Table 3-13. Radiological atmospheric releases from NTS for 2006 ............................................................3-20

Table 3-14. Tons of criteria air pollutant emissions released on the NTS from permitted

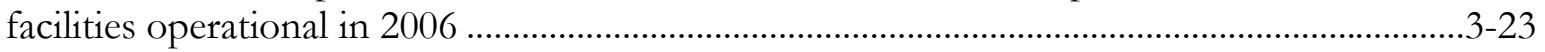

Table 3-15. Criteria air pollutants and HAPS released on the NTS since 1996 ...........................................3-24

Table 3-16. Performance emission testing, state inspection, and/or corrective actions taken in 2006......3-25

Table 3-17. Chemicals released during tests conducted at the Area 5 NPTEC in 2006..............................3-26

Table 3-18. Chemicals released during tests conducted at the Port Gaston facility in 2006.........................3-27

Table 3-19. Types and weights of explosives detonated at BEEF in 2006...................................................3-27

Table 4-1. Gross alpha, gross beta, and tritium analysis results for offsite wells in 2006 ..........................4-8 Table 4-2. Gross alpha, gross beta, and tritium analysis results for offsite springs in 2006......................4-10 
Table 4-3. Gross alpha, gross beta, and tritium analysis results for NTS potable water supply wells in 2006 .

Table 4-4. Gross alpha, gross beta, and tritium analysis results for NTS monitoring wells in 2006 ........4-16

Table 4-5. Radiological results for E Tunnel Pond effluent pertaining to Water Pollution

Control Permit NEV 96021 ...............................................................................................4-18

Table 4-6. $\quad$ Routine radiological water monitoring results for E-Tunnel Ponds in 2006 ..........................4-19

Table 4-7. Tritium water monitoring results for NTS sewage lagoons in 2006 ....................................4-20

Table 4-8. Radiochemistry analysis results from UGTA well samples analyzed in 2006 .........................4-21

Table 4-9. Water quality monitoring parameters and sampling design for NTS public drinking

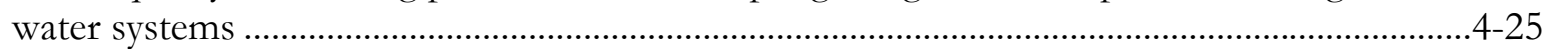

Table 4-10. Water quality analysis results for NTS public drinking water systems in 2006 .......................4-26

Table 4-11. Water quality analysis results for NTS sewage lagoon influent waters in 2006........................4-29

Table 4-12. Water toxicity analysis results for NTS sewage lagoon pond water in 2006 ...........................4-29

Table 5-1. Annual direct radiation exposure rates measured at TLD locations on

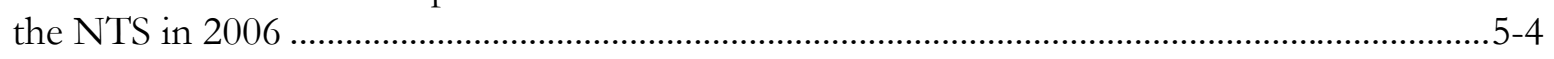

Table 5-2. Summary statistics for 2006 annual direct radiation exposure by TLD

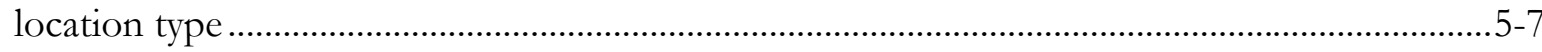

Table 6-1. Gross alpha results for the CEMP offsite ASN in 2006 ..........................................................6-4

Table 6-2. Gross beta results for the CEMP offsite ASN in 2006 .............................................................6-5

Table 6-3. TLD monitoring results for the CEMP offsite ASN in 2006 ......................................................

Table 6-4. PIC monitoring results for the CEMP offsite ASN in 2006....................................................6-9

Table 6-5. Average natural background radiation for selected U.S. cities (excluding radon) ....................6-10

Table 6-6. CEMP water monitoring locations sampled in 2006 ...............................................................6-12

Table 6-7. Tritium results for CEMP offsite surface water and spring discharges in 2006 ......................6-14

Table 6-8. Tritium results for CEMP offsite wells 2006 ............................................................................6-15

Table 7-1. Plant species sampled at T2 and the T2 control site in 2006 .................................................. $7-4$

Table 7-2. Concentrations of man-made radionuclides in plants from T2 and the T2 control

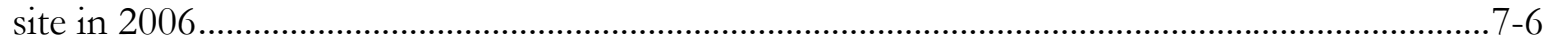

Table 7-3. Concentrations of man-made radionuclides in animals from T2 and the T2 control

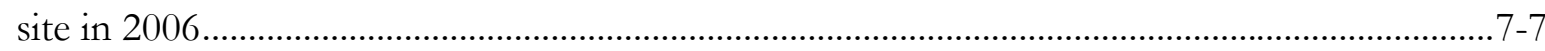

Table 8-1. Hypothetical annual dose to a human consuming NTS jackrabbits based on 2006 samples ...8-3

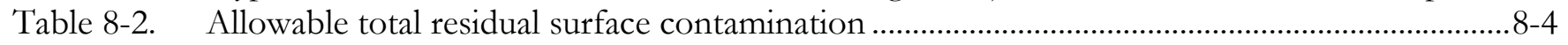

Table 8-3. Estimated radiological dose to the general public from 2006 NTS operations .........................8-5

Table 8-4. Site-specific dose assessment for terrestrial plants and animals sampled at T2 in 2006...........8-8

Table 9-1. Key documents required for Area 3 RWMS and Area 5 RWMS operations ............................9-2

Table 9-2. Results of groundwater monitoring of UE5 PW-1, UE5 PW-2, and UE PW-3 in 2006 ..........9-4

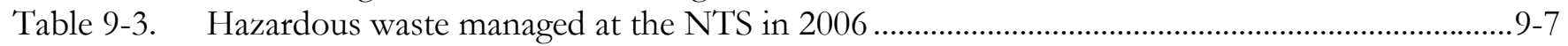

Table 9-4. Environmental restoration activities conducted in 2006 ..........................................................9-10

Table 9-5. Quantity of solid wastes disposed in NTS landfills in calendar year 2006..............................9-13

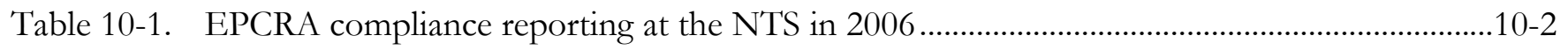

Table 10-2. EPCRA reportable releases of toxic chemicals in 2006 ............................................................10-3 
Table 11-1. Waste reduction through P2/WM activities by year...........................................................11-3

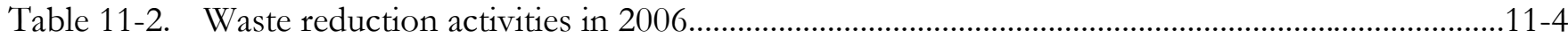

Table 12-1. Summary data for cultural resources inventories and historical evaluations

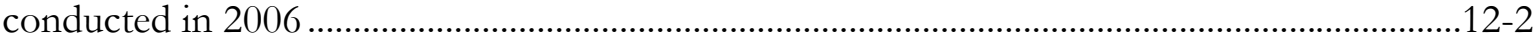

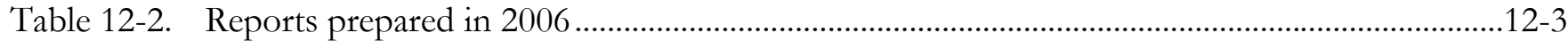

Table 12-3. Culturally affiliated tribes and organizations in the CGTO ...................................................12-5

Table 13-1. Compliance limits and status for NTS operations in tortoise habitat .....................................13-3

Table 13-2. Important plants which are known to occur on or adjacent to the NTS ................................13-4

Table 13-3. Important animals which are known to occur on or adjacent to the NTS..............................13-5

Table 13-4. Records of bird mortality and injury on the NTS in 2006 ................................................... 13-14

Table 13-5. Number of individual horses observed on the NTS by age class, gender, and year

Table 13-6. Comparison of plant density and cover at revegetated sites versus plant density and cover at their reference undisturbed sites as measured in 2006 ..................................... 13-17

Table 13-7. Precipitation history and presence of top species contributing to fine fuels........................ 13-18

Table 17-1. 2006 EMS objectives and targets ..............................................................................................17-5

Table 18-1. Summary of field duplicate samples for compliance monitoring in 2006...............................18-7

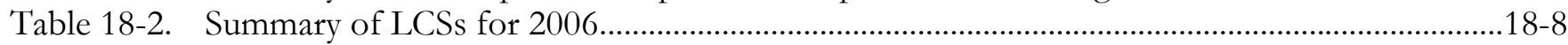

Table 18-3. Summary of laboratory blank samples for 2006 ...................................................................18-9

Table 18-4. Summary of 2006 radiological MAPEP reports ....................................................................... 18-10

Table 18-5. Summary of inter-laboratory comparison TLD samples for the subcontract dosimetry group in 2006 .......................................................................................................... 18-10

Table 19-1. Summary of field duplicate samples for oversight monitoring in 2006 ..................................19-4

Table 19-2. Summary of LCSs for oversight monitoring in 2006 ............................................................19-5

Table 19-3. Summary of laboratory blank samples for oversight monitoring in 2006 ............................19-5

Table 19-4. Summary of inter-laboratory comparison samples of the subcontract radiochemistry laboratory for oversight monitoring in 2006

Table 19-5. Summary of inter-laboratory comparison TLD samples of the subcontract dosimetry group for oversight monitoring in 2006 ...... 


\subsection{Introduction and Helpful Information}

\subsection{Site Location}

The U.S. Department of Energy, National Nuclear Security Administration Nevada Site Office (NNSA/NSO) directs the management and operation of the Nevada Test Site (NTS) which is located in Nye County in south-central Nevada (Figure 1-1). The southeast corner of the NTS is about 88 kilometers $(\mathrm{km})(55$ miles [mi]) northwest of the center of Las Vegas in Clark County. By highway, it is about $105 \mathrm{~km}$ (65 mi) from the center of Las Vegas to Mercury. Mercury, located at the southern end of the NTS, is the main base camp for worker housing and administrative operations for the NTS.

The NTS encompasses about 3,561 square kilometers $\left(\mathrm{km}^{2}\right)(1,375$ square miles [mi']). It varies from 46 to $56 \mathrm{~km}$ ( 28 to $35 \mathrm{mi}$ ) in width from west to east and from 64 to $88 \mathrm{~km}$ (40 to $55 \mathrm{mi})$ from north to south. The NTS is surrounded on all sides by federal lands (Figure 1-1). It is bordered on the southwest corner by the Yucca Mountain Project Area, on the west and north by the Nevada Test and Training Range (NTTR), on the east by an area used by both the NTTR and the Desert National Wildlife Range, and on the south by Bureau of Land Management lands. The combination of the NTTR and the NTS represents one of the larger unpopulated land areas in the United States, comprising some $14,200 \mathrm{~km}^{2}\left(5,470 \mathrm{mi}^{2}\right)$.

\subsection{Environmental Setting}

The NTS is located in the southern part of the Great Basin, the northern-most sub-province of the Basin and Range Physiographic Province. The NTS terrain is typical of much of the Basin and Range Physiographic Province, characterized by generally north-south trending mountain ranges and intervening valleys. These mountain ranges and valleys, however, are modified on the NTS by very large volcanic calderas (Figure 1-2).

The principal valleys within the NTS are Frenchman Flat, Yucca Flat, and Jackass Flats (Figure 1-2). Both Yucca and Frenchman Flat are topographically closed and contain dry lake beds, or playas, at their lowest elevations. Jackass Flats is topographically open, and surface water from this basin flows off the NTS via the Fortymile Wash. The dominant highlands of the NTS are Pahute Mesa and Rainier Mesa (high volcanic plateaus), Timber Mountain (a resurgent dome of the Timber Mountain caldera complex), and Shoshone Mountain. In general, the slopes of the highland areas are steep and dissected, and the slopes in the lowland areas are gentle and less eroded. The lowest elevation on the NTS is 823 meters $(\mathrm{m})$ (2,700 feet [ft]) in Jackass Flats in the southeast, and the highest elevation is $2,341 \mathrm{~m}(7,680 \mathrm{ft})$ on Rainier Mesa in the north-central region.

The topography of the NTS has been altered by historic U.S. Department of Energy (DOE) actions, particularly underground nuclear testing. The principal effect of testing has been the creation of numerous collapse sinks ("craters") in Yucca Flat basin and a lesser number of "craters" on Pahute and Rainier Mesas. Shallow detonations were also performed during Project Plowshare to determine the potential uses of nuclear devices for large-scale excavation.

The reader is directed to Attachment A: Nevada Test Site Description, included as a separate file on the compact disc of this 2006 report, where the geology, hydrology, climatology, ecology, and cultural resources of the NTS are described. 


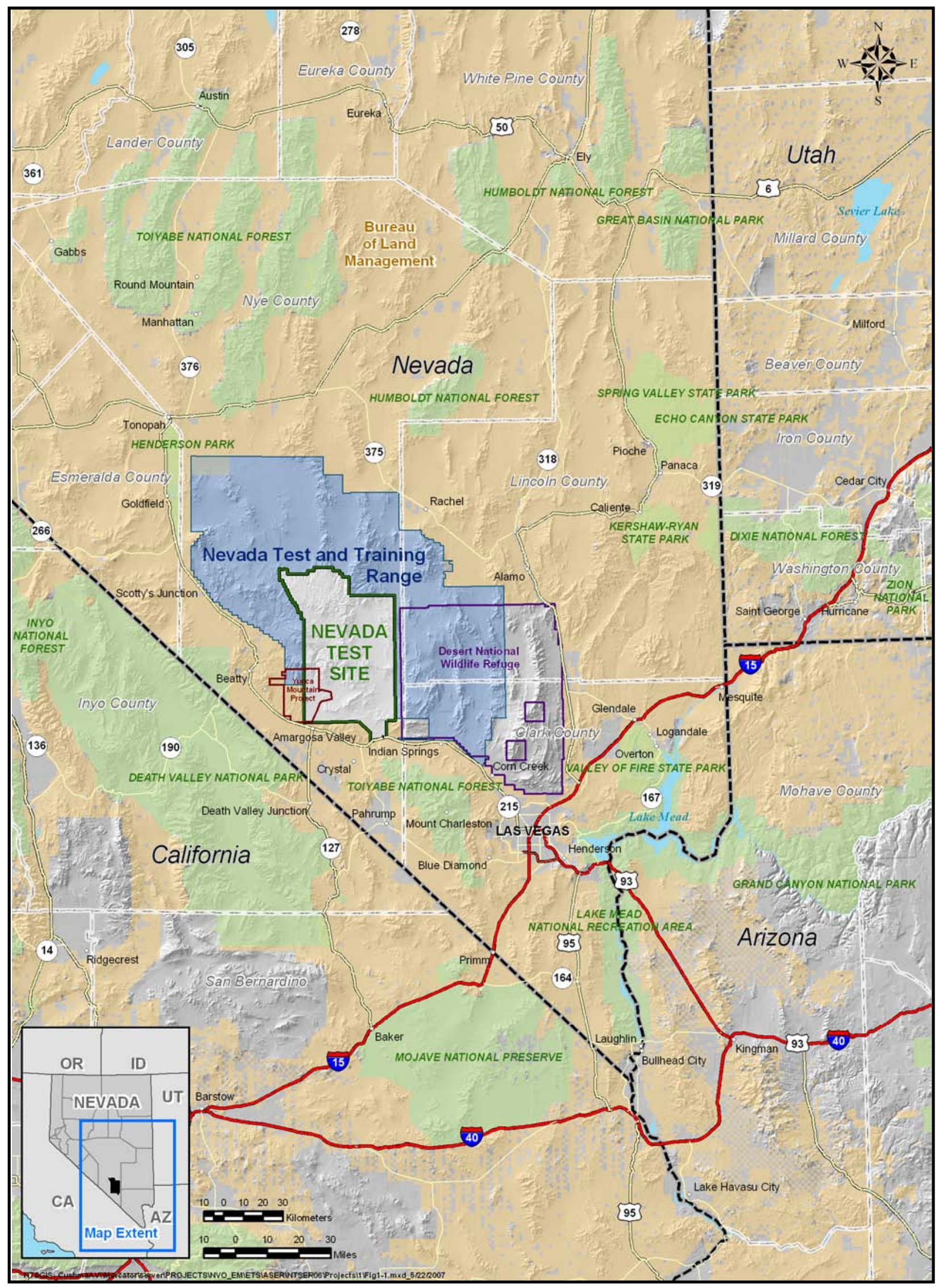

Figure 1-1. NTS vicinity map 


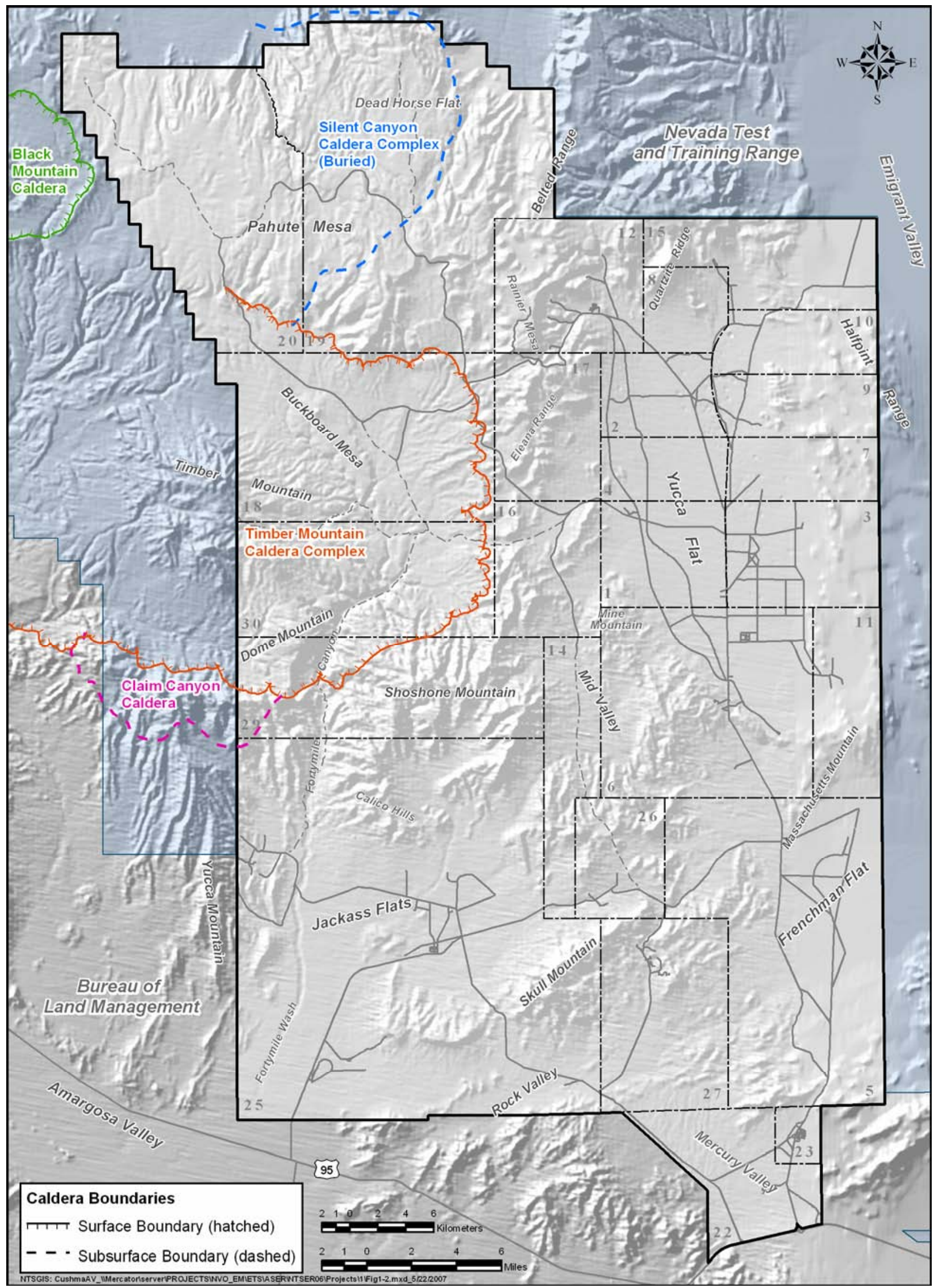

Figure 1-2. Major topographic features of the NTS 


\subsection{Site History}

The history of the NTS, as well as its current missions, directs the focus and design of the environmental monitoring and surveillance activities on and near the site. Between 1940 and 1950, the area now known as the NTS was under the jurisdiction of Nellis Air Force Base and was part of the Nellis Bombing and Gunnery Range. The NTS was established in 1950 to be the primary location for testing the nation's nuclear explosive devices and supported nuclear testing from 1951 to 1992. The NTS currently conducts only subcritical nuclear experiments. Fact sheets on many of the historical tests and projects mentioned below can be found at $<\underline{\text { http: } / / w w w . n v . d o e . g o v / l i b r a r y / f a c t s h e e t s . a s p x}>$.

Atmospheric Tests - Tests conducted through the 1950s were predominantly atmospheric tests. These tests involved a nuclear explosive device detonated while on the ground surface, on a steel tower, suspended from tethered balloons, dropped from an aircraft, or placed on a rocket. Several tests were categorized as "safety experiments," and "storage-transportation tests," involving the destruction of a nuclear device with non-nuclear explosives. Some of these tests resulted in the dispersion of plutonium in the test vicinity. One of these test areas lies just north of the NTS boundary at the south end of the NTTR, and four others involving storage-transportation are at the north end of the NTTR. These test areas have been monitored for radionuclides in the past $(1996-2000)$ in support of remediation projects, two of which were completed. The three remaining sites will be monitored again once restoration of these sites begins. All nuclear device tests are listed in United States Nuclear Tests, July 1945 through September 1992 (DOE, 2000a).

Underground Tests - The first underground test, a cratering test, was conducted in 1951. The first totally-contained underground test was in 1957. Testing was discontinued during a moratorium that began October 31, 1958, but was resumed in September 1961 after tests by the Union of Soviet Socialist Republics began. Since late 1962, nearly all tests have been conducted in sealed vertical shafts drilled into Yucca Flat and Pahute Mesa or in horizontal tunnels mined into Rainier Mesa. From 1951 to 1992, a total of 828 underground nuclear tests was conducted at the NTS. Approximately one third of these tests were detonated near or below the water table; this has resulted in the contamination of groundwater in some areas. In 1996, DOE, U.S. Department of Defense (DoD), and the state of Nevada entered into a Federal Facility Agreement and Consent Order which established Corrective Action Units on the NTS that delineated and defined areas of concern for groundwater contamination.

Cratering Tests - Five earth-cratering (shallow-burial) tests were conducted over the period of 1962 through 1968 as part of the Plowshare Program that explored peaceful uses of nuclear explosives. The first and highest yield Plowshare crater test, Sedan (U.S. Public Health Service, 1963) was detonated at the northern end of Yucca Flat on the NTS. The second highest yield crater test was Schooner, located in the northwest corner of the NTS. From these tests, mixed fission products, tritium, and plutonium were entrained in the soil ejected from the craters and deposited on the ground surrounding the craters.

Other Tests - Other nuclear-related experiments at the NTS have included the BREN series (Bare Reactor Experiment - Nevada series) in the early 1960s conducted in Area 4. These tests were performed with a 14-million electron volt neutron generator mounted on a $465-\mathrm{m}(1,527-\mathrm{ft})$ steel tower to produce neutron and gamma radiation for the purpose of estimating the radiation doses received by survivors of Hiroshima and Nagasaki. The tower was moved in 1966 to Area 25 and used for conducting Operation HENRE (High-Energy Neutron Reactions Experiment), jointly funded by the DoD and the Atomic Energy Commission (AEC) to provide information for the AEC's Division of Biology and Medicine. From 1959 through 1973, a series of open-air nuclear reactor, nuclear engine, and nuclear furnace tests were conducted in Area 25, and a series of tests with a nuclear ramjet engine were conducted in Area 26. Erosion of metal cladding on the reactor fuel released some fuel particles that caused negligible deposition of radionuclides on the ground. Most of the radiation released from these tests was gaseous in the form of radio-iodines, radio-xenons, and radio-kryptons.

\subsection{Site Mission}

NNSA/NSO directs the management and operation of the NTS and seven satellite sites across the nation. Los Alamos National Laboratory, Lawrence Livermore National Laboratory, and Sandia National Laboratories are the principal organizations that sponsor and implement the nuclear weapons programs at the NTS. From 
January 1 to June 30, 2006, Bechtel Nevada was the Management and Operating (M\&O) contractor accountable for the successful execution of work and ensuring that work was performed in compliance with environmental regulations. On July 1, 2006, National Security Technologies, LLC, became the responsible M\&O contractor. The seven satellite sites of the NTS include the North Las Vegas Facility (NLVF), Cheyenne Las Vegas Facility (CLVF), Remote Sensing Laboratory (RSL)-Nellis, RSL-Andrews, Livermore Operations, Los Alamos Operations, and Special Technologies Laboratory. These sites all provide support to enhance the NTS as a site for weapons experimentation and nuclear test readiness. This report addresses environmental monitoring and compliance only at the NTS and its three Nevada satellite sites: NLVF, CLVF, and RSL-Nellis (see Appendix A). The three major NTS missions include National Security, Environmental Management, and Stewardship of the NTS. The programs which support these missions include Stockpile Stewardship, Homeland Security, Test Readiness, Environmental Restoration, Waste Management, and Facilities and Infrastructure.

\section{NTS Missions and Programs}

\section{National Security}

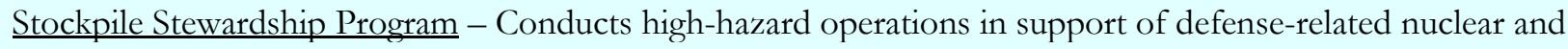
national security experiments.

Homeland Security Program - Provides support facilities, training facilities, and capabilities for government agencies involved in counterterrorism activities, emergency response, first responders, national security technology development, and nonproliferation technology development.

Test Readiness Program - Maintains the capability to resume underground nuclear weapons testing, if directed.

\section{Environmental Management}

Environmental Restoration Program - Characterizes and remediates the environmental legacy of nuclear weapons and other testing at the NTS and at offsite locations, and develops and deploys technologies that enhance environmental restoration.

Waste Management - Manages and safely disposes of low-level waste received from DOE- and DoD-approved facilities throughout the U.S. and mixed low-level waste generated in Nevada by NNSA/NSO, and safely manages and characterizes hazardous and transuranic wastes for offsite disposal.

\section{Stewardship of the NTS}

Facilities and Infrastructure - Maintains the buildings, roads, utilities, and facilities required to support all NTS programs and to provide a safe environment for NTS workers.

\subsection{Primary Operations and Activities}

NTS activities in 2006 continued to be diverse, with the primary role being to help ensure that the existing U.S. stockpile of nuclear weapons remains safe and reliable. Facilities that support this national security mission include the U1a Facility, Big Explosives Experimental Facility, Device Assembly Facility, and Joint Actinide Shock Physics Experimental Research (JASPER) Facility (Figure 1-3). Facilities that support the Homeland Security program include the new Radiological/Nuclear Countermeasures Test and Evaluation Complex (Rad/NucCTEC) (Figure 1-3), which was expected to be operational in October 2006, but is currently on hold. Facilities that support the Waste Management Program include the Area 5 Radioactive Waste Management Complex (RWMC) and the Area 3 Radioactive Waste Management Site (RWMS) (Figure 1-3). Other NTS activities include demilitarization activities; controlled spills of hazardous material at the Non-Proliferation Test and Evaluation Complex (NPTEC) (Figure 1-3); remediation of industrial sites; processing of waste destined for the Waste Isolation Pilot Plant in Carlsbad, New Mexico, or the Idaho National Laboratory in Idaho Falls, Idaho; disposal of radioactive and mixed waste; and environmental research. Land use by each of the NTS missions occur within zones designated by the land-use map shown in Figure 1-4. It is the resultant Record of Decision land use map for the 1996 programmatic NTS Environmental Impact Statement (DOE, 1996a), as depicted in the NTS Resource Management Plan (DOE, 1998). 


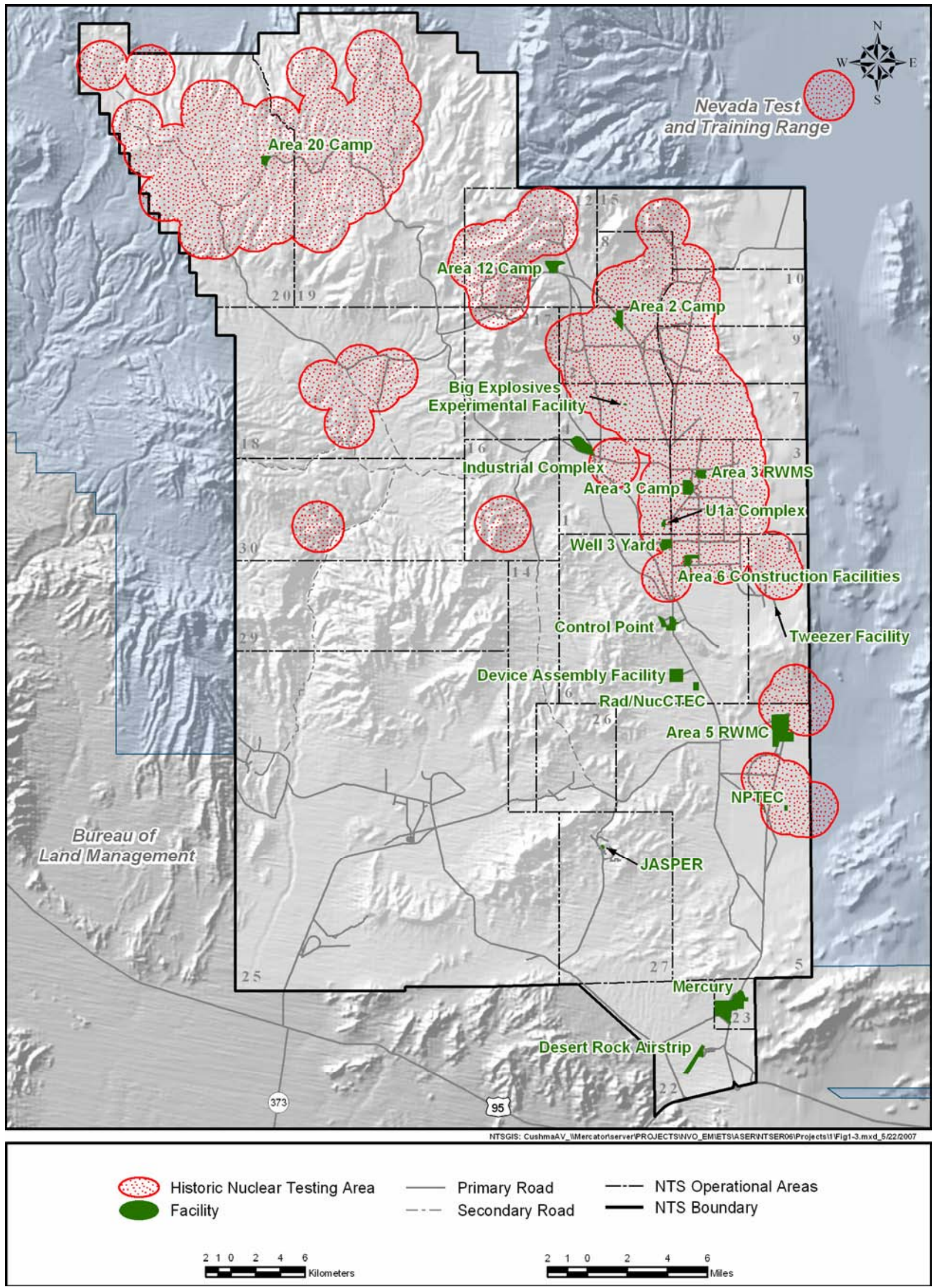

Figure 1-3. NTS operational areas, principal facilities, and past nuclear testing areas 


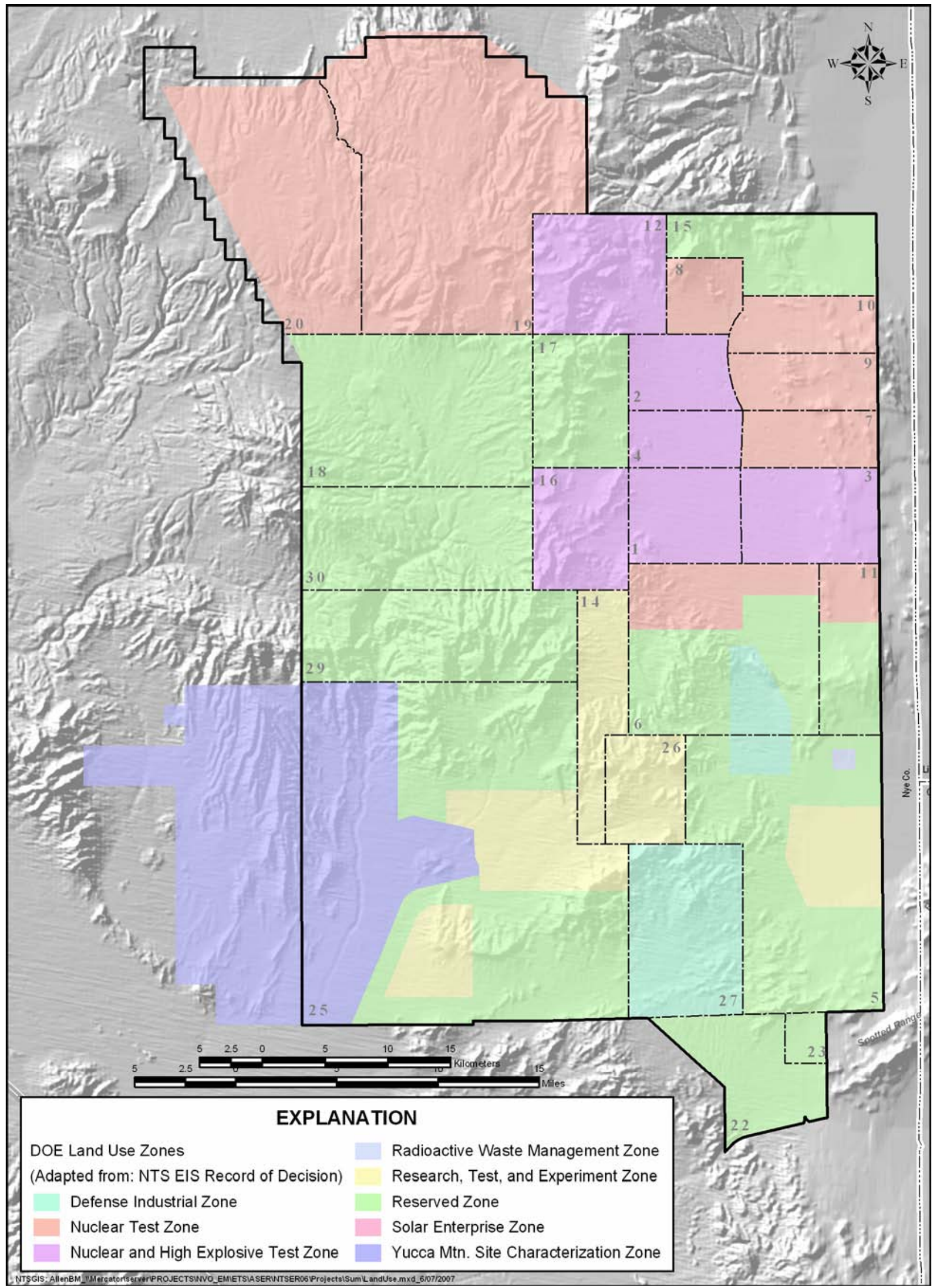

Figure 1-4. NTS land-use map (Source: DOE, 1998) 


\subsection{Populations Near the NTS}

The population of the area surrounding the NTS (see Figure 1-1) is predominantly rural. The population estimates for Nevada communities has been estimated by the Nevada State Demographer Office up through July 1, 2005 (Hardcastle, 2007). The annual population estimate for Nevada counties, cities, and unincorporated towns is 2,623,050, with all but 748,213 residing in Clark County. The total population estimate for Nye County is 44,795 and includes the communities of Amargosa (1,435), Beatty (1,025), Gabbs (313), Manhattan (122), Pahrump (36,645), Round Mountain (787), and Tonopah (2,600). The largest of the Nye County communities is Pahrump, which is approximately $50 \mathrm{mi}(80 \mathrm{~km})$ south of the NTS Control Point facility located near the center of the NTS.

Neighboring Lincoln County to the east of the NTS includes a few small communities including Alamo (432), Caliente (1,002), Panaca (558), and Pioche (703). Neighboring Clark County is the major population center of Nevada and has an estimated total population of 1,874,837. Mesquite, on the northwest border of Arizona, has an estimated population of 17,656 .

The Mojave Desert of California, which includes Death Valley National Park, lies along the southwestern border of Nevada. This area is still predominantly rural; however, tourism at Death Valley National Park swells the population to more than 5,000 on any particular day during holiday periods when the weather is mild.

The extreme southwestern region of Utah is more developed than the adjacent portion of Nevada. The population estimates for Utah communities are based on projections for the year 2005 by Utah's Associations of Government and Governor's Office of Planning and Budget, Demographic and Economic Analysis (2000). The largest community is St. George, located $220 \mathrm{~km}(137 \mathrm{mi})$ east of the NTS, with a population of 56,497. The next largest town, Cedar City, is located $280 \mathrm{~km}(174 \mathrm{mi})$ east-northeast of the NTS and has a population of 24,410.

The extreme northwestern region of Arizona is mostly rangeland, except for that portion in the Lake Mead recreation area. In addition, several small communities lie along the Colorado River. The largest towns in the area are Bullhead City, $165 \mathrm{~km}$ (103 mi) south-southeast of the NTS, with an estimated population of 39,930, and Kingman, located $280 \mathrm{~km}$ (174 mi) southeast of the NTS, with an estimated population of 27,635 (July 1, 2006 population estimates, Arizona Department of Economic Security, 2007).

\subsection{Understanding Data in this Report}

\subsubsection{Scientific Notation}

Scientific notation is used in this report to express very large or very small numbers. A very small number is expressed with a negative exponent, for example $2.0 \times 10^{-5}$. To convert this number from scientific notation to a more traditional number, the decimal point must be moved left by the number of places equal to the exponent ( 5 in this case). The number thus becomes 0.00002 .

Very large numbers are expressed in scientific notation with a positive exponent. The decimal point should be moved to the right by the number of places equal to the exponent. The number 1,000,000,000 could be presented in scientific notation as $1.0 \times 10^{9}$.

\subsubsection{Unit Prefixes}

Units for very small and very large numbers are commonly expressed with a prefix. The prefix signifies the amount of the given unit. For example, the prefix k, or kilo-, means 1,000 of a given unit. Thus $1 \mathrm{~kg}$ (kilogram) is $1,000 \mathrm{~g}$ (grams). Other prefixes used in this report are listed in Table 1-1.

Table 1-1. Unit prefixes

\begin{tabular}{||lcl||}
\hline Prefix & Abbreviation & \multicolumn{1}{c||}{ Meaning } \\
\hline mega- & $\mathrm{M}$ & $1,000,000\left(1 \times 10^{6}\right)$ \\
kilo- & $\mathrm{k}$ & $1,000\left(1 \times 10^{3}\right)$ \\
centi- & $\mathrm{C}$ & $0.01\left(1 \times 10^{-2}\right)$ \\
milli- & $\mathrm{m}$ & $0.001\left(1 \times 10^{-3}\right)$ \\
micro- & $\mu$ & $0.000001\left(1 \times 10^{-6}\right)$ \\
nano- & $\mathrm{n}$ & $0.000,000,1\left(1 \times 10^{-9}\right)$ \\
pico- & $\mathrm{p}$ & $0.000,000,000,0001\left(1 \times 10^{-12}\right)$ \\
\hline
\end{tabular}




\subsubsection{Units of Radioactivity}

Much of this report deals with levels of radioactivity in various environmental media. The basic unit of radioactivity used in this report is the curie (Ci) (Table 1-2). The curie describes the amount of radioactivity present, and amounts are usually expressed in terms of fractions of curies in a given mass or volume (e.g., picocuries per liter). The curie is historically defined as the rate of nuclear disintegrations that occur in $1 \mathrm{~g}$ of the radionuclide radium-226, which is 37 billion nuclear disintegrations per second. For any other radionuclide, $1 \mathrm{Ci}$ is the quantity of the radionuclide that decays at this same rate. Nuclear disintegrations produce spontaneous emissions of alpha or beta particles, gamma radiation, or combinations of these.
Table 1-2. Units of radioactivity

\begin{tabular}{|ll||}
\hline Symbol & \multicolumn{1}{c||}{ Name } \\
\hline $\mathrm{Ci}$ & curie \\
$\mathrm{cpm}$ & counts per minute \\
$\mathrm{mCi}$ & millicurie $\left(1 \times 10^{-3} \mathrm{Ci}\right)$ \\
$\mu \mathrm{Ci}$ & microcurie $\left(1 \times 10^{-6} \mathrm{Ci}\right)$ \\
$\mathrm{nCi}$ & nanocurie $\left(1 \times 10^{-9} \mathrm{Ci}\right)$ \\
$\mathrm{pCi}$ & picocurie $\left(1 \times 10^{-12} \mathrm{Ci}\right)$ \\
$\mathrm{aCi}$ & attocurie $\left(1 \times 10^{-18} \mathrm{Ci}\right)$ \\
\hline
\end{tabular}

\subsubsection{Radiological Dose Units}

The amount of ionizing radiation energy absorbed by a living organism is expressed in terms of radiological dose. Radiological dose in this report is usually written in terms of effective dose equivalent and reported numerically in units of millirem (mrem) (Table 1-3). Millirem is a term that relates ionizing radiation to biological effect or risk to humans. A dose of $1 \mathrm{mrem}$ has a biological effect similar to the dose received from an approximate 1-day exposure to natural background radiation. An acute (short-term) dose of 100,000 to 400,000 mrem can cause radiation sickness in humans. An acute dose of 400,000 to $500,000 \mathrm{mrem}$, if left untreated, results in death approximately 50 percent of the time. Exposure to lower amounts of radiation (1,000 mrem or less) produces no immediate observable effects, but long-term (delayed) effects are possible. The average person in the United States receives an annual dose of approximately 300 mrem from exposure to naturally produced radiation. Medical and dental X rays, air travel, and tobacco smoking add to this total.

The unit "rad," for radiation absorbed dose, is also used in this report. The rad is a measure of the energy absorbed by any material, whereas a "rem," for roentgen equivalent man, relates to both the amount of radiation energy absorbed by humans and its consequence. A roentgen $(\mathrm{R})$ is a measure of radiation exposure. Generally speaking, $1 \mathrm{R}$ of exposure will result in an effective dose equivalent of $1 \mathrm{rem}$. Additional information on radiation and dose terminology can be found in the Glossary (Appendix B).

\subsubsection{International System of Units for Radioactivity and Dose}

In some instances in this report, radioactivity and radiological dose values are expressed in other units in addition to $\mathrm{Ci}$ and mrem. These units are the becquerel (Bq) and the millisievert $(\mathrm{mSv})$, respectively. The $\mathrm{Bq}$ and $\mathrm{Sv}$ belong to the International System of Units (SI), and their inclusion in this report is mandated by DOE. SI units are the internationally accepted units and may eventually be the standard for reporting both radioactivity and radiation dose in the United States. One Bq is equivalent to one nuclear disintegration per second.

The unit of radiation absorbed dose ( $\mathrm{rad}$ ) has a corresponding SI unit called the gray (Gy). The roentgen measure of radiation exposure has no SI equivalent. Table 1-4 provides the multiplication factors for converting to and from SI units.
Table 1-4. Conversion table for SI units

\begin{tabular}{||llc||}
\hline \multicolumn{1}{|c}{$\begin{array}{c}\text { To Convert } \\
\text { From }\end{array}$} & \multicolumn{1}{c|}{ To } & $\begin{array}{c}\text { Multiply } \\
\text { By }\end{array}$ \\
\hline becquerel $(\mathrm{Bq})$ & picocurie $(\mathrm{pCi})$ & 27 \\
curie $(\mathrm{Ci})$ & becquerel $(\mathrm{Bq})$ & $3.7 \times 10^{10}$ \\
gray $(\mathrm{Gy})$ & rad & 100 \\
mrem & msievert $(\mathrm{mSv})$ & 0.01 \\
msievert $(\mathrm{mSv})$ & mrem & 100 \\
picocurie $(\mathrm{pCi})$ & becquerel $(\mathrm{Bq})$ & 0.03704 \\
rad & gray $(\mathrm{Gy})$ & 0.01 \\
sievert $(\mathrm{Sv})$ & rem & 100 \\
\hline
\end{tabular}




\subsubsection{Radionuclide Nomenclature}

Radionuclides are frequently expressed with the one- or two-letter chemical symbol for the element. Radionuclides may have many different isotopes, which are shown by a superscript to the left of the symbol. This number is the atomic weight of the isotope (the number of protons and neutrons in the nucleus of the atom). Radionuclide symbols, many of which are used in this report, are shown in Table 1-5 along with the half-life of each radionuclide. The half-life is the time required for one-half the radioactive atoms in a given amount of material to decay. For example, after one half-life, half of the original atoms will have decayed; after two half-lives, three-fourths of the original atoms will have decayed; and after three half-lives, seveneighths of the original atoms will have decayed, and so on. The notation ${ }^{236+238} \mathrm{Ra}$ and similar notations in this report (e.g., ${ }^{239+240} \mathrm{Pu}$ ) are used when the analytical method does not distinguish between the isotopes, but reports the total amount of both.

\subsubsection{Units of Measurement}

Both metric and non-metric units of measurement are used in this report. Metric system and U.S. customary units and their respective equivalents are shown in Table 1-6 on the following page.

\subsubsection{Measurement Variability}

There is always uncertainty associated with the measurement of environmental contaminants. For radioactivity, a major source of uncertainty is the inherent randomness of radioactive decay events.

Uncertainty in analytical measurements is also the consequence of variability related to collecting and analyzing the samples. This variability is associated with reading or recording the result, handling or processing the sample, calibrating the counting instrument, and numerical rounding.

The uncertainty of a measurement is denoted by following the result with an uncertainty value which is preceded by the plus-or-minus symbol, \pm . This uncertainty value gives information on what the measurement might be if the same sample were analyzed again under identical conditions. The uncertainty value implies that approximately 95 percent of the time the average of many measurements would give a value somewhere between the reported value minus the uncertainty value and the reported value plus the uncertainty value.

If the reported concentration of a given constituent is smaller than its associated uncertainty (e.g., $40 \pm 200$ ), the sample may not contain that constituent. Such low concentration values are considered to be below detection, meaning the concentration of the constituent in the sample is so low that it is undetected by the method and/or instrument.
Table 1-5. Radionuclides and their halflives

\begin{tabular}{|c|c|c|}
\hline Symbol & Radionuclide & Half-Life (a) \\
\hline${ }^{241} \mathrm{Am}$ & americium-241 & $432.2 \mathrm{yr}$ \\
\hline${ }^{7} \mathrm{Be}$ & beryllium-7 & $53.44 \mathrm{~d}$ \\
\hline${ }^{14} \mathrm{C}$ & carbon-14 & $5,730 \mathrm{yr}$ \\
\hline${ }^{134} \mathrm{Cs}$ & cesium-134 & $2.1 \mathrm{yr}$ \\
\hline${ }^{137} \mathrm{Cs}$ & cesium-137 & $30 \mathrm{yr}$ \\
\hline${ }^{51} \mathrm{Cr}$ & chromium-51 & $27.7 \mathrm{~d}$ \\
\hline${ }^{60} \mathrm{Co}$ & cobalt -60 & $5.3 \mathrm{yr}$ \\
\hline${ }^{152} \mathrm{Eu}$ & europium-152 & $13.3 \mathrm{yr}$ \\
\hline${ }^{154} \mathrm{Eu}$ & europium-154 & $8.8 \mathrm{yr}$ \\
\hline${ }^{155} \mathrm{Eu}$ & europium-155 & $5 \mathrm{yr}$ \\
\hline${ }^{3} \mathrm{H}$ & tritium & $12.35 \mathrm{yr}$ \\
\hline${ }^{129} \mathrm{I}$ & iodine-129 & $1.6 \times 10^{7} \mathrm{yr}$ \\
\hline $131 \mathrm{I}$ & iodine-131 & $8 \mathrm{~d}$ \\
\hline${ }^{40} \mathrm{~K}$ & potassium-40 & $1.3 \times 10^{8} \mathrm{yr}$ \\
\hline${ }^{85} \mathrm{Kr}$ & krypton-85 & $10^{7} \mathrm{yr}$ \\
\hline $212 \mathrm{~Pb}$ & lead-212 & $10.6 \mathrm{~h}$ \\
\hline${ }^{238} \mathrm{Pu}$ & plutonium-238 & $87.7 \mathrm{hr}$ \\
\hline${ }^{239} \mathrm{Pu}$ & plutonium-239 & $2.4 \times 10^{4} \mathrm{yr}$ \\
\hline${ }^{240} \mathrm{Pu}$ & plutonium-240 & $6.5 \times 10^{3} \mathrm{yr}$ \\
\hline${ }^{241} \mathrm{Pu}$ & plutonium-241 & $14.4 \mathrm{yr}$ \\
\hline${ }^{226} \mathrm{Ra}$ & radium-226 & $1.62 \times 10^{3} \mathrm{yr}$ \\
\hline${ }^{228} \mathrm{Ra}$ & radium-228 & $5.75 \mathrm{yr}$ \\
\hline${ }^{220} \mathrm{Rn}$ & radon-220 & $56 \mathrm{~s}$ \\
\hline${ }^{222} \mathrm{Rn}$ & radon-222 & $3.8 \mathrm{~d}$ \\
\hline${ }^{103} \mathrm{Ru}$ & ruthenum-103 & $39.3 \mathrm{~d}$ \\
\hline${ }^{106} \mathrm{Ru}$ & ruthenum-106 & $368.2 \mathrm{~d}$ \\
\hline${ }^{125} \mathrm{Sb}$ & antimony-125 & $2.8 \mathrm{yr}$ \\
\hline${ }^{113} \mathrm{Sn}$ & tin-113 & $115 \mathrm{~d}$ \\
\hline${ }^{90} \mathrm{Sr}$ & strontium-90 & $29.1 \mathrm{yr}$ \\
\hline${ }^{99} \mathrm{Tc}$ & technetium-99 & $2.1 \times 10^{5} \mathrm{yr}$ \\
\hline${ }^{232} \mathrm{Th}$ & thorium-232 & $1.4 \times 10^{10} \mathrm{yr}$ \\
\hline $\mathrm{U}^{(\mathrm{b})}$ & uranium total & $\ldots$ - (c) \\
\hline${ }^{234} \mathrm{U}$ & uranium-234 & $2.4 \times 10^{5} \mathrm{yr}$ \\
\hline${ }^{235} \mathrm{U}$ & uranium-235 & $7 \times 10^{8} \mathrm{hr}$ \\
\hline${ }^{238} \mathrm{U}$ & uranium-238 & $4.5 \times 10^{9} \mathrm{yr}$ \\
\hline $65 \mathrm{Zn}$ & zinc-65 & $243.9 \mathrm{~d}$ \\
\hline${ }^{95} \mathrm{Zr}$ & zirconium-95 & $63.98 \mathrm{~d}$ \\
\hline \multicolumn{3}{|c|}{$\begin{array}{l}\text { (a) From Shleien, } 1992 \\
\text { (b) Total uranium may also be indicated by } \\
\text { U- natural (U-nat) or U-mass } \\
\text { (c) Natural uranium is a mixture dominated by }{ }^{238} \mathrm{U} \text {, } \\
\text { thus the half-life is approximately } 4.5 \times 10^{9} \text { years } \\
\end{array}$} \\
\hline
\end{tabular}


Table 1-6. Metric and U.S. customary unit equivalents

\begin{tabular}{|c|c|c|c|}
\hline Metric Unit & $\begin{array}{l}\text { U.S. Customary } \\
\text { Equivalent Unit }\end{array}$ & U.S. Customary Unit & Metric Equivalent Unit \\
\hline \multicolumn{4}{|l|}{ Length } \\
\hline 1 centimeter $(\mathrm{cm})$ & 0.39 inches (in.) & 1 inch (in.) & 2.54 centimeters $(\mathrm{cm})$ \\
\hline 1 millimeter $(\mathrm{mm})$ & 0.039 inches (in.) & & 25.4 millimeters $(\mathrm{mm})$ \\
\hline \multirow[t]{2}{*}{1 meter $(\mathrm{m})$} & 3.28 feet $(\mathrm{ft})$ & 1 foot $(\mathrm{ft})$ & 0.3048 meters $(\mathrm{m})$ \\
\hline & 1.09 yards $(\mathrm{yd})$ & 1 yard $(\mathrm{yd})$ & 0.9144 meters $(\mathrm{m})$ \\
\hline 1 kilometer $(\mathrm{km})$ & 0.62 miles (mi) & 1 mile (mi) & 1.6093 kilometers $(\mathrm{km})$ \\
\hline \multicolumn{4}{|l|}{ Volume } \\
\hline 1 liter (L) & 0.26 gallons (gal) & 1 gallon (gal) & 3.7853 liters $(\mathrm{L})$ \\
\hline \multirow[t]{2}{*}{1 cubic meter $\left(\mathrm{m}^{3}\right)$} & 35.32 cubic feet $\left(\mathrm{ft}^{3}\right)$ & 1 cubic foot $\left(\mathrm{ft}^{3}\right)$ & 0.028 cubic meters $\left(\mathrm{m}^{3}\right)$ \\
\hline & 1.35 cubic yards $\left(\mathrm{yd}^{3}\right)$ & 1 cubic yard $\left(\mathrm{yd}^{3}\right)$ & 0.765 cubic meters $\left(\mathrm{m}^{3}\right)$ \\
\hline \multicolumn{4}{|l|}{ Weight } \\
\hline 1 gram $(\mathrm{g})$ & 0.035 ounces $(\mathrm{oz})$ & 1 ounce $(\mathrm{oz})$ & 28.6 gram $(\mathrm{g})$ \\
\hline 1 kilogram (kg) & 2.21 pounds $(\mathrm{lb})$ & 1 pound $(\mathrm{lb})$ & 0.373 kilograms $(\mathrm{kg})$ \\
\hline 1 metric ton (mton) & 1.10 short ton $(2,000 \mathrm{lb})$ & 1 short ton $(2,000 \mathrm{lb})$ & 0.90718 metric ton (mton) \\
\hline \multicolumn{4}{|l|}{ Geographic area } \\
\hline 1 hectare & 2.47 acres & 1 acre & 0.40 hectares \\
\hline \multicolumn{4}{|l|}{ Radioactivity } \\
\hline 1 becquerel $(\mathrm{Bq})$ & $2.7 \times 10^{-11}$ curie $(\mathrm{Ci})$ & 1 curie $(\mathrm{Ci})$ & $3.7 \times 10^{-10}$ becquerel $(\mathrm{Bq})$ \\
\hline \multicolumn{4}{|l|}{ Radiation dose } \\
\hline $1 \mathrm{rem}$ & 0.01 sievert $(\mathrm{Sv})$ & 1 sievert $(\mathrm{Sv})$ & $100 \mathrm{rem}$ \\
\hline \multicolumn{4}{|l|}{ Temperature } \\
\hline${ }^{\circ} \mathrm{C}=\left({ }^{\circ} \mathrm{F}-32\right) / 1.8$ & & ${ }^{\circ} \mathrm{F}=\left({ }^{\circ} \mathrm{C} \times 1.8\right)+32$ & \\
\hline
\end{tabular}

\subsubsection{Mean and Standard Deviation}

The mean of a set of data is the usual average of those data. The standard deviation (SD) of sample data relates to the variation around the mean of a set of individual sample results; it is defined as the square root of the average squared difference of individual data values from the mean. This variation includes both measurement variability and actual variation between monitoring periods (weeks, months, or quarters, depending on the particular analysis). The sample mean and standard deviation are estimates of the average and the variability that would be seen in a large number of

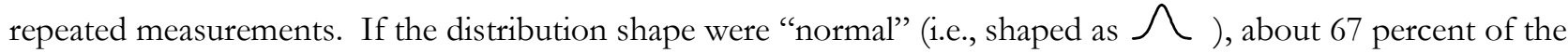
measurements would be within the mean \pm SD and 95 percent would be within the mean \pm 2 SD.

\subsubsection{Standard Error of the Mean}

Just as individual values are accompanied by counting uncertainties, mean values (averages) are accompanied by uncertainty. The standard deviation of the distribution of sample mean values is known as the standard error of the mean (SE). The SE conveys how accurate of an estimate the mean value is based on the samples that were collected and analyzed. The \pm value presented to the right of a mean value is equal to $2 \times \mathrm{SE}$ ( 2 multiplied by the SE). The \pm value implies that approximately 95 percent of the time the average of many calculated means will fall somewhere between the reported value minus the $2 \mathrm{x}$ SE value and the reported value plus the $2 \times \mathrm{SE}$ value.

\subsubsection{Median, Maximum, and Minimum Values}

Median, maximum, and minimum values are reported in some sections of this report. A median value is the middle value when all the values are arranged in order of increasing or decreasing magnitude. For example, the median value in the series of numbers, 123345556 , is 4 . The maximum value would be 6 and the minimum value would be 1 . 


\subsubsection{Less Than (<) Symbol}

The less than $(<)$ symbol is used to indicate that the actual measured value may be smaller than the number given. For example, $<0.09$ would indicate that the actual value is less than 0.09 . In this report, $<$ is often used in reporting the amounts of nonradiological contaminants in a sample when the amounts are less than the analytical laboratory's reporting limit for that contaminant in that sample. For example, the measurement of benzene in sewage lagoon pond water is reported as $<0.005$ milligrams per liter, which implies that the actual amount of benzene present, if any, was unable to be determined below this level given the sample and analysis methods used. For some constituents the notation "ND" is also used to indicate that the constituent in question was not detected. The measurements of radionuclide concentrations are reported whether or not they are below the usual reporting limit (the minimum detectable concentration [see Glossary, Appendix B]).

\subsubsection{Negative Radionuclide Concentrations}

There is always a small amount of natural radiation in the environment. The instruments used in the laboratory to measure radioactivity in environmental media are sensitive enough to measure the natural, or background, radiation along with any contaminant radiation in a sample. To obtain a true measure of the contaminant level in a sample, the natural, or background, radiation level must be subtracted from the total amount of radioactivity measured by an instrument. Because of the randomness of radioactive emissions and the very low concentrations of some contaminants, it is possible to obtain a background measurement that is larger than the actual contaminant measurement. When the larger background measurement is subtracted from the smaller contaminant measurement, a negative result is generated. The negative results are reported because they are useful when conducting statistical evaluations of the data.

\subsubsection{Understanding Graphic Information}

Some of the data graphed in this report are plotted using logarithmic scales. Logarithmic (log) scales are used in plots where the values are of widely different magnitudes at different locations and/or different times. Log scales use equal distances to represent equal ratios of values, whereas in linear scales equal distances represent equal differences in values. For example, a log scale would use the same distance to represent a change from 2 to 4 as a change from 10 to 20 or a change from 700 to 1,400 .

For example, compare Figures 1-5 and 1-6. Both show long-term trends in annual mean ${ }^{3} \mathrm{H}$ concentrations in air samples. The use of the log scale in Figure 1-5 allows for the Schooner data to be represented on the same plot with the same scale as the data from the other stations with lower mean concentrations, without losing the detail of the year-to-year variation in the data from those other stations. The compliance level (CL) (see Glossary, Appendix B), $\left(1500 \times 10^{-6}\right.$ picocuries per milliliter $\left.[\mathrm{pCi} / \mathrm{mL}]\right)$, can also be plotted on the log scale. Using the original units, as in Figure 1-6, one either loses the detail in the year-to-year variation at most stations or (the option selected in Figure 16) multiplies the Schooner values by 0.1 and the CL by 0.01 to retain that detail. 


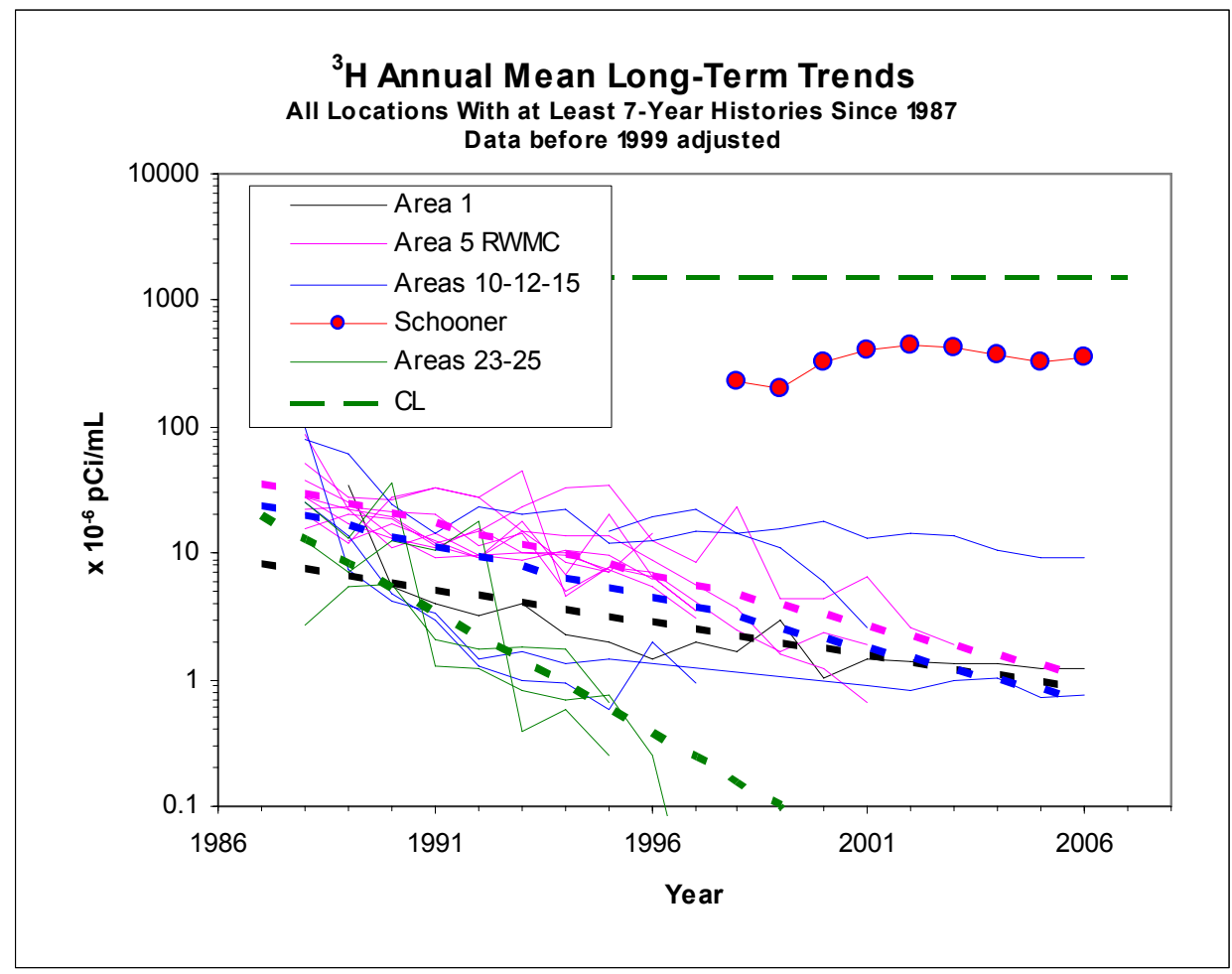

Figure 1-5. Data plotted using a log scale

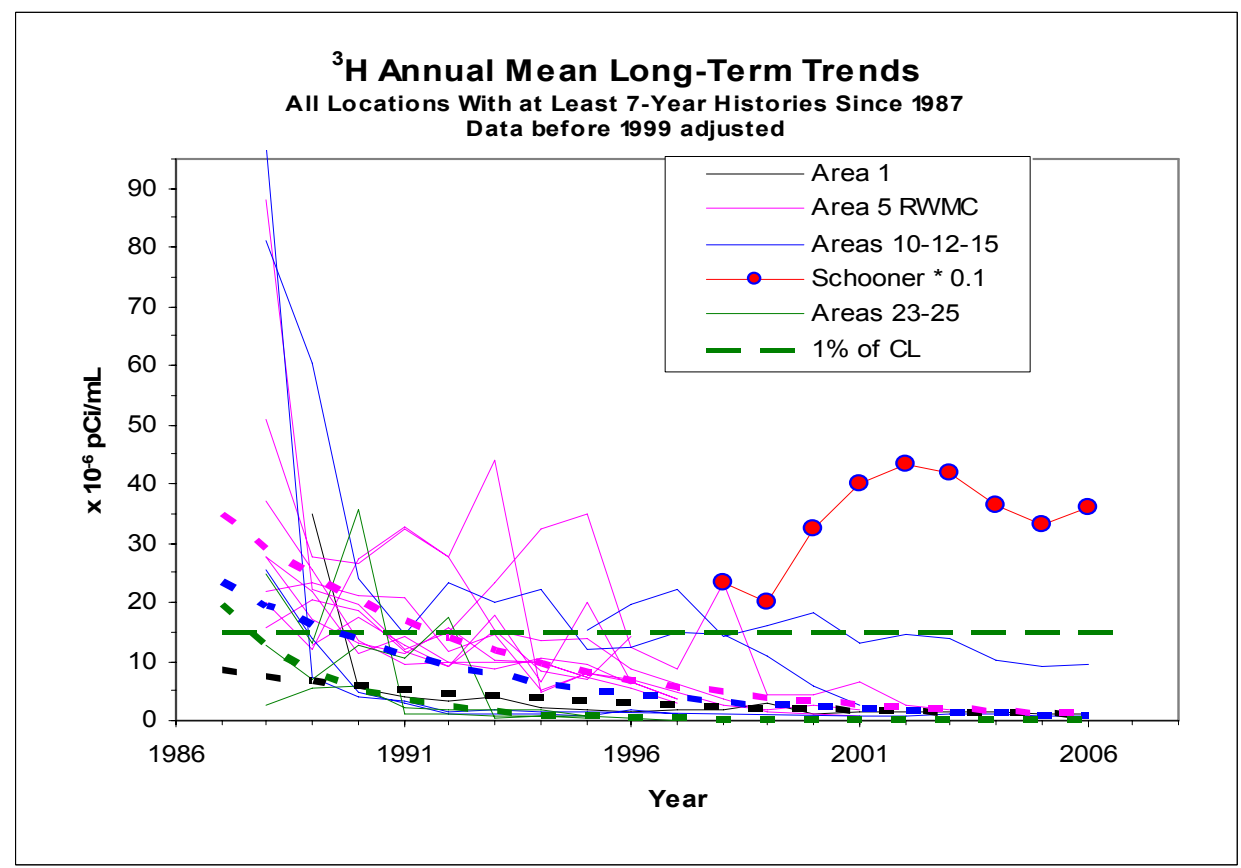

Figure 1-6. Data plotted using a linear scale 


\section{THIS PAGE INTENTIONALLY LEFT BLANK}




\subsection{Compliance Summary}

Environmental regulations pertinent to operations on the Nevada Test Site (NTS) and its Nevada satellite facilities (North Las Vegas Facility [NLVF], Cheyenne Las Vegas Facility, and Remote Sensing Laboratory [RSL]-Nellis) are listed in this Compliance Summary. They include federal and state laws, state permit requirements, Executive Orders (EOs), U.S. Department of Energy (DOE) Orders, and state agreements. They dictate how the U.S. Department of Energy, National Nuclear Security Administration Nevada Site Office (NNSA/NSO) conducts operations on and off the NTS to ensure the protection of the environment and the public. The regulations are grouped by topic. A compliance status table is presented for each topical group of regulations. Each table lists those measures or actions which are tracked or performed annually to ensure compliance with a regulation. A description of the field monitoring efforts, actions, and results which support the data in each table can be found in subsequent sections of this document, as noted in the "Reference Section" column of each table. Noncompliance incidents or compliance issues, if any, are included in the topical subsections along with a listing of compliance reports generated during or for the reporting year. The last table presented in this section is a list of all environmental permits for the NTS and its satellite facilities for 2006.

\subsection{Air Quality}

Clean Air Act (CAA), National Emission Standards for Hazardous Air Pollutants (NESHAP) - Under Title III of the CAA, NESHAP was established to control those pollutants that might reasonably be anticipated to result in either an increase in mortality or an increase in serious irreversible or incapacitating but reversible illness. Industry-wide national emissions standards were developed for 22 of the 189 designated hazardous air pollutants (HAPs). Radionuclides and asbestos were among the 22 HAPs for which standards were established. NESHAP compliance activities at the NTS and satellite facilities are limited to radionuclide monitoring and reporting and notification of asbestos abatement.

CAA, National Ambient Air Quality Standards (NAAQS) - Title I of the CAA established the NAAQS to limit levels of pollutants in the air for six "criteria" pollutants: sulfur dioxide, nitrogen oxides, carbon monoxide, ozone, lead, and particulate matter. Title V of the CAA authorizes the states to implement permit programs in order to regulate emissions of the criteria pollutants. At the NTS there is one main permit that regulates operations and emissions from aggregate-producing facilities, fuel-burning equipment, fuel storage, project-specific activities associated with the Non-Proliferation Test and Evaluation Complex (NPTEC), Test Cell C Facility, and the Tactical Demilitarization Development Project. Detonations conducted at the Big Explosives Experimental Facility (BEEF) and the Explosives Ordnance Disposal Unit (EODU) are also included in the permit. Nevada air quality permits specify emission limits for criteria pollutants (except ozone and lead) that are based on published emissions values for other similar industries and on operational data specific to the NTS. Lead is considered a HAP as well as a criteria pollutant, and emissions of lead are reported as part of the total HAPs emissions. Quantities of NAAQS and HAPS emissions from operations at the NTS are calculated and submitted each year to the state of Nevada. The NTS air permit also specifies recordkeeping and reporting requirements, performance testing requirements, visible emissions (opacity) limits for equipment or facilities, opacity field monitoring requirements, particulate monitoring requirements, and certification requirements for personnel conducting opacity monitoring.

State of Nevada regulations prohibit the open burning of combustible refuse and other materials unless specifically exempted by an authorized variance (Nevada Administrative Code [NAC] 445B.22067). At the NTS, Open Burn Variances are routinely obtained for fire extinguisher training, support vehicle live-fire training, and various emergency management exercises.

The NTS satellite facilities discussed in Appendix A operate under air quality permits that require the annual reporting of hours of operation, emissions quantities of criteria pollutants and HAPs, and summaries of significant malfunctions and repairs. 
CAA, New Source Performance Standards (NSPS) - The NSPS were established by Title I of the CAA to set minimum nationwide emission limitations of regulated air pollutants (HAPs and criteria pollutants mentioned above) and for various industrial categories of facilities. The state of Nevada has adopted the NSPS and regulates emissions from subject facilities through state law (Nevada Revised Statutes [NRS] 445B as codified in NAC 445B). At the NTS, some of the screens and conveyor belts that were manufactured after August 1981 are subject to NSPS under the category of Nonmetallic Mineral Processing Plants. Some of the bulk fuel storage tanks constructed after July 1984 must also comply with NSPS requirements. The NSPS imposes more stringent standards, including a reduced allowance of visible emissions (opacity) than under NAAQS. NSPS compliance activities on the NTS are reported to the state of Nevada. No NTS satellite facilities are subject to the NSPS regulations.

CAA, Stratospheric Ozone Protection - Title VI (Section 608) of the CAA establishes production limits and a schedule for the phase-out of ozone-depleting substances (ODS). ODS are defined as those substances that are known or could reasonably be anticipated to cause or contribute to stratospheric ozone depletion. Under Section 608, the U.S. Environmental Protection Agency (EPA) has established regulations through 40 Code of Federal Regulations (CFR) Part 82 that include: (1) maximizing recycling of ozone-depleting compounds during servicing and disposal of air conditioning and refrigeration equipment; (2) establishing requirements for recycling and recovery equipment, technicians, and reclaimers; (3) requiring the repair of substantial leaks in certain air conditioning and refrigeration equipment; and (4) establishing safe disposal requirements. While there are no reporting requirements for ODS, recordkeeping to document the usage of ODS and technician certification is required. Under Section 608, the EPA may conduct random inspections to determine compliance.

At the NTS, refrigerants containing ODS are mainly used in air conditioning units in vehicles, buildings, refrigerators, water fountains, vending machines, and laboratory equipment. Halon 1211 and 1301, now classified as ODS, have been used in the past in fire extinguishers. Self-assessments are conducted periodically to document adherence to Title VI of the CAA.

Other NTS Air Quality Permit Requirements - Under Title V, Part 70 of the CAA amendments, all owners or operators of Part 70 sources must pay annual fees to the state of Nevada. Any source which has the potential to emit 45.4 metric tons (mtons) (50 tons) or more of any regulated air pollutant, except carbon monoxide, must pay an annual fee of $\$ 3,000$. Any source that has the potential to emit less than 22.7 mtons ( 25 tons) per year of any regulated air pollutant, except carbon monoxide, must pay an annual fee of $\$ 250$. NTS operations are subject to these fees for the emission of criteria pollutants. In addition to permit fees, NNSA/NSO must allow the state of Nevada Bureau of Air Pollution Control to conduct inspections of NTS facilities and operations that are regulated by state air quality permits.

Section VII of the NTS Class II Air Quality Operating Permit, No. AP9711-0549.01 (Surface Area Disturbance Conditions), requires implementation of an ongoing program to control fugitive dust using the best practicable methods.

\subsubsection{Compliance Issues}

Performance emissions testing is required for point sources (equipment with emissions stacks) regulated by the NTS air permit. In 2006, the Area 23 Incinerator was permanently shut down and removed from the NTS air permit. The Area 27 Joint Actinide Shock Physics Experimental Research (JASPER) generator exceeded the 100-hour operating limit that requires emissions testing; it also exceeded the 90-day testing deadline. The exceedances were reported to NNSA/NSO and to the state's Bureau of Air Pollution Control. The JASPER generator failed its performance emission test. The Bureau of Air Pollution Control was notified of the test results, and the JASPER generator was shut down (see Section 3.2.2). Any environmental effects of excess emissions from the failed generator prior to shutdown is expected to have been negligible because the equipment is used so infrequently. 


\subsubsection{Compliance Reports}

The following reports were generated for 2006 NTS operations in compliance with air quality regulations:

- National Emissions Standards for Hazardous Air Pollutants, Calendar Year 2006 (submitted to EPA Region IX)

- Annual Asbestos Abatement Notification Form, submitted to EPA Region IX

- Calendar Year 2006 Actual Production/Emissions Reporting Form, submitted to the Nevada Division of Environmental Protection

- Quarterly Class II Air Quality Reports, submitted to the Nevada Division of Environmental Protection

- NPTEC Pre-test and Post-test Reports, submitted to the Nevada Division of Environmental Protection

The following reports were generated for 2006 operations at NTS satellite facilities in compliance with air quality regulations:

- Clark County Air Emission Inventory for North Las Vegas Facility, submitted to the Clark County Department of Air Quality and Environmental Management

- Clark County Air Emissions Inventory for Remote Sensing Laboratory, submitted to the Clark County Department of Air Quality and Environmental Management

\subsubsection{Compliance Status}

See Table 2-1 for a summary of how NNSA/NSO complied with air quality and protection regulations at the NTS and its satellite facilities in 2006. 
Table 2-1. NTS compliance status with applicable air quality regulations

\begin{tabular}{|c|c|c|c|}
\hline Compliance Measure/Actions & Compliance Limit & Compliance Status - 2006 & $\begin{array}{c}\text { Section } \\
\text { Reference (a) }\end{array}$ \\
\hline \multicolumn{4}{|l|}{ Clean Air Act - NESHAP } \\
\hline Annual dose equivalent from all radioactive air emissions & $\begin{array}{l}10 \mathrm{mrem} / \mathrm{yr}^{(b)} \\
(0.1 \mathrm{mSv} / \mathrm{yr})\end{array}$ & Compliant & 3.1 .5 \\
\hline $\begin{array}{l}\text { Notify EPA Region IX if the number of linear feet }(\mathrm{ft}) \text { or square feet }\left(\mathrm{ft}^{2}\right) \text { of } \\
\text { asbestos to be removed from a facility exceeds limit }\end{array}$ & 260 linear $\mathrm{ft}$ or $160 \mathrm{ft}^{2}$ (c) & Compliant & 3.2 .8 \\
\hline Maintain asbestos abatement plans, data records, activity/maintenance records & For up to 75 years & Compliant & 3.2.8 \\
\hline Submit quarterly reports of calculated emissions at the NTS to the state & $\begin{array}{c}\text { Due } 30 \text { days after end of } \\
\text { quarter }\end{array}$ & Compliant & 3.2.1 \\
\hline Submit annual report of calculated emissions at the NTS to the state & Due March 1 & Compliant & 3.2 .1 \\
\hline $\begin{array}{l}\text { Number of gallons of fuel used, hours of operation, and rate of } \\
\text { aggregate/concrete production by permitted equipment/facility at the NTS }\end{array}$ & Limit varies $(\mathrm{d})$ & Compliant & 3.2 .3 \\
\hline $\begin{array}{l}\text { Tons of emissions of each criteria pollutant produced by permitted } \\
\text { equipment/facility at the NTS based on calculations }\end{array}$ & PTE (e) varies & Compliant & $\begin{array}{c}\text { 3.2.1; } \\
\text { Table 3-12 }\end{array}$ \\
\hline Conduct opacity readings from permitted equipment/facility & Quarterly & Compliant & 3.2 .4 \\
\hline Conduct particulate monitoring for NPTEC and BEEF releases/detonations & Per test & Compliant & 3.2.5 \\
\hline Percent opacity of emissions from permitted equipment/facility at the NTS & $20 \%$ & Compliant & 3.2.4 \\
\hline $\begin{array}{l}\text { Submit test plans/final analysis reports for each chemical release test at NPTEC } \\
\text { or elsewhere and submit annual report of all chemicals released during the } \\
\text { year to the state }\end{array}$ & Annual report due March 1 & Compliant & $\begin{array}{l}\text { 3.2.5; } \\
\text { Table 3-17; } \\
\text { Table 3-18 }\end{array}$ \\
\hline $\begin{array}{l}\text { Submit annual report of calculated emissions at the NLVF and the RSL-Nellis } \\
\text { to Clark County }\end{array}$ & Due March 31 & Compliant & $\begin{array}{l}\text { A.1.3; } \\
\text { A.3.2 }\end{array}$ \\
\hline $\begin{array}{l}\text { Tons of emissions of each criteria pollutant produced by permitted } \\
\text { equipment/facility at the NTS based on calculations }\end{array}$ & PTE (e) varies & Compliant & $\begin{array}{l}\text { Table A-4; } \\
\text { Table A-8 }\end{array}$ \\
\hline
\end{tabular}


Table 2-1. NTS compliance status with applicable air quality regulations (continued)

\begin{tabular}{|c|c|c|c|}
\hline Compliance Measure/Actions & Compliance Limit & Compliance Status - 2006 & $\begin{array}{c}\text { Section } \\
\text { Reference }^{(\mathrm{a})}\end{array}$ \\
\hline \multicolumn{4}{|l|}{ Clean Air Act - NSPS } \\
\hline Percent opacity of emissions from permitted equipment/facility & $10 \%$ & Compliant & 3.2 .4 \\
\hline \multicolumn{4}{|l|}{ Clean Air Act - Stratospheric Ozone Protection } \\
\hline \multicolumn{4}{|l|}{ Other Nevada Air Quality Permit Regulations } \\
\hline Control fugitive dust for land disturbing activities & NA & Compliant & 3.2 .9 \\
\hline $\begin{array}{l}\text { Allow Nevada Bureau of Air Pollution Control access to conduct inspections } \\
\text { of facilities and operations regulated by state air permits }\end{array}$ & NA & Compliant & 3.2.2 \\
\hline
\end{tabular}

(a) The section(s) within this document that describe how compliance summary data were collected

(b) $\mathrm{mrem} / \mathrm{yr}=$ millirem per year; $\mathrm{mSv} / \mathrm{yr}=$ millisievert per year

(c) 260 linear $\mathrm{ft}$ or $160 \mathrm{ft}^{2}=79.3$ linear meters (m) or $14.9 \mathrm{~m}^{2}$

(d) Compliance limit is specific for each piece of permitted equipment/facility

(e) Potential to emit (PTE) = the quantities of criteria pollutants that each facility/piece of equipment would emit annually if it were operated for the maximum number of hours specified in the state air permit

(f) Not applicable 


\subsection{Water Quality and Protection}

Clean Water Act (CWA) -Prohibits the discharge of pollutants from point sources to waters of the U.S. without a National Pollutant Discharge Elimination System (NPDES) permit. The CWA also gives the EPA, or the approved state environmental control agency, the authority to implement pollution control programs. The CWA sets water quality standards for all contaminants in surface waters. At the NTS, CWA regulations are followed through compliance with permits issued by the Nevada Division of Environmental Protection (NDEP) and the Nevada State Health Division, Bureau of Health Protection Services (BHPS) for wastewater discharges and disposal of wastewater from facilities. NTS operations do not require any NPDES permits. A permanent NPDES permit was issued to NNSA/NSO in November 2006 for the discharge of pumped groundwater at the NLVF (see Appendix A).

Safe Drinking Water Act (SDWA) - Protects the quality of drinking water in the United States. It authorizes the EPA to establish safe standards of purity and requires all owners or operators of public water systems to comply with National Primary Drinking Water Standards (health-related standards). State governments, which assume this power from the EPA, also set Secondary Standards which are related to taste, odor, and visual aspects of drinking water. Nevada state law pertaining to public water systems (NAC 445A) ensures that such water systems meet the EPA water quality standards specified under the SDWA.

NAC 445A - Water Controls (Public Water Systems) - Enforces the SDWA requirements and sets standards for permitting, design, construction, operation, maintenance, certification of operators, and water quality of public water systems (PWS). The NTS has three PWS and two potable water hauler trucks which BHPS regulates through the issuance of permits. Although the SDWA sets drinking water standards for radionuclides, the state of Nevada does not require radionuclide monitoring of drinking water on the NTS because the NTS does not have a "community water system" (i.e., a PWS having at least 15 service connections and used by year-round residents). However, all potable water supply wells are monitored on the NTS for radionuclides in compliance with DOE Order 5400.5 Radiation Protection of the Public and the Environment (see Section 2.3).

NAC 444 and 445A - Water Controls (Water Pollution Control) - Regulates the collection, treatment, and disposal of wastewater and sewage at the NTS. The requirements of this state regulation are issued in permits for E Tunnel effluent waters, sewage lagoons, septic tanks, and septic hauler contractors and pumpers. Perched groundwater which seeps out of E Tunnel in Area 12 is contained and monitored annually for radiological contaminants and quarterly for non-radiological contaminants as required under an NDEP permit issued to the Defense Threat Reduction Agency. NNSA/NSO holds a general permit issued by NDEP covering two active and nine inactive sewage lagoon systems. Water quality and toxicity of the active sewage lagoons are monitored quarterly and annually, respectively, to meet permit requirements. The 23 septic systems on the NTS each process less than 5,000 gallons per day (gal/d) $(18,927$ liters/day), therefore they are not regulated by NDEP. The Bureau of Federal Facilities (BFF) regulates the NTS septic systems as commercial individual systems which treat domestic sewage only in quantities less than $5,000 \mathrm{gal} / \mathrm{d}$. The BFF does not require collection or analysis of sewage samples from these septic systems. The BHPS regulates the permits that NNSA/NSO holds for five septic tank pumpers and one septic tank pumping contractor's license.

NAC 534 - Nevada Division of Water Resources Regulations for Water Well and Related Drilling - Regulates the drilling and construction of new wells and the reworking of existing wells in order to prevent the wasting of underground waters and their pollution or contamination. Two site operations that are affected by this state regulation are the Underground Test Area (UGTA) Project and the Borehole Management Project. New water wells are drilled for ongoing UGTA investigations of site-specific hydrogeologic characteristics, underground source terms, and contaminant movement through groundwater. Over 1,100 existing boreholes on the NTS are being plugged according to these regulations, under the Borehole Management Project. 


\subsubsection{Compliance Issues}

All drinking water and wastewater samples in 2006 met regulatory water quality standards with two exceptions:

(1) the Area 12 PWS exceeded the drinking water standard for lead (see Section 4.2.1.1), and (2) and the levels of total dissolved solids (TDS) in two of the three sewage outfalls at NLVF exceeded the permit limits (see Appendix A, Section A.1.1.1).

\subsubsection{Compliance Reports}

The following reports were generated for NTS operations in 2006 in compliance with water quality regulations:

- Quarterly Monitoring Report for Nevada Test Site Sewage Lagoons submitted to NDEP (in compliance with permit GNEV93001)

- Results of water quality analyses for PWS were sent to the state throughout the year as they were obtained from the laboratory

- Water Pollution Control Permit NEV 96021, Quarterly Monitoring Report (for E Tunnel effluent monitoring) submitted to NDEP

- Water Pollution Control Permit NEV 96021, Quarterly Monitoring Report and Annual Summary Report for E Tunnel Waste Water Disposal System (DTRA, 2006)

The following reports were generated for operations at the NTS satellite facilities in 2006 in compliance with water quality regulations:

- Self-Monitoring Report for the National Nuclear Security Administration's North Las Vegas Facility: Permit VEH-112 submitted to the City of North Las Vegas

- Quarterly reports titled Remote Sensing Laboratory Self Monitoring Report-Permit No. CCWRD-080 submitted to the Clark County Water Reclamation District

- Two additional monitoring reports titled Remote Sensing Laboratory Additional Monitoring Reports - Permit No. CCWRD-080 submitted to Clark County Water Reclamation District

- Reports of groundwater discharge volumes for NLVF temporary NPDES permits TNEV2004364, TNEV2005437, and TNEV2006369 submitted each month to NDEP

\subsubsection{Compliance Status}

See Table 2-2 for a summary of how NNSA/NSO complied with air quality and protection regulations at the NTS and its satellite facilities in 2006. 
Table 2-2. NTS compliance status with applicable water quality and protection regulations

\begin{tabular}{|c|c|c|c|}
\hline Compliance Measure/Action & Compliance Limit & Compliance Status - 2006 & $\begin{array}{c}\text { Section } \\
\text { Reference }^{(a)}\end{array}$ \\
\hline \multicolumn{4}{|l|}{$\begin{array}{l}\text { Safe Drinking Water Act and Nevada Water Controls (NAC 445A - Water } \\
\text { Controls - Public Water Systems) }\end{array}$} \\
\hline Number of water samples containing coliform bacteria & 3 per month & Compliant & 4.2.1.1; Table 4-10 \\
\hline Concentration of inorganic contaminants in Area 12 PWS & Limit varies(c) & Noncompliant for lead & 4.2.1.1; Table 4-10 \\
\hline Concentration of inorganic Phase II contaminants in all PWS & Limit varies & Compliant & 4.2.1.1; Table 4-10 \\
\hline $\begin{array}{l}\text { Adhere to design, construction, maintenance, and operation regulations } \\
\text { specified by permits }\end{array}$ & $\mathrm{NA}^{(\mathrm{d})}$ & Compliant & - \\
\hline Allow BHPS access to conduct inspections of PWS and water hauling trucks & NA & Compliant & 4.2.1.2 \\
\hline \multicolumn{4}{|l|}{$\begin{array}{l}\text { Clean Water Act - NPDES/State Pollutant Discharge Elimination System } \\
\text { Permits }\end{array}$} \\
\hline $\begin{array}{l}\text { Measure and report volume of pumped groundwater discharged at the } \\
\text { NLVF }\end{array}$ & NA & Compliant & $\begin{array}{l}\text { Appendix A, } \\
\text { A.1.1.2; Table A-3 }\end{array}$ \\
\hline \multicolumn{4}{|l|}{$\begin{array}{l}\text { Clean Water Act and Nevada Water Pollution Controls - Sewage Disposal } \\
\text { (NAC } 444 \text { - Sewage Disposal) }\end{array}$} \\
\hline $\begin{array}{l}\text { Adhere to all design/construction/operation requirements for new systems } \\
\text { and those specified in } 23 \text { septic system permits, } 5 \text { septic tank pumper } \\
\text { permits, and } 1 \text { septic tank pumping contractor permit }\end{array}$ & NA & Compliant & 4.2 .3 \\
\hline \multicolumn{4}{|l|}{$\begin{array}{l}\text { Clean Water Act and Nevada Water Pollution Controls (NAC 445A - Water } \\
\text { Pollution Controls) }\end{array}$} \\
\hline $\begin{array}{l}\text { Value of 5-day Biological Oxygen Demand (BOD5), total suspended } \\
\text { solids (TSS), and } \mathrm{pH} \text { in one sewage lagoon water sample sampled quarterly }\end{array}$ & $\begin{array}{l}\text { BOD5: varies } \\
\text { TSS: no limit } \\
\text { pH: } 6.0-9.0 \text { S.U. }\end{array}$ & $\begin{array}{l}\text { Compliant - Samples collected } \\
\text { in Jan., Apr., Jul, and Oct. }\end{array}$ & $\begin{array}{c}\text { 4.2.3.1; } \\
\text { Table } 4-11\end{array}$ \\
\hline $\begin{array}{l}\text { Concentration of } 36 \text { contaminants in the filtrate from one sewage lagoon } \\
\text { sample collected annually from each of two permitted facilities }\end{array}$ & Limit varies & $\begin{array}{l}\text { Compliant - concentrations } \\
\text { within limits }\end{array}$ & $\begin{array}{c}\text { 4.2.3.2; } \\
\text { Table } 4-12\end{array}$ \\
\hline Inspection by operator of active sewage lagoon systems & Weekly & Compliant & 4.2 .3 .3 \\
\hline Inspection by operator of inactive sewage lagoon systems & Quarterly & Compliant & 4.2.3.3 \\
\hline $\begin{array}{l}\text { Submit quarterly monitoring reports for } 2 \text { active sewage lagoons (for } \\
\text { Areas } 6 \text { and 23) }\end{array}$ & $\begin{array}{l}\text { Due end of Jan., } \\
\text { Apr., Jul., Oct. }\end{array}$ & Compliant & - \\
\hline
\end{tabular}


Table 2-2. NTS compliance status with applicable water quality and protection regulations (continued)

\begin{tabular}{|c|c|c|c|}
\hline Compliance Measure/Action & Compliance Limit & Compliance Status - 2006 & $\begin{array}{c}\text { Section } \\
\text { Reference }^{(a)}\end{array}$ \\
\hline \multicolumn{4}{|l|}{$\begin{array}{l}\text { Clean Water Act and Nevada Water Pollution Controls (NAC 445A - Water } \\
\text { Pollution Controls) (continued) }\end{array}$} \\
\hline Allow NDEP access to conduct inspections of active sewage lagoon systems & NA & Compliant & 4.2.3.3 \\
\hline $\begin{array}{l}\text { Concentrations of tritium }\left({ }^{3} \mathrm{H}\right) \text {, gross alpha }(\alpha) \text {, and gross beta }(\beta) \text {, (in } \\
\text { picocuries per liter }[\mathrm{pCi} / \mathrm{L}]) \text {, and } 16 \text { nonradiological contaminants/water } \\
\text { quality parameters in E Tunnel effluent water samples collected quarterly }\end{array}$ & $\begin{array}{c}{ }^{3} \mathrm{H}: 1,000,000 \mathrm{pCi} / \mathrm{L} \\
\alpha: 35 \mathrm{pCi} / \mathrm{L} \\
\beta: 100 \mathrm{pCi} / \mathrm{L} \\
\text { Non-rad: Limit varies }\end{array}$ & Compliant & $\begin{array}{l}\text { 4.1.8: } \\
\text { Table } 4-5\end{array}$ \\
\hline $\begin{array}{l}\text { Concentrations of } 18 \text { contaminants in water samples from three NLVF sewage } \\
\text { outfalls and all sludge and liquid samples from the NLVF sand/oil interceptor }\end{array}$ & Limit varies & $\begin{array}{l}\text { Noncompliant for TDS at } \\
\text { Outfall B and Outfall C2 }\end{array}$ & $\begin{array}{l}\text { A.1.1.1; } \\
\text { Table A-2 }\end{array}$ \\
\hline $\begin{array}{l}\text { Concentrations of } 12 \text { contaminants in water samples from sewage outfall at } \\
\text { the RSL-Nellis }\end{array}$ & Limit varies & Compliant & $\begin{array}{c}\text { A.3.1; } \\
\text { Table A-7 }\end{array}$ \\
\hline \multicolumn{4}{|l|}{$\begin{array}{l}\text { NAC } 534 \text { - Nevada Division of Water Resources Regulations for Water Well } \\
\text { and Related Drilling }\end{array}$} \\
\hline $\begin{array}{l}\text { Maintain state well-drilling license for personnel supervising well } \\
\text { construction/reconditioning }\end{array}$ & NA & $\begin{array}{l}\text { Compliant - licensed personnel } \\
\text { supervised deepening of } \\
\text { ER-16-1 well }\end{array}$ & -- \\
\hline File notices of intent and affidavits of responsibility for plugging & NA & $\begin{array}{l}\text { Compliant - filed revised notice } \\
\text { of intent for deepening of } \\
\text { ER-16-1 well }\end{array}$ & -- \\
\hline Adhere to well construction requirements/waivers & NA & $\begin{array}{l}\text { Compliant - } 112 \text { boreholes } \\
\text { plugged for Borehole } \\
\text { Management Program }\end{array}$ & -- \\
\hline Maintain required records and submit required reports & NA & $\begin{array}{l}\text { Compliant - annual borehole } \\
\text { plugging report submitted to } \\
\text { Nevada Division of Water } \\
\text { Resources }\end{array}$ & -- \\
\hline
\end{tabular}

(a) The section(s) within this document that describe how compliance summary data were collected

(b) Not detectable

(c) Compliance limit is specific for each contaminant; see referenced tables for specific limits

(d) Not applicable 


\subsection{Radiation Dose Protection}

Clean Air Act (CAA), National Emission Standards for Hazardous Air Pollutants (NESHAP) - NESHAP (40 CFR 61 Subpart H) establishes a radiation dose limit of 10 millirem per year (mrem/yr) (0.1 millisievert per year $[\mathrm{mSv} / \mathrm{yr}])$ to individuals in the general public from the air pathway. Sources of radioactive air emissions on the NTS include: (1) evaporation of tritiated water (HTO) from containment ponds; (2) diffusion of HTO vapor from the soil at Area 5 Radioactive Waste Management Complex, Sedan crater, and Schooner crater; (3) release of tritium gas during calibration of analytical equipment at Building 650 in Area 23; and (4) resuspension of plutonium and americium from contaminated soil at nuclear device safety test and atmospheric test locations. NESHAP also specifies "Concentration Levels for Environmental Compliance" (abbreviated as CLs) for radionuclides. A CL is the annual average concentration of a radionuclide that could deliver a dose of $10 \mathrm{mrem} / \mathrm{yr}$. The CLs are provided for facilities which use air sampling at offsite receptor locations to demonstrate compliance.

Safe Drinking Water Act (SDWA) - The National Primary Drinking Water Regulations (40 CFR 141), promulgated by the SDWA, requires that the maximum contaminate level goal for any radionuclide be zero. But, when this is not possible (e.g., in groundwater containing naturally-occurring radionuclides), the SDWA specifies that the concentration of one or more radionuclides should not result in a whole body or organ dose greater than $4 \mathrm{mrem} / \mathrm{yr}$ $(0.04 \mathrm{mSv} / \mathrm{yr})$. Sources of radionuclide contamination in groundwater at the NTS are the underground nuclear tests detonated near or below the water table.

DOE Order 450.1, Environmental Protection Program - Requires federal facilities to: (1) conduct environmental monitoring to detect, characterize, and respond to releases from DOE activities, (2) assess impacts, (3) estimate dispersal patterns in the environment, (4) characterize the pathways of exposure to members of the public, (5) characterize the exposures and doses to individuals and to the population, and (6) evaluate the potential impacts to the biota in the vicinity of a DOE activity. Such releases, exposures, and doses apply to radiological contaminants.

DOE Order 5400.5, Radiation Protection of the Public and the Environment - This Order and its flow-down procedural standards establishes requirements for: (1) measuring radioactivity in the environment, (2) applying the ALARA (As Low As Reasonably Achievable) process to all operations, (3) using mathematical models for estimating radiation doses, (4) releasing property having residual radioactive material, and (5) maintaining records demonstrating compliance with the requirements. This Order sets a radiation dose limit of $100 \mathrm{mrem} / \mathrm{yr}(1 \mathrm{mSv} / \mathrm{yr})$ above background levels to individuals in the general public from all pathways of exposure combined. It also provides the derived concentration guides (DCGs) for all radionuclides. The DCGs are the annual average concentrations of a radionuclide that could deliver a dose of $100 \mathrm{mrem} / \mathrm{yr}$. The DCGs are provided as reference values to use in radiological protection programs at DOE facilities. The NESHAP CLs mentioned above are more conservative than one-tenth of the DCGs because they are computed with different dose models.

DOE Standard DOE-STD-1153-2002, A Graded Approach for Evaluating Radiation Doses to Aquatic and Terrestrial Biota - Provides methods, computer models, and guidance in implementing a graded approach to evaluating the radiation doses to populations of aquatic animals, terrestrial plants, and terrestrial animals residing on DOE facilities (DOE, 2002a), A dose limit of $1 \mathrm{rad}$ per day (rad/d) (10 milligray [mGy]/d) for terrestrial plants and aquatic animals, and of $0.1 \mathrm{rad} / \mathrm{d}(1 \mathrm{mGy} / \mathrm{d})$ for terrestrial animals is specified by this DOE standard. Dose rates below these levels are believed to cause no measurable adverse effects to populations of plants and animals.

DOE Order 435.1, Radioactive Waste Management - Ensures that all DOE radioactive waste is managed in a manner that is protective of the worker, public health and safety, and the environment. It directs how radioactive waste management operations are conducted on the NTS. These requirements are summarized in Section 2.4. The manual for this Order (DOE M435.1-1) specifies that operations at the Area 3 and Area 5 Radioactive Waste Management Sites (RWMSs) must not contribute a dose to the general public in excess of $25 \mathrm{mrem} / \mathrm{yr}$.

\subsubsection{Compliance Reports}

In compliance with NESHAP under the CAA, the report National Emission Standards for Hazardous Air Pollutants, Calendar Year 2006, was submitted to EPA Region IX in June 2007. This Nevada Test Site Environmental Report 2006 was generated to report 2006 compliance with DOE Order 5400.5 and DOE-STD-1153-2002. 


\subsubsection{Compliance Status}

Table 2-3 presents a summary of how NNSA/NSO complied with radiation protection regulations at the NTS and its satellite facilities in 2006.

Table 2-3. NTS compliance status with regulations for radiation protection of the public and the environment

\begin{tabular}{|c|c|c|c|}
\hline Compliance Measure & Compliance Limit & $\begin{array}{l}\text { Compliance } \\
\text { Status - } 2006\end{array}$ & $\begin{array}{c}\text { Section } \\
\text { Reference }^{(a)}\end{array}$ \\
\hline \multicolumn{4}{|l|}{ Clean Air Act - NESHAP } \\
\hline $\begin{array}{l}\text { Annual dose to the general public from all radioactive } \\
\text { air emissions }\end{array}$ & $\begin{array}{l}10 \mathrm{mrem} / \mathrm{yr} \\
(0.1 \mathrm{mSv} / \mathrm{yr})\end{array}$ & Compliant & 3.1.5 \\
\hline \multicolumn{4}{|l|}{ Safe Drinking Water Act } \\
\hline $\begin{array}{l}\text { Annual dose to the general public from drinking } \\
\text { water }\end{array}$ & $\begin{array}{c}4 \mathrm{mrem} / \mathrm{yr} \\
(0.04 \mathrm{mSv} / \mathrm{yr})\end{array}$ & Compliant $t^{(\mathfrak{b})}$ & $\begin{array}{c}\text { 4.1.4; } \\
\text { Table 4-1 }\end{array}$ \\
\hline \multicolumn{4}{|l|}{$\begin{array}{l}\text { DOE Order 5400.5, Radiation Protection of the Public } \\
\text { and the Environment }\end{array}$} \\
\hline $\begin{array}{l}\text { Annual dose above background levels to the general } \\
\text { public from all pathways }\end{array}$ & $\begin{array}{l}100 \mathrm{mrem} / \mathrm{yr} \\
(1 \mathrm{mSv} / \mathrm{yr})\end{array}$ & Compliant & $\begin{array}{l}\text { 8.1.7; Table 8-3; } \\
\text { A.1.5; Table A-5 }\end{array}$ \\
\hline $\begin{array}{l}\text { Total residual surface contamination of property } \\
\text { released offsite (in disintegrations per minute per } \\
100 \text { square centimeters }\left[\mathrm{dpm} / 100 \mathrm{~cm}^{2}\right] \text { ) }\end{array}$ & $\begin{array}{l}300-15,000 \mathrm{dpm} / 100 \mathrm{~cm}^{2} \\
\text { depending on } \\
\text { radionuclide }\end{array}$ & Compliant & 8.1 .6 \\
\hline \multicolumn{4}{|l|}{$\begin{array}{l}\text { DOE STD 1153-2002, A Graded Approach for Evaluating } \\
\text { Radiation Doses to Aquatic and Terrestrial Biota }\end{array}$} \\
\hline Absorbed radiation dose to terrestrial plants & $\begin{array}{c}1 \mathrm{rad} / \mathrm{d} \\
(0.01 \mathrm{~Gy} / \mathrm{d})\end{array}$ & Compliant & 8.2 \\
\hline Absorbed radiation dose to aquatic animals & $1 \mathrm{rad} / \mathrm{d}$ & Compliant & 8.2 \\
\hline Absorbed radiation dose to terrestrial animals & $\begin{array}{l}0.1 \mathrm{rad} / \mathrm{d} \\
(1 \mathrm{mGy} / \mathrm{d})\end{array}$ & Compliant & 8.2 \\
\hline \multicolumn{4}{|l|}{ DOE Order 435.1, Radioactive Waste Management } \\
\hline $\begin{array}{l}\text { Annual dose to the general public due to RWMS } \\
\text { operations }\end{array}$ & $\begin{array}{l}25 \mathrm{mrem} / \mathrm{yr} \\
(0.25 \mathrm{mSv} / \mathrm{yr})\end{array}$ & Compliant $^{(c)}$ & 5.3 .2 \\
\hline \multicolumn{4}{|l|}{ DOE Order 450.1, Environmental Protection Program } \\
\hline Conduct radiological environmental monitoring & $\mathrm{NA}^{(\mathrm{d})}$ & Compliant & $\begin{array}{l}3.1 ; 4.1 ; 5.0 ; \\
\quad 6.0 ; 7.0\end{array}$ \\
\hline Detect and characterize radiological releases & NA & Compliant & $\begin{array}{l}\text { 3.1; } 4.1 ; 5.0 ; 6.0 ; \\
\quad \text { Table 3-13 }\end{array}$ \\
\hline Characterize pathways of exposure to the public & NA & Compliant & 8.1 .1 \\
\hline $\begin{array}{l}\text { Characterize exposures and doses to individuals, the } \\
\text { population, and biota }\end{array}$ & NA & Compliant & $8.1 ; 8.2$ \\
\hline
\end{tabular}

(a) The section(s) within this document that describe how compliance summary data were collected.

(b) Migration of radioactivity in groundwater to offsite wells has never been detected.

(c) Nearest populations to the Area 3 and 5 RWMSs are Amargosa Valley (55 kilometers [km] away) and Cactus Springs (36 km away), respectively. They are too distant to receive any radiation exposure from operations at the sites.

(d) Not applicable. 


\subsection{Radioactive and Nonradioactive Waste Management and Environmental Restoration}

10 CFR 830: Nuclear Safety Management - Establishes requirements for the safe management of work at DOE's nuclear facilities. It governs the possession and use of special nuclear and byproduct materials. Part 830 also covers activities at facilities where no nuclear material is present such as facilities that prepare the non-nuclear components of nuclear weapons, but which could cause radiological damage at a later time. It governs the conduct of the "management and operating contractor and other persons at DOE nuclear facilities" (including visitors to the facility). When coupled with the Price-Anderson Amendments Act (PAAA) of 1988 (Section 234A to the Atomic Energy Act), it provides DOE with authority to assess civil penalties for violation of rules, regulations, or orders relating to nuclear safety by contractors, subcontractors, and suppliers who are indemnified under PAAA.

DOE Order 435.1, Radioactive Waste Management - Ensures that all DOE radioactive waste is managed in a manner that is protective of the worker, public health and safety, and the environment. Activities conducted on the NTS subject to this Order include: (1) characterization of low level radioactive waste (LLW) and low level mixed radioactive waste (LLMW) generated by DOE within the state of Nevada; (2) disposal of LLW and LLMW at the Area 3 and Area 5 RWMSs; (3) characterization, visual examination, and repackaging of transuranic (TRU) waste at the Waste Examination Facility south of the Area 5 RWMS; and (4) loading of TRU waste at the Area 5 RWMS for shipment to Idaho National Environmental Engineering Laboratory.

Atomic Energy Act (AEA) of 1954 (42 U.S.C. Sect. 2011 et seq.) - Ensures the proper management of source, special nuclear, and byproduct material. At the NTS, AEA regulations are followed through compliance with DOE Order 435.1 and 10 CFR 830.

40 CFR 265 (Groundwater Monitoring) Subpart F (40 CFR 265.92) - Requires groundwater monitoring to verify the performance of waste disposal facilities so as to protect groundwater from buried radioactive and mixed wastes (MW). The Pit 3 Mixed Waste Disposal Unit (P03U) at the Area 5 RWMS requires groundwater monitoring to verify the performance of the pit under this regulation, and as specified by a Resource Conservation and Recovery Act (RCRA) Part B permit (see below).

Resource Conservation and Recovery Act (RCRA) - Ensures the safe and environmentally responsible management of hazardous (see Glossary, Appendix B) and non-hazardous solid waste. RCRA and the Hazardous and Solid Waste Amendments of 1984 constitute the statutory basis for the regulation of hazardous waste (HW) and underground storage tanks (USTs). Under Section 3006, the EPA authorizes Nevada to administer and enforce HW permits for many NNSA/NSO facilities. In November 2005, Nevada renewed the RCRA Part B Permit (NEV HW0021). The permit regulates the operation of the Hazardous Waste Storage Unit (HWSU) in Area 5, the EODU in Area 11, and authorizes the disposal of LLMW generated from DOE offsite facilities in P03U at the Area 5 RWMS. Part II.K.2 of the permit requires preparation of an EPA Biennial Hazardous Waste Report of all HW volumes generated at the NTS and at the NLVF during a year. The permit also prescribes post-closure monitoring for five closed waste sites that were closed under RCRA as Corrective Action Units (CAUs) (see Section 9.4.2).

The NTS has five USTs and RSL-Nellis has 4 USTs. The tanks are either (1) fully regulated under RCRA and registered with the state; (2) regulated under RCRA and registered with the state of Nevada, but deferred from leak detection requirements; or (3) excluded from federal and state regulation. The UST program reports, upgrades, and removes USTs in accordance with regulatory compliance schedules.

RCRA also requires generators of HW to have a program in place to reduce the volume or quantity and toxicity of such waste. These requirements and NTS compliance with them are addressed under the Pollution Prevention and Waste Minimization sections of this report (Section 2.7, Section 11.0).

The specific Nevada laws which govern HW management operations under Permit NEV HW0021 are Disposal of Hazardous Waste (NRS 459-400-459.600), Facilities for Management of Hazardous Waste (NAC 44.842-444.8482), Disposal of Hazardous Waste (NAC 444.850-444.8746), and Limitations on Issuance of Permits (NAC 444.960). 


\section{Comprehensive Environmental Response, Compensation, and Liability Act (CERCLA)/Superfund} Amendments and Reauthorization Act (SARA) - Provides a framework for the cleanup of waste sites containing hazardous substances and an emergency response program in the event of a release of a hazardous substance to the environment. No HW cleanup operations on the NTS are regulated under CERCLA; they are regulated under RCRA instead. The only applicable requirements of CERCLA pertain to an emergency response program for hazardous substance releases (see Emergency Planning and Community Right-to-Know Act in Section 2.5).

Federal Facility Compliance Act (FFCA) - Extends the full range of enforcement authorities in federal, state, and local laws for management of HWs to federal facilities. The FFCA of 1992, signed by NNSA/NSO and the state of Nevada, requires the identification of existing quantities for MW, the proposal of methods and technologies of MW treatment and management, the creation of enforceable timetables, and the tracking and completion of deadlines.

Federal Facility Agreement and Consent Order (FFACO) - Pursuant to Section 120(a)(4) of CERCLA and to Sections 6001 and 3004(u) of RCRA, the DOE, U.S. Department of Defense, and the state of Nevada entered into a FFACO in May 1996. It addresses the environmental restoration of historically contaminated sites at the NTS, parts of Tonopah Test Range, parts of the Nevada Test and Training Range (NTTR), the Central Nevada Test Area, and the Project Shoal Area. Under the FFACO, hundreds of sites have been identified for cleanup and closure. An individual site is called a Corrective Action Site (CAS). Multiple CASs are often grouped into CAUs.

40 CFR Subchapter I, Parts 239-299: Solid Wastes - At the NTS, these federal solid waste management regulations are followed through compliance with permits issued by the NDEP.

NAC 444.570-7499 - Solid Waste Disposal Controls - Enforces the federal regulations pertaining to solid wastes. This Nevada regulation sets standards for solid waste management systems, including the storage, collection, transportation, processing, recycling, and disposal of solid waste. The NTS has one inactive and four active permitted landfills. The Area 5 Asbestiform Low-Level Solid Waste Disposal Unit P07U is inactive. Active units include the Area 5 Asbestiform Low-Level Solid Waste Disposal Unit P06U), Area 6 Hydrocarbon Disposal Site, Area 9 U10c Solid Waste Disposal Site, and Area 23 Solid Waste Disposal Site. These landfills are designed, constructed, operated, maintained, and monitored in adherence to the requirements of their state-issued permits.

\subsubsection{Compliance Reports}

The following reports were prepared in 2006 or 2007 to comply with environmental regulations for waste management and environmental restoration operations conducted on the NTS in 2006. All CAU/CAS reports prepared in 2006 as per the FFACO schedule are presented in Table 9-4 of Section 9.4.1.

- Annual Asbestos Disposal Report (for the Area 5 Asbestiform Low-Level Solid Waste Disposal Site P06U)

- Quarterly LLW/MLLW Disposal Reports (for all active LLW and MW disposal cells)

- 2005 EPA Biennial Hazardous W aste Report for the Nevada Test Site and North Las Vegas Facility (Note: this 2005 report was prepared and submitted to NDEP in February 2006, but was erroneously not included in DOE, 2006b

- Biannual Neutron Monitoring Report for the Nevada Test Site Area 9 10c and Area 6 Hydrocarbon Landfills

- Nevada Test Site 2006 Data Report: Groundwater Monitoring Program Area 5 Radioactive Waste Management Site (National Security Technologies, LLC, 2007a)

- Post-closure monitoring reports for the five RCRA Part B-identified CAUs

- January-June 2006 Biannual Solid Waste Disposal Site Report for the Nevada Test Site Area 23 Sanitary Landfill

- July-December 2006 Biannual Solid Waste Disposal Site Report for the Nevada Test Site Area 23 Sanitary Landfill

- 2006 Annual Solid Waste Disposal Site Report for the NTS Area 6 Hydrocarbon Landfill and Area 9 U10c Landfills

- Nevada Test Site 2006 Waste Management Monitoring Report Area 3 and Area 5 Radioactive Waste Management Sites (NSTec, 2007b)

\subsubsection{Compliance Status}

See Table 2-4 for a summary of how NNSA/NSO complied with waste management and environmental restoration regulations at the NTS in 2006. 
Table 2-4. NTS compliance status with applicable waste management and environmental restoration regulations

\begin{tabular}{|c|c|c|c|}
\hline Compliance Measure/Action & Compliance Limit & $\begin{array}{l}\text { Compliance } \\
\text { Status - } 2006\end{array}$ & $\begin{array}{c}\text { Section } \\
\text { Reference }^{(a)}\end{array}$ \\
\hline $\begin{array}{l}10 \text { CFR 830: Nuclear Facilities } \\
\text { Completion and maintenance of proper conduct of operations documents required for } \\
\text { Class II Nuclear Facility for disposal/characterization/storage of radioactive waste }\end{array}$ & $\begin{array}{l}\text { Six types of guiding documents } \\
\text { required }\end{array}$ & Compliant & $\begin{array}{c}\text { 9.1.1; } \\
\text { Table } 9-1\end{array}$ \\
\hline \multicolumn{4}{|l|}{ DOE Order 435.1 Radioactive Waste Management } \\
\hline $\begin{array}{l}\text { Establishment of Waste Acceptance Criteria for radioactive wastes received for } \\
\text { disposal/storage at Area } 3 \text { and } 5 \text { RWMSs }\end{array}$ & $N A^{(b)}$ & Compliant & $\begin{array}{c}\text { 9.1.1; } \\
\text { Table 9-1 }\end{array}$ \\
\hline Track volume of disposed LLW at Area 3 and Area 5 RWMSs (in cubic meters $\left[\mathrm{m}^{3}\right]$ ) & NA & $28,803 \mathrm{~m}^{3}$ & 9.1 .3 \\
\hline \multicolumn{4}{|l|}{$\begin{array}{l}40 \text { CFR } 265.92 \text { and Resource Conservation and Recovery Act (as enforced through permits } \\
\text { issued by the state of Nevada) }\end{array}$} \\
\hline $\begin{array}{l}\text { Volume of disposed LLMW at Pit } 3 \text { Mixed Waste Disposal Unit (P03U) (in cubic meters } \\
{\left[\mathrm{m}^{3}\right] \text { or cubic feet }\left[\mathrm{ft}^{3}\right] \text { ) }}\end{array}$ & $20,000 \mathrm{~m}^{3}\left(706,293 \mathrm{ft}^{3}\right)$ & Compliant & $\begin{array}{c}\text { 9.2.1; } \\
\text { Table 9-3 }\end{array}$ \\
\hline Volume of stored non-radioactive HW stored at the HWSU & $\begin{array}{l}61,600 \text { liters } \\
(16,280 \text { gallons })\end{array}$ & Compliant & $\begin{array}{c}\text { 9.2.2; } \\
\text { Table 9-3 }\end{array}$ \\
\hline $\begin{array}{l}\text { Weight of approved explosive ordnance wastes detonated at the EODU (in kilograms } \\
{[\mathrm{kg}] \text { or pounds [lbs]) }}\end{array}$ & $\begin{array}{l}45.4 \mathrm{~kg}(100 \mathrm{lbs}) \text { at a time, not to } \\
\text { exceed } 1 \text { detonation event/hour }\end{array}$ & Compliant & $\begin{array}{c}\text { 9.2.3; } \\
\text { Table 9-3 }\end{array}$ \\
\hline $\begin{array}{l}\text { Submit quarterly reports of volume of wastes received at P03U, HWSU, and EODU to } \\
\text { the state of Nevada }\end{array}$ & $\begin{array}{l}\text { Due April, July, October, } \\
\text { January }\end{array}$ & Compliant & 9.2 \\
\hline
\end{tabular}


Table 2-4. NTS compliance status with applicable waste management and environmental restoration regulations (continued)

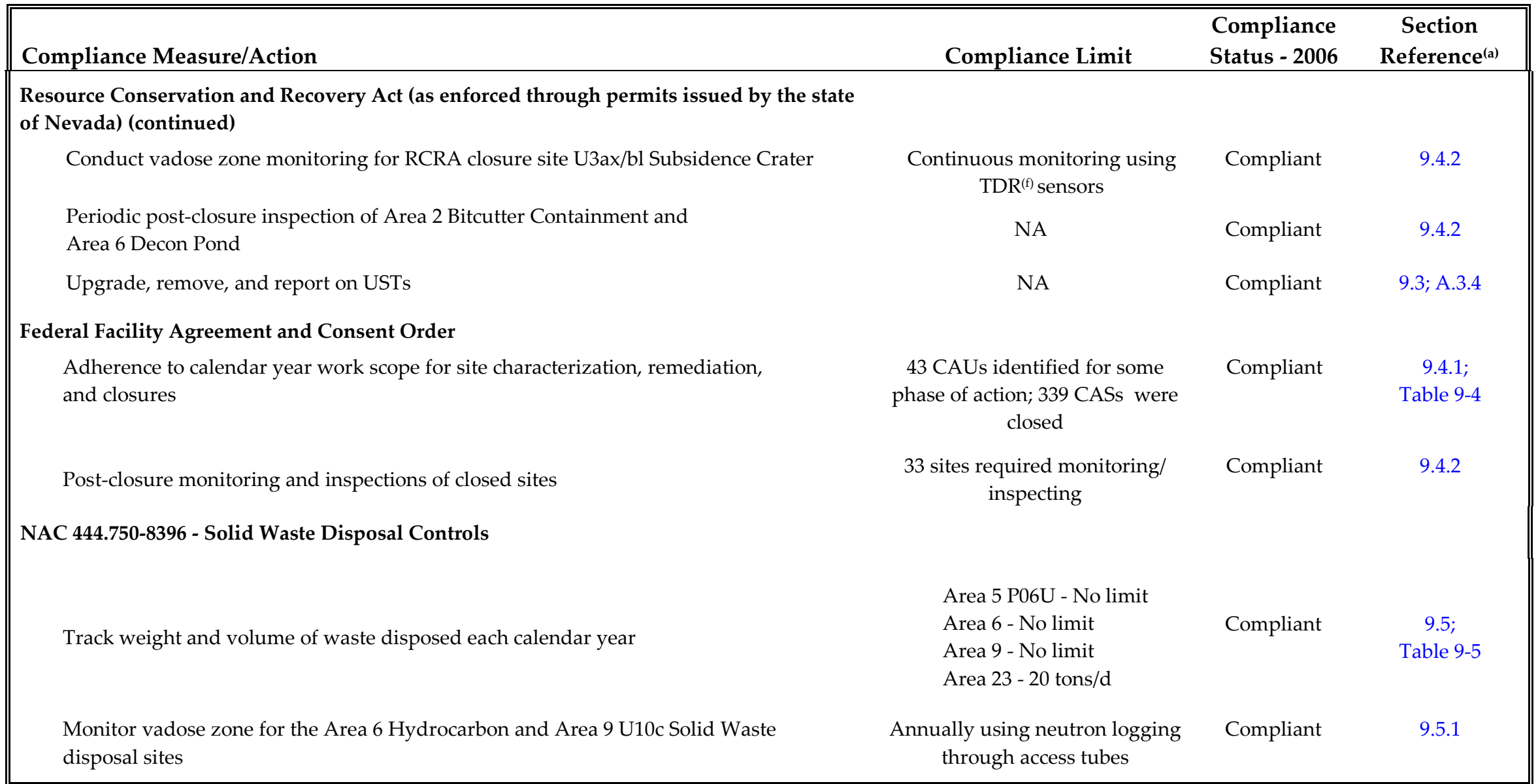

(a) The section(s) within this document that describe how compliance summary data were collected

(b) Not applicable

(c) $\mathrm{mmhos} / \mathrm{cm}=$ milli-mhos per centimeter

(d) $\mathrm{mg} / \mathrm{L}=$ milligram per liter

(e) $\mu \mathrm{g} / \mathrm{L}=$ micrograms per liter

(f) Time domain reflectometry 


\subsection{Hazardous Materials Control and Management}

Toxic Substances Control Act (TSCA) - Requires testing and regulation of chemical substances that enter the consumer market. Since the NTS does not produce chemicals, compliance with TSCA is primarily directed toward management of polychlorinated biphenyls (PCBs). The regulations implementing TSCA for the state of Nevada contain record keeping requirements for PCB activities (NAC 444.9452). At the NTS, remediation activities and maintenance of fluorescent lights can result in the disposal of PCB-contaminated waste and light ballasts. Disposal of these items on the NTS is regulated.

Federal Insecticide, Fungicide, and Rodenticide Act (FIFRA) - Sets forth procedures and requirements for pesticide registration, labeling, classification, devices for use, and certification of applicators. The use of certain pesticides (called "restricted-use pesticides") are regulated. The use of non-restricted-use pesticides (as available in consumer products) is not regulated. On the NTS, only non-restricted-use pesticides are applied under the direction of a state of Nevada certified applicator. Pesticide applications in food service facilities are subcontracted to statecertified vendors who provide these services.

Emergency Planning and Community Right-to-Know Act (EPCRA) - This act is a free-standing provision under Title III of the 1986 SARA Title III amendments to CERCLA. It requires that federal, state, and local emergency planning authorities be provided information regarding the presence and storage of hazardous substances and their planned and unplanned environmental releases, including provisions and plans for responding to emergency situations involving hazardous materials. EO 12856, Federal Compliance with Right-to-Know Laws and Pollution Prevention Requirements, requires all federal facilities to comply with the provisions of EPCRA. Under EPCRA, NNSA/NSO is required to submit reports pursuant to Sections 302, 304, 311, 312, and 313 of SARA Title III described below.

Section 302-303, Planning Notification - Requires that the state emergency response commission and the local emergency planning committee be notified when an extremely hazardous substance (EHS) is present at a facility in excess of the threshold planning quantity. An inventory of the location and amounts of all hazardous substances stored on the NTS and its satellite facilities is maintained. Inventory data are included in an annual report called the Nevada Combined Agency (NCA) Report. Also, NNSA/NSO monitors hazardous materials while they are in transit on the NTS through a hazardous materials notification system called HAZTRAK.

Section 304, Extremely Hazardous Substances Release Notification - Requires that the local emergency planning committee and state emergency response agencies be notified immediately of accidental or unplanned releases of an EHS to the environment. Also, the national response center is notified if the release exceeds the CERCLA reportable quantity for the particular hazardous substance.

Section 311-312, Material Safety Data Sheet (MSDS)/Chemical Inventory - Requires facilities to provide applicable emergency response agencies with MSDSs, or a list of MSDSs for each hazardous chemical stored on site. This is essentially a one-time reporting unless chemicals or products change. Any new MSDSs are provided annually in the NCA Report. Section 312 requires facilities to report maximum amounts of chemicals onsite at any one time. This report is submitted to the State Emergency Response Commission, the Local Emergency Planning Committee, and the local fire departments.

Section 313, Toxic Release Inventory (TRI) Reporting - Requires facilities to submit an annual report entitled "Toxic Chemical Release Inventory, Form R" to the EPA and to the state of Nevada if annual usage quantities of listed toxic chemicals exceed specified thresholds. Lead releases on the NTS above threshold limits are reported to the EPA and the State Emergency Response Commission in the TRI, Form R report.

NAC 555 - Control of Insects, Pests, and Noxious Weeds - Provides regulatory framework for certification of several classifications of registered pesticide and herbicide applicators in the state of Nevada. The Nevada Department of Agriculture administers this program and has the primary role to enforce FIFRA in Nevada. 
Inspections of pesticide/herbicide applicator programs are carried out by NDOA. Restricted-use pesticides are not used by NSTec at the NTS.

NAC 444 - Polychlorinated Biphenyls (PCBs) - This code incorporates by reference the federal requirements for the handling, storage, and disposal of PCBs at the NTS.

State of Nevada Chemical Catastrophe Prevention Act - This state act directed the NDEP to develop and implement an accident prevention program which was named the Chemical Accident Prevention Program. The act requires registration of facilities storing EHSs above listed thresholds. A report is submitted to the NDEP if any storage quantity thresholds are exceeded.

\subsubsection{Compliance Reports}

The following reports were generated for 2006 NNSA/NSO operations on the NTS and its satellite facilities in compliance with hazardous materials control and management regulations:

- Nevada Combined Agency Report - Calendar Year 2006, submitted to state and local agencies

- Toxic Release Inventory Report, Form R for CY2006 Operations, submitted to the EPA and to the state of Nevada

- Calendar Year (CY) 2006 Polychlorinated Biphenyls (PCBs) Report for the Nevada Test Site (NTS), submitted to NNSA/NSO (no longer required to be submitted to the EPA)

\subsubsection{Compliance Status}

See Table 2-5 for a summary of how NNSO/NSA complied with regulations for hazardous materials control and management at the NTS and its satellite facilities in 2006. 
Table 2-5. NTS compliance status with applicable regulations for hazardous substance control and management

\begin{tabular}{|c|c|c|c|}
\hline Compliance Measure/Action & Compliance Limit & Compliance Status - 2006 & $\begin{array}{c}\text { Section } \\
\text { Reference }\end{array}$ \\
\hline \multicolumn{4}{|l|}{ Toxic Substances Control Act (TSCA) and } \\
\hline \multicolumn{4}{|l|}{ NAC 444 - Polychlorinated Biphenyls } \\
\hline Storage and offsite disposal of PCB materials & Required if $>50 \mathrm{ppm}^{(\mathrm{b})} \mathrm{PCBs}$ & Compliant & 10.1 \\
\hline Storage and onsite disposal of PCB materials & Allowed if $<50 \mathrm{ppm}$ PCBs & Compliant & 10.1 \\
\hline $\begin{array}{l}\text { Disposal of bulk product waste containing PCBs generated } \\
\text { by remediation and site operations }\end{array}$ & $\begin{array}{l}\text { Case-by-case approval by } \\
\text { NDEP }\end{array}$ & Compliant & 10.1 \\
\hline $\begin{array}{l}\text { Generate report of quantities of PCB liquids and materials } \\
\text { disposed offsite during previous calendar year }\end{array}$ & Due July 1 of following year & Compliant & 10.1 \\
\hline \multicolumn{4}{|l|}{$\begin{array}{l}\text { Federal Insecticide, Fungicide, and Rodenticide Act (FIFRA) and } \\
\text { NAC } 555 \text { - Control of Insects, Pests, and Noxious Weeds }\end{array}$} \\
\hline $\begin{array}{l}\text { Application of restricted-use pesticides are conducted under } \\
\text { the direct supervision of a state-certified applicator }\end{array}$ & $\mathrm{NA}^{(\mathrm{c})}$ & Compliant & 10.2 \\
\hline $\begin{array}{l}\text { Maintain state certification of onsite pesticide and herbicide } \\
\text { applicator }\end{array}$ & NA & Compliant & 10.2 \\
\hline \multicolumn{4}{|l|}{ Emergency Planning and Community Right-to-Know Act (EPCRA) } \\
\hline Section 302-303 Planning Notification & $\begin{array}{l}\text { NCA Report due in March for } \\
\text { previous calendar year }\end{array}$ & Compliant & $\begin{array}{l}\text { 10.3; A.1.4; } \\
\text { A.3.3 }\end{array}$ \\
\hline Section 304 - EHS Release Notification & $\begin{array}{l}\text { Notification Report due } \\
\text { immediately after a release }\end{array}$ & Compliant & $\begin{array}{l}\text { 10.3; A.1.4; } \\
\text { A.3.3 }\end{array}$ \\
\hline Section 311-312 - MSDS/Chemical Inventory & $\begin{array}{l}\text { NCA Report due in March for } \\
\text { previous calendar year }\end{array}$ & Compliant & $\begin{array}{l}\text { 10.3; A.1.4; } \\
\quad \text { A.3.3 }\end{array}$ \\
\hline Section 313 - TRI Reporting & $\begin{array}{l}\text { TRI Report, Form R due July } 1 \\
\text { for previous calendar year }\end{array}$ & Compliant & $\begin{array}{l}\text { 10.3; A.1.4; } \\
\text { A.3.3 }\end{array}$ \\
\hline \multicolumn{4}{|l|}{ State of Nevada Chemical Catastrophe Prevention Act } \\
\hline $\begin{array}{l}\text { Registration of NTS with the state if EHSs are stored above } \\
\text { listed threshold quantities }\end{array}$ & $\begin{array}{l}\text { NDEP-CAPP }(\mathrm{d}) \text { Report due } \\
\text { June 21, } 2006\end{array}$ & Compliant & 10.4 \\
\hline
\end{tabular}

\footnotetext{
(a) The section(s) within this document that describe how compliance summary data were collected

(b) $\mathrm{ppm}=$ parts per million

(c) Not applicable

(d) Chemical Accident Prevention Program
} 


\subsection{National Environmental Policy Act}

Before any project or activity is initiated at the NTS, it must be evaluated for possible impacts to the environment. Under the National Environmental Policy Act (NEPA), federal agencies are required to consider environmental effects and values and reasonable alternatives before making a decision to implement any major federal action that may have a significant impact on the human environment. NNSA/NSO uses four levels of documentation to demonstrate compliance with NEPA:

- Environmental Impact Statement (EIS) - a full disclosure of the potential environmental effects of proposed actions and the reasonable alternatives to those actions

- Environmental Assessment (EA) - a concise discussion of proposed actions and alternatives and the potential environmental effects to determine if an EIS is necessary

- Supplement Analysis (SA) - a collection and analysis of information for an action already addressed in an existing EIS or EA used to determine whether a supplemental EIS or EA should be prepared, a new EIS or EA should be prepared, or no further NEPA documentation is required

- Categorical Exclusion (CX) - a category of actions which do not have a significant adverse environment impact based on similar previous activities, and for which, therefore, neither an EA nor an EIS is required

A NEPA Environmental Evaluation Checklist (Checklist) is completed for all proposed projects or activities on the NTS, as required under the NNSA/NV Work Acceptance Process Procedural Instructions (Carlson, 2000). The Checklist is reviewed by the NNSA/NSO NEPA Compliance Officer to determine whether the activity's environmental impacts have been addressed in existing NEPA documents. If a proposed project has not been covered under any previous NEPA analysis and it does not qualify as a CX, then a new NEPA analysis is performed. The NEPA analysis may result in preparation of a new EA or a new SA to the existing programmatic NTS EIS (DOE, 1996a). The NEPA Compliance Officer must approve each Checklist before a project proceeds. Table 2-6 presents a summary of how NNSA/NSO complied with NEPA in 2006 for 97 projects.

Table 2-6. NTS NEPA compliance activities conducted in 2006

\section{Results of NEPA Checklist Reviews / NEPA Compliance Activities}

23 projects were exempted from further NEPA analysis because they were of CX status.

66 projects were exempted from further NEPA analysis due to their inclusion under previous analysis in the NTS EIS (DOE, 1996a) and its Record of Decision.

1 project was exempted from further NEPA analysis due to its inclusion under previous analysis in the Final Environmental Impact Statement for the Proposed Relocation of Technical Area 18 Capabilities and Materials at the Los Alamos National Laboratory (DOE, 2002b).

The EA titled Environmental Assessment for Large-Scale, Open-Air Explosive Detonation DIVINE STRAKE at the Nevada Test Site (DOE, 2005b) was revised and reissued (DOE, 2006a).

2 projects were exempted from further NEPA analysis due to their inclusion under previous analysis in the Environmental Assessment for Large-Scale, Open-Air Explosive Detonation DIVINE STRAKE at the Nevada Test Site (DOE, 2005b; DOE, 2006a).

1 project was exempted from further NEPA analysis due to its inclusion under previous analysis in the Final

Environmental Assessment for Activities Using Biological Simulants and Releases of Chemicals at the Nevada Test Site (DOE, 2004a).

2 projects were exempted from further NEPA analysis due to their inclusion under previous analysis in the Environmental Assessment for Hazardous Materials Testing at the Hazardous Materials Spill Center, Nevada Test Site (DOE, 2002c) and in the Final Environmental Assessment for Activities Using Biological Simulants and Release of Chemicals at the Nevada Test Site (DOE, 2004a).

1 project was exempted from further NEPA analysis due to its inclusion under previous analysis in the Environmental Assessment for the Radiological/Nuclear Countermeasures Test and Evaluation Complex (DOE, 2004b). 


\subsection{Pollution Prevention and Waste Minimization}

Resource Conservation and Recovery Act (RCRA) - Through 42 USC 6922 (b)(1) of RCRA, generators of hazardous waste are required to have a program in place to reduce the volume or quantity and toxicity of such waste to the degree determined by the generator to be economically practicable. The EPA was required to develop a list of types of commercially-available products (e.g., copy machine paper, plastic desk top items) and then specify that a certain minimum percentage of the product type's content be comprised of recycled materials if they are to be purchased by a federal agency (e.g., all federally-purchased copy machine paper must be comprised of a minimum of 30 percent recycled paper). It then requires federal facilities to have a procurement process in place to ensure that they purchase product types which satisfy the EPA-designated minimum percentages of recycled material.

EO 13101, Greening the Government through Waste Prevention, Recycling and Federal AcquisitionRequires federal facilities to incorporate waste prevention and recycling into daily operations. It requires federal facilities to maintain an affirmative procurement process that ensures that 100 percent of products purchased which are found on the EPA-designated product list contain recycled material at the EPA-specified minimum content.

DOE Order 450.1, Environmental Protection Program - Requires federal facilities to implement an Environmental Management System (EMS) that includes pollution prevention. The EMS must be fully integrated into the site Integrated Safety Management System (ISMS).

NDEP Hazardous Waste Permit Number NEV HW0021 - This state permit requires NNSA/NSO to maintain an Annual Waste Minimization Summary Report in the Facility Operating Records. This report should include a description of the efforts taken during the year to reduce the volume and toxicity of waste generated as per RCRA, as well as a description of the changes in volume and toxicity of waste actually achieved during the year in comparison to previous years to the extent such information is available for the years prior to 1984 .

\subsubsection{Compliance Reports}

The compliance reports for 2006 activities performed to comply with pollution prevention and waste minimization (P2/WM) directives are presented in Table 2-7.

\subsubsection{Compliance Status}

See Table 2-7 for a summary of how NNSA/NSO complied with P2/WM regulations in 2006. 
Table 2-7. NTS compliance status with applicable P2/WM regulations

\begin{tabular}{|c|c|c|c|}
\hline Compliance Measure/Action & $\begin{array}{l}\text { Compliance } \\
\text { Limit/Goal }\end{array}$ & $\begin{array}{l}\text { Compliance } \\
\text { Status } 2006\end{array}$ & $\begin{array}{c}\text { Section } \\
\text { Reference (a) }\end{array}$ \\
\hline \multicolumn{4}{|l|}{ Resource Conservation and Recovery Act of 1976 (RCRA) } \\
\hline $\begin{array}{l}\text { Have a program in place to reduce the volume or quantity and } \\
\text { toxicity of generated hazardous waste to the degree it is } \\
\text { economically practicable }\end{array}$ & $\mathrm{NA}^{(\mathrm{b})}$ & Compliant & 11.1 \\
\hline $\begin{array}{l}\text { Have a process in place to ensure that EPA-designated-list } \\
\text { products are purchased containing the minimum content of } \\
\text { recycled materials }\end{array}$ & NA & Compliant & 11.1 \\
\hline \multicolumn{4}{|l|}{$\begin{array}{l}\text { EO 13101, Greening the Government through Waste Prevention, } \\
\text { Recycling and Federal Acquisition }\end{array}$} \\
\hline Incorporate waste prevention and recycling into daily operations & NA & Compliant & 11.1 \\
\hline $\begin{array}{l}\text { Percent of all purchased items which contain the minimum } \\
\text { content of recycled material as specified on the EPA-designated } \\
\text { product list }\end{array}$ & $100 \%$ & $\begin{array}{l}\text { Noncompliant } \\
\quad 73 \%\end{array}$ & 11.1 \\
\hline $\begin{array}{l}\text { Submit a } 2006 \text { fiscal year RCRA/EO } 13101 \text { Report to } \\
\text { DOE/Headquarters (HQ) by entering the site's data into the } \\
\text { DOE/HQ electronic database }\end{array}$ & $\begin{array}{l}\text { Due } \\
\text { December 15, } \\
2006\end{array}$ & Compliant & - \\
\hline \multicolumn{4}{|l|}{ DOE Order 450.1, Environmental Protection Program } \\
\hline $\begin{array}{l}\text { Submit a } 2006 \text { fiscal year (October 1, } 2005 \text { - September 31, 2006) } \\
\text { Waste Generation and Pollution Prevention Progress Report to } \\
\text { DOE/HQ }\end{array}$ & $\begin{array}{l}\text { Due } \\
\text { December 15, } \\
2006\end{array}$ & Compliant & 11.3 \\
\hline \multicolumn{4}{|l|}{ NDEP Hazardous Waste Permit Number NEV HW0021 } \\
\hline $\begin{array}{l}\text { Submit a } 2006 \text { calendar year Waste Minimization Summary } \\
\text { Report to NDEP }\end{array}$ & $\begin{array}{c}\text { Due by } \\
\text { March 1, } 2007\end{array}$ & Compliant & 11.3 \\
\hline
\end{tabular}

(a) The section(s) within this document that describe how compliance summary data were collected

(b) Not applicable 


\subsection{Historic Preservation and Cultural Resource Protection}

National Historic Preservation Act of 1966, as amended - This Act presents the goals of federal participation in historic preservation and delineates the framework for federal activities. Section 106 requires federal agencies to take into account the effects of their undertakings on properties included in, or eligible for inclusion in, the National Register of Historic Places (NRHP) and to consult with interested parties. The Section 106 process involves the agency reviewing background information, identifying eligible properties for the NRHP within the area of potential effect through consultation with the Nevada Historic Preservation Officer (SHPO), making a determination of effect (when applicable), and developing a mitigation plan when an adverse effect is unavoidable. Determinations of eligibility, effect, and mitigation are conducted in consultation with the SHPO and, in some cases, the federal Advisory Council on Historic Preservation. Section 110 sets out the broad historic preservation responsibilities of federal agencies and is intended to ensure that historic preservation is fully integrated into the ongoing programs of all federal agencies. It requires federal agencies to develop and implement a Cultural Resources Management Plan, to identify and evaluate the eligibility of historic properties for long-term management as well as for future projectspecific planning; and to maintain archaeological collections and their associated records at professional standards. At the NTS, a long-term management strategy includes: (1) monitoring NRHP-listed and eligible properties to determine if environmental or other actions are negatively affecting the integrity or other aspects of eligibility and (2) taking corrective actions if necessary.

EO 11593, Protection and Enhancement of the Cultural Environment - Reinforces the obligation of federal agencies to conduct adequate surveys to locate any and all sites of historic value under their jurisdiction.

Archeological Resources and Protection Act of 1979 - The purpose of this act is to secure, for the present and future benefit of the American people, the protection of archaeological resources and sites which are on public and Indian lands, and addresses the irreplaceable heritage of archaeological sites and materials. It requires the issuance of a federal archaeology permit to qualified archaeologists for any work that involves excavation or removal of archaeological resources on federal and Indian lands and notification to Indian tribes of these activities. Unauthorized excavation, removal, damage, alteration, or defacement of archaeological resources is prohibited, as is the sale, purchase, exchange, transport, receipt of, or offer for sale of, such resources. Criminal and civil penalties apply to such actions. Information concerning the nature and location of any archaeological resource may not be made available to the public unless the federal land manager determines that the disclosure would not create a risk of harm to the resources or site. The Secretary of Interior is required to submit an annual report at the end of each fiscal year to Congress which reports the scope and effectiveness of all federal agencies' efforts on the protection of archaeological resources, specific projects surveyed, resources excavated or removed, damage or alterations to sites, criminal and civil violations, the results of permitted archaeological activities, and the costs incurred by the federal government to conduct this work. All archaeologists working at the NTS must have qualifications that meet federal standards and must work under a permit issued by NNSA/NSO. In the event of vandalism, NNSA/NSO would need to investigate the actions.

American Indian Religious Freedom Act of 1978 - This law established the government policy to protect and preserve for American Indians their inherent right of freedom to believe, express, and exercise the traditional religions, including but not limited to access to sites, use and possession of sacred objects, and the freedom to worship through ceremonials and traditional rites. Locations exist on the NTS that have religious significance to Western Shoshone and Southern Paiute; visits to these places involve prayer and other activities. Access is provided by NNSA/NSO as long as there are no safety or health hazards.

Native American Graves Protection and Repatriation Act (NAGPRA) of 1990 - This act requires federal agencies to identify Native American human remains, funerary objects, sacred objects, and objects of cultural patrimony in their possession. Agencies are required to prepare an inventory of human remains and associated funerary objects, as well as a summary with a general description of sacred objects, objects of cultural patrimony, and unassociated funerary objects. Through consultation with Native American tribes, the affiliation of the remains and objects are determined and the tribes can request repatriation of their cultural items. The agency is required to publish a notice of inventory completion in the Federal Register. The law also protects the physical location where human 
remains are placed during a death rite or ceremony. The NTS artifact collection is subject to NAGPRA and the locations of American Indian human remains at the NTS must to be protected from NTS activities.

\subsubsection{Reporting Requirements}

NNSA/NSO submits Section 106 cultural resources survey reports and historical evaluations to the Nevada SHPO for review and concurrence. Mitigation plans and mitigation documents also are submitted to the Nevada SHPO and some types of documents go to the Advisory Council on Historic Preservation and the National Park Service. Reports containing restricted data on site locations are not available to the public. Some technical reports, however, are available to the public upon request and can be obtained from the National Technical Information Service. The 2006 reports submitted to agencies are discussed in Chapter 12.

\subsubsection{Compliance Status}

See Table 2-8 for a summary of how NNSA/NSO complied with historic preservation and cultural resource protection regulations on the NTS in 2006.

Table 2-8. NTS compliance status with historic preservation regulations

\begin{tabular}{|c|c|c|}
\hline Compliance Action & $\begin{array}{l}\text { Compliance } \\
\text { Status - } 2006\end{array}$ & $\begin{array}{c}\text { Section } \\
\text { Reference }^{(a)}\end{array}$ \\
\hline \multicolumn{3}{|l|}{$\begin{array}{l}\text { National Historic Preservation Act of } 1966 \text { and } \\
\text { EO 11593, Protection and Enhancement of the Cultural Environment }\end{array}$} \\
\hline Maintain and implement NTS Cultural Resources Management Plan & Compliant & - - \\
\hline $\begin{array}{l}\text { Conduct cultural resources inventories and evaluations of historic } \\
\text { structures }\end{array}$ & Compliant & $\begin{array}{c}\text { 12.1; } \\
\text { Table } 12-1\end{array}$ \\
\hline Make determinations of eligibility to the National Register & Compliant & $\begin{array}{c}\text { 12.1.2; } \\
\text { Table 12-1 }\end{array}$ \\
\hline Make assessments of impact to eligible properties & Compliant & 12.1.2 \\
\hline Manage artifact collection as per required professional standards & Compliant & 12.2 \\
\hline \multicolumn{3}{|l|}{ Archaeological Resources and Protection Act of 1979} \\
\hline Conduct archaeological work by qualified personnel & Compliant & - \\
\hline Determine if archaeological sites have been damaged & Compliant & 12.1.3.2 \\
\hline $\begin{array}{l}\text { Complete and submit Secretary of the Interior Archaeology } \\
\text { Questionnaire }\end{array}$ & Compliant & 12.1.3.3 \\
\hline \multicolumn{3}{|l|}{ American Indian Religious Freedom Act of 1978} \\
\hline $\begin{array}{l}\text { Allow American Indians access to NTS locations for ceremonies } \\
\text { and traditional use }\end{array}$ & Compliant & 12.3 \\
\hline \multicolumn{3}{|l|}{ Native American Graves Protection and Repatriation Act } \\
\hline $\begin{array}{l}\text { Consult with affiliated Native American Indian tribes regarding } \\
\text { repatriation of cultural items }\end{array}$ & Completed & 12.2 \\
\hline Protect Native American Indian burial locations on NTS & Compliant & 12.2 \\
\hline \multicolumn{3}{|l|}{ Overall Requirement } \\
\hline Consult with tribes regarding various cultural resources issues & Compliant & 12.3 \\
\hline
\end{tabular}

(a) The section(s) within this document that describe how compliance summary data were collected 


\subsection{Conservation and Protection of Biota and Wildlife Habitat}

Endangered Species Act (ESA) - Section 7 of this act requires federal agencies to ensure that their actions do not jeopardize the continued existence of federally listed endangered or threatened species or their critical habitat. The threatened desert tortoise is the only animal protected under the ESA which may be impacted by NTS operations. NTS activities within tortoise habitat are conducted so as to comply with the terms and conditions of Biological Opinions issued by the U.S. Fish and Wildlife Service (FWS) to NNSA/NSO.

Migratory Bird Treaty Act (MBTA) - Prohibits the harming of any migratory bird, their nest, or eggs without authorization by the Secretary of the Interior. All but five of the 239 bird species observed on the NTS (Wills and Ostler, 2001) are protected under this act. Biological surveys are conducted for projects to prevent direct harm to protected birds, nests, and eggs.

Bald Eagle Protection Act - Prohibits the capture or harming of bald and golden eagles without special authorization. Both bald and golden eagles occur on the NTS. Biological surveys are conducted for projects to prevent direct harm to eagles and their nests and eggs.

Clean Water Act (CWA), Section 404, Wetlands Regulations - Regulates land development affecting wetlands by requiring a permit obtained from the U.S. Army Corps of Engineers (USACE) to discharge dredged or fill material into waters of the United States, which includes most wetlands on public and private land. NTS projects are evaluated for their potential to disturb wetlands and their need for a Section 404 permit application. Based on recent rulings, no natural NTS wetland may meet the criteria of a "jurisdictional" wetland subject to Section 404 regulations. However, final determination from the USACE regarding the status of NTS wetlands has yet to be received.

National Wildlife Refuge Administration Act - Forbids a person to knowingly disturb or injure vegetation or kill vertebrate or invertebrate animals or their nests or eggs on any National Wildlife Refuge lands unless permitted by the Secretary of the Interior. The boundary of the Desert National Wildlife Refuge (DNWR), land administered within this System, is approximately $5 \mathrm{~km}(3.1 \mathrm{mi})$ downwind of the NPTEC in Area 5. Biological monitoring is conducted to verify that tests conducted at the NPTEC do not disperse toxic chemicals that could harm biota on the DNWR.

EO 11990, Protection of Wetlands - Requires governmental agencies to minimize the destruction, loss, or degradation of wetlands and to preserve and enhance the natural and beneficial values of wetlands in carrying out the agency's responsibilities, including managing federal lands and facilities. Projects are evaluated for their potential to disturb the more than 20 natural water sources on the NTS. NTS wetlands are monitored to document their status and use by wildlife, even though they may not meet the criteria for "jurisdictional" status under the CWA.

EO 11988, Floodplain Management - Ensures protection of property and human wellbeing within a floodplain and protection of floodplains themselves. The Federal Emergency Management Agency publishes guidelines and specifications for assessing alluvial fan flooding. NNSA/NSO generally satisfies EO 11988 through DOE Order 420.1, Facility Safety, and invoked standards. DOE Order 420.1 and the associated implementation guide for mitigation of natural phenomena hazards call for a graded approach to assessing risk to all facilities (structures, systems, and components [SSC]) from potential natural hazards. Chapter 4 of DOE Standard 1020 (DOE-STD-1020-2002) provides flood design and evaluation criteria for SSC. Evaluations of flood hazards at the NTS are generally conducted to ensure protection of property and human well-being.

EO 13186, Responsibilities of Federal Agencies to Protect Migratory Birds - Directs federal agencies to take certain actions to further implement the MBTA if agencies have, or are likely to have, a measurable negative effect on migratory bird populations. It also directs federal agencies to support the conservation intent of the MBTA and conduct actions, as practicable, to benefit the health of migratory bird populations. NTS projects are evaluated for their potential to impact such bird populations.

EO 13112, Invasive Species - Directs federal agencies to act to prevent the introduction of, or to monitor and control, invasive (non-native) species, to provide for restoration of native species, and to exercise care in taking 
actions that could promote the introduction or spread of invasive species. Land-disturbing activities on the NTS have resulted in the spread of numerous invasive plant species. Habitat reclamation and other controls are evaluated and conducted when feasible to control such species and meet the purposes of this EO.

Wild Free-Roaming Horse and Burro Act - Requires the protection, management, and control of wild horses and burros on public lands and calls for the management and protection of these animals in a manner that is designed to achieve and maintain a thriving natural ecological balance. Wild horses on the NTS may wander off the NTS onto public lands and therefore are protected under this act. This act makes it unlawful to harm wild horses and burros.

DOE Order 450.1, Environmental Protection Program - Requires federal facilities to address the protection of site resources from wildland and operational fires and the protection of the environment and biota from site activities through the integration of an EMS into each site's ISMS (see Section 2.10). Annual surveys of vegetation fuel hazards, ecosystem mapping, surveys for protected and important species, and habitat revegetation are conducted to meet the intent of this Order.

Five-Party Cooperative Agreement - Agreement between NNSA/NSO, NTTR, FWS, Bureau of Land Management (BLM), and the state of Nevada Clearinghouse that calls for cooperation in conducting resource inventories and developing resource management plans for wild horses and burros and to maintain favorable habitat on federally withdrawn lands for these animals. BLM considers NTS a zero herd-size management area.

NNSA/NSO consults with BLM regarding any issue of NTS horse management. Biologist conduct periodic horse census surveys on the NTS.

NAC 503.010-503.104 - Protection of Wildlife - Identifies Nevada animal species, both protected and un-protected, and prohibits the harm of protected species without special permit. Over 200 bird species and 1 bat species on the NTS are State-protected. Biological surveys are conducted for projects to prevent direct harm to protected birds, nests, eggs, and protected bats.

NAC 527.270 - Protection of Flora - Requires that the State Forester Firewarden determine the protective status of Nevada plants and prohibits removal or destruction of protected plants without special permit. Currently, no Stateprotected plant species are known to occur on the NTS. Annual reviews of the status of NTS plants are conducted.

\subsubsection{Compliance Issues}

Four deaths recorded among migratory birds in 2006 were related to NTS activities (roadkill and electrocution, see Table 13-4). No feasible mitigation actions were identified or taken to reduce future bird mortality from these causes.

\subsubsection{Compliance Reports}

The following reports were prepared in 2006 or 2007 to meet regulation requirements or to document compliance for all activities conducted in 2006:

- Annual Report of Actions Taken Under Authorization of the Biological Opinion on NTS Activities (File No. 1-5-96-F-33)January 1, 2006 Through December 31, 2006

- Annual Report for Handling Permit 26952 for 2006, submitted via email to Nevada Division of Wildlife (Julie Meadows)

- Annual Report for Federal Migratory Bird Scientific Collecting Permit MB008695-0, submitted via FAX to FWS Portland Office

- Annual Report for Federal Migratory Bird Special Purpose Possession Permit (Dead Permit) MB037277-0, submitted via FAX to FWS Portland Office

\subsubsection{Compliance Status}

See Table 2-9 for a summary of how NNSA/NSO complied with regulations related to the conservation and protection of biota and wildlife habitat on the NTS in 2006. 
Table 2-9. NTS compliance status with applicable biota and wildlife habitat regulations

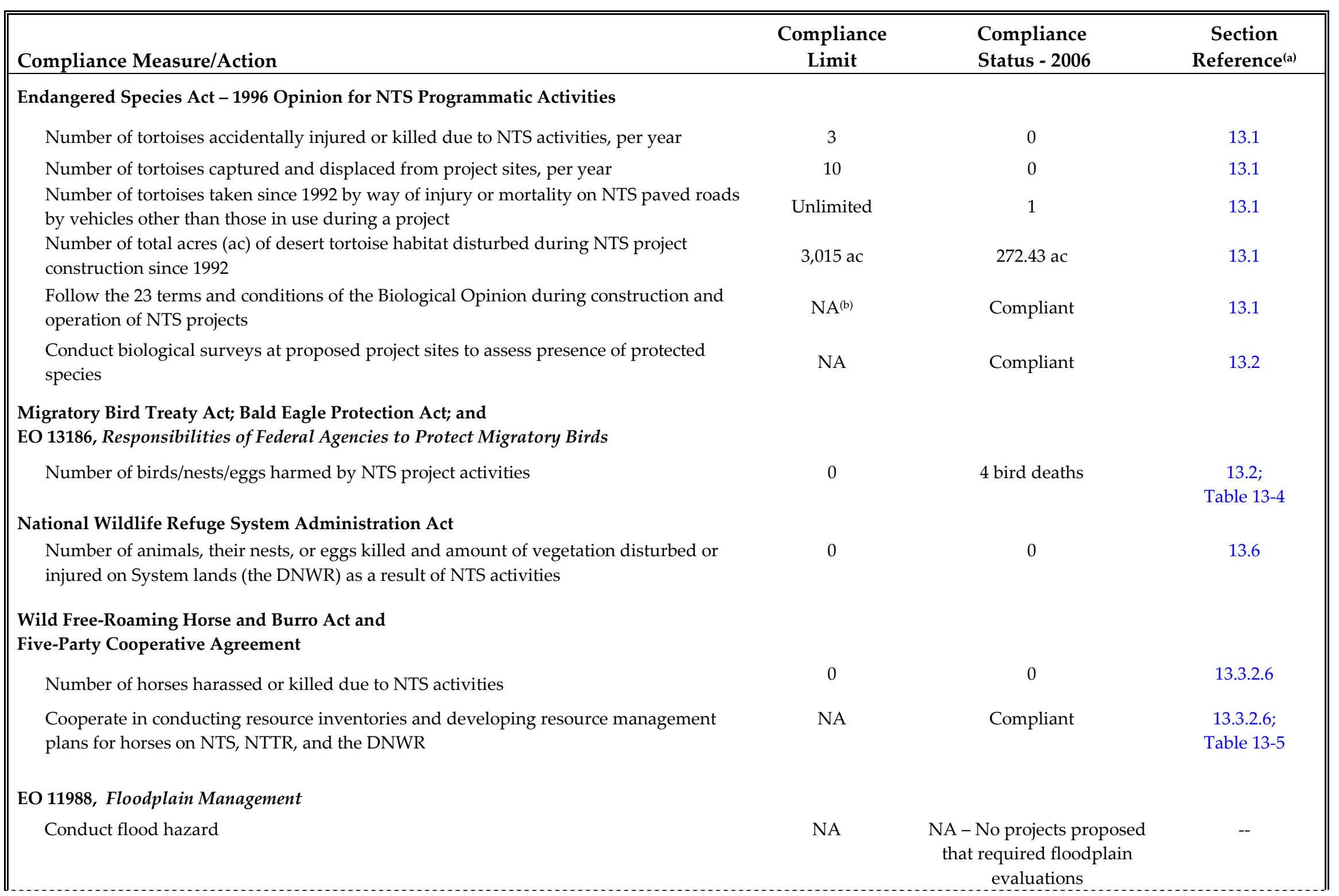




\begin{tabular}{|c|c|c|c|}
\hline Compliance Measure/Action & $\begin{array}{l}\text { Compliance } \\
\text { Limit }\end{array}$ & $\begin{array}{l}\text { Compliance } \\
\text { Status - } 2006\end{array}$ & $\begin{array}{c}\text { Section } \\
\text { Reference }^{(a)}\end{array}$ \\
\hline \multicolumn{4}{|l|}{$\begin{array}{l}\text { Clean Water Act, Section 404-Wetlands Regulations and } \\
\text { EO 11990, Protection of Wetlands }\end{array}$} \\
\hline Number of wetlands disturbed by NTS activity & NA & 0 & 13.3.4 \\
\hline \multicolumn{4}{|l|}{ EO 13112, Invasive Species } \\
\hline $\begin{array}{l}\text { Evaluate feasibility of conducting habitat reclamation and other controls to control } \\
\text { spread of invasive species }\end{array}$ & NA & Compliant & $\begin{array}{l}\text { 13.1, 13.4, } \\
\text { Table } 13-6\end{array}$ \\
\hline \multicolumn{4}{|l|}{$\begin{array}{l}\text { NAC 503.010-503.104 and NAC 527.270 - Nevada Protective Measures for } \\
\text { Wildlife and Flora }\end{array}$} \\
\hline $\begin{array}{l}\text { Number of state-protected animals harmed or killed and number of state-protected } \\
\text { plants collected or harmed due to NTS activities }\end{array}$ & 0 & 4 bird deaths & $\begin{array}{l}\text { 13.3.2.3; } \\
\text { Table 13-4 }\end{array}$ \\
\hline
\end{tabular}

(a) The sections within this document that describe how compliance summary data were collected

(b) Not applicable 


\subsection{Environmental Management System}

EO 13148, Greening the Government through Leadership in Environmental Management - Requires federal facilities to have an EMS that considers potential environmental impacts in all aspects of its work. This is especially important in the work planning and budgeting stages. Pollution prevention, eliminating potential wastes, and recycling materials must always be addressed when planning work. The EO required that the EMS be in place by the end of 2005.

DOE Order 450.1, Environmental Protection Program - Requires each DOE facility to implement an EMS which is a continuing cycle of planning, implementing, evaluating, and improving processes and actions undertaken to achieve environmental goals. The objectives are to implement sound stewardship practices that are protective of the air, water, land, and other natural and cultural resources impacted by DOE operations, by which DOE cost-effectively meets or exceeds compliance with applicable environmental, public health, and resource protection laws, regulations, and DOE requirements. The Order required each DOE site's EMS to be fully integrated into their site's ISMS by the end of 2005.

\subsubsection{Compliance Reports}

No reports were required in 2006 to comply with this Executive Order and DOE Order. Chapter 17 presents the status and 2006 activities related to NSTec's EMS.

\subsubsection{Compliance Status}

See Table 2-10 for a summary of how NNSA/NSO complied with EMS regulations.

Table 2-10. NTS compliance status with EMS regulations

\begin{tabular}{||lcc||}
\hline \hline Compliance Measure/Action & $\begin{array}{c}\text { Compliance } \\
\text { Status - 2006 }\end{array}$ & $\begin{array}{c}\text { Section } \\
\text { Reference }^{(a)}\end{array}$ \\
\hline $\begin{array}{l}\text { EO 13148, Greening the Government through Leadership in } \\
\text { Environmental Management }\end{array}$ & \\
$\quad \begin{array}{l}\text { Have an EMS in place by end of 2005 } \\
\text { DOE Order 450.1, Environmental Protection Program }\end{array}$ & Compliant & 17.0 \\
$\quad \begin{array}{l}\text { Incorporate the EMS into the site's ISMS } \\
\text { Implement the EMS by annually identifying } \\
\text { environmental aspects, objectives, targets, and goals, and } \\
\text { tracking environmental measures to improve processes }\end{array}$ & Compliant & 17.0 \\
\hline
\end{tabular}




\subsection{Occurrences, Unplanned Releases, and Continuous Releases}

Comprehensive Environmental Response, Compensation, and Liability Act (CERCLA) - Continuous release reporting under Section 103 requires that a non-permitted hazardous substance release that is equal to or greater than its reportable quantity be reported to the National Response Center. The EPA requires all facilities that release a hazardous substance meeting the Section 103(f) requirements to report annually to EPA and perform an annual evaluation of releases. CERCLA requirements applicable to NTS operations also pertain to an emergency response program for hazardous substance releases to the environment (see discussion of EPCRA in Section 2.5).

Emergency Planning and Community Right-to-Know Act (EPCRA) - This act is described in Section 2.5. See Table 2-5 for summary of compliance to EPCRA pertaining to unplanned environmental releases of hazardous substances.

40 CFR 302.1 - 302.8: Designation, Reportable Quantities, and Notification - Requires facilities to notify federal authorities of spills or releases of certain hazardous substances designated under CERCLA and the CWA. It specifies what quantities of hazardous substance spills/releases must be reported to authorities and delineates the notification procedures for a release that equals or exceeds the reportable quantities.

DOE Order 231.1A, Environment, Safety, and Health Reporting - This Order includes the requirement for reporting environmental occurrences. Along with DOE M 231.1-2, Occurrence Reporting and Processing of Operations Information, it requires the establishment and maintenance of a system for reporting operations information related to DOE-owned and leased facilities, for processing that information to identify the root causes of environmental occurrences, and for providing appropriate corrective action for such occurrences.

NAC 445A.345-445.348 - Notification of Release of Pollutant - Requires state notification for the unplanned or accidental releases of specified quantities of pollutants, hazardous wastes, and contaminants.

Water Pollution Control General Permit GNEV93001 - This general wastewater discharge permit issued by the state to the NTS specifies that no petroleum products will be discharged into treatment works without first being processed through an oil/water separator or other approved methods. It also specifies how NNSA/NSO shall report each bypass, spill, upset, overflow, or release of treated or untreated sewage.

Other NTS Permits/Agreements - As with General Permit GNEV93001, there are other state permits and agreements cited in previous subsections of this chapter (e.g., FFACO) that specify that accidents or events of noncompliance must be reported. These include events that may create an environmental hazard.

\subsubsection{Compliance Status}

There are no continuous releases on the NTS or at its satellite facilities.

In 2006, no reportable environmental occurrence happened at the NTS or at its satellite facilities. 


\subsection{Summary of Permits}

Table 2-11 presents the complete list of all federal and state permits active during calendar year 2006 that were issued to NNSA/NSO and to NSTec for NTS, NLVF, and RSL-Nellis operations and which have been referenced in previous subsections of this chapter. The table includes those pertaining to air quality monitoring, operation of drinking water and sewage systems, hazardous materials and hazardous waste management and disposal, and endangered species protection. Reports associated with these permits are submitted to the appropriate designated state or federal office. Copies of reports may be obtained upon request.

Table 2-11. Environmental permits required for NTS and NTS site facility operations

\begin{tabular}{|c|c|c|c|}
\hline $\begin{array}{l}\text { Permit } \\
\text { Number }\end{array}$ & Description & Expiration Date & Reporting \\
\hline Air Quality & NTS & & \\
\hline AP9711-0549.01 & NTS Class II Air Quality Operating Permit & June 25, 2009 & Annually \\
\hline $06-28$ & NTS Burn Variance (Various Locations) & March 12, 2007 & None \\
\hline \multirow[t]{2}{*}{$06-49$} & $\begin{array}{l}\text { NTS Open Burn Variance, NTS, A-23, Facility \#23-T00200 } \\
\text { (NTS Fire \& Rescue Training Center) }\end{array}$ & April 30, 2007 & None \\
\hline & NLVF & & \\
\hline \multirow[t]{2}{*}{ Facility 657, Mod. 2} & $\begin{array}{l}\text { Clark County Authority to Construct/Operating Permit for a } \\
\text { Testing Laboratory }\end{array}$ & None & March \\
\hline & RSL-Nellis & & \\
\hline NY-0360-12NTNC & Areas 6 and 23 & September 30, 2007 & None \\
\hline NY-4098-12NTNC & Area 25 & September 30, 2007 & None \\
\hline NY-4099-12NTNC & Area 12 & September 30, 2007 & None \\
\hline NY-0835-12NP & NTS Water Hauler \#84846 & September 30, 2007 & None \\
\hline NY-0836-12NP & NTS Water Hauler \#84847 & September 30, 2007 & None \\
\hline \multicolumn{4}{|c|}{ NTS Septic Systems and Pumpers } \\
\hline NY-1054 & Septic System, Area 3 (Waste Management Offices) & None & None \\
\hline NY-1069 & Septic System, Area 18 (820 $0^{\text {th }}$ Red Horse Squadron) & None & None \\
\hline NY-1076 & Septic System, Area 6 (Airborne Response Team Hangar) & None & None \\
\hline NY-1085 & Septic System, Area 25 (Central Support Area) & None & None \\
\hline NY-1086 & Septic System, Area 25 (Reactor Control Point) & None & None \\
\hline NY-1087 & Septic System, Area 27 (Able Compound) & None & None \\
\hline NY-1089 & Septic System, Area 12 (Camp) & None & None \\
\hline NY-1090 & $\begin{array}{l}\text { Septic System, Area } 6 \text { (Los Alamos National Laboratory } \\
\text { Construction Camp Site) }\end{array}$ & None & None \\
\hline NY-1091 & Septic System, Area 23 (Gate 100) & None & None \\
\hline
\end{tabular}


Table 2-11. Environmental permits required for NTS and NTS site facility operations (continued)

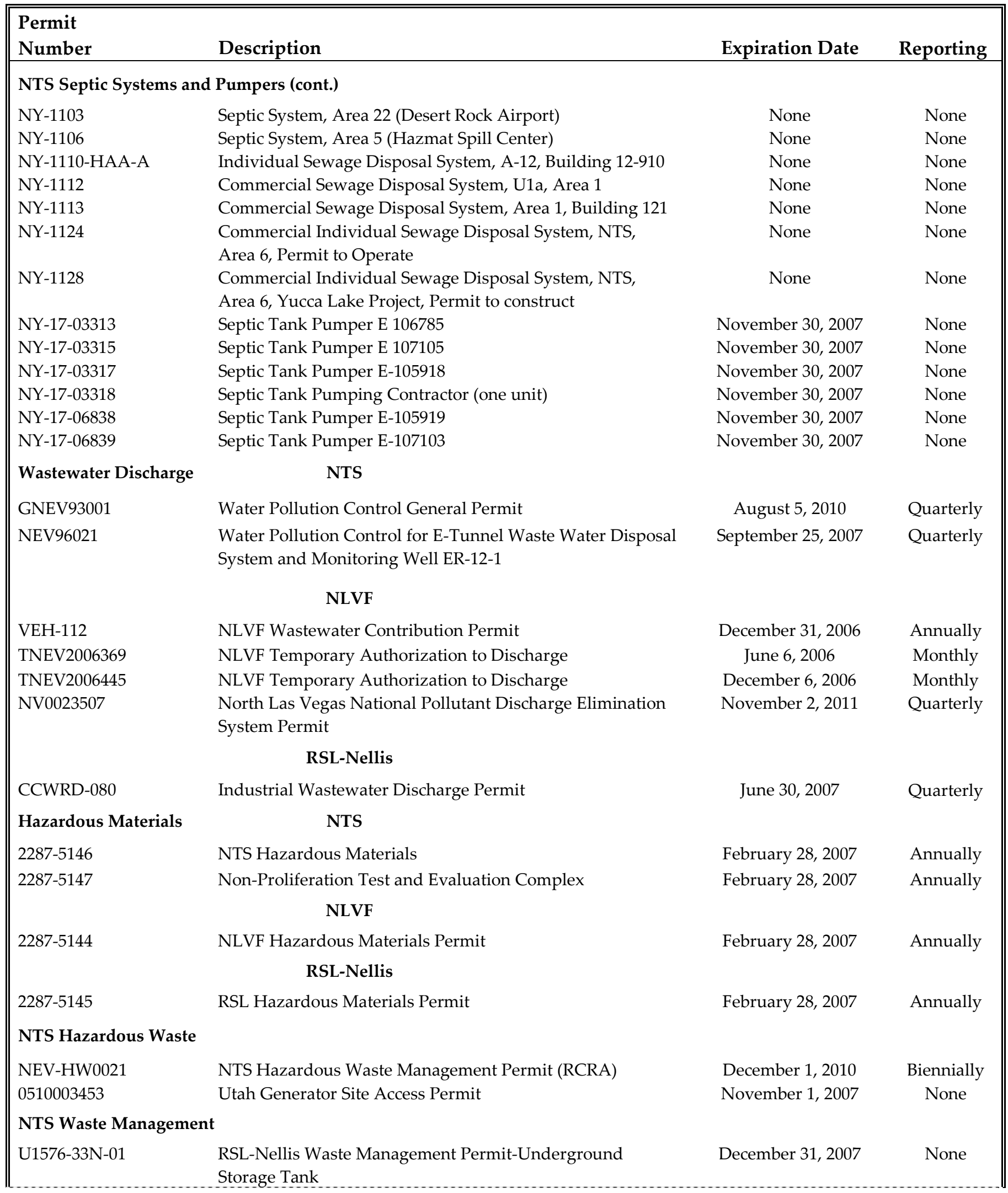


Table 2-11. Environmental permits required for NTS and NTS site facility operations (continued)

\begin{tabular}{|c|c|c|c|}
\hline \begin{tabular}{|l} 
Permit \\
Number
\end{tabular} & Description & Expiration Date & Reporting \\
\hline \multicolumn{4}{|l|}{ NTS Disposal Sites } \\
\hline SW 1300001 & Area 5 Asbestiform Low-Level Solid Waste Disposal Site & Post-closure (a) $^{(1)}$ & Annually \\
\hline SW 1309702 & Area 6 Hydrocarbon Disposal Site & Post-closure & Annually \\
\hline SW 1309703 & Area 9 U10c Solid Waste Disposal Site & Post-closure & Annually \\
\hline SW 1309704 & Area 23 Solid Waste Disposal Site & Post-closure & Annually \\
\hline \multicolumn{4}{|c|}{ Endangered Species/Wildlife/Special Use } \\
\hline File No. 1-5-96-F-33 & $\begin{array}{l}\text { U.S. Fish and Wildlife Service - Desert Tortoise Incidental } \\
\text { Take Authorization (Biological Opinion for Programmatic } \\
\text { NTS Activities) }\end{array}$ & December 31, 2006 & Annually \\
\hline MB008695-0 & $\begin{array}{l}\text { U.S. Fish and Wildlife Service - Migratory Bird Scientific } \\
\text { Collecting Permit }\end{array}$ & December 31, 2009 & Annually \\
\hline MB037277-1 & $\begin{array}{l}\text { U.S. Fish and Wildlife Service - Migratory Bird Special } \\
\text { Purpose Possession - Dead Permit }\end{array}$ & March 31, 2009 & Annually \\
\hline S26952 & $\begin{array}{l}\text { Nevada Division of Wildlife - Scientific Collection of } \\
\text { Wildlife Samples }\end{array}$ & December 31, 2006 & Annually \\
\hline SUP LAME 25AO 1324 & $\begin{array}{l}\text { U.S. Department of the Interior, National Park Service } \\
\text { Special Use Permit - issued for fly-over missions by RSL- } \\
\text { Nellis over Lake Mead National Recreation Area to establish } \\
\text { a natural environmental background radiation reference } \\
\text { standard test line for equipment calibration. }\end{array}$ & December 31, 2007 & $\begin{array}{c}\text { None } \\
\text { Required }\end{array}$ \\
\hline
\end{tabular}

(a) Permit expires 30 years after closure of the landfill 


\subsection{Radiological and Nonradiological Air Monitoring}

Section 3.1 of this chapter presents the results of radiological air monitoring conducted on the Nevada Test Site (NTS) to ensure compliance with radioactive air emission standards (see Section 2.1). Sources of radioactive air emissions from the NTS include evaporation of tritiated water from containment ponds; diffusion of tritiated water vapor from the soil at Area 3 and Area 5 Radioactive Waste Management Sites (RWMSs), Sedan crater, and Schooner crater; release of tritium gas during equipment calibrations at Building 650 in Area 23; and resuspension of plutonium and americium from contaminated soil at historical nuclear device safety test locations and atmospheric test locations. In 2006, radiological monitoring was conducted by Bechtel Nevada (BN) (up through June 30) and then by National Security Technologies, LLC (NSTec), Environmental Technical Services. The concentrations of radioactivity in air samples are used to assess radiological dose to the general public in the vicinity of the NTS. The assessed dose to the public from all pathways of exposure (i.e., air, water, direct radiation exposure, and consumption of game animals) is presented in Section 8.0 (Radiological Dose Assessment).

An oversight air monitoring program has been established by the U.S. Department of Energy, National Nuclear Security Administration Nevada Site Office (NNSA/NSO) to monitor radionuclide contamination of air within communities adjacent to the NTS. This independent oversight program is managed by the University of Nevada's Desert Research Institute (DRI) of the Nevada System of Higher Education. DRI's 2006 offsite air monitoring results are presented in Section 6.0.

Section 3.2 of this chapter presents the results of non-radiological air quality assessments conducted on the NTS to ensure compliance with current air quality permits (see Section 2.1). NTS operations which are potential sources of non-radiological air pollution include aggregate production, surface disturbance (e.g., construction), release of fugitive dust from driving on unpaved roads, use of fuel-burning equipment, open burning, venting from bulk fuel storage facilities, and releases of various chemicals during testing at the Non-Proliferation Test and Evaluation Complex (NPTEC) or at other release areas. In 2006, air quality assessments were conducted by BN (up through June 30) and then by NSTec Environmental Services (ES).

\subsection{Radiological Air Monitoring}

U.S. Department of Energy (DOE) Order 5400.5, Radiation Protection of the Public and the Environment, and the Clean Air Act (CAA) National Emission Standards for Hazardous Air Pollutants (NESHAP) require air monitoring for radiological emissions at the NTS. Radiological air monitoring is conducted to ensure that no significant emission source that contributes to calculable offsite exposures is ignored and that the NTS is in full compliance with the requirements of DOE Order 5400.5 and the CAA. To accomplish this, an air surveillance network comprised of air particulate samplers and samplers for tritium in atmospheric moisture has been established. The objectives and design of the network are described in detail in the Routine Radiological Environmental Monitoring Plan (DOE, 2003a). The network monitors airborne radioactivity near NTS sites at which radioactivity from past nuclear testing was deposited on and in the soil, at NTS operating facilities that may produce radioactive air emissions, and along the boundaries of the NTS. Data from all sampling stations are analyzed to meet the specific goals listed below.

Also listed below are the analytes monitored in order to perform dose assessments. They are the radionuclides most likely to be present in the air as a result of past or current NTS operations. These analytes were selected based on the results of NTS inventories of radionuclides in surface soil (McArthur, 1991), and upon their volatility and availability for resuspension. In addition, uranium is included on this list because depleted uranium (see Glossary, Appendix B) ordinances are used during exercises in Areas 20 and 25. It is analyzed for in air samples only from selected sampling locations in the vicinity of these areas. Also, gross alpha and gross beta readings are used in air monitoring as a rapid screening measure. 


\begin{tabular}{|c|c|c|}
\hline Radiological Air Monitoring Goals & \multicolumn{2}{|c|}{ Analytes Monitored } \\
\hline $\begin{array}{l}\text { Measure radionuclide concentrations in air at or near historic or current } \\
\text { operation sites which have the potential to release airborne radioactivity } \\
\text { to (1) detect and identify local and site-wide trends, (2) identify } \\
\text { radionuclides emitted to air, and (3) detect accidental and unplanned } \\
\text { releases. }\end{array}$ & $\begin{array}{l}\text { Americium-241 } \\
(241 \mathrm{Am})\end{array}$ & $\begin{array}{l}\text { Uranium-233+234 } \\
(233+234 \mathrm{U})\end{array}$ \\
\hline $\begin{array}{l}\text { Determine if radioactive air emissions from past or present NTS activities } \\
\text { result in a radiation dose, called the committed effective dose equivalent } \\
\text { (CEDE) (see Glossary, Appendix B), to any member of the public that } \\
\text { exceeds the NESHAP standard of } 10 \text { millirem per year (mrem/yr) }\end{array}$ & $\begin{array}{l}\text { Tritium } \\
\left({ }^{3} \mathrm{H}\right)\end{array}$ & $\begin{array}{l}\text { Uranium-238 } \\
(238 \mathrm{U})\end{array}$ \\
\hline $\begin{array}{l}\text { Provide point source operational monitoring as required under NESHAP } \\
\text { for any facility that has the potential to emit radionuclides into the air } \\
\text { which could cause a dose greater than } 0.1 \mathrm{mrem} / \mathrm{yr}(0.001 \mathrm{mSv} / \mathrm{yr}) \text { to any } \\
\text { member of the public. }\end{array}$ & $\begin{array}{l}\text { Plutonium- } 239+240 \\
(239+240 \mathrm{Pu})\end{array}$ & $\begin{array}{l}\text { Gross beta } \\
\text { radioactivity }\end{array}$ \\
\hline $\begin{array}{l}\text { Provide data to determine if radioactive air emissions from past or } \\
\text { present NTS activities result in a radiation dose to any member of the } \\
\text { public from all pathways (air, water, food) that exceeds the DOE } \\
\text { Order } 5400.5 \text { standard of } 100 \mathrm{mrem} / \mathrm{yr}(1 \mathrm{mSv} / \mathrm{yr}) \text {. }\end{array}$ & \multicolumn{2}{|c|}{$\begin{array}{l}{ }^{239+240} \mathrm{Pu},{ }^{233+234} \mathrm{U} \text {, and }{ }^{235+236} \mathrm{U} \text { are reported } \\
\text { as the sum of isotope concentrations since } \\
\text { the analytical method cannot readily } \\
\text { distinguish the individual isotopes. }\end{array}$} \\
\hline
\end{tabular}

\subsubsection{Monitoring System Design}

Environmental Samplers - There are 19 sampling stations referred to as environmental samplers. They include 3 stations which have only low-volume air particulate samplers, 1 which has only a tritium sampler, and 15 which have both air particulate and tritium samplers (Figure 3-1). They are located throughout the NTS in or near diffuse radiation sources. The sources include areas with (1) radioactivity in surface soil that can be resuspended by the wind, (2) tritium that transpires or evaporates from plants and soil at the sites of past nuclear cratering tests, and (3) tritium that evaporates from ponds receiving tritiated water either pumped from contaminated wells or directed from tunnels that cannot be sealed shut. Sampling and analysis of air particulates and tritium were performed at these stations as described in Section 3.1.2. Radionuclide concentrations measured at these stations are used for trending, determining ambient background concentrations in the environment, and monitoring for unplanned releases of radioactivity. Air concentrations approaching 10 percent of the NESHAP Concentration Levels (CLs) for Environmental Compliance (second column of Table 3-1) are investigated for causes so that they may be mitigated to avoid exceeding regulatory dose limits.

Critical Receptor Samplers - Six of the 15 samplers which have combined air particulate and tritium sampling stations are located near the boundaries and the center of the NTS and are approved by the U.S. Environmental Protection Agency (EPA) Region IX as critical receptor samplers (Figure 3-1). Radionuclide concentrations measured at these six stations are used to assess compliance with the NESHAP dose limit to the public of $10 \mathrm{mrem} / \mathrm{yr}$ $(0.1 \mathrm{mSv} / \mathrm{yr})$. Analysis of air particulate and tritium data obtained at these six stations was performed as described in Section 3.1.2 below. The annual average concentrations from each station were then compared with the concentration limits listed in Table 3-1. To be in compliance with NESHAP, the annual average concentrations must be less than the concentration limits in Table 3-1. If multiple radionuclides are detected at a station, then compliance with NESHAP is demonstrated when the sum of the fractions, determined by dividing each radionuclide's concentration by its concentration limit and then adding the fractions together, is less than 1.0. 


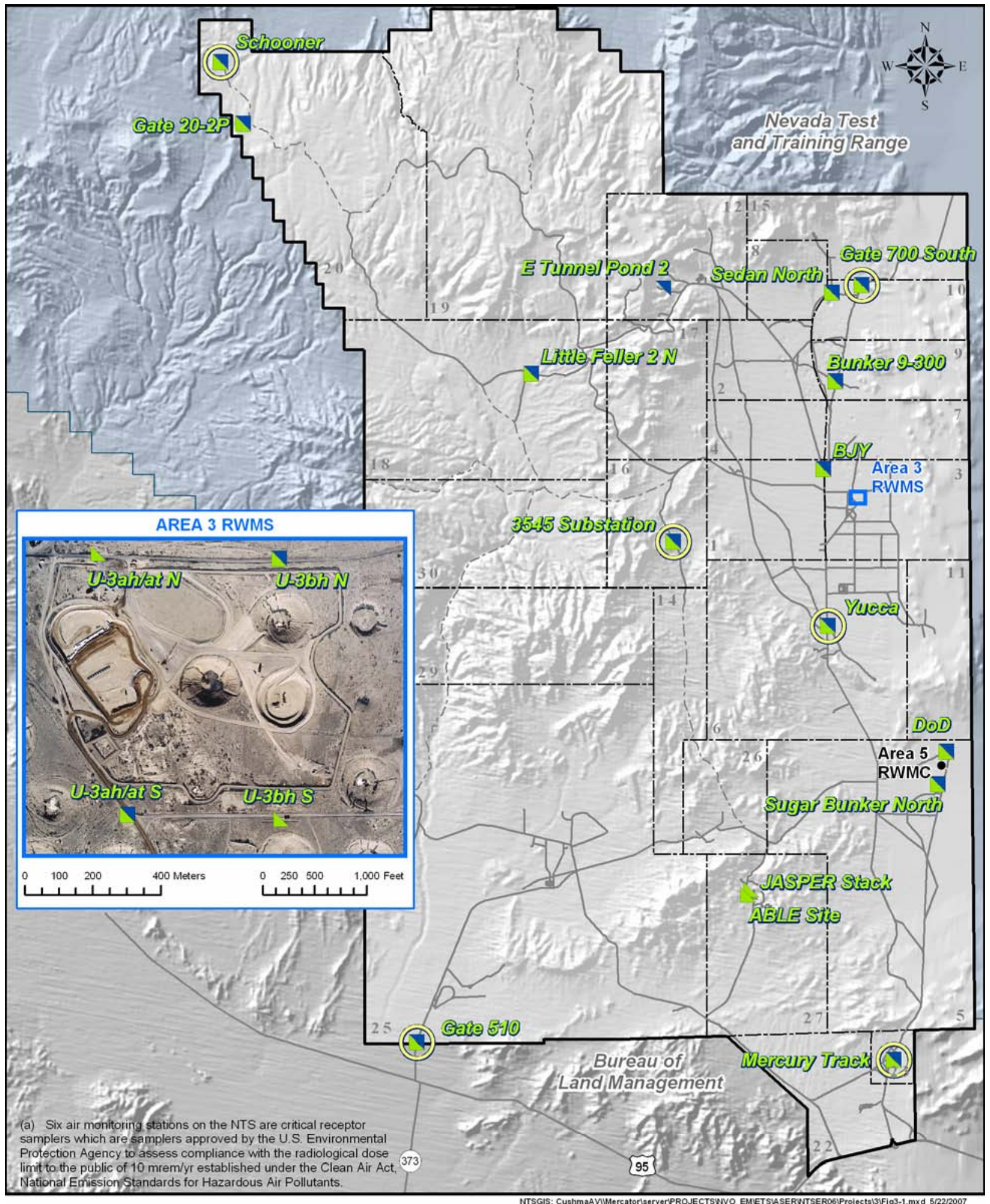

\section{Air Sampling Network}

A Air Particulate (AP) Station

Tritium (HTO) Station

$\checkmark \mathrm{AP}$ and HTO Station

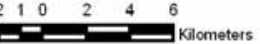

Critical Receptor Sampler ${ }^{\text {(a) }}$

Transportation and Boundaries

- Primary Road

-- Secondary Road

---NTS Operational Areas

- NTS Boundary

Figure 3-1. Radiological air sampling network on the NTS in 2006 
Table 3-1. Regulatory concentration limits for radionuclides in air

\begin{tabular}{||ccc||}
\hline & \multicolumn{2}{c||}{ Concentration $\left(\mathbf{x ~ 1 0 ^ { - 1 5 }}\right.$ microcuries/milliliter $\left.[\mu \mathrm{Ci} / \mathrm{mL}]\right)$} \\
\cline { 2 - 3 } Radionuclide & $\begin{array}{c}\text { NESHAP Concentration Level for } \\
\text { Environmental Compliance (CL) }\end{array}$ & Derived Concentration Guide (DCG) $)^{(\mathbf{b})}$ \\
\hline${ }^{241} \mathrm{Am}$ & 1.9 & 2 \\
${ }^{137} \mathrm{Cs}$ & 19 & 40,000 \\
${ }^{3} \mathrm{H}$ & $1,500,000$ & $10,000,000$ \\
${ }^{238} \mathrm{Pu}$ & 2.1 & 3 \\
${ }^{239} \mathrm{Pu}$ & 2 & 2 \\
${ }^{233} \mathrm{U}$ & 7.1 & 9 \\
${ }^{234} \mathrm{U}$ & 7.7 & 9 \\
${ }^{235} \mathrm{U}$ & 7.1 & 10 \\
${ }^{236} \mathrm{U}$ & 7.7 & 10 \\
${ }^{238} \mathrm{U}$ & 8.3 & 10 \\
\hline \hline
\end{tabular}

Note: Both the CL and DCG values represent the annual average concentration which would result in a CEDE of $10 \mathrm{mrem} / \mathrm{yr}$ which is the federal dose limit to the public from all radioactive air emissions. When they differ, the CLs are more conservative than the DCGs. They are computed using different dose models.

(a) From Table 2, Appendix E of 40 Code of Federal Regulations (CFR) 61, 1999

(b) From Chapter 3 of DOE Order 5400.5, 1990, see Glossary, Appendix B for definition

Point-Source (Stack) Sampler - One facility on the NTS, the Joint Actinide Shock Physics Experimental Research (JASPER) facility in Area 27 (Figure 3-1), requires stack monitoring because it has the potential to emit airborne radionuclides that could result in an offsite radiation dose $\geq 0.1 \mathrm{mrem} / \mathrm{yr}$. Air emissions from the facility are filtered through a high efficiency particulate air (HEPA) filter. Lawrence Livermore National Laboratory (LLNL) performs stack monitoring down-stream of the filter. Environmental sampling of air particulates adjacent to the facility is performed as stated in Section 3.1.2. If air concentrations of any man-made radionuclide were found above the minimum detectable concentration (MDC), (see Glossary, Appendix B), an assessment of offsite dose to the public would be performed to determine NESHAP compliance and LLNL would investigate the cause of the emission and implement corrective actions.

\subsubsection{Air Particulate and Tritium Sampling Methods}

A weekly sample of airborne particulates was collected from each air sampling station by drawing air through a 10-centimeter (4-inch) diameter glass-fiber filter at a constant flow rate of 85 liters per minute $(\mathrm{L} / \mathrm{min}$ ) (3 cubic feet per minute). The particulate filter is mounted in a filter holder that faces downward at a height of 1.5 meters (m) (5 feet [ft]) above ground. A run-time clock measures the operating time. The run time, multiplied by $85 \mathrm{~L} / \mathrm{min}$ yields the volume of air sampled, which is about 860 cubic $\mathrm{m}\left(\mathrm{m}^{3}\right)\left(30,000\right.$ cubic $\left.\mathrm{ft}\left[\mathrm{ft}^{3}\right]\right)$ during a typical seven-day sampling period. The air sampling rates were measured at the start and end of each sampling period with a mass-flow meter.

The 10-cm diameter filters were analyzed for gross alpha and gross beta radioactivity after a five-day holding time to allow for the decay of the progeny of naturally-occurring radon and thoron. The filters collected within each month were composited for each station, analyzed by gamma spectroscopy, and then analyzed for ${ }^{239+240} \mathrm{Pu}$ and ${ }^{241} \mathrm{Am}$ by alpha spectroscopy after radiochemical separation. To monitor for any potential emissions from exerceses using depleted uranium, the filter composites from Yucca (Area 6), Substation 3545 (Area 16), Gate 20-2p (Area 20), Gate 510 (Area 25), and Able Site (Area 27) were also analyzed for uranium isotopes by alpha spectroscopy.

Tritiated water vapor in the form of ${ }^{3} \mathrm{H}^{3} \mathrm{HO}$ or ${ }^{3} \mathrm{HHO}$ (collectively referred to as $\mathrm{HTO}$ ) was sampled continuously over two-week periods at each tritium sampling station. Tritium samplers were operated with elapsed time meters at a flow rate of about 566 cubic centimeters per minute $\left(1.2 \mathrm{ft}^{3}\right.$ per hour). The total volume sampled is determined from 
the product of the sampling period and the flow rate (about $11 \mathrm{~m}^{3}$ [14.4 cubic yards] over a two-week sampling period). The HTO was removed from the air stream by two molecular sieve columns connected in series (one for routine collection and a second one to indicate if breakthrough occurred during collection). These columns were exchanged biweekly. An aliquot of the total moisture collected was extracted from the first column and analyzed for tritium by liquid scintillation counting. In all cases measured activity in units per sample are converted to units per volume of air prior to analysis and reporting in the following sections.

Routine quality control air samples (e.g., duplicates, blanks, and spikes) are also incorporated into the analytical suites on a frequent basis. The reader is directed to Section 18.0 for a discussion of quality assurance/quality control protocols and procedures utilized for radiological air monitoring.

\subsubsection{Presentation of Air Sampling Data}

The annual average concentration for each radionuclide at each sampling location is presented in data tables in the following results sections. The annual average concentration for each radionuclide was calculated from uncensored analytical results for individual samples; i.e., values less than the sample-specific MDC were included in the calculation. A column is included in each table indicating the percentage of the analytical results that were greater than their analysis-specific MDCs.

Annual average concentrations are also expressed in the tables as percentages of the CL (the second column of Table 3-1). In graphs of concentration data, the CL or some percentage of the CL is included as a green horizontal line. The CL for each radionuclide was used instead of the DCG, as it was always the lesser of the two for those radionuclides for which these limits differed. The CL (or fraction thereof) is shown in graphs for reference only and not to demonstrate compliance with NESHAP dose limits; assessment of compliance is based upon annual average concentrations, not upon the single measurement results shown in the graphs.

For convenience in reporting, values shown in the tables in the following result sections are frequently formatted to a greater number of significant digits than can be justified by the accuracy of the measurements, which is typically two significant figures (e.g., 2500, 25, 2.5, or 0.025).

\subsubsection{Air Sampling Results from Environmental Samplers}

All elevated radionuclide concentrations in the 2006 air samples shown in the tables and graphs are attributed to the resuspension of legacy contamination in surface soils and to the evaporation and transpiration of tritium from the soil and plants at sites of past nuclear tests and of low-level radioactive waste burial.

Monitoring results for the point-source station at JASPER are included in the tables in this section. These results are not included in NTS-wide averages of air concentrations due to legacy contamination.

\subsubsection{Americium-241}

During 2006, 40 percent of ${ }^{241} \mathrm{Am}$ measurements exceeded their MDCs (see Table 3-2). This is slightly higher than for 2005 (35 percent) and slightly lower than for 2004 (41 percent). The mean concentration over all locations was $21 \times 10^{-18} \mu \mathrm{Ci} / \mathrm{mL}$. This is slightly lower than 2005; both 2005 and 2006 are higher than preceding years. This increase comes from elevated concentrations in the late summer at a few locations in Areas 1, 3, and 9, most notably Bunker 9-300; see Figure 3-2. The annual mean concentration at Bunker 9-300 was $179 \times 10^{-18} \mu \mathrm{Ci} / \mathrm{mL}$, which is 9 percent of the compliance limit. These increased measurements (as well as those of ${ }^{238} \mathrm{Pu},{ }^{239+240} \mathrm{Pu}$, and gross alpha) are attributed to increased field activity resulting in resuspension of soils containing legacy plutonium contamination. 
Table 3-2. Concentrations of ${ }^{241} \mathrm{Am}$ in air samples collected in 2006

\begin{tabular}{|c|c|c|c|c|c|c|c|c|c|c|}
\hline \multirow[b]{2}{*}{$\begin{array}{l}\text { NTS } \\
\text { Area }\end{array}$} & \multirow[b]{2}{*}{ Location } & \multirow[b]{2}{*}{$\begin{array}{c}\text { Number of } \\
\text { Samples }\end{array}$} & \multicolumn{8}{|c|}{${ }^{241} \mathrm{Am}\left(x 1^{-18} \mu \mathrm{Ci} / \mathrm{mL}\right)$} \\
\hline & & & Mean & $\begin{array}{l}\% \text { of } \\
\text { CL }^{(a)}\end{array}$ & Median & SD (b) & $\operatorname{Min}(\mathrm{c})$ & $\operatorname{Max}(d)$ & $\begin{array}{l}\text { Mean } \\
\text { MDC }\end{array}$ & $\begin{array}{c}\%> \\
\text { MDC }\end{array}$ \\
\hline 1 & BJY & 12 & 15.58 & 0.8 & 12.61 & 14.08 & -1.55 & 36.98 & 8.03 & 58.3 \\
\hline 3 & U-3ah/at N & 12 & 33.43 & 1.8 & 12.87 & 51.85 & 3.92 & 161.73 & 7.12 & 75.0 \\
\hline 3 & U-3ah/at S & 12 & 47.09 & 2.5 & 34.69 & 43.31 & 1.09 & 128.25 & 6.96 & 66.7 \\
\hline 3 & U-3bh N & 12 & 25.07 & 1.3 & 11.25 & 33.36 & -0.61 & 97.54 & 8.04 & 58.3 \\
\hline 3 & U-3bh S & 12 & 15.72 & 0.8 & 12.55 & 13.24 & 0.62 & 44.34 & 7.48 & 75.0 \\
\hline 5 & DoD & 12 & 2.87 & 0.2 & 3.52 & 2.45 & -1.92 & 5.61 & 8.23 & 16.7 \\
\hline 5 & Sugar Bunker N & 12 & 3.65 & 0.2 & 2.72 & 4.77 & -2.18 & 15.67 & 10.64 & 16.7 \\
\hline 6 & Yucca & 12 & 10.33 & 0.5 & 2.92 & 16.81 & 0.21 & 56.08 & 6.12 & 33.3 \\
\hline 9 & Bunker 9-300 & 12 & 178.52 & 9.4 & 175.85 & 98.57 & 29.80 & 400.83 & 7.16 & 100.0 \\
\hline 10 & Gate 700 S & 12 & 2.02 & 0.1 & 1.58 & 3.44 & -3.32 & 7.62 & 6.99 & 25.0 \\
\hline 10 & Sedan N & 12 & 10.41 & 0.5 & 10.00 & 9.11 & 0.50 & 31.86 & 7.07 & 66.7 \\
\hline 16 & 3545 Substation & 11 & 7.79 & 0.4 & 2.07 & 15.37 & -1.87 & 48.39 & 9.59 & 22.7 \\
\hline 18 & Little Feller $2 \mathrm{~N}$ & 12 & 4.10 & 0.2 & 3.62 & 3.52 & -0.98 & 11.16 & 7.62 & 33.3 \\
\hline 20 & Gate 20-2P & 12 & 1.47 & 0.1 & 0.49 & 4.55 & -1.86 & 14.96 & 8.08 & 16.7 \\
\hline 20 & Schooner & 12 & 4.31 & 0.2 & 2.29 & 5.38 & -0.43 & 17.07 & 7.24 & 33.3 \\
\hline 23 & Mercury Track & 12 & 2.38 & 0.1 & 1.43 & 3.45 & 0.00 & 12.79 & 6.42 & 16.7 \\
\hline 25 & Gate 510 & 12 & 2.94 & 0.2 & 1.23 & 3.73 & -0.21 & 12.75 & 7.84 & 4.2 \\
\hline 27 & ABLE Site & 11 & 1.87 & 0.1 & 1.83 & 2.48 & -2.46 & 6.52 & 8.47 & 4.5 \\
\hline All En & ironmental Samplers & 214 & 20.68 & 1.1 & 3.90 & 49.88 & -3.32 & 400.83 & 7.71 & 40.4 \\
\hline 27 & JASPER Stack & 12 & 22.38 & 1.2 & 13.42 & 42.24 & -18.43 & 132.68 & 71.67 & 8.3 \\
\hline
\end{tabular}

Blue-shaded locations are EPA-approved critical receptor sampler stations.

The orange-shaded location is a point-source sampler station.

Non-shaded locations are environmental sampler stations.

Green shading indicates that some percentage of samples had concentrations above the sample-specific MDC.

(a) CL is the NESHAP Concentration Level for Environmental Compliance (see Table 3-1).

(b) Standard deviation (c) Minimum (d) Maximum

Note: The CL for ${ }^{241} \mathrm{Am}$ is $1,900 \times 10^{-18} \mu \mathrm{Ci} / \mathrm{mL}$.

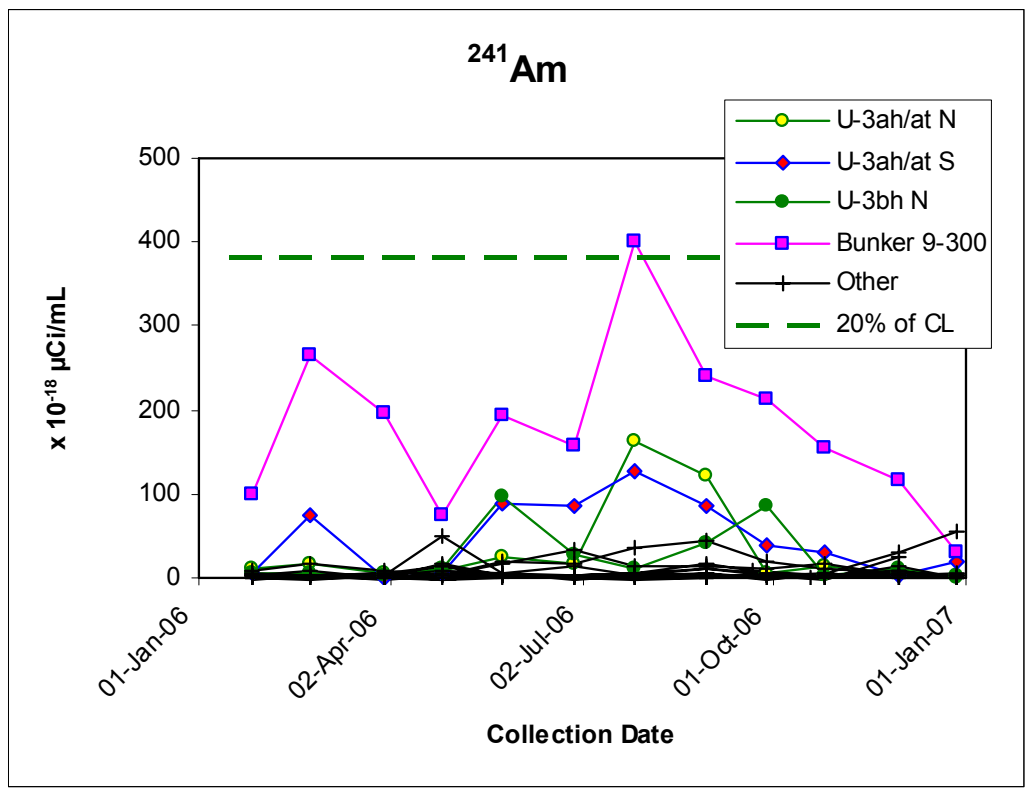

Figure 3-2. Concentrations of ${ }^{241} \mathrm{Am}$ in air samples collected in 2006 


\subsubsection{Cesium-137}

During 2006, no ${ }^{137}$ Cs measurements exceeded their MDCs. Mean values for all environmental locations were near or slightly below zero. No plot is provided because of the low measurement levels (Table 3-3).

Table 3-3. Concentrations of ${ }^{137} \mathrm{Cs}$ in air samples collected in 2006

\begin{tabular}{|c|c|c|c|c|c|c|c|c|c|c|}
\hline \multirow[b]{2}{*}{$\begin{array}{l}\text { NTS } \\
\text { Area }\end{array}$} & \multirow[b]{2}{*}{ Location } & \multirow[b]{2}{*}{$\begin{array}{c}\text { Number of } \\
\text { Samples }\end{array}$} & \multicolumn{8}{|c|}{${ }^{137} \mathrm{Cs}\left(\times 10^{-17} \mu \mathrm{Ci} / \mathrm{mL}\right)$} \\
\hline & & & Mean & $\begin{array}{l}\% \text { of } \\
\text { CL (a) }\end{array}$ & Median & $\mathrm{SD}^{(\mathrm{b})}$ & $\operatorname{Min}^{(c)}$ & $\operatorname{Max}(\mathrm{d})$ & $\begin{array}{l}\text { Mean } \\
\text { MDC }\end{array}$ & $\begin{array}{c}\%> \\
\mathrm{MDC}\end{array}$ \\
\hline 1 & BJY & 11 & 4.36 & 0.2 & 1.33 & 29.78 & -44.09 & 54.95 & 73.26 & 0.0 \\
\hline 3 & U-3ah/at N & 12 & -6.89 & -0.4 & -12.43 & 19.01 & -35.52 & 26.38 & 66.13 & 0.0 \\
\hline 3 & U-3ah/at Ss & 12 & 8.01 & 0.4 & -0.81 & 26.43 & -27.24 & 67.84 & 72.23 & 0.0 \\
\hline 3 & U-3bh N & 11 & -3.27 & -0.2 & -1.30 & 14.17 & -25.74 & 18.77 & 76.23 & 0.0 \\
\hline 3 & U-3bh S & 12 & 7.84 & 0.4 & 2.58 & 21.89 & -17.95 & 60.04 & 71.31 & 0.0 \\
\hline 5 & DoD & 12 & 1.46 & 0.1 & 1.63 & 29.07 & -53.41 & 55.82 & 72.77 & 0.0 \\
\hline 5 & Sugar Bunker N & 12 & -2.74 & -0.1 & -4.09 & 21.64 & -42.04 & 29.93 & 91.50 & 0.0 \\
\hline 6 & Yucca & 12 & -5.78 & -0.3 & -15.80 & 37.05 & -54.19 & 48.53 & 73.79 & 0.0 \\
\hline 9 & Bunker 9-300 & 11 & 11.68 & 0.6 & 8.19 & 14.28 & -12.16 & 45.13 & 68.57 & 0.0 \\
\hline 10 & Gate 700 S & 12 & -8.82 & -0.5 & -1.70 & 31.77 & -80.90 & 29.34 & 72.99 & 0.0 \\
\hline 10 & Sedan N & 12 & 3.52 & 0.2 & -1.06 & 43.55 & -63.11 & 112.02 & 87.44 & 0.0 \\
\hline 16 & 3545 Substation & 12 & -5.77 & -0.3 & -1.27 & 24.73 & -59.00 & 27.48 & 82.16 & 0.0 \\
\hline 18 & Little Feller $2 \mathrm{~N}$ & 12 & -3.07 & -0.2 & 3.36 & 29.60 & -82.63 & 35.21 & 76.65 & 0.0 \\
\hline 20 & Gate 20-2P & 12 & 2.85 & 0.2 & 11.85 & 34.02 & -91.11 & 31.13 & 74.90 & 0.0 \\
\hline 20 & Schooner & 12 & -2.79 & -0.1 & 6.08 & 35.50 & -71.63 & 40.14 & 70.60 & 0.0 \\
\hline 23 & Mercury Track & 12 & -1.18 & -0.1 & 0.05 & 23.20 & -44.97 & 30.50 & 76.91 & 0.0 \\
\hline 25 & Gate 510 & 12 & -3.12 & -0.2 & 3.50 & 32.43 & -79.42 & 33.33 & 70.73 & 0.0 \\
\hline 27 & ABLE Site & 11 & -1.34 & -0.1 & -7.06 & 21.00 & -32.45 & 30.79 & 71.29 & 0.0 \\
\hline All En & vironmental Samplers & 212 & -0.34 & 0.0 & 1.52 & 27.76 & -91.11 & 112.02 & 75.02 & 0.0 \\
\hline 27 & JASPER Stack & 12 & -64.93 & -3.4 & -58.66 & 97.35 & -255.72 & 146.41 & 586.12 & 0.0 \\
\hline
\end{tabular}

Blue-shaded locations are EPA-approved critical receptor sampler stations.

The orange-shaded location is a point-source sampler station.

Non-shaded locations are environmental sampler stations.

(a) CL is the NESHAP Concentration Level for Environmental Compliance (see Table 3-1).

(b) Standard deviation

(c) Minimum

(d) Maximum

Note: The CL for ${ }^{137} \mathrm{Cs}$ is $1,900 \times 10^{-17} \mu \mathrm{Ci} / \mathrm{mL}$.

\subsubsection{Plutonium Isotopes}

During 2006, 14 percent of ${ }^{238} \mathrm{Pu}$ measurements exceeded their MDCs, about the same as in 2005. The overall mean concentration $\left(2.8 \times 10^{-18} \mu \mathrm{Ci} / \mathrm{mL}\right)$ is slightly lower than in 2005 as well. As with ${ }^{241} \mathrm{Am}$, the 2005 and 2006 values are somewhat higher than in preceding years. This increase is due to the increased concentrations measured at Bunker 9-300 in Area 9; the annual mean at that location was $17.6 \times 10^{-18} \mu \mathrm{Ci} / \mathrm{mL}$. This is just 0.8 percent of the CL (see Table 3-4 and Figure 3-3). 
Table 3-4. Concentrations of ${ }^{238} \mathrm{Pu}$ in air samples collected in 2006

\begin{tabular}{|c|c|c|c|c|c|c|c|c|c|c|}
\hline \multirow[b]{2}{*}{$\begin{array}{l}\text { NTS } \\
\text { Area }\end{array}$} & \multirow[b]{2}{*}{ Location } & \multirow[b]{2}{*}{$\begin{array}{c}\text { Number of } \\
\text { Samples }\end{array}$} & \multirow[b]{2}{*}{ Mean } & \multicolumn{7}{|c|}{${ }^{238} \mathrm{Pu}\left(\times 10^{-18} \mu \mathrm{Ci} / \mathrm{mL}\right)$} \\
\hline & & & & $\begin{array}{l}\% \text { of } \\
C L^{\text {(a) }}\end{array}$ & Median & $\mathrm{SD}^{(\mathrm{b})}$ & $\operatorname{Min}^{(c)}$ & $\operatorname{Max}(d)$ & $\begin{array}{l}\text { Mean } \\
\text { MDC }\end{array}$ & $\begin{array}{c}\%> \\
\text { MDC }\end{array}$ \\
\hline 1 & BJY & 12 & 1.77 & 0.1 & 0.95 & 2.77 & -1.05 & 8.48 & 8.71 & 8.3 \\
\hline 3 & U-3ah/at N & 12 & 4.54 & 0.2 & 3.20 & 5.33 & -2.68 & 15.91 & 7.24 & 25.0 \\
\hline 3 & U-3ah/at S & 12 & 5.89 & 0.3 & 6.48 & 4.53 & 0.00 & 13.33 & 8.70 & 33.3 \\
\hline 3 & U-3bh N & 12 & 2.50 & 0.1 & 0.80 & 3.55 & -2.22 & 8.47 & 7.90 & 25.0 \\
\hline 3 & U-3bh S & 12 & 0.96 & 0.0 & 0.33 & 2.71 & -2.48 & 7.37 & 9.09 & 25.0 \\
\hline 5 & DoD & 12 & 0.17 & 0.0 & -0.09 & 1.76 & -1.99 & 4.18 & 8.48 & 0.0 \\
\hline 5 & Sugar Bunker N & 12 & 1.16 & 0.1 & 0.72 & 3.29 & -3.76 & 8.93 & 8.99 & 8.3 \\
\hline 6 & Yucca & 12 & 2.27 & 0.1 & 1.61 & 2.72 & -1.18 & 8.95 & 6.41 & 8.3 \\
\hline 9 & Bunker 9-300 & 12 & 17.61 & 0.8 & 16.35 & 9.51 & 2.64 & 39.32 & 9.68 & 75.0 \\
\hline 10 & Gate 700 S & 12 & 1.24 & 0.1 & 1.55 & 1.04 & -0.76 & 2.65 & 6.47 & 0.0 \\
\hline 10 & Sedan N & 12 & 3.63 & 0.2 & 2.56 & 4.21 & -3.02 & 13.16 & 9.65 & 16.7 \\
\hline 16 & 3545 Substation & 12 & 3.79 & 0.2 & 0.15 & 9.62 & -2.10 & 31.77 & 8.25 & 16.7 \\
\hline 18 & Little Feller 2 N & 12 & 1.46 & 0.1 & 1.24 & 2.44 & -2.82 & 5.78 & 8.23 & 0.0 \\
\hline 20 & Gate $20-2 P$ & 12 & 0.25 & 0.0 & -0.01 & 1.58 & -1.66 & 4.29 & 7.54 & 0.0 \\
\hline 20 & Schooner & 12 & 1.33 & 0.1 & 0.90 & 2.37 & -1.16 & 8.03 & 9.07 & 8.3 \\
\hline 23 & Mercury Track & 12 & -0.26 & 0.0 & -0.15 & 1.92 & -2.83 & 4.42 & 10.54 & 0.0 \\
\hline 25 & Gate 510 & 12 & 0.45 & 0.0 & 0.27 & 2.18 & -2.91 & 5.27 & 7.28 & 0.0 \\
\hline 27 & ABLE Site & 12 & 1.07 & 0.1 & 0.43 & 1.52 & -0.29 & 4.33 & 7.19 & 0.0 \\
\hline \multicolumn{11}{|c|}{ All Environmental } \\
\hline 27 & JASPER Stack & 11 & 3.88 & 0.2 & 0.12 & 10.19 & -9.91 & 23.74 & 62.39 & 0.0 \\
\hline
\end{tabular}

Blue-shaded locations are EPA-approved critical receptor sampler stations.

The orange-shaded location is a point-source sampler station.

Non-shaded locations are environmental sampler stations.

Green shading indicates that some percentage of samples had concentrations above the sample-specific MDC.

(a) CL is the NESHAP Concentration Level for Environmental Compliance (see Table 3-1).

(b) Standard deviation (c) Minimum (d) Maximum

Note: The CL for ${ }^{238} \mathrm{Pu}$ is $2,100 \times 10^{-18} \mu \mathrm{Ci} / \mathrm{mL}$.

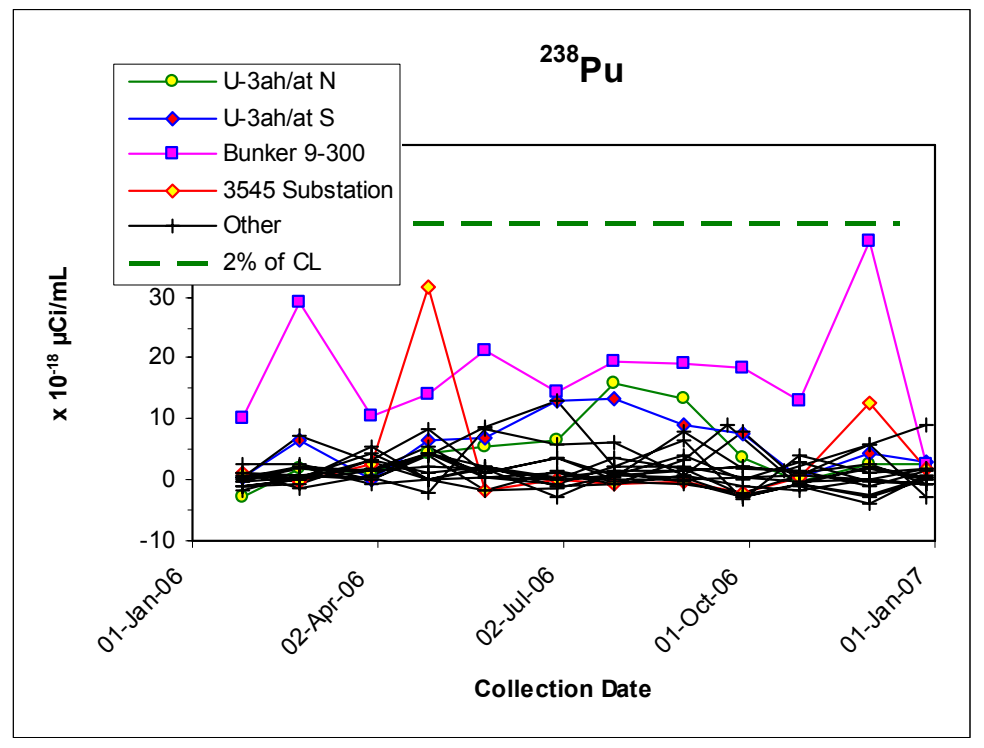

Figure 3-3. Concentrations of ${ }^{238} \mathrm{Pu}$ in air samples collected in 2006 
The isotopes ${ }^{239+240} \mathrm{Pu}$ (analytical methods cannot readily distinguish between these two) are of greater abundance and hence greater interest. Overall, 62 percent of measurements exceeded their MDCs. The overall mean of $138 \times 10^{-18} \mu \mathrm{Ci} / \mathrm{mL}$ is modestly lower than in $2005\left(148 \times 10^{-18} \mu \mathrm{Ci} / \mathrm{mL}\right)$; again, these are higher than preceding years (48, 38, and 55 in 2004, 2003, and 2002 respectively). As with ${ }^{241} \mathrm{Am}$ and ${ }^{238} \mathrm{Pu}$, this increase is attributed to resuspension of soil in Areas 1,3, and 9. The annual mean at Bunker 9-300, the highest location, was $1,201 \times 10^{-18} \mu \mathrm{Ci} / \mathrm{mL}$; this is 60 percent of the CL (see Table 3-5 and Figure 3-4).

Table 3-5. Concentrations of ${ }^{239+240} \mathrm{Pu}$ in air samples collected in 2006

\begin{tabular}{|c|c|c|c|c|c|c|c|c|c|c|}
\hline \multirow[b]{2}{*}{$\begin{array}{l}\text { NTS } \\
\text { Area }\end{array}$} & \multirow[b]{2}{*}{ Location } & \multirow[b]{2}{*}{$\begin{array}{c}\text { Number of } \\
\text { Samples }\end{array}$} & \multicolumn{8}{|c|}{${ }^{239+240} \mathrm{Pu}\left(\times 10^{-18} \mu \mathrm{Ci} / \mathrm{mL}\right)$} \\
\hline & & & Mean & $\begin{array}{l}\% \text { of } \\
C^{(a)} \\
\end{array}$ & Median & $\mathrm{SD}^{(\mathrm{b})}$ & $\operatorname{Min}^{(c)}$ & $\operatorname{Max}(d)$ & $\begin{array}{l}\text { Mean } \\
\text { MDC }\end{array}$ & $\begin{array}{c}\%> \\
\text { MDC }\end{array}$ \\
\hline 1 & BJY & 11 & 94.02 & 4.7 & 60.47 & 86.08 & 1.56 & 248.04 & 8.12 & 86.4 \\
\hline 3 & U-3ah/at N & 11 & 248.94 & 12.4 & 115.63 & 358.62 & 17.90 & 1101.29 & 6.77 & 100.0 \\
\hline 3 & U-3ah/at S & 11 & 349.33 & 17.5 & 308.79 & 304.18 & 45.32 & 1012.94 & 10.35 & 100.0 \\
\hline 3 & U-3bh N & 11 & 171.88 & 8.6 & 57.70 & 226.22 & 4.22 & 614.42 & 10.63 & 90.9 \\
\hline 3 & U-3bh S & 11 & 112.82 & 5.6 & 67.79 & 111.44 & 14.19 & 380.37 & 8.57 & 100.0 \\
\hline 5 & DoD & 11 & 18.50 & 0.9 & 7.49 & 36.02 & 0.00 & 125.55 & 10.29 & 45.5 \\
\hline 5 & Sugar Bunker N & 11 & 23.75 & 1.2 & 8.64 & 43.29 & -3.76 & 144.27 & 8.84 & 63.6 \\
\hline 6 & Yucca & 11 & 53.42 & 2.7 & 14.96 & 128.83 & 1.50 & 440.40 & 5.81 & 77.3 \\
\hline 9 & Bunker 9-300 & 12 & $1,201.19$ & 60.1 & $1,116.64$ & 622.14 & 179.69 & $2,449.50$ & 5.67 & 100.0 \\
\hline 10 & Gate 700 S & 11 & 14.98 & 0.7 & 13.84 & 11.07 & -1.32 & 34.91 & 8.88 & 63.6 \\
\hline 10 & Sedan N & 12 & 57.49 & 2.9 & 47.75 & 51.23 & 6.00 & 169.28 & 10.09 & 91.7 \\
\hline 16 & 3545 Substation & 11 & 17.94 & 0.9 & 4.85 & 37.14 & 2.16 & 128.53 & 5.74 & 54.5 \\
\hline 18 & Little Feller $2 \mathrm{~N}$ & 11 & 10.28 & 0.5 & 6.29 & 11.86 & -2.89 & 31.36 & 6.91 & 54.5 \\
\hline 20 & Gate $20-2 P$ & 11 & 2.67 & 0.1 & 2.09 & 2.87 & -1.86 & 7.88 & 6.99 & 31.8 \\
\hline 20 & Schooner & 11 & 5.04 & 0.3 & 2.29 & 7.52 & -1.98 & 22.35 & 7.81 & 18.2 \\
\hline 23 & Mercury Track & 11 & 2.32 & 0.1 & 2.38 & 2.71 & -1.65 & 7.68 & 11.43 & 0.0 \\
\hline 25 & Gate 510 & 11 & 2.77 & 0.1 & 1.42 & 3.70 & -1.50 & 9.58 & 6.62 & 27.3 \\
\hline 27 & ABLE Site & 11 & 2.59 & 0.1 & 3.68 & 1.98 & -1.48 & 4.54 & 7.61 & 4.5 \\
\hline \multicolumn{2}{|c|}{ All Environmental Samplers } & 200 & 137.74 & 6.9 & 12.11 & 344.50 & -3.76 & 2449.50 & 8.17 & 62.0 \\
\hline 27 & JASPER Stack & 10 & 16.83 & 0.8 & 11.79 & 25.59 & -24.40 & 59.04 & 67.14 & 0.0 \\
\hline
\end{tabular}

Blue-shaded locations are EPA-approved critical receptor sampler stations.

The orange-shaded location is a point-source sampler station.

Non-shaded locations are environmental sampler stations.

Green shading indicates that some percentage of samples had concentrations above the sample-specific MDC.
(a) CL is the NESHAP Concentration Level for Environmental Compliance (see Table 3-1).
(b) Standard deviation
(c) Minimum
(d) Maximum

Note: The CL for ${ }^{239+240} \mathrm{Pu}$ is $2,000 \times 10^{-18} \mu \mathrm{Ci} / \mathrm{mL}$. 


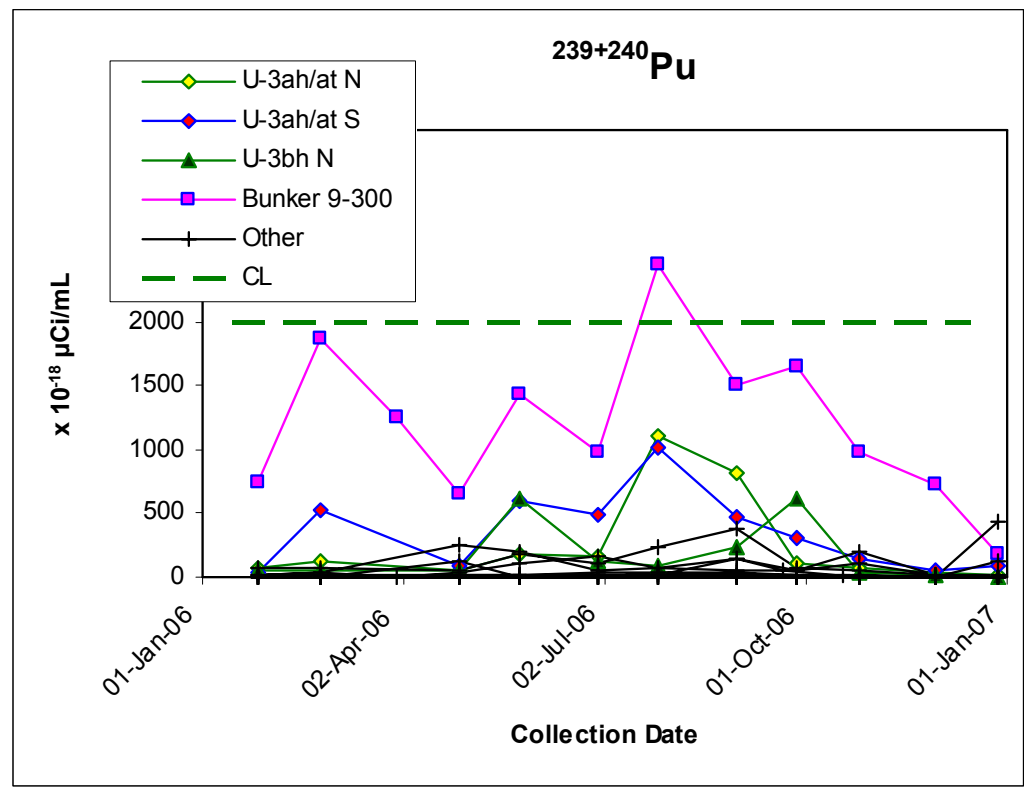

Figure 3-4. Concentrations of ${ }^{239+240} \mathrm{Pu}$ in air samples collected in 2006

The time series plots for ${ }^{241} \mathrm{Am},{ }^{238} \mathrm{Pu}$, and ${ }^{239+240} \mathrm{Pu}$ at Bunker 9-300 in Figures 3-2, 3-3, and 3-4 are highly correlated. This is because ${ }^{241} \mathrm{Am}$ is the long-lived daughter product obtained when ${ }^{241} \mathrm{Pu}$ (a short-lived isotope created along with the more common $\mathrm{Pu}$ isotopes) decays by beta emission. Hence, both ${ }^{239+240} \mathrm{Pu}$ and ${ }^{241} \mathrm{Am}$ (and also ${ }^{238} \mathrm{Pu}$ ) tend to be found together in particles of $\mathrm{Pu}$ remaining from past nuclear tests. The half-life of ${ }^{241} \mathrm{Pu}$ is 14.4 years, whereas that of ${ }^{241} \mathrm{Am}$ is 433 years; consequently, the concentrations of ${ }^{241} \mathrm{Am}$ in NTS soils will gradually increase for about 80 years and then decrease. These isotopes are made airborne by soil disturbances.

Figures 3-5 and 3-6 show long-term trends in ${ }^{239+240} \mathrm{Pu}$ annual mean concentrations at locations with at least 15 -year data histories since 1971. The estimated average annual rates of decline for the groups of NTS areas shown range from 3.4 percent for Areas 1 and 3 to 17.2 percent for Areas 18, 19, and 20. These rates are all considerably faster than can be attributed to radioactive decay, as the half-lives of ${ }^{239} \mathrm{Pu}$ and ${ }^{240} \mathrm{Pu}$ are 24,110 and 6,537 years, respectively. The decreases are therefore attributed to immobilization of Pu particles in soil and/or decrease in activities that result from soil resuspension. The half-life of the relatively less abundant ${ }^{238} \mathrm{Pu}$ is 88 years.

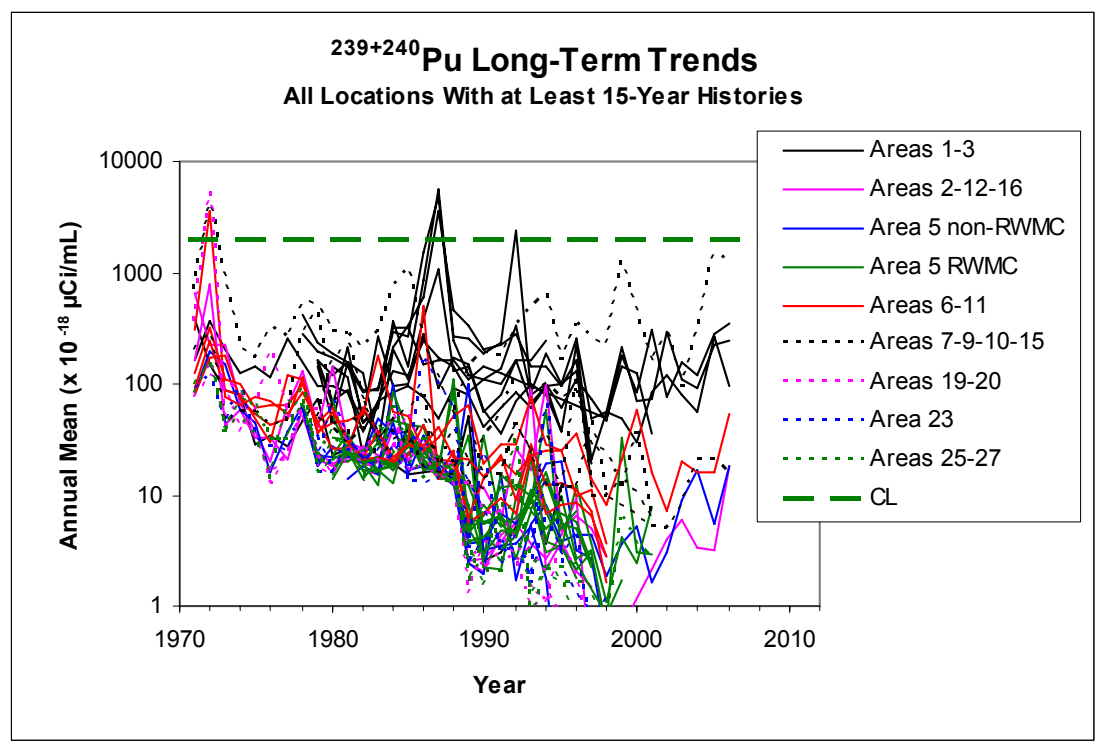

Figure 3-5. Long-term trends in average annual mean ${ }^{239+240} \mathrm{Pu}$ for NTS area groups 


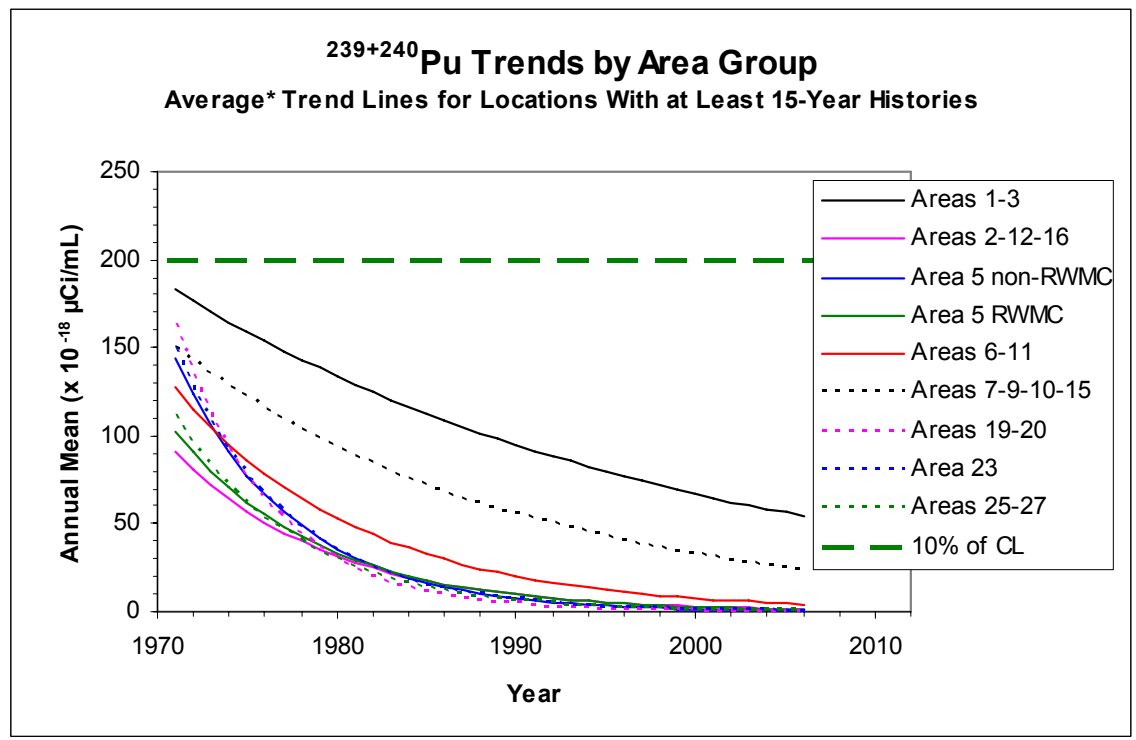

Figure 3-6. Fitted average long-term trends in ${ }^{239+240} \mathrm{Pu}$ mean values by NTS area groups

\subsubsection{Uranium Isotopes}

Uranium analyses were performed for samples from Areas 6, 16, 25, 27, and one location (Gate 20-2P) in Area 20. Exercises using depleted uranium ordinances have been conducted in Areas 20 and 25. The annual mean concentrations at locations where samples where analyzed by radiochemistry for uranium isotopes are shown in Table 3-6. Note that the scale factor in Table 3-6 is the same for ${ }^{233+234} \mathrm{U}$ and ${ }^{238} \mathrm{U}$, but an order of magnitude lower for $235+236 \mathrm{U}$. Ninety-eight and 100 percent of the ${ }^{233+234} \mathrm{U}$ and ${ }^{238} \mathrm{U}$ measurements exceeded their MDCs, respectively; that proportion is 60 percent for ${ }^{235+236} \mathrm{U}$. These are very close to the proportions observed in 2005 and 2004 . Mean concentrations of ${ }^{233+234} \mathrm{U}$ and ${ }^{238} \mathrm{U}$ isotopes are likewise similar to those for 2005 and 2004, but higher than the mean values for the preceding three years. The mean concentrations remain less than 2.5 percent of the CLs for ${ }^{233+234} \mathrm{U}$ and ${ }^{238} \mathrm{U}$, and at most 0.2 percent of the CL for ${ }^{235+236} \mathrm{U}$. No substantial or statistically significant differences were observed between stations.

The ratios of the isotope concentrations are given in Table 3-7, and Table 3-8 presents the expected values of those ratios for uranium from different sources. Medians and means of both the ${ }^{238} \mathrm{U} / 233+234 \mathrm{U}$ and ${ }^{238} \mathrm{U} / 235+236 \mathrm{U}$ ratios are below the expected value for natural uranium in the direction of enriched uranium, the former very slightly and the latter somewhat more so, although not as much as with the 2005 data. Because of the larger degree of uncertainty associated with measurements of the very low concentrations of ${ }^{235}+236 \mathrm{U}$, the former mean ratio is taken to be a more reliable indication of the source of the uranium, which appears to be essentially natural. In particular, there is no suggestion of any contribution from depleted uranium.

Table 3-6. Concentrations of uranium isotopes in air samples collected in 2006

\begin{tabular}{|c|c|c|c|c|c|c|c|c|c|c|}
\hline \multirow[b]{2}{*}{$\begin{array}{l}\text { NTS } \\
\text { Area }\end{array}$} & \multirow[b]{2}{*}{ Location } & \multirow[b]{2}{*}{$\begin{array}{l}\text { Number of } \\
\text { Samples }\end{array}$} & \multicolumn{8}{|c|}{${ }^{233+234} \mathrm{U}\left(\times 1^{-17} \mu \mathrm{Ci} / \mathrm{mL}\right)$} \\
\hline & & & Mean & $\begin{array}{l}\% \text { of } \\
\text { CL (a) }\end{array}$ & Median & $\mathrm{SD}^{(\mathrm{b})}$ & $\operatorname{Min}^{(c)}$ & $\operatorname{Max}^{(d)}$ & $\begin{array}{l}\text { Mean } \\
\text { MDC }\end{array}$ & $\begin{array}{c}\%> \\
\text { MDC }\end{array}$ \\
\hline 6 & Yucca & 11 & 16.56 & 2.3 & 18.37 & 5.37 & 3.23 & 21.69 & 1.26 & 100.0 \\
\hline 16 & 3545 Substation & 11 & 17.15 & 2.4 & 18.70 & 5.10 & 3.80 & 21.99 & 1.46 & 100.0 \\
\hline 20 & Gate $20-2 P$ & 11 & 16.93 & 2.4 & 18.52 & 5.54 & 0.73 & 20.04 & 1.42 & 90.9 \\
\hline 25 & Gate 510 & 11 & 17.53 & 2.5 & 17.87 & 4.71 & 5.30 & 22.24 & 1.11 & 100.0 \\
\hline 27 & ABLE Site & 11 & 17.53 & 2.5 & 17.87 & 4.71 & 5.30 & 22.24 & 1.11 & 100.0 \\
\hline & All Locations & 55 & 16.94 & 2.4 & 18.48 & 4.89 & 0.73 & 22.26 & 1.29 & 98.2 \\
\hline
\end{tabular}


Table 3-6. Concentrations of uranium isotopes in air samples collected in 2006 (continued)

\begin{tabular}{|c|c|c|c|c|c|c|c|c|c|c|}
\hline \multirow[b]{2}{*}{$\begin{array}{l}\text { NTS } \\
\text { Area }\end{array}$} & \multirow[b]{2}{*}{ Location } & \multirow[b]{2}{*}{$\begin{array}{c}\text { Number of } \\
\text { Samples }\end{array}$} & \multicolumn{8}{|c|}{${ }^{235+236} \mathrm{U}\left(\times 10^{-18} \mu \mathrm{Ci} / \mathrm{mL}\right)$} \\
\hline & & & Mean & $\begin{array}{l}\% \text { of } \\
C^{\text {(a) }}\end{array}$ & Median & Std ${ }^{(b)}$ & $\operatorname{Min}^{(c)}$ & $\operatorname{Max}^{(d)}$ & $\begin{array}{l}\text { Mean } \\
\text { MDC }\end{array}$ & $\begin{array}{c}\%> \\
\text { MDC }\end{array}$ \\
\hline 6 & Yucca & 11 & 9.70 & 0.1 & 8.76 & 5.33 & 1.96 & 21.74 & 10.54 & 54.5 \\
\hline 16 & 3545 Substation & 11 & 12.29 & 0.2 & 12.36 & 7.56 & 2.74 & 31.99 & 9.95 & 63.6 \\
\hline 20 & Gate $20-2 \mathrm{P}$ & 11 & 10.35 & 0.1 & 11.10 & 4.38 & 4.14 & 17.48 & 11.53 & 54.5 \\
\hline 25 & Gate 510 & 12 & 20.64 & 0.3 & 15.93 & 15.89 & 8.82 & 62.36 & 21.28 & 62.5 \\
\hline \multirow[t]{3}{*}{27} & ABLE Site & 11 & 10.01 & 0.1 & 9.04 & 7.16 & 1.02 & 25.06 & 10.88 & 54.5 \\
\hline & All Locations & 55 & 10.67 & 0.2 & 10.07 & 5.77 & 1.02 & 31.99 & 10.39 & 60.0 \\
\hline & & & \multicolumn{8}{|c|}{${ }^{238} \mathrm{U}\left(\mathrm{x} 10^{-17} \mu \mathrm{Ci} / \mathrm{mL}\right)$} \\
\hline 6 & Yucca & 11 & 16.67 & 2.0 & 17.34 & 5.35 & 3.23 & 23.66 & 1.13 & 100.0 \\
\hline 16 & 3545 Substation & 11 & 16.30 & 2.0 & 17.59 & 4.45 & 4.14 & 20.81 & 1.20 & 100.0 \\
\hline 20 & Gate $20-2 \mathrm{P}$ & 11 & 16.66 & 2.0 & 18.28 & 5.53 & 1.34 & 21.07 & 1.04 & 100.0 \\
\hline 25 & Gate 510 & 11 & 16.50 & 2.0 & 17.94 & 4.71 & 2.80 & 20.45 & 0.99 & 100.0 \\
\hline 27 & ABLE Site & 11 & 15.88 & 1.9 & 17.01 & 4.98 & 4.43 & 22.07 & 1.17 & 100.0 \\
\hline & All Locations & 55 & 16.40 & 2.0 & 17.63 & 4.84 & 1.34 & 23.66 & 1.11 & 100.0 \\
\hline
\end{tabular}

Blue-shaded locations are EPA-approved critical receptor sampler stations.

Non-shaded locations are environmental sampler stations.

Green shading indicates that some percentage of samples had concentrations above the sample specific MDC.

(a) CL is the NESHAP Concentration Level for Environmental Compliance (see Table 3-1).

(b) Standard deviation

(c) Minimum

(d) Maximum

Note: The CL for ${ }^{233+234} \mathrm{U}$ is about $710 \times 10^{-17} \mu \mathrm{Ci} / \mathrm{mL}$.

Note: The CL for ${ }^{235+236} \mathrm{U}$ is about 7,100 $\times 10^{-18} \mu \mathrm{Ci} / \mathrm{mL}$.

Note: The CL for ${ }^{238} \mathrm{U}$ is $830 \times 10^{-17} \mu \mathrm{Ci} / \mathrm{mL}$.

Table 3-7. Observed values of uranium isotope ratios

\begin{tabular}{||lcc||}
\hline & $\begin{array}{c}\text { Isotope Ratio Values } \\
\end{array}$ & \\
& ${ }^{238} \mathbf{U} /{ }^{233+234} \mathbf{U}$ & ${ }^{238} \mathbf{U} /{ }^{235+236} \mathbf{U}$ \\
\hline $\begin{array}{l}\text { Median } \\
95 \% \text { CI for Mean (a) }\end{array}$ & 0.95 & 16.4 \\
$(0.94,1.03)$ & $(14.1,19.8)$ \\
\hline
\end{tabular}

(a) arithmetic mean for the ${ }^{238} U /{ }^{233+234} U$ ratio, geometric mean for the ${ }^{238} \mathrm{U} / 235+236 \mathrm{U}$ ratio

Table 3-8. Expected ratios of uranium isotopes by type of source

\begin{tabular}{|lcc||}
\hline \multirow{2}{*}{ Source } & \multicolumn{2}{c|}{ Expected Isotope Ratios } \\
& ${ }^{238} \mathbf{U} /{ }^{233+234} \mathbf{U}$ & ${ }^{238} \mathbf{U} /{ }^{235+236} \mathbf{U}$ \\
\hline Natural & $\sim 1.0$ & $\sim 21$ \\
Enriched & $\sim 0.1$ & $\sim 5.2$ \\
Depleted & $\sim 0.9$ & $\sim 62$ \\
\hline
\end{tabular}




\subsubsection{Tritium}

Measurements of tritium in air vary widely across the NTS. Overall 52 percent of atmospheric moisture samples have tritium $\left({ }^{3} \mathrm{H}\right)$ concentrations above their MDCs; this proportion ranges from 100 percent at Schooner, E Tunnel Pond, and Sedan N to less than 20 percent at Little Feller 2 N, Gate 510, and Mercury Track. The spatial patterns are very similar to those observed in 2005, with minor exceptions discussed below. See Table 3-9 for summary statistics.

The highest mean concentration was found at Schooner $\left(360 \times 10^{-6}\right.$ picocuries per milliliter $\left.[\mathrm{pCi} / \mathrm{mL}]\right)$. The next highest is $9.4 \times 10^{-6} \mathrm{pCi} / \mathrm{mL}$ at Sedan N. These data are shown in Figure 3-7. Note that the Schooner values are plotted at one-tenth their actual values in order to allow the variation at other locations to be visible. The Schooner annual mean is 24 percent of the CL. The mean concentrations at other locations are at most 0.6 percent of the CL.

Table 3-9. Concentrations of tritium in air samples collected in 2006

\begin{tabular}{|c|c|c|c|c|c|c|c|c|c|c|}
\hline \multirow[b]{2}{*}{$\begin{array}{l}\text { NTS } \\
\text { Area }\end{array}$} & \multirow[b]{2}{*}{ Location } & \multirow{2}{*}{$\begin{array}{c}\text { Number } \\
\text { of } \\
\text { Samples }\end{array}$} & \multicolumn{8}{|c|}{${ }^{3} \mathrm{H}$ Concentration $\left(\times 10^{-6} \mathrm{pCi} / \mathrm{mL}\right)$} \\
\hline & & & Mean & $\begin{array}{l}\% \text { of } \\
\text { CL } \\
\end{array}$ & Median & $\mathrm{SD}^{(\mathrm{b})}$ & $\operatorname{Min}(\mathrm{c})$ & $\operatorname{Max}(d)$ & $\begin{array}{l}\text { Mean } \\
\text { MDC }\end{array}$ & $\begin{array}{c}\%> \\
\text { MDC }\end{array}$ \\
\hline 1 & BJY & 24 & 1.24 & 0.1 & 1.27 & 0.90 & -0.01 & 3.13 & 0.98 & 58.3 \\
\hline 3 & U-3ah/at S & 25 & 1.17 & 0.1 & 1.13 & 0.84 & 0.06 & 2.66 & 0.87 & 52.0 \\
\hline 3 & U-3bh N & 26 & 0.71 & 0.0 & 0.65 & 0.53 & -0.07 & 1.63 & 0.89 & 44.2 \\
\hline 5 & DoD & 25 & 3.23 & 0.2 & 1.47 & 3.18 & 0.36 & 13.19 & 0.91 & 72.0 \\
\hline 5 & Sugar Bunker N & 25 & 4.03 & 0.3 & 2.39 & 4.36 & -0.30 & 18.11 & 0.91 & 84.0 \\
\hline 6 & Yucca & 26 & 0.61 & 0.0 & 0.49 & 0.35 & 0.01 & 1.54 & 0.92 & 32.7 \\
\hline 9 & Bunker 9-300 & 25 & 2.66 & 0.2 & 2.42 & 2.07 & 0.39 & 6.60 & 0.94 & 76.0 \\
\hline 10 & Gate 700 S & 25 & 0.76 & 0.1 & 0.65 & 0.63 & -0.26 & 2.21 & 0.94 & 40.0 \\
\hline 10 & Sedan N & 24 & 9.38 & 0.6 & 6.67 & 8.56 & 1.07 & 28.02 & 0.92 & 100.0 \\
\hline 12 & E Tunnel Pond 2 & 15 & 6.51 & 0.4 & 6.75 & 3.16 & 1.43 & 11.75 & 0.92 & 100.0 \\
\hline 16 & 3545 Substation & 24 & 0.38 & 0.0 & 0.36 & 0.41 & -0.37 & 1.34 & 0.87 & 25.0 \\
\hline 18 & Little Feller $2 \mathrm{~N}$ & 25 & 0.39 & 0.0 & 0.45 & 0.51 & -0.77 & 1.73 & 0.90 & 16.0 \\
\hline 20 & Gate $20-2 \mathrm{P}$ & 26 & 0.38 & 0.0 & 0.35 & 0.48 & -0.60 & 1.78 & 0.89 & 23.1 \\
\hline 20 & Schooner & 25 & 360.31 & 24.0 & 183.58 & 401.58 & 19.16 & $1,228.06$ & 1.59 & 100.0 \\
\hline 23 & Mercury Track & 26 & 0.34 & 0.0 & 0.32 & 0.41 & -0.47 & 1.40 & 0.97 & 19.2 \\
\hline 25 & Gate 510 & 26 & 0.34 & 0.0 & 0.23 & 0.39 & -0.20 & 1.61 & 0.95 & 11.5 \\
\hline \multicolumn{2}{|c|}{ All Environmental Samplers } & 392 & 24.84 & 1.7 & 0.79 & 132.65 & -0.77 & 1228.06 & 0.96 & 51.8 \\
\hline
\end{tabular}

Blue-shaded locations are EPA-approved critical receptor sampler stations.

Non-shaded locations are environmental sampler stations.

Green shading indicates that some percentage of samples had concentrations above the sample-specific MDC.

(a) CL is the NESHAP Concentration Level for Environmental Compliance (see Table 3-1).

(b) Standard deviation

(c) Minimum

(d) Maximum

Note: The CL for ${ }^{3} \mathrm{H}$ is $1,500 \times 10^{6} \mathrm{pCi} / \mathrm{mL}$. 


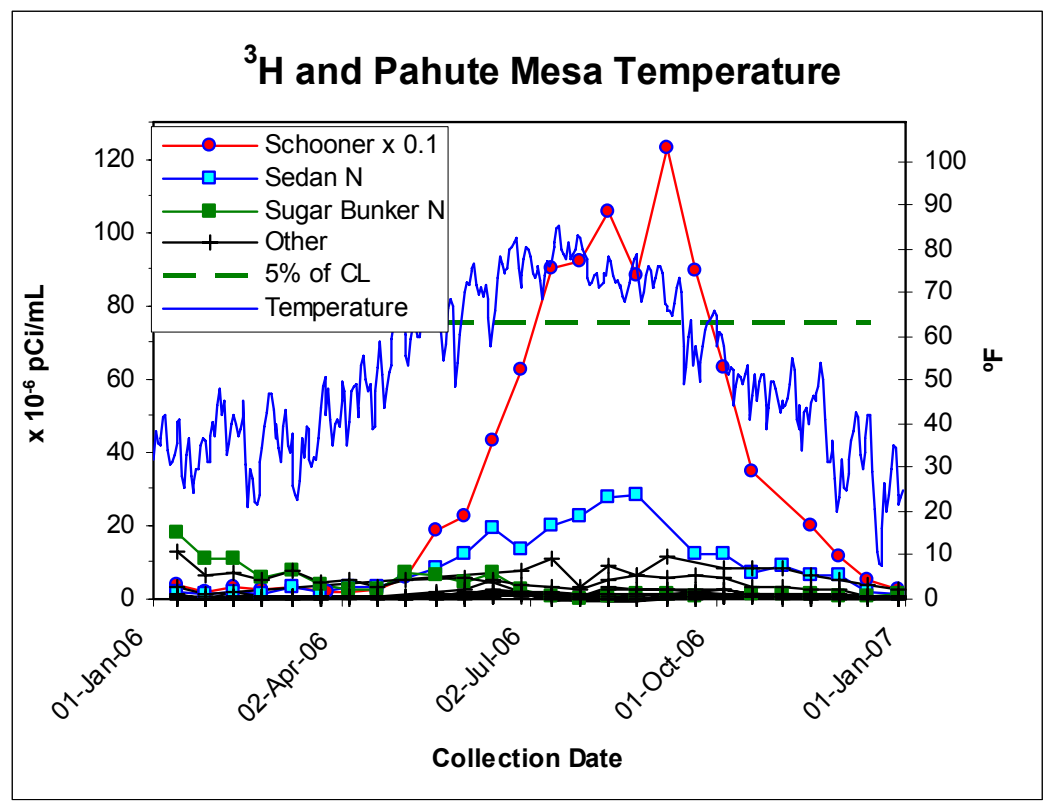

Figure 3-7. Concentrations of tritium in air samples collected in 2006 and Pahute Mesa air temperature

The tritium found at Schooner, Sedan N, and E Tunnel Pond comes primarily from tritium used in past nuclear tests. During detonations, the ${ }^{3} \mathrm{H}$ is oxidized into tritiated water, which remains in the ejecta from the craters and the rubble in tunnel shafts until it evaporates. The rate of evaporation increases as the temperature increases during the summer months, with some lag to allow for heating of the soil; conversely, rainfall can temporarily suppress the evaporation by saturating the soil and diluting the surface moisture with rain water. Figure 3-7 shows the relationship between ${ }^{3} \mathrm{H}$ measurements and the average daily temperature at Pahute Mesa, where Schooner is located; Figure 3-8 shows the time and amount of precipitation events in that area.

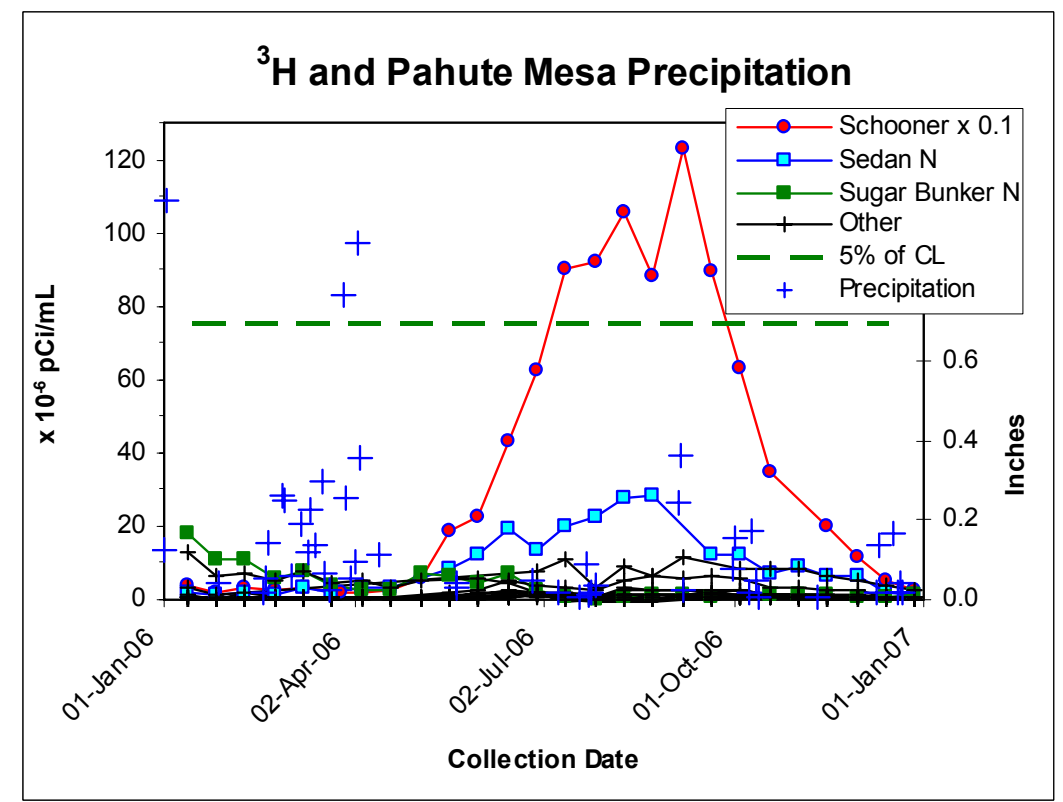

Figure 3-8. Concentrations of tritium in air samples collected in 2006 and Pahute Mesa precipitation 
At the end of 2005, elevated measurements of ${ }^{3} \mathrm{H}$ occurred at Sugar Bunker N and DoD, as reported in the Nevada Test Site Environmental Report 2005 (DOE, 2006b). These levels tapered off through the first few months of 2006, after which the measurements returned to background levels. The annual mean values for these locations are at most 0.2 percent of the CL.

Figure 3.9 shows long-term trends for the annual means of all locations with at least seven-year histories since 1987, color-coded by NTS area. At most locations, the ${ }^{3} \mathrm{H}$ measurements have been decreasing fairly rapidly from year to year; the average decline rate is around 19 percent per year across all locations. This ranges from 5.5 percent per year at BJY in Area 1 to an average of 36 percent per year in Areas 23 and 25. During 1998, a more efficient sampling system (molecular sieve) was incorporated. The trend plots and decline rates presented here (Figures 3-8 and 3-9) are adjusted for the impact of this more efficient system.

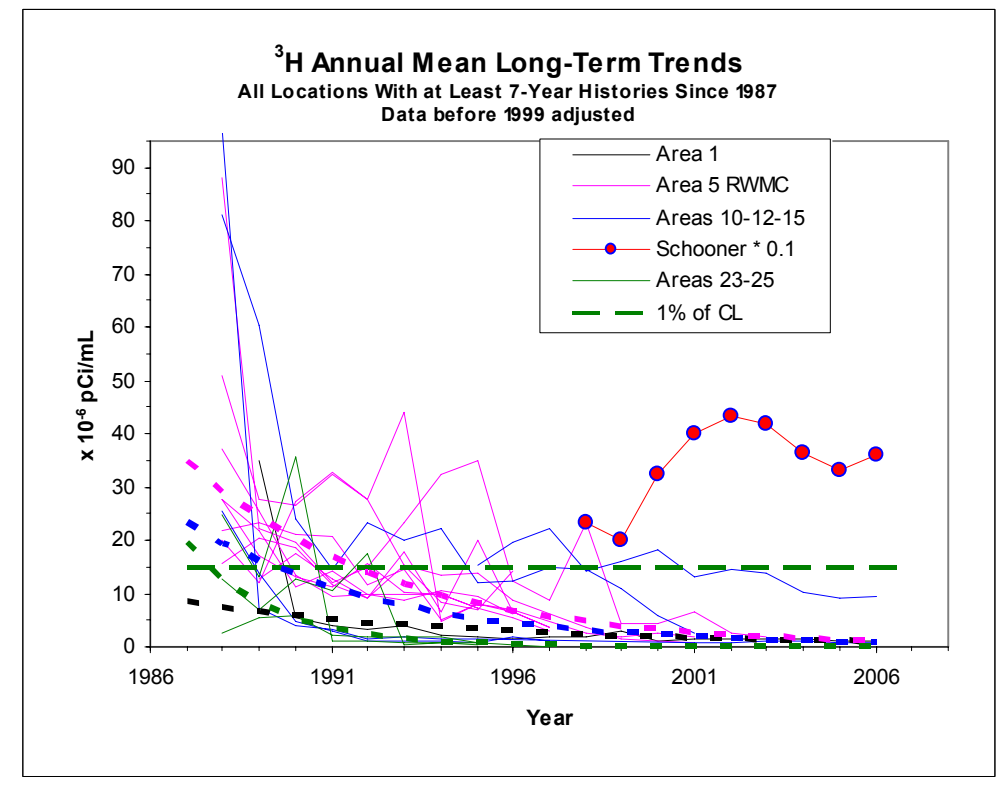

Figure 3-9. Average long-term trends in tritium at locations having at least 7 years of data

The exception to the generally-decreasing trend occurs at Schooner, where on average the air concentrations of tritium have been increasing at an average rate of 6 percent per year. As Figure 3-10 shows, however, this is not a consistent trend, but rather appears to be related to the temperatures on Pahute Mesa during the summer months.

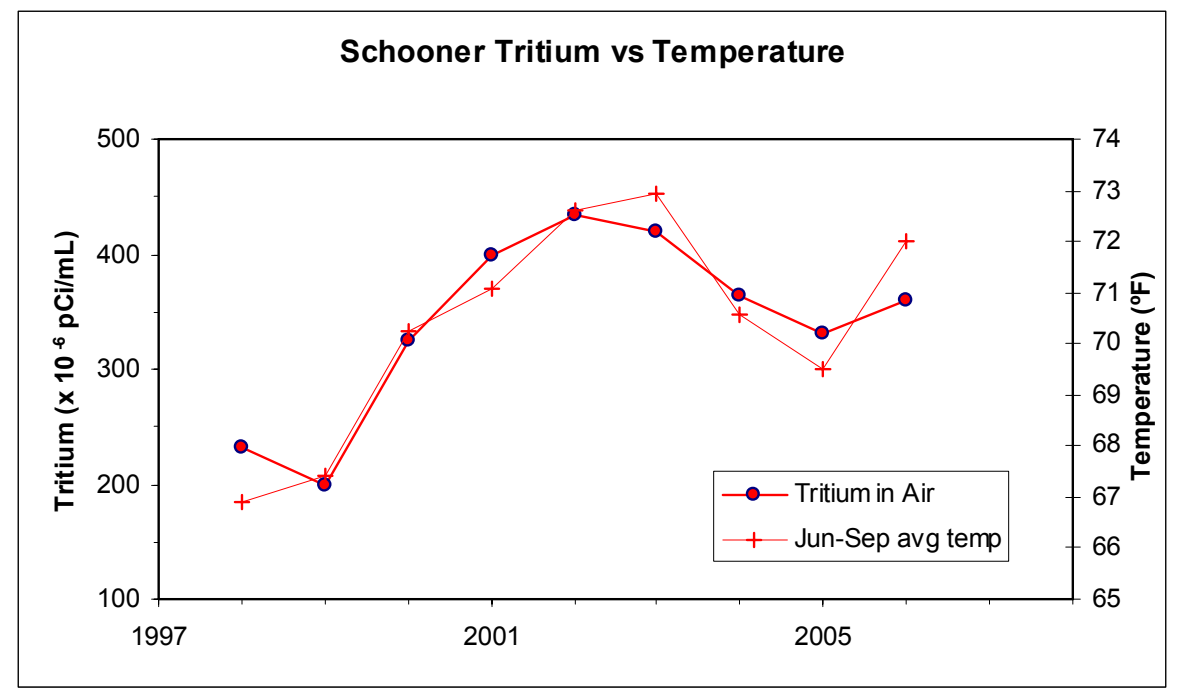

Figure 3-10. Tritium emissions at Schooner and June-September average temperatures at Pahute Mesa 


\subsubsection{Gross Alpha and Gross Beta}

The concentrations of gross alpha and gross beta radioactivity in air samples collected from all environmental samplers in 2006 are shown in Tables 3-10 and 3-11 and Figures 3-11 and 3-12. Since these radioactivities include naturally-occurring ${ }^{40} \mathrm{~K},{ }^{7} \mathrm{Be}$, uranium, thorium, and the daughter isotopes of uranium and thorium in uncertain proportions, a meaningful CL cannot be constructed. These analyses are useful in that they can be performed just five days after sample collection to identify any increases requiring investigation.

Overall, 38 percent of gross alpha measurements exceeded their MDCs, nearly the same as in 2005 and only slightly higher than 2004. The overall mean measurements are slightly higher than 2005 as well. The biggest increase in measurements over 2005 is found at Bunker 9-300; this corresponds to the increased concentrations of ${ }^{241} \mathrm{Am},{ }^{238} \mathrm{Pu}$, and ${ }^{239+240} \mathrm{Pu}$ present during the summer.

All of the gross beta measurements exceeded their MDCs in 2006; it was nearly 100 percent in 2005 and 2004 as well. The mean value is slightly higher than in 2005; there is only one outstanding value to highlight in Figure 3-12. The week-to-week parallel variation between sampling locations is much more pronounced with gross beta than with gross alpha which continues the pattern of prior years.

Table 3-10. Gross alpha radioactivity in air samples collected in 2006

\begin{tabular}{|c|c|c|c|c|c|c|c|c|c|}
\hline \multirow[b]{2}{*}{$\begin{array}{l}\text { NTS } \\
\text { Area }\end{array}$} & \multirow[b]{2}{*}{ Location } & \multirow{2}{*}{$\begin{array}{c}\text { Number } \\
\text { of } \\
\text { Samples }\end{array}$} & \multicolumn{7}{|c|}{ Gross Alpha (x 10-16 $\mu \mathrm{Ci} / \mathrm{mL})$} \\
\hline & & & Mean & Median & $\mathrm{SD}^{\text {(a) }}$ & $\operatorname{Min}^{(b)}$ & $\operatorname{Max}(c)$ & $\begin{array}{l}\text { Mean } \\
\text { MDC }\end{array}$ & $\begin{array}{c}\%> \\
\text { MDC }\end{array}$ \\
\hline 1 & BJY & 52 & 24.64 & 21.73 & 14.91 & -2.23 & 80.10 & 27.66 & 38.5 \\
\hline 3 & U-3ah/at N & 52 & 28.61 & 26.73 & 19.30 & 4.54 & 116.00 & 27.41 & 51.9 \\
\hline 3 & U-3ah/at S & 50 & 34.17 & 28.80 & 21.89 & 0.00 & 87.50 & 27.28 & 52.0 \\
\hline 3 & U-3bh N & 52 & 25.84 & 25.88 & 17.21 & 0.00 & 105.70 & 27.36 & 44.2 \\
\hline 3 & U-3bh S & 52 & 24.27 & 24.67 & 11.22 & 0.00 & 45.00 & 27.54 & 42.3 \\
\hline 5 & DoD & 52 & 20.05 & 18.81 & 9.92 & -4.48 & 47.30 & 27.45 & 24.0 \\
\hline 5 & Sugar Bunker N & 45 & 34.60 & 33.86 & 16.98 & 3.40 & 91.80 & 28.56 & 64.4 \\
\hline 6 & Yucca & 51 & 26.78 & 25.63 & 15.71 & 2.71 & 102.60 & 27.50 & 38.2 \\
\hline 9 & Bunker 9-300 & 52 & 60.26 & 58.93 & 34.82 & 7.99 & 157.60 & 27.61 & 78.8 \\
\hline 10 & Gate 700 S & 51 & 23.78 & 24.90 & 11.75 & 1.16 & 56.00 & 28.18 & 41.2 \\
\hline 10 & Sedan N & 49 & 22.25 & 21.90 & 13.78 & -3.45 & 55.40 & 28.42 & 26.5 \\
\hline 16 & 3545 Substation & 50 & 18.50 & 16.10 & 10.40 & 1.10 & 54.30 & 27.52 & 23.0 \\
\hline 18 & Little Feller 2 N & 52 & 19.73 & 20.86 & 11.84 & -3.31 & 42.60 & 27.56 & 26.9 \\
\hline 20 & Gate $20-2 \mathrm{P}$ & 51 & 18.59 & 19.44 & 11.39 & -11.65 & 45.00 & 27.97 & 23.5 \\
\hline 20 & Schooner & 51 & 18.58 & 16.58 & 12.25 & -2.28 & 46.80 & 27.20 & 27.5 \\
\hline 23 & Mercury Track & 51 & 18.02 & 18.12 & 9.88 & -3.39 & 43.40 & 27.47 & 23.5 \\
\hline 25 & Gate 510 & 52 & 20.74 & 20.37 & 12.33 & -5.60 & 49.50 & 27.57 & 35.6 \\
\hline 27 & ABLE Site & 50 & 17.72 & 18.69 & 7.60 & -1.16 & 30.80 & 27.33 & 17.0 \\
\hline \multicolumn{2}{|c|}{ All Environmental Samplers } & 924 & 915 & 25.37 & 22.31 & 18.55 & -11.65 & 157.55 & 27.64 \\
\hline 27 & JASPER Stack & 50 & 269.73 & 9.87 & 1753.81 & -686.16 & 12339.40 & 1160.66 & 3.0 \\
\hline
\end{tabular}

Blue-shaded locations are EPA-approved critical receptor sampler stations.

The orange-shaded location is a point-source sampler station.

Non-shaded locations are environmental sampler stations.

Green shading indicates that some percentage of samples had concentrations above the sample-specific MDC.
(a) Standard deviation
(b) Minimum
(c) Maximum 
Table 3-11. Gross beta radioactivity in air samples collected in 2006

\begin{tabular}{|c|c|c|c|c|c|c|c|c|c|}
\hline \multirow[b]{2}{*}{$\begin{array}{l}\text { NTS } \\
\text { Area }\end{array}$} & \multirow[b]{2}{*}{ Location } & \multirow[b]{2}{*}{$\begin{array}{c}\text { Number } \\
\text { of } \\
\text { Samples }\end{array}$} & \multicolumn{7}{|c|}{ Gross Beta $\left(\times 10^{-15} \mu \mathrm{Ci} / \mathrm{mL}\right)$} \\
\hline & & & Mean & Median & $\mathrm{SD}^{\text {(a) }}$ & $\operatorname{Min}^{(b)}$ & $\operatorname{Max}(c)$ & $\begin{array}{l}\text { Mean } \\
\text { MDC }\end{array}$ & $\begin{array}{c}\%> \\
\text { MDC }\end{array}$ \\
\hline 1 & BJY & 52 & 19.03 & 18.57 & 5.07 & 8.00 & 30.98 & 4.13 & 100.0 \\
\hline 3 & U-3ah/at N & 52 & 19.13 & 19.10 & 4.72 & 7.67 & 30.51 & 4.10 & 100.0 \\
\hline 3 & U-3ah/at S & 50 & 19.89 & 20.56 & 5.15 & 9.09 & 29.88 & 4.08 & 100.0 \\
\hline 3 & U-3bh N & 52 & 19.28 & 19.57 & 5.50 & 7.91 & 32.32 & 4.09 & 100.0 \\
\hline 3 & U-3bh S & 52 & 19.47 & 19.38 & 4.90 & 9.90 & 29.72 & 4.12 & 100.0 \\
\hline 5 & DoD & 52 & 20.04 & 19.84 & 5.19 & 9.64 & 33.76 & 4.10 & 100.0 \\
\hline 5 & Sugar Bunker N & 45 & 21.33 & 20.92 & 5.06 & 8.69 & 34.07 & 4.32 & 100.0 \\
\hline 6 & Yucca & 51 & 20.41 & 20.81 & 5.41 & 9.13 & 33.51 & 4.12 & 100.0 \\
\hline 9 & Bunker 9-300 & 52 & 19.50 & 20.02 & 5.23 & 9.41 & 29.24 & 4.12 & 100.0 \\
\hline 10 & Gate 700 S & 51 & 18.90 & 19.14 & 5.27 & 5.57 & 32.63 & 4.23 & 100.0 \\
\hline 10 & Sedan N & 49 & 18.20 & 18.59 & 4.86 & 7.69 & 28.63 & 4.24 & 100.0 \\
\hline 16 & 3545 Substation & 50 & 18.27 & 17.38 & 5.31 & 7.57 & 36.30 & 4.13 & 100.0 \\
\hline 18 & Little Feller $2 \mathrm{~N}$ & 52 & 17.76 & 18.20 & 4.78 & 6.88 & 27.62 & 4.12 & 100.0 \\
\hline 20 & Gate $20-2 \mathrm{P}$ & 51 & 18.04 & 18.08 & 5.01 & 5.76 & 29.63 & 4.18 & 100.0 \\
\hline 20 & Schooner & 51 & 18.58 & 18.16 & 4.96 & 7.14 & 28.20 & 4.06 & 100.0 \\
\hline 23 & Mercury Track & 51 & 19.02 & 19.85 & 5.13 & 6.59 & 29.00 & 4.11 & 100.0 \\
\hline 25 & Gate 510 & 52 & 19.86 & 20.52 & 5.18 & 10.99 & 32.42 & 4.12 & 100.0 \\
\hline 27 & ABLE Site & 50 & 18.41 & 18.40 & 5.17 & 7.43 & 30.24 & 4.08 & 100.0 \\
\hline \multicolumn{2}{|c|}{ All Environmental Samplers } & 925 & 915 & 19.16 & 19.42 & 5.14 & 5.57 & 36.30 & 4.13 \\
\hline 27 & JASPER Stack & 50 & 66.41 & 1.02 & 471.11 & -41.00 & 3329.63 & 177.50 & 4.0 \\
\hline
\end{tabular}

Blue-shaded locations are EPA-approved critical receptor sampler stations.

The orange-shaded location is a point-source sampler station.

Non-shaded locations are environmental sampler stations.

Green shading indicates that some percentage of samples had concentrations above the sample-specific MDC.
(a) Standard deviation
(b) Minimum
(c) Maximum

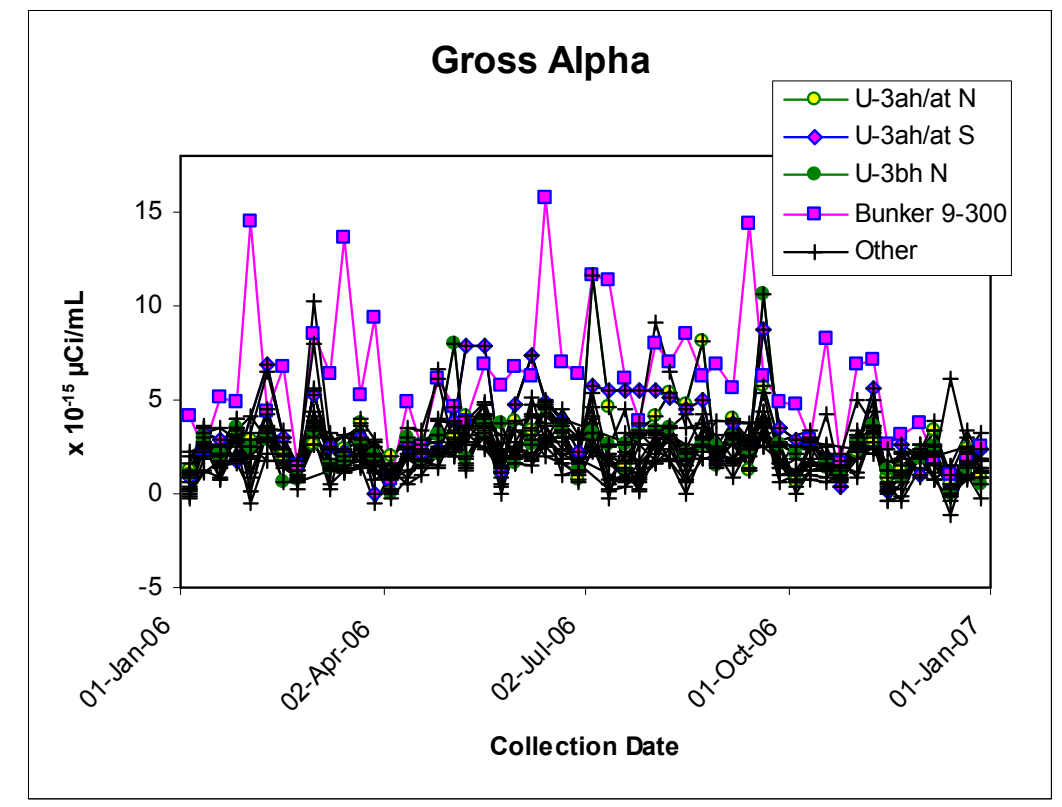

Figure 3-11. Gross alpha radioactivity in air samples collected in 2006 


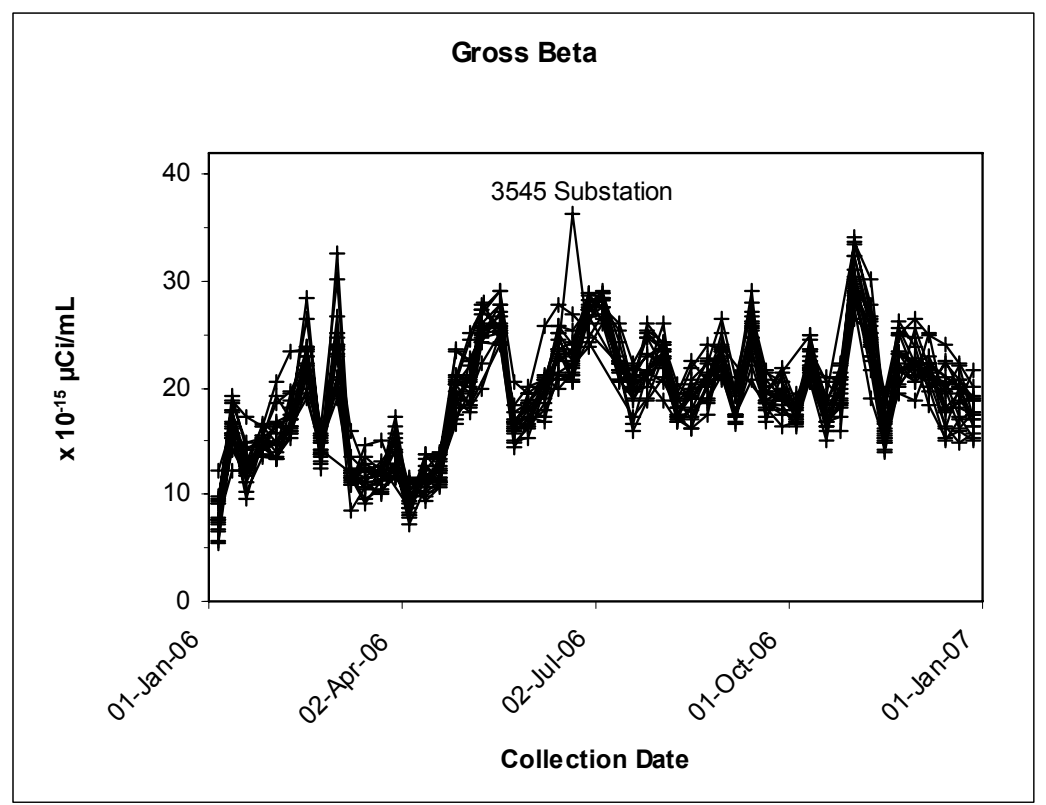

Figure 3-12. Gross beta radioactivity in air samples collected in 2006

\subsubsection{Air Sampling Results from Critical Receptor Samplers}

The following radionuclides were detected at three or more of the critical receptor samplers: ${ }^{241} \mathrm{Am},{ }^{238} \mathrm{Pu},{ }^{239+240} \mathrm{Pu}$, ${ }^{233}+234 \mathrm{U},{ }^{235}+236 \mathrm{U},{ }^{238} \mathrm{U}$, and ${ }^{3} \mathrm{H}$ (see Tables 3-2, 3-4, 3-5, 3-6, and 3-9, respectively). All measured concentrations of these radionuclides were well below their CLs. The uranium isotopes are attributed to naturally-occurring uranium (see Section 3.1.4.3). The concentration of each measured radionuclide (excluding uranium, since it has been determined to be of natural origin) at each of the six critical receptor samplers was divided by its respective CL (see Table 3-1) to obtain a "fraction of CL." These fractions were then summed for each location. The sum of these fractions at each critical receptor sampler is less than 1.0 (Table 3-12) demonstrating that the NESHAP dose limit (10 $\mathrm{mrem} / \mathrm{yr}$ ) at these critical receptor locations was not exceeded. The highest radiation dose (CEDE) at a critical receptor location would be approximately $2.5 \mathrm{mrem} / \mathrm{yr}$ for a hypothetical individual residing at Schooner.

Table 3-12. Sum of percents of compliance levels for radionuclides detected at critical receptor samplers

\begin{tabular}{||cccc||}
\hline $\begin{array}{c}\text { Radionuclides Included in } \\
\text { Sum of Percents }{ }^{(a)}\end{array}$ & $\begin{array}{c}\text { NTS } \\
\text { Area }\end{array}$ & Location & $\begin{array}{c}\text { Sum of Fractions of Compliance } \\
\text { Levels (CLs) }\end{array}$ \\
\hline & 6 & Yucca & 0.032 \\
& 10 & Gate $700 \mathrm{~S}$ & 0.009 \\
${ }^{241} \mathrm{Am},{ }^{238} \mathrm{Pu},{ }^{239+240} \mathrm{Pu},{ }^{3} \mathrm{H}$ & 16 & 3545 Substation & 0.015 \\
& 20 & Schooner & 0.249 (b) \\
& 23 & Mercury & 0.002 \\
& 25 & Gate 510 & 0.003 \\
\hline
\end{tabular}

(a) ${ }^{233+234} \mathrm{U},{ }^{235+236} \mathrm{U}$, and ${ }^{238} \mathrm{U}$ are not included in sum of percents. All uranium detected in air particulate samples was determined to be naturally occurring, based on the isotopic ratios.

(b) This equates to a hypothetical receptor at this location receiving a CEDE of $2.5 \mathrm{mrem} / \mathrm{yr}$. 


\subsubsection{Air Sampling Results from Point-Source (Stack) Sampler}

Analyses of the 2006 air samples from the stack sampler at the JASPER facility contained only one measurement of a man-made radionuclide ( ${ }^{241} \mathrm{Am}$ ) above its MDC (see Tables 3-2 through 3-5). For the year, the mean of the ${ }^{241} \mathrm{Am}$ measurements was only 1.2 percent of the CL. The detected ${ }^{241} \mathrm{Am}$ was likely from ambient air since no plutonium (source-term at JASPER) was detected and outside air occasionally gets pulled through the stack sampler during diagnostic tests when the blowers are purposely blocked from exhausting through the stack. The HEPA filters at the facility appeared to function as intended; therefore, no radionuclide emission rate or offsite dose was calculated for this potential NTS radiation source (see Section 8.0).

\subsubsection{Emission Evaluations for Planned Projects}

In 2006, several planned projects were evaluated to determine if they have the potential to release airborne radionuclides which would expose the public to a dose greater than $0.1 \mathrm{mrem} / \mathrm{yr}(0.001 \mathrm{mSv} / \mathrm{yr})$. For any project or facility with this potential, the EPA requires point-source operational monitoring like that conducted at the JASPER facility. Those projects that were evaluated are listed below. Evaluations were performed using the EPA-approved atmospheric diffusion model called the Clean Air Package 1988, Versions 2.0 or 3.0 (CAP88-PC). CAP88-PC computes the CEDE for an offsite maximally exposed individual (MEI) from air emissions, in mrem/yr. The CEDE to the MEI for all these projects were well below the limit of $0.1 \mathrm{mrem} / \mathrm{yr}$. The detailed air emission dose evaluations for each project are presented in Warren and Grossman (2007).

- Remediation activities for Corrective Action Unit (CAU) 214: Bunkers and Storage Areas in Areas 5, 11, and 25

- A series of experiments planned by the Dense Plasma Focus project in Area 11

- Construction activities for the Legacy Compliance Project in radiologically-impacted portions of Area 8

- Air emissions from a research project in Area 14

\subsubsection{Unplanned Releases}

No unplanned radionuclide releases occurred on the NTS during 2006.

\subsubsection{Total NTS Radiological Atmospheric Releases}

Each year, all existing operations and new construction projects and modifications to existing facilities involving the use of radioactive materials are reviewed to identify those operations that can result in airborne emissions of radioactivity. The following quantities are measured or calculated to obtain the total annual quantity of radiological atmospheric releases from the NTS:

- The quantity of tritium gas released during the calibration of laboratory equipment

- The quantity of tritium released through evaporation from containment ponds or open tanks, estimated from the measured tritium concentrations in water discharged into them and assuming that all water is completely evaporated during the year

- The quantity of tritium released from the Area 3 and Area 5 RWMSs and from Schooner and Sedan crater sites, estimated using: (1) the EPA-approved atmospheric diffusion model called CAP88-PC, and (2) the annual mean concentration of tritium in air measured by environmental air samplers at locations near these sources

- The quantity of other radionuclides resuspended in air from areas of known soil contamination, calculated from an inventory of radionuclides in surface soil determined by the Radionuclide Inventory and Distribution Program (McArthur, 1991), a resuspension model (Nuclear Regulatory Commission [NRC], 1983), and equation parameters derived at the NTS (DOE, 1992) 
Emission sources identified in 2006 were:

- Release of tritium gas during the calibration of analytical equipment in Building 650, Area 23

- Evaporation of tritium from E Tunnel containment ponds in Area 12 which received water seeping from the Tunnel complex

- Evaporation of tritium from Area 5 Sewage Lagoon which received liquid effluents from the Building A-1 basement at the North Las Vegas Facility

- Release of uranium from a research project in Area 14

- Evapotranspiration of tritium from the Sedan and Schooner craters and from the areas including the Area 3 and Area 5 RWMSs

- Resuspension of ${ }^{241} \mathrm{Am}$ and ${ }^{239+240} \mathrm{Pu}$ from soil deposits on the NTS

Table 3-13 presents the radionuclide emission rates (in $\mathrm{Ci} / \mathrm{yr}$ ) at these identified source locations. Brief descriptions of the methods used for estimating these quantities are given in the table footnotes. More detailed descriptions are reported in Warren and Grossman (2007). In the last row of the table, the total amounts of ${ }^{241} \mathrm{Am}$ and ${ }^{239+240} \mathrm{Pu}$ emissions from soil re-suspension are presented. They are the sum of emission rates computed for each area of the NTS with surface contamination (Areas $1-11,12,13,15,16,17,18,19,20$, and 30). Other radionuclides $\left({ }^{60} \mathrm{Cs}\right.$, ${ }^{90} \mathrm{Sr}$, ${ }^{137} \mathrm{Cs},{ }^{152} \mathrm{Eu},{ }^{154} \mathrm{Eu},{ }^{155} \mathrm{Eu}$, and ${ }^{238} \mathrm{Pu}$ ), although found in surface soils during past radiation surveys, were not included since combined, they contributed only ten percent or less to the total MEI dose.

Table 3-13. Radiological atmospheric releases from NTS for 2006

\begin{tabular}{|c|c|c|}
\hline Source & Radionuclide & $\begin{array}{c}\text { Annual Quantity } \\
\text { (Ci) }\end{array}$ \\
\hline Area 23 Building 650 & ${ }^{3} \mathrm{H}$ & $0.0000225^{(\mathrm{a})}$ \\
\hline Area 12 E Tunnel Ponds & ${ }^{3} \mathrm{H}$ & $9.8^{(\mathrm{b})}$ \\
\hline Area 5 Sewage Lagoon & ${ }^{3} \mathrm{H}$ & $0.0003^{(b)}$ \\
\hline Area 3 RWMS & ${ }^{3} \mathrm{H}$ & $54^{(\mathrm{c})}$ \\
\hline Area 5 RWMS & ${ }^{3} \mathrm{H}$ & $19^{\text {(c) }}$ \\
\hline Area 14 & $\mathrm{U}$ & 0.0001 \\
\hline Area 20 Schooner & ${ }^{3} \mathrm{H}$ & $77(\mathrm{c})$ \\
\hline Area 10 Sedan & ${ }^{3} \mathrm{H}$ & $85^{\text {(c) }}$ \\
\hline All Sources Total & ${ }^{3} \mathbf{H}$ & 245 \\
\hline Grouped NTS Areas Total & ${ }^{241} \mathrm{Am}$ & $0.047^{(\mathrm{d})}$ \\
\hline Grouped NTS Areas Total & ${ }^{239+240} \mathrm{Pu}$ & $0.29^{(\mathrm{d})}$ \\
\hline
\end{tabular}

(a) Quantity of tritium gas released during the calibration of laboratory equipment.

(b) Estimated from ${ }^{3} \mathrm{H}$ concentration in water discharged into containment ponds, assuming all water completely evaporated.

(c) Estimated from calculations with CAP88-PC and annual mean concentration of ${ }^{3} \mathrm{H}$ in air measured by air sampling at a location near the emission source.

(d) Calculated from inventory of radionuclides in surface soil determined by Radionuclide Inventory and Distribution Program (McArthur, 1991), a re-suspension model (NRC, 1983), and equation parameters derived at the NTS (DOE, 1992).

\subsubsection{Environmental Impact}

The concentrations of man-made radionuclides in air on the NTS were all less than the regulatory concentration limits specified by federal regulations. Long-term trends of ${ }^{239+240} \mathrm{Pu}$ and tritium in air continue to show a decline with time. All radionuclides detected by environmental air samplers in 2006 appear to be from legacy deposits of radioactivity on and in the soil from past nuclear tests. There was no significant contribution to radioactive air emissions from NTS operational facilities in 2006. 


\subsection{Nonradiological Air Quality Assessment}

Nonradiological air monitoring and air quality assessments ${ }^{1}$ are conducted to document compliance with the current state of Nevada air quality permit that regulates specific operations or facilities on the NTS. The state of Nevada has adopted the CAA standards which include NESHAP, National Ambient Air Quality Standards (NAAQS), and New Source Performance Standards (NSPS) (see Section 2.1). Therefore, requirements set forth in the NTS air permit issued by the state are also in compliance with these national standards. Specifically omitted from this section is NESHAP compliance for radionuclide emissions, which is presented in Section 3.1. In 2006, assessments, facility/equipment monitoring, record-keeping, and reporting activities related to air quality on the NTS were conducted by ES personnel to meet the program goals shown in the table below. ES personnel collected and tracked the compliance measures shown in the table below.

\section{Air Quality Assessment Program Goals}

Ensure that NTS operations comply with all the requirements of current air quality permits issued by the state of Nevada for NTS operations.

Ensure that air emissions of criteria pollutants (sulfur dioxide $\left.\left[\mathrm{SO}_{2}\right]\right)$, nitrogen oxides [NOx], carbon monoxide [CO], volatile organic compounds ([VOCs], and particulate matter do not exceed limits established under NAAQS.

Ensure that NTS operations comply with the asbestos abatement reporting requirements under NESHAP.

Document usage of ozone-depleting substances (ODS) to comply with Title VI of the CAA.

\section{Compliance Measures}

Tons of emissions of criteria pollutants produced annually

Gallons of fuel burned annually

Hours of operation of equipment per year

Rate at which aggregate and concrete is produced

Quarterly opacity readings

Pounds of chemicals released from Non-Proliferation Test and Evaluation Complex (NPTEC) facilities

Amount of asbestos in existing structures removed or scheduled for removal

NNSA/NSO has been issued a Class II Air Quality Operating Permit (AP9711-0549.01) for NTS activities. Class II permits are issued for sources of air pollutants considered "minor" and where annual emissions must not exceed 100 tons of any one criteria pollutant (see Glossary, Appendix B), or 10 tons of any one hazardous air pollutant (HAP), or 25 tons of any combination of HAPs. The NTS facilities regulated by this permit include:

- Over 15 facilities/185 pieces of equipment in Areas 1, 3, 5, 6, 12, and 23

- $\quad$ NPTEC in Area 5

- $\quad$ Site-Wide Chemical Release Areas

- Big Explosives Experimental Facility (BEEF)

- Explosives Ordnance Disposal Unit

In March 2006, this permit was modified to include a number of revisions. The more noteworthy revisions included: (1) removal of the Area 23 incinerator from the permit, (2) a change in the due date for the NPTEC summary report to the state from 60 days following a test to quarterly, (3) and renaming of the Area 25 Test Cell C Facility to SiteWide Chemical Release Areas to reflect the ability to release small amounts of certain chemicals at various other NTS

1The word "assessment" versus "monitoring" is used in this section. Adherence to most nonradiological air quality standards on the NTS does not require field collection and analysis of air samples (activities called "monitoring" in this report). Instead, adherence to NTS air quality permits for nonradiological emissions usually involves the review of records, gathering of operational information, visible emissions evaluations, and calculation of emissions. 
locations. In December 2006, a second modification package was submitted to the state. The modification included the deletion of some equipment, a reduction in hours for many of the generators and compressors, and the addition of a small industrial shredder. The revised permit was issued in March 2007.

Facilities regulated by the NTS Class II Air Quality Operating Permit must adhere to the recordkeeping and operational requirements specified in the permit. Compliance is verified by conducting periodic site walk-downs, observations of equipment while in operation, and a review of the records associated with each permitted facility. A description of the various activities performed or measures tracked in order to meet permit requirements and the results of 2006 air quality activities are described below.

\subsubsection{Emissions of Criteria Air Pollutants and Hazardous Air Pollutants}

A source's regulatory status is determined by the maximum number of tons of criteria pollutants and nonradiological HAPs it may emit in a 12-month period if it were operated for the maximum number of hours and at the maximum production amounts specified in the source's air permit. This maximum emission quantity, known as the "Potential to Emit" (PTE), is specified in an Air Emissions Inventory of all permitted NTS facilities and equipment. Each year, the state issues to NNSA/NSO Actual Production/Emissions Reporting Forms for the NTS air permit. They are used to report the actual hours of operation, gallons of fuel burned, etc., for each permitted facility/piece of equipment. Using these data, emissions of the criteria pollutants and HAPs are calculated and reported. The forms are completed by ES personnel and returned to NNSA/NSO for submittal to the state. The state uses the submitted information to determine annual maintenance and emissions fees and to document that calculated emission quantities do not exceed the PTEs. Because lead is considered a HAP as well as a criteria pollutant, NTS lead emissions for permitted operations are reported to the state as part of the total HAPs emissions. Lead emissions from non-permitted activities such as soldering and weapons use are covered under the Emergency Planning and Community Right-to-Know Act and are reported to the EPA (see Section 10.3).

In 2006, examination of records for permitted facilities and equipment indicated that all operational parameters were being properly tracked. Approximately 4.57 tons ( 4.15 metric tons [mtons]) of criteria pollutants were emitted from NTS facilities and equipment that were operational in 2006 (Table 3-14). No PTEs were exceeded. The majority of the emissions were NOx from diesel generators and volatile organic compounds from the bulk storage of gasoline. The quantity of HAPs released in 2006 was 1.87 tons (Table 3-15). The Calendar Year 2006 Actual Production/Emissions Reporting Form was submitted to the Nevada Division of Environmental Protection (NDEP) on February 28, 2007. Table 3-15 and Figure 3-13 show the calculated tons of air pollutants released on the NTS since 1996.

Field measurements (versus calculated emissions) of particulate matter equal to or less than 10 microns in diameter (PM10) is required for two permitted facilities: the BEEF and the NPTEC. A minimum of one portable PM10 sampler is required to be located at each facility. The sampling systems must operate and record ambient PM10 concentrations at least each day a detonation or chemical release occurs. The PM10 emissions are reported to the state in reports specific to each series of detonations or chemical releases (see Section 3.2.5).

Unless specifically exempted, the open burning of any combustible refuse, waste, garbage, or oil; or for salvage operations, is prohibited. Open burning for other purposes, including personnel training, is allowed if approved in advance by the state (Nevada Administrative Code 445B.22067). Approval is denoted by the issuance of an Open Burn Variance prior to each burn. Exceptions to this include the Open Burn Variances issued to NNSA/NSO for fire extinguisher training at the NTS and for support-vehicle live-fire training evolutions. These Open Burn Variances are renewed annually and require 24-hour advance notification to the state prior to each burn. There were approximately 60 fire extinguisher training sessions and 15 vehicle burns conducted throughout 2006. Quantities of criteria pollutants produced by open burns are not required to be calculated. 
Table 3-14. Tons of criteria air pollutant emissions released on the NTS from permitted facilities operational in 2006

\begin{tabular}{|c|c|c|c|c|c|c|c|c|c|c|}
\hline \multirow[b]{3}{*}{ Facility } & \multicolumn{10}{|c|}{ Calculated Tons(a) of Emissions } \\
\hline & \multicolumn{2}{|c|}{$\begin{array}{c}\text { Particulate } \\
\text { Matter } \\
\text { (PM10)(b) }^{(\mathbf{b})}\end{array}$} & \multicolumn{2}{|c|}{$\begin{array}{l}\text { Carbon Monoxide } \\
\text { (CO) }\end{array}$} & \multicolumn{2}{|c|}{$\begin{array}{c}\text { Nitrogen } \\
\text { Oxides (NOx) }\end{array}$} & \multicolumn{2}{|c|}{$\begin{array}{l}\text { Sulfur Dioxide } \\
\qquad\left(\mathrm{SO}_{2}\right)\end{array}$} & \multicolumn{2}{|c|}{$\begin{array}{l}\text { Volatile Organic } \\
\text { Compounds (VOC) }\end{array}$} \\
\hline & Actual & PTE $^{(\mathbf{c})}$ & Actual & PTE & Actual & PTE & Actual & PTE & Actual & PTE \\
\hline Wet Aggregate Plant & 0.36 & 5.52 & $\mathrm{NA}^{(\mathrm{d})}$ & NA & NA & NA & NA & NA & NA & NA \\
\hline Concrete Batch Plant & 0.19 & 3.64 & NA & NA & NA & NA & NA & NA & NA & NA \\
\hline $\begin{array}{l}\text { Cementing Equipment } \\
\text { (Units Controlled by } \\
\text { Baghouse } 10 \text { Only) }\end{array}$ & 0.02 & 0.51 & NA & NA & NA & NA & NA & NA & NA & NA \\
\hline Miscellaneous Conveyors & 0.002 & 0.21 & $\mathrm{~N} / \mathrm{A}$ & $\mathrm{N} / \mathrm{A}$ & $\mathrm{N} / \mathrm{A}$ & N/A & N/A & N/A & $\mathrm{N} / \mathrm{A}$ & N/A \\
\hline Miscellaneous Hoppers & 0.0003 & 0.35 & N/A & N/A & N/A & N/A & N/A & N/A & N/A & N/A \\
\hline Portable Screening Plant & 0.06 & 1.02 & NA & NA & NA & NA & NA & NA & NA & NA \\
\hline BEEF & 0.00003 & 8.0 & 0.00005 & 0.535 & 0 & 0.07 & 0 & 0.003 & 0 & 0.007 \\
\hline Diesel Fired Generators & 0.06 & 1.73 & 0.43 & 10.24 & 1.9 & 17.87 & 0.03 & 3.13 & 0.06 & 2.16 \\
\hline Bulk Gasoline Storage Tank & NA & NA & NA & NA & NA & NA & NA & NA & 1.19 & 3.92 \\
\hline Bulk Diesel Fuel Storage Tank & NA & NA & NA & NA & NA & NA & NA & NA & 0.01 & 0.02 \\
\hline NPTEC & 0 & 3.00 & 0 & 3.26 & 0.122 & 3.02 & 0 & 3.00 & 0.15 & 10.0 \\
\hline Total by Pollutant & 0.69 & 23.98 & 0.43 & 14.04 & 2.02 & 20.96 & 0.03 & 6.13 & 1.40 & 16.11 \\
\hline Total Emissions & & & & & 4.57 Act & 81.22 & & & & \\
\hline
\end{tabular}

(a) For metric tons (mtons), multiply tons by 0.9072

(b) Particulate matter equal to or less than 10 microns in diameter

(c) Potential to Emit - the quantity of criteria pollutant that each facility/piece of equipment would emit annually if it were operated for the maximum number of hours at the maximum production rate specified in the air permit

(d) Not applicable because the permit does not regulate the emissions of this pollutant for this facility 
Table 3-15. Criteria air pollutants and HAPS released on the NTS since 1996

\begin{tabular}{|c|c|c|c|c|c|c|c|c|c|c|c|}
\hline \multirow[b]{2}{*}{ Pollutant } & \multicolumn{11}{|c|}{ Total Emissions (tons/yr)(a) } \\
\hline & 1996 & 1997 & 1998 & 1999 & 2000 & 2001 & 2002 & 2003 & 2004 & 2005 & 2006 \\
\hline Particulate Matter (PM10)(b) & 2.89 & 1.67 & 1.11 & 1.7 & 1.46 & 2.05 & 3.61 & 2.39 & 0.94 & 0.84 & 0.69 \\
\hline Carbon Monoxide (CO) & 0.04 & 5.28 & 1.85 & 1.87 & 2.76 & 4.84 & 4.6 & 1.79 & 0.24 & 0.15 & 0.43 \\
\hline Nitrogen Oxides (NOx) & 0.16 & 19.79 & 7.57 & 8.07 & 12.75 & 22.23 & 21.09 & 8.11 & 1.01 & 0.69 & 2.02 \\
\hline Sulfur Dioxide $\left(\mathrm{SO}_{2}\right)$ & 0.3 & 0.85 & 0.37 & 0.42 & 0.98 & 1.68 & 1.62 & 0.76 & 0.12 & 0.04 & 0.03 \\
\hline Volatile Organic Compounds (VOC) & 2.82 & 0.94 & 11.76 & 1.99 & 1.89 & 2.01 & 2.1 & 1.21 & 4.60 & 1.94 & 1.40 \\
\hline Hazardous Air Pollutants (HAPs) & NR & NR & NR & NR & 0.01 & 0.03 & 0.01 & 0 & 0.41 & 0.05 & $1.87^{(d)}$ \\
\hline
\end{tabular}

(a) For mtons, multiply tons by 0.9072

(b) Particulate matter equal to or less than 10 microns in diameter

(c) Not reported

(d) 92 percent of HAPs were emitted during chemical spill tests at NPTEC, $<0.006$ percent were from lead from all permitted operations

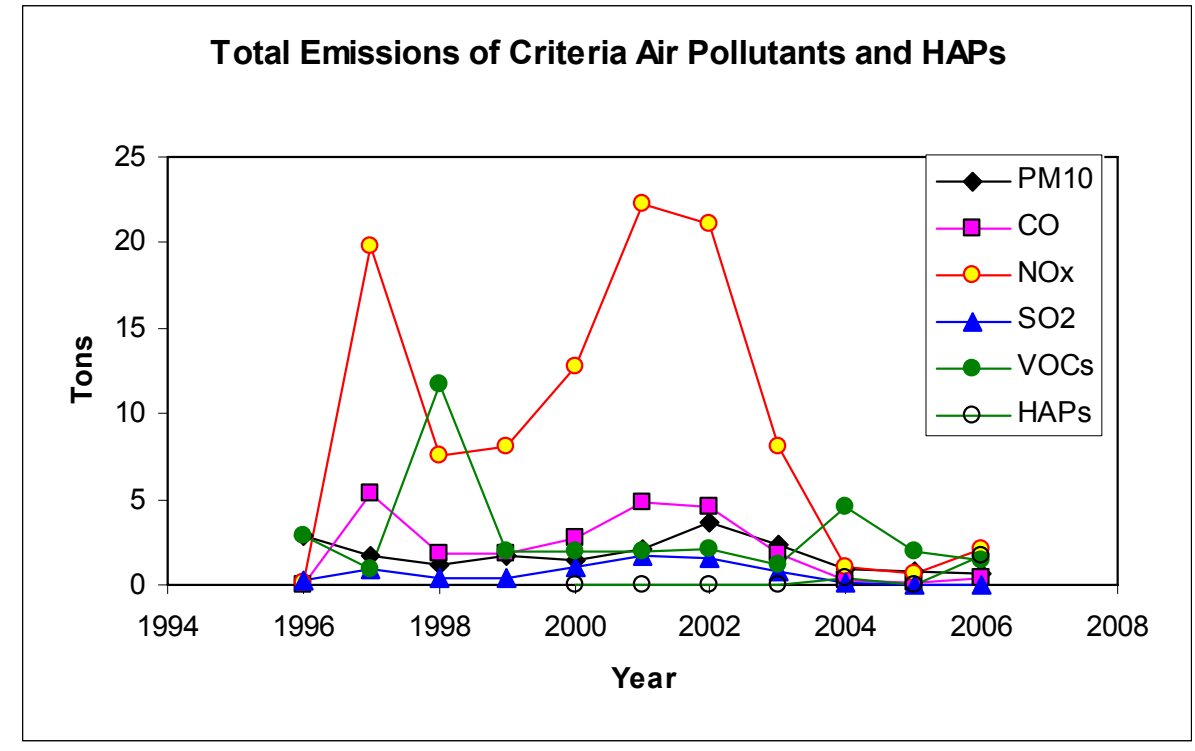

Figure 3-13 Criteria air pollutants released on the NTS since 1996

\subsubsection{Performance Emission Testing and State Inspection}

The NTS air permit requires performance emission testing of equipment that vents emissions through stacks (called "point sources"). The tests must be conducted once during the five-year life of the NTS air permit for each specified source. Testing is conducted by inserting a probe into the stack while the equipment is operating. Visible emissions readings must also be conducted by a certified evaluator during the tests (see Section 3.2.4 below). In 2006, corrective actions were taken for three pieces of equipment which failed performance emission tests conducted in June 2005 . In 2006, the Area 27 JASPER generator exceeded the 100-hour operating limit that requires emissions testing; it also exceeded the 90-day testing deadline. The exceedances were reported to NNSA/NSO and to the state's Bureau of Air Pollution Control. In 2006, performance emission tests were conducted for both the JASPER and the Area 23 Building 650 generators and for two other generators that had been repaired (Table 3-16). The Nevada Bureau of Air Pollution Control was notified of all equipment failures.

On July 11, the state of Nevada conducted an inspection of the Area 23 Incinerator and the Area 23 diesel generator located in Building 725 (Table 3-16). The state's inspection confirmed that both pieces of equipment had been satisfactorily disconnected to prevent further usage. During the July 11 inspection, the Area 6 Portable Screen Plant 
was observed in operation. The operation was virtually dust free. However, the inspector noted that the emissions controls specified in the air permit (i.e., water spray bars) were not being used, but rather the material was pre-wetted. The NTS air permit is being modified to indicate that pre-wetting is used as an emissions control.

Table 3-16. Performance emission testing, state inspection, and/or corrective actions taken in 2006

\begin{tabular}{|c|c|c|c|}
\hline Point Source & Test Dates & Results & $\begin{array}{c}\text { State Inspection and/or } \\
\text { Corrective Action }\end{array}$ \\
\hline Area 23 Building 725 Generator & $\mathrm{NA}^{(\mathrm{a})}$ & NA & $\begin{array}{l}\text { Shut down in June, 2006. State inspection } \\
\text { July 2006. Was removed from air permit in } 2007 .\end{array}$ \\
\hline Area 23 Incinerator & June 2005 & Failed & $\begin{array}{l}\text { Shut down, removed from air permit in 2006. State } \\
\text { inspection July } 2006 \text {. }\end{array}$ \\
\hline Device Assembly Facility (DAF) & June 2005 & Failed & Shut down, repaired, retested in 2006 \\
\hline Generator & March 2006 & Passed & None \\
\hline Area 6 Dual-stack Generator & $\begin{array}{l}\text { June } 2005 \\
\text { April } 2006\end{array}$ & $\begin{array}{l}\text { Failed } \\
\text { Passed }\end{array}$ & $\begin{array}{l}\text { Shut down, repaired, retested in } 2006 \\
\text { None }\end{array}$ \\
\hline Area 23 Building 650 Generator & April 2006 & Passed & None \\
\hline Area 27 JASPER Generator & September 2006 & Failed & Shut down, no decision yet as to future action \\
\hline
\end{tabular}

(a) Not applicable. After 100 hours of operation, generator was shut down without conducting test.

\subsubsection{Production Rates/Hours of Operation}

Compliance with operational parameters such as production rates and hours of operation is verified through an examination of the data generated for the annual report to the state. The number of hours that equipment operates throughout a year is determined either by meter readings or by recording the operating hours in a logbook each time the equipment is operated. Permit requirements specific to each piece of equipment dictate the frequency in which readings are obtained. Production rates for construction facilities such as the aggregate-producing plant are calculated using the hours of operation and amount of material produced. Logbooks are maintained to record this information. Gallons of fuel used are calculated preferably by recording tank levels each time that the tank is filled. If this is not possible, then calculations are performed by using industry standards and the hours of operation. In 2006, production rates, hours of operation, and gallons of fuel used all were within the specified permit limits and were used to calculate the tons of air pollutants emitted (see Table 3-14 above).

\subsubsection{Opacity Readings}

Under Title 40 CFR Part 60, personnel that conduct visible emissions evaluations must be certified semiannually by a qualified organization. A form similar to one appearing in Title 40 CFR Part 60 for conducting visible emissions evaluations is used to record and document the readings. Visual readings are taken every 15 seconds. A minimum of 24 consecutive readings is required for a valid reading. The average of the 24 readings must not exceed the permitspecified limit (20 percent for NAAQS, 10 percent for NSPS). The NTS air permit requires that readings be obtained once each quarter that the equipment is used and be kept on file. This applies to construction equipment only. Readings are taken for all other permitted facilities and equipment periodically but are not recorded.

During 2006, five ES personnel were certified by Carl Koontz Associates to obtain opacity readings. Readings were taken for the following NTS facilities regulated under the NAAQS opacity limit of 20 percent: Area 1 Concrete Batch Plant, Area 1 Wet Aggregate Plant, Area 6 Storage Silos, and the Portable Screen Plant. Readings for these facilities ranged from 0 to 10 percent. Readings were also obtained during the performance emission tests for the Area 27 DAF Generator in March, the Area 6 Dual-stack Generator in April, the Area 23 Building 650 Generator in April, and the JASPER Generator in September. Readings for these facilities were below the 20 percent limit and ranged from 0 to 15 percent opacity. Equipment on the NTS that is regulated by the stricter 10 percent opacity limit under the NSPS includes miscellaneous conveyor belts, screens and hoppers, and also the Area 1 pugmill. During 2006, one conveyor and hopper were used for the Unicorn project. Results of the opacity readings ranged from 0 to 5 percent. 


\subsubsection{NPTEC and BEEF Reporting}

In addition to annual reporting, the NTS air quality operating permit for the NPTEC and the site-wide chemical releases requires the submittal of test plans and final analysis reports to the state for each chemical release or release series. Test plans provide detailed information regarding the types and quantities of chemicals to be released, a description of how they will be released, and environmental and chemical hazards. For the BEEF, quarterly test plans and final reports must be submitted for the types and weights of explosives used and estimated emissions that may be released.

In 2006, 4 chemical tests consisting of 40 releases were conducted at the Area 5 NPTEC. One chemical test that included 9 releases was conducted at the Area 26 Port Gaston facility. The tests included:

- Tarantula -- Black Widow Releases (13 releases at NPTEC)

- Tarantula -- Brown Recluse Releases (2 releases at NPTEC)

- Tarantula II - Engineering Checkout Releases (2 releases at NPTEC)

- DuPont Fuming Acids Workshop (23 releases at NPTEC)

- Raven Project (9 releases at the Port Gaston facility)

A completion report was submitted to NNSA/NSO for transmittal to NDEP's Bureau of Air Pollution Control at the conclusion of each test. Tables 3-17 and 3-18 summarize the total quantities of all chemicals released during tests.

Table 3-17. Chemicals released during tests conducted at the Area 5 NPTEC in 2006

\begin{tabular}{||lcc||}
\hline Chemical & Total Released (kg) & Total Released (lb) $)^{(\mathbf{a})}$ \\
\hline 1,1,1,2-Tetrafluorethane & 109.22 & 239.52 \\
Acetylene & 5.19 & 11.38 \\
Ammonia & 51.47 & 112.87 \\
Chlorine & 6.62 & 14.52 \\
Chlorosulfonic acid & 819 & 1,796 \\
Diethyl ethylphosphonate & 17.39 & 38.14 \\
Dimethyl methylphosphonate & 40.33 & 88.44 \\
Dodecane & 2.33 & 5.11 \\
Ethanol & 36.82 & 80.75 \\
Ethylene & 63.43 & 139.10 \\
Hydrogen chloride & 9 & 20 \\
Hydrogen fluoride & 2.93 & 6.43 \\
Isopropyl alcohol & 25.43 & 55.77 \\
Kerosene & $>2$ & $>4$ \\
Methyl iodide & $>4.1$ & $>9.0$ \\
Methyl salicylate & 7.72 & 16.93 \\
n-Butyl alcohol & 4.7 & 10.31 \\
Nitric acid & 0.65 & 1.43 \\
Nitrogen dioxide & 47.28 & 103.69 \\
Nitrous oxide & 133.61 & 293.00 \\
OLEUM & 632 & 1,386 \\
Propylene & 40 & 88 \\
Sulfur hexafluoride & 40.19 & 88.14 \\
Tributyl phosphate & 43.68 & 95.79 \\
Triethylamine & 0.133 & 0.292 \\
Triethyl phosphate & 14.2 & $231 . .1$ \\
Trimethylamine & 13.48 & 29.56 \\
\hline \hline
\end{tabular}

(a) 1 pound $(\mathrm{lb})=0.456$ kilograms $(\mathrm{kg})$ 
Table 3-18. Chemicals released during tests conducted at the Port Gaston facility in 2006

\begin{tabular}{||lcc||}
\hline Chemical & $\begin{array}{c}\text { Total Amount } \\
\text { Released }(\mathbf{k g})\end{array}$ & $\begin{array}{c}\text { Total Amount } \\
\text { Released (lb) }\end{array}$ \\
\hline Cyanogen chloride & $<0.585$ & $<1.29$ \\
Hydrogen chloride & $<2.43$ & $<5.37$ \\
Hydrochloric acid (37\%) & $<10.62$ & $<23.47$ \\
Potassium cyanide & $<6.75$ & $<14.92$ \\
Potassium permanganate & $<6.75$ & $<14.92$ \\
\hline
\end{tabular}

(a) $11 \mathrm{~b}=0.456 \mathrm{~kg}$

The majority of BEEF activities involve sensitive or classified information. To protect confidentiality of data, summary reports are submitted on a quarterly basis rather than for each test or test series. Table 3-19 is a summary of the general types and weights of explosives detonated during tests conducted in 2006. Emissions generated from these releases are summarized in Table 3-14.

Table 3-19. Types and weights of explosives detonated at BEEF in 2006

\begin{tabular}{||lcc||}
\hline Type of Explosive & $\begin{array}{c}\text { Total Amount } \\
\text { Released }(\mathbf{k g})\end{array}$ & $\begin{array}{c}\text { Total Amount } \\
\text { Released (lb)(a) }\end{array}$ \\
\hline Detonator materials & 109.64 & 240.43 \\
Nitramine/binder & 81.77 & 179.32 \\
\hline \hline
\end{tabular}

(a) $11 \mathrm{~b}=0.456 \mathrm{~kg}$

\subsubsection{Tactical Demilitarization Development (TaDD) Project Reporting}

The TaDD project is located in Area 11 at the NTS. This facility was developed as a prototype of a portable burn facility to dispose of unneeded Shillelagh tactical military rocket motors. As such, TaDD was added to the NTS air quality operating permit because of the emissions generated during each burn. Emissions are controlled by a baghouse, HEPA, and ultra high-efficiency filters. Permit requirements include annual reporting of hours of operation and emissions and an opacity limit of 20 percent.

The TaDD facility has not been used due to lack of funding. It is listed in the renewed air permit with zero allowable operating hours and is expected to be removed from the air permit in 2007.

\subsubsection{ODS Recordkeeping}

ODS recordkeeping requirements applicable to NTS operations include maintaining, for a minimum of three years, evidence of technician certification, recycling/recovery equipment approval, and servicing records for appliances containing $22.7 \mathrm{~kg}(50 \mathrm{lb})$ or more of refrigerant. Compliance with recordkeeping and certification requirements for the use and disposition of ODS is verified through periodic assessments. The assessments include a records review and interviews with managers and technicians associated with the use, disposition, and purchase of refrigerants. Under Section 608 of the CAA, EPA may conduct random inspections to determine compliance.

An assessment of the NTS ODS program was conducted in 2006. It was determined that the regulatory requirements of Title VI (Section 608) of the CAA for the protection of stratospheric ozone were generally being met. The NSTec company directive for air pollution and permitting, which contains a section on ODS, will be revised in 2007. The ODS section will provide guidance on servicing and disposal of ODS appliances, recycling ODS material and maximizing the use of safe alternatives to ODS due to their required phase-out. 


\subsubsection{Asbestos Abatement}

A NESHAP notification is submitted annually to the EPA for the next calendar year. This notification provides an estimate of the quantities of asbestos-containing materials that are expected to be removed from small projects: removal of less than 80 linear $\mathrm{m}$ (260 linear $\mathrm{ft})$, less than 15 square meters $\left(\mathrm{m}^{2}\right)\left(160\right.$ square feet $\left.\left[\mathrm{ft}^{2}\right]\right)$, or less than 1 cubic meter $\left(\mathrm{m}^{3}\right)$ (35 cubic feet $\left[\mathrm{ft}^{3}\right]$ ). These projections are submitted to EPA in an Annual Asbestos Abatement Notification Form. A Notification of Demolition and Renovation Form is also submitted to EPA at least 10 working days prior to the start of each project if either (1) no asbestos is present in a facility scheduled for demolition, or (2) if quantities of asbestos-containing materials to be removed are estimated to equal or exceed 80 linear $\mathrm{m}, 15 \mathrm{~m}^{2}$, or $1 \mathrm{~m}^{3}$. The recordkeeping requirements for asbestos abatement activities on the NTS include maintaining air and bulk sampling data records, abatement plans, and operations and maintenance activity records for up to 75 years and maintaining location-specific records of asbestos-containing materials for a minimum of 75 years.

Compliance with recordkeeping requirements is verified through periodic internal assessments. The assessments include a records review and interviews with managers and technicians associated with asbestos abatement. NNSA/NSO informal reviews are performed periodically.

An Annual Asbestos Abatement Notification Form was submitted to the EPA on October 18, 2005, which projected that 45.7 linear $\mathrm{m}(250$ linear $\mathrm{ft})$ and $23.2 \mathrm{~m}^{2}\left(150 \mathrm{ft}^{2}\right)$ of asbestos-containing material would be removed from small projects from NTS facilities in 2006. However, two large asbestos abatement projects arose in 2006: the Phoenix Landfill in Area 25 for which 1,073 $\mathrm{m}^{3}\left(29,000 \mathrm{ft}^{3}\right)$ of asbestos-containing materials were excavated/removed, and Warehouse 1 in Area 23 for which $186 \mathrm{~m}^{2}\left(2,000 \mathrm{ft}^{2}\right)$ of asbestos-containing materials were removed prior to demolition of that building. A Notification of Demolition and Renovation Form was submitted to EPA within 10 working days prior to the start of each project. The rest of the asbestos abatement activities throughout the NTS complex were minor in scope, involving the removal of amounts below the reporting threshold. Asbestos abatement records continued to be maintained as required.

\subsubsection{Fugitive Dust Control}

The NTS Class II Air Quality Operating Permit states that the best practical methods should be used to prevent particulate matter from becoming airborne prior to the construction, repair, demolition, or use of unpaved or untreated areas. Methods and materials that are typically used to control fugitive dust include presoaking, water sprays, dust palliatives, gravelling or paving haul routes, revegetating, reducing vehicle speeds, and either covering stockpiles or watering them. At the NTS, the main method of dust control is the use of water sprays.

During 2006, NSTec personnel conducted several fugitive dust readings of operations throughout the NTS that included the Radiological/Nuclear Countermeasures Test and Evaluation Complex, the Portable Screen Plant, and the Area 1 Concrete Batch Plant. No excessive fugitive dust was noted.

\subsubsection{Environmental Impact}

During 2006, NTS activities produced a total of only 4.57 tons of criteria pollutants and 1.87 tons of HAPs. These small quantities had little, if any, impact to air quality on the NTS and at offsite locations. Emissions of pollutants for 2006 were significantly less than those generated during the heightened activity that occurred in the years prior to the nuclear weapons testing moratorium.

Impacts of the chemical release tests at the NPTEC are minimized by controlling the amount and duration of each release. Biological monitoring at the NPTEC is performed whenever there is a risk of significant exposure to downwind plants and animals from the planned tests (see Section 13.6). NSTec biologists review all chemical release test plans to determine the level of field monitoring needed for each test. To date, chemical releases at the NPTEC (and at Port Gaston in 2006) have used such small quantities (when dispersed into the air) that downwind test-specific monitoring has not been necessary. No measurable impacts to downwind plants or animals have been observed. 


\subsection{Radiological and Nonradiological Water Monitoring}

This chapter presents radiological and nonradiological monitoring results for surface water and groundwater from on and off the Nevada Test Site (NTS). Surface water and groundwater includes natural springs, drinking water, non-potable groundwater, and water discharged into domestic and wastewater systems on the NTS. In 2006, several programs or projects were involved in water monitoring. These included: (1) routine radiological monitoring conducted by Bechtel Nevada (BN) and National Security Technologies, LLC (NSTec), Environmental Technical Services (ETS) under the Routine Radiological Environmental Monitoring Plan (RREMP) (U.S. Department of Energy [DOE], 2003b), (2) water quality assessments of permitted water systems conducted by BN and NSTec Environmental Services, and (3) water sampling and analysis conducted by the Underground Test Area (UGTA) Project. Water monitoring is conducted to comply with applicable state and federal regulations (see Section 2.2) as well as to address the concerns of stakeholders who reside within the vicinity of the NTS.

Section 4.1 presents the concentrations of radioactivity in water samples. These data are used to calculate radiological dose to the general public residing near the NTS via drinking water; these results are provided in Section 8.0 (Radiological Dose Assessment).

The Community Environmental Monitoring Program was established by the U.S. Department of Energy, National Nuclear Security Administration Nevada Site Office (NNSA/NSO) to independently monitor radionuclide contamination of offsite springs and water supply systems. This independent oversight program is managed by the Desert Research Institute (DRI). DRI's 2006 monitoring results for surface and groundwater are presented in Section 6.2.

Section 4.2 of this chapter presents the results of nonradiological monitoring of drinking water and domestic and industrial wastewaters on the NTS.

\subsection{Radiological Surface Water and Groundwater Monitoring}

There have been 828 underground nuclear tests conducted at the NTS. Approximately one third of these tests were detonated near or below the water table (DOE, 1996a; DOE, 2000a). This legacy of nuclear testing has resulted in the contamination of groundwater in some areas. The Federal Facilities Agreement and Consent Order established Corrective Action Units (CAUs) that delineated and defined areas of concern for groundwater contamination on the NTS (DOE, 1996a). Figure 4-1 shows the locations of underground nuclear tests and areas of potential groundwater contamination. To safeguard the public's health and safety and comply with applicable federal, state, and local environmental protection regulations as well as DOE directives, groundwater on and near the NTS is monitored for radioactivity. Monitoring in the past was conducted by the U.S. Public Health Service, U.S. Geological Survey, the U.S. Environmental Protection Agency (EPA), and others. In 1998, BN was tasked by NNSA/NSO to establish and manage an NTS integrated and comprehensive radiological environmental monitoring program. The RREMP (DOE, 2003b) describes groundwater monitoring objectives, regulatory drivers, and quality assurance protocols.

The purpose of radiological water monitoring is to determine whether concentrations of radionuclides in groundwater and surface water bodies at the NTS and its vicinity pose a threat to public health or the environment. Toward this end, the monitoring program collects and analyses water samples to meet the goals shown below.

In addition to RREMP-driven monitoring, the UGTA Project (see Section 14.0) collects data from wells to define groundwater flow rates and directions to determine the nature and location of aquifers. Data from these studies are used to determine whether radionuclides from nuclear testing have moved appreciable distances from original test locations. Groundwater sampling and radiological analysis results for 2006 from UGTA wells are presented in Section 4.1 .10 of this chapter. 


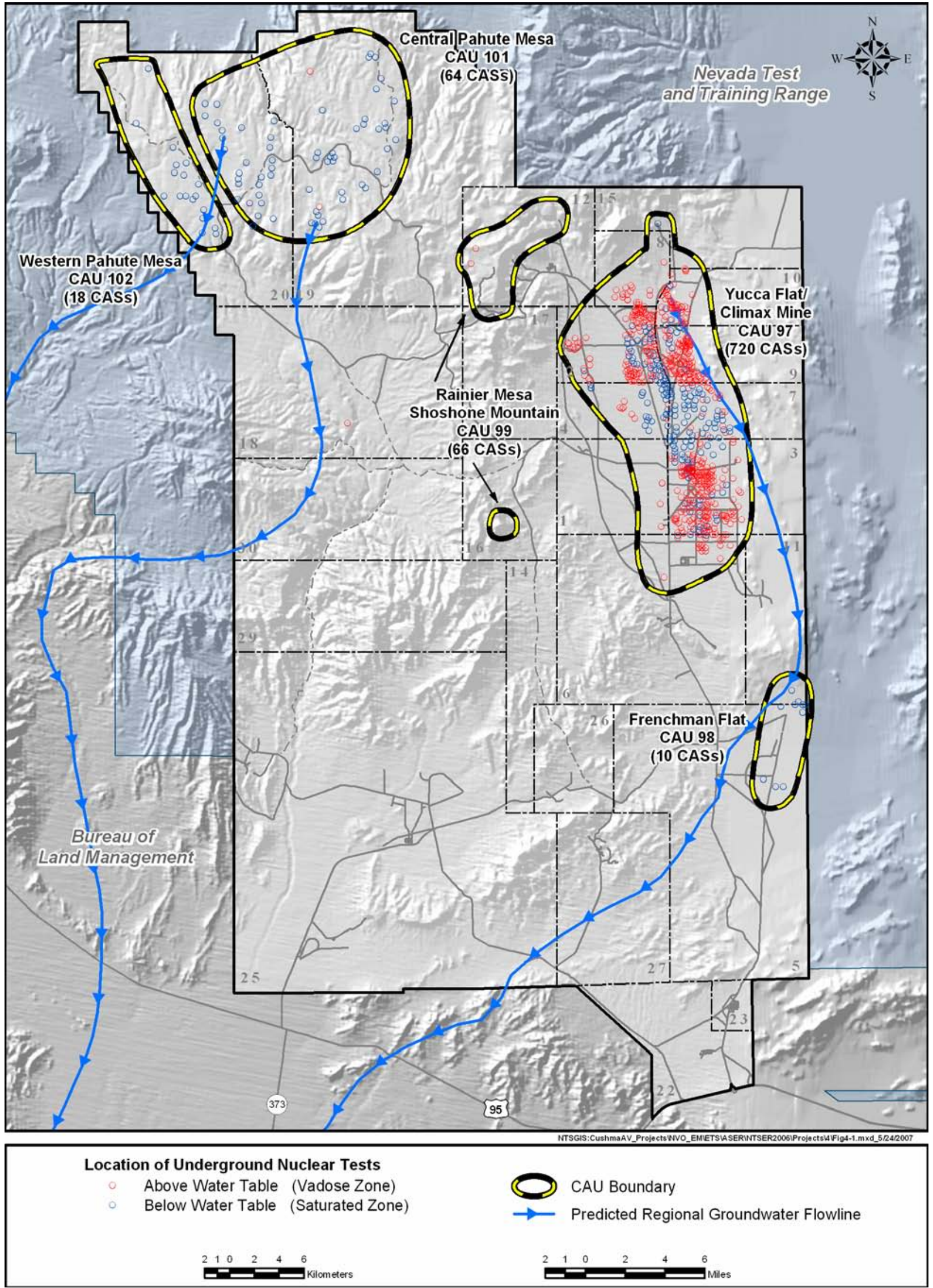

Figure 4-1. Areas of potential groundwater contamination on the NTS 


\begin{tabular}{|c|c|}
\hline $\begin{array}{c}\text { Radiological Surface Water and Groundwater Monitoring } \\
\text { Program Goals }\end{array}$ & Analytes Monitored \\
\hline \multirow{2}{*}{$\begin{array}{l}\text { Determine if radionuclide concentrations of offsite and onsite water } \\
\text { supply wells exceed the safe drinking water standards established by the } \\
\text { EPA under the Safe Drinking Water Act or the dose limits to the general } \\
\text { public set by DOE Order } 5400.5 \text {. }\end{array}$} & Tritium $\left({ }^{3} \mathrm{H}\right)$ \\
\hline & Gross alpha radioactivity \\
\hline \multirow{2}{*}{$\begin{array}{l}\text { Determine if radionuclide concentrations in surface waters on the NTS } \\
\text { expose terrestrial and aquatic animals to doses which exceed those set by } \\
\text { DOE (DOE-STD-1153-2002) to protect wildlife populations. }\end{array}$} & Gross beta radioactivity \\
\hline & Gamma-emitting radionuclides \\
\hline \multirow{2}{*}{$\begin{array}{l}\text { Determine if permitted facilities on the NTS are in compliance with } \\
\text { permit discharge limits for radionuclides. }\end{array}$} & Plutonium-238 (238Pu) \\
\hline & Plutonium-239+240 $(239+240 \mathrm{Pu})$ \\
\hline \multirow{3}{*}{$\begin{array}{l}\text { Determine if radionuclide concentrations in onsite and offsite natural } \\
\text { springs and non-potable water wells (monitoring wells), including those } \\
\text { within CAUs, indicate that NNSA/NSO activities have had an impact on } \\
\text { the environment. Strict drinking water standards are often used as a } \\
\text { monitoring action level for this determination. }\end{array}$} & Carbon-14 $\left({ }^{14} \mathrm{C}\right)$ \\
\hline & Strontium-90 ( $\left.{ }^{90} \mathrm{Sr}\right)$ \\
\hline & Technetium-99 ( $\left.{ }^{99} \mathrm{Tc}\right)$ \\
\hline
\end{tabular}

The selection of analytes for groundwater monitoring under the RREMP (DOE, 2003b) is based on the radiological source term from historical nuclear testing, regulatory/permit requirements, and characterization needs. The isotopic inventory remaining from nuclear testing is presented in the most recent environmental impact statement for NTS activities (DOE, 1996a) and in a recent Lawrence Livermore National Laboratory (LLNL) document (Bowen et al., 2001). Many of the radioactive species generated from subsurface testing have very short half-lives, sorb strongly onto the solid phase, or are bound into what is termed "melt glass" and are not available for groundwater transport in the near term (Smith, 1993; Smith et al., 1995). Tritium $\left({ }^{3} \mathrm{H}\right)$ is the radioactive species created in the greatest quantities and is widely believed to be the most mobile. Tritium is therefore the primary target analyte; it represents the greatest concern to users of groundwater on and around the NTS for at least the next 100 years due to its high mobility and concentration (DOE, 1996a; International Technology Corporation, 1997).

Tritium analyses are done on all water samples. Analyses for gross alpha and gross beta radioactivity and gammaemitting radionuclides are also conducted on all water samples as rapid screening measures. Gross alpha and gross beta radioactivity can include activity from both natural and man-made radionuclides, if any are present. Naturallyoccurring deposits of certain minerals in water can contribute to both alpha radiation (e.g., isotopes of uranium and radium-226 [226Ra]) and beta radiation (e.g., radium-228 [228Ra] and potassium-40 [ $\left.{ }^{40} \mathrm{~K}\right]$ ). The analyses for gammaemitting radionuclides by gamma spectroscopy can identify the presence of specific man-made radionuclides (e.g., americium-241 [ $\left.{ }^{241} \mathrm{Am}\right]$, cesium-137 [ $\left.{ }^{137} \mathrm{Cs}\right]$, cobalt-60 [ $\left.{ }^{60} \mathrm{Co}\right]$, and europium-152 and $-154\left[{ }^{152} \mathrm{Eu}\right.$ and $\left.{ }^{154} \mathrm{Eu}\right]$ ) as well as natural radionuclides (e.g., actinium-228 [ ${ }^{228} \mathrm{Ac}$, lead-212 [212 $\left.\mathrm{Pb}\right],{ }^{40} \mathrm{~K}$, uranium-235 [235U], and thorium-234 $\left.\left[{ }^{234} \mathrm{Th}\right]\right)$. Specific analyses for ${ }^{238} \mathrm{Pu},{ }^{239+240} \mathrm{Pu},{ }^{14} \mathrm{C},{ }^{90} \mathrm{Sr},{ }^{99} \mathrm{Tc},{ }^{241} \mathrm{Am}$, and uranium isotopes are performed on selected water samples to help characterize sampled locations. Radium analyses were discontinued in 2005 because previous analyses indicate ${ }^{226} \mathrm{Ra}$ is not a major source of measured gross alpha activity and ${ }^{228} \mathrm{Ra}$ is not a major source of measured gross beta activity. Water analyses also include chemical parameters to characterize the groundwater chemistry and hydrology, but these measures are not presented in this report. 


\subsubsection{Water Monitoring Locations}

The NTS groundwater and surface water monitoring network is located in a complex hydrogeologic setting (see Nevada Test Site Description included on the compact disc version of this report). The RREMP (DOE, 2003b) identifies a groundwater monitoring network of 78 wells to be sampled at frequencies ranging from once every three months to once every three years. Two of the wells, ASH-B Piezometer \#1 and ASH-B Piezometer \#2, are actually separate pieziometers within the same borehole. There are also ten additional wells (seven offsite and three onsite) not identified in the RREMP which have been added to the network and which are sampled opportunistically or at the suggestion of NNSA/NSO. Of all these 88 wells, 72 have been sampled at least once since 1999. These 72 include 33 offsite wells, 10 onsite water supply wells, and 29 onsite monitoring wells (Figure 4-2). Those wells not sampled since 1999, but identified in the RREMP, include 15 onsite monitoring wells and 1 offsite well. They are not sampled because they are either not accessible, are used for other purposes, are blocked, provide water samples that are of poor quality or are contaminated (disqualifying them from monitoring), or contain waters with known high levels of radiological contamination which are not expected to change. The next revision of the RREMP will document these changes. In 2006, a network of 41 groundwater locations was sampled (Figure 4-2) and included:

- 16 offsite wells

- 10 onsite water supply wells (6 potable, 4 non-potable)

- 15 onsite monitoring wells ( 3 are compliance wells for the Area 5 Radioactive Waste Management Site)

Two routinely sampled onsite wells, UE-18r and ER-19-1, were not sampled in 2006 because the roads to the wells were impassable.

The RREMP identifies seven offsite springs that are sampled at intervals from once a year to once every three years (Figure 4-3). Three onsite springs, not identified in the RREMP, were sampled in 2005 but no onsite springs were sampled in 2006. The RREMP also identifies one containment pond system and three sewage lagoons that are sampled once every three months to once a year. There are six additional onsite sewage lagoons not identified in the RREMP which have been sampled opportunistically. Only two of the three sewage lagoons are currently active and were sampled in 2006. The surface water monitoring locations sampled in 2006 (Figure 4-3) included:

- 7 offsite springs

- 1 NTS operations-related containment pond system (E Tunnel ponds)

- 2 onsite sewage lagoons

The UGTA Project sampled 3 wells in 2006. These samples were analyzed for radionuclides and are briefly discussed in Section 4.1.10 below.

\subsubsection{Water Sampling/Analysis Methods}

Water sampling methods are based, in part, on the characteristics and configurations of the sample locations. For example, wells with dedicated pumps may be sampled from the associated plumbing (e.g., spigots) at the wellhead, while wells without pumps may be sampled via a wireline bailer or a portable pumping system. Grab samples are typically obtained from the springs.

Six of the monitoring program wells are constructed with multiple strings of casing/tubing or multiple completion zones comprised of discrete intervals of slotted casing which access different horizons of the penetrated hydrostratigraphic units. The sample depths for these six wells are:

- 590, 622, 649, and 701 meters (m) (1,935, 2,040, 2,130, and 2,300 feet [ft]) below ground surface (bgs) in HTH \#1

- 518 and $649 \mathrm{~m}(1,700$ and 2,130 ft) bgs in UE-18r

- 475 and $608 \mathrm{~m}(1,560$ and 1,994 ft) bgs in PM-3

- 826 and $1000 \mathrm{~m}(2,710$ and 3,280 ft) bgs in ER-19-1

- 114 and 312 m (375 and 1025 ft) bgs in ASH-B (ASH-B Piezometer \#2 and ASH-B Piezometer \#1)

- 615 and $679 \mathrm{~m}(2017$ and $2228 \mathrm{ft})$ bgs in ER-6-1

Only HTH\#1 and PM-3 were sampled in 2006. The other multiple depth wells were not sampled in 2006. 


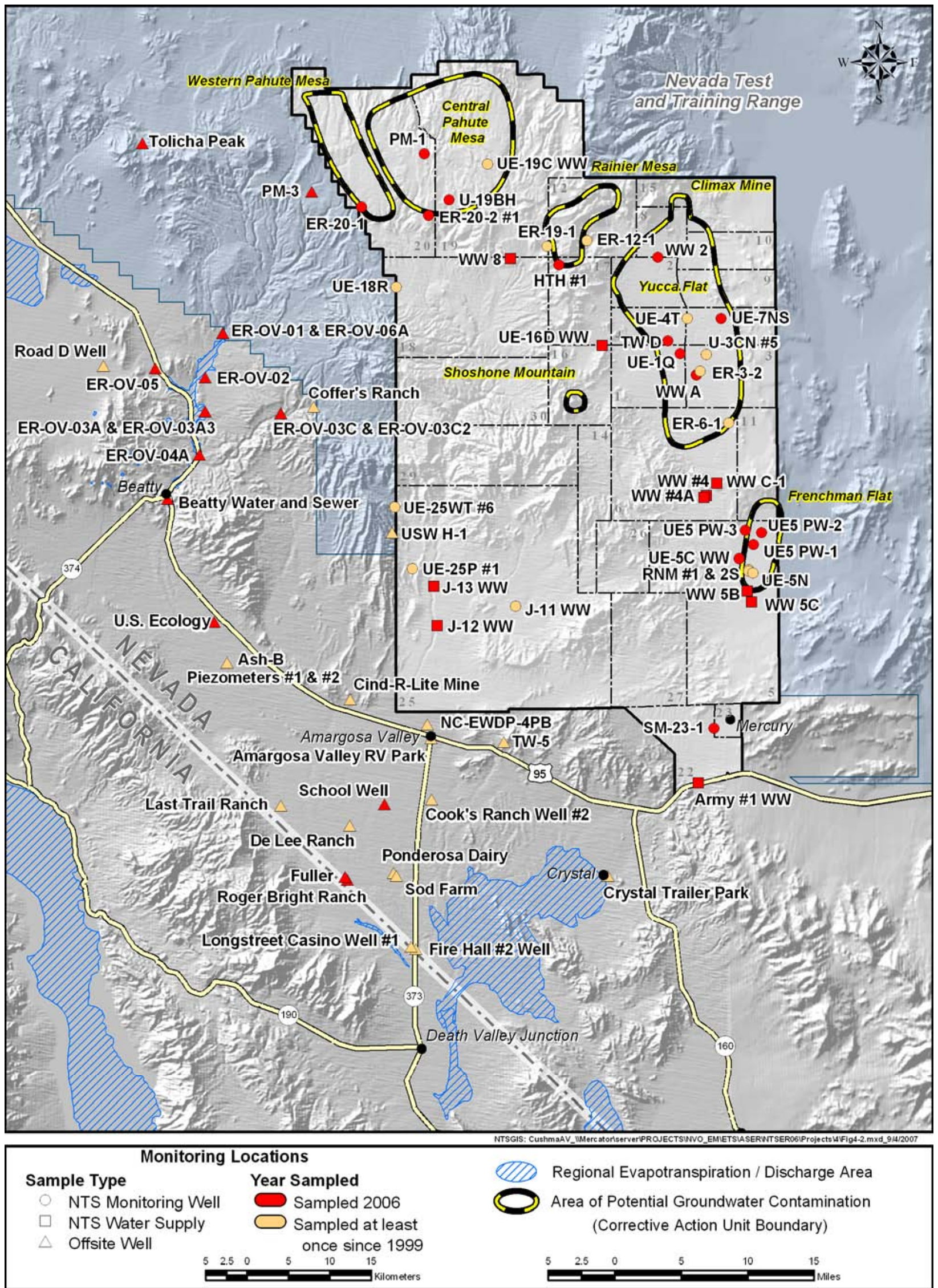

Figure 4-2. RREMP well monitoring locations sampled on and off the NTS in 2006 


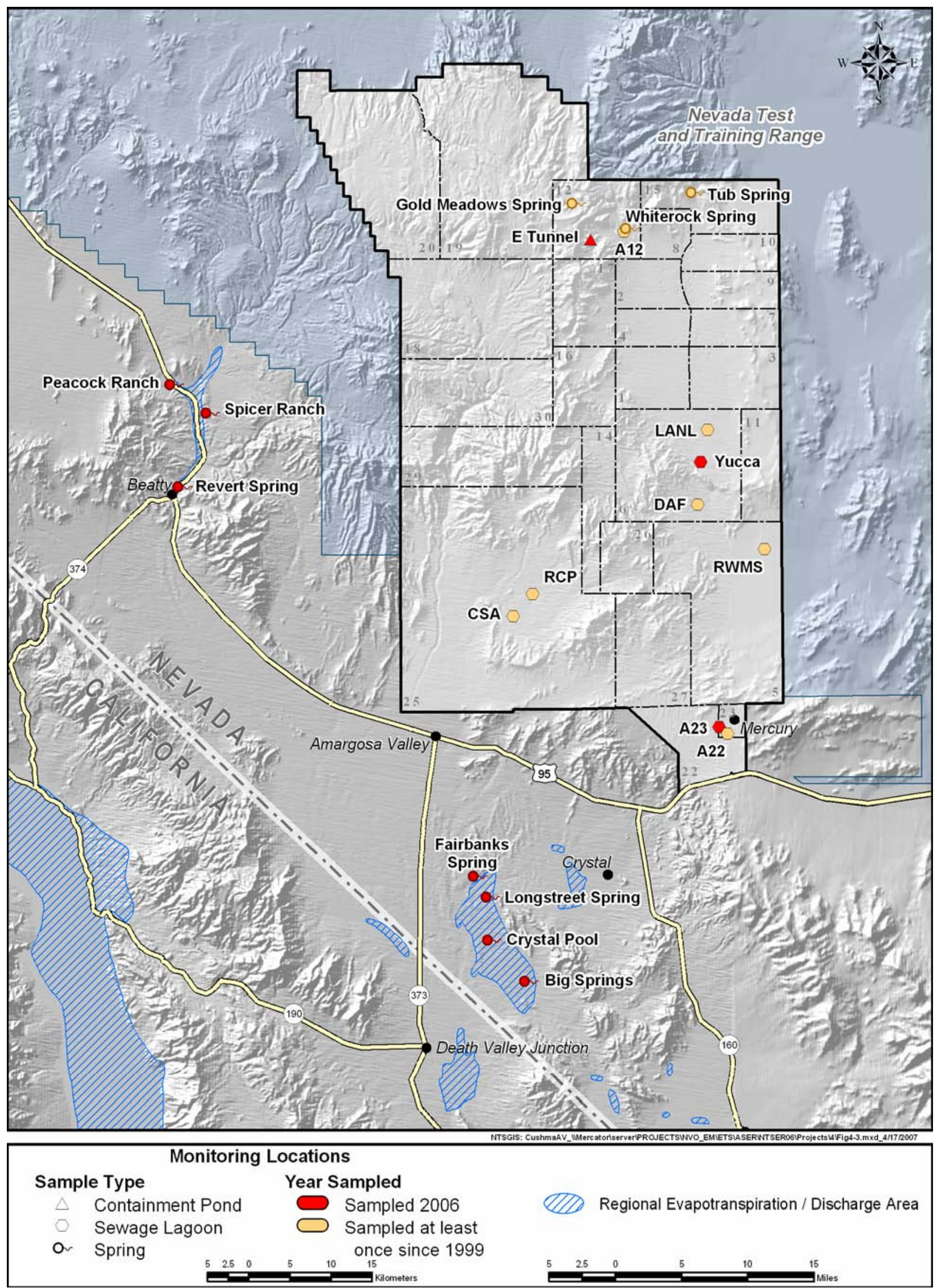

Figure 4-3. RREMP spring and surface water monitoring locations sampled on and off the NTS in 2006 
Sampling frequencies and requisite analyses for routine radiological water monitoring are based on location and type of sampling point as defined in the RREMP (DOE, 2003b). During each monitoring year, not every water sample is analyzed for every analyte, per the design criteria of the RREMP. In 2006, tritium analyses were performed on all samples. Other analyses were performed on specific samples based on the probability of their detection or on whether they had been screened for previously at that location.

To achieve a sufficiently low detection limit, most tritium analyses were conducted after the samples were enriched. The enrichment process concentrates tritium in a sample to provide an effective minimum detectable concentration (MDC) (see Glossary, Appendix B) for the sample-specific laboratory analysis. Sample-specific MDCs for laboratory analysis, reported in each results table, ranged from 11 to 37 picocuries per liter (pCi/L) with an average of $18.7 \mathrm{pCi} / \mathrm{L}$. The MDC for standard (non-enriched) tritium analyses typically ranges from $200-400 \mathrm{pCi} / \mathrm{L}$.

Routine quality control samples (e.g., duplicates, blanks, and spikes) are also incorporated into the analytical streams on a frequent basis. The reader is directed to Section 18.0 for a thorough discussion of quality assurance/quality control protocols and procedures utilized for radiological water monitoring.

\subsubsection{Presentation of Water Sampling Data}

The following sections present only concentrations that were above the MDC for gamma-emitting radionuclides, plutonium, ${ }^{14} \mathrm{C},{ }^{90} \mathrm{Sr}$, and ${ }^{99} \mathrm{Tc}$. Concentration values of gross alpha, gross beta, and tritium, whether they are below or above the sample-specific MDCs, are presented for all water samples in the data tables.

The uncertainty values presented in the data tables of this chapter represent the counting uncertainty ("error") of the analytical method. This does not include the uncertainty associated with sample collection or the preparation and concentration of tritium during the enrichment process. A statistical analysis of all background samples analyzed between 1999 and 2005 was conducted to obtain an estimate of the tritium decision level (Lc) (see Glossary, Appendix B). The background samples were from wells with no known tritium. The analysis suggests an $\mathrm{L}_{\mathrm{C}}$ for tritium of approximately $20 \mathrm{pCi} / \mathrm{L}$. When measured tritium data from sample blanks analyzed during the same period were added to the background well samples, the $\mathrm{Lc}$ increased to $25 \mathrm{pCi} / \mathrm{L}$. When only the sample blanks were retained in the analysis, the $\mathrm{L}_{\mathrm{C}}$ increased to around $39 \mathrm{pCi} / \mathrm{L}$. These analyses indicate that measured tritium levels in the blanks are higher than tritium levels in the well samples. In computing these $\mathrm{L}_{\mathrm{C}}$ values, ETS requires there be 99 percent confidence that the sample contains tritium above background. Moreover, about 1 percent of the background data values were found to be atypical and were deleted from the computation; this suggests that sporadic anomalies may be an inherent feature of the tritium sampling, enrichment, and analysis process.

All values shown in the tables in the following results sections are formatted to two significant figures based on the accuracy of the measurements (e.g., 2500, 25, 2.5, or 0.025).

\subsubsection{Results from Offsite Wells}

The 16 offsite well locations sampled in 2006 included 3 private domestic wells, 3 community wells, and 10 NNSA/NSO wells related to NTS activities (see Figure 4-2). The 2006 data indicate that groundwater at the offsite locations has not been impacted by NTS nuclear testing operations.

The initial tritium results for grab samples from ER-OV-03C, ER-OV-03C2, ER-OV-04A and field duplicate samples from ER-OV-03A3, PM-3, and School Well were slightly above the MDC. The remaining tritium results for the offsite wells were all less than the MDC. Reanalysis results from the same samples that were above the MDC were non-detectable except for the School Well field duplicate sample. The School Well duplicate sample reanalysis result was slightly above the sample-specific MDC, but the grab sample result collected on the same date was below the MDC. The reanalyzed tritium results along with tritium $\left({ }^{3} \mathrm{H}\right)$ results from the other offsite wells are provided in Table 4-1.

Gross alpha and gross beta radioactivity were detected in most offsite well samples collected in 2006 (Table 4-1). None of the 2006 results are greater than the EPA maximum contaminant level (MCL) in drinking water for gross alpha of $15 \mathrm{pCi} / \mathrm{L}$ or the EPA level of concern for gross beta of $50 \mathrm{pCi} / \mathrm{L}$. 
Table 4-1. Gross alpha, gross beta, and tritium analysis results for offsite wells in 2006

\begin{tabular}{|c|c|c|c|c|c|c|c|c|c|c|c|c|}
\hline \multirow{2}{*}{$\begin{array}{l}\text { Monitoring Location } \\
\text { Non-Potable NNSA/NSC }\end{array}$} & \multirow{2}{*}{$\begin{array}{c}\text { Date } \\
\text { Sampled }\end{array}$} & \multicolumn{4}{|c|}{$\begin{array}{c}\text { Gross } \alpha \pm \\
\text { Uncertainty)(a) } \\
(\mathrm{MDC})(\mathrm{pCi} / \mathrm{L})^{(\mathrm{b})}\end{array}$} & \multicolumn{3}{|c|}{$\begin{array}{c}\text { Gross } \beta \pm \\
\text { Uncertainty (MDC) } \\
(\mathrm{pCi} / \mathrm{L})^{(\mathrm{c})}\end{array}$} & \multicolumn{4}{|c|}{$\begin{array}{c}{ }^{3} \mathrm{H} \pm \\
\text { Uncertainty }(\mathrm{MDC}) \\
(\mathrm{pCi} / \mathrm{L})^{(\mathrm{d})}\end{array}$} \\
\hline & & & & & & & & & & & & \\
\hline ER-OV-01 & $11 / 28 / 2006$ & 5.8 & \pm & 1.5 & $(1.4)$ & 5.4 & \pm 1.4 & $(2.0)$ & 11 & \pm & 7.5 & (12) \\
\hline ER-OV-02 & $11 / 28 / 2006$ & 7.9 & \pm & 1.8 & (1.3) & 3.6 & \pm 1.3 & $(2.0)$ & 7.4 & \pm & 7.2 & (12) \\
\hline ER-OV-02 FD ${ }^{(\mathrm{e})}$ & $11 / 28 / 2006$ & \multicolumn{4}{|c|}{$\mathrm{NA}^{(\mathrm{f})}$} & \multicolumn{3}{|c|}{ NA } & 10 & \pm & 7.5 & (12) \\
\hline ER-OV-03A & $11 / 21 / 2006$ & \multicolumn{4}{|c|}{ NS(g) } & \multicolumn{3}{|c|}{ NS } & 8.1 & \pm & 7.3 & (12) \\
\hline ER-OV-03A3 & $11 / 28 / 2006$ & \multicolumn{4}{|c|}{ NS } & \multicolumn{3}{|c|}{ NS } & 11 & \pm & 7.7 & (12) \\
\hline ER-OV-03A3 FD & $11 / 28 / 2006$ & \multicolumn{4}{|c|}{ NS } & \multicolumn{3}{|c|}{ NS } & 5.4 & \pm & 7.6 & (13) \\
\hline ER-OV-03C & $11 / 27 / 2006$ & 7.4 & \pm & 1.8 & (1.4) & 1.1 & $\pm \quad 1.0$ & (1.9) & 1.2 & \pm & 7.4 & (13) \\
\hline ER-OV-03C2 & $11 / 27 / 2006$ & 7.5 & \pm & 1.7 & $(0.92)$ & 2.0 & \pm 1.06 & (1.9) & 13 & & 11 & (19) \\
\hline ER-OV-03C2 FD & $11 / 27 / 2006$ & 6.3 & \pm & 1.5 & $(1.2)$ & 0.66 & $\pm \quad 1.0$ & (1.9) & & & NA & \\
\hline ER-OV-04A & $11 / 29 / 2006$ & \multicolumn{4}{|c|}{ NS } & \multicolumn{3}{|c|}{ NS } & 1.4 & & & (12) \\
\hline ER-OV-05 & $11 / 28 / 2006$ & \multicolumn{4}{|c|}{ NS } & \multicolumn{3}{|c|}{ NS } & 9.6 & & 7.4 & (12) \\
\hline ER-OV-06A & $11 / 28 / 2006$ & 3.9 & \pm & 1.2 & (1.3) & 4.6 & \pm 1.3 & $(2.0)$ & 12 & \pm & 7.7 & (12) \\
\hline ER-OV-06A FD & $11 / 28 / 2006$ & & & NA & & & NA & & 9.2 & \pm & 7.3 & (12) \\
\hline PM-3 (1,560 ft bgs) & $6 / 28 / 2006$ & & & NS & & & NS & & 23 & \pm & & $(23)$ \\
\hline PM-3 (1,560 ft bgs) FD & $6 / 28 / 2006$ & & & NS & & & NS & & 9.0 & \pm & 16 & $(28)$ \\
\hline PM-3 (1,993 ft bgs) & $6 / 28 / 2006$ & & & NS & & & NS & & 3.5 & \pm & 13 & $(22)$ \\
\hline \multicolumn{13}{|c|}{ Private/Community Drinking Water Wells } \\
\hline Beatty Water and Sewer & $10 / 17 / 2006$ & & & NS & & \multicolumn{3}{|c|}{ NS } & 12 & \pm & 9.8 & $(16)$ \\
\hline Fuller Property & $10 / 17 / 2006$ & & & NS & & \multicolumn{3}{|c|}{ NS } & 11 & \pm & 10 & $(16)$ \\
\hline Roger Bright Ranch & $10 / 17 / 2006$ & & & NS & & \multicolumn{3}{|c|}{ NS } & 15 & \pm & 10 & $(16)$ \\
\hline Roger Bright Ranch FD & $10 / 17 / 2006$ & & & NS & & \multicolumn{3}{|c|}{ NS } & 13 & \pm & & $(18)$ \\
\hline School Well & $10 / 17 / 2006$ & & & NS & & \multicolumn{3}{|c|}{ NS } & 13 & \pm & 10 & (16) \\
\hline School Well FD & $10 / 17 / 2006$ & & & NS & & \multicolumn{3}{|c|}{ NS } & 23 & \pm & 13 & (20) \\
\hline Tolicha Peak & $10 / 31 / 2006$ & 1.3 & \pm & 1.2 & $-(1.9)$ & 3.2 & \pm 0.4 & $(0.5)$ & 9.3 & \pm & 11 & $(17)$ \\
\hline U.S. Ecology & $10 / 17 / 2006$ & \multicolumn{4}{|c|}{ NS } & \multicolumn{3}{|c|}{ NS } & 13 & \pm & 10 & $(16)$ \\
\hline
\end{tabular}

Green shaded results are considered detected (result is greater than the sample-specific MDC)

(a) \pm 2 standard deviations

(b) The EPA established MCL in drinking water for gross alpha $(\alpha)$ is $15 \mathrm{pCi} / \mathrm{L}$

(c) The EPA "Level of Concern" in drinking water for gross beta $(\beta)$ is $50 \mathrm{pCi} / \mathrm{L}$

(d) The EPA established MCL in drinking water for ${ }^{3} \mathrm{H}$ is $20,000 \mathrm{pCi} / \mathrm{L}$

(e) FD = field duplicate

(f) NA = not analyzed in FD sample

(g) NS = not scheduled for analysis in 2006, analysis run once every 2-3 years, last analyzed in 2005

Samples from wells ER-OV-01, ER-OV-02, ER-OV-03C, ER-OV-03C2, and ER-OV-06A were also analyzed for gamma-emitting radionuclides, ${ }^{238} \mathrm{Pu}$, and ${ }^{239+240} \mathrm{Pu}$. No man-made or natural radionuclides were detected.

Among the 33 offsite wells which have been sampled at least once since 1999, there are no detectable trends in gross alpha or gross beta activity (Figure 4-4). Most measured gross alpha and gross beta levels are below EPA MCL or levels of concern for drinking water. In 2006, the 9 Oasis Valley wells (ER-OV-01, ER-OV-02, ER-OV-03A, ER-OV-03A3, ER-OV-03C, ER-OV-03C2, ER-OV-04A, ER-OV-05, and ER-OV-06A) were purged and sampled with a pump which resulted in slightly lower gross alpha and gross beta activities. Previously, many of these wells were not purged and were sampled with a bailer. There are no detectable trends in tritium activity (Figure 4-5) from 2000 to 2006. Most measured tritium concentrations are below the MDC. 


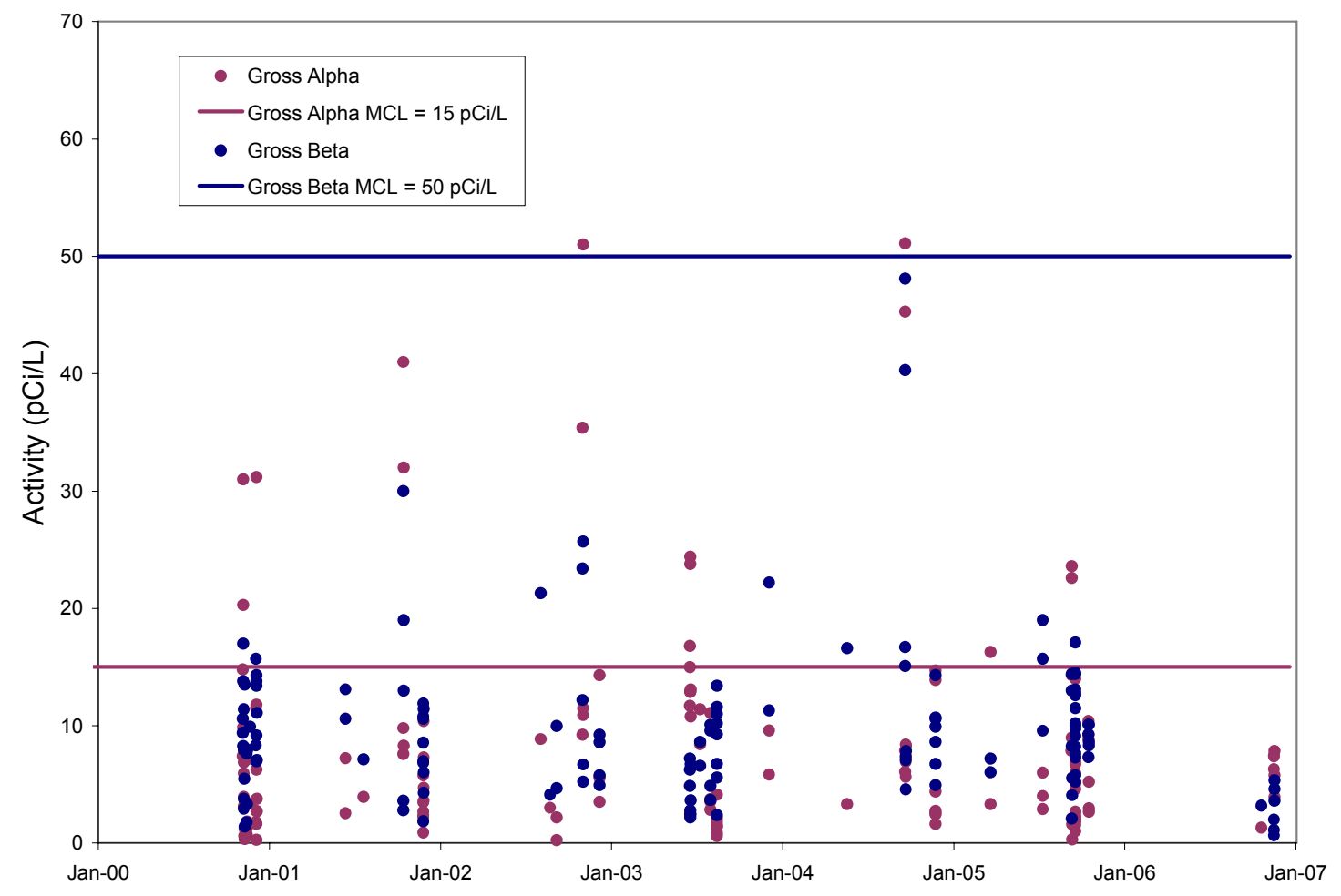

Figure 4-4. Gross alpha and gross beta levels in offsite wells from 2000 to 2006

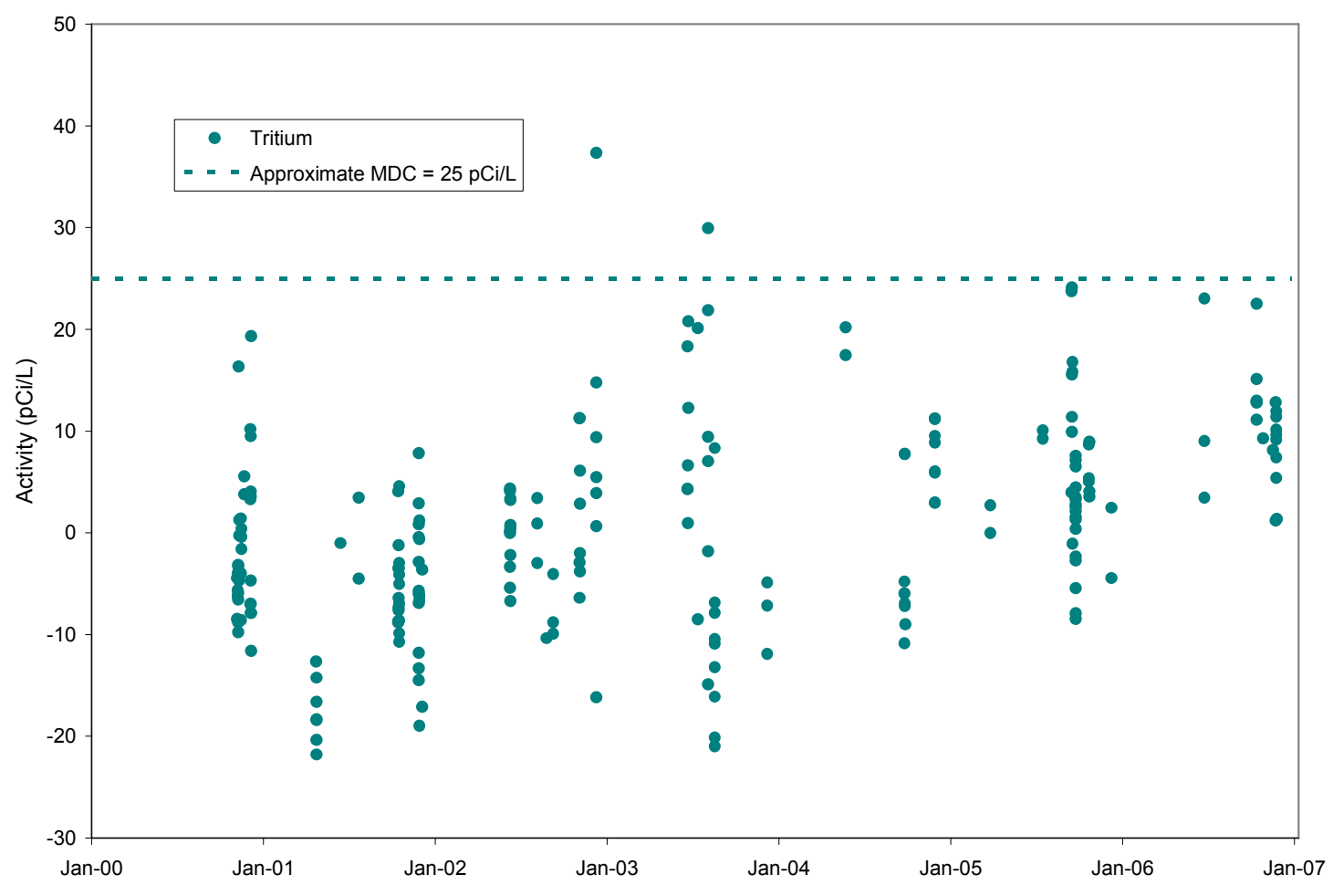

Figure 4-5. Tritium concentrations in offsite wells from 2000 to 2006 


\subsubsection{Results from Offsite Springs}

No detectable concentrations of tritium were found in the seven offsite springs sampled (Table 4-2, Figure 4-3). The initial tritium results for grab samples from Big Springs, Peacock Ranch, Revert Spring, and Spicer Ranch and the initial tritium results for duplicate samples from Crystal Pool, Peacock Ranch, Revert Spring, and Spicer Ranch were slightly above the MDC. The remaining tritium results were less than the MDC. Reanalysis results from the same samples that were above the MDC were all nondetectable. The original tritium results that are below the MDC and the reanalysis results are provided in Table 4-2.

There were no analyses for man-made or natural gamma-emitting radionuclides in 2006 on samples from offsite springs.

Detectable concentrations of gross alpha and gross beta were present in water collected from the springs, although all but one of the measured concentrations are below the EPA MCL and level of concern for drinking water (Table 4-2). The measured gross alpha activity at Spicer Ranch is slightly above the EPA MCL of $15 \mathrm{pCi} / \mathrm{L}$. This measurable gross alpha and gross beta radioactivity is likely from natural sources.

Among the seven offsite springs that have been sampled at least once since 1999, there are no detectable trends in gross alpha or gross beta activity (Figure 4-6) or in tritium concentrations from 2000 to 2006 (Figure 4-7). Alpha and beta levels have mostly been below the EPA MCL for drinking water, and tritium concentrations have all been below the MDC.

Table 4-2. Gross alpha, gross beta, and tritium analysis results for offsite springs in 2006

\begin{tabular}{|c|c|c|c|c|c|c|c|c|c|c|c|c|c|}
\hline \multirow{2}{*}{$\begin{array}{l}\text { Monitoring Location } \\
\text { Big Springs }\end{array}$} & \multirow{2}{*}{$\begin{array}{c}\text { Date } \\
\text { Sampled }\end{array}$} & \multicolumn{4}{|c|}{$\begin{array}{c}\text { Gross } \alpha \pm \\
\text { Uncertainty)(a) }(\mathrm{MDC}) \\
(\mathrm{pCi} / \mathrm{L})^{(\mathrm{b})}\end{array}$} & \multicolumn{4}{|c|}{$\begin{array}{c}\text { Gross } \beta \pm \\
\text { Uncertainty (MDC) } \\
(\mathrm{pCi} / \mathrm{L})^{(\mathrm{c})} \\
\end{array}$} & \multicolumn{4}{|c|}{$\begin{array}{c}{ }^{3} \mathrm{H} \pm \\
\text { Uncertainty (MDC) } \\
(\mathrm{pCi} / \mathrm{L})^{(\mathrm{d})}\end{array}$} \\
\hline & & 2.4 & \pm & 1.2 & (1.8) & 7.6 & \pm & 0.65 & $(0.66)$ & 13 & \pm & 12 & (19) \\
\hline Crystal Pool & $10 / 24 / 2006$ & 3.5 & \pm & 1.4 & $(2.0)$ & 7.3 & \pm & 0.63 & $(0.68)$ & 9.1 & \pm & 11 & (18) \\
\hline Crystal Pool FD(e) & $10 / 24 / 2006$ & \multicolumn{4}{|c|}{$\mathrm{NA}^{(\mathrm{f})}$} & \multicolumn{4}{|c|}{ NA } & 9.9 & \pm & 11 & (19) \\
\hline Fairbanks Spring & $10 / 24 / 2006$ & -0.54 & \pm & 1.2 & $(2.0)$ & 5.8 & \pm & 0.54 & $(0.63)$ & 16 & \pm & 11 & (18) \\
\hline Fairbanks Spring FD & $10 / 24 / 2006$ & \multicolumn{4}{|c|}{ NA } & \multicolumn{4}{|c|}{ NA } & 12 & \pm & 10 & (16) \\
\hline Longstreet Spring & $10 / 24 / 2006$ & 3.0 & \pm & 1.3 & (1.9) & 5.8 & \pm & 0.59 & $(0.63)$ & 13 & \pm & 10 & (16) \\
\hline Peacock Ranch & $10 / 31 / 2006$ & 4.8 & \pm & 1.6 & $(2.0)$ & 9.1 & \pm & 0.83 & $(0.86)$ & 2.0 & \pm & 11 & (19) \\
\hline Peacock Ranch FD & $10 / 31 / 2006$ & 3.5 & \pm & 1.5 & (1.9) & 7.4 & \pm & 0.91 & $(0.88)$ & \multicolumn{4}{|c|}{ NA } \\
\hline Revert Spring & $10 / 31 / 2006$ & 14 & \pm & 2.0 & $(1.8)$ & 3.8 & \pm & 0.53 & $(0.57)$ & 9.3 & \pm & 12 & (19) \\
\hline Revert Spring FD & $10 / 31 / 2006$ & \multicolumn{4}{|c|}{ NA } & \multicolumn{4}{|c|}{ NA } & 4.4 & \pm & 11 & (19) \\
\hline Spicer Ranch & $10 / 31 / 2006$ & 16 & \pm & 2.1 & $(2.0)$ & 6.1 & \pm & 0.64 & $(0.61)$ & 12 & \pm & 10 & (17) \\
\hline Spicer Ranch FD & $10 / 31 / 2006$ & \multicolumn{4}{|c|}{ NA } & & & NA & & 13 & \pm & 13 & $(20)$ \\
\hline
\end{tabular}

Green shaded results are considered detected (result is greater than the sample-specific MDC)

Yellow shaded result is greater than the EPA-designated levels shown below:
(a) \pm 2 standard deviations
(b) The EPA established MCL in drinking water for gross alpha $(\alpha)$ is $15 \mathrm{pCi} / \mathrm{L}$
(c) The EPA "Level of Concern" in drinking water for gross beta $(\beta)$ is $50 \mathrm{pCi} / \mathrm{L}$
(d) The EPA established MCL in drinking water for ${ }^{3} \mathrm{H}$ is $20,000 \mathrm{pCi} / \mathrm{L}$
(e) FD = field duplicate sample
(f) NA = not analyzed in FD sample 


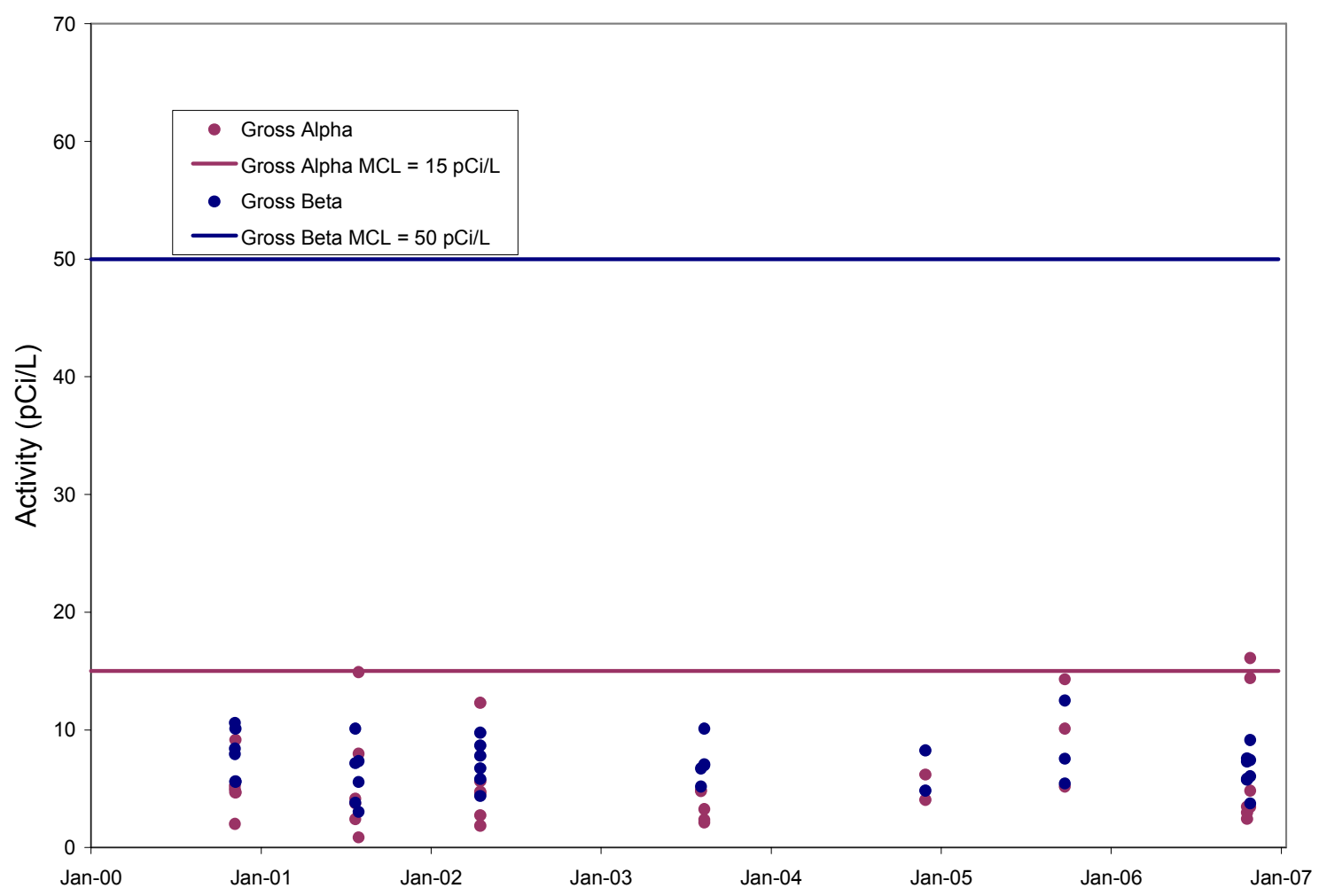

Figure 4-6. Gross alpha and gross beta levels in offsite springs from 2000 to 2006

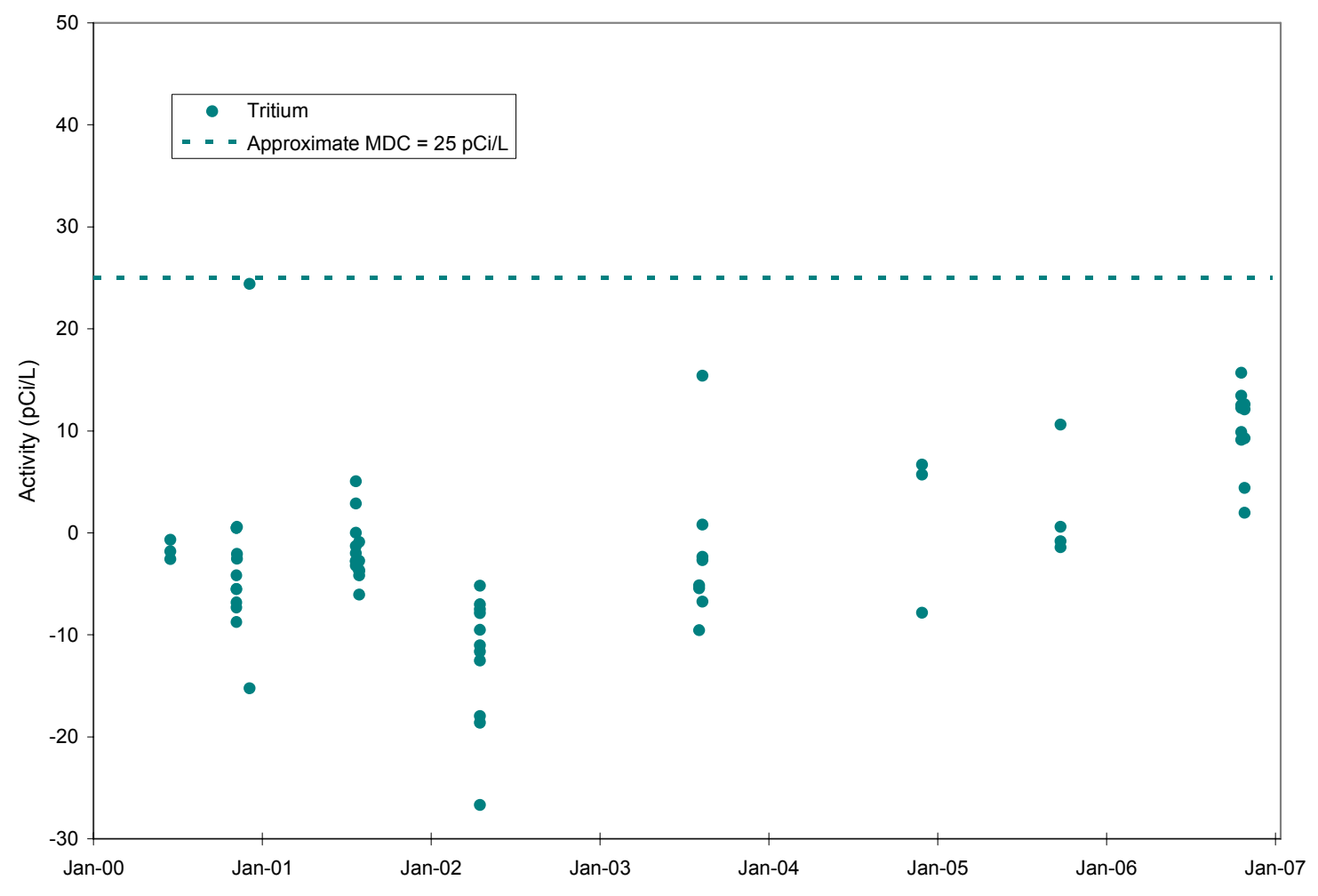

Figure 4-7. Tritium concentrations in offsite springs from 2000 to 2006 


\subsubsection{Results from NTS Water Supply Wells}

Results from the ten NTS water wells (six permitted potable and four non-potable) sampled in 2006 (see Figure 4-2) continue to indicate that nuclear testing has not impacted the NTS water supply network. All but two water samples had non-detectable concentrations of tritium (Table 4-3). The duplicate samples from UE-16D and WW C-1 collected in October were slightly above the MDC. In both cases the tritium results from the grab samples, collected at the same time as the duplicate samples, were below the MDC. These wells are non-potable water supply wells. Prior to 1994, WW C-1 had a history of validated tritium detections because this well was injected with approximately 0.1 to 0.2 curies of tritium in 1962 by a researcher conducting a tracer test (Lyles, 1990). Since 1995, tritium concentrations in WW C-1 have remained below the MDC.

The radiological analytes that were principally detectable in the NTS water supply wells are gross alpha and gross beta radioactivity (Table 4-3). This activity likely represents the presence of naturally-occurring radionuclides, since there was a general lack of corresponding detectable man-made radionuclides in the samples. Neither gross alpha nor gross beta ctivity exceeded EPA-established Levels of Concern or the established MCLs for drinking water (Table 4-3).

No man-made gamma-emitting radionuclides or other man-made radionuclides were detected in the water supply well samples.

These ten wells have been sampled routinely since 1999. No detectable trends in gross alpha or gross beta activity (Figure 4-8) or in tritium concentrations (Figure 4-9) have been found from 2000 to 2006.

The Nevada State Health Division, Bureau of Health Protection Services (BHPS) independently sampled all the NTS water supply wells, except Army \#1 Well, at least once in 2006. BHPS and BN/NSTec ETS personnel sampled supply wells at the same time in January, April, and October of 2006. The BHPS sample results also indicate that man-made radionuclides are at or below the MDCs and that naturally-occurring radioactive materials such as thorium and uranium decay chain radionuclides are within normal ranges (BHPS, 2006a; 2006b; 2006c).

Table 4-3. Gross alpha, gross beta, and tritium analysis results for NTS water supply wells in 2006

\begin{tabular}{|c|c|c|c|c|c|c|c|c|c|c|c|c|c|}
\hline \multirow{2}{*}{$\begin{array}{l}\text { Monitoring } \\
\text { Location } \\
\text { Army \#1 WW }\end{array}$} & \multirow{2}{*}{$\begin{array}{l}\text { Date Sampled } \\
5 / 1 / 2006\end{array}$} & \multicolumn{4}{|c|}{$\begin{array}{c}\text { Gross } \alpha \pm \\
\text { Uncertainty })^{(\mathrm{a})}(\mathrm{MDC}) \\
(\mathrm{pCi} / \mathrm{L})^{(\mathrm{b})}\end{array}$} & \multicolumn{4}{|c|}{$\begin{array}{c}\text { Gross } \beta \pm \\
\text { Uncertainty } \\
(\mathrm{MDC})(\mathrm{pCi} / \mathrm{L})^{(\mathrm{c})}\end{array}$} & \multicolumn{4}{|c|}{$\begin{array}{c}{ }^{3} \mathrm{H} \pm \\
\text { Uncertainty (MDC) } \\
(\mathrm{pCi} / \mathrm{L})^{(\mathrm{d})}\end{array}$} \\
\hline & & 2.4 & \pm & 0.58 & $(0.48)$ & 5.3 & & 1.1 & $(1.0)$ & -7.2 & \pm & 13 & (23) \\
\hline & 5/1/2006 FD(e) & \multicolumn{4}{|c|}{$\mathrm{NA}^{(\mathrm{f})}$} & \multicolumn{4}{|c|}{ NA } & -11 & \pm & 14 & (23) \\
\hline & $8 / 29 / 2006$ & 3.4 & \pm & 1.3 & $(1.6)$ & 4.9 & & 0.8 & $(0.92)$ & 10 & \pm & 7.3 & (12) \\
\hline & 8/29/2006 FD & \multicolumn{4}{|c|}{ NA } & \multicolumn{4}{|c|}{ NA } & 7.2 & \pm & 7.1 & (12) \\
\hline & $10 / 4 / 2006$ & 2.6 & \pm & 1.1 & (1.5) & 5.2 & & 1.6 & (2.5) & 8.2 & \pm & 6.9 & (11) \\
\hline \multirow{4}{*}{$\begin{array}{l}\mathrm{J}-12 \mathrm{WW} \\
\text { (permitted, } \\
\text { potable well) }\end{array}$} & $1 / 24 / 2006$ & 0.27 & \pm & 1.0 & $(1.9)$ & 2.6 & \pm & 0.81 & (1.0) & 7.0 & \pm & 13 & (23) \\
\hline & $4 / 11 / 2006$ & -3.6 & \pm & 1.3 & $(1.9)$ & 2.5 & \pm & 0.49 & $(0.64)$ & -8.1 & \pm & 13 & (22) \\
\hline & $7 / 25 / 2006$ & 0.64 & \pm & 0.32 & $(0.4)$ & 4.7 & \pm & 1.0 & $(0.99)$ & -10 & \pm & 12 & (21) \\
\hline & $10 / 4 / 2006$ & 0.80 & \pm & 0.77 & $(1.4)$ & 5.3 & \pm & 1.6 & (2.4) & 7.0 & \pm & 6.9 & (11) \\
\hline $\begin{array}{l}\text { J-13 WW } \\
\text { (permitted, } \\
\text { potable well) }\end{array}$ & $1 / 24 / 2006$ & -1.1 & \pm & 1.18 & $(1.9)$ & 1.8 & \pm & 0.63 & $(0.85)$ & 3.4 & \pm & 13 & (22) \\
\hline \multirow[t]{7}{*}{ UE-16D WW } & $1 / 24 / 2006$ & 3.7 & \pm & 1.5 & $(2.1)$ & 4.5 & \pm & 0.66 & $(0.79)$ & 0.00 & \pm & 13 & (23) \\
\hline & $4 / 11 / 2006$ & 4.1 & \pm & 1.4 & $(2.0)$ & 4.1 & \pm & 0.60 & $(0.74)$ & -0.31 & \pm & 14 & (23) \\
\hline & 4/11/2006 FD & 4.4 & \pm & 1.4 & (1.9) & 4.1 & \pm & 0.60 & $(0.75)$ & \multicolumn{4}{|c|}{ NA } \\
\hline & $7 / 25 / 2006$ & 3.0 & \pm & 0.63 & $(0.35)$ & 6.4 & \pm & 1.3 & (1.0) & 1.3 & \pm & 12 & (21) \\
\hline & 7/25/2006 FD & \multicolumn{4}{|c|}{ NA } & \multicolumn{4}{|c|}{ NA } & -1.3 & \pm & 12 & (21) \\
\hline & $10 / 4 / 2006$ & 5.0 & \pm & 1.7 & (1.9) & 8.7 & \pm & 2.1 & (2.6) & 10 & \pm & 7.4 & (12) \\
\hline & 10/4/2006 FD & \multicolumn{4}{|c|}{ NA } & \multicolumn{4}{|c|}{ NA } & 13 & \pm & 7.4 & $(12)$ \\
\hline
\end{tabular}


Table 4-3. Gross alpha, gross beta, and tritium analysis results for NTS water supply wells in 2006 (continued)

\begin{tabular}{|c|c|c|c|c|c|c|c|c|c|c|c|c|c|}
\hline \multirow{4}{*}{$\begin{array}{l}\text { Monitoring } \\
\text { Location }\end{array}$} & \multirow{2}{*}{$\begin{array}{l}\text { Date Sampled } \\
1 / 24 / 2006\end{array}$} & \multicolumn{4}{|c|}{$\begin{array}{l}\text { Gross } \alpha \pm \text { Uncertainty) })^{(a)} \\
\quad(\mathrm{MDC})(\mathrm{pCi} / \mathrm{L})^{(\mathrm{b})}\end{array}$} & \multicolumn{4}{|c|}{$\begin{array}{c}\text { Gross } \beta \pm \\
\text { Uncertainty } \\
(\mathrm{MDC})(\mathrm{pCi} / \mathrm{L})^{(\mathrm{c})}\end{array}$} & \multicolumn{4}{|c|}{$\begin{array}{c}{ }^{3} \mathrm{H} \pm \\
\text { Uncertainty }(\mathrm{MDC}) \\
(\mathrm{pCi} / \mathrm{L})^{(\mathrm{d})}\end{array}$} \\
\hline & & 9.4 & \pm & 2.0 & $(1.9)$ & 3.7 & \pm & 0.72 & $(0.78)$ & 3.5 & \pm & 13 & (23) \\
\hline & $4 / 11 / 2006$ & 7.1 & \pm & 1.6 & $(2.0)$ & 4.4 & \pm & 0.44 & $(0.47)$ & -11 & \pm & 14 & (23) \\
\hline & $7 / 25 / 2006$ & 4.4 & \pm & 0.90 & (0.49) & 4.9 & \pm & 1.0 & $(1.0)$ & -14 & \pm & 12 & (22) \\
\hline & 7/25/2006 FD & 4.2 & \pm & 0.86 & $(0.54)$ & 5.0 & \pm & 1.1 & (1.0) & -4.1 & \pm & 12 & (21) \\
\hline & $10 / 4 / 2006$ & 4.5 & \pm & 1.5 & (1.6) & 5.4 & \pm & 1.6 & $(2.5)$ & 8.0 & \pm & 7.0 & (11) \\
\hline \multirow{7}{*}{$\begin{array}{l}\text { WW \#4A } \\
\text { (permitted, } \\
\text { potable well) }\end{array}$} & $1 / 24 / 2006$ & 4.7 & \pm & 1.4 & (1.9) & 4.9 & \pm & 0.57 & $(0.63)$ & 3.4 & \pm & 13 & (22) \\
\hline & 1/24/2006 FD & \multicolumn{4}{|c|}{ NA } & \multicolumn{4}{|c|}{ NA } & 3.5 & \pm & 13 & (23) \\
\hline & $4 / 11 / 2006$ & 4.6 & \pm & 1.4 & (1.9) & 4.7 & \pm & 0.56 & $(0.56)$ & -6.5 & \pm & 13 & (21) \\
\hline & 4/11/2006 FD & \multicolumn{4}{|c|}{ NA } & \multicolumn{4}{|c|}{ NA } & -2.0 & \pm & 14 & (23) \\
\hline & $7 / 25 / 2006$ & 4.4 & \pm & 0.89 & $(0.47)$ & 5.7 & \pm & 1.2 & $(1.2)$ & -1.7 & \pm & 13 & (22) \\
\hline & 7/25/2006 FD & 4.1 & \pm & 0.84 & $(0.48)$ & 6.7 & \pm & 1.3 & $(1.1)$ & \multicolumn{4}{|c|}{ NA } \\
\hline & $10 / 4 / 2006$ & 5.6 & \pm & 1.6 & (1.3) & 7.5 & \pm & 1.9 & (2.5) & 10 & \pm & 7.1 & (11) \\
\hline WW 5B & $1 / 24 / 2006$ & 4.0 & \pm & 1.5 & (2.1) & 8.1 & \pm & 0.66 & $(0.65)$ & 0.00 & \pm & 13 & (23) \\
\hline (permitted, & $4 / 11 / 2006$ & 6.5 & \pm & 1.5 & (1.8) & 11 & \pm & 0.66 & $(0.51)$ & -9.1 & \pm & 13 & (22) \\
\hline \multirow[t]{2}{*}{ potable well) } & $7 / 25 / 2006$ & 3.3 & \pm & 0.73 & $(0.46)$ & 11 & \pm & 1.8 & (0.99) & -9.5 & \pm & 12 & (21) \\
\hline & $10 / 4 / 2006$ & 2.9 & \pm & 1.4 & (1.9) & 12 & \pm & 2.5 & $(2.6)$ & 5.9 & \pm & 6.7 & (11) \\
\hline \multirow[t]{5}{*}{ WW 5C } & $1 / 24 / 2006$ & 11 & \pm & 1.72 & (1.9) & 5.5 & \pm & 0.61 & $(0.64)$ & 3.5 & \pm & 13 & (23) \\
\hline & 1/24/2006 FD & 9.7 & \pm & 1.8 & $(2.0)$ & 4.2 & \pm & 0.70 & $(0.82)$ & \multicolumn{4}{|c|}{ NA } \\
\hline & $4 / 11 / 2006$ & 12 & \pm & 1.9 & (2.0) & 8.6 & \pm & 0.64 & (0.59) & -12 & \pm & 14 & (23) \\
\hline & $7 / 25 / 2006$ & 4.2 & \pm & 0.92 & $(0.67)$ & 6.1 & \pm & 1.3 & $(1.1)$ & 0.00 & \pm & 13 & (22) \\
\hline & $10 / 4 / 2006$ & 5.1 & \pm & 1.6 & (1.5) & 6.2 & \pm & 1.7 & (2.5) & 3.7 & \pm & 6.9 & (11) \\
\hline \multirow{4}{*}{$\begin{array}{l}\text { WW } 8 \\
\text { (permitted, } \\
\text { potable well) }\end{array}$} & $1 / 24 / 2006$ & -0.86 & \pm & 1.1 & (1.9) & 1.8 & \pm & 0.65 & $(0.86)$ & 3.4 & \pm & 13 & (22) \\
\hline & $7 / 25 / 2006$ & 0.048 & \pm & 0.39 & $(0.67)$ & 2.8 & \pm & 0.80 & $(1.0)$ & -24 & \pm & 21 & (37) \\
\hline & $10 / 4 / 2006$ & 0.88 & \pm & 0.93 & $(1.8)$ & 3.0 & \pm & 1.4 & (2.6) & 2.6 & \pm & 7.1 & (12) \\
\hline & 10/4/2006 FD & 0.17 & \pm & 0.70 & (1.6) & 2.2 & \pm & 1.4 & $(2.8)$ & \multicolumn{4}{|c|}{ NA } \\
\hline \multirow[t]{2}{*}{ WW C-1 } & $10 / 4 / 2006$ & 11 & \pm & 2.3 & (1.5) & 15 & \pm & 2.9 & $(2.1)$ & 11 & \pm & 7.3 & (12) \\
\hline & $10 / 4 / 2006 \mathrm{FD}$ & \multicolumn{4}{|c|}{ NA } & \multicolumn{4}{|c|}{ NA } & 14 & \pm & 7.4 & (12) \\
\hline
\end{tabular}

Green shaded results are considered detected (result is greater than the sample-specific MDC)
(a) \pm 2 standard deviations
(b) The EPA established MCL in drinking water for gross alpha $(\alpha)$ is $15 \mathrm{pCi} / \mathrm{L}$
(c) The EPA "Level of Concern" in drinking water for gross beta $(\beta)$ is $50 \mathrm{pCi} / \mathrm{L}$
(d) The EPA established MCL in drinking water for ${ }^{3} \mathrm{H}$ is $20,000 \mathrm{pCi} / \mathrm{L}$
(e) FD = field duplicate sample
(f) NA = not analyzed in FD sample 


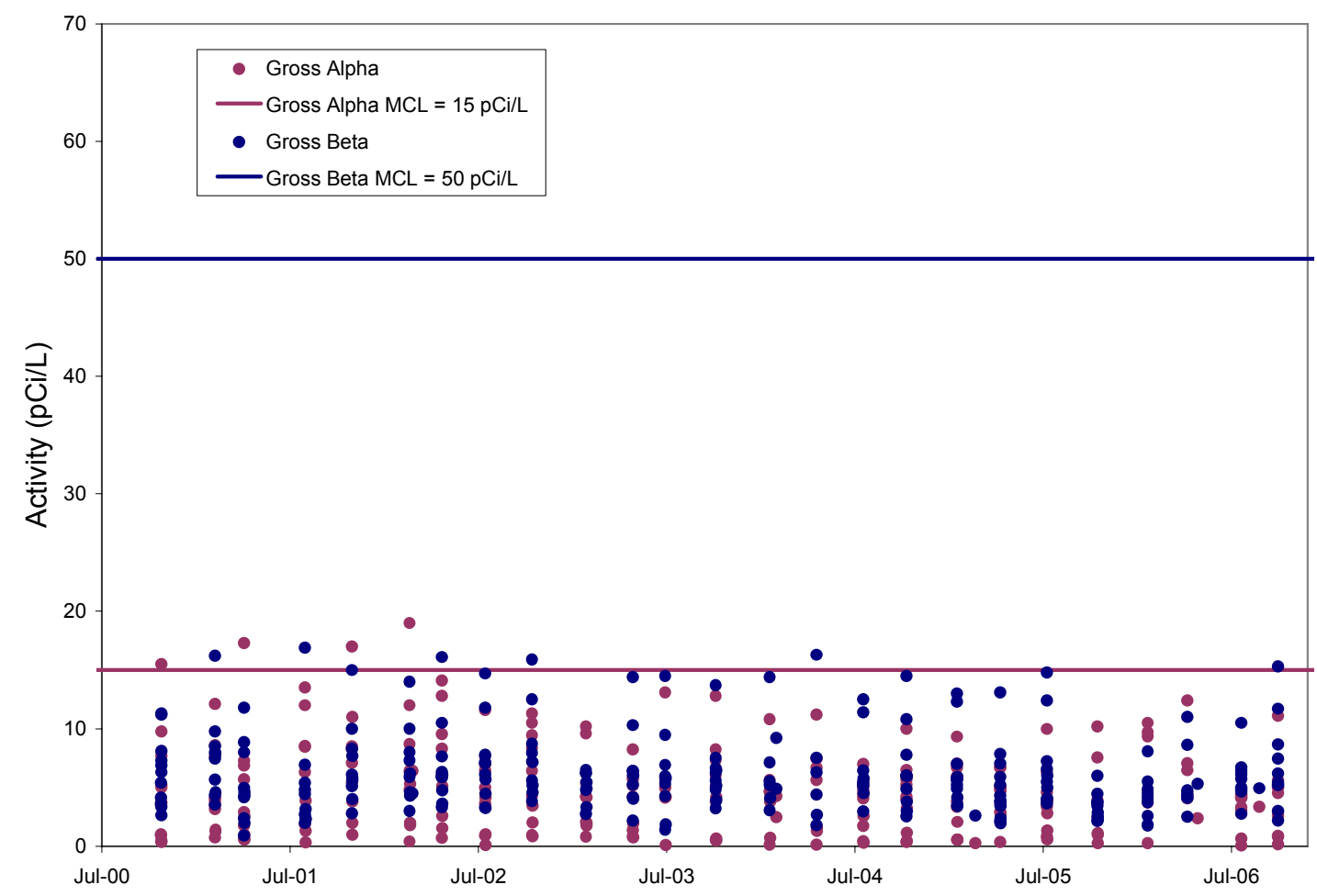

Figure 4-8. Gross alpha and gross beta levels in NTS water supply wells from 2000 to 2006

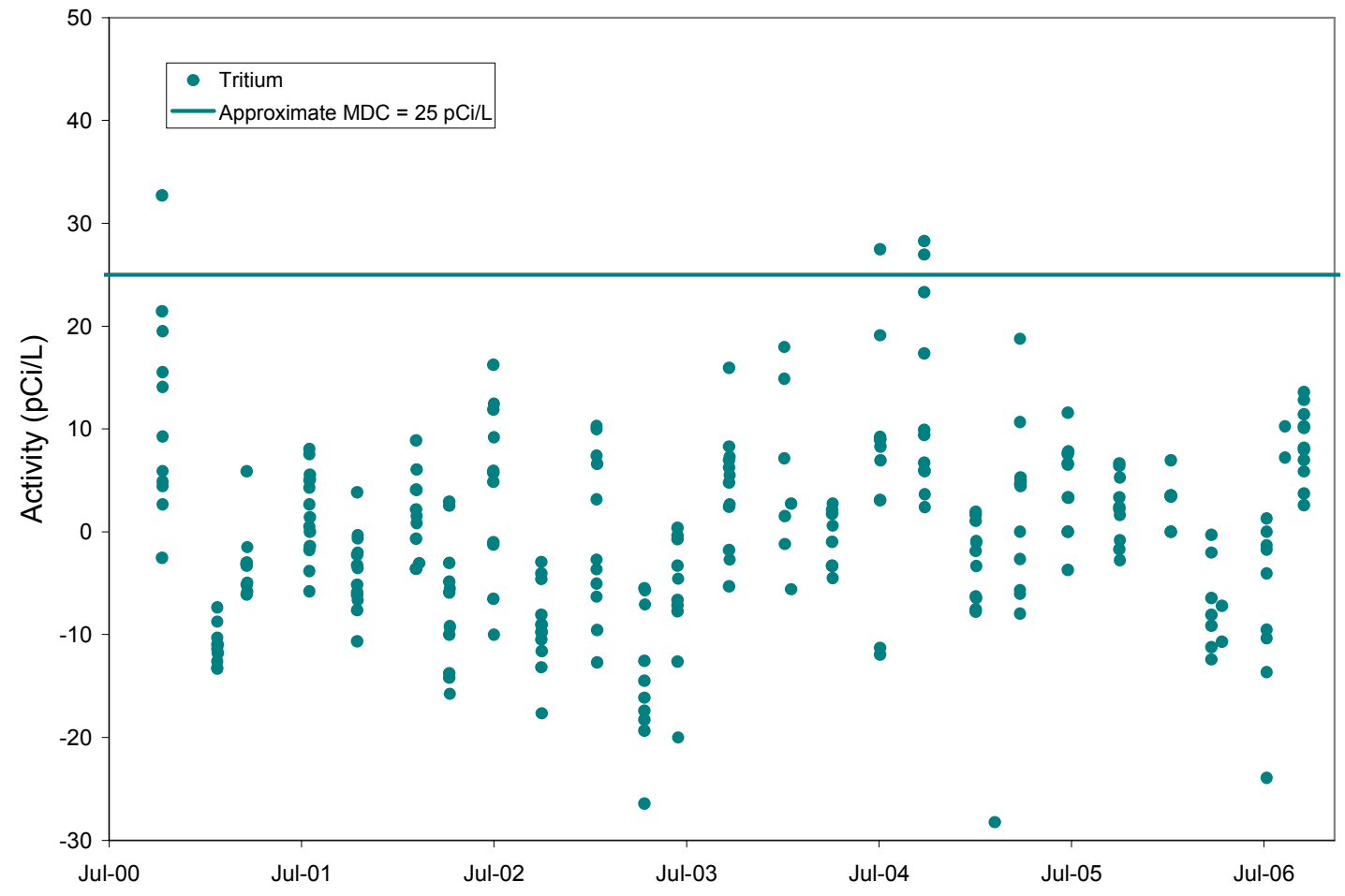

Figure 4-9. Tritium concentrations in NTS water supply wells from 2000 to 2006 


\subsubsection{Results from NTS Monitoring Wells}

Analytical results from the network of onsite monitoring wells (see Figure 4-2) indicate that migration of radionuclides from the underground test areas is not significant. Four onsite monitoring wells (PM-1, U-19BH, UE-7NS, and WW A) are known to have detectable concentrations of tritium, although they are all well below the EPA MCL of $20,000 \mathrm{pCi} / \mathrm{L}$. In 2006, the tritium activity in U-19BH was below the MDC (Table 4-4). Each of these four wells is located within 1 kilometer $(\mathrm{km})$ (0.6 miles [mi]) of an historical underground nuclear test. These wells are discussed below, and their historic tritium concentrations are shown in Figure 4-10.

In 2006, there were also measured tritium levels above the MDC at ER-20-2 \#1; however, the tritium levels are only slightly above the very low sample-specific MDCs (Table 4-4). Tritium was not detectable in other samples from onsite monitoring wells during 2006 (Table 4-4).

PM-1 - This well is located in the Central Pahute Mesa CAU. It is constructed with unslotted casing from the surface to 2,300 $\mathrm{m}$ (7,546 ft) bgs and is an open hole from 2,300 to 2,356 $\mathrm{m}$ (7,546 to 7,730 ft) bgs. Results from depth profile sampling below the static water level in 2001 show a decreasing tritium concentration with depth, indicating that tritium is entering the borehole near the static water level at approximately $643 \mathrm{~m}(2,109 \mathrm{ft})$ bgs. Potential sources include the underground nuclear tests FARM (U-20ab), GREELEY (U-20g), and KASSERI (U-20z). The FARM test is closest to PM-1 but is believed to be down-gradient. GREELY and KASSERI tests are both upgradient from PM-1 at distances of 2,429 $\mathrm{m}(7,969 \mathrm{ft})$ and 1,196 m (3,924 ft), respectively.

U-19BH - This well is located in the Central Pahute Mesa CAU. It is an unexpended emplacement borehole. There were several nuclear detonations conducted near U-19BH, but the source of the tritium in the borehole is unclear. Previous investigations suggest that the water in the well originates from a perched aquifer, but identifying the likely source of tritium is difficult due to a lack of data regarding the perched system (Brikowski et al., 1993). The results from a tracer test conducted in the well indicate that there is minimal flow across the borehole (Brikowski et al., 1993). The lack of measurable flow in the well suggests that the chemistry of the water sampled from the borehole may not be representative of the aquifer. The tritium concentrations measured since 1999 at U-19BH show a downward trend (Figure 4-10).

UE-7NS - This well is located in the Yucca Flat CAU and was drilled $137 \mathrm{~m}(449 \mathrm{ft})$ from the BOURBON underground nuclear test (U-7n) which was conducted in 1967. This well was routinely sampled between 1978 and 1987, with the resumption of sampling in 1991. Tritium levels in this well have been decreasing in recent years (Figure 4-10). UE-7NS is the second known location on the NTS where the regionally important lower carbonate aquifer (LCA) has been impacted by radionuclides from nuclear testing (Smith et al., 1999). The first location where the LCA has been impacted by radionuclides from nuclear testing is Well UE-2CE located less the $200 \mathrm{~m}$ (656 ft) from the NASH test conducted in Yucca Flat in 1967. Well UE-2CE is not currently configured for routine sampling.

WW A - This well is completed in alluvium in the Yucca Flat CAU. It is located within $1 \mathrm{~km}(0.6 \mathrm{mi})$ of 14 underground nuclear tests, most of which appear to be up-gradient of the well. The well has had measurable tritium since the late 1980s. The marked increase between 1985 and 1999 suggests inflow of tritium to this well

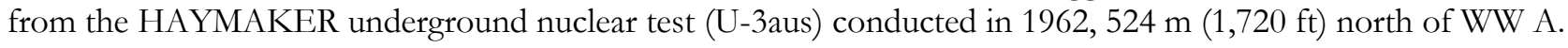
This well, which supplied non-potable water for construction, was shut down in the early 1990s. The tritium concentrations measured since 2000 at WW A indicate a slight downward trend (Figure 4-10).

Detectable concentrations of gross alpha and gross beta were present in water collected from NTS onsite monitoring wells in 2006. The low measurable gross alpha and gross beta radioactivity in these wells is likely from natural sources. The high levels of gross alpha and gross beta activity in U-19BH are likely related to contamination. No man-made radionuclides were detected by gamma spectroscopy analyses at concentrations above their respective MDCs in any of the NTS monitoring wells in 2006. Low levels of naturally-occurring ${ }^{40} \mathrm{~K}$ were detected in a sample from TW D, and low levels of naturally-occurring ${ }^{234}$ Th were detected in a sample from WW 2. 
Table 4-4. Gross alpha, gross beta, and tritium analysis results for NTS monitoring wells in 2006

\begin{tabular}{|c|c|c|c|c|c|c|c|c|c|c|c|c|c|}
\hline \multirow{2}{*}{$\begin{array}{l}\text { Monitoring Location } \\
\text { ER-20-1 }\end{array}$} & \multirow{2}{*}{$\begin{array}{c}\begin{array}{c}\text { Date } \\
\text { Sampled }\end{array} \\
8 / 8 / 2006\end{array}$} & \multicolumn{4}{|c|}{$\begin{array}{c}\text { Gross } \alpha \pm \\
\text { Uncertainty) } \\
(\mathrm{MDC})(\mathrm{pCi} / \mathrm{L})^{(\mathrm{b})}\end{array}$} & \multicolumn{4}{|c|}{$\begin{array}{c}\text { Gross } \beta \pm \\
\text { Uncertainty (MDC) } \\
(\mathrm{pCi} / \mathrm{L})^{(\mathrm{c})}\end{array}$} & \multicolumn{4}{|c|}{$\begin{array}{c}{ }^{3} \mathrm{H} \pm \\
\text { Uncertainty } \\
(\mathrm{MDC})(\mathrm{pCi} / \mathrm{L})^{(\mathrm{d})}\end{array}$} \\
\hline & & & & $\mathrm{NS}^{(\mathrm{e})}$ & & & & NS & & 11 & \pm & 7 & (12) \\
\hline ER-20-2 \#1 & 8/8/2006 & & & NS & & & & NS & & 12 & \pm & 7.2 & (12) \\
\hline ER-20-2 \#1 FD ${ }^{(\mathrm{f})}$ & $8 / 8 / 2006$ & & & NS & & & & NS & & 13 & \pm & 7.1 & (11) \\
\hline PM-1 & 6/28/2006 & & & NS & & & & NS & & 141 & \pm & 18 & (23) \\
\hline SM-23-1 & $11 / 8 / 2006$ & 3.9 & \pm & 2.4 & (2.6) & 11 & \pm & 2.2 & (1.9) & 5.7 & & 7.6 & (13) \\
\hline SM-23-1 FD & $11 / 8 / 2006$ & 3.8 & \pm & 2.3 & $(2.4)$ & 9.6 & \pm & 2.0 & (1.7) & & & A & \\
\hline U-19BH & $4 / 18 / 2006$ & 31 & \pm & 5.3 & $(0.78)$ & 40 & \pm & 6.7 & $(1.8)$ & 19 & \pm & 15 & (24) \\
\hline U-19BH FD & $4 / 18 / 2006$ & & & $\mathrm{NA}^{\mathrm{g}}$ & & & & NA & & 21 & \pm & 15 & (24) \\
\hline UE-1Q & $2 / 8 / 2006$ & 5.2 & \pm & 1.4 & (1.9) & 8.6 & \pm & 0.65 & $(0.65)$ & 6.8 & \pm & 13 & (22) \\
\hline UE-1Q FD & $2 / 8 / 2006$ & & & NA & & & & NA & & 6.6 & \pm & 13 & (22) \\
\hline UE-5C WW & $2 / 14 / 2006$ & 21 & \pm & 4.1 & $(2.0)$ & 49 & \pm & 8.5 & $(4.1)$ & 8.7 & \pm & 17 & (28) \\
\hline UE-5C WW FD & $2 / 14 / 2006$ & & & NA & & & & NA & & 4.6 & \pm & 17 & (30) \\
\hline UE5PW-1 ${ }^{(\mathrm{h})}$ & $4 / 26 / 2006$ & & & NS & & & & NS & & -1.2 & \pm & 10 & (17) \\
\hline UE5PW-1 FD & $4 / 26 / 2006$ & & & NS & & & & NS & & 2.2 & \pm & 11 & (19) \\
\hline UE5PW-1 & $10 / 10 / 2006$ & & & NS & & & & NS & & 12 & \pm & 11 & (18) \\
\hline UE5PW-1 FD & $10 / 10 / 2006$ & & & NS & & & & NS & & 2.3 & \pm & 10 & (18) \\
\hline UE5PW-2 ${ }^{(\mathrm{h})}$ & 4/26/2006 & & & NS & & & & NS & & -5.5 & \pm & 11 & (18) \\
\hline UE5PW-2 FD & 4/26/2006 & & & NS & & & & NS & & 0.13 & \pm & 11 & (18) \\
\hline UE5PW-2 & $10 / 10 / 2006$ & & & NS & & & & NS & & 7.6 & \pm & 11 & (18) \\
\hline UE5PW-2 FD & $10 / 10 / 2006$ & & & NS & & & & NS & & 11 & \pm & 11 & (18) \\
\hline UE5PW-3(h) & $4 / 26 / 2006$ & & & NS & & & & NS & & -5.5 & \pm & 11 & (19) \\
\hline UE5PW-3 FD & $4 / 26 / 2006$ & & & NS & & & & NS & & -7.9 & \pm & 13 & (22) \\
\hline UE5PW-3 & $10 / 10 / 2006$ & & & NS & & & & NS & & 12 & \pm & 11 & (18) \\
\hline UE5PW-3 FD & $10 / 10 / 2006$ & & & NS & & & & NS & & 16 & \pm & 11 & (18) \\
\hline UE-7NS & $5 / 2 / 2006$ & 0.62 & \pm & 0.37 & $(0.55)$ & 4.4 & \pm & 1.1 & $(1.2)$ & 114 & \pm & 22 & (20) \\
\hline UE-7NS FD & $5 / 2 / 2006$ & & & NA & & & & NA & & 126 & \pm & 23 & (20) \\
\hline HTH \#1 (1935ft bgs) & $4 / 19 / 2006$ & 1.4 & \pm & 0.56 & $(0.69)$ & 0.83 & \pm & 0.76 & $(1.4)$ & -3.8 & \pm & 14 & $(24)$ \\
\hline HTH \#1 (2040 ft bgs) & $4 / 19 / 2006$ & 1.2 & \pm & 0.56 & $(0.80)$ & 0.83 & \pm & 0.82 & (1.5) & -13 & \pm & 14 & (24) \\
\hline HTH \#1 (2130 ft bgs) & $4 / 19 / 2006$ & 0.63 & \pm & 0.52 & $(0.91)$ & 0.49 & \pm & 0.79 & (1.5) & -7.5 & \pm & 14 & (23) \\
\hline HTH \#1 (2300 ft bgs) & $4 / 19 / 2006$ & 1.1 & \pm & 0.57 & $(0.86)$ & 0.41 & \pm & 0.79 & (1.5) & -14 & \pm & 15 & (25) \\
\hline TW D & $2 / 8 / 2006$ & 0.31 & \pm & 1.0 & $(1.8)$ & 6.7 & \pm & 0.54 & $(0.55)$ & 0.00 & \pm & 17 & (29) \\
\hline TW D FD & $2 / 8 / 2006$ & & & NA & & & & NA & & 8.4 & \pm & 16 & (27) \\
\hline
\end{tabular}


Table 4-4. Gross alpha, gross beta, and tritium analysis results for NTS monitoring wells in 2006 (continued)

\begin{tabular}{|c|c|c|c|c|c|c|c|c|c|c|c|c|}
\hline \multirow{3}{*}{$\begin{array}{l}\text { Monitoring Location } \\
\text { WW A } \\
\text { WW A FD }\end{array}$} & \multirow{2}{*}{$\begin{array}{c}\text { Date } \\
\text { Sampled } \\
2 / 7 / 2006\end{array}$} & \multicolumn{4}{|c|}{$\begin{array}{c}\text { Gross } \alpha \pm \\
\text { Uncertainty }(\mathrm{MDC})^{(\mathrm{a})} \\
(\mathrm{pCi} / \mathrm{L})^{(\mathrm{b})}\end{array}$} & \multicolumn{4}{|c|}{$\begin{array}{c}\text { Gross } \beta \pm \\
\text { Uncertainty (MDC) } \\
(\mathrm{pCi} / \mathrm{L})^{(\mathrm{c})}\end{array}$} & \multicolumn{3}{|c|}{$\begin{array}{c}{ }^{3} \mathrm{H} \pm \\
\text { Uncertainty } \\
(\mathrm{MDC})(\mathrm{pCi} / \mathrm{L})^{(\mathrm{d})}\end{array}$} \\
\hline & & 0.60 & \pm & 1.0 & $(1.8)$ & 5.5 & \pm & 0.61 & $(0.59)$ & 484 & \pm 35 & (28) \\
\hline & $2 / 7 / 2006$ & -0.85 & \pm & 1.0 & $(1.7)$ & 4.5 & \pm & 0.52 & $(0.51)$ & & NA & \\
\hline WW 2 (2750 ft bgs) & 2/7/2006 & 1.1 & \pm & 1.1 & $(1.9)$ & 5.0 & \pm & 0.45 & $(0.47)$ & 4.4 & \pm 17 & (29) \\
\hline WW 2 (2750 ft bgs) FD & $2 / 7 / 2006$ & 2.2 & \pm & 1.1 & $(1.6)$ & 6.2 & \pm & 0.65 & $(0.61)$ & & NA & \\
\hline WW 2 (2442 ft bgs) & 9/7/2006 & 1.8 & \pm & 0.76 & $(0.98)$ & 6.2 & \pm & 0.78 & $(1.0)$ & 9.7 & \pm 7.1 & (11) \\
\hline WW 2 (2442 ft bgs) FD & 9/7/2006 & & & NA & & & & NA & & 6.0 & \pm 7.1 & (12) \\
\hline
\end{tabular}

Green shaded results are considered detected (result is greater than the sample-specific MDC)

Yellow shaded results are equal to or greater than the EPA-designated levels shown below for each analyte

(a) \pm 2 standard deviations

(b) The EPA established MCL in drinking water for gross alpha $(\alpha)$ is $15 \mathrm{pCi} / \mathrm{L}$

(c) The EPA "Level of Concern" in drinking water for gross beta $(\beta)$ is $50 \mathrm{pCi} / \mathrm{L}$

(d) The EPA established MCL in drinking water for ${ }^{3} \mathrm{H}$ is $20,000 \mathrm{pCi} / \mathrm{L}$

(e) NS = not scheduled for analysis in 2006, analysis run once every 2 years, last analyzed in 2005

(f) FD = field duplicate sample

(g) NA = not analyzed in FD sample

(h) Compliance well for validation of waste pit P03U at Area 5 RWMS (see Section 9.1.6)

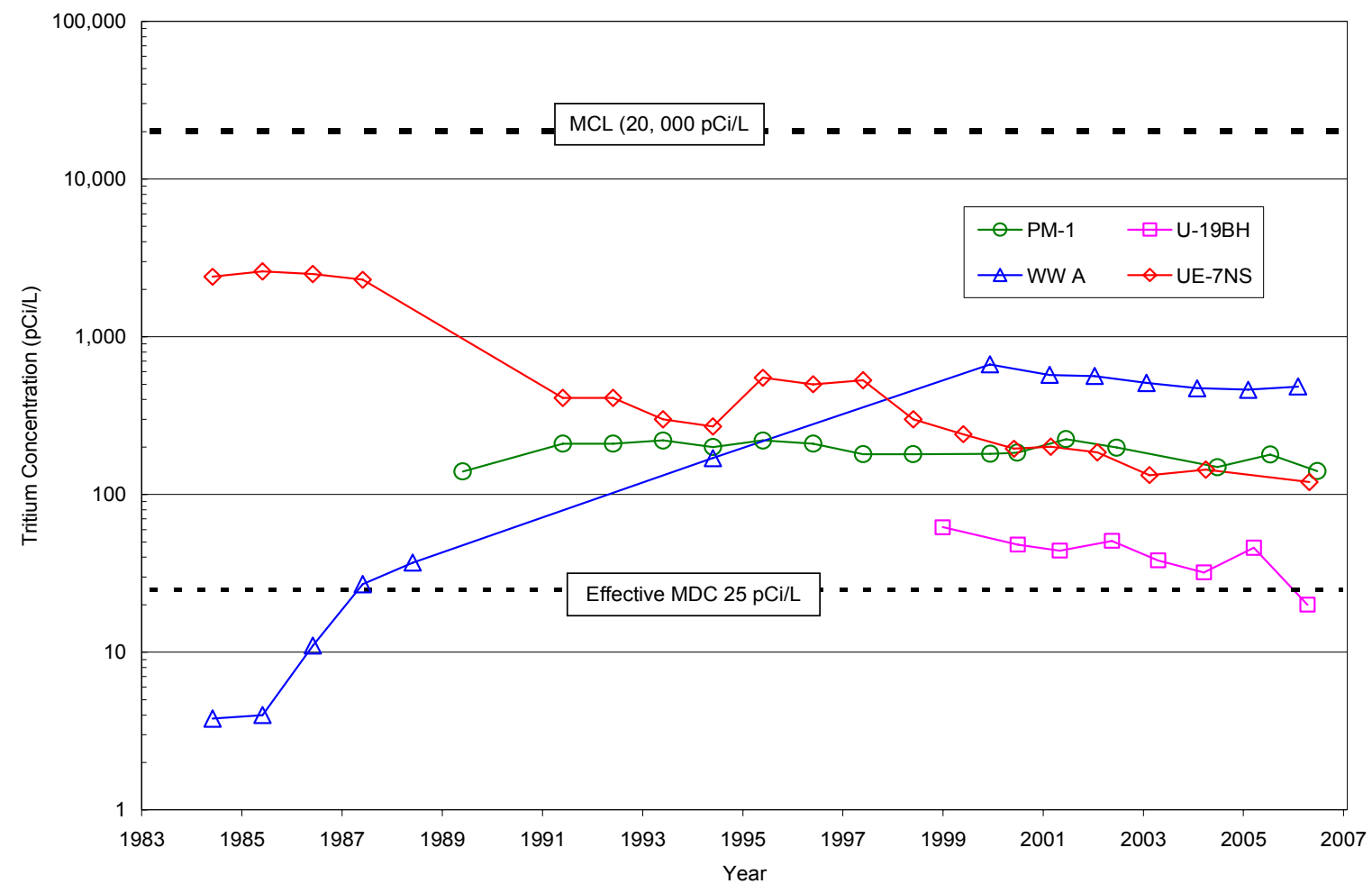

Figure 4-10. Concentrations of tritium in wells with a history of detectable levels 


\subsubsection{Results from NTS E Tunnel Ponds}

Five primary basins were constructed to collect and hold water discharged from the E Tunnels in Area 12 where nuclear testing was conducted in the past (see Figure 4-3). The water is perched groundwater that has percolated through fractures in the tunnel system. The Defense Threat Reduction Agency (DTRA) conducts monitoring of effluent waters from $\mathrm{E}$ Tunnel to determine if radionuclides and nonradiological contaminants exceed the allowable contaminant levels regulated under a state water pollution control permit (NEV 96021), which is issued to DTRA. During October 2006, a DTRA contract company sampled the tunnel effluent near where water is discharged.

During November, NSTec personnel sampled tunnel effluent, water from Pond 4, water from Pond 5, and sediment from the basin of Ponds 3, 4, and 5. Effluent water was analyzed by DTRA for tritium, gross alpha, and gross beta (Table 4-5) and for 16 nonradiological contaminants and water quality parameters (DTRA, 2006). All other samples were analyzed by NSTec for tritium (water samples only), gamma-emitting radionuclides, plutonium, ${ }^{90} \mathrm{Sr}$, and ${ }^{241} \mathrm{Am}$ (Table 4-6).

Table 4-5. Radiological results for E Tunnel Pond effluent pertaining to Water Pollution Control Permit NEV 96021

\begin{tabular}{||lcc||}
\hline Parameter & Permissible Limit $(\mathrm{pCi} / \mathrm{L})$ & Average Measured Value $(\mathrm{pCi} / \mathrm{L})$ \\
\hline Tritium & $1,000,000$ & 604,000 \\
Gross Alpha & 35 & 16.8 \\
Gross Beta & 100 & 50.8 \\
\hline \hline
\end{tabular}

Source: Water Pollution Control Permit NEV 96021 Quarterly Monitoring Report and Annual Summary Report for E Tunnel Waste Water Disposal System (DTRA, 2006)

All samples had radionuclide concentrations above their MDC (Table 4-6), with tritium being the highest. While tritium concentrations in pond water and tunnel effluent were elevated, they were about 40 percent lower than the limit allowed under permit NEV 96021 for that discharge system (Table 4-5). Tritium was found in all tunnel effluent and pond water samples at concentrations slightly lower than previous years' samples (Figure 4-11). Concentrations of ${ }^{90} \mathrm{Sr},{ }^{137} \mathrm{Cs}$, plutonium, and ${ }^{241} \mathrm{Am}$ were at levels comparable with the past four years.

Due to the elevated concentrations of radionuclides in the E Tunnel containment ponds, the ponds are fenced and posted with radiological warning signs. Given that the ponds are available to wildlife, animals are also sampled under RREMP monitoring to assess potential radiological doses to wildlife and to humans consuming game animals (see Section 7.0 and Section 8.0). 
Table 4-6. Routine radiological water monitoring results for E-Tunnel Ponds in 2006

\begin{tabular}{|c|c|c|c|c|c|c|}
\hline Sample & $\begin{array}{c}{ }^{3} \mathrm{H} \pm \text { Uncertainty } \\
\text { (MDC) }\end{array}$ & $\begin{array}{c}{ }^{90} \mathrm{Sr} \pm \text { Uncertainty } \\
\text { (MDC) }\end{array}$ & $\begin{array}{c}{ }^{137} \mathrm{Cs} \pm \\
\text { Uncertainty } \\
\text { (MDC) }\end{array}$ & $\begin{array}{c}{ }^{238} \mathbf{P u} \pm \text { Uncertainty } \\
\text { (MDC) }\end{array}$ & $\begin{array}{c}{ }^{239+240} \mathrm{Pu} \pm \text { Uncertainty } \\
\text { (MDC) }\end{array}$ & $\begin{array}{c}{ }^{241} \mathrm{Am} \pm \text { Uncertainty } \\
\text { (MDC) }\end{array}$ \\
\hline \multicolumn{7}{|c|}{ Water - Concentration units are $\mathrm{pCi} / \mathrm{L}$} \\
\hline Influent to Pond 4 & $560000 \pm 85000$ & $0.38 \pm 0.24 \quad(0.46)$ & $32 \pm 9.6 \quad(12)$ & $0.48 \pm 0.12 \quad(0.033)$ & $3.8 \pm 0.67 \quad(0.029)$ & $0.25 \pm 0.075 \quad(0.034)$ \\
\hline Pond 4 Water & $540000 \pm 83000$ & $0.38 \pm 0.24 \quad(0.45)$ & $34 \pm 7.7 \quad(7.5)$ & $0.45 \pm 0.11 \quad(0.022)$ & $3.7 \pm 0.65 \quad(0.027)$ & $0.33 \pm 0.089 \quad(0.024)$ \\
\hline Pond 5 Water & $540000 \pm 83000$ & $0.54 \pm 0.27 \quad(0.47)$ & $37 \pm 8.9 \quad(9.3)$ & $0.39 \pm 0.11 \quad(0.040)$ & $3.2 \pm 0.62 \quad(0.014)$ & $0.27 \pm 0.079 \quad(0.030)$ \\
\hline Pond 5 Water FD(b) & $550000 \pm 84000$ & $0.59 \pm 0.27 \quad(0.45)$ & $28 \pm 8.0 \quad(9.0)$ & $0.47 \pm 0.11 \quad(0.026)$ & $3.4 \pm 0.60 \quad(0.021)$ & $0.25 \pm 0.076 \quad(0.030)$ \\
\hline \multicolumn{7}{|c|}{ Sediment - Concentration units are $\mathrm{pCi} / \mathrm{g}$} \\
\hline Pond 3 Sediment & $\mathrm{NA}^{(\mathrm{c})}$ & $1.8 \pm 0.56 \quad(0.46)$ & $81 \pm 9.8 \quad(0.53)$ & $0.25 \pm 0.052(0.0065)$ & $2.8 \pm 0.47 \quad(0.0065)$ & $0.39 \pm 0.080 \quad(0.0034)$ \\
\hline Pond 4 Sediment & NA & $0.88 \pm 0.35 \quad(0.44)$ & $62 \pm 7.4 \quad(0.33)$ & $0.31 \pm 0.062(0.0026)$ & $1.8 \pm 0.31 \quad(0.0026)$ & $0.28 \pm 0.061 \quad(0.011)$ \\
\hline Pond 4 Sediment FD & NA & $0.84 \pm 0.36 \quad(0.50)$ & $93 \pm 11 \quad(0.38)$ & $0.20 \pm 0.042(0.0075)$ & $1.6 \pm 0.27 \quad(0.0025)$ & $0.14 \pm 0.033$ \\
\hline Pond 5 Sediment & NA & $0.11 \pm 0.22$ & $26 \pm 3.3 \quad(0.37)$ & $0.067 \pm 0.020$ & $0.46 \pm 0.086(0.0026)$ & $0.053 \pm 0.018 \quad(0.0091)$ \\
\hline
\end{tabular}

Green shaded results are considered detected (results greater than the sample-specific MDC)

(a) \pm 2 standard deviations

(b) FD = Field duplicate

(c) Not applicable: tritium is not measured in samples which do not contain water 


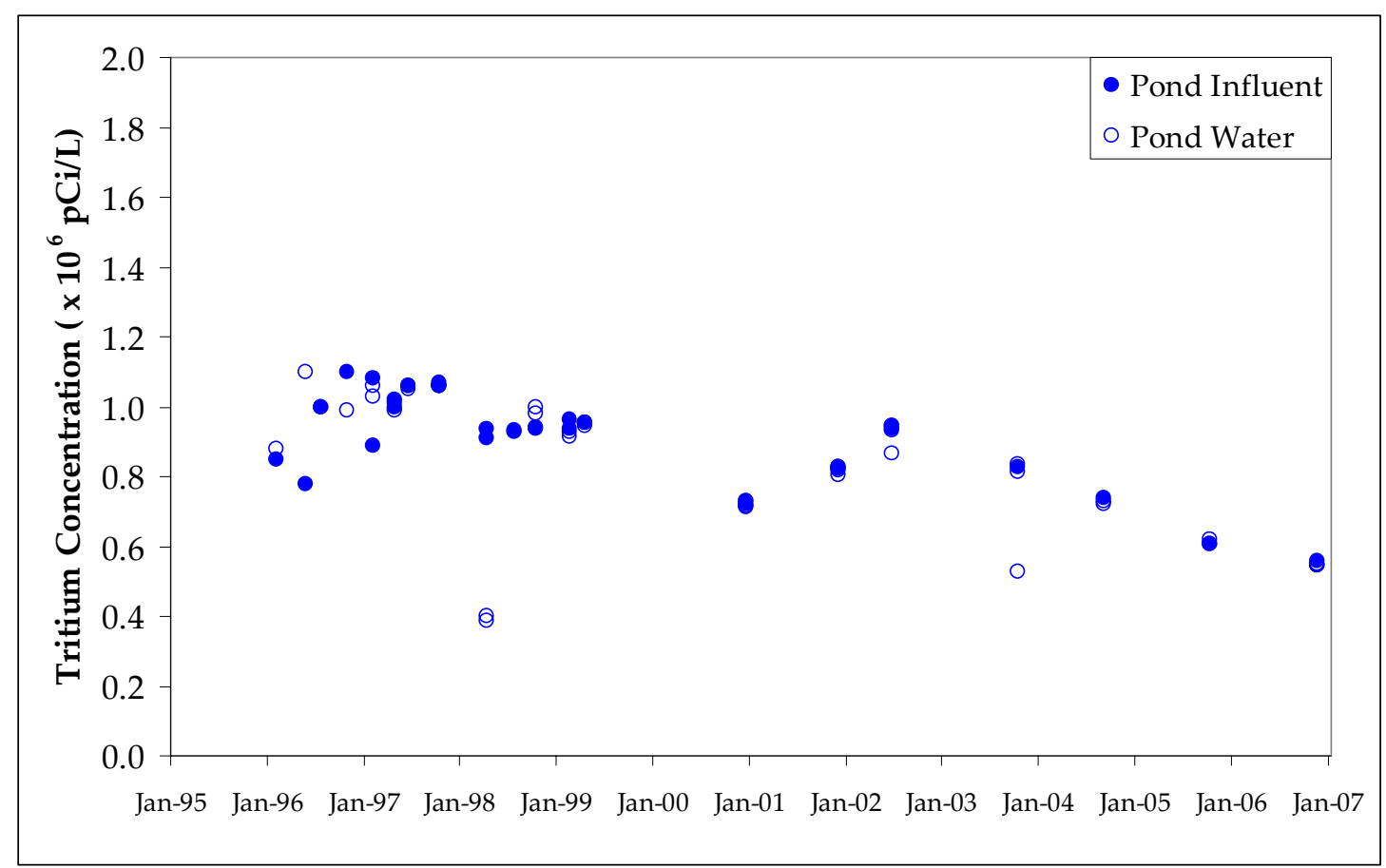

Figure 4-11. Tritium concentration in E Tunnel Ponds from 1995 to 2006

\subsubsection{Results from NTS Sewage Lagoons}

Each sewage lagoon at the NTS is part of a closed system used for the evaporative treatment of sanitary sewage. Sewage storage and treatment at the NTS has transitioned from lagoons to septic systems at several locations in recent years. Two permitted sewage lagoons remain: Area 6 Yucca and Area 23 Mercury (A23) (see Figure 4-3). The permits for these lagoons do not require that the water or sediments be monitored for radioactivity (see Section 4.2.3). However, to more completely demonstrate the proper management of effluents on the NTS, limited radiological analyses are conducted for these lagoons under the RREMP (DOE, 2003b).

The lagoon water samples were analyzed for tritium using standard (un-enriched) analyses and by gamma spectroscopy for other radionuclides. No tritium was detected at concentrations above MDCs in the lagoon water samples (Table 4-7) and no man-made gamma-emitting radionuclides were detected.

Table 4-7. Tritium water monitoring results for NTS sewage lagoons in 2006

\begin{tabular}{||ccrccc||}
\hline \multirow{2}{*}{ Monitoring Location } & \multicolumn{4}{c||}{${ }^{3} \mathbf{H} \pm$ Uncertainty ${ }^{(\mathbf{a})}$ (MDC) } \\
(pCi/L) \\
\hline Area 23 Mercury & Date Sampled & 89.3 & \pm 118 & $(194)$ \\
& $01 / 25 / 2006$ & 64.1 & \pm & 131 & $(218)$ \\
& $04 / 11 / 2006$ & -27.8 & \pm & 121 & $(210)$ \\
Area 6 Yucca & $07 / 18 / 2006$ & 61.2 & \pm & 111 & $(185)$ \\
& $10 / 11 / 2006$ & 94.8 & \pm & 120 & $(198)$ \\
& $01 / 25 / 2006$ & -50.8 & \pm & 125 & $(219)$ \\
& $04 / 11 / 2006$ & 42 & \pm & 126 & $(212)$ \\
& $07 / 18 / 2006$ & 74.7 & \pm & 111 & $(184)$ \\
\hline
\end{tabular}

(a) \pm 2 standard deviations 


\subsubsection{UGTA Wells}

In 2006, the UGTA Project deepened the ER-16-1 Rainier Mesa/Shoshone Mountain investigation well and completed the well as a water level measurement well. No groundwater samples were collected from this well.

The UGTA Project installed pumps and collected groundwater samples from wells ER-12-4, U-12s, and WW 2 (USGS HTH \#2) (Figure 4-12). The first two wells were in Area 12 (Rainier Mesa) and the third in Area 2 (Yucca Flat). These three wells were purged using downhole electric submersible pumps prior to the collection of samples. A multi-agency team consisting of personnel from Stoller-Navarro Joint Venture (SNJV), Los Alamos National Laboratory (LANL), DRI, and LLNL collected groundwater samples from these three wells. During purging and sampling, water temperature, $\mathrm{pH}$, and conductivity were measured. Samples were then analyzed for selected radionuclides as well as gross alpha and gross beta. Groundwater data are maintained in the UGTA Project geochemical database by SNJV, Las Vegas, Nevada. These three wells are classified as not contaminated, and groundwater from them was pumped into unlined sumps or discharged to the ground surface. The tritium concentration of groundwater samples from the three wells were all below the detection limit (Table 4-8). Gross alpha and beta radioactivity were detected in most samples at levels just above detection limits. No man-made radionuclides were detected in the wells.

There were no post-shot or near-cavity wells sampled by UGTA during 2006.

Table 4-8. Radiochemistry analysis results from UGTA well samples analyzed in 2006

\begin{tabular}{|c|c|c|c|c|}
\hline UGTA Well & $\begin{array}{c}\text { Date } \\
\text { Sampled }\end{array}$ & $\begin{array}{c}{ }^{3} \mathrm{H} \pm \mathrm{ERR}^{(\mathrm{a})}(\mathrm{DL})^{(\mathrm{b})} \\
\mathrm{pCi} / \mathrm{L}\end{array}$ & $\begin{array}{c}\text { Gross Alpha } \pm \text { ERR (DL) } \\
\text { pCi/L }\end{array}$ & $\begin{array}{c}\text { Gross Beta } \pm \text { ERR (DL) } \\
\mathrm{pCi} / \mathrm{L}\end{array}$ \\
\hline ER-12-4 & $4 / 25 / 2006$ & $20 \pm 210$ & $0.58 \pm 0.35(0.53)$ & $4.6 \pm 1(1.1)$ \\
\hline ER-12-4 FD(c) & $4 / 25 / 2006$ & $-70 \pm 180$ & $0.18 \pm 0.33(0.6)$ & $3.86 \pm 0.94(1.11)$ \\
\hline U-12s & $8 / 22 / 2006$ & $20 \pm 200$ & $1.9 \pm 1(1.5)$ & $5.5 \pm 1.7(2.7)$ \\
\hline U-12s FD & $8 / 22 / 2006$ & $-80 \pm 190$ & $2.9 \pm 1.1$ & $5.4 \pm 1.7$ (2.6) \\
\hline WW 2 & 9/7/2006 & $-90 \pm 190$ & $1.8 \pm 1(1.2)$ & $6.7 \pm 2(2.3)$ \\
\hline WW-2 FD & 9/7/2006 & $-130 \pm 190$ & $1.4 \pm 1$ & $6.9 \pm 2.1(2.3)$ \\
\hline
\end{tabular}

(a) ERR $=$ the range of error in the measurement based on the reported value, taking into account the Instrument Detection Limit (IDL) (see Glossary, Appendix B)

(b) $\mathrm{DL}=$ sample detection limit reported by laboratory

(c) FD = Field duplicate

\subsubsection{Environmental Impact}

The 2006 tritium data provide no evidence that radionuclides have traveled significant distances from underground testing areas or to offsite water supply wells or springs. None of the offsite springs, the private offsite water supply wells, or the 10 offsite NNSA/NSO monitoring wells sampled had levels of tritium consistently above MDCs.

Even on the NTS, groundwater monitoring results indicate that migration of radionuclides from the underground test areas is not significant. Groundwater from four monitoring wells on the NTS is known to consistently have tritium at levels above detection, and they are each within $1 \mathrm{~km}(0.6 \mathrm{mi})$ of an historical underground nuclear test. They have the highest levels of tritium of all wells monitored under the RREMP program. Their concentrations of tritium are still less than 3 percent of the EPA MCL for drinking water of $20,000 \mathrm{pCi} / \mathrm{L}$, and no trend of rising tritium concentrations in these wells have been observed since 2000.

The radiological impact to water resources from current and past activities on the NTS is groundwater contamination from man-made radionuclides within the UGTA Project CAUs shown in Figure 4-1. The current NTS activity of containing tritium-contaminated waters in lined sumps (as for the UGTA Project post-shot wells) and in the E Tunnel ponds exposes NTS wildlife to tritium in their drinking water or aquatic habitat. The effect on wildlife to this radiological exposure is addressed in Section 8.2 of this report and in previous annual environmental reports (DOE, 2004c; 2005a). 


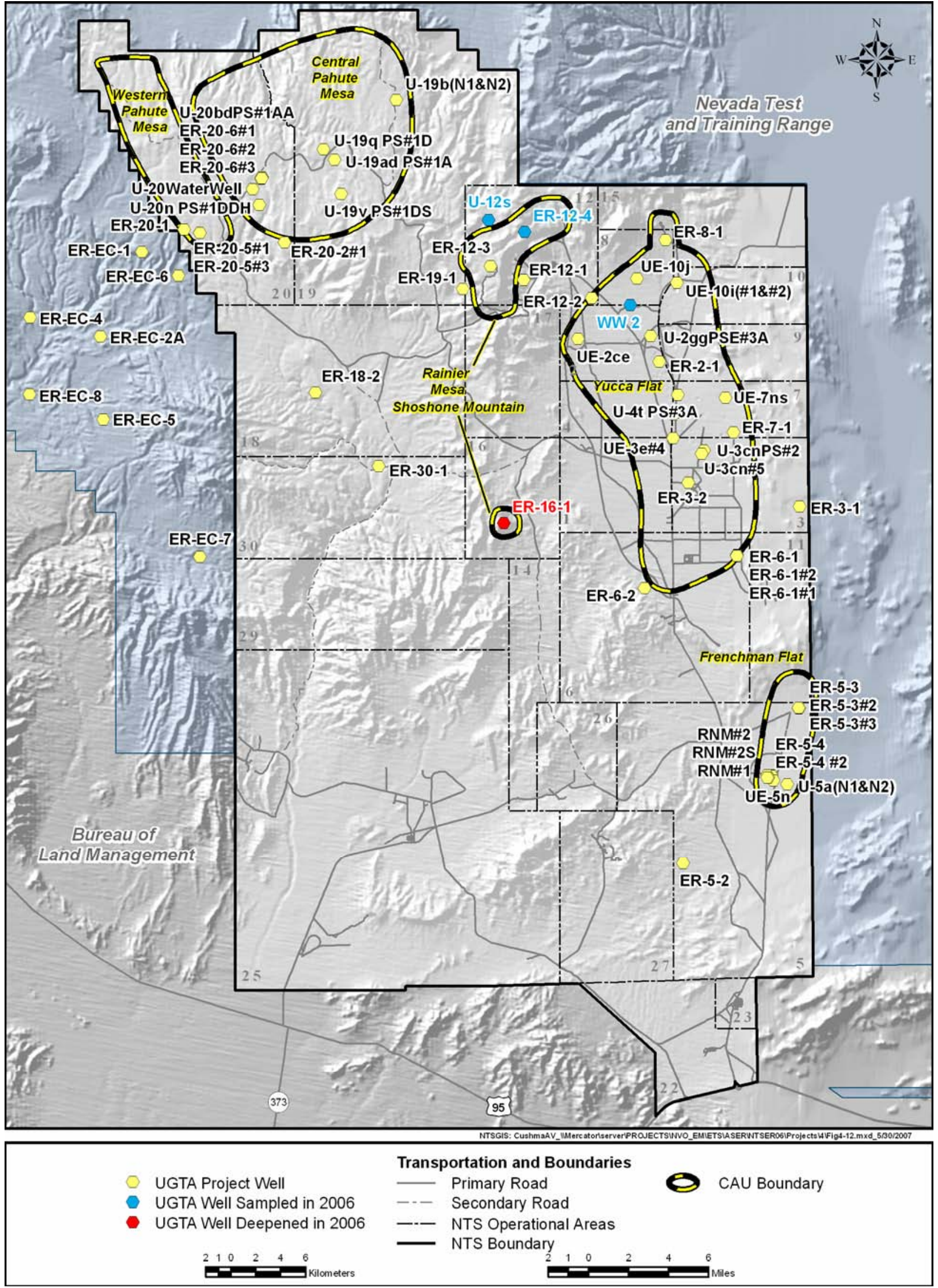

Figure 4-12. UGTA Project wells on and off the NTS 


\subsection{Nonradiological Drinking Water and Wastewater Monitoring}

The quality of drinking water and wastewater on the NTS is regulated by federal and state laws. The design, construction, operation, and maintenance of many of the drinking water and wastewater systems are regulated under state permits. BN, and then NSTec was tasked with ensuring that such systems meet the applicable water quality standards and permit requirements (see Section 2.2). The NTS nonradiological water monitoring goals are shown below. BN/NSTec ES personnel met these goals by conducting field water sampling and analyses, performing assessments, and maintaining documentation. The major compliance measures/actions that ES personnel monitor/performed on the NTS are also shown below. This section describes the results of 2006 monitoring. Radiological monitoring of drinking water on and off the NTS is presented in the preceding Sections 4.1.4 and 4.1.6.

\begin{tabular}{||l||l||}
\hline \multicolumn{1}{|c|}{ Nonradiological Water Monitoring Goals } & \multicolumn{1}{c||}{ Compliance Measures/Actions } \\
\hline $\begin{array}{l}\text { Ensure that the operation of NTS public water systems } \\
\text { (PWSs) and private water systems provide high-quality } \\
\text { drinking water to workers and visitors of the NTS. }\end{array}$ & $\begin{array}{l}\text { Number of PWS samples containing coliform } \\
\text { bacteria }\end{array}$ \\
$\begin{array}{l}\text { Determine if NTS PWS are operated in accordance with the } \\
\text { requirements in Nevada Administrative Code (NAC) 445A } \\
\text { under permits issued by the state. }\end{array}$ & $\begin{array}{l}\text { Concentration of inorganic contaminants and } \\
\text { inorganic Phase II contaminants in PWS samples }\end{array}$ \\
$\begin{array}{l}\text { Determine if the operation of commercial septic systems to } \\
\text { process domestic wastewater on the NTS meets operational } \\
\text { standards in accordance with the requirements NAC 445A } \\
\text { under permits issued by the state. } \\
\begin{array}{l}\text { Determine if the operation of industrial wastewater systems } \\
\text { on the NTS meets operational standards of federal and state } \\
\text { regulations as prescribed under the GNEV93001 state permit. }\end{array}\end{array}$ & $\begin{array}{l}\text { (BODs), total suspended solids (TSS), and pH in } \\
\text { sewage lagoon water }\end{array}$ \\
\hline
\end{tabular}

\subsubsection{Drinking Water Monitoring}

Six permitted wells supply the potable water needs of NTS operations (Figure 4-13); these are grouped into three PWSs (Figure 4-13) that were operated by BN and then NSTec in 2006. The PWSs are operated in accordance with the requirements in NAC 445A under permits issued by the BHPS, which are renewed annually. Two BHPSpermitted tanker trucks are also used to haul potable water from permitted wells to private NTS water systems and remote work sites. As mentioned in the 2005 NTS Environmental Report, to adhere to new, lower allowable drinking water concentrations for arsenic, the Army \#1 WW and WW 5C wells were taken off the Area 23 and 6 PWS (NV0000360) in 2005. WW C-1 was taken off the same PWS due to elevated total dissolved solids and the water's hardness. The permit for the Area 23 and 6 PWS was revised in 2006 upon BHPS's approval of water project completion reports documenting deactivation of the wells. Army \#1 WW, WW 5C, and WW C-1 wells were all officially taken off the permit for the Area 23 and 6 PWS in 2006.

\subsubsection{Water Quality of PWS and Permitted Water-Hauling Trucks}

The three PWS must meet water quality standards for National Primary and Secondary Drinking Water Standards. The PWS must also meet other standards and conditions listed in the regulations relating to design, operation, and maintenance. For work locations at the NTS that are not part of a public water system, NNSA/NSO hauls potable water for use in decontamination and sanitation. The NTS uses two water tanker trucks which are permitted by the BHPS to haul water to a public water system. Normal use of these trucks involves hauling to private water systems and to hand-washing stations at construction sites, activities which are not subject to permitting. NNSA/NSO, however, retains the permits in case of emergency. These permits are also renewed annually. 


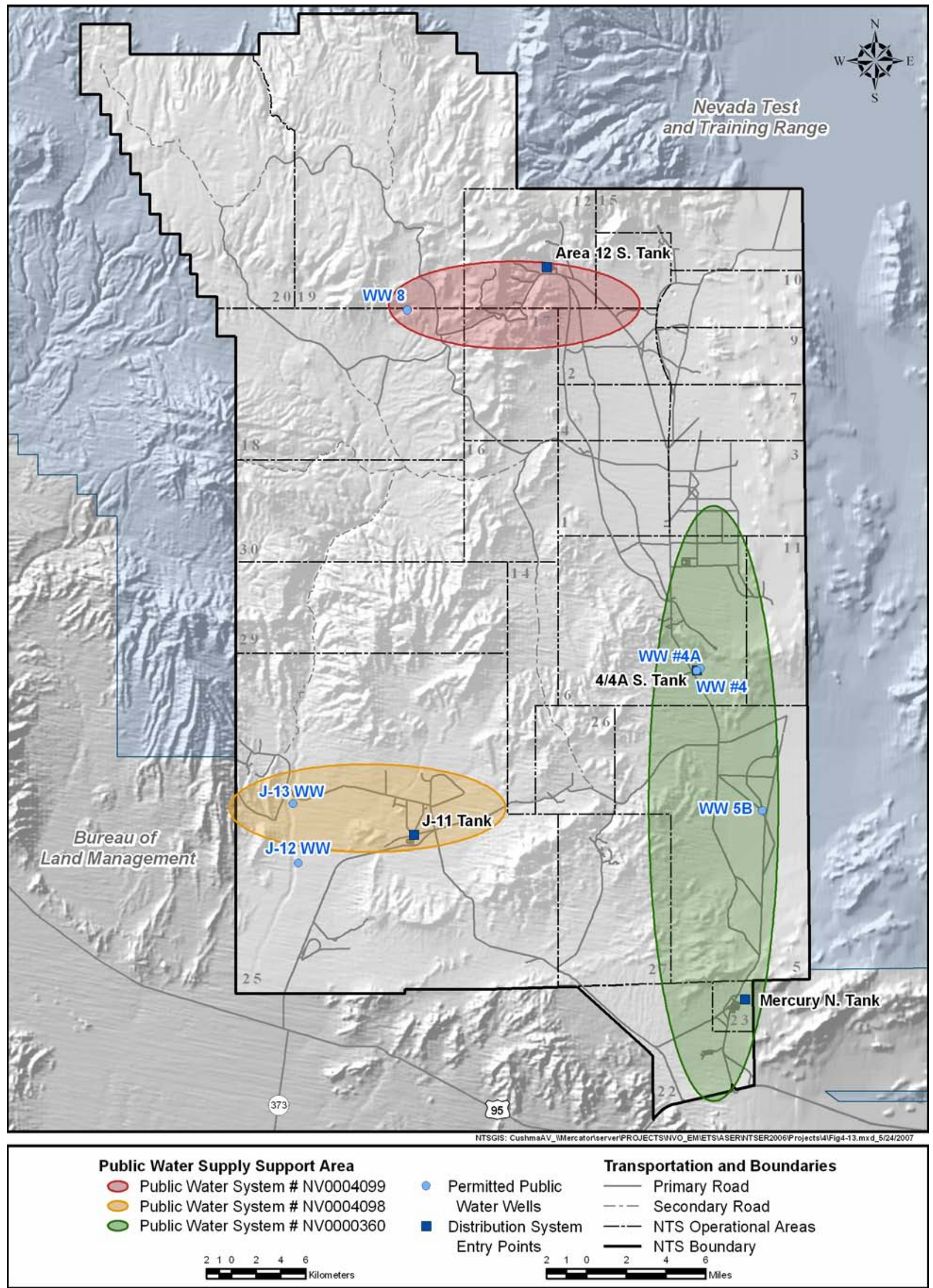

Figure 4-13. Drinking water systems on the NTS 
The two permitted potable water-hauling trucks are subject to water quality standards for coliform bacteria. Table 4-9 lists the water quality parameters monitored in 2006, sample frequencies, and sample locations. The largest PWS (Area 23 and 6) serves the main work areas of the NTS. It was monitored monthly for coliform bacteria at nine locations approved by the BHPS within the distribution systems. The two smaller systems (Area 12 and Area 25) were monitored quarterly for coliform bacteria. At all building locations, the sampling point for coliform bacteria is one of the sinks within one of the building's bathrooms. Monitoring for other contaminants took place at the four points of entry to the PWSs. Although not required by regulation or permit, the private water systems were monitored quarterly for coliform bacteria to ensure safe drinking water. All potable water-hauling trucks were monitored monthly for coliform bacteria.

All water samples were collected in accordance with accepted practices and the analyses were performed by state-approved laboratories. Approved analytical methods listed in NAC 445A and Title 40 Code of Federal Regulations (CFR) 141 were used by the laboratories.

Table 4-9. Water quality monitoring parameters and sampling design for NTS public drinking water systems

\begin{tabular}{|c|c|c|c|}
\hline PWS & Contaminant & $\begin{array}{c}2006 \text { Monitoring } \\
\text { Requirement }\end{array}$ & Monitoring Locations \\
\hline \multirow[t]{2}{*}{ Area 23 and 6} & Coliform Bacteria & $\begin{array}{l}36 \text { samples ( } 3 \text { buildings per } \\
\text { month and } 4 \text { samples per } \\
\text { building) }\end{array}$ & $\begin{array}{l}\text { Buildings 5-7, U1H restroom, 6-609, } \\
\text { 6-900, 22-1, 23-180, 23-701, 23-777, } \\
23-1103\end{array}$ \\
\hline & $\begin{array}{l}\text { Nitrate and Nitrite (an } \\
\text { Inorganic Phase II Chemical) }\end{array}$ & $\begin{array}{l}2 \text { samples (1 per entry point } \\
\text { per year) }\end{array}$ & $\frac{\text { Two entry points: }}{\text { Mercury N. Tank }}$ \\
\hline \multirow[t]{3}{*}{ Area 12} & Coliform Bacteria & 4 samples ( 1 per quarter) & Building 12-45 \\
\hline & $\begin{array}{l}\text { Nitrate and Nitrite (an } \\
\text { Inorganic Phase II Chemical) }\end{array}$ & $\begin{array}{l}1 \text { sample ( } 1 \text { per entry point } \\
\text { per year) }\end{array}$ & One entry point: Area 12 S. Tank \\
\hline & $\begin{array}{l}\text { Lead (an Inorganic } \\
\text { Contaminant) }\end{array}$ & $\begin{array}{l}5 \text { samples ( } 1 \text { per building } \\
\text { per year) }\end{array}$ & $\begin{array}{l}\text { Buildings: } 12-31,12-34,12-35,12-910 \text {, } \\
12-928\end{array}$ \\
\hline \multirow[t]{2}{*}{ Area 25} & Coliform Bacteria & 4 samples ( 1 per quarter) & Building 25-4320 \\
\hline & $\begin{array}{l}\text { Nitrate and Nitrite (an } \\
\text { Inorganic Phase II Chemical) }\end{array}$ & $\begin{array}{l}1 \text { sample ( } 1 \text { per entry point } \\
\text { per year) }\end{array}$ & One entry point: J-11 Tank \\
\hline \multicolumn{4}{|l|}{ Truck } \\
\hline $\begin{array}{l}\text { Water-Hauling } \\
\text { Truck } 84846\end{array}$ & Coliform Bacteria & 12 samples (1 per month) & $\begin{array}{l}\text { From water tank on truck after filling at } \\
\text { Area } 6 \text { potable water fill stand }\end{array}$ \\
\hline $\begin{array}{l}\text { Water-Hauling } \\
\text { Truck } 84847\end{array}$ & Coliform Bacteria & 12 samples (1 per month) & $\begin{array}{l}\text { From water tank on truck after filling at } \\
\text { Area } 6 \text { potable water fill stand }\end{array}$ \\
\hline
\end{tabular}

In 2006, monitoring results (Table 4-10) indicated that the PWS and the permitted water-hauling trucks complied with National Primary Drinking Water Quality Standards with one exception. The Area 12 water system (PWS NV0004099) exceeded the action level for lead in the samples collected in April 2006. The high level is attributed to the camp's inactivity and resultant lack of flushing within the service lines. Based on the information NSTec provided to NDEP concerning use of the water system, BHPS granted NSTec approval in September 2006 to reclassify this PWS to a non-community transient system, and monitoring of the system's water quality has been reduced to coliform sampling only. 
Table 4-10. Water quality analysis results for NTS public drinking water systems in 2006

\begin{tabular}{|c|c|c|c|c|}
\hline \multirow[b]{2}{*}{ Contaminant } & \multirow[b]{2}{*}{$\begin{array}{c}\text { Maximum } \\
\text { Contaminant } \\
\text { Level }(\mathrm{mg} / \mathrm{L})\end{array}$} & \multicolumn{3}{|c|}{ Results (mg/L) } \\
\hline & & Area 23 and 6 PWS & $\begin{array}{l}\text { Area } 12 \\
\text { PWS }\end{array}$ & $\begin{array}{c}\text { Area } 25 \\
\text { PWS }\end{array}$ \\
\hline Coliform Bacteria (a) & $\begin{array}{l}\text { Coliforms present } \\
\text { in } 1 \text { sample/month }\end{array}$ & $\begin{array}{l}\text { Present in } 1 \text { sample } \\
\text { from Building 22-1 in } \\
\text { October; present in } 1 \\
\text { sample from Building } \\
\text { 6-900 in November }\end{array}$ & $\begin{array}{l}\text { Absent in all } \\
\text { samples }\end{array}$ & $\begin{array}{l}\text { Absent in all } \\
\text { samples }\end{array}$ \\
\hline \multicolumn{5}{|c|}{ Inorganic Chemicals - Phase II } \\
\hline Fluoride & 2.0 & $\mathrm{NA}^{(\mathrm{c})}$ & NA & 1.9 \\
\hline Nitrate & $10($ as N) & $3.4-3.8$ & 1.1 & 2.3 \\
\hline Nitrite & $1($ as $N)$ & $\mathrm{ND}^{(\mathrm{d})}-0.070$ & NA & 0.20 \\
\hline \multicolumn{5}{|l|}{ Inorganic Chemicals } \\
\hline Lead & 0.015 & NA & $0.037^{(\mathrm{e})}$ & NA \\
\hline
\end{tabular}

Yellow shading indicates a water quality measure that exceeded maximum contaminant levels

(a) Coliform bacteria were not present in any samples collected from Water-Hauling Trucks 84846 and 84847 nor from the following private water systems: Joint Actinide Shock Physics Experimental Research (JASPER) Compound, U3ah/at Complex, Area 6 Weather Station, and G Tunnel Office.

(c) $\mathrm{NA}=$ Not applicable

(d) $\mathrm{ND}=$ Not detectable

(e) 90 th percentile of 5 samples (1 sample/building)

\subsubsection{Sanitary Survey of PWS and Inspection of Permitted Water-Hauling Trucks}

The BHPS conducts a periodic sanitary survey of the permitted PWS. A sanitary survey consists of an inspection of the wells, tanks, and other visible portions of the PWS to ensure that they are maintained in a sanitary configuration. As non-community water systems, the minimum survey frequency for a sanitary survey is five years. The BHPS has been performing the survey more frequently, however. The BHPS inspects the two water-hauling trucks annually at the time of permit renewal to make sure they still meet the requirements of NAC 445A.

The BHPS conducted a sanitary survey of the PWS in 2006. No significant deficiencies were noted, and corrections of nonsignificant deficiencies are in progress. BHPS conducted an annual inspection of the permitted water-hauling trucks in 2006; no findings were noted.

\subsubsection{Domestic Wastewater Monitoring}

To obtain a permit for a proposed new NTS septic system, an assessment is conducted to ensure that the sources producing discharges are domestic in nature. NSTec and the state of Nevada conduct this assessment. After the design of a new system is completed, a permit package is submitted through NNSA/NSO to the state. Subsequent to state approval, a "permit to construct" is issued. After construction, the state conducts a final inspection. Upon approval, the state issues a "permit to operate."

Existing septic systems that are not permitted may be permitted by submitting a narrative describing facility operations, flow test results, tank and leach field sizing, engineering drawings, personnel numbers, existing flow (volume) information, and a fixture count. The application is reviewed by the state and an onsite inspection is conducted by BHPS. Approval results in the issuance of a "permit to operate." 
There are seven active septic systems being used in place of inactive lagoons on the NTS (Figure 4-14). These are inspected periodically for sediment loading and are pumped as required. A state-permitted septic pumping contractor is used. The state conducts onsite inspections of pumper trucks and pumping contractor operations.

ES personnel perform management assessments of permitted facilities and services to determine and document adherence to permit conditions. The assessments are performed according to existing directives and procedures.

In 2006, the following compliance actions relating to domestic wastewater on the NTS occurred:

- One new septic system was permitted at the NTS. This system was for the Area 6 Radiological/Nuclear Countermeasures Test and Evaluation Complex (Permit NY-1124).

- A septic system design was initiated and approved for Area 6 Criticality Experiments Facility. Construction should be completed in 2007.

- A septic tank pumping contractor permit (NY-17-03318), septic tank pump truck permits (NY-17-03313, NY-17-03315, NY-17-03317, NY-17-06838), and a septic tanker permit (NY-17-06839) were approved by the state and renewed in July 2006.

\subsubsection{Industrial Wastewater Monitoring}

Industrial discharges on the NTS were limited to two operating sewage lagoon systems in 2005: Area 6 Yucca Lake and Area 23 Mercury (these lagoon systems also receive domestic wastewater) (Figure 4-14). The Area 6 Yucca Lake system consists of two primary lagoons and two secondary lagoons. All lagoons in this system are lined using compacted native soils that meet the state of Nevada requirements for transmissivity $\left(10^{-7}\right.$ centimeters per second).

The Area 23 Mercury system consists of one primary lagoon, a secondary lagoon, and an infiltration basin. In 2006, a project was completed that lined the secondary lagoon using a geosynthetic clay liner and a high-density polyethylene liner. Water Pollution Control General Permit GNEV93001 will be reissued, and the new permit will have reduced monitoring requirements starting in 2007.

Both sewage systems are monitored quarterly for influent quality and annually for influent toxicity. The locations where water samples were collected for analysis within each sewage system include:

- Each influent headwork for systems where there is direct access to influent flows

- Each pond near the lagoon's inlet for systems where there is no direct access to influent flows

- Each infiltration basin at a place where a sample most closely representing the infiltrating waste water can be collected

Composite samples were collected over a period of 8 hours at the Area 6 Yucca Lake and Area 23 Mercury systems. All water samples were collected in accordance with accepted practices, and the analyses were performed by state-approved laboratories. Approved analytical methods listed in NAC 445A and Title 40 CFR 141 were used by the laboratories.

\subsubsection{Quarterly Analysis of Influent Water Quality}

A composite sample from each influent headwork was collected quarterly. The composite sample was analyzed for three parameters: $\mathrm{BOD}_{5}$, TSS, and $\mathrm{pH}$ (Table 4-11). The compliance limits for these parameters, established under Water Pollution Control General Permit GNEV93001, are shown in Table 4-11. All quarterly monitoring results for $\mathrm{BOD}_{5}$, TSS, and $\mathrm{pH}$ for sewage system influent waters were within permit limits in 2006 with one exception. One $\mathrm{BOD}_{5}$ Mean Daily Load was exceeded at the Area 23 Mercury Sewage lagoons in the second quarter. The weekly inspection reports were examined and there were no problems observed with respect to odor or color, and no septic conditions were observed. The Area 23 Mercury Lagoon was resampled in the second quarter for $\mathrm{BOD}_{5}$. These results showed that the lagoons were once again in compliance and no other action was taken by NSTec nor requested by the state of Nevada. 


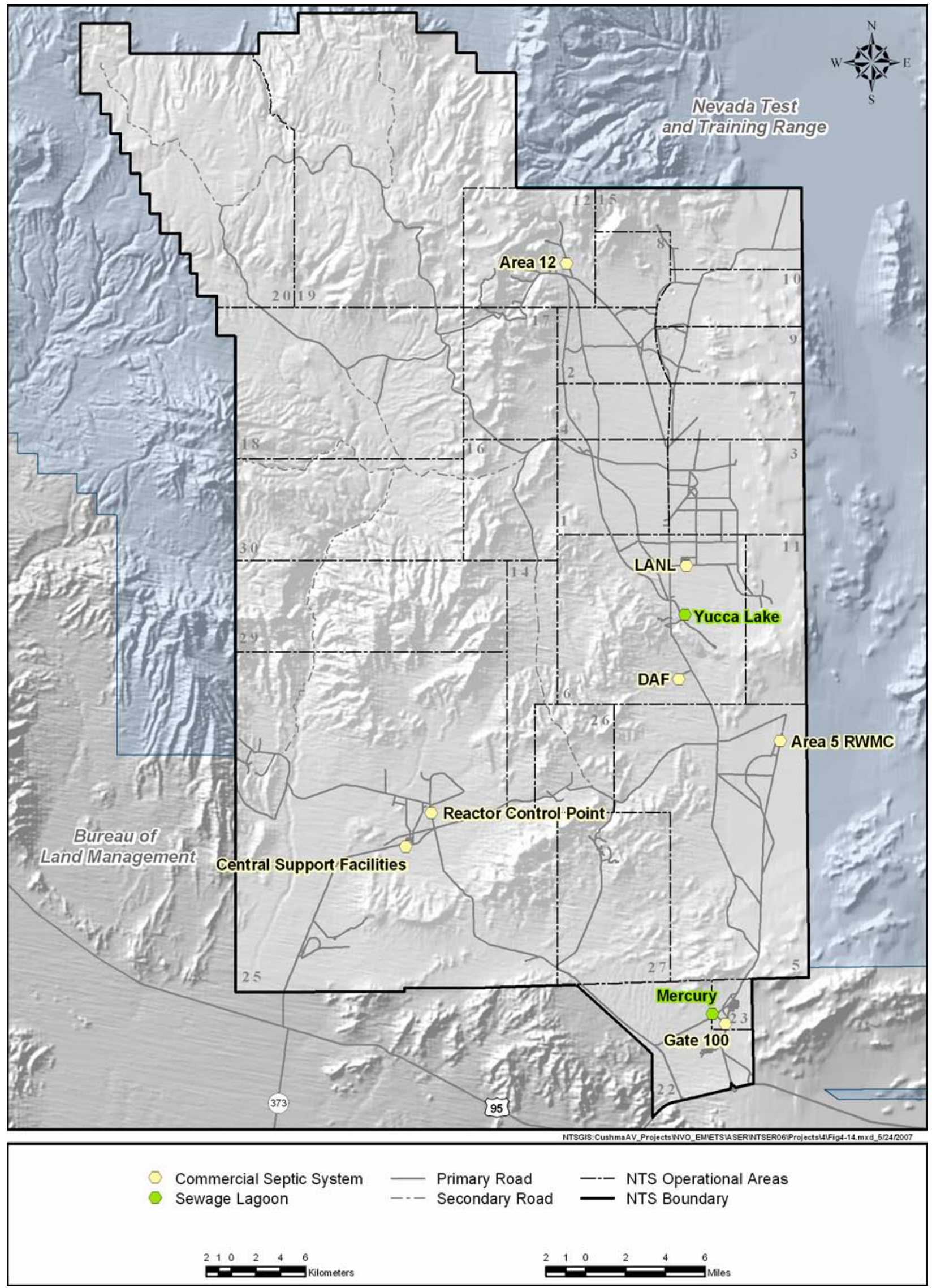

Figure 4-14. Active permitted sewage disposal systems on the NTS 
Table 4-11. Water quality analysis results for NTS sewage lagoon influent waters in 2006

\begin{tabular}{||lccc||}
\hline & & \multicolumn{2}{c||}{ Minimum and Maximum Values from Quarterly Samples } \\
\cline { 3 - 4 } Parameter & Units & Area 6 Yucca Lake & Area 23 Mercury \\
\hline BOD5 & $\mathrm{mg} / \mathrm{L}$ & $120.0-200$ & $45.0-300$ \\
BOD5 Permit Limit & & No Limit & No Limit \\
BOD5 Mean Daily Load (a) & $\mathrm{kg} / \mathrm{d}$ & $3.67-7.34$ & $7.26-42.2$ \\
BOD5 Mean Daily Load Limit & & 8.66 & 37.5 \\
TSS & $\mathrm{mg} / \mathrm{L}$ & $65.4-137$ & $76.3-200.0$ \\
TSS Permit Limit & & No Limit & No Limit \\
pH & S.U. (b) & $8.21-8.60$ & $7.64-8.29$ \\
pH Permit Limit & & $6.0-9.0$ & $6.0-9.0$ \\
\hline \hline
\end{tabular}

(a) $\mathrm{BOD}_{5}$ Mean Daily Load in kilograms per day $(\mathrm{kg} / \mathrm{d})=(\mathrm{mg} / \mathrm{L}$ BOD $\times$ liters per day $(\mathrm{L} / \mathrm{d})$ average flow $\times 3.785) / 10^{6}$

(b) Standard units of $\mathrm{pH}$

\subsubsection{Annual Analysis of Toxicity of Sewage Lagoon Pond Waters}

A grab sample from the Area 23 Mercury primary lagoon and an equal-volume composite sample from the two Area 6 Yucca Lake primary lagoons were collected in July.

Each grab and composite sample was filtered, the solids discarded, and the filtrate analyzed directly, using methods of analysis cited in EPA Publication SW-846. Each sample was analyzed for those contaminants listed in Table 4-12. The limits for these contaminants are also specified under state permit; they are the same limits specified in 40 CFR 261.24, Table 1, Maximum Concentration of Contaminants for the Toxicity Characteristic. Annual monitoring of Area 6 Yucca Lake and Area 23 Mercury sewage lagoon waters adjacent to lagoon inlets showed that no contaminants exceeded permit limits (Table 4-12).

Table 4-12. Water toxicity analysis results for NTS sewage lagoon pond water in 2006

\begin{tabular}{|c|c|c|c|}
\hline Contaminant $\mathrm{t}^{(\mathrm{a})}$ & $\operatorname{Limit}^{(b)}(\mathrm{mg} / \mathrm{L})$ & $\begin{array}{c}\text { Area } 6 \text { Yucca } \\
(\mathrm{mg} / \mathrm{L})\end{array}$ & $\begin{array}{c}\text { Area } 23 \text { Mercury } \\
(\mathrm{mg} / \mathrm{L})\end{array}$ \\
\hline Benzene & 0.5 & $<0.005$ & $<0.005$ \\
\hline Carbon Tetrachloride & 0.5 & $<0.005$ & $<0.005$ \\
\hline Chlorobenzene & 100 & $<0.005$ & $<0.005$ \\
\hline Chloroform & 6.0 & $<0.005$ & $<0.005$ \\
\hline Cresol (Total) & 200 & $<0.010$ & $<0.010$ \\
\hline $2,4-\mathrm{D}$ & 10 & $<0.010$ & $<0.010$ \\
\hline 1,4-Dichlorobenzene & 7.5 & $<0.010$ & $<0.010$ \\
\hline 1,2-Dichloroethane & 0.5 & $<0.005$ & $<0.005$ \\
\hline 1,1-Dichlorethylene & 0.7 & $<0.005$ & $<0.005$ \\
\hline 2,4-Dinitrotoluene & 0.13 & $<0.010$ & $<0.010$ \\
\hline Hexachlorobenzene & 0.13 & $<0.010$ & $<0.010$ \\
\hline Hexachlorobutadiene & 0.5 & $<0.010$ & $<0.010$ \\
\hline Hexachloroethane & 3.0 & $<0.010$ & $<0.010$ \\
\hline Methylethyl Ketone & 200 & $<0.010$ & $<0.010$ \\
\hline Nitrobenzene & 2.0 & $<0.010$ & $<0.010$ \\
\hline Pentachlorophenol & 100 & $<0.025$ & $<0.025$ \\
\hline Pyridine & 5.0 & $<0.010$ & $<0.010$ \\
\hline Trichloroethylene & 0.5 & $<0.005$ & $<0.005$ \\
\hline 2,4,5-Trichlorophenol & 400 & $<0.025$ & $<0.025$ \\
\hline 2,4,6-Trichlorophenol & 2.0 & $<0.010$ & $<0.010$ \\
\hline Vinyl Chloride & 0.2 & $<0.010$ & $<0.010$ \\
\hline Arsenic & 5.0 & 0.0099 & 0.0075 \\
\hline Barium & 100 & 0.0284 & 0.0246 \\
\hline
\end{tabular}


Table 4-12. Water toxicity analysis results for NTS sewage lagoon pond water in 2006 (continued)

\begin{tabular}{|c|c|c|c|}
\hline Contaminant ${ }^{(a)}$ & $\operatorname{Limit}^{(b)}(\mathrm{mg} / \mathrm{L})$ & $\begin{array}{c}\text { Area } 6 \text { Yucca } \\
(\mathrm{mg} / \mathrm{L})\end{array}$ & $\begin{array}{c}\text { Area } 23 \text { Mercury } \\
(\mathrm{mg} / \mathrm{L})\end{array}$ \\
\hline Cadmium & 1.0 & $<0.0007$ & $<0.0007$ \\
\hline Chromium & 5.0 & 0.0024 & 0.0018 \\
\hline Lead & 5.0 & $<0.00231$ & $<0.00231$ \\
\hline Mercury & 0.2 & $<0.0001$ & $<0.0001$ \\
\hline Selenium & 1.0 & $<0.0047$ & $<0.0047$ \\
\hline Silver & 5.0 & 0.00095 & $<0.0007$ \\
\hline
\end{tabular}

(a) Starting in 2006, unnecessary monitoring contaminants were removed to comply with Appendix A parameters located in discharge permit GNEV93001.

(b) Source: 40 CFR 261.24, Table 1

\subsubsection{Sewage System Inspections}

The sewage system operators inspect active systems weekly and inactive lagoon systems quarterly. State of Nevada inspections of active and inactive lagoon systems are conducted annually. Operators inspect for abnormal conditions, weeds, algae blooms, pond color, abnormal odors, dike erosion, burrowing animals, discharge from ponds or lagoons, depth of staff gauge, crest level, excess insect population, maintenance/repairs needed, and general conditions.

In 2006, there were no notable findings relating to the permitted lagoons and their weekly inspections. Although the Nevada Division of Environmental Protection did not conduct an annual inspection of active and inactive sewage lagoon systems in 2006, field maintenance programs aided in keeping the lagoons, sites, and access roads functional. 


\subsection{Direct Radiation Monitoring}

U.S. Department of Energy (DOE) Order 5400.5, Radiation Protection of the Public and the Environment, and DOE Order 435.1, Radioactive Waste Management, have requirements to protect the public and environment from exposure to radiation (see Section 2.3). Energy from radionuclides present in the Nevada Test Site (NTS) environment could potentially be deposited inside humans and animals through inhalation and ingestion. Section 3.1 and Section 4.1 present the results of monitoring radionuclides in air and water on the NTS. Monitoring results are used to estimate internal radiation dose to the public via inhalation and ingestion. Energy absorbed from radioactive materials residing outside the body results in an external dose. In 2006, external dose was measured under the Direct Radiation Monitoring Program of Bechtel Nevada and National Security Technologies, LLC, Environmental Technical Services. This section presents the results of monitoring direct ionizing radiation on the NTS from all sources, including natural radioactivity from cosmic or terrestrial sources and from man-made radioactive sources. These data are then used to document and trend gamma radiation exposure rates on the NTS.

Direct radiation monitoring is conducted to assess the state of the external radiation environment, detect changes in that environment, and measure gamma radiation levels near potential exposure sites. DOE Order 450.1, Environmental Protection Program, states that environmental monitoring should be conducted to detect, characterize, and respond to releases from DOE activities, assess impacts, and estimate dispersal patterns in the environment. In addition, DOE Order 5400.5 states that "it is also an objective that potential exposures to members of the public be as low as is reasonably achievable (ALARA)".

\section{Direct Radiation Monitoring Program Goals}

Assess the proportion of dose to the public which comes from background radiation versus NTS operations

Measure the potential external dose to a member of the public in order to determine if the total dose (internal and external) exceeds 100 millirem per year (mrem/yr) (1 millisievert [mSv]/yr), the dose limit of DOE Order 5400.5

Determine if radiation levels from the Radioactive Waste Management Sites (RWMSs) are likely to result in a dose exceeding the $25 \mathrm{mrem} / \mathrm{yr}(0.25 \mathrm{mSv} / \mathrm{yr})$ dose limit to members of the public as specified in DOE M 435.1-1

Monitor operational activities involving radioactive material, radiation-generating devices, or accidental releases of radioactive material to ensure exposure to members of the public are kept ALARA as stated in DOE Order 5400.5

Determine if the absorbed radiation dose (in a unit of measure called a rad [see Glossary, Appendix B]) from external radiation exposure to NTS terrestrial plants and aquatic animals is less than $1 \mathrm{rad}$ per day $(1 \mathrm{rad} / \mathrm{d})(0.01$ gray $[\mathrm{Gy}] / \mathrm{d}$ ), and if the absorbed radiation dose to NTS terrestrial animals is less than $0.1 \mathrm{rad} / \mathrm{d}$ (1 milligray $[\mathrm{mGy}] / \mathrm{d}$ ) (limits prescribed by DOE Order 5400.5 and DOE Standard DOE-STD-1153-2002)

Determine the exposure rates through time at various soil contamination areas to fulfill the requirements of DOE Order 450.1 to characterize releases in the environment

An oversight monitoring program has been established by the U.S. Department of Energy, National Nuclear Security Administration Nevada Site Office to independently monitor direct radiation within communities adjacent to the NTS. This independent oversight is provided through the Community Environmental Monitoring Program (CEMP) and managed by the Desert Research Institute (DRI). DRI's 2006 direct radiation monitoring results are presented in Sections 6.1.2 and 6.1.3.

\subsection{Measurement of Direct Radiation}

Direct radiation is exposure to electromagnetic (i.e., gamma and X-ray) radiation. Electromagnetic radiation is able to travel long distances through air and to penetrate living tissue causing ionization within the body tissues. In contrast, alpha and beta particles do not travel far in air (a few centimeters for alpha and about 10 meters $(\mathrm{m})(32.8$ feet [ft]) for beta particles). Alpha particles deposit only negligible energy externally; they rarely penetrate the outer dead layer of skin. Beta particles are generally absorbed in the immediate layers of skin below the outer layer. 
Direct radiation exposure is usually reported in the unit milliroentgen $(\mathrm{mR})$, which is a measure of exposure in terms of numbers of ionizations in air. Generally, the dose in human tissue resulting from an exposure from the most common external radionuclides can be approximated by equating a $1 \mathrm{mR}$ exposure with a 1 millirem (mrem) $(0.01$ millisievert $[\mathrm{mSv}])$ dose.

\subsection{Thermoluminescent Dosimetry (TLD) Surveillance Network Design}

Monitoring is performed on the NTS because some NTS areas have elevated radiation levels resulting from one or more of the following: (1) historical weapons testing, (2) current and past radioactive waste management activities, and (3) current operational activities involving radioactive material or radiation-generating devices. Monitoring is provided by a surveillance network of TLDs on the NTS. The objectives and design of the network are described in detail in the Routine Radiological Environmental Monitoring Plan (RREMP) (DOE, 2003b). For more details on sampling and analysis methods, the reader is encouraged to refer to the RREMP.

TLDs measure ionizing radiation exposure from all sources, including natural and man-made radioactivity. The TLD used is the Panasonic UD-814AS, which consists of four elements housed in an air-tight, water-tight, ultraviolet-lightprotected case. A slightly shielded lithium borate element is used to check low-energy radiation levels. The average of three calcium sulfate elements is used to measure penetrating gamma radiation.

A pair of TLDs is placed at $1.0 \pm 0.3 \mathrm{~m}$ (28 to 51 inches [in.]) above the ground at each monitoring location and is exchanged for analysis quarterly. The quarterly analysis of TLDs is performed using automated TLD readers that are calibrated and maintained by the BN/NSTec Radiological Control Department (RCD). Reference TLDs are exposed to $100 \mathrm{mR}$ from a ${ }^{137} \mathrm{Cs}$ radiation source under tightly controlled conditions. These are then read along with TLDs collected from the environment to calibrate their response.

In 2006, there were 109 active environmental TLD locations on the NTS (Figure 5-1). They include the following numbers and types of locations:

- Background (B) - 10 locations where radiation effects from NTS operations are negligible.

- Environmental 1 (E1) - 41 locations where there is no measurable radioactivity from past operations but which are of interest due to either (1) the presence of personnel or the public in the area or (2) the potential for receiving radiation exposure from a current operation.

- Environmental 2 (E2) - 35 locations where there is measurable added radioactivity from past operations and the locations are of interest due to (1) the potential for personnel to be in the area and (2) the need to monitor exposure trends in the area. Some locations fitting this description are grouped with the WO category below.

- Waste Operations (WO) - 17 locations in and around the Area 3 RWMS and the Area 5 Radioactive Waste Management Complex (RWMC).

- Control (C) - 6 locations in Building 650 in Mercury. Control TLDs are kept in stable environments and are used as a quality check on the TLDs and the analysis process.

\subsubsection{Data Quality}

Quality assurance and quality control (QA/QC) protocols, including data quality objectives, have been developed and are maintained as essential elements of direct radiation monitoring, as directed by the RREMP. The QA/QC requirements established for the monitoring program include the use of sample packages to thoroughly document each sampling event, provide rigorous management of databases, and document completion of essential training. Agreement between the results provided by the paired TLDs at each location was very good, with an average relative percent difference between measurements of 2.5 percent for 2006. Quarterly results from Control TLDs were not significantly different from those of previous years. These exhibited quarter-to-quarter coefficients of variation ranging from 1.9 to 8.9 percent and averaging 7.4 percent in 2006. This is a measure of the inherent variation associated with the TLD sampling process; values for control locations ranged from 1.2 to 10.0 percent in recent years. The RCD maintains certification through the DOE Laboratory Accreditation Program for dosimetry. 


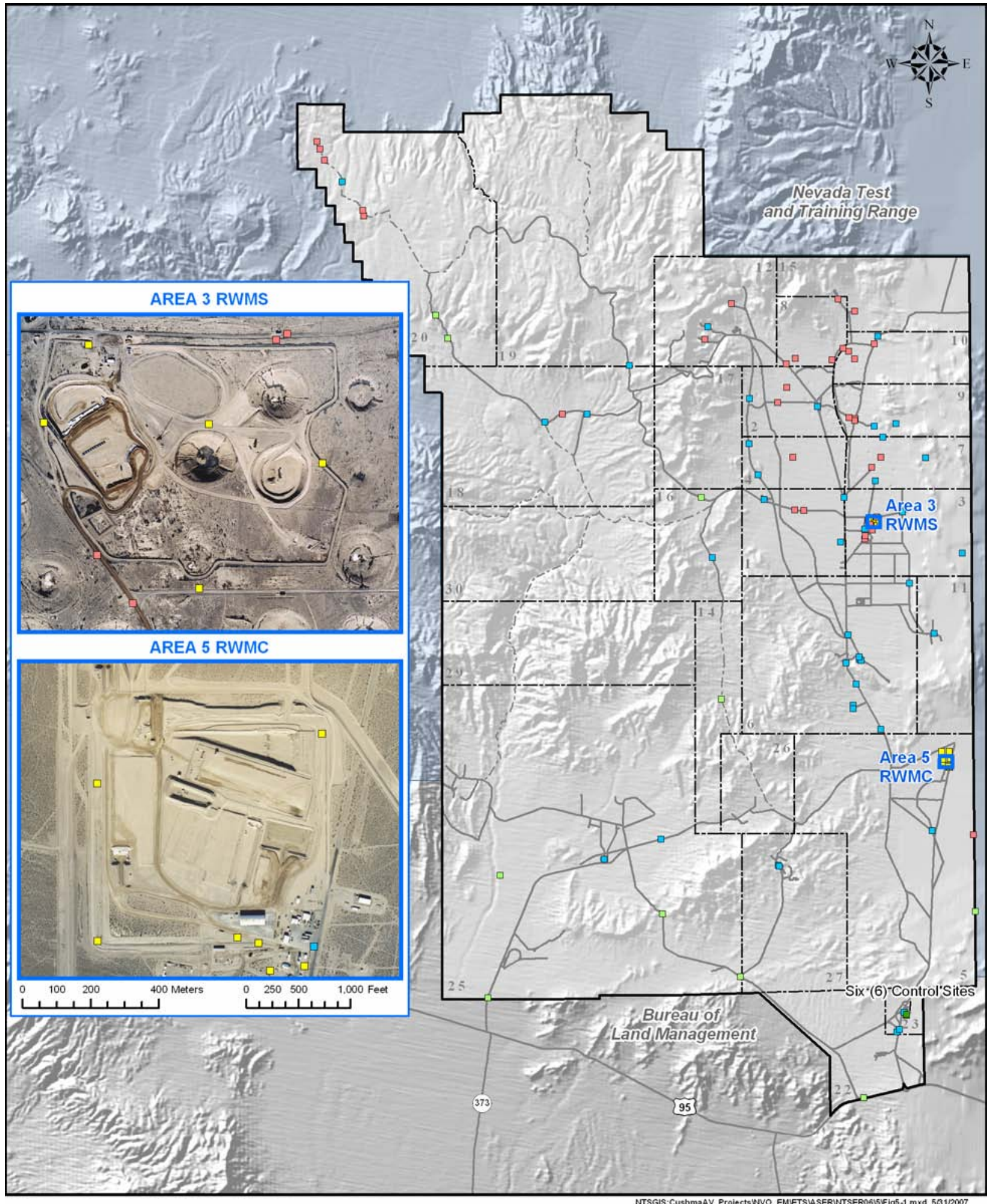

Color Code for TLD Categories

$\square$ Background: Unaffected by past NTS operations

- Control: Stations in a controlled environment $\square$ Environmental 1: Area with negligible radioactivity

Environmental 2: Area with measurable radioactivity

Waste Operations: Area around waste operations

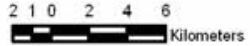

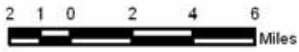

Figure 5-1. Location of TLDs on the NTS 


\subsubsection{Data Reporting}

Direct radiation is reported and maintained in a database as exposure per unit of time, $\mathrm{mR}$ per day (mR/d), calculated by dividing the measured $\mathrm{mR}$ exposure per quarter for each TLD by the number of days in the quarter. For annual reporting purposes, these are multiplied by 365. The estimated annual exposure is the average of the four quarterly annualized values; this is used to determine compliance with federal annual direct radiation exposure limits.

\subsection{Results}

Estimated annual exposures for all TLD locations are summarized in Table 5-1; summary statistics for the five location types are given in Table 5-2. During 2006, the average of the estimated annual exposures at background locations was $125 \mathrm{mR}$; these ranged from 82 to $164 \mathrm{mR}$ over nine of ten background locations for which data were available (Table 5-2). Data were not available at one of the background locations (3.3 Mi SE of Aggregate Pit) due to the TLDs being either missing from the location or found on the ground which is an unacceptable condition for valid data. A 95 percent prediction interval (PI) for annual exposures based on the average of background location values for 2005 and 2006 is 40.8 to $197.0 \mathrm{mR}$.

For comparison, the CEMP estimated annual exposure in Las Vegas, Nevada (at 2,040 ft elevation) was $103 \mathrm{mR}$ during 2006 (see Table 6-3). Estimated exposures at CEMP locations ranged from $78 \mathrm{mR}$ at Pahrump (2,550 ft elevation) to $154 \mathrm{mR}$ at Sarcobatus Flats (4,015 ft elevation). There is a generally increasing relationship between exposure and elevation, with a correlation coefficient around 0.45 . For comparison, the NTS background locations with lowest and highest estimated exposures are at elevations 3,569 ft and 5,700 ft, respectively. Exposure estimates at all locations include the contribution from natural sources. Dose limits prescribed by DOE orders only apply to exposures above background levels.

Table 5-1. Annual direct radiation exposure rates measured at TLD locations on the NTS in 2006

\begin{tabular}{|c|c|c|c|c|c|c|c|c|}
\hline \multirow{2}{*}{$\begin{array}{l}\text { NTS } \\
\text { Area }\end{array}$} & \multirow[b]{2}{*}{ Location } & \multirow{2}{*}{$\begin{array}{c}\text { Location } \\
\text { Type }\end{array}$} & \multirow{2}{*}{$\begin{array}{c}\text { Number of } \\
\text { Quarters }\end{array}$} & \multicolumn{5}{|c|}{ Estimated Annual Exposure (mR/yr) } \\
\hline & & & & $\operatorname{Mean}^{(b)}$ & Median $^{(b)}$ & $\operatorname{SD}^{(b)}$ & $\operatorname{Min}^{(b)}$ & $\operatorname{Max}^{(\mathbf{b})}$ \\
\hline 5 & 3.3 Mi SE of Aggregate Pit & $\mathrm{B}$ & 0 & * & * & * & * & * \\
\hline 14 & Mid-Valley & $\mathrm{B}$ & 3 & 143 & 142 & 3 & 140 & 146 \\
\hline 16 & Stake P-3 & B & 4 & 122 & 122 & 2 & 119 & 124 \\
\hline 20 & Stake A-112 & $\mathrm{B}$ & 4 & 164 & 164 & 1 & 163 & 166 \\
\hline 20 & Stake A-118 & B & 4 & 156 & 156 & 2 & 154 & 158 \\
\hline 22 & Army \#1 Water Well & B & 4 & 86 & 87 & 3 & 83 & 89 \\
\hline 25 & Gate $25-4-\mathrm{P}$ & $\mathrm{B}$ & 4 & 134 & 134 & 2 & 132 & 136 \\
\hline 25 & Guard Station 510 & $\mathrm{~B}$ & 2 & 127 & 127 & 1 & 126 & 127 \\
\hline 25 & Jackass Flats \& A-27 Roads & B & 4 & 82 & 81 & 2 & 80 & 84 \\
\hline 25 & Skull Mtn Pass & $\mathrm{B}$ & 4 & 109 & 110 & 1 & 108 & 110 \\
\hline 23 & Building 650 Dosimetry & $\mathrm{C}$ & 4 & 60 & 60 & 1 & 59 & 61 \\
\hline 23 & Lead Cabinet, 1 & $\mathrm{C}$ & 4 & 26 & 26 & 2 & 25 & 29 \\
\hline 23 & Lead Cabinet, 2 & $\mathrm{C}$ & 4 & 26 & 26 & 2 & 25 & 28 \\
\hline 23 & Lead Cabinet, 3 & $\mathrm{C}$ & 4 & 27 & 26 & 2 & 24 & 29 \\
\hline 23 & Lead Cabinet, 4 & $\mathrm{C}$ & 4 & 27 & 26 & 2 & 25 & 30 \\
\hline 23 & Lead Cabinet, 5 & $\mathrm{C}$ & 4 & 26 & 26 & 2 & 24 & 29 \\
\hline 1 & BJY & E1 & 4 & 120 & 119 & 4 & 117 & 125 \\
\hline 1 & Sandbag Storage Hut & E1 & 4 & 115 & 114 & 3 & 113 & 119 \\
\hline 1 & Stake C-2 & E1 & 4 & 120 & 120 & 5 & 114 & 126 \\
\hline 2 & Stake M-140 & E1 & 4 & 134 & 133 & 4 & 131 & 139 \\
\hline 2 & Stake TH-58 & E1 & 4 & 97 & 95 & 5 & 93 & 104 \\
\hline 3 & LANL Trailers & E1 & 2 & 122 & 122 & 2 & 121 & 124 \\
\hline 3 & Stake OB-20 & E1 & 4 & 89 & 89 & 3 & 86 & 92 \\
\hline 3 & Well ER 3-1 & E1 & 1 & 131 & 131 & * & 131 & 131 \\
\hline
\end{tabular}


Table 5-1. Annual direct radiation exposure rates measured at TLD locations on the NTS in 2006 (continued)

\begin{tabular}{|c|c|c|c|c|c|c|c|c|}
\hline \multirow{2}{*}{$\begin{array}{l}\text { NTS } \\
\text { Area }\end{array}$} & \multirow[b]{2}{*}{ Location } & \multirow{2}{*}{$\begin{array}{c}\text { Location } \\
\text { Type }^{(a)}\end{array}$} & \multirow{2}{*}{$\begin{array}{c}\text { Number of } \\
\text { Quarters }\end{array}$} & \multicolumn{5}{|c|}{ Estimated Annual Exposure (mR/yr) } \\
\hline & & & & Mean $^{(b)}$ & Median $^{(b)}$ & $\operatorname{SD}^{(b)}$ & $\operatorname{Min}^{(b)}$ & $\operatorname{Max}^{(\mathbf{b})}$ \\
\hline 4 & Stake TH-41 & E1 & 4 & 112 & 112 & 3 & 110 & 115 \\
\hline 4 & Stake TH-48 & E1 & 4 & 123 & 122 & 4 & 119 & 129 \\
\hline 5 & Water Well 5B & E1 & 3 & 113 & 114 & 1 & 112 & 114 \\
\hline 6 & CP-6 & E1 & 4 & 71 & 72 & 2 & 68 & 72 \\
\hline 6 & DAF East & E1 & 4 & 97 & 97 & 2 & 95 & 99 \\
\hline 6 & DAF North & E1 & 4 & 103 & 104 & 3 & 100 & 106 \\
\hline 6 & DAF South & E1 & 4 & 137 & 137 & 1 & 136 & 138 \\
\hline 6 & DAF West & E1 & 4 & 84 & 84 & 3 & 81 & 87 \\
\hline 6 & Decon Facility NW & E1 & 4 & 131 & 131 & 2 & 130 & 133 \\
\hline 6 & Decon Facility SE & E1 & 4 & 134 & 135 & 4 & 130 & 138 \\
\hline 6 & Stake OB-11.5 & E1 & 4 & 132 & 133 & 2 & 129 & 135 \\
\hline 6 & Yucca Compliance & E1 & 4 & 92 & 92 & 3 & 89 & 95 \\
\hline 6 & Yucca Oil Storage & E1 & 3 & 101 & 101 & 4 & 97 & 104 \\
\hline 7 & Reitmann Seep & E1 & 2 & 130 & 130 & 1 & 130 & 131 \\
\hline 7 & Stake H-8 & E1 & 4 & 130 & 128 & 4 & 127 & 135 \\
\hline 9 & Papoose Lake Road & E1 & 4 & 89 & 90 & 3 & 86 & 92 \\
\hline 9 & U-9CW South & E1 & 3 & 104 & 105 & 2 & 101 & 105 \\
\hline 9 & V \& G Road Junction & E1 & 3 & 115 & 113 & 5 & 112 & 120 \\
\hline 10 & Gate 700 South & E1 & 4 & 133 & 131 & 6 & 129 & 142 \\
\hline 11 & Stake A-21 & E1 & 4 & 133 & 132 & 2 & 131 & 136 \\
\hline 12 & Upper N Pond & E1 & 4 & 133 & 130 & 6 & 130 & 141 \\
\hline 16 & 3545 Substation & E1 & 4 & 143 & 142 & 3 & 140 & 146 \\
\hline 18 & Stake A-83 & E1 & 4 & 149 & 149 & 1 & 147 & 150 \\
\hline 18 & Stake F-11 & E1 & 4 & 149 & 149 & 1 & 147 & 150 \\
\hline 19 & Stake P-41 & E1 & 4 & 161 & 161 & 3 & 158 & 165 \\
\hline 20 & Stake J-41 & E1 & 4 & 140 & 141 & 4 & 134 & 143 \\
\hline 23 & Gate 100 Truck Parking 1 & E1 & 4 & 105 & 96 & 39 & 68 & 160 \\
\hline 23 & Gate 100 Truck Parking 2 & E1 & 4 & 64 & 63 & 4 & 62 & 70 \\
\hline 23 & Mercury Fitness Track & E1 & 4 & 59 & 59 & 3 & 57 & 64 \\
\hline 25 & HENRE & E1 & 4 & 124 & 124 & 2 & 121 & 126 \\
\hline 25 & NRDS Warehouse & E1 & 4 & 125 & 125 & 3 & 122 & 129 \\
\hline 27 & Cafeteria & E1 & 4 & 115 & 114 & 3 & 112 & 120 \\
\hline 27 & JASPER-1 & E1 & 4 & 115 & 115 & 2 & 113 & 116 \\
\hline 1 & Bunker 1-300 & E2 & 4 & 121 & 121 & 2 & 119 & 123 \\
\hline 1 & $\mathrm{~T} 1$ & E2 & 4 & 293 & 291 & 8 & 286 & 303 \\
\hline 2 & Stake L-9 & E2 & 4 & 174 & 174 & 5 & 169 & 178 \\
\hline 2 & Stake N-8 & E2 & 4 & 565 & 567 & 19 & 541 & 586 \\
\hline 3 & Stake A-6.5 & E2 & 3 & 144 & 144 & 4 & 140 & 148 \\
\hline 3 & T3 & E2 & 4 & 387 & 391 & 9 & 374 & 393 \\
\hline 3 & T3 West & E2 & 4 & 372 & 376 & 14 & 352 & 383 \\
\hline 3 & T3A & E2 & 4 & 448 & 453 & 12 & 431 & 458 \\
\hline 3 & T3B & E2 & 4 & 474 & 474 & 7 & 468 & 482 \\
\hline 3 & U-3co North & E2 & 4 & 199 & 197 & 6 & 193 & 208 \\
\hline 3 & U-3co South & E2 & 4 & 150 & 149 & 2 & 148 & 153 \\
\hline 4 & Stake A-9 & E2 & 4 & 692 & 691 & 38 & 657 & 729 \\
\hline 5 & Frenchman Lake & E2 & 3 & 379 & 385 & 10 & 367 & 385 \\
\hline 7 & Bunker 7-300 & E2 & 4 & 247 & 248 & 8 & 237 & 253 \\
\hline 7 & $\mathrm{~T} 7$ & E2 & 4 & 118 & 118 & 2 & 116 & 120 \\
\hline
\end{tabular}


Table 5-1. Annual direct radiation exposure rates measured at TLD locations on the NTS in 2006 (continued)

\begin{tabular}{|c|c|c|c|c|c|c|c|c|}
\hline \multirow[b]{2}{*}{$\begin{array}{l}\text { NTS } \\
\text { Area }\end{array}$} & \multirow[b]{2}{*}{ Location } & \multirow[b]{2}{*}{$\begin{array}{c}\text { Location } \\
\text { Type }^{(a)}\end{array}$} & \multirow[b]{2}{*}{$\begin{array}{c}\text { Number of } \\
\text { Quarters }\end{array}$} & \multicolumn{5}{|c|}{ Estimated Annual Exposure (mR) } \\
\hline & & & & Mean $^{(b)}$ & Median $^{(b)}$ & $\mathrm{SD}^{(\mathbf{b})}$ & $\operatorname{Min}^{(b)}$ & $\operatorname{Max}^{(\mathbf{b})}$ \\
\hline 8 & BANEBERRY 1 & E2 & 4 & 409 & 404 & 13 & 399 & 428 \\
\hline 8 & Road 8-02 & E2 & 4 & 127 & 125 & 6 & 123 & 137 \\
\hline 8 & Stake K-25 & E2 & 4 & 107 & 105 & 4 & 104 & 113 \\
\hline 8 & Stake M-152 & E2 & 4 & 166 & 167 & 3 & 162 & 169 \\
\hline 9 & B9A & E2 & 4 & 134 & 133 & 3 & 131 & 139 \\
\hline 9 & Bunker 9-300 & E2 & 4 & 126 & 123 & 6 & 122 & 134 \\
\hline 9 & T9B & E2 & 4 & 545 & 538 & 16 & 535 & 568 \\
\hline 10 & Circle \& L Roads & E2 & 4 & 123 & 122 & 4 & 120 & 130 \\
\hline 10 & Sedan East Visitor Box & E2 & 4 & 135 & 135 & 4 & 130 & 140 \\
\hline 10 & Sedan West & E2 & 3 & 249 & 246 & 12 & 239 & 263 \\
\hline 10 & $\mathrm{~T} 10$ & E2 & 4 & 269 & 267 & 8 & 261 & 281 \\
\hline 12 & T-Tunnel \#2 Pond & E2 & 4 & 259 & 259 & 5 & 254 & 266 \\
\hline 12 & Upper Haines Lake & E2 & 4 & 109 & 108 & 4 & 105 & 114 \\
\hline 15 & EPA Farm & E2 & 2 & 117 & 117 & 4 & 114 & 120 \\
\hline 18 & JOHNNIE BOY North & E2 & 4 & 149 & 149 & 3 & 146 & 152 \\
\hline 20 & PALANQUIN & E2 & 4 & 236 & 235 & 9 & 226 & 249 \\
\hline 20 & SCHOONER-1 & E2 & 4 & 771 & 783 & 41 & 713 & 806 \\
\hline 20 & SCHOONER-2 & E2 & 4 & 279 & 279 & 7 & 270 & 287 \\
\hline 20 & SCHOONER-3 & E2 & 4 & 146 & 145 & 4 & 142 & 151 \\
\hline 20 & Stake J-31 & E2 & 4 & 170 & 170 & 2 & 167 & 172 \\
\hline 3 & A3 RWMS Center & WO & 4 & 142 & 144 & 4 & 136 & 145 \\
\hline 3 & A3 RWMS East & WO & 4 & 137 & 137 & 3 & 133 & 140 \\
\hline 3 & A3 RWMS North & WO & 4 & 125 & 125 & 3 & 121 & 129 \\
\hline 3 & A3 RWMS South & WO & 4 & 372 & 373 & 11 & 357 & 383 \\
\hline 3 & A3 RWMS West & WO & 4 & 127 & 128 & 3 & 122 & 129 \\
\hline 5 & A5 RWMS East Gate & WO & 4 & 115 & 114 & 4 & 112 & 120 \\
\hline 5 & A5 RWMS Expansion NE & WO & 4 & 140 & 140 & 1 & 139 & 142 \\
\hline 5 & A5 RWMS Expansion NW & WO & 4 & 146 & 146 & 3 & 142 & 148 \\
\hline 5 & A5 RWMS NE Corner & WO & 4 & 127 & 127 & 2 & 125 & 130 \\
\hline 5 & A5 RWMS NW Corner & WO & 4 & 127 & 127 & 2 & 125 & 129 \\
\hline 5 & A5 RWMS South Gate & WO & 4 & 110 & 110 & 2 & 107 & 112 \\
\hline 5 & A5 RWMS SW Corner & WO & 4 & 127 & 127 & 2 & 126 & 131 \\
\hline 5 & Building 5-31 & WO & 4 & 112 & 112 & 4 & 108 & 118 \\
\hline 5 & WEF East & WO & 4 & 129 & 128 & 5 & 125 & 135 \\
\hline 5 & WEF North & WO & 4 & 128 & 127 & 5 & 122 & 135 \\
\hline 5 & WEF South & WO & 4 & 136 & 133 & 10 & 128 & 151 \\
\hline 5 & WEF West & WO & 3 & 133 & 131 & 9 & 124 & 143 \\
\hline
\end{tabular}

* = No measurements available to calculate

(a) Location types:

$\mathrm{B}=$ Background locations

$\mathrm{C}=$ Control locations

E1 = Environmental locations with exposure rates near background but monitored for potential for increased exposure rates due to NTS operations

$\mathrm{E} 2=$ Environmental locations with measurable radioactivity from past operations, excluding those designated WO

$\mathrm{WO}=$ Locations in or near waste operations

(b) Mean, median, standard deviation (SD), minimum, and maximum values from quarterly estimates. In general, each quarterly estimate is

the average of two TLD readings per location 
Table 5-2. Summary statistics for 2006 annual direct radiation exposure by TLD location type

\begin{tabular}{||ccccccc||}
\hline & & \multicolumn{5}{c||}{ Estimated Annual Exposure (mR) } \\
\cline { 3 - 7 } Location Type & $\begin{array}{c}\text { Number of } \\
\text { Locations }\end{array}$ & Mean $^{(\mathrm{a})}$ & Median $^{(\mathrm{a})}$ & SD $^{(\mathrm{a})}$ & Min $^{(\mathrm{a})}$ & Max $^{(\mathrm{a})}$ \\
\hline Background (B) & 10 & 125 & 127 & 29 & 82 & 164 \\
Control (C) & 6 & 32 & 27 & 14 & 26 & 60 \\
Environmental 1 (E1) & 41 & 116 & 120 & 23 & 59 & 161 \\
Environmental 2 (E2) & 35 & 268 & 199 & 175 & 107 & 771 \\
Waste Operations (WO) & 17 & 143 & 128 & 60 & 110 & 372 \\
\hline \hline
\end{tabular}

(a) Mean, median, standard deviation, minimum, and maximum values from annual estimated exposures

\subsubsection{Potential Exposure to the Public along the NTS Boundary}

Most of the NTS is not accessible to the public, as only the southern portion of the NTS boundary borders public land. Therefore, the only place the public has potential for exposure to direct radiation from the NTS is along the southern boundary. Gate 100 is the primary entrance point to the NTS. The outer parking areas are accessible to the public. Trucks hauling radioactive materials, primarily low-level radioactive waste being shipped for disposal in the RWMSs, often park outside Gate 100 while waiting for entry to the NTS. Two TLD locations were established in October 2003 to monitor this truck parking area. The TLD on the north end of the parking area (Gate 100 Truck Parking 2) had an estimated annual exposure of $64 \mathrm{mR}$, with quarterly estimates varying between 62 and $70 \mathrm{mR}$, all within the range of background exposures observed at the NTS.

The TLD location on the west side of the parking area (Gate 100 Truck Parking 1) had an estimated annual exposure of $220 \mathrm{mR}$ during 2005, as discussed in the Nevada Test Site Environmental Report 2005 (DOE, 2006b). Quarterly exposure estimates had returned to background (i.e. similar to Gate 100 Truck Parking 2 values) by the fourth quarter of 2005 and remained there during the first quarter of 2006. For all of 2006, the yearly estimated exposure was $105 \mathrm{mR}$, with quarterly values ranging from 68 to $160 \mathrm{mR}$. It is likely that waste shipments entering the NTS are responsible for a typical quarter-to-quarter variation.

While the public has access only to the southern portions of the NTS borders, other people may have access to other boundaries of the NTS. The great majority of the NTS is bounded by the Nevada Test and Training Range (NTTR). Military or other personnel on the NTTR who are not classified as radiation workers would also be subject to the $100 \mathrm{mrem} / \mathrm{yr}$ public dose limit. The only place a radiological boundary extends beyond the NTS is in the Frenchman Lake region of Area 5 along the southeast boundary of the NTS. A TLD location was established in July 2003 near the NTS boundary in the Frenchman Lake playa. The estimated annual exposure at Frenchman Lake during 2006 was $379 \mathrm{mR}$ (down from $391 \mathrm{mR}$ in 2005). The resulting above-background dose of approximately 215 to $313 \mathrm{mrem}$, depending on which background value is used, would exceed the $100 \mathrm{mrem}$ dose limit to a person residing year-round at this location; however, there are no living quarters or full-time workers in this vicinity.

\subsubsection{Exposure Rates at RWMSs}

The Radioactive Waste Management Manual, DOE M 435.1-1 (DOE, 2001), states that low-level waste disposal facilities shall be operated, maintained, and closed so that a reasonable expectation exists that annual dose to members of the public shall not exceed $25 \mathrm{mrem}$. Given that the RWMSs are located well within the NTS boundaries, no members of the public could access these areas for significant periods of time. Exposures are still measured by TLDs located at the RWMSs to show the potential dose to a hypothetical person residing year-round at each RWMS.

The Area 3 RWMS is located in Yucca Flat. Between 1952 and 1972, 60 nuclear weapons tests were conducted within $400 \mathrm{~m}$ of the Area 3 RWMS boundary. Fourteen of these tests were atmospheric tests which left radionuclidecontaminated surface soil and, therefore, elevated radiation exposures across the area. Waste pits in the Area 3 RWMS are subsidence craters from seven subsurface tests that are being filled with low-level radioactive waste. These are then covered with clean soil, resulting in lower exposures inside the Area 3 RWMS compared with the average exposures at the fence line or in Area 3 outside the fence line. 
During 2006, the exposures measured inside Area 3 RWMS and three of four measurements at the boundary were within the range of background exposures (Figure 5-2). The estimated exposure above the range of NTS background levels at one location on the RWMS boundary is associated with historic above-ground nuclear weapon test locations. Given this, current Area 3 RWMS operations would have contributed negligible external exposure to a hypothetical person residing at the Area 3 RWMS boundary during 2006.

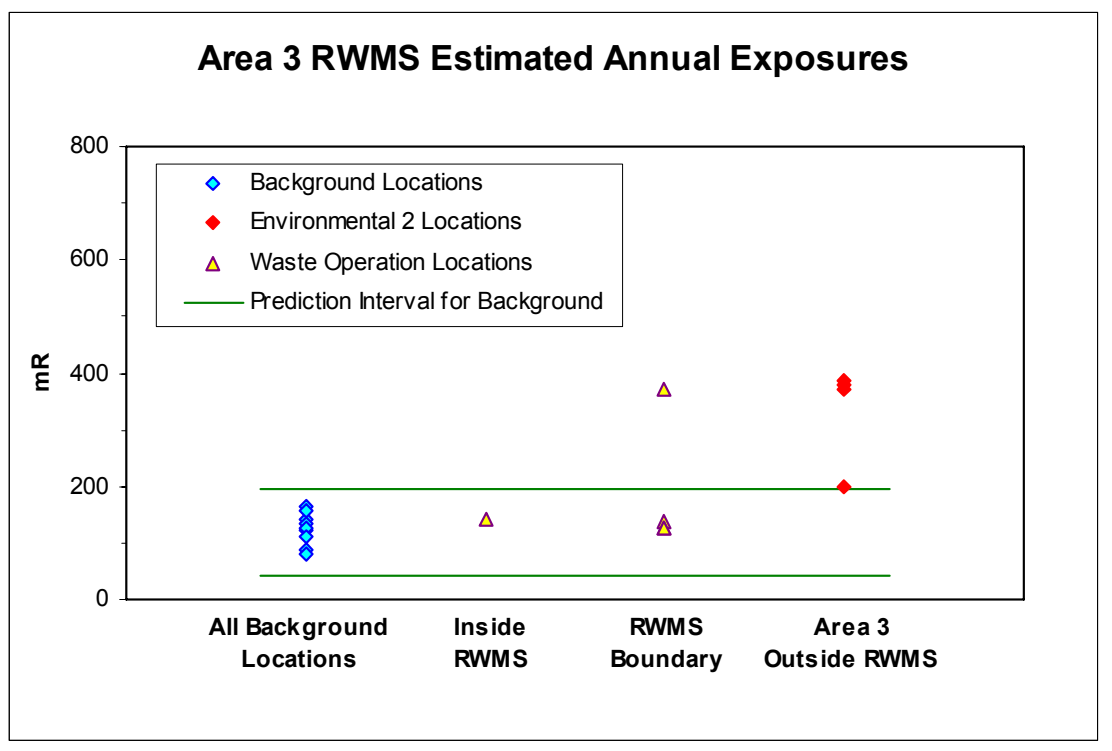

Figure 5-2. 2006 annual exposure rates in and around Area 3 RWMS and at background locations

The Area 5 Radioactive Waste Management Complex (RWMC), consisting of the Area 5 RWMS along with ancillary support facilities, is located in the northern portion of Frenchman Flat. Twenty-five nuclear weapons tests were conducted within 6.3 kilometers $(\mathrm{km})(3.9$ miles [mi]) of the Area 5 RWMC between 1951 and 1971. Fifteen of these were atmospheric tests and, of the remaining ten, nine released radioactivity to the surface which contribute to exposures in the area. No nuclear weapons testing occurred within the boundaries of the Area 5 RWMC itself. During 2006, estimated annual exposures at Area 5 RWMC TLD locations were within the range of exposures measured at NTS background locations (Figure 5-3). The one exposure rate measured outside the RWMC in Area 5 that was higher than background levels was within $0.5 \mathrm{~km}(0.3 \mathrm{mi})$ of 6 atmospheric tests in Frenchman Lake Playa.

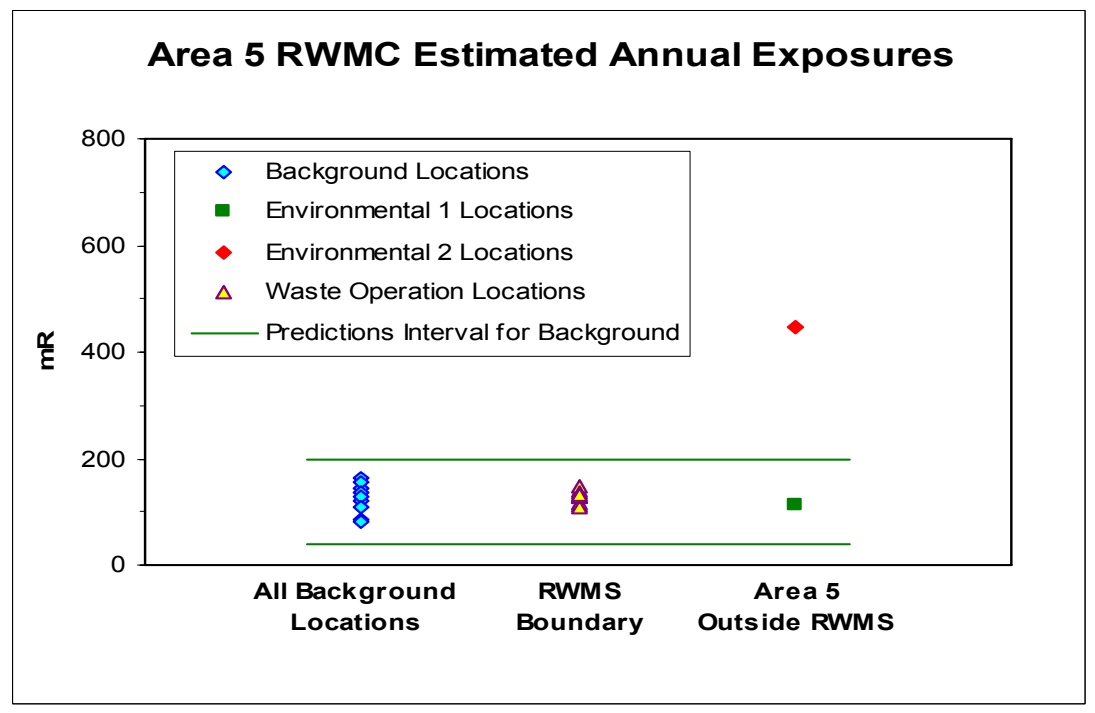

Figure 5-3. 2006 annual exposure rates around Area 5 RWMS and at background locations 


\subsubsection{Exposures from NTS Operational Activities}

During 2006, there were 41 TLDs in locations where there is negligible radioactivity from past operations but which are of interest due to either the presence of personnel or the public in the area or due to the potential for receiving radiation exposure from current operations (Environmental 1 locations). The estimated mean annual exposure at these locations was $116 \mathrm{mR}$, slightly lower than the mean estimated annual exposure at background locations (see Table 5-2). Overall, annual exposures were not different between background and Environmental 1 locations (Figure 5-4); the estimated annual exposures at all Environmental 1 locations were within the background-based PIs.

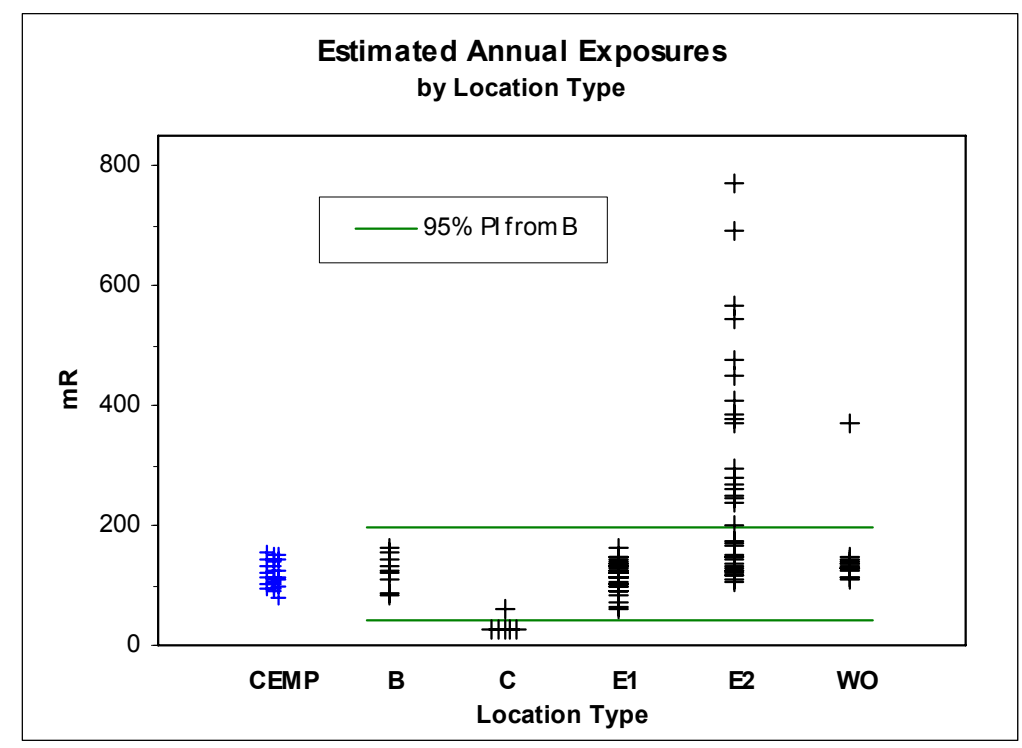

Figure 5-4. 2006 annual exposure rates on the NTS by location type and off the NTS (CEMP stations)

\subsubsection{Exposure to NTS Plants and Animals}

The TLD location with the highest annual exposure (Schooner-1) had its highest measured exposure rate of $2.21 \mathrm{mR} / \mathrm{d}$ during the second quarter $(806 \mathrm{mR} / \mathrm{yr}$, see Table 5-1). At an elevation near the ground (e.g., $3 \mathrm{~cm}$ [1.2 in.]), the exposure would be about four times higher than at the 1-m (3.3-ft) height where TLDs are placed. Therefore, the daily exposure rate near the ground surface at the Schooner-1 location would be less than $10 \mathrm{mR} / \mathrm{d}$. This would result in an external dose that is approximately 10 percent of the most stringent total dose rate to biota, which is the $0.1 \mathrm{rad} / \mathrm{d}$ (approximately $100 \mathrm{mR} / \mathrm{d}$ ) limit to terrestrial animals mandated by DOE-STD-1153-2002. Hence, doses to plants and animals from external radiation exposure at NTS monitoring locations are low compared with the mandated dose limit.

\subsubsection{Exposure Rate Patterns in the Environment over Time}

DOE Order 450.1 states that environmental monitoring should be conducted to characterize releases from DOE activities. Continued monitoring of exposures at locations of past releases on the NTS helps to do this. Small quarter-to-quarter changes are normally seen in exposure rates from all locations. In 2006, for example, the first quarter was higher than the others. The differences were statistically significant $(p=0.000)$ for all location types except Waste Operations, but fairly small: a 3.0 percent difference between the first quarter and the lowest (third) quarter for Background locations, 5.0 percent for Environmental 1 locations (third quarter was low), and 5.26 percent for Environmental 2 locations(fourth quarter was low). The largest quarter-to-quarter relative differences were seen in the Control locations (15.1 percent between first and fourth quarters), which suggests that systematic analytical variability is a major, but not the only, contributing factor to the observed quarter-to-quarter variation. 
Long-term trends are displayed in Figure 5-5 by location type for locations that have been monitored for at least ten years. The Schooner-1 TLD location, which has the highest exposure of any current NTS location, is not included in this figure because it was established in 2003. The two highest exposures shown in Figure 5-5, at Stake A-9 and Stake N-8, continue to decrease by 4.1 and 5.7 percent per year, respectively; these correspond to half-lives of about 17 and 12 years. The next four highest exposures shown are at T-Tunnel \#2 Pond, Sedan West, Bunker 7-300, Sedan West, and U-3co North, which are decreasing by 0.7, 4.1, 1.5, and 2.5 percent per year since 1989, respectively. All six of these locations are in the Environmental 2 category at known contaminated sites, with the predominant photonemitting radionuclides being ${ }^{137} \mathrm{Cs},{ }^{60} \mathrm{Co},{ }^{152} \mathrm{Eu}$, and ${ }^{241} \mathrm{Am}$. The observed decreases are due to a combination of natural radioactive decay and the dispersal of radionuclides in the environment. Exposures at all other locations with long-term data have been relatively stable over time, indicating little added radioactivity at those locations; see Figure 5-5.

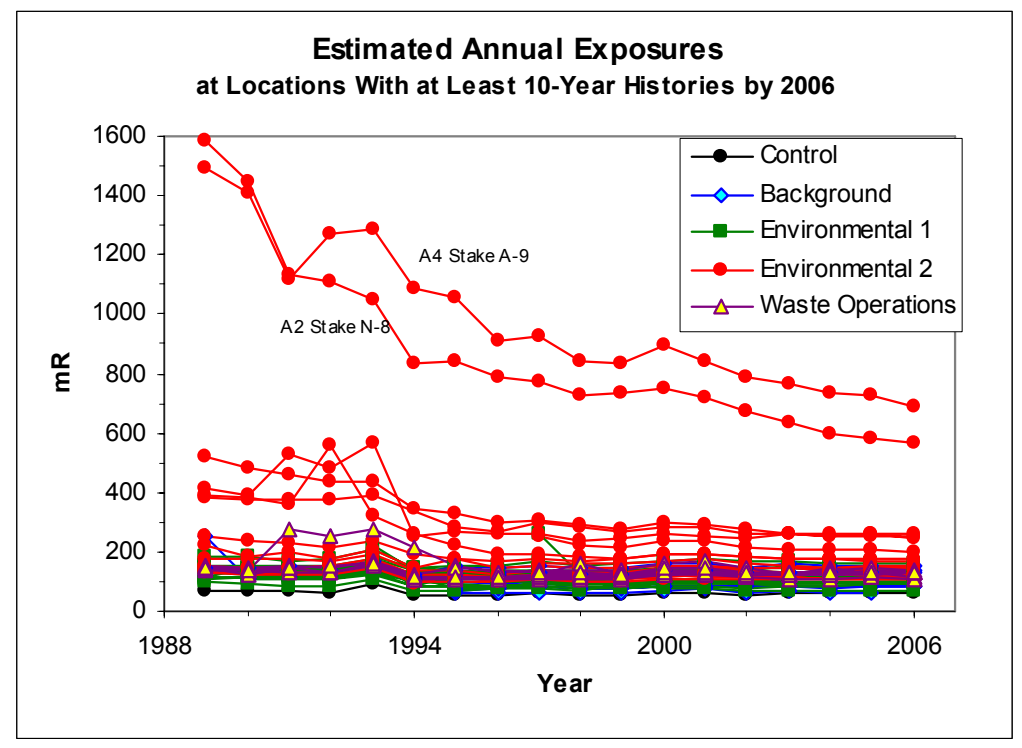

Figure 5-5. Trend in direct radiation exposure measured at TLD locations

\subsection{Environmental Impact}

Direct radiation exposure to the public from NTS operations in 2006 was negligible. Radionuclides historically released to the environment on the NTS have resulted in localized elevated exposures. These areas of elevated exposure are not open to the public nor are there personnel working in these areas full-time. Overall exposures at the RWMSs appear to be generally lower inside or at the boundary compared with those outside the RWMSs. This is likely due to the presence of radionuclides released from historical testing distributed throughout the area around the RWMSs compared with the clean soil used inside the RWMSs to cap waste pits. The external dose to plants and animals at the location with the highest measured exposure was a small fraction of the dose limit to biota; hence no detrimental effects to biota from external radiation exposure are expected at the NTS. 


\subsection{Oversight Radiological Monitoring of Air and Water}

Community oversight for the Nevada Test Site (NTS) is provided through the Community Environmental Monitoring Program (CEMP) whose mission is to monitor and communicate environmental data that are relevant to the safety and well-being of participating communities and their surrounding areas. Previously, the CEMP network functioned as a first line of offsite detection of potential radiation releases from underground nuclear tests at the NTS, and it can be outfitted to fulfill this role again should underground testing resume. It currently exists as a nonregulatory public informational and outreach program, although quarterly reporting of monitoring data is furnished to the U.S. Environmental Protection Agency Region IX as a supplemental requirement to NTS onsite monitoring. The CEMP is sponsored by the U.S. Department of Energy, National Nuclear Security Administration Nevada Site Office (NNSA/NSO), and is administered and operated by the Desert Research Institute (DRI) of the Nevada System of Higher Education.

Monitored and collected data include, but are not necessarily limited to, background and airborne radiation data, meteorological data, and tritium concentrations in community and ranch drinking water wells. Network stations, located in Nevada, Utah, and California are managed by local citizens, many of them high school science teachers, whose routine tasks are to ensure equipment is operating normally and collect air filters and route them to the DRI for analysis. These Community Environmental Monitors (CEMs) are also available to discuss the monitoring results with the public and to speak to community and school groups. DRI's responsibilities include maintaining the physical monitoring network through monthly visitations by environmental radiation monitoring specialists, who also participate in training and interfacing with CEMs and interacting with other local community members and organizations to provide information related to the monitoring data. DRI also provides public access to the

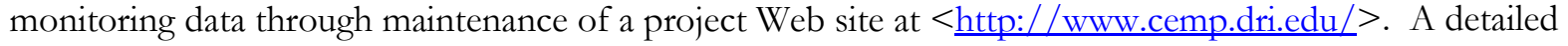

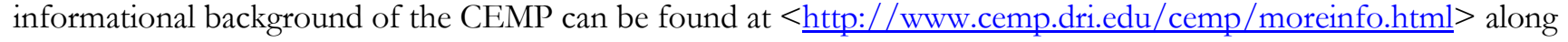
with more detailed descriptions of the various types of sensors found at the stations and on outreach activities conducted by the CEMP.

\subsection{Offsite Air Monitoring}

During 2006, 29 CEMP stations managed by DRI comprised the Air Surveillance Network (ASN) (Figure 6-1). Two new stations were established during the past year, one between Shoshone and Tecopa, California (February 2006), and one in Duckwater, Nevada (November 2006). Data for the Duckwater station represents only about six weeks of collection due to its installation late in the year. The ASN stations include various equipment, as described below. The Mesquite, Nevada CEMP station is shown in Figure 6-2.

CEMP Low-Volume Air Sampling Network - During 2006, the CEMP ASN included continuously operating lowvolume particulate air samplers located at 27 of the 29 CEMP station locations. No low-volume air samplers were located at Medlins Ranch or Warm Springs Summit, Nevada, during 2006. Duplicate air samples were collected from up to three ASN stations each week. The duplicate samplers are operated at randomly selected stations for three months (one calendar quarter) before being moved to a new location.

Glass-fiber filters from the low-volume particulate samplers are collected by the CEMs, mailed to DRI, then prepared and forwarded to an independent laboratory to be analyzed for gross alpha and gross beta activity. Samples are held for a minimum of seven days after collection to allow for the decay of naturally- occurring radon progeny. Upon completion of the gross alpha/beta analyses, the filters are returned to DRI to be composited on a quarterly basis for gamma spectroscopy analysis. 


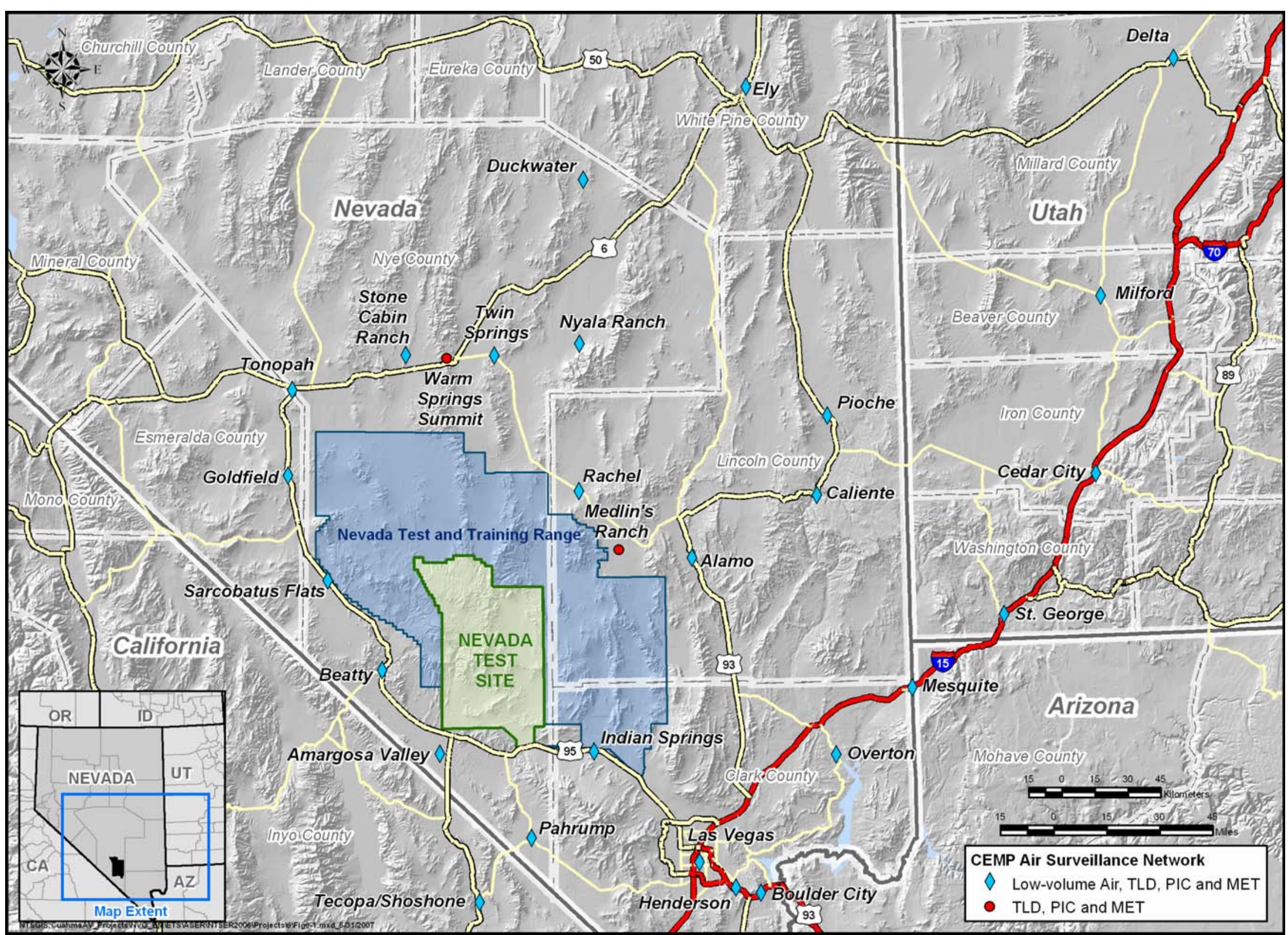




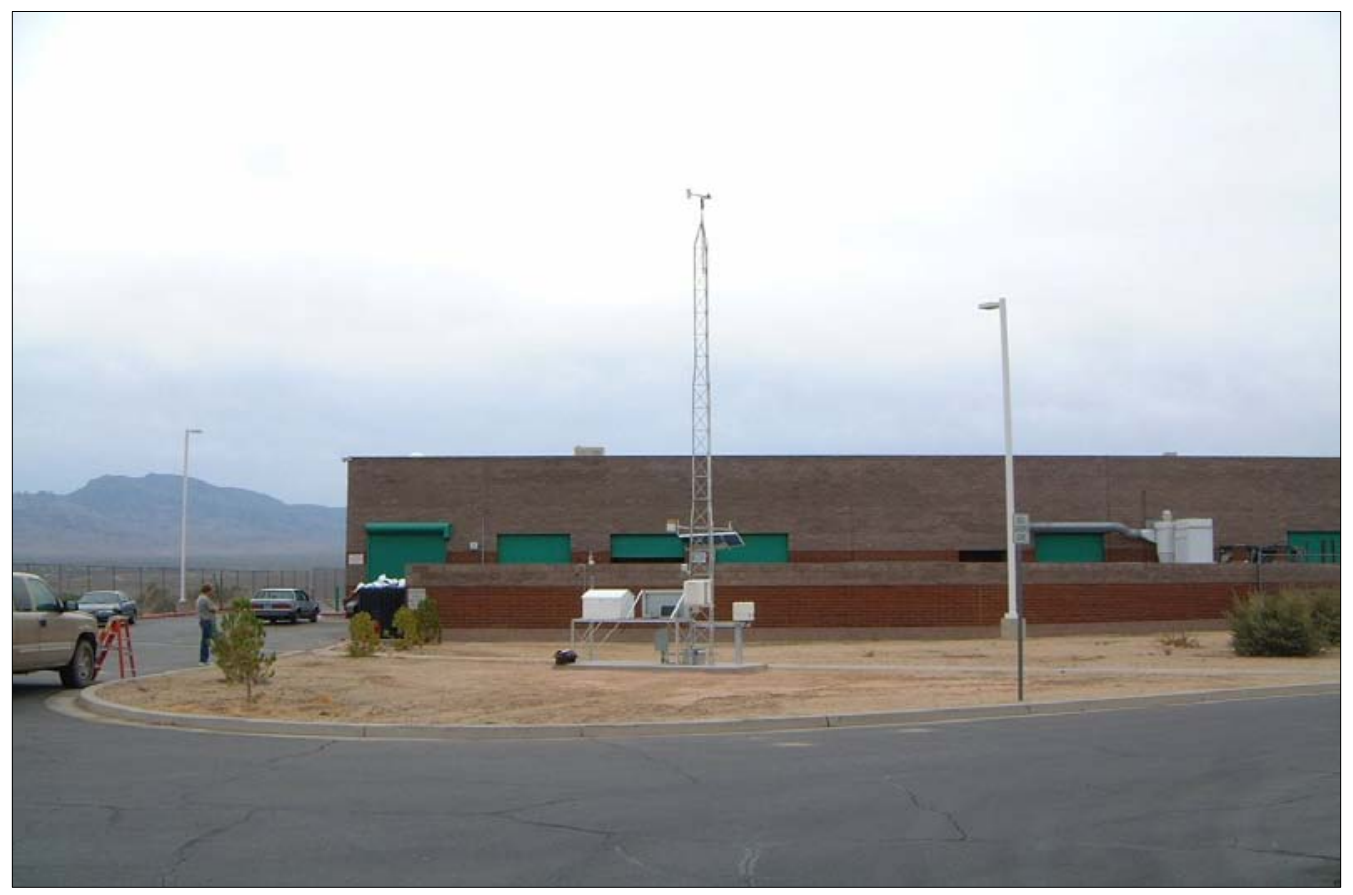

Figure 6-2. CEMP station at Mesquite, Nevada

CEMP Thermoluminescent Dosimetry (TLD) Network - TLD is another of the essential components of environmental radiological assessments. This is used to determine both individual and population external exposure to ambient radiation from natural and artificial sources. In 2006, the TLD network consisted of fixed environmental TLDs at 28 of the 29 CEMP stations (see Figure 6-1). A TLD is not currently deployed at Warm Springs Summit due to limited access during the winter months. The TLD used was a Panasonic UD-814AS. Within the TLD, a slightly shielded lithium borate element is used to check low-energy radiation levels while three calcium sulfate elements are used to measure penetrating gamma radiation. For quality assurance (QA) purposes, duplicate TLDs are deployed at three randomly-selected environmental stations. An average daily exposure rate was calculated for each quarterly exposure period. The average of the quarterly values was multiplied by 365.25 days to obtain the total annual exposure for each station.

CEMP Pressurized Ion Chamber (PIC) Network - The PIC detector measures gamma radiation exposure rates, and because of its sensitivity may detect low-level exposures that go undetected by other monitoring methods. PICs are in place at all 29 stations in the CEMP network (see Figure 6-1). The primary function of the PIC network is to detect changes in ambient gamma radiation due to human activities. In the absence of such activities, ambient gamma radiation rates vary naturally among locations reflecting differences in altitude (cosmic radiation), radioactivity in the soil (terrestrial radiation), and slight variations at a single location due to weather patterns. Since the addition of a full suite of meteorological instrumentation at the CEMP stations, variations in PIC readings caused by weather events such as precipitation or changes in barometric pressure are more readily identified. These variations can be easily

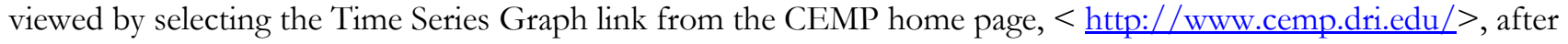
selecting a desired station and then selecting the desired variables.

CEMP Meteorological (MET) Network - Because changing weather conditions can have a significant effect on measurable levels of background radiation, meteorological instrumentation is in place at each of the 29 CEMP stations. The MET network includes sensors that measure air temperature, humidity, wind speed and direction, solar radiation, barometric pressure, precipitation, and soil temperature and moisture data. All of these data can be observed real-time at the onsite station display, and archived data are accessible by accessing the CEMP home page at $<$ http://www.cemp.dri.edu/>. 


\subsubsection{Air Particulate Sampling Results}

A sample of airborne particulates from a CEMP ASN station is collected by drawing air through a 2-inch (5-centimeter) diameter glass-fiber filter at a constant flow rate of 2 cubic feet $\left(\mathrm{ft}^{3}\right)$ per minute (86.6 liters per minute) at standard temperature and pressure. The actual flow rate and volume are measured and recorded with an in-line airflow calibrator. The particulate filter is mounted in a filter holder that faces downward at a height of $5 \mathrm{ft}(1.5$ meter $[\mathrm{m}]$ ) above the ground. The total actual volume collected ranges from approximately 19,000 to 28,000 $\mathrm{ft}^{3}$ (538 to 793 cubic meters $\left.\left[\mathrm{m}^{3}\right]\right)$ depending on the elevation of the station and changes in air temperature and/or pressure.

\subsubsection{Gross Alpha and Gross Beta}

Gross alpha and beta analysis in airborne particulate samples are used to screen for long-lived radionuclides in the air. The mean annual gross alpha activity across all sample locations was $1.36 \pm 0.48 \times 10^{-15}$ microcuries per milliliter $(\mu \mathrm{Ci} / \mathrm{mL})\left(5.03 \pm 1.78 \times 10^{-5}\right.$ Becquerels $\left.[\mathrm{Bq}] / \mathrm{m}^{3}\right)($ Table 6-1). Most of the results for 2006 exceeded the analytical minimum detectable concentration (MDC) (see Glossary, Appendix B) and, overall, are similar to results from previous years. Figure 6-3 shows the long-term maximum, mean, and minimum alpha trend for the CEMP stations as a whole.

Table 6-1. Gross alpha results for the CEMP offsite ASN in 2006

\begin{tabular}{|c|c|c|c|c|c|}
\hline \multirow[b]{2}{*}{ Sampling Location } & \multirow{2}{*}{$\begin{array}{c}\text { Number } \\
\text { of } \\
\text { Samples }\end{array}$} & \multicolumn{4}{|c|}{ Concentration $\left(\times 10^{-15} \mu \mathrm{Ci} / \mathrm{mL}\left[3.7 \times 10^{-5} \mathrm{~Bq} / \mathrm{m}^{3}\right]\right)$} \\
\hline & & Mean & $\begin{array}{c}\text { Standard } \\
\text { Deviation }\end{array}$ & Minimum & Maximum \\
\hline Alamo & 52 & 1.62 & 0.74 & 0.52 & 3.91 \\
\hline Amargosa Valley & 53 & 1.23 & 0.57 & 0.52 & 3.23 \\
\hline Beatty & 51 & 1.32 & 0.62 & 0.44 & 2.97 \\
\hline Boulder City & 53 & 2.33 & 0.87 & 0.58 & 4.41 \\
\hline Caliente & 53 & 1.70 & 0.73 & 0.55 & 3.43 \\
\hline Cedar City & 53 & 1.06 & 0.40 & 0.39 & 2.31 \\
\hline Delta & 53 & 1.11 & 0.41 & 0.43 & 2.53 \\
\hline Duckwater & 6 & 2.78 & 0.60 & 1.78 & 3.47 \\
\hline Ely & 51 & 0.95 & 0.43 & 0.21 & 1.90 \\
\hline Garden Valley & 53 & 1.12 & 0.43 & 0.48 & 2.41 \\
\hline Goldfield & 53 & 1.28 & 0.77 & 0.36 & 3.87 \\
\hline Henderson & 50 & 1.14 & 0.39 & 0.34 & 2.36 \\
\hline Indian Springs & 50 & 1.00 & 0.33 & 0.28 & 1.77 \\
\hline Las Vegas & 53 & 2.55 & 1.00 & 0.69 & 5.64 \\
\hline Mesquite & 53 & 1.24 & 0.46 & 0.34 & 2.47 \\
\hline Milford & 51 & 1.21 & 0.54 & 0.32 & 2.98 \\
\hline Nyala Ranch & 53 & 0.87 & 0.32 & 0.34 & 1.72 \\
\hline Overton & 53 & 1.48 & 0.71 & 0.54 & 3.67 \\
\hline Pahrump & 53 & 1.37 & 0.79 & 0.26 & 4.46 \\
\hline Pioche & 53 & 1.03 & 0.40 & 0.49 & 2.20 \\
\hline Rachel & 39 & 1.14 & 0.84 & 0.31 & 5.82 \\
\hline Sarcobatus Flats & 51 & 1.66 & 0.83 & 0.28 & 3.36 \\
\hline Stone Cabin Ranch & 53 & 1.03 & 0.34 & 0.47 & 2.09 \\
\hline St. George & 53 & 1.17 & 0.40 & 0.30 & 2.28 \\
\hline Tecopa/Shoshone & 41 & 1.28 & 0.56 & 0.32 & 2.92 \\
\hline Tonopah & 51 & 1.06 & 0.50 & 0.36 & 2.78 \\
\hline Twin Springs & 53 & 0.98 & 0.32 & 0.42 & 1.70 \\
\hline \multicolumn{6}{|c|}{ Network Mean $=1.36 \pm 0.48 \times 10^{-15} \mu \mathrm{Ci} / \mathrm{ml}$} \\
\hline
\end{tabular}




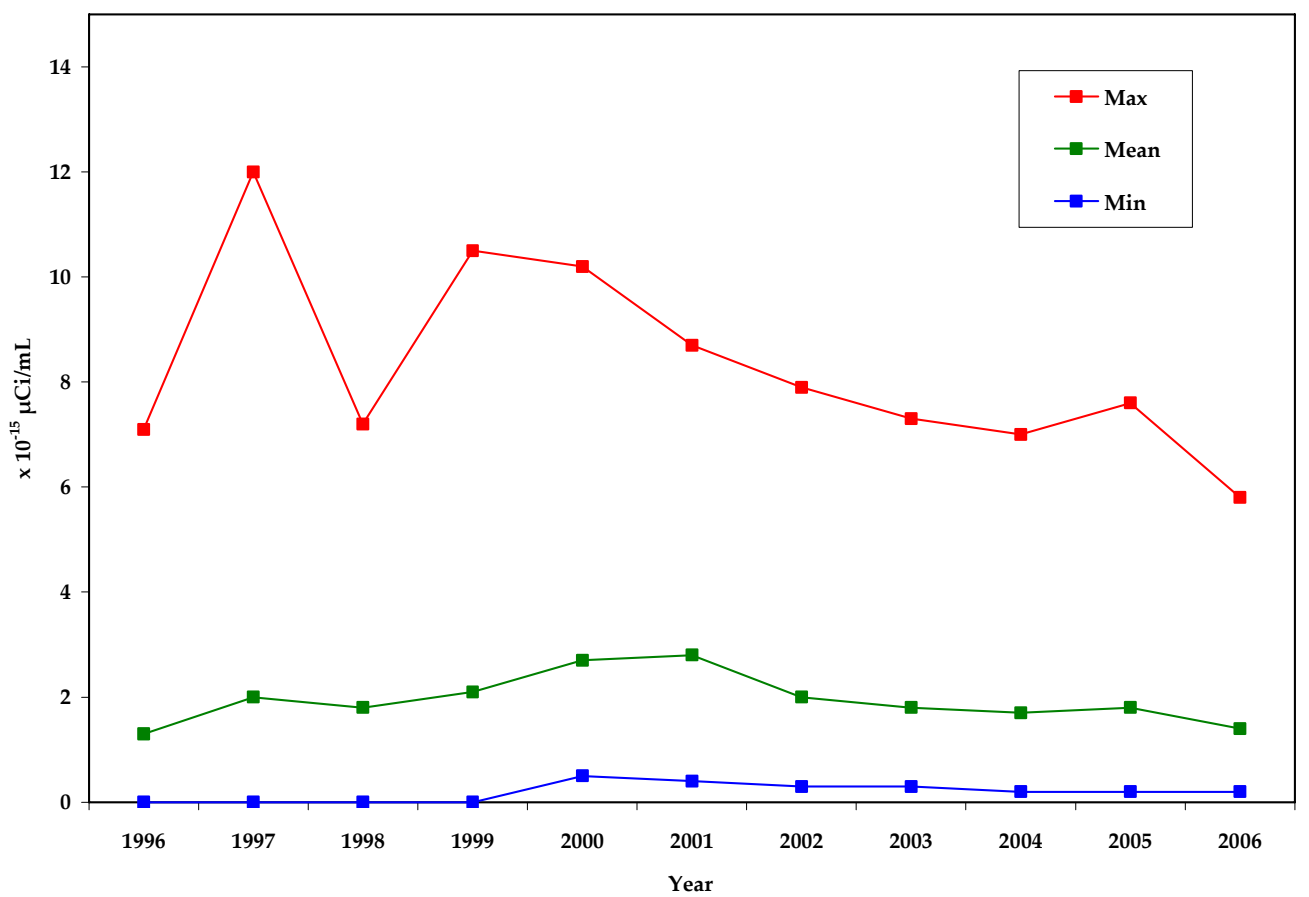

Figure 6-3. Historical trend for gross alpha analysis for all CEMP stations

The mean annual gross beta activity across all sample locations was $2.22 \pm 0.21 \times 10^{-14} \mu \mathrm{Ci} / \mathrm{mL}$

$\left(8.21 \pm 0.78 \times 10^{-4} \mathrm{~Bq} / \mathrm{m}^{3}\right)($ Table 6-2). Most of these results also exceeded the MDC, and are similar to previous years' data. Figure 6-4 shows the long-term maximum, mean, and minimum beta trend for the CEMP stations as a whole.

Table 6-2. Gross beta results for the CEMP offsite ASN in 2006

\begin{tabular}{|c|c|c|c|c|c|}
\hline \multirow[b]{2}{*}{ Sampling Location } & \multirow[b]{2}{*}{$\begin{array}{c}\text { Number of } \\
\text { Samples }\end{array}$} & \multicolumn{4}{|c|}{ Concentration $\left(\times 10^{-14} \mu \mathrm{Ci} / \mathrm{mL}\left[3.7 \times 10^{-4} \mathrm{~Bq} / \mathrm{m}^{3}\right]\right)$} \\
\hline & & Mean & $\begin{array}{l}\text { Standard } \\
\text { Deviation }\end{array}$ & Minimum & Maximum \\
\hline Alamo & 52 & 2.23 & 0.64 & 1.29 & 4.52 \\
\hline Amargosa Valley & 53 & 2.20 & 0.66 & 0.99 & 3.97 \\
\hline Beatty & 51 & 2.20 & 0.69 & 0.74 & 3.95 \\
\hline Boulder City & 53 & 2.47 & 0.87 & 1.12 & 5.46 \\
\hline Caliente & 53 & 2.41 & 0.68 & 1.14 & 4.51 \\
\hline Cedar City & 53 & 1.99 & 0.56 & 0.90 & 3.37 \\
\hline Delta & 53 & 2.23 & 0.80 & 0.97 & 5.75 \\
\hline Duckwater & 6 & 2.78 & 0.60 & 1.78 & 3.42 \\
\hline Ely & 51 & 2.02 & 0.59 & 1.06 & 3.18 \\
\hline Garden Valley & 53 & 2.19 & 0.55 & 1.13 & 3.37 \\
\hline Goldfield & 53 & 2.02 & 0.60 & 0.92 & 3.33 \\
\hline Henderson & 50 & 2.17 & 0.72 & 0.95 & 4.78 \\
\hline Indian Springs & 50 & 2.00 & 0.54 & 1.01 & 3.31 \\
\hline Las Vegas & 53 & 2.55 & 0.81 & 1.26 & 5.30 \\
\hline
\end{tabular}


Table 6-2. Gross beta results for the CEMP offsite ASN in 2006 (continued)

\begin{tabular}{|c|c|c|c|c|c|}
\hline \multirow[b]{2}{*}{ Sampling Location } & \multirow[b]{2}{*}{$\begin{array}{l}\text { Number of } \\
\text { Samples }\end{array}$} & \multicolumn{4}{|c|}{ Concentration $\left(\times 10^{-14} \mu \mathrm{Ci} / \mathrm{mL}\left[3.7 \times 10^{-4} \mathrm{~Bq} / \mathrm{m}^{3}\right]\right)$} \\
\hline & & Mean & $\begin{array}{l}\text { Standard } \\
\text { Deviation }\end{array}$ & Minimum & Maximum \\
\hline Mesquite & 53 & 2.38 & 0.77 & 1.19 & 4.74 \\
\hline Milford & 51 & 2.36 & 0.79 & 1.01 & 5.04 \\
\hline Nyala Ranch & 53 & 1.95 & 0.66 & 1.05 & 5.12 \\
\hline Overton & 53 & 2.42 & 0.75 & 1.20 & 5.66 \\
\hline Pahrump & 53 & 2.18 & 0.67 & 0.89 & 3.86 \\
\hline Pioche & 53 & 1.98 & 0.61 & 0.92 & 3.76 \\
\hline Rachel & 39 & 2.22 & 0.71 & 0.71 & 3.85 \\
\hline Sarcobatus Flats & 51 & 2.25 & 0.61 & 1.00 & 3.79 \\
\hline Stone Cabin & 53 & 1.98 & 0.53 & 0.50 & 2.86 \\
\hline St. George & 53 & 2.41 & 0.86 & 1.05 & 5.07 \\
\hline Tecopa/Shoshone & 41 & 2.39 & 0.91 & 0.87 & 6.10 \\
\hline Tonopah & 51 & 1.95 & 0.59 & 0.88 & 3.01 \\
\hline Twin Springs & 53 & 2.13 & 0.71 & 1.06 & 5.13 \\
\hline $\begin{array}{l}\text { Network Mean }=2.22 \\
\text { Mean } M D C=0.12 \times 10\end{array}$ & $\begin{array}{l}\times 10^{-14} \mu \mathrm{Ci} / \mathrm{m} \\
\mathrm{i} / \mathrm{mL}\end{array}$ & Stan & d Error of $M$ & $M D C=0.01 x$ & ${ }^{14} \mu \mathrm{Ci} / \mathrm{mL}$ \\
\hline
\end{tabular}

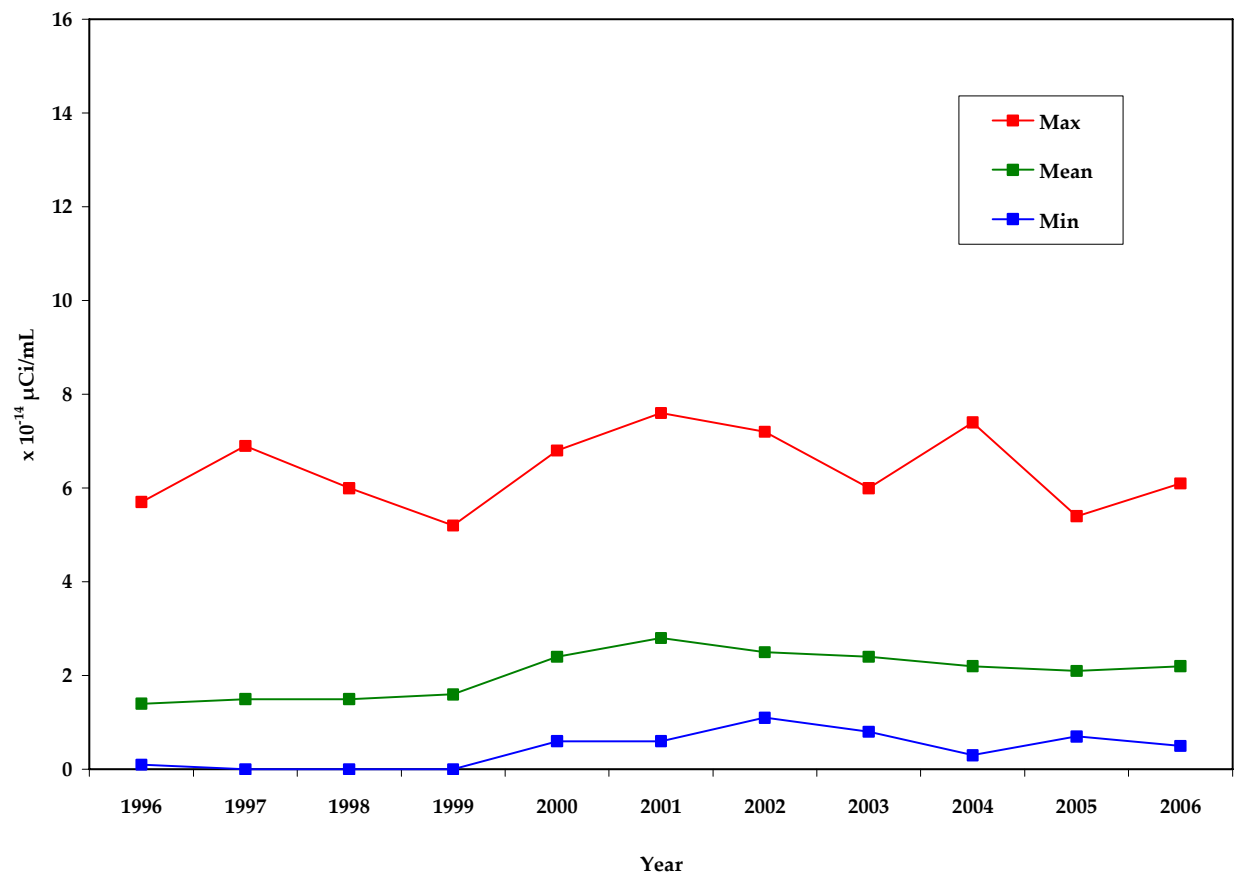

Figure 6-4. Historical trend for gross beta analysis for all CEMP stations

The overall gross alpha results show a generally increasing trend from 1996 to 2001 before slightly trending downward the last five years. Likewise, the gross beta results show a similar trend beginning in 1998. These trends are also reflected by most of the stations on an individual basis. This trend is most likely explained as being a result of persistent drought conditions throughout the southwest and Great Basin states. Drought in these regions has existed 
to varying degrees since 1996. These dry conditions could be directly responsible for an increase in suspended air particles collected by the air-sampling network. The apparent spikes in the maximum trend lines for gross alpha and beta are the result of a single analysis for that year. These analyses occurred prior to the CEMP being directed by DRI, so specific information is not available.

\subsubsection{Gamma Spectroscopy}

Gamma spectroscopy analysis was performed on all samples from the low-volume air-sampling network. The filters were composited by station on a quarterly basis after gross alpha/beta analysis. As in previous years, all samples were gamma-spectrum negligible with respect to man-made radionuclides (i.e., gamma-emitting radionuclides were not detected). In most of the samples, naturally occurring ${ }^{7} \mathrm{Be}$ was detected above the analytical MDC. This radionuclide is produced by cosmic ray interaction with nitrogen in the atmosphere. The mean annual activity for ${ }^{7} \mathrm{Be}$ for the sampling network was $88.1 \pm 24.9 \times 10^{-15} \mu \mathrm{Ci} / \mathrm{mL}$.

\subsubsection{TLD Results}

TLDs measure ionizing radiation from all sources, including natural radioactivity from cosmic or terrestrial sources and from man-made radioactive sources. The TLDs are mounted in a plexiglass holder approximately $1 \mathrm{~m}$ above the ground, and are exchanged quarterly. TLD results are not presented for Warm Springs Summit at this time since its access is limited in the winter months. This does not allow for a proper quarterly change of the TLD as required. TLD results are not presented for Duckwater, as a TLD was not placed at the station until January of 2007. The total annual exposure for 2006 ranged from 77 milliroentgens (mR) (0.77 millisieverts [mSv]) at Pahrump, Nevada, to $154 \mathrm{mR}(1.54 \mathrm{mSv})$ at Sarcobatus Flats, Nevada, with a mean annual exposure of $119 \mathrm{mR}(1.19 \mathrm{mSv})$ for all operating locations. Results are summarized in Table 6-3 and are consistent with previous years' data. Figure 6-5 shows the long-term trend for the CEMP stations as a whole.

Table 6-3. TLD monitoring results for the CEMP offsite ASN in 2006

\begin{tabular}{|c|c|c|c|c|c|}
\hline \multirow{2}{*}{$\begin{array}{l}\text { Sampling } \\
\text { Location }\end{array}$} & \multirow{2}{*}{$\begin{array}{c}\text { Number of } \\
\text { Days }\end{array}$} & \multicolumn{3}{|c|}{ Daily Exposure (mR) } & \multirow{2}{*}{$\begin{array}{c}\text { Total Annual } \\
\text { Exposure (mR) }\end{array}$} \\
\hline & & Mean & Minimum & Maximum & \\
\hline Alamo & 364 & 0.33 & 0.31 & 0.38 & 121 \\
\hline Amargosa Valley & 371 & 0.30 & 0.28 & 0.34 & 109 \\
\hline Beatty & 364 & 0.39 & 0.36 & 0.41 & 142 \\
\hline Boulder City & 358 & 0.30 & 0.28 & 0.31 & 108 \\
\hline Caliente & 364 & 0.34 & 0.32 & 0.35 & 123 \\
\hline Cedar City & 364 & 0.26 & 0.26 & 0.27 & 96 \\
\hline Delta & 364 & 0.28 & 0.27 & 0.29 & 101 \\
\hline Ely & 364 & 0.31 & 0.26 & 0.41 & 115 \\
\hline Garden Valley & 372 & 0.42 & 0.40 & 0.43 & 152 \\
\hline Goldfield & 364 & 0.34 & 0.33 & 0.36 & 125 \\
\hline Henderson & 358 & 0.32 & 0.30 & 0.33 & 145 \\
\hline Indian Springs & 371 & 0.20 & 0.26 & 0.28 & 98 \\
\hline Las Vegas & 350 & 0.28 & 0.26 & 0.30 & 103 \\
\hline Medlin's Ranch & 370 & 0.39 & 0.37 & 0.42 & 142 \\
\hline Mesquite & 358 & 0.29 & 0.28 & 0.32 & 107 \\
\hline Milford & 364 & 0.40 & 0.37 & 0.41 & 144 \\
\hline Nyala Ranch & 370 & 0.31 & 0.29 & 0.32 & 112 \\
\hline Overton & 358 & 0.26 & 0.24 & 0.29 & 95 \\
\hline Pahrump & 371 & 0.21 & 0.20 & 0.22 & 78 \\
\hline Pioche & 364 & 0.31 & 0.31 & 0.32 & 113 \\
\hline Rachel & 364 & 0.37 & 0.33 & 0.39 & 134 \\
\hline Sarcobatus Flats & 364 & 0.42 & 0.40 & 0.44 & 154 \\
\hline Stone Cabin Ranch & 370 & 0.38 & 0.29 & 0.43 & 140 \\
\hline
\end{tabular}


Table 6-3. TLD monitoring results for the CEMP offsite ASN in 2006 (continued)

\begin{tabular}{||lccccc||}
\hline Sampling & Number of & \multicolumn{3}{c}{ Daily Exposure (mR) } & Total Annual \\
\cline { 3 - 5 } Location & Days & Mean & Minimum & Maximum & Exposure (mR) \\
\hline St. George & 364 & 0.24 & 0.22 & 0.27 & 89 \\
Tecopa/Shoshone & 371 & 0.31 & 0.31 & 0.31 & 113 \\
Tonopah & 365 & 0.36 & 0.33 & 0.38 & 132 \\
Twin Springs & 371 & 0.42 & 0.36 & 0.46 & 153 \\
\hline Overall Annual Mean $=\mathbf{1 1 9} \mathbf{~} \mathbf{m R}$ & \multicolumn{4}{|l}{} \\
\hline
\end{tabular}

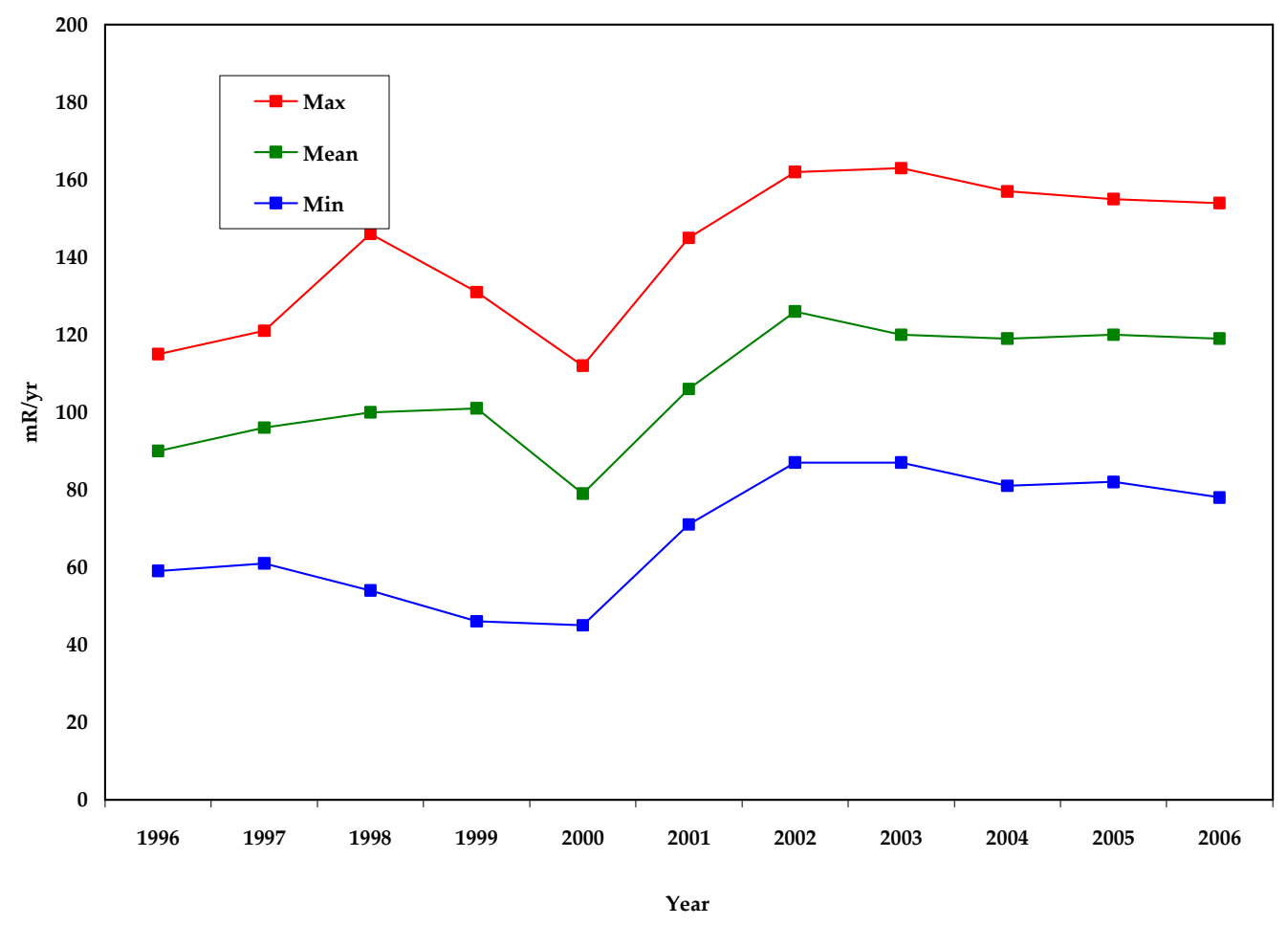

Figure 6-5. Historical trend for TLD analysis for all CEMP stations

As with the gross alpha and beta results, the TLD data also shows a generally increasing trend from 1996 to 2002 before showing a slight decrease the last four years. This again may be consistent with drought conditions observed in the regions around the monitoring network. As the soil becomes drier due to lack of precipitation, the naturallyoccurring radionuclides may more easily escape into the atmosphere as part of the increased suspended particle load. This could result in an increase in natural radioactivity detected by the TLD, similar to the gross alpha and beta results.

\subsubsection{PIC Results}

The PIC data presented in this section are based on daily averages of gamma exposure rates from each station. Table 6-4 contains the maximum, minimum, and standard deviation of daily averages (in microroentgens per hour $[\mu \mathrm{R} / \mathrm{hr}])$ for the periods during 2006 when telemetry data were available. It also shows the average gamma exposure rate for each station during the year (in $\mu \mathrm{R} / \mathrm{hr}$ ) as well as the total annual exposure (in $\mathrm{mR}$ per year [mR/yr]). The Shoshone/Tecopa station includes data from mid-February through 2006. The Duckwater station was installed in November 2006, and therefore includes data from November and December only. The exposure rate ranged from $72.27 \mathrm{mR} / \mathrm{yr}(0.72 \mathrm{mSv})$ in Pahrump to $183.08 \mathrm{mR} / \mathrm{yr}(1.83 \mathrm{mSv})$ in Milford, Utah. Background levels of 
environmental gamma exposure rates in the United States (from combined effects of terrestrial and cosmic sources) vary between 49 and $247 \mathrm{mR} / \mathrm{yr}$ (BEIR III, 1980). Averages for selected regions of the United States were compiled by the U.S. Environmental Protection Agency and are shown in Table 6-5. The annual exposure levels observed at the CEMP stations in 2006 are well within these United States background levels.

Table 6-4. PIC monitoring results for the CEMP offsite ASN in 2006

\begin{tabular}{|c|c|c|c|c|c|}
\hline \multirow[b]{2}{*}{ Sampling Location } & \multicolumn{4}{|c|}{ Daily Average Gamma Exposure Rate $(\mu \mathrm{R} / \mathrm{hr})$} & \multirow{2}{*}{$\begin{array}{c}\text { Annual } \\
\text { Exposure } \\
(\mathrm{mR} / \mathrm{yr})\end{array}$} \\
\hline & Mean & $\begin{array}{c}\text { Standard } \\
\text { Deviation }\end{array}$ & Minimum & Maximum & \\
\hline Alamo & 13.33 & 0.23 & 12.49 & 14.17 & 116.77 \\
\hline Amargosa Valley & 12.63 & 0.15 & 11.95 & 13.31 & 110.64 \\
\hline Beatty & 15.71 & 0.74 & 12.97 & 18.45 & 137.62 \\
\hline Boulder City & 15.62 & 0.13 & 14.62 & 15.62 & 132.45 \\
\hline Caliente & 15.79 & 0.30 & 14.87 & 16.70 & 138.28 \\
\hline Cedar City & 11.25 & 0.21 & 10.43 & 12.07 & 98.55 \\
\hline Delta & 10.75 & 0.75 & 8.61 & 12.89 & 94.17 \\
\hline Duckwater & 14.40 & 0.47 & 13.50 & 15.30 & 126.14 \\
\hline Ely & 11.16 & 0.81 & 9.05 & 13.27 & 97.76 \\
\hline Garden Valley & 18.51 & 0.50 & 17.06 & 19.96 & 162.15 \\
\hline Goldfield & 15.15 & 0.36 & 14.23 & 16.07 & 132.71 \\
\hline Henderson & 15.09 & 0.12 & 14.65 & 15.52 & 132.14 \\
\hline Indian Springs & 11.60 & 0.22 & 10.87 & 12.32 & 101.57 \\
\hline Las Vegas & 10.67 & 0.12 & 10.21 & 11.12 & 93.43 \\
\hline Medlin's Ranch & 16.63 & 0.37 & 15.61 & 17.65 & 145.68 \\
\hline Mesquite & 11.79 & 0.16 & 11.29 & 12.29 & 103.28 \\
\hline Milford & 20.90 & 0.36 & 19. 34 & 22. 46 & 183.08 \\
\hline Nyala Ranch & 13.38 & 0.45 & 12.01 & 14.75 & 117.21 \\
\hline Overton & 10.76 & 0.19 & 9.58 & 10.76 & 89.09 \\
\hline Pahrump & 8.25 & 0.13 & 7.87 & 8.63 & 72.27 \\
\hline Pioche & 14.82 & 0.62 & 13.14 & 16.49 & 129.78 \\
\hline Rachel & 15.70 & 0.30 & 14.78 & 16.61 & 137.49 \\
\hline Sarcobatus Flats & 17.59 & 0.26 & 16.53 & 18.64 & 154.04 \\
\hline Stone Cabin Ranch & 17.18 & 0.75 & 15.67 & 18.69 & 150.50 \\
\hline St. George & 9.31 & 0.20 & 8.75 & 9.86 & 81.51 \\
\hline Tecopa/Shoshone & 15.05 & 0.17 & 14.50 & 15.60 & 131.84 \\
\hline Tonopah & 15.99 & 0.29 & 15.00 & 16.98 & 140.07 \\
\hline Twin Springs & 19.57 & 0.58 & 17.85 & 21.28 & 171.39 \\
\hline Warm Springs Summit & 19.58 & 0.47 & 18.04 & 21.12 & 171.52 \\
\hline
\end{tabular}


Table 6-5. Average natural background radiation for selected U.S. cities (excluding radon)

\begin{tabular}{||l|c||}
\hline City & Radiation (mR/yr) \\
\hline Denver, CO & 164.6 \\
Tampa, FL & 63.7 \\
Portland, OR & 86.7 \\
Los Angeles, CA & 73.6 \\
St. Louis, MO & 87.9 \\
Rochester, NY & 88.1 \\
Wheeling, WV & 111.9 \\
Richmond, VA & 64.1 \\
New Orleans, LA & 63.7 \\
Fort Worth, TX & 68.7 \\
\hline \hline
\end{tabular}

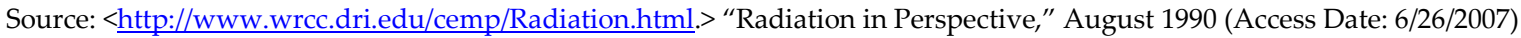

\subsubsection{Environmental Impact}

Results of analyses conducted on data obtained from the CEMP network of low-volume particulate air samplers, TLDs, and PICs showed no measurable evidence at CEMP station locations of offsite impact from radionuclides originating on the NTS. Activity observed in gross alpha and beta analyses of low-volume air sampler filters was consistent with previous years' results and are within the range of activity found in other communities of the United States which are not adjacent to man-made radiation sources. Also, no man-made gamma-emitting radionuclides were detected. Likewise, TLD and PIC results remained consistent with previous years' background levels and are well within average background levels observed in other parts of the United States (see Table 6-5).

Occasional elevated gamma readings (10-50 percent above normal average background) were always associated with precipitation events and/or low barometric pressure. Low barometric pressure can result in the release of naturally-occurring radon and its daughter products from the surrounding soil and rock substrates. Precipitation events can result in the "rainout" of globally-distributed radionuclides occurring as airborne particulates in the upper atmosphere. Figure 6-6, generated from the CEMP Web site, illustrates an example of this phenomenon.

\section{Amargosa Valley Nevada}

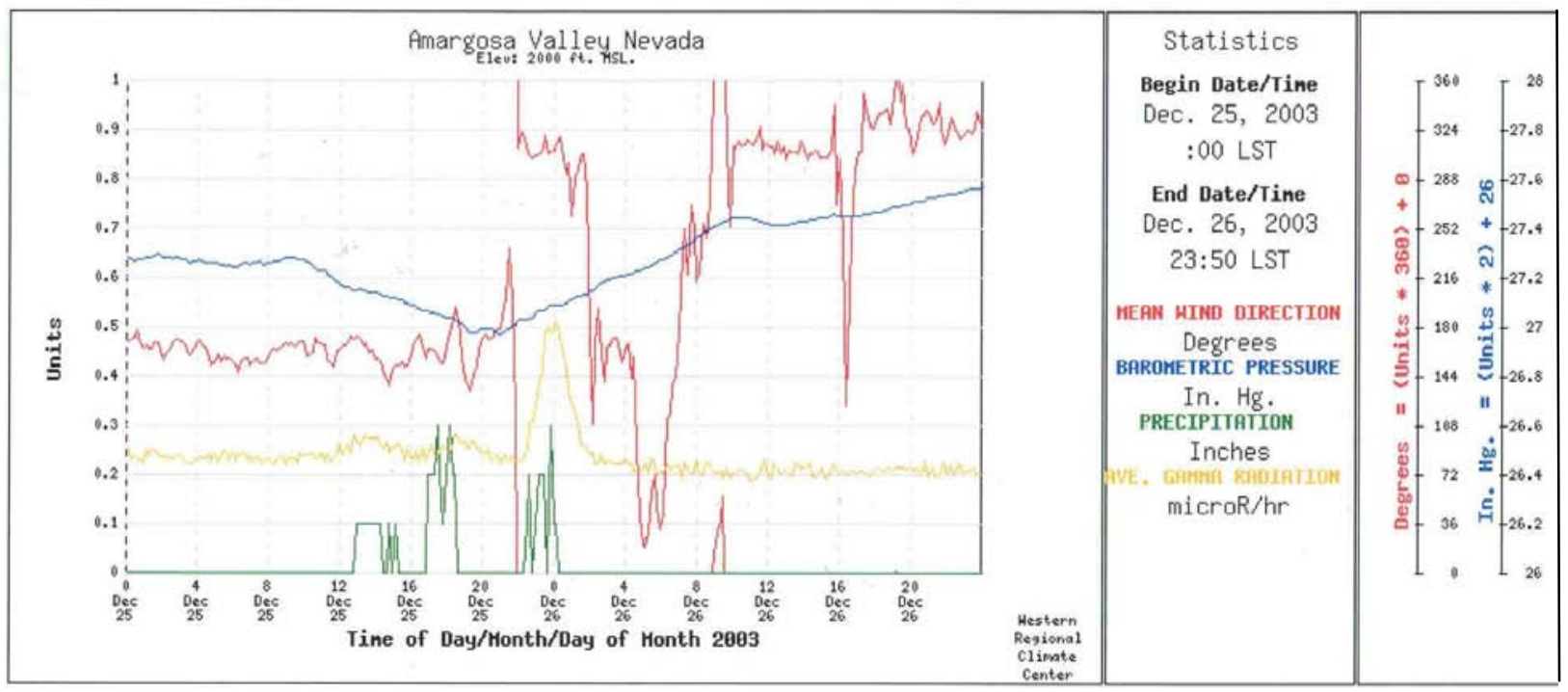

Figure 6-6. The effect of meteorological phenomena on background gamma readings 


\subsection{Offsite Surface and Groundwater Monitoring}

During 2006, the DRI was tasked by NNSA/NSO to provide independent verification of the tritium activity within some of the offsite groundwater wells, surface waters, and springs used for water supplies in areas surrounding the NTS. Samples collected by DRI personnel provide, in some cases, a direct comparison to the results obtained by National Security Technologies, LLC (NSTec), under the Routine Radiological Environmental Monitoring Plan (RREMP) (Section 4.1).

The sole analyte for this project was tritium. Tritium is one of the most abundant radionuclides generated by an underground nuclear test and, since it is a constituent of the water molecule itself, it is also one of the most mobile.

\subsubsection{Sample Locations and Methods}

During the period of June 27 to October 24, 2006, 4 springs, 20 wells, and 3 surface water bodies were sampled either directly or through municipal water supply systems. Sample locations were selected based upon input from the CEMs and local ranch owners participating in the CEMP project. All wells were sampled utilizing downhole submersible pumps. Samples from surface water bodies were obtained via discharge from a faucet or valve connected to the water supply system that pumps that body of water. Springs were sampled by hand at the orifice, along surface drainage, or from the water supply system connected to the spring discharge. Each well was pumped a minimum of 5 to 15 minutes prior to sampling to purge water from the pump tubing and well annulus. This process ensured that the resultant sample was representative of local groundwater. Table 6-6 lists all of the sample points, their locations, the date they were sampled, and the sampling method. The locations of the sample points are shown in Figure 6-7.

\subsubsection{Procedures and Quality Assurance}

DRI utilized several methods to ensure that radiological results reported herein conform to current QA protocols (see Section 19.0 for a detailed description of the CEMP QA program). This was achieved through the use of standard operating procedures, field QA samples, and laboratory QA procedures. DRI's standard operating procedures are detailed procedures that describe the method and materials, using step-by-step instructions, which are required to collect field water quality samples and protect the samples from tampering and environmental conditions that may alter their chemistry.

The second tier of QA utilized on this project consisted of field QA samples. The intent of these samples and procedures was to provide direct measures of the contribution of radioactive material that was derived from the bottles, sampling equipment, and the environment to the activity of tritium measured within the samples. Duplicate samples were collected to establish a measure of the repeatability of the analysis. Eight samples (23 percent of the sample load) were collected for the purposes of meeting field QA requirements. Laboratory QA controls consisted of the utilization of published laboratory techniques for the analysis of tritium, method blanks, laboratory control samples, and laboratory duplicates. The laboratory QA samples provide a measure of the accuracy and the confidence of the reported results.

The method by which tritium samples were analyzed was changed in 2006. Prior to 2006, samples were analyzed at DRI using enriched tritium analysis. The tritium laboratory at DRI was closed in 2006. Samples collected in 2006 were analyzed using gas proportional counting at the University of Miami. Detection limits were low enough that enrichment was not required. The decision level ( $\mathrm{L}_{\mathrm{C}}$ ) (see Glossary, Appendix B) of tritium ranged from 10.5 to 16.0 picocuries per liter $(\mathrm{pCi} / \mathrm{L})$. The $\mathrm{L}_{\mathrm{C}}$ is the result that must be exceeded before there is a 95 percent confidence that the sample contains radioactive material above background. The MDC (see Glossary, Appendix B) for tritium was approximately $24 \mathrm{pCi} / \mathrm{L}$. NSTec reports that the MDC for enriched tritium analyses for the RREMP water samples ranged from 11 to $37 \mathrm{pCi} / \mathrm{L}$ with an average of $18.7 \mathrm{pCi} / \mathrm{L}$ (see Section 4.1.2). 


\begin{tabular}{|c|c|c|c|c|}
\hline Monitoring Location Description & Latitude & Longitude & $\begin{array}{c}\text { Date } \\
\text { Sampled }\end{array}$ & Sample Collection Method \\
\hline Adaven Springs & 3808.25 & -11536.20 & $6 / 28 / 2006$ & By hand from stream discharging from spring orifice \\
\hline $\begin{array}{l}\text { Alamo city water supply system - source of water is } \\
\text { municipal well field }\end{array}$ & 3721.74 & -11510.14 & $7 / 05 / 2006$ & By hand from municipal water well \\
\hline Amargosa Valley school well & 3634.16 & -11627.66 & $8 / 01 / 2006$ & By hand at wellhead \\
\hline Beatty Water and Sewer - municipal well & 3654.94 & -11645.65 & $10 / 01 / 2006$ & By hand at wellhead at utility headquarters \\
\hline $\begin{array}{l}\text { Boulder City - at Hemingway Park from municipal water } \\
\text { distribution system }\end{array}$ & 3559.74 & -11449.90 & $8 / 24 / 2006$ & $\begin{array}{l}\text { By hand from a drinking fountain inside Hemingway Park, } \\
\text { water originates from Lake Mead }\end{array}$ \\
\hline Caliente municipal water supply well & 3736.93 & -11430.98 & $8 / 15 / 2006$ & By hand at well in municipal well field \\
\hline $\begin{array}{l}\text { Cedar City municipal water supply well about } \\
10 \text { miles (mi) west of town }\end{array}$ & 3739.84 & -11313.03 & $8 / 17 / 2006$ & By hand at wellhead, sampled new well location this year \\
\hline Delta municipal well & 3921.59 & -11234.65 & $8 / 16 / 2006$ & By hand at well head \\
\hline Ely municipal water source & 3913.80 & -11454.01 & $6 / 28 / 2006$ & $\begin{array}{l}\text { By hand from spring, discharge used as municipal water } \\
\text { supply }\end{array}$ \\
\hline $\begin{array}{l}\text { Goldfield Municipal Water Supply well about } 12 \mathrm{mi} \\
\text { north of town }\end{array}$ & 3752.41 & -11714.76 & $8 / 21 / 2006$ & By hand at wellhead, sampled new well location this year \\
\hline $\begin{array}{l}\text { Henderson CCSN - source of water is municipal water } \\
\text { system originating at Lake Mead }\end{array}$ & 3600.43 & -11457.95 & $8 / 24 / 2006$ & $\begin{array}{l}\text { By hand from faucet inside college building; water originates } \\
\text { from Lake Mead }\end{array}$ \\
\hline Indian Springs municipal well & 3606.87 & -11508.85 & $10 / 20 / 2006$ & By hand at wellhead, sampled new well location this year \\
\hline Las Vegas Valley Water District \#103 & 3613.94 & -11515.13 & $8 / 23 / 2006$ & By hand at wellhead \\
\hline Medlin's Ranch - spring $11 \mathrm{mi}$ west of ranch house & 3724.10 & -11532.25 & $7 / 05 / 2006$ & By hand at kitchen faucet \\
\hline Mesquite Municipal Water Supply Well 3 mi S.E. of town & 3646.40 & -11403.26 & $8 / 23 / 2006$ & By hand at well head \\
\hline Milford municipal well & 3822.88 & -11259.78 & $8 / 16 / 2006$ & By hand at wellhead \\
\hline Nyala Ranch water well & 3814.93 & -11543.72 & $6 / 27 / 2006$ & By hand from front yard hose faucet at house \\
\hline $\begin{array}{l}\text { Overton water well located at Arrow Canyon about } 10 \mathrm{mi} \\
\text { west of town }\end{array}$ & 3644.06 & -11444.87 & $8 / 23 / 2006$ & By hand at wellhead \\
\hline Pahrump municipal utility well \#11 & 3612.32 & -11559.12 & $8 / 02 / 22006$ & By hand at wellhead \\
\hline Pioche municipal well located $1 \mathrm{mi}$ east of town & 3756.98 & -11425.78 & $8 / 15 / 2006$ & By hand at wellhead \\
\hline Rachel - Little Ale Inn well & 3738.79 & -11544.75 & $6 / 27 / 2006$ & By hand from bar faucet inside Lil Ale Inn Restaurant \\
\hline Sarcobatus Flats well & 3716.78 & -11701.92 & $8 / 02 / 2006$ & By hand at wellhead \\
\hline St. George Quail Creek Reservoir & 3710.43 & -11323.96 & $8 / 17 / 2006$ & $\begin{array}{l}\text { By hand at water treatment plant, water originates from } \\
\text { Quail Creek Reservoir }\end{array}$ \\
\hline Stone Cabin Ranch Spring & 3812.51 & -11637.95 & $6 / 27 / 2006$ & By hand from outside house faucet at new location this year \\
\hline Tecopa Residential Well & 3755.60 & -11615.71 & $10 / 20 / 2006$ & By hand at well head \\
\hline Tonopah public utilities well field located $10 \mathrm{mi}$ from town & 3811.68 & -11704.70 & $10 / 24 / 2006$ & By hand at wellhead \\
\hline Twin Springs Ranch Well & 3813.02 & -11609.83 & $6 / 27 / 2006$ & By hand from well head, sampled new location this year \\
\hline
\end{tabular}

Note: Sample locations were resurveyed in 2004 using global positioning satellite data. The following sample locations were moved in 2006: Indian Springs was moved approximately $1.4 \mathrm{~km}$ on request by the facility manager. Cedar City sampled a new well this year. Goldfield sampled a new well this year. Stone Cabin was sampled at an outside faucet at an adjacent house this year. The origin of Twin Springs Ranch water has, in the past, been erroneously reported as being from a spring on location. In actuality, water originates from a well drilled near the spring. All updated sample locations are shown in Figure 6-7. 


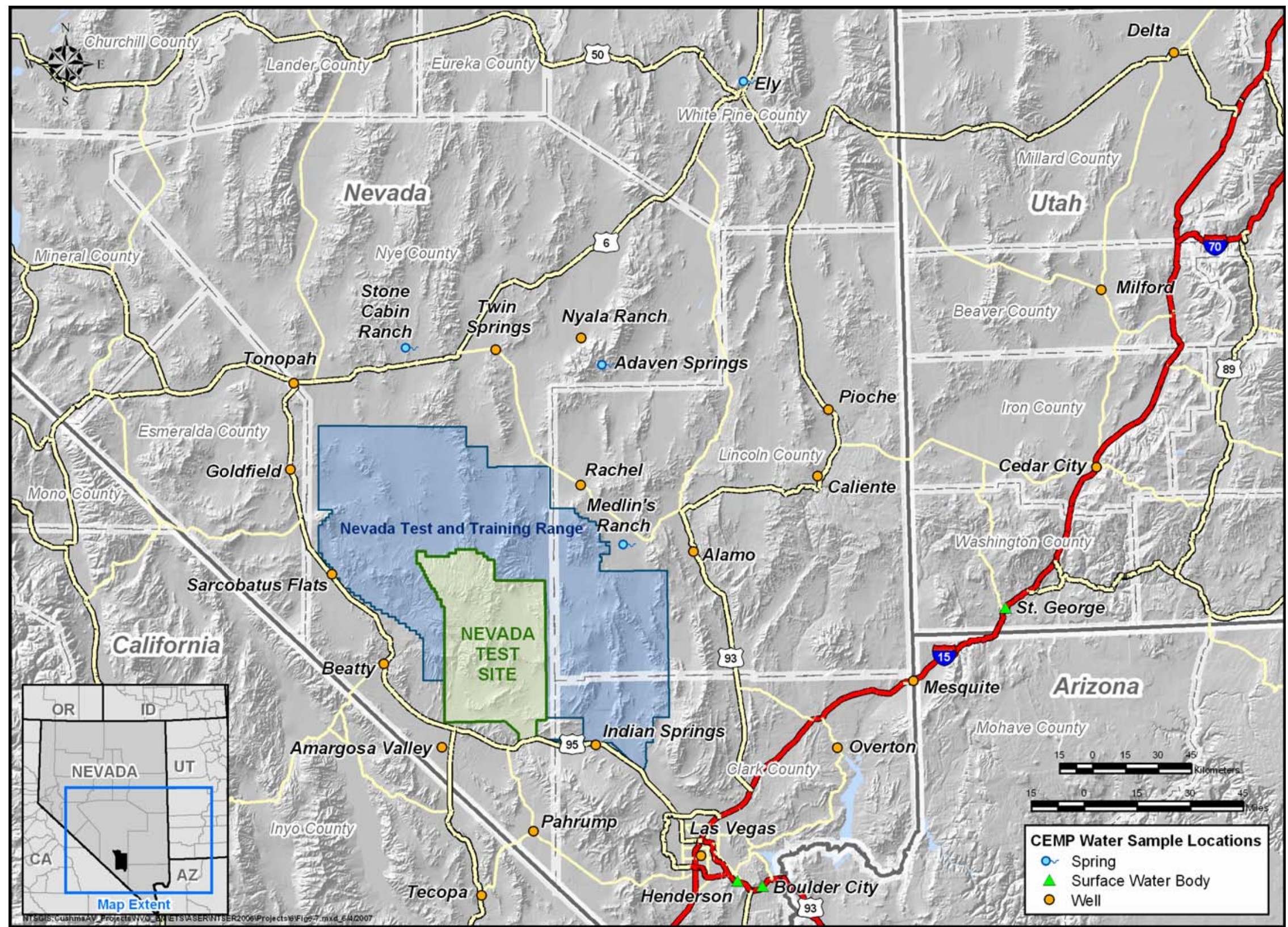

Figure 6-7. 2006 CEMP water monitoring locations 


\subsubsection{Results of Surface Water and Spring Discharge Monitoring}

Measured tritium $\left({ }^{3} \mathrm{H}\right)$ concentrations from the springs and surface waters ranged from 0 to $35.4 \mathrm{pCi} / \mathrm{L}$ (Table 6-7). Four of the samples, Ely, Medlin's Ranch, Stone Cabin Ranch, and St. George, yielded results that were indistinguishable from background (i.e., $\leq \mathrm{L}_{\mathrm{C}}$ ). The Adaven Springs and Henderson samples were above background (i.e., $\geq \mathrm{L}_{\mathrm{C}}$ ), yet the activity was too low to quantitatively distinguish from background at 95 percent confidence (i.e, < MDC). Boulder City had a tritium activity that was sufficiently high to quantify above background with 95 percent confidence (i.e., $\geq$ MDC). The water in these samples originated from Lake Mead. Slightly elevated tritium activities in Lake Mead are well documented by previous investigations (U.S. Department of Energy [DOE], 2002d; 2003b; 2004c; 2005a) and are due to residual tritium persisting in the environment that originated from global atmospheric nuclear testing. The Henderson sample also originates from Lake Mead. The discrepancy between the Henderson and Boulder City samples are due to fairly large uncertainties associated with each sample. All tritium results were well below the safe drinking water limit of $20,000 \mathrm{pCi} / \mathrm{L}$. The majority of sample results were statistically similar to results reported by DRI in the Nevada Test Site Environmental Report 2005 (DOE, 2005a). The exceptions consist of Medlin's Ranch, Boulder City, and Henderson. In 2005, Medlin's Ranch was reported as $10 \pm$ $18 \mathrm{pCi} / \mathrm{L}$, which exceeded the $\mathrm{L}_{\mathrm{C}}$ associated with that analysis $(7 \mathrm{pCi} / \mathrm{L})$. This year's result are below the Lc. Boulder City and Henderson were both reported in 2005 to have activities of $24 \pm 24 \mathrm{pCi} / \mathrm{L}$. This year, Boulder City increased by approximately $11 \mathrm{pCi} / \mathrm{L}$ and Henderson decreased by approximately $8 \mathrm{pCi} / \mathrm{L}$ despite the samples having a common point of origin. The degree to which the aforementioned values fluctuate from year to year is consistent with and due to the relatively high level of uncertainty associated with each sample.

Table 6-7. Tritium results for CEMP offsite surface water and spring discharges in 2006

\begin{tabular}{|c|c|c|c|c|}
\hline \multirow{2}{*}{$\frac{\text { Monitoring Location }}{\text { Adaven Springs }}$} & \multicolumn{3}{|c|}{$\begin{array}{c}{ }^{3} \mathrm{H} \pm \text { Uncertainty }^{(\mathrm{a})} \\
(\mathrm{pCi} / \mathrm{L})\end{array}$} & \multirow{2}{*}{$\begin{array}{c}\begin{array}{c}\mathrm{Lc} \\
(\mathrm{pCi} / \mathrm{L})\end{array} \\
12\end{array}$} \\
\hline & 22.6 & \pm & 12.8 & \\
\hline Ely Municipal Water Source - springs 3 to 4 mi west of town & 9.7 & \pm & 12.8 & 12 \\
\hline Medlin's Ranch - spring located 11 mi west of ranch house & 0.0 & \pm & 19.2 & 12 \\
\hline Stone Cabin Ranch & 0.0 & \pm & 19.2 & 12 \\
\hline Boulder City - Source of Water is Lake Mead & 35.4 & \pm & 25.8 & 12 \\
\hline Henderson - Source of Water is Lake Mead & 16.1 & \pm & 19.4 & 12 \\
\hline St. George - Source of Water is Quail Creek Reservoir & 9.7 & \pm & 12.8 & 12 \\
\hline
\end{tabular}

(a) \pm 2 standard deviations

\subsubsection{Results of Groundwater Monitoring}

The results for the 20 groundwater tritium analyses from the DRI Tritium Laboratory are presented in Table 6-8. Two new sample locations, Mesquite and Tecopa were added this year. The measured activities ranged from -12.9 to $12.9 \mathrm{pCi} / \mathrm{L}$. All but one of the samples yielded results that were statistically indistinguishable from background $\left(\leq \mathrm{L}_{\mathrm{C}}\right)$ and were well below the safe drinking water limit of $20,000 \mathrm{pCi} / \mathrm{L}$. The only sample to exceed background $\left(\geq \mathrm{L}_{\mathrm{c}}\right)$ was Milford. The difference between the 2005 reported activity for Milford $(1 \pm 20 \mathrm{pCi} / \mathrm{L})$ was statistically indistinguishable from this year's result due to relatively large uncertainties associated with each sample. No statistically significant trends were evident when the results were compared to samples taken in previous years. 
Table 6-8. Tritium results for CEMP offsite wells in 2006

\begin{tabular}{||lrrrr||}
\hline Monitoring Location & \multicolumn{3}{c}{$\begin{array}{c}\text { 3 } \mathbf{H} \text { Uncertainty(a) } \\
\text { (pCi/L) }\end{array}$} & $\begin{array}{c}\text { Lc } \\
\text { (pCi/L) }\end{array}$ \\
\hline Alamo City & -9.7 & \pm & 19.4 & 12 \\
Amargosa Valley & -6.4 & \pm & 12.8 & 12 \\
Beatty & -12.9 & \pm & 12.8 & 12 \\
Caliente & -3.2 & \pm & 12.8 & 12 \\
Cedar City & 0.0 & \pm & 12.8 & 12 \\
Delta & 6.4 & \pm & 12.8 & 12 \\
Goldfield & -9.7 & \pm & 12.8 & 12 \\
Indian Springs & 9.7 & \pm & 12.8 & 12 \\
Las Vegas & 3.2 & \pm & 19.4 & 12 \\
Mesquite & 0.0 & $+/-$ & 12.8 & 12 \\
Milford & 12.9 & \pm & 12.8 & 12 \\
Nyala Ranch & 9.7 & \pm & 19.4 & 12 \\
Overton & 6.4 & \pm & 12.8 & 12 \\
Pahrump & 3.2 & \pm & 12.8 & 12 \\
Pioche & 6.4 & \pm & 12.8 & 12 \\
Rachel & 3.2 & \pm & 12.8 & 12 \\
Sarcobatus Flats & -3.2 & \pm & 12.8 & 12 \\
Tecopa & 3.2 & $+/-$ & 12.8 & 12 \\
Tonopah & -3.2 & \pm & 12.8 & 12 \\
Twin Springs Ranch & 3.2 & \pm & 12.8 & \\
\hline
\end{tabular}

(a) \pm 2 standard deviations

\subsubsection{Environmental Impact}

Results of the CEMP tritium analyses conducted on selected offsite groundwater wells and water supply systems surrounding the NTS showed no evidence of tritium migration offsite via groundwater. Most of the samples analyzed were below the $\mathrm{L}_{\mathrm{C}}$ for tritium (see Tables 6-7 and 6-8). The greatest observed activity, $35.4 \mathrm{pCi} / \mathrm{L}$ for Boulder City, was well below the safe drinking water standard of 20,000 pCi/L. 


\section{THIS PAGE INTENTIONALLY LEFT BLANK}




\subsection{Radiological Biota Monitoring}

Historical atmospheric nuclear weapons testing and outfalls from underground nuclear tests provide a source of radiation contamination and exposure to Nevada Test Site (NTS) plants and animals (biota). U.S. Department of Energy (DOE) Order 5400.5, Radiation Protection of the Public and the Environment, requires that all DOE sites monitor radioactivity in the environment to ensure that the public does not receive a radiological dose greater than 100 millirems per year (mrem/yr) from all pathways of exposure, including the ingestion of contaminated plants and animals. The DOE also requires monitoring to determine if the radiological dose to aquatic and terrestrial biota on site exceeds DOE-established limits expressed in rad (for radiation absorbed dose, see Glossary, Appendix B) per day $(\mathrm{rad} / \mathrm{d})$.

Current NTS land use precludes the harvest of plants or plant parts (e.g., pine nuts and wolf berries) for direct consumption by humans. Therefore, the ingestion of game animals is the primary potential biotic pathway for radionuclide contamination from the NTS to the public. Game birds and game mammals that occur on the NTS may travel off the site and become available, through hunting, for consumption by the public. Game animals are therefore monitored under the Routine Radiological Environmental Monitoring Plan (RREMP) (DOE, 2003a). In 2006, National Security Technologies, LLC, Environmental Technical Services, conducted the monitoring.

Game animals and plants are sampled annually from known contaminated sites on the NTS to estimate hypothetical doses to hunters (i.e., the public), measure the potential for radionuclide transfer through the food chain, and determine if NTS plants and animals themselves are exposed to radiation levels harmful to their populations. This section describes the biota monitoring program designed to meet public and environmental radiation protection regulations (see Section 2.3) and presents the results of field sampling and analyses in 2006. The reader is directed to the RREMP (DOE, 2003a) for a more detailed description of monitoring design and methods. The estimated radiological dose, both to humans consuming game animals from the NTS and to biota found in contaminated areas of the NTS, that was calculated based on 2006 monitoring data is presented in Section 8.0.

\section{Radiological Biota Monitoring Goals}

Determine if the potential dose to humans consuming game animals from the NTS is less than $100 \mathrm{mrem} / \mathrm{yr}$, the limit set by DOE Order 5400.5

Determine if the absorbed radiation dose to NTS biota is less than the following limits set by DOE Order 5400.5 and DOE Standard DOE-STD-1153-2002:

$<1 \mathrm{rad} / \mathrm{d}$ for terrestrial plants and aquatic animals

$<0.1 \mathrm{rad} / \mathrm{d}$ for terrestrial animals
Analytes Measured in Plant and Animal Tissues

Americium-241 (241 Am)

Cesium-137 ( $\left.{ }^{137} \mathrm{Cs}\right)$

Tritium $\left({ }^{3} \mathrm{H}\right)$

Plutonium-239+240 $\left({ }^{239+240} \mathrm{Pu}\right)$

Strontium-90 ( $\left.{ }^{90} \mathrm{Sr}\right)$

Uranium isotopes

\subsection{Species Selection}

The goal for vegetation monitoring is to sample the most contaminated plants within the NTS environment. Contaminated plants are generally found inside demarcated radiological areas near the "ground zero" locations of historical above-ground nuclear tests. The plant species selected for sampling represent the most dominant plant life forms (e.g., trees, shrubs, herbs, or grasses) at these sites. Woody vegetation (i.e., shrubs versus forbs or grasses) is primarily selected for sampling because such vegetation is reported to have deeper penetrating roots and higher concentrations of tritium $\left({ }^{3} \mathrm{H}\right)$ (Hunter and Kinnison, 1998). Additionally, this vegetation serves as a major source of browse for game animals that might eat such vegetation and potentially migrate offsite. Grasses and forbs are also sampled when present, however, because they are also a source of food for wildlife. Plant parts collected for analysis represent new growth over the past year. 
Three criteria were used to determine which animal species to monitor for assessing potential dose to the public: 1) the species should have a relatively high probability of entering the human food chain; 2) the species should have a home range which overlaps a contaminated site and, as a result, have the potential for relatively high radionuclide body burdens from exposure to contaminated soil, air, water, or plants at the contaminated site; and 3) the species should be sufficiently abundant at a site to acquire an adequate tissue sample for laboratory analysis. These criteria limited the candidate game animals on the NTS to those listed below.

\begin{tabular}{||ccc||}
\hline \multicolumn{2}{|c|}{ Candidate } & NTS Game Animals \\
\hline \multicolumn{1}{|c|}{ Birds } & Small Mammals & Large Mammals \\
Mourning dove & Cottontail rabbit & Mule deer \\
(Zenaida macroura) & (Sylvilagus audubonii) & (Odocoileus hemionus) \\
Chukar & Jackrabbit & Pronghorn antelope \\
(Alectoris chukar) & (Lepus californicus) & (Antilocapra americana) \\
Gambel's quail & & \\
(Callipepla gambelii) & & \\
\hline
\end{tabular}

Mule deer and pronghorn antelope are only collected as the opportunity arises if they are found dead on the NTS (e.g., from accidentally being hit by a vehicle). Tissues from other game species, such as predators, may be collected opportunistically as well.

No native fish or amphibians are found in surface waters of the NTS. There is no potential radiological dose pathway directly from NTS aquatic animals to humans. No aquatic invertebrates or non-native fish or amphibians are sampled for radionuclide tissue analyses.

\subsection{Site Selection}

The monitoring design focuses on sampling those sites having the highest known concentrations of radionuclides in other media (e.g., soil and surface water) and sites that have relatively high densities of candidate game animals. Currently, five sites are selected for regular monitoring; each site is sampled at least once every five years. These sites are E Tunnel Ponds, Palanquin, Sedan, T2, and Plutonium Valley (Figure 7-1). The control site selected for each contaminated site has similar biological and physical features. Control sites are sampled to document radionuclide levels representative of background. In 2006, the T2 site and its control were sampled. Other sites may be monitored if new sites become radiologically contaminated or if contamination conditions change (e.g., through the addition of water pumped from contaminated ground water or from soil disturbance).

The T2 site is located in Area 2 in the northern portion of the NTS. Four nuclear weapons tests were conducted on the surface of the T2 site from 1952 to 1957 (DOE, 2000a). All of these weapons were placed on towers and totaled 99 kilotons. Contaminants resulting from these tests were primarily ${ }^{3} \mathrm{H},{ }^{90} \mathrm{Sr},{ }^{137} \mathrm{Cs},{ }^{239+240} \mathrm{Pu}$, and ${ }^{241} \mathrm{Am}$. A control area for T2 is located about 18 kilometers (11.2 miles) south-southwest of the sample site in Mid-Valley, Area 14. Any of the candidate game species are likely to be present at the $\mathrm{T} 2$ and control sites. 


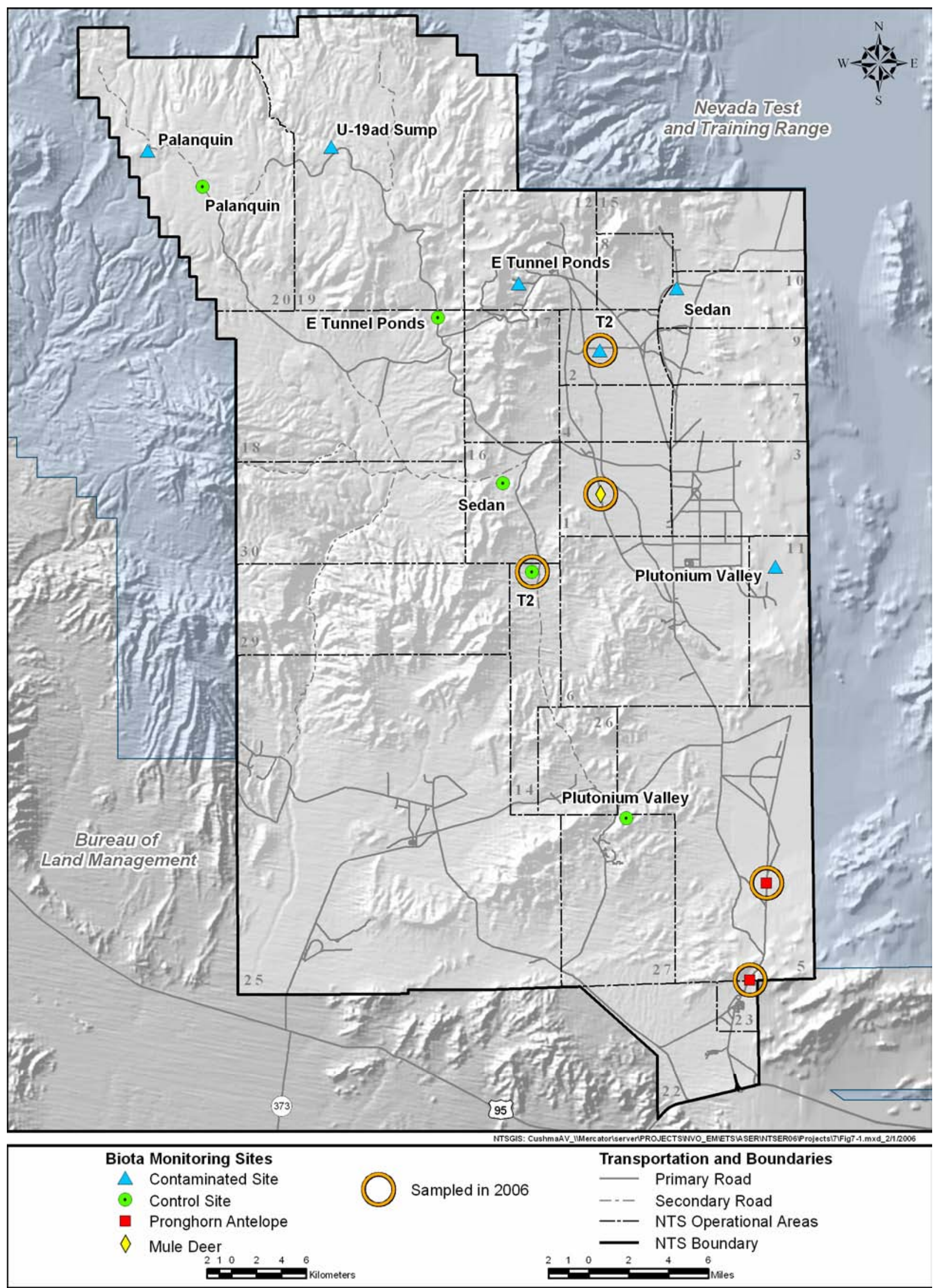

Figure 7-1. Radiological biota monitoring sites on the NTS and sites sampled in 2006 


\subsection{Sampling Methods}

During 2006, biota samples were successfully collected at the T2 and the T2 control site. Sample methods and the numbers and types of samples collected are described below.

\subsubsection{Plants}

Plant sampling occurred June 28, 2006. At each site, two samples of each plant species shown in Table 7-1 were collected. These species represent the dominant shrubs present at each site. Each sample consisted of about 300 to 500 grams (10.6 to 17.6 ounces) of fresh-weight plant material and consisted of a composite of material from many plants of the same species in the sample area. Only current year's growth was collected from each plant and consisted of new green leaves and stems. Green leaves and stems were hand-plucked and stored in airtight plastic bags. Rubber gloves were used by samplers and changed between each composite sample collected. Samples were labeled and stored in an ice chest. Within four hours of collection, the samples were delivered to the laboratory. Water was separated from plant samples by distillation. Water and dried plant tissues were submitted to a commercial laboratory for analysis of radionuclides. Water from plants was analyzed for ${ }^{3} \mathrm{H}$ and dried plant tissue was analyzed for gammaemitting radionuclides, ${ }^{90} \mathrm{Sr}$, uranium, plutonium, and ${ }^{241} \mathrm{Am}$.

Table 7-1. Plant species sampled at T2 and the T2 control site in 2006

\begin{tabular}{|c|c|c|c|c|}
\hline Plant Common Name & $\begin{array}{c}\text { Name } \\
\text { Abbreviation }^{(a)}\end{array}$ & Plant Scientific Name & $\mathrm{T} 2$ & T2 Control Site \\
\hline Blackbrush & CORA & Coleogyne ramosissima & & $x$ \\
\hline Brittlebrush & ENVI & Encelia virginensis & $x$ & \\
\hline Nevada jointfir & EPNE & Epheda nevadensis & & $x$ \\
\hline Rubber rabbitbrush & ERNA & Ericameria nauseosus & $x$ & $x$ \\
\hline Burrobush & HYSA & Hymenoclea salsola & $x$ & \\
\hline
\end{tabular}

(a) Plant name abbreviation used in the sample results table (Table 7-2)

\subsubsection{Animals}

State and federal permits were secured to trap and analyze rabbits, Gambel's quail, chukar, and mourning doves during 2006 as well as to sample road-killed, large game animals. Animal trapping took place July through August. Live-traps were run for a total of 78 trap-nights. Three jackrabbits were trapped at the T2 site and one jackrabbit was trapped at the T2 control site.

Opportunistic sampling of three big game animals occurred during 2006. All of these were mortalities due to being hit by an automobile. The first was a mule deer on Tippipah Highway on Yucca Flat in Area 1. The second was a pronghorn on Mercury Highway in Area 23, and the third was a pronghorn from the 5-01 road in Area 5. Only muscle tissue samples were taken from these animals.

In the laboratory, animal specimens were separated into two samples: a muscle tissue sample and a sample representing the whole body minus the portion of muscle (body fraction). All samples were individually homogenized using an industrial meat grinder and food processor. Water was distilled from the samples and submitted to a laboratory for ${ }^{3} \mathrm{H}$ analysis. Past results have shown no difference in ${ }^{3} \mathrm{H}$ concentrations in water from muscle tissue versus the rest of the body. Therefore, there was only one water sample for each animal (water from muscle and the body fraction were combined). The dried tissue samples were also submitted, muscle tissue and body fraction separately, to a laboratory for analysis of gamma-emitting radionuclides, ${ }^{90} \mathrm{Sr}$, uranium, plutonium, and ${ }^{241} \mathrm{Am}$. 


\section{$7.4 \quad$ Results}

\subsubsection{Plants}

Concentrations of man-made radionuclides detected in 2006 NTS plant samples are shown in Table 7-2. Uranium was detected, but at levels and isotopic ratios consistent with natural uranium. All plant samples from the T2 site had detectable concentrations of man-made radionuclides. These radionuclides were ${ }^{3} \mathrm{H},{ }^{90} \mathrm{Sr},{ }^{238} \mathrm{Pu},{ }^{239+240} \mathrm{Pu}$, and ${ }^{241} \mathrm{Am}$. Only two samples from the T2 control site had concentrations of man-made radionuclides slightly higher than the minimum detectable concentration (MDC). Given the low concentrations, analysis uncertainty, and the fact that about 5 percent of all samples can be expected to be a false positive, there is question whether these results were true detections.

Figure 7-2 displays average concentrations of radionuclides detected in plant samples collected from the T2 site during 2006 compared with those detected in samples last collected from the T2 site in 2002. While 2006 average concentrations were lower than those from 2002 for all detected radionuclides, variability between samples within sample years was high enough to make them not significantly different.

\subsubsection{Animals}

Man-made radionuclides were detected in all animals collected from the T2 site. Only trace amounts of ${ }^{239+240} \mathrm{Pu}$ and ${ }^{241} \mathrm{Am}$ were detected in the rabbit from the $\mathrm{T} 2$ control site. The ${ }^{239+240} \mathrm{Pu}$ in muscle is a questionable detection given the high counting error associated with it. Uranium was detected, but at levels and isotopic ratios not different from those expected with natural uranium. Of all detected radionuclides, ${ }^{3} \mathrm{H}$ had the highest concentrations, with ${ }^{137} \mathrm{Cs}$ following at much lower concentrations. As expected, the most ${ }^{90} \mathrm{Sr}$, plutonium, and ${ }^{241} \mathrm{Am}$ were detected in the body fraction of animals because these isotopes tend to concentrate in bone tissue or be bound with soil in the gut rather than concentrating in muscle tissue. No man-made radionuclides were detected in large game animals sampled during 2006.

Figure 7-3 displays average concentrations of radionuclides detected in animal samples collected from the T2 site during 2006 compared with those detected in samples last collected from the T2 site in 2002. Average concentrations between sample years were not significantly different.

\subsection{Environmental Impact}

As expected, higher concentrations of radionuclides were detected in biota sampled at the T2 site. This location contained radioactivity associated with historic testing of nuclear weapons. While radionuclides were detected, they pose negligible risk to humans. The potential dose to a person hunting and consuming these animals is well below dose limits to members of the public (see Section 8.1.4). Also, radionuclide concentrations were below levels considered harmful to the health of the plants or animals. The dose resulting from observed concentrations were less than 1 percent of dose limits set to protect populations of plants and animals (see Section 8.2). 
Table 7-2. Concentrations of man-made radionuclides in plants from T2 and the T2 control site in 2006

\begin{tabular}{|c|c|c|c|c|c|c|c|c|c|c|c|c|c|}
\hline Sample & \multicolumn{2}{|c|}{${ }^{3} \mathbf{H}^{(\mathbf{b})}$} & \multicolumn{2}{|c|}{${ }^{90} \mathrm{Sr}^{(\mathrm{c})}$} & \multicolumn{3}{|c|}{${ }^{238} \mathbf{P} \mathbf{u}^{(\mathrm{c})}$} & \multicolumn{3}{|c|}{${ }^{239 / 240} \mathbf{P u}^{(\mathrm{c})}$} & \multicolumn{3}{|c|}{${ }^{241} \mathbf{A m}^{(\mathrm{c})}$} \\
\hline \multicolumn{14}{|l|}{ T2 } \\
\hline ENVI \#2 & 2,400 & $\pm \quad 370$ & 0.59 & $\pm \quad 0.09$ & 0.006 & \pm & 0.008 & 0.017 & \pm & 0.010 & 0.016 & \pm & 0.015 \\
\hline ERNA \#1 & 650 & $\pm \quad 250$ & 0.12 & $\pm \quad 0.06$ & 0.004 & \pm & 0.007 & 0.032 & \pm & 0.014 & 0.008 & \pm & 0.012 \\
\hline ERNA \#2 & 1,100 & $\pm \quad 280$ & 0.12 & $\pm \quad 0.05$ & 0.005 & \pm & 0.006 & 0.032 & \pm & 0.014 & -0.004 & \pm & 0.007 \\
\hline \% Above MDC (Average MDC): & $100^{\circ}$ & o (314) & $100 \%$ & o (0.08) & $33 \%$ & $(0.0$ & & 100 & o ( & .008) & $33 \%$ & $(0.6$ & \\
\hline \multicolumn{14}{|l|}{ T2 - Control } \\
\hline ERNA \#1 & 340 & $\pm \quad 220$ & 0.02 & $\pm \quad 0.03$ & 0.001 & \pm & 0.004 & 0.002 & \pm & 0.004 & 0.005 & \pm & 0.008 \\
\hline ERNA \#2 & 260 & $\pm \quad 210$ & -0.03 & $\pm \quad 0.03$ & -0.001 & \pm & 0.003 & 0.004 & \pm & 0.005 & 0.000 & \pm & 0.005 \\
\hline EPNE \#2 & 230 & $\pm \quad 210$ & 0.00 & $\pm \quad 0.03$ & 0.001 & \pm & 0.003 & 0.007 & \pm & 0.006 & 0.000 & \pm & 0.003 \\
\hline \% Above MDC (Average MDC): & \multicolumn{2}{|c|}{$17 \%(338)$} & \multicolumn{2}{|c|}{$0 \%(0.06)$} & \multicolumn{3}{|c|}{$0 \%(0.009)$} & \multicolumn{3}{|c|}{$17 \%(0.008)$} & \multicolumn{3}{|c|}{$0 \%(0.014)$} \\
\hline
\end{tabular}

Green-shaded results are considered detected (results greater than the sample-specific MDC).

(a) \pm 2 standard deviations

(b) picocuries per liter water from sample

(c) picocuries per gram dry weight of sample 
Table 7-3. Concentrations of man-made radionuclides in animals from T2 and the T2 control site in 2006

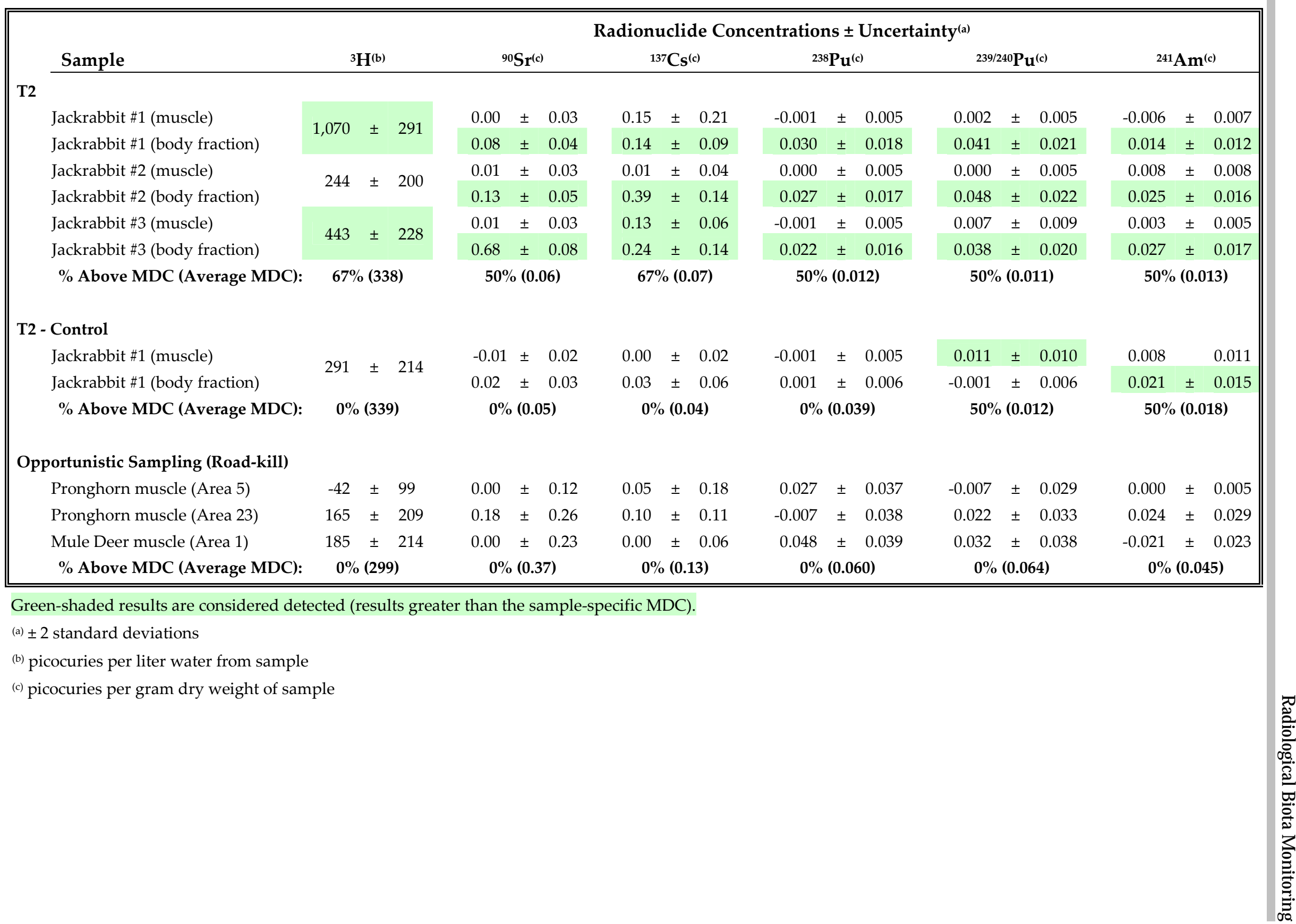




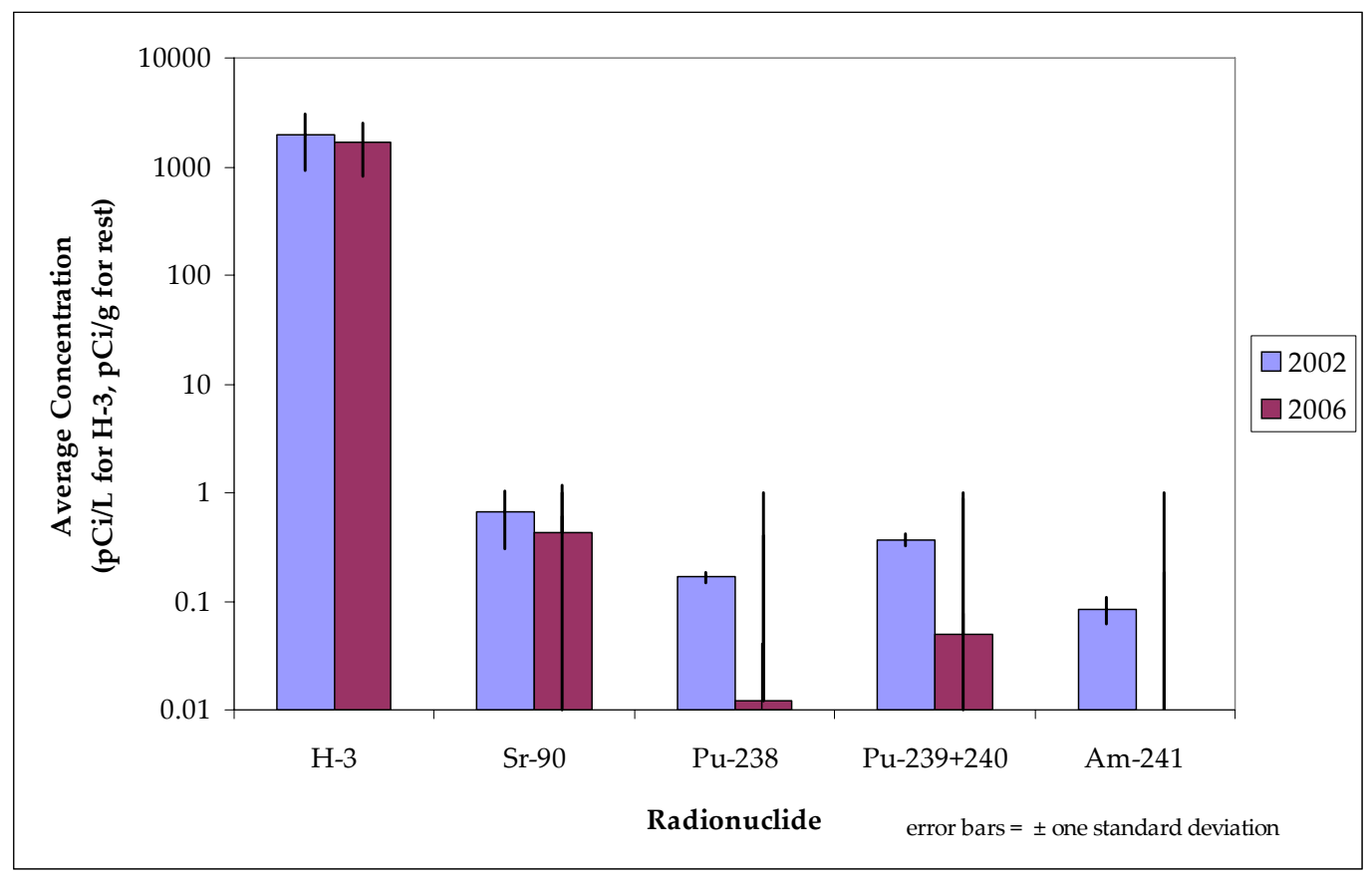

Figure 7-2. Concentrations of man-made radionuclides in plants from T2, 2002 and 2006

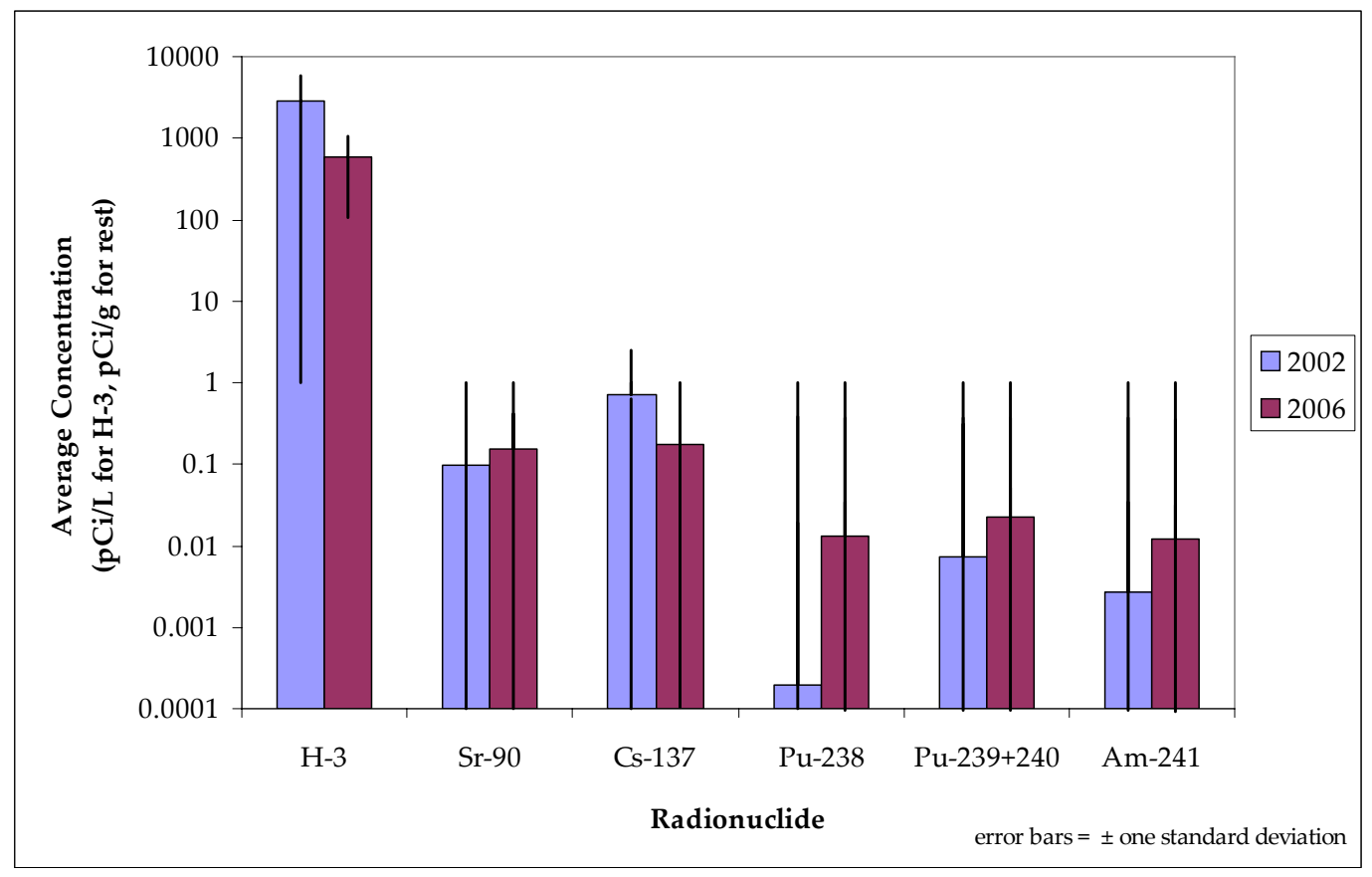

Figure 7-3. Concentrations of man-made radionuclides in animals from T2, 2002 and 2006 


\subsection{Radiological Dose Assessment}

U.S. Department of Energy (DOE) Order 450.1, Environmental Protection Program, and DOE Order 5400.5, Radiation Protection of the Public and the Environment (see Section 2.3), require DOE facilities to estimate the radiological dose to the general public and to plants and animals in the environment caused by past or present facility operations. This chapter uses data gathered by Bechtel Nevada (BN) and National Security Technologies, LLC (NSTec), in 2006 and radiation surveys in the past that inventoried the radionuclide content of Nevada Test Site (NTS) surface soils to estimate these radiological doses with the aid of mathematical models. The data used are presented in Sections 3.0 through 7.0 of this report and include the 2006 results for onsite compliance monitoring of air, water, direct radiation, and biota, and the offsite monitoring results of air, direct radiation, and water conducted under the Community Environmental Monitoring Program (CEMP). The specific goals for the dose assessment component of radiological monitoring are shown below along with the compliance measures which are calculated in order to accomplish these assessment goals.

\section{Radiological Dose Assessment Goals}

Determine if the maximum radiation dose to a member of the general public from airborne radionuclide emissions at the NTS is less than the Clean Air Act, National Emission Standards for Hazardous Air Pollutants (NESHAP) limit of 10 millirems per year (mrem/yr) $(0.1$ millisieverts $[\mathrm{mSv}] / \mathrm{yr})$

Determine if the total radiation dose to a member of the general public from all possible pathways (direct exposure, inhalation, ingestion of water and food) as a result of NTS operations is less than the limit of $100 \mathrm{mrem} / \mathrm{yr}$ established by DOE Order 5400.5

Determine if the radiation dose (in a unit of measure called a rad [see Glossary, Appendix B]) to NTS biota is less than the following limits set by DOE Order 5400.5 and DOE Standard DOE-STD-1153-2002:

$<1 \mathrm{rad}$ per day $(\mathrm{rad} / \mathrm{d})$ for terrestrial plants and aquatic animals

$<0.1 \mathrm{rad} / \mathrm{d}$ for terrestrial animals

\section{Compliance Measures}

Annual average concentrations of radionuclides at six NTS critical-receptor air sampling locations compared to the Concentration Levels for Environmental Compliance, Table 2, Appendix E, 40 Code of Federal Regulations (CFR) 61 (NESHAP)

Committed effective dose equivalent (CEDE) for an offsite resident from all pathways, in $\mathrm{mrem} / \mathrm{yr}$ (or $\mathrm{mSv} / \mathrm{yr}$ )

Absorbed dose to onsite plants and animals, in $\mathrm{rad} / \mathrm{d}$

\subsection{Radiological Dose to the Public}

Several steps are taken to compute radiological dose to the public from all pathways. This section briefly describes these steps, identifies how field monitoring data interface with other NTS data sources (e.g., radionuclide inventory data) to provide input to the dose estimates, and presents the results of each step.

\subsubsection{Possible Exposure Pathways to the Public}

As prescribed in the Routine Radiological Environmental Monitoring Plan (DOE, 2003b), BN/NSTec routinely sampled air, groundwater, and biota to document the amount of radioactivity in these media and to provide data that can be used to assess the radiation dose received by the general public.

The potential pathways by which a member of the general public residing offsite might receive a radiation dose resulting from past or present NTS operations include:

1. Inhalation of, ingestion of, or direct external exposure to airborne radionuclide emissions transported offsite by wind 
2. Ingestion of meat from wild game animals which drink from surface waters and eat vegetation containing NTS-related radioactivity

3. Drinking contaminated water from underground aquifers containing radionuclides which have migrated from the sites of past underground nuclear tests

4. Exposure to direct radiation along the borders of the NTS

5. Exposure to direct radiation from the release of property (e.g., equipment, building materials) containing residual radioactive material

In 2006, only the wind transport pathway (pathway 1) and the ingestion of wild game (pathway 2) were considered possible pathways of exposure to the public residing offsite. The subsections below address all of the potential pathways and their contribution to public dose estimated for 2006.

\subsubsection{Dose to the Public from NTS Air Emissions}

Six air particulate and tritium sampling stations located near the boundaries and the center of the NTS are approved by the U.S. Environmental Protection Agency (EPA) Region IX as critical receptor samplers to demonstrate compliance with the NESHAP public dose limit from air emissions of $10 \mathrm{mrem} / \mathrm{yr}$. Analysis of air particulate and tritium data obtained at these six stations was performed in 2006 (Section 3.1.5). To be in compliance with NESHAP, the annual average concentration of an airborne radionuclide must be less than its NESHAP Concentration Level for Environmental Compliance (CL) (see Table 3-1 of Section 3.1.1). The CL for each radionuclide represents the annual average concentration of that radionuclide in air which would result in a CEDE of $10 \mathrm{mrem} / \mathrm{yr}$. If multiple radionuclides are detected at a station, then compliance with NESHAP is demonstrated when the sum of the fractions (determined by dividing each radionuclide's concentration by its concentration limit and then adding the fractions together) is less than 1.0 .

The following radionuclides were detected at three or more of the critical receptor samplers: americium-241 $(241 \mathrm{Am})$, plutonium-238 $\left({ }^{238} \mathrm{Pu}\right)$, plutonium-239+240 $\left({ }^{239+240} \mathrm{Pu}\right)$, uranium-233 $+234\left({ }^{233+234} \mathrm{U}\right)$, uranium-235 $236\left({ }^{235+236} \mathrm{U}\right)$, uranium-238 $\left({ }^{238} \mathrm{U}\right)$, and tritium $\left({ }^{3} \mathrm{H}\right)$ (Section 3.1.5). All concentrations of these radionuclides were well below their CLs. The uranium isotopes are attributed to naturally-occurring uranium. The concentration of each measured radionuclide (excluding uranium, since it has been determined to be of natural origin) at each of the six critical receptor samplers was divided by its respective CL to obtain a "fraction of CL." These fractions were then summed for each location and all were less than 1.0 (see Table 3-12, Section 3.1.5). As in previous years, the 2006 data from the six critical receptor samplers show that the NESHAP dose limit to the public of $10 \mathrm{mrem} / \mathrm{yr}$ was not exceeded. The Schooner critical receptor station in the far northwest corner of the NTS had the highest concentrations of radioactive air emissions, yet an individual residing at this station would experience a dose from air emissions of only $2.5 \mathrm{mrem} / \mathrm{yr}, 25$ percent of the admissible does limit. No one resides at this location, and the dose at offsite populated locations 20-80 kilometers $(\mathrm{km})$ (12-50 miles [mi]) from the Schooner station would be much lower due to wind dispersion.

In previous years (1992-2004), the air transport model called Clean Air Package 1988 (CAP88-PC) was used to calculate the dose to the public from NTS air emissions, including diffuse emissions from legacy soil contamination. Beginning in 2005, CAP88-PC was no longer used to estimate public dose from ongoing legacy-related airborne radionuclide sources on the NTS (Grossman, 2006). The EPA approved this action in 2001 and DOE concurred (DOE, 2004d). The air sampling data from the critical receptor stations provide a more accurate and conservative estimate of potential dose to the public than the CAP88-PC model. See Sections 3.1 and 8.0 of the Nevada Test Site Environmental Report 2005 (DOE, 2006b) for discussions on this change in dose assessment methods.

New planned projects, however, will continue to be evaluated each year for NESHAP compliance by running the CAP88-PC model (see Sections 3.1.7-3.1.9). No planned projects evaluated in 2006, or new activities executed and monitored in 2006, produced airborne emissions which resulted in a calculated dose that would be a noticeable addition to the dose from legacy soil contamination $(0.2 \mathrm{mrem} / \mathrm{yr})$. 


\subsubsection{Dose to the Public from Ingestion of Wild Game from the NTS}

There are few data suggesting that NTS small game animals travel offsite and become available to hunters. However, they are sampled on the NTS near contaminated areas as a conservative (worst case) estimate of the levels of radionuclides that hunters may consume if game animals did leave the NTS and were harvested. In 2006, jackrabbits were sampled from the T2 site and the T2 control site, and 1 mule deer and 2 pronghorn antelope were opportunistically sampled (see Section 7.0) for radioanalysis.

Tritium and ${ }^{137} \mathrm{Cs}$ were detected in the muscle tissue (the edible portion) of all jackrabbits collected from the T2 site (see Table 7-3, Section 7.0). Also, trace levels of ${ }^{239+240} \mathrm{Pu}$ were detected in the muscle tissue of the one jackrabbit sampled from the T2 control site. No man-made radionuclides were detected in muscle tissue from the deer or antelope, so no potential dose was calculated from consuming these large game species. The potential dose from consuming jackrabbits sampled from the T2 and the T2 control site were calculated using the following assumptions:

- One individual consumed 20 jackrabbits over the year (these numbers are the possession limits set for these species by the Nevada Division of Wildlife)

- $\quad$ Each jackrabbit consumed contained the average concentration of radionuclides (expressed as picocuries per liter $(\mathrm{pCi} / \mathrm{L})$ or picocuries per gram $(\mathrm{pCi} / \mathrm{g})$ that was detected in muscle tissue for the jackrabbits sampled

- $\quad$ Radionuclides detected in muscle tissue from any jackrabbit were included in dose calculations from each location

- The amount of jackrabbit meat consumed was the average weight in grams (g) of muscle on the animals sampled

- The moisture content of jackrabbit meat consumed was equivalent to the average moisture content measured in muscle tissue samples

The CEDE was calculated using dose conversion factors (DOE, 1988) multiplied by the total activity estimated to be consumed for each of the detected radionuclides. The resultant potential doses are shown in Table 8-1. The highest estimated CEDE was $0.12 \mathrm{mrem}(0.0012 \mathrm{mSv})$ which is only 0.12 percent of the annual dose limit for members of the public. It assumes that 20 jackrabbits would be consumed. The maximum potential dose from consuming just one jackrabbit would be 0.002 mrem for jackrabbits from the T2 site and 0.006 for jackrabbits from the T2 control site.

The radionuclide contributing most to dose was ${ }^{239+240} \mathrm{Pu}$ though, at the T2 site, tritium had the highest concentrations. Tritium produces a relatively low dose because it only emits low energy beta particles and has a short biological half-life. The CEDE was higher for the one jackrabbit from the T2 control site due to its questionable level of $239+240 \mathrm{Pu}$ in muscle.

To put these potential doses in perspective, the dose from naturally-occurring cosmic radiation received during a onehour airplane flight at 39,000 feet is about $0.5 \mathrm{mrem}(0.005 \mathrm{mSv})$ or about four times higher than the CEDE from consuming 20 jackrabbits like the ones sampled in 2006.

Table 8-1. Hypothetical annual dose to a human consuming NTS jackrabbits based on 2006 samples

\begin{tabular}{|c|c|c|c|c|c|}
\hline Sample Location & \multicolumn{2}{|c|}{$\begin{array}{c}\text { Average Radionuclide } \\
\text { Concentrations } \\
\text { (a) }\end{array}$} & $\begin{array}{l}\text { Dose Conversion Factor } \\
(\mathrm{mrem} / \mathrm{pCi} \text { ingested)(b) }\end{array}$ & $\begin{array}{c}\text { CEDE } \\
\left(\text { mrem) }{ }^{(c)}\right.\end{array}$ & $\begin{array}{l}\text { Total CEDE } \\
\text { (mrem) }\end{array}$ \\
\hline \multirow[t]{3}{*}{ T2 } & ${ }^{3} \mathrm{H}$ & $586 \mathrm{pCi} / \mathrm{L}$ & 0.000000063 & 0.0003 & \multirow{3}{*}{0.04} \\
\hline & ${ }^{137} \mathrm{Cs}$ & $0.09 \mathrm{pCi} / \mathrm{g}^{(\mathrm{d})}$ & 0.000050 & 0.0112 & \\
\hline & ${ }^{239+240} \mathrm{Pu}$ & $0.003 \mathrm{pCi} / \mathrm{g}^{(\mathrm{d})}$ & 0.0043 & 0.0321 & \\
\hline \multirow[t]{3}{*}{ T2 - Control } & ${ }^{3} \mathrm{H}$ & $291 \mathrm{pCi} / \mathrm{L}$ & 0.000000063 & 0.0001 & \multirow{3}{*}{0.12} \\
\hline & ${ }^{137} \mathrm{Cs}$ & $0.00 \mathrm{pCi} / \mathrm{g}^{(\mathrm{d})}$ & 0.000050 & 0.0000 & \\
\hline & ${ }^{239+240} \mathrm{Pu}$ & $0.011 \mathrm{pCi} / \mathrm{g}^{(\mathrm{d})}$ & 0.0043 & 0.1178 & \\
\hline
\end{tabular}

(a) Negative values were set to zero prior to obtaining average

(b) Dose conversion factors for human ingestion are from DOE (1988)

(c) CEDE calculation assumes $9960 \mathrm{~g}$ of meat were consumed (20 jackrabbits $x 498 \mathrm{~g}$ muscle weight for each jackrabbit)

(d) $\mathrm{pCi} / \mathrm{g}$ dry weight; water content $=75 \%$ by weight 


\subsubsection{Dose to the Public from Drinking Contaminated Groundwater}

The migration of radioactivity in groundwater has not been detected in the past or in 2006 (see Section 4.1). Therefore, drinking contaminated groundwater is not a possible pathway of exposure to the public residing offsite.

\subsubsection{Dose to the Public from Direct Radiation Exposure Along NTS Borders}

The direct exposure pathway from gamma radiation to the public is monitored annually (see Section 5.0). In 2006, the only place where the public had the potential to be exposed to direct radiation along the NTS borders was at Gate 100, the primary entrance to the site on the southern NTS border. Trucks hauling radioactive materials, primarily low-level radioactive waste being shipped for disposal at the Area 3 and 5 Radioactive Waste Management Sites, park outside Gate 100 while waiting for entry approval. Only during these times is there a potential for exposure to the public. However, no member of the public resides or remains full-time at the Gate 100 truck parking area.

\subsubsection{Dose to the Public from Release of Property Containing Residual Radioactive Material}

DOE's radiation protection framework and dose limits are centered around an "all sources and all pathways" philosophy. The release of property off of the NTS which contains residual radioactive material is another type of release to the environment and potential contributor to the dose received by the public.

No vehicles, equipment, structures, or other materials can be released from the NTS unless the amount of radiological contamination on such items is less than the authorized limits specified in the NV/YMP Radiological Control Manual (Table 8-2) (DOE, 2000b) as specified in DOE Order 5400.5, Radiation Protection of the Public and the Environment. Items proposed for unrestricted release must be surveyed to document compliance with the release criteria.

In 2000, DOE placed a moratorium on the release of scrap material from radiological areas for recycling. This moratorium is still in effect. Government vehicles and equipment are routinely released or excessed when they are no longer needed by NTS projects or if they are required to be replaced. They are permitted to be released based on a combination of process knowledge and direct and indirect surveys such that the release criteria of Table 8-2 are met. However, NSTec Radiological Control does not authorize the release of materials off the NTS that have detectable radioactivity above background levels, even if these levels are less than the criteria levels shown in Table 8-2.

Some building structures on the NTS once housed uncontained contamination. NSTec Radiological Control has no plans to release such structures off the NTS. If, in the future, there are plans to do so, the criteria for their unrestricted release will be determined through agreements between the affected stakeholders (e.g., DOE and the state of Nevada).

During 2006, no vehicles, equipment, or other materials with detectable residual radioactivity were released, therefore, radiological dose to the public from such materials is assumed to be negligible.

Table 8-2. Allowable total residual surface contamination

\begin{tabular}{|c|c|c|c|}
\hline \multirow[b]{2}{*}{ Radionuclide } & \multicolumn{3}{|c|}{ Residual Surface Contamination $\left(\mathrm{dpm} / 100 \mathrm{~cm}^{2}\right)$ (a) } \\
\hline & Removable & $\begin{array}{c}\text { Total } \\
\text { (Fixed \& Removable) }\end{array}$ & $\begin{array}{l}\text { Maximum Allowable } \\
\text { Fixed \& Removable }\end{array}$ \\
\hline Transuranics, ${ }^{125} \mathrm{I},{ }^{129} \mathrm{I},{ }^{226} \mathrm{Ra},{ }^{227} \mathrm{Ac},{ }^{228} \mathrm{Ra},{ }^{228} \mathrm{Th},{ }^{230} \mathrm{Th},{ }^{231} \mathrm{~Pa}$ & 20 & 100 & 300 \\
\hline Th-natural, ${ }^{90} \mathrm{Sr},{ }^{126} \mathrm{I},{ }^{131} \mathrm{I},{ }^{133} \mathrm{I},{ }^{223} \mathrm{Ra},{ }^{224} \mathrm{Ra},{ }^{232} \mathrm{U},{ }^{232} \mathrm{Th}$ & 200 & 1,000 & 3,000 \\
\hline $\begin{array}{l}\text { U-natural, }{ }^{235} \mathrm{U},{ }^{238} \mathrm{U} \text { and associated decay products, } \\
\text { alpha emitters }\end{array}$ & 1,000 & 5,000 & 15,000 \\
\hline $\begin{array}{l}\text { Beta-gamma emitters (radionuclides with decay modes } \\
\text { other than alpha emission or spontaneous fission) } \\
\text { except }{ }^{90} \mathrm{Sr} \text { and others noted above }\end{array}$ & 1,000 & 5,000 & 15,000 \\
\hline
\end{tabular}

(a) disintegrations per minute per 100 square centimeters

Source: DOE, $2000 \mathrm{~b}$ 


\subsubsection{Total Offsite Dose to the Public from all Pathways}

DOE Order 5400.5, Radiation Protection of the Public and the Environment, establishes a radiation dose limit to a member of the general public from all possible pathways as a result of DOE facility operations. This limit is $100 \mathrm{mrem} / \mathrm{yr}$ over and above background radiation and includes the air transport pathway, ingestion pathway, and direct exposure pathway. For 2006, the only two possible pathways of public exposure to man-made radionuclides from current or past NTS activities included the air transport pathway and the ingestion of game animals. The doses from these two pathways are combined below to present an estimate of the total 2006 dose to the maximally exposed individual (MEI) (see Glossary, Appendix B) residing offsite.

The dose estimate for an offsite MEI from radionuclides in air is expected to be no greater than $0.2 \mathrm{mrem} / \mathrm{yr}$ (Figure 8-1). If the offsite MEI is assumed to eat 20 jackrabbits from the NTS (see Table 8-1), this individual may receive an estimated additional $0.12 \mathrm{mrem} / \mathrm{yr}(0.0012 \mathrm{mSv} / \mathrm{yr})$ dose. The total CEDE to this MEI would be $0.32 \mathrm{mrem} / \mathrm{yr}(0.0032 \mathrm{mSv} / \mathrm{yr})$ (Table 8-3). The total dose of $0.32 \mathrm{mrem} / \mathrm{yr}$ is 0.32 percent of the DOE limit of $100 \mathrm{mrem} / \mathrm{yr}$ and about 0.1 percent of the total dose the MEI receives from natural background radiation (340 mrem/yr) (Figure 8-2).

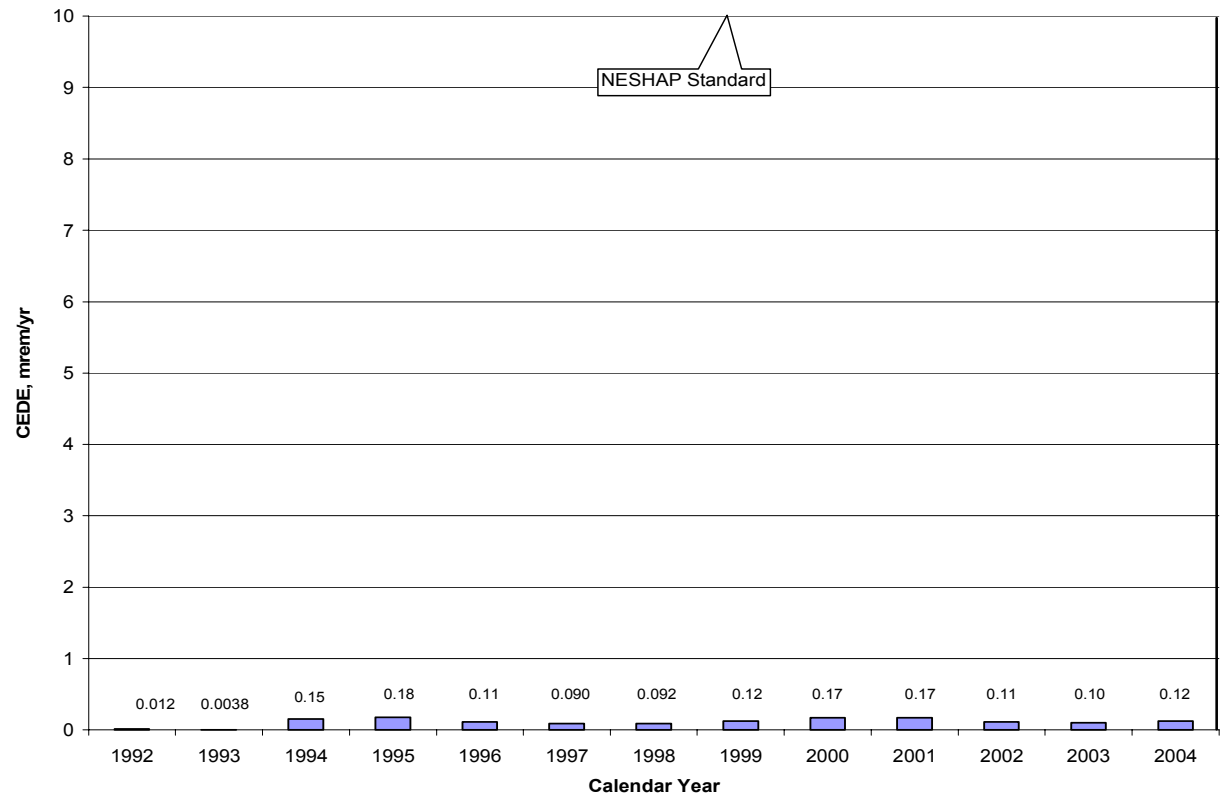

Figure 8-1. Estimated radiation dose from NTS air emissions to the offsite MEI from 1992 to 2004

Table 8-3. Estimated radiological dose to the general public from 2006 NTS operations

\begin{tabular}{|c|c|c|c|}
\hline \multirow[b]{2}{*}{ Pathway } & \multicolumn{2}{|c|}{ Dose to MEI } & \multirow{2}{*}{$\begin{array}{l}\text { Percent of DOE } \\
\text { 100-mrem/yr Limit }\end{array}$} \\
\hline & (mrem/yr) & (mSv/yr) & \\
\hline Air (a) & 0.2 & 0.002 & 0.2 \\
\hline Water (b) & 0 & 0 & 0 \\
\hline Wildlife (c) & 0.12 & 0.0012 & 0.12 \\
\hline Direct (d) & 0 & 0 & 0 \\
\hline All Pathways & 0.32 & 0.0032 & 0.32 \\
\hline
\end{tabular}

(a) Assumed from historical data from 1992 to 2004

(b) Based on all offsite groundwater sampling in 2006 (Sections 4.1 and 5.2)

(c) Assumes that the MEI consumes 20 jackrabbits from the NTS (Table 8-1)

(d) Based on 2006 gamma radiation monitoring data (Sections 5.0, 6.1), 2006 property release tracking information (Section 8.1.6), and previous years' CAP88-PC dose estimates 


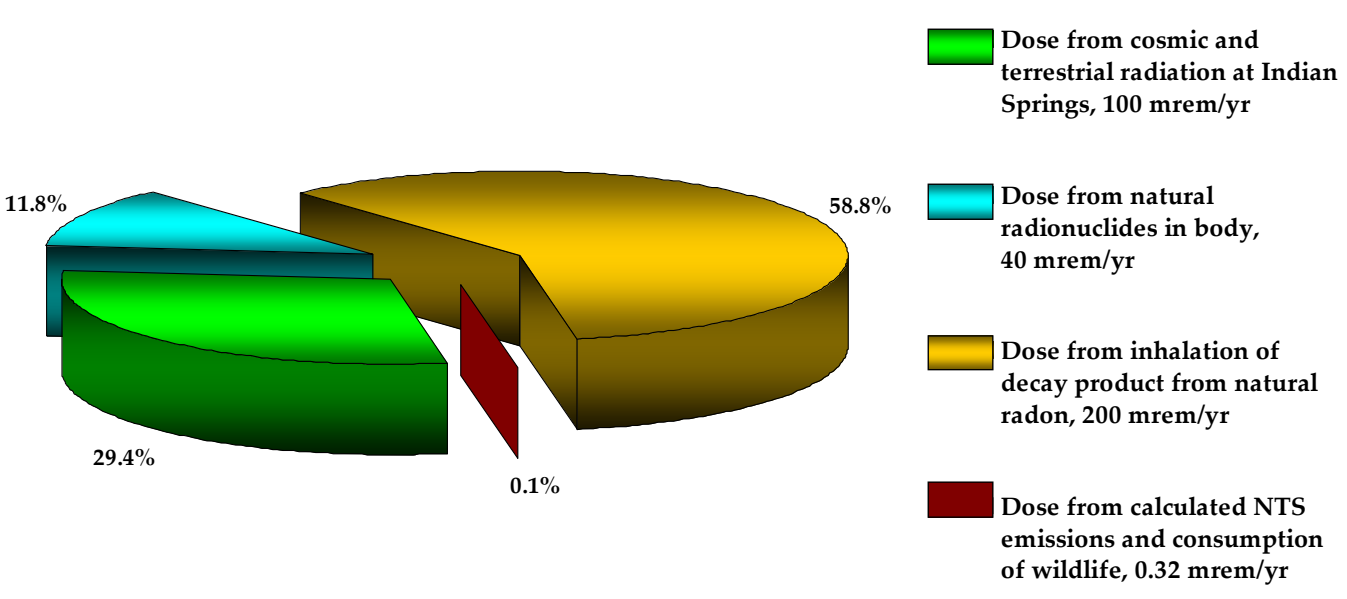

Figure 8-2. Comparison of radiation dose to the MEI and the natural radiation background (percent of total)

Natural background radiation consists of cosmic radiation, terrestrial radiation, radiation from radionuclides (primarily potassium-40 $\left[{ }^{40} \mathrm{~K}\right]$ ) within the composition of the human body, and radiation from the inhalation of naturallyoccurring radon and its progeny. The cosmic and terrestrial components of background radiation shown in Figure 8-2 were estimated from the annual mean radiation exposure rate measured with a pressurized ion chamber (PIC) at Indian Springs by the CEMP (98 milliroentgens per year [mR/yr], see Table 6-4 in Section 6.0). The radiation exposure in air measured by the PIC in units of $\mathrm{mR} / \mathrm{yr}$ is approximately equivalent to the unit of $\mathrm{mrem} / \mathrm{yr}$ for tissue. The portion of the background dose from the internally deposited, naturally-occurring radionuclides, and from the inhalation of radon and its daughters shown in Figure 8-2 were estimated as $40 \mathrm{mrem} / \mathrm{yr}$ and $200 \mathrm{mrem} / \mathrm{yr}$, respectively, using the approximations by the National Council on Radiation Protection (NCRP) (NCRP, 1996).

\subsubsection{Collective Population Dose}

The collective population dose to residents within $80 \mathrm{~km}(50 \mathrm{mi})$ of the NTS emission sources was not estimated in 2006 because this assessment depends upon CAP88-PC estimations which were not calculated. The collective population dose has been below 0.6 person-rem/yr for the period 1992 to 2004 (Figure 8-3). The DOE approved the discontinuance of reporting collective population dose because it is so low for the NTS. The DOE recommended, however, that the U.S. Department of Energy, National Nuclear Security Administration Nevada Site Office should consider reporting it once again if ever it exceeds 1.0 person-rem/yr (DOE, 2004d).

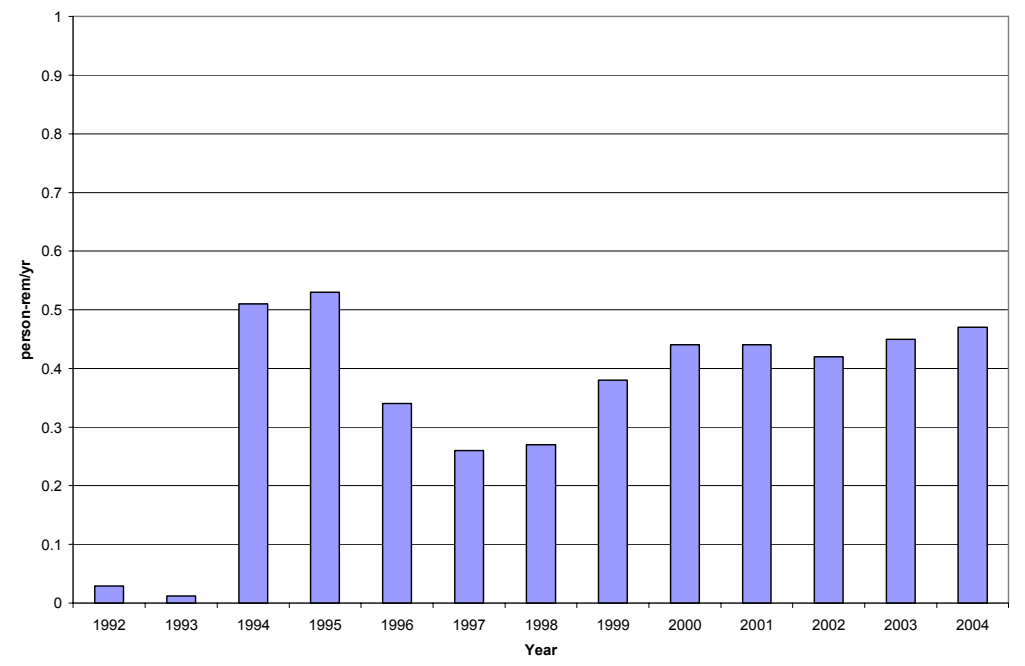

Figure 8-3. Collective population dose within $80 \mathrm{~km}$ of NTS emission sources from 1992 to 2004 


\subsection{Dose to Aquatic and Terrestrial Biota}

DOE Order 450.1, Environmental Protection Program, requires DOE facilities to evaluate the potential impacts of radiation exposure to biota in the vicinity of DOE activities. DOE Standard 1153-2002, A Graded Approach for Evaluating Radiation Doses to Aquatic and Terrestrial Biota (DOE, 2002a) was developed by DOE's Biota Dose Assessment Committee to assist in such an evaluation. The following radiological dose limits were established (DOE, 2002a). Dose rates equal to or less than these are expected to have no direct, observable effect on plant or animal reproduction:

- $\quad 1 \mathrm{rad} / \mathrm{d}(0.01$ grays per day [Gy/d]) for aquatic animals

- $1 \mathrm{rad} / \mathrm{d}(0.01 \mathrm{~Gy} / \mathrm{d})$ for terrestrial plants

- $\quad 0.1 \mathrm{rad} / \mathrm{d}(1$ milligrays per day $[\mathrm{mGy} / \mathrm{d}])$ for terrestrial animals

The goal for the NTS biota dose assessment component of radiological monitoring is to determine if the established dose limits shown above are exceeded at the NTS using the graded approach for dose evaluation described in DOE Standard 1153-2002. The standard also provides concentration values for radionuclides in soil, water, and sediment that are to be used as a guide for determining if biota are potentially receiving radiation doses that exceed the limits. These concentrations are called the Biota Concentration Guide (BCG) values. They are defined as the minimum concentration of a radionuclide that would cause dose limits to be exceeded using very conservative uptake and exposure assumptions.

The graded approach is a three-step process consisting of a data assembly step, a general screening step, and an analysis step. The analysis step consists of site-specific screening, site-specific analysis, and site-specific biota dose assessment. The following information is required by the graded approach:

- Identification of terrestrial and aquatic habitats on the NTS that have radionuclides in soil, water, or sediment

- Identification of terrestrial and aquatic biota on the NTS that occur in contaminated habitats and which are at risk of exposure

- Measured or calculated radionuclide concentrations in soil, water, and sediment in contaminated habitats on the NTS that can be compared to BCG values to determine the potential for exceeding biota dose limits

- Measured radionuclide concentrations in NTS biota, soil, water, and sediment in contaminated habitats on the NTS to estimate site-specific dose to biota

A comprehensive biota dose assessment for the NTS using the graded approach was reported in the Nevada Test Site Environmental Report 2003 (DOE, 2004c). This dose assessment demonstrated that the potential radiological dose to biota on the NTS was not likely to exceed dose limits. No data exist to suggest that NTS surface contamination conditions have changed, therefore, the terrestrial biota dose evaluation conclusion remains the same for 2006.

\subsubsection{Site-Specific Biota Dose Assessment}

Most of the graded approach for assessing dose to biota is based on radionuclide concentrations in soil, water, and sediment. The site-specific biota dose assessment phase however, centers on the actual collection and analysis of biota. Animal and plant samples were collected from the known-contaminated T2 site (see Figure 7-1) during 2006. Sampling methods and radionuclide concentrations in these samples are presented in Section 7.0. To obtain a predicted dose to biota at the T2 site, the RESRAD-BIOTA, Version 1.21 computer model (DOE, 2004e) was used. Input to the model included the average concentrations of radionuclides in soil, as reported by McArthur and Kordas (1985) and decay-corrected to 2003, and the maximum measured concentrations in animals and plants sampled from the T2 site (see Tables 7-2 and 7-3). Internal dose is calculated using measured concentrations in biota tissue, and external dose is predicted from the average soil concentrations.

Average doses were estimated to be $0.0034 \mathrm{rad} / \mathrm{d}$ for plants and $0.0030 \mathrm{rad} / \mathrm{d}$ for animals (Table 8-4). Dose from internal radionuclides accounted for about 17 percent of the total for animals while it accounted for about 26 percent for plants; this difference is attributable primarily to the higher concentration of ${ }^{239+240} \mathrm{Pu}$ in the plants. The total estimated dose rates are 0.3 percent and 3 percent of the dose limits, respectively, for terrestrial plants and animals. 
Table 8-4. Site-specific dose assessment for terrestrial plants and animals sampled at T2 in 2006

\begin{tabular}{|c|c|c|c|c|c|c|}
\hline \multirow[b]{4}{*}{ DOE Dose Limit: } & \multicolumn{6}{|c|}{ Estimated Radiological Dose (rad/d) } \\
\hline & \multicolumn{3}{|c|}{ To Plants ${ }^{(a)}$} & \multicolumn{3}{|c|}{ To Animals } \\
\hline & $\begin{array}{c}\text { Internal } \\
0.0009\end{array}$ & $\begin{array}{c}\text { External } \\
0.0025\end{array}$ & $\begin{array}{c}\text { Total } \\
0.0034\end{array}$ & $\begin{array}{c}\text { Internal } \\
0.0005\end{array}$ & $\begin{array}{c}\text { External } \\
0.0025\end{array}$ & $\begin{array}{r}\text { Total } \\
0.0030\end{array}$ \\
\hline & & & 1 & & & 0.1 \\
\hline
\end{tabular}

(a) For list of plant species sampled, see Table 7-1 in Section 7.0

\subsubsection{Environmental Impact}

Based on the graded approach for assessing potential dose to biota, the plants and animals on the NTS are not expected to be exposed to significantly large radiological doses that may be detrimental to their populations. Work will continue to refine this dose assessment, especially in the area of defining dose evaluation areas. Boundaries of plant and animal populations intersecting contaminated areas will be further evaluated in an attempt to ensure that potential populations within currently defined areas are not missed. 


\subsection{Waste Management and Environmental Restoration}

Several federal and state regulations govern the safe management, storage, and disposal of radioactive, hazardous, and solid wastes generated or received on the Nevada Test Site (NTS) for the purpose of protecting the environment and the public (see Section 2.4). This section describes both the waste management and environmental restoration operations conducted under the U.S. Department of Energy, National Nuclear Security Administration Nevada Site Office (NNSA/NSO) Environmental Management Program and summarizes the activities performed in 2006 to meet all environmental/public safety regulations. The goals of the program are shown below. The compliance measures and actions tracked and taken to meet the program goals are also listed.

\begin{tabular}{|c|c|}
\hline $\begin{array}{c}\text { Waste Management and } \\
\text { Environmental Restoration Goals }\end{array}$ & Compliance Measures/Actions \\
\hline $\begin{array}{l}\text { Manage and safely dispose of the following wastes } \\
\text { generated by NNSA/NSO and the U.S. Department of } \\
\text { Defense (DoD) operations: } \\
\text { Low-level radioactive waste (LLW) } \\
\text { Low-level radioactive mixed waste (LLMW) } \\
\text { Hazardous waste (HW) } \\
\text { Continue to characterize, inspect, repackage, load, and } \\
\text { ship transuranic (TRU) wastes stored on an interim } \\
\text { basis at the NTS to either the Waste Isolation Pilot } \\
\text { Plant (WIPP) in Carlsbad, New Mexico or to the Idaho } \\
\text { National Laboratory (INL) } \\
\text { Characterize and remediate historic sites contaminated } \\
\text { by NNSA/NSO testing activities } \\
\text { Manage and safely dispose of solid/sanitary wastes } \\
\text { generated by NNSA/NSO }\end{array}$ & $\begin{array}{l}\text { Completion/maintenance of documents required for a } \\
\text { Class II Nuclear Facility Establishment of Waste } \\
\text { Acceptance criteria for radioactive wastes received for } \\
\text { disposal/storage } \\
\text { Volume of disposed LLW } \\
\text { Volume of stored non-radioactive hazardous waste } \\
\text { Volume of disposed LLMW } \\
\text { Weight of approved explosive ordnance wastes detonated } \\
\text { Vadose zone monitoring } \\
\text { Groundwater monitoring } \\
\text { Site characterization, remediation, closure, and post- } \\
\text { closure site monitoring } \\
\text { Weight and volume of solid waste disposed }\end{array}$ \\
\hline
\end{tabular}

\subsection{Radioactive Waste Management}

U.S. Department of Energy (DOE) Order 435.1, Radioactive Waste Management, requires that DOE radioactive waste management activities be systematically planned, documented, executed, and evaluated. Radioactive waste is managed to protect the public, the environment, and workers from exposure to radiation from radioactive materials and to comply with all applicable federal, state, and local laws and regulations; Executive Orders; and DOE directives. The major tasks within Radioactive Waste Management include:

- Verifying that NTS waste acceptance criteria are met for waste received

- Characterization of LLW and LLMW that has been generated by the DOE within the state of Nevada

- Disposal of LLW and LLMW at the Radioactive Waste Management Complex (RWMC) comprised of the Area 3 Radioactive Waste Management Site (RWMS) and the Area 5 RWMS

- Characterization, visual examination, and repackaging of TRU waste at the Waste Examination Facility (WEF) at the RWMC

- Loading of TRU waste at the Area 5 RWMS for shipment to either the WIPP or INL 


\subsubsection{Maintenance of Key Documents}

Table 9-1 lists the key documents which must be current and in place at each RWMS for disposal operations to occur. In 2006, all of these key documents were maintained and two were revised.

Table 9-1. Key documents required for Area 3 RWMS and Area 5 RWMS operations

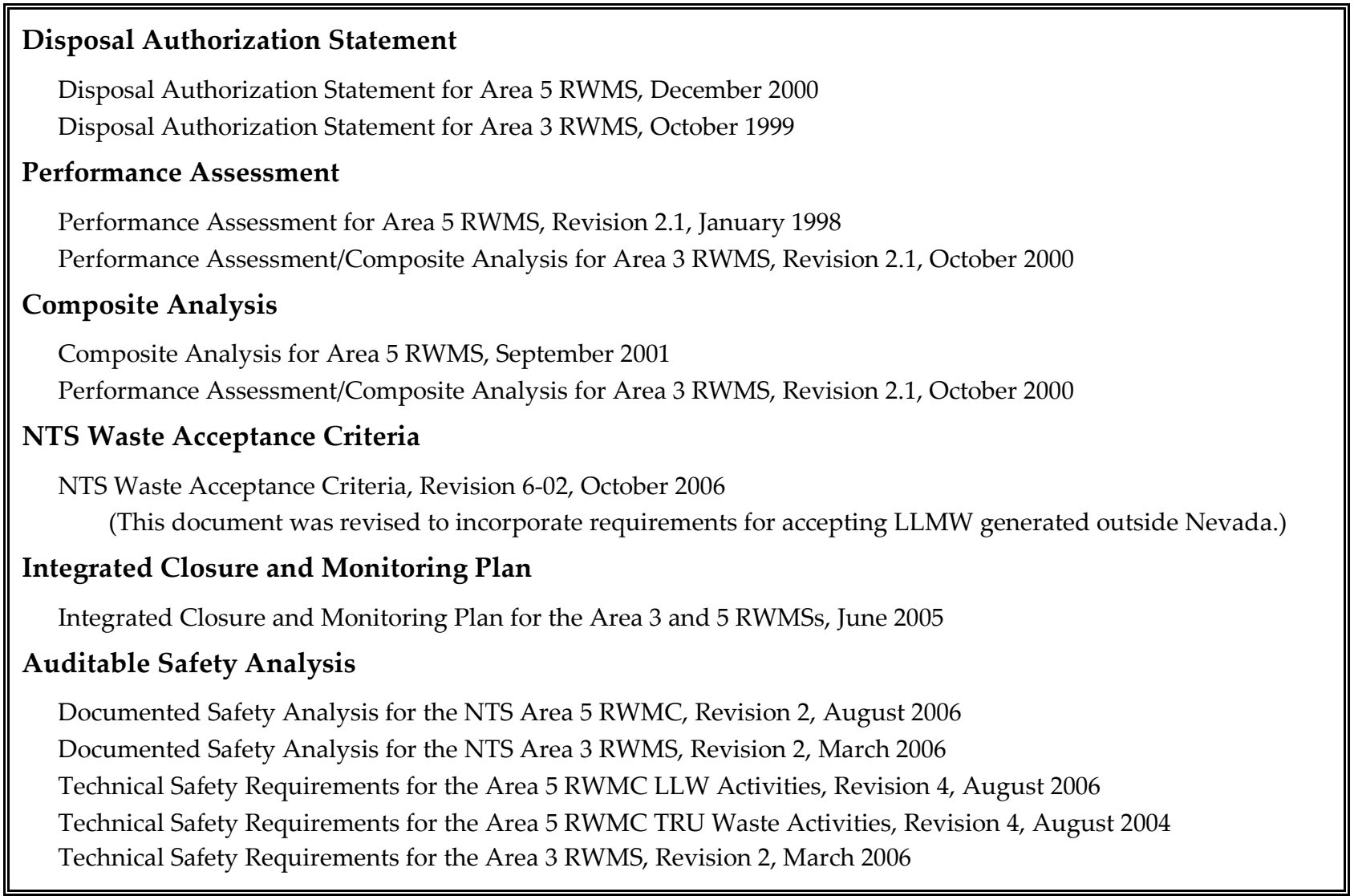

\subsubsection{Characterization of LLW and LLMW}

Waste Generator Services (WGS) characterizes LLW and LLMW generated by the DOE within Nevada, primarily at the NTS. Characterization is performed utilizing either knowledge of the generating process or sampling and analysis. Following the characterization of a waste stream, a Waste Profile is completed for approval by an appropriate disposal facility. The Waste Profile delineates the pedigree of the waste, including but not limited to a description of the waste generating process, physical and chemical characteristics, radioactive isotopes and their quantities, and detailed packaging information. WGS then packs and ships approved waste streams in accordance with U.S. Department of Transportation requirements to either the Area 3 or Area 5 RWMS or to an offsite treatment, storage, and disposal facility.

In 2006, LLW and MW were characterized by WGS for the following general waste stream categories:

- Lead Solids

- Sealed Sources

- Miscellaneous Debris

- Contact Water
- Compactable Trash

- Condensate Water 


\subsubsection{Disposal of LLW and LLMW}

The RWMC operates as a Category II Nuclear Facility. The RWMC, which includes the Area 3 and the Area 5 RWMSs, is designed and operated to perform three functions:

- Dispose of LLW from NNSA/NSO activities performed on and off the NTS and from other offsite generators in the state of Nevada.

- Dispose of DOE LLW from around the DOE complex, primarily from the cleanup of sites associated with the manufacture of weapons components.

- Dispose of LLMW from around the DOE complex.

All generators of waste streams must first request to dispose of waste, submit a request to NNSA/NSO requesting to ship waste to the NTS for disposal, submit profiles characterizing specific waste streams, meet the NTS Radioactive Waste Acceptance Criteria, and receive programmatic approval from NNSA/NSO. The NTS Radioactive Waste Acceptance Criteria are based on how well the site is predicted to perform in containing radioactive waste and ensuring that the environment and the public will not be exposed to significant radiation. The NNSA/NSO assesses and predicts the long-term performance of LLW disposal sites by conducting a Performance Assessment (PA) and a Composite Analysis (CA). A PA is a systematic analysis of the potential risks posed by a waste disposal site to the public and to the environment. A CA is an assessment of the risks posed by all wastes disposed in a LLW disposal site and by all other sources of residual contamination that may interact with the disposal site. PA and CA documents are developed as a result of these activities. The RWMC receives LLW generated within the DOE complex from numerous DOE sites across the United States, LLW from DoD sites that carry a national security classification, and LLMW generated within the DOE complex for disposal.

Disposal consists of placing waste in unlined cells and trenches. Soil backfill is applied over the waste in a single lift, which is approximately 2.4 meters $(\mathrm{m})(8 \mathrm{feet}[\mathrm{ft}])$ thick, as rows of containers reach approximately $1.2 \mathrm{~m}(4 \mathrm{ft})$ below the original grade. The Area 5 RWMS includes 81 hectares (ha) (200 acres [ac]) of existing and proposed disposal cells for burial of both LLW and LLMW, and approximately $202 \mathrm{ha}(500 \mathrm{ac})$ of land available for future radioactive disposal cells. Waste disposal at the Area 5 RWMS has occurred in a 37 ha $(92 \mathrm{ac})$ portion of the site since the early 1960s. This part of the Area 5 RWMS (commonly referred to as the "92-Acre Area") consists of 31 disposal cells (pits and trenches) and 13 Greater Confinement Disposal (GCD) boreholes (listed below). This site is used for disposal of waste in drums, soft sided containers, large cargo containers, and boxes. The 92 acre area is expected to be filled and closed by 2010, and new cells extending to the north and west are expected to close by 2027. LLW and LLMW disposal services are expected to continue at Area 5 RWMS as long as the DOE complex requires the disposal of wastes from the weapons program.

31 Disposal Cells at Area 5 RWMS:

6 active which receive standard LLW

1 active and permitted to receive asbestiform LLW (P06U)

1 active and permitted by the State to receive LLMW (P03U)

11 operationally closed containing LLW

11 cells operationally closed containing LLW and LLMW

(Corrective Action Unit [CAU] 111)

1 operationally closed containing asbestiform LLW (P07U)

\section{GCD Boreholes at Area 5 RWMS:}

4 inactive (open but have not received any waste) 4 closed containing TRU waste

5 closed containing LLW

Disposal operations at the Area 3 RWMS began in the late 1960s. The Area 3 RWMS consists of seven craters making up five disposal cells. Each subsidence crater was created by an underground weapons test. Until July 1, 2006 when the site was placed into inactive status, the site was used for disposal of bulk LLW waste, such as soils or debris, and waste in large cargo containers. The site consists of the following seven craters:
3 Disposal Cells (Inactive Status):
2 Closed Cells:
2 Undeveloped Cells:
$\mathrm{U} 3 \mathrm{ah} / \mathrm{at}$
$\mathrm{U} 3 \mathrm{ax} / \mathrm{bl}$ (CAU 110)
$\mathrm{U} 3 \mathrm{az}$
U3bh
U3bg 
In calendar year 2006, the Area 3 and 5 RWMSs received shipments containing 28,803 cubic meters ( $\mathrm{m}^{3}$ ) $\left(1,009,680\right.$ cubic feet [ $\left.\left.\mathrm{ft}^{3}\right]\right)$ of LLW for disposal and $212 \mathrm{~m}^{3}\left(7,497 \mathrm{ft}^{3}\right)$ of LLMW. The majority of disposed LLW and all of the LLMW were received from offsite generators. Only $1,779 \mathrm{~m}^{3}\left(62,809 \mathrm{ft}^{3}\right)$ of the LLW disposed in 2006 was generated onsite. Fiscal year 2006 (October 1 - September 30) volumes of waste shipments are reported in DOE (2007).

In 2006, the Area 5 RWMS received and disposed of 55.87 tons (net weight) of asbestos-form LLW at P06U.

\subsubsection{TRU Waste Operations}

The TRU-Pad/Transuranic Pad Cover Building (TPCB) at the Area 5 RWMC is a Resource Conservation and Recovery Act (RCRA) Part B interim status facility designed for the safe storage of TRU waste generated by Lawrence Livermore National Laboratory and other small- quantity sites. The TPCB accepts TRU waste from NTS generators including the Joint Actinide Shock Physics Experimental Research facility. The TPCB stores TRU waste until it is characterized at the WEF at the Area 5 RWMC. Once characterized, the TRU waste is loaded at the mobile loading unit for shipment either to the WIPP at Carlsbad, New Mexico, for disposal or to an interim site for further characterization. Current agreements between NNSA/NSO and WIPP plan for TRU waste shipments to be completed by September 2008. In 2006, TRU waste stored at the TPCB continued to be characterized, visually inspected, repackaged, and prepared for shipment.

\subsubsection{Assessments}

In 2006, assessments were conducted at the RWMC in accordance with National Security Technologies, LLC (NSTec) procedures. Schedules for management self-assessments (MSAs) are developed for the RWMC. In addition to the MSAs performed internally at the RWMC, assessments were performed periodically by other NSTec organizations, NNSA/NSO, and the Defense Nuclear Facilities Safety Board. The results of each assessment and any required corrective action(s) were logged for NNSA/NSO in the companywide issues tracking system known as CaWeb.

\subsubsection{Groundwater Monitoring for Low-level Waste Pit P03U}

P03U is operated according to RCRA Interim Status standards for the disposal of mixed LLW. Title 40 Code of Federal Regulations (CFR) 265 (Groundwater Monitoring) Subpart F (40 CFR 265.92) requires groundwater monitoring to verify the performance of $\mathrm{P} 03 \mathrm{U}$ to protect groundwater from buried radioactive wastes. Wells UE5 PW-1, UE5 PW-2, and UE5 PW-3 are monitored for this purpose; these wells comprise 3 of the 14 onsite monitoring wells sampled periodically for radionuclide analyses of groundwater (see Section 4.1.7). Investigation levels (ILs) for five indicators of groundwater contamination (Table 9-2) were established by NNSA/NSO and the Nevada Division of Environmental Protection (NDEP) for these three wells in 1998. Further groundwater analyses will be required if the results from all replicate samples exceed a parameter's IL. In 2006, the average total organic carbon (TOC) result of 1.12 milligrams per liter (mg/L) at UE5 PW-2 in October 2006 exceeds the IL. The individual TOC results for this average value are $2.3 \mathrm{mg} / \mathrm{L}, 0.56 \mathrm{mg} / \mathrm{L}$, and $<0.5 \mathrm{mg} / \mathrm{L}$. None of the other water samples collected semi-annually from the wells had average contaminant levels above their ILs (Table 9-2). General water chemistry parameters are also monitored; all sample analysis results are presented in NSTec (2007a). Table 4-4 of Section 4.1.7 presents the tritium results for UE5 PW-1, UE5 PW-2, and UE5 PW-3.

Table 9-2. Results of groundwater monitoring of UE5 PW-1, UE5 PW-2, and UE PW-3 in 2006

\begin{tabular}{|lcc||}
\hline Parameter & Investigation Level (IL) & Sample Levels \\
\hline $\mathrm{pH}$ & $<7.6 \mathrm{or}>9.2 \mathrm{~S} . \mathrm{U}^{(\mathrm{a})}$ & 8.03 to $8.34 \mathrm{~S} . \mathrm{U}$. \\
Specific conductance (SC) & $0.440 \mathrm{mmhos} / \mathrm{cm}^{(\mathrm{b})}$ & 0.341 to $0.384 \mathrm{mmhos} / \mathrm{cm}$ \\
Total organic carbon (TOC) & $1 \mathrm{mg} / \mathrm{L}$ & $<0.5-1.12 \mathrm{mg} / \mathrm{L}$ \\
Total organic halides (TOX) & $50 \mu \mathrm{g} / \mathrm{L}^{(\mathrm{c})}$ & $<5.0-7.3 \mu \mathrm{g} / \mathrm{L}$ \\
Tritium $\left({ }^{3} \mathrm{H}\right)$ & $2,000 \mathrm{pCi} / \mathrm{L}^{(\mathrm{d})}$ & $-6.71-13.77 \mathrm{pCi} / \mathrm{L}$ \\
\hline
\end{tabular}

(a) S.U. = standard unit(s) (for measuring $\mathrm{pH}$ )

(b) $\mathrm{mmhos} / \mathrm{cm}=$ millimhos per centimeter

Source: NSTec, 2007a

(c) $\mu \mathrm{g} / \mathrm{L}=$ microgram(s) per liter

(d) $\mathrm{pCi} / \mathrm{L}=$ picocuries per liter 
Waste Management and Environmental Restoration

\subsubsection{Vadose Zone Monitoring}

Monitoring of the vadose zone (unsaturated zone above the water table) is conducted at the RWMC to demonstrate that: (1) the PA assumptions at the RWMSs are valid regarding the hydrologic conceptual models used, including soil water contents, and upward and downward flux rates and (2) that there is negligible infiltration of precipitation into zones of buried waste at the RWMSs. Vadose zone monitoring (VZM) offers many advantages over groundwater monitoring, including detecting potential problems long before groundwater resources would be impacted, allowing corrective actions to be made early, and being less expensive than groundwater monitoring. All VZM conducted in 2006 continued to demonstrate that there is negligible infiltration of precipitation into zones of buried waste at the RWMC and that the performance criteria of the waste disposal cells are being met to prevent contamination of groundwater and the environment. A few components of the VZM monitoring program implemented in 2006 are presented below. For more details on the program refer to the Nevada Test Site 2006 W aste Management Monitoring Report Area 3 and Area 5 Radioactive Waste Management Sites (NSTec, 2007b).

\subsubsection{Area 3 RWMS Drainage Lysimeter Facility}

In December 2000, a Drainage Lysimeter Facility was constructed immediately northwest of the U-3ax/bl disposal unit at the Area 3 RWMS. The facility consists of eight cylindrical drainage lysimeters, each $3.1 \mathrm{~m}(10.0 \mathrm{ft})$ in diameter and $2.4 \mathrm{~m}(8.0 \mathrm{ft})$ deep. Each lysimeter is filled with native soil and packed to mimic the U-3ax/bl soil cover. Each lysimeter has eight Time-Domain Reflectometry (TDR) probes to measure moisture content depth profiles paired with eight heat dissipation probes to measure soil water potential depth profiles. Measured water contents at the bottom of the lysimeters and drainage from the lysimeters provide an indirect measure of potential drainage from the $\mathrm{U}-3 \mathrm{ax} / \mathrm{bl}$ soil cover. The lysimeter facility was constructed to fulfill data needs including reducing uncertainty in the expected performance of monolayer-evapotranspiration closure covers under various surface vegetation treatments and climatic change scenarios such as increased rainfall.

There are three surface vegetation treatments subject to two climate treatments on the lysimeters. The three surface vegetation treatments are bare soil; natural plant recolonization (primarily by invader species Salsola tragus [prickly Russian thistle], Halogeton glomeratus [halogeton], and Sisymbrium alitissimum [tumblemustard]); and revegetation with former plant community species (primarily Atriplex confertifolia [shadscale], Krascheninnikovia lanata [winterfat], Ephedra nevadensis [Nevada ephedra], and Achnatherum hymenoides [Indian ricegrass]). The bare soil lysimeters mimic operational waste covers, the invader species lysimeters mimic operational waste covers that are not maintained, and revegetation lysimeters mimic final closure covers. The climate treatments are natural precipitation and three times the amount of natural precipitation. The increased precipitation lysimeters receive natural precipitation and are irrigated at a rate equal to two times natural precipitation.

No drainage has ever occurred from any of the four non-irrigated lysimeters, but moisture did accumulate at the bottom of the bare-soil lysimeter and the revegetated lysimeter. After a period of heavy precipitation in the fall of 2004 and the the spring of 2006, there was drainage from every irrigated lysimeter, but the vegetated lysimeters had much less drainage than the bare soil lysimeter. Measured volumetric water contents confirm that vegetation effectively removes moisture from the lysimeters, helping prevent deep percolation of infiltrated precipitation.

\subsubsection{Area 5 RWMS Weighing Lysimeter Facility}

The Area 5 Weighing Lysimeter Facility consists of two precision weighing lysimeters located about $400 \mathrm{~m}(0.25 \mathrm{mi})$ southwest of the Area 5 RWMS. Each lysimeter consists of a 2 x 4-m $(6.6$ x 13-ft) by 2-m (6.6-ft) deep steel box filled with soil. The load cells in each lysimeter can measure approximately 0.1 millimeters $(0.004$ inches [in.]) of precipitation or evapotranspiration. One lysimeter is vegetated with native plant species at the approximate density of the surrounding desert, and one lysimeter is kept bare to simulate operational waste covers at the Area 5 RWMS. The load cells have been monitored continuously since March 1994, providing an accurate dataset of the surface water balance at the Area 5 RWMS. 
The weighing lysimeter data represent a simplified water balance: the change in soil water storage is equal to precipitation minus evaporation on bare lysimeters, or precipitation minus evapotranspiration on vegetated lysimeters. The water balance is simplified because no drainage can occur through the solid bottoms of the lysimeters and because a 2.5 centimeters $(\mathrm{cm})(1 \mathrm{in}$.) lip around the edge of the lysimeters prevents run-on and runoff. No water has ever accumulated at the bottom of the vegetated lysimeter. Heavy precipitation and low E rates during the period from October 2004 to February 2005 combined with initially higher water contents, resulted in water accumulating at the bottom of the bare lysimeter starting in March 2005. Long-term numerical simulations (30 years) using a unit gradient bottom boundary were used to determine the amount of drainage that would have occurred if water could drain from the lysimeters. These simulations indicate an average of $1.0 \mathrm{~cm}$ per year of water reaches the bottom of the bare lysimeter and that essentially no water reaches the bottom of the vegetated lysimeter (Desotell et al., 2006).

\subsubsection{RWMS Waste Cover Automated Monitoring}

Automated monitoring systems are installed in the operational covers on Pits P03U, P04U, and P05U; the floor of P05U underneath the waste; and the closure cover on $\mathrm{U}-3 \mathrm{x} / \mathrm{bl}$. These monitoring systems measure moisture content depth profiles with TDR probes. The system at $\mathrm{P} 05 \mathrm{U}$ also has heat dissipation probes to measure water potential depth profiles. The precipitation events, beginning in October 2004, infiltrated into the operational covers of Pits P03U, P04U, and P05U, and percolated below the deepest probes at $180 \mathrm{~cm}$ (71 in.) in March 2005. This moisture is below the range of substantial surface evaporation, and the observed gradual drying at these locations is most likely due to downward percolation. This is the deepest observed moisture percolation in the operational covers. Precipitation percolated to $152 \mathrm{~cm}$ (60 in.) in the U-3x/bl closure cover by March 2005 but was removed to the atmosphere by evapotranspiration in six months. The measurements in the floor of P05U do not show any evidence of water movement.

\subsubsection{RWMS Supplemental Automated Monitoring}

Additional automated data-acquisition stations are maintained to provide ancillary data in support of the more direct monitoring of RWMS disposal units and the lysimeters in Areas 3 and 5. These stations include meteorological towers that continuously measure precipitation, air temperature, humidity, wind speed, wind direction, barometric pressure, and solar radiation.

\subsubsection{Gas-phase Tritium Monitoring}

Tritium monitoring is conducted via soil gas sampling at Well GCD-05U, one of the 13 GCD boreholes at the Area 5 RWMS. Radioactive wastes were buried in this borehole from 36 to $20 \mathrm{~m}$ (119 to $65 \mathrm{ft}$ ) below the surface. The borehole was then backfilled with clean soil. Monitoring provides a direct measure of changes in tritium activity with depth due to degradation of waste containers, advection, and diffusion. The 17-year trend in results indicates that upward migration of tritium through the soil from the buried waste is extremely slow. The tritium concentrations from sample ports adjacent to the buried waste at depths of 20,26, 33, and $36 \mathrm{~m}(65,85,110$, and $119 \mathrm{ft})$ have increased by a factor of three since 1990, with the highest concentration of 381 microcuries per cubic meter $\left(\mu \mathrm{Ci} / \mathrm{m}^{3}\right)$ of soil gas measured at $26 \mathrm{~m}(85 \mathrm{ft})$ in September 2001. Tritium concentrations have remained constant and low at about $0.01 \mu \mathrm{Ci} / \mathrm{m}^{3}$ in soil gas samples taken above the tritium source at depths of $3,6,9$, and $12 \mathrm{~m}(10,20,30$, and $40 \mathrm{ft})$.

\subsubsection{Radon Flux}

Radon flux measurements were taken on the U-3ax/bl cover at the Area 3 RWMS and on the P06U and P14U covers at the Area 5 RWMS during 2006. Electrets inserted in domes (Rad Elec, Inc.) measure radon flux from the ground. None of the radon flux measurements from the covers are higher than those from undisturbed or control locations. 


\subsection{Hazardous Waste Management}

Hazardous wastes (HW) (see Glossary, Appendix B) regulated under RCRA are generated at the NTS from a broad range of activities including onsite laboratories, paint shops, vehicle maintenance, communications and photo operations, and environmental restoration of historic contaminated sites (see Section 9.3). HW exclude radioactive wastes by definition; a waste which is both hazardous and radioactive is termed a mixed waste. The RCRA Part B Permit (NEV HW0021) regulates the operation of three HW facilities on the NTS: P03U at the Area 5 RWMS, the Hazardous Waste Storage Unit (HWSU) in Area 5, and the Explosive Ordnance Disposal Unit (EODU) in Area 11. Quarterly reports are submitted to the state of Nevada which document the weight of HW received each quarter at each of these HW units for management (i.e., for disposal, temporary storage, or detonation). Quarterly fees are paid to the state based on the weights of HW received. Also, Part II.K.2 of the permit requires preparation of a U.S. Environmental Protection Agency Biennial Hazardous Waste Report of all hazardous waste volumes generated at the NTS and at the NLVF during a year. This biennial report is prepared for odd-numbered years and is submitted the following February. Quarterly 2006 reports and the 2005 biennial report were submitted on time.

\subsubsection{Pit P03U}

Pit P03U began receiving LLMW from offsite DOE facilities in April 2006. P03U received a total of 182.29 tons in 2006 (Table 9-3).

\subsubsection{Hazardous Waste Storage Unit and Waste Accumulation Areas}

The HWSU is a pre-fabricated, rigid steel framed, roofed shelter which is permitted to store a maximum of 61,600 liters (16,280 gallons) of approved waste at a time. HW generated at NSTec restoration sites off the NTS (e.g., at the Tonopah Test Range [T'TR]) or generated at the North Las Vegas Facility are direct-shipped to approved disposal facilities. HW generated at restoration sites or other project sites on the NTS are also direct-shipped if the sites generate bulk, non-packaged HW which is not accepted at the HWSU for storage. HW would also be directshipped in the unlikely case when the waste volume capacity of the HWSU is approaching its permitted limits. Satellite accumulation areas (SAAs) and 90-day hazardous waste accumulation areas (HWAAs) are used at the NTS for the temporary storage of HW prior to shipment offsite or to the HWSU.

In 2006, a total of 11.83 tons of HW was managed at the HWSU which included treatment, storage, and disposal activities (Table 9-3). The HW managed at the HWSU in 2006 included drums of liquid polychlorinated biphenyls (PCBs) (see Section 10.1). In 2006, no HW was direct-shipped from NTS SAAs, but a total of 384.45 tons of HW were direct-shipped offsite from HWAAs (Table 9-3). No storage limits were exceeded. Quarterly reports of applicable waste quantities were submitted on time to NDEP.

\subsubsection{EODU}

Conventional explosive wastes are generated at the NTS from tunnel operations, the NTS firing range, the resident national laboratories, and other activities. The permit allows NNSA/NSO to treat explosive ordnance wastes at the EODU by open detonation of no more than 45.4 kilograms $(\mathrm{kg})(100 \mathrm{lb})$ of approved waste at a time, not to exceed one detonation event per hour. In 2006, no explosive ordnance were detonated at the EODU (Table 9-3).

Table 9-3. Hazardous waste managed at the NTS in 2006

\begin{tabular}{||lc||}
\hline \hline Permitted Unit & Total Waste Managed (tons) (a) \\
\hline P03U & 182.29 \\
HWSU & 11.83 \\
HWSU - PCB Waste & 2.346 \\
HWAAs & $384.45^{(\mathrm{b})}$ \\
EODU & 0 \\
\hline
\end{tabular}

(a) The permitted storage limit for LLMW at P03U is 20,000 $\mathrm{m}^{3}\left(706,293 \mathrm{ft}^{3}\right)$, and for HW at the HWSU, it is 61,600 liters $(16,280$ gallons). However, the reporting units are tons, by which quarterly fees to the state of Nevada are based.

(b) Tons shipped directly offsite from HWAAs. 


\subsection{Underground Storage Tank (UST) Management}

By 1998, the NTS UST program met all regulatory compliance schedules for the reporting, upgrading, or removal of documented USTs. The NNSA/NSO operates one deferred UST and three excluded USTs at the Device Assembly Facility. The NNSA/NSO also maintains a fully-regulated UST at the Area 6 helicopter pad which is not in service.

\subsection{Environmental Restoration - Remediation of Historic Contaminated Sites}

In April 1996, the DOE, DoD, and the state of Nevada entered into a Federal Facility Agreement and Consent Order (FFACO) to address the environmental restoration of historic contaminated sites at the NTS, parts of TTR, parts of the Nellis Air Force Range (now known as the Nevada Test and Training Range, the Central Nevada Test Area, and the Project Shoal Area. These sites, known as Corrective Action Sites (CASs), may be contaminated with both radioactive and non-radioactive wastes. Appendix VI of the FFACO describes the strategy that will be employed to plan, implement, and complete environmental corrective actions at facilities where nuclear-related operations were conducted. Stoller-Navarro Joint Venture conducts most site characterization activities, while the NTS Management and Operations contractor (Bechtel Nevada and then NSTec) conducted site restoration, soil remediation, and some facility decontamination and decommissioning activities in 2006.

\subsubsection{Corrective Actions}

The corrective action strategy is based on four steps: (1) identifying the CASs, (2) grouping the CASs into Corrective Action Units (CAUs), (3) prioritizing the CAUs for funding and work, and (4) implementing the corrective action investigations (CAIs) and/or corrective actions, as applicable. CASs are broadly organized into the following four categories based on the source of contamination:

- Industrial Sites - CASs located on the NTS and T'TR where activities were conducted that supported nuclear testing activities

- Underground Test Area (UGTA) Sites - CASs located where underground nuclear test have resulted or might result in local or regional impacts to groundwater resources

- Soil Sites - CASs where tests have resulted in extensive surface and/or shallow subsurface contamination

- Nevada Off-Sites - Additional CASs associated with underground nuclear testing at the Project Shoal Area and the Central Nevada Test Area, located in northern and central Nevada, respectively

Identifying CASs - The first step in the strategy is to identify CASs potentially requiring CAIs and/or corrective actions. As CASs are identified, a literature search may be completed and each CAS is verified on aerial photographs or in the field to confirm its location and site condition. A data repository has been created containing or referencing all information currently available for each CAS.

Grouping CASs into CAUs - A CAU may have several CASs or only one. In addition to the four categories noted above, criteria for grouping CASs into CAUs include the following:

- Potential source of contamination

- Agency responsible for cleanup of the CAS

- Function of the CAS and the nature of the contamination

- Geographic proximity of CASs to one another

- Potential for investigation or cleanup of grouped CASs to be accomplished within a similar time frame 
Implementing Corrective Action Investigations and/or Corrective Actions - When a CAU is assigned priority and funding, environmental restoration activities follow a formal work process beginning with a Data Quality Objectives (DQO) meeting between the NNSA/NSO, Defense Threat Reduction Agency, NDEP, and contractors. If existing information about the nature and extent of contamination at the CASs is insufficient to evaluate and select preferred corrective actions, a CAI will be conducted. A Corrective Action Investigation Plan (CAIP) is prepared that provides a conceptual model of the site and defines how the site is to be characterized in conformance with the DQO process.

Site characterization is performed in the field and documented in a Corrective Action Decision Document (CADD). This document provides the information that either confirms or modifies the preliminary conceptual model. If suitable information is available to make a decision, a remedial action alternative is selected that best provides site closure. In some instances, additional site characterization may be required before the CADD can be prepared.

If a site requires a closure action, a Corrective Action Plan (CAP) is prepared that will implement the recommended remedial action/closure alternative. A CAP is comprised of the following elements for site closure: a detailed scope of work, target field schedule, quality control measures, waste management strategy, design specifications/drawings (when applicable), verification sampling strategies (for clean closures), and other information necessary for satisfying the specific closure requirements. Some sites also require a Post-Closure Plan as the site or parts of the site are closed in place. Information on field inspections, types of monitoring, monitoring frequency, and maintenance/repairs are provided in an Annual Post-Closure Monitoring Report.

Once the closure has been completed, a Closure Report is prepared. This report provides information on the scope of work performed, results of verification sampling, as-built drawings, waste management, and post closure requirements for closed-in-place sites, etc. Some sites are closed under the Streamlined Approach for Environmental Restoration (SAFER) process identified in the FFACO. These sites typically have enough information available to remediate the site within a shorter duration. For such sites, a SAFER plan is prepared that will implement the plan for site closure. After closure, a SAFER closure report is prepared that documents the scope of work performed.

The NDEP is a participant throughout the remediation process. The Community Advisory Board (CAB) is also kept informed by NNSA/NSO of the progress made. The Board's comments are strongly considered before final prioritization of corrective actions. A public participation working group made up of representatives from DOE, $\mathrm{DoD}$, the state of Nevada, and the $\mathrm{CAB}$ meets twice a year to discuss quarterly progress, upcoming environmental restoration activities, priority-setting activities established under the FFACO, and the level of public involvement required.

Table 9-4 lists the 43 CAUs for which some step of the site remediation process was completed in calendar year 2006. All 2006 milestones were met. A total of 339 CASs was closed, either under the SAFER process or the standard closure process.

\subsubsection{Post-Closure Monitoring and Inspections}

There are nine sites on the NTS for which remediation was indicated or completed under RCRA regulations prior to enactment of the FFACO. Eight have been closed and are referred to as historic RCRA closure units. For the ninth site, the Area 5 Retired Mixed Waste Pits and Trenches, the NDEP has determined that NNSA/NSO shall close the site (in the future) subject to the conditions of 40 CFR 265.310. Three of the eight RCRA closure units require no further post-closure monitoring (Area 23 Building 650 Leachfield, Area 6 Steam Cleaning Effluent Ponds, and Area 2 U-2bu Subsidence Crater). Three of the eight closed units require quarterly site inspections (Area 6 Decon Pond [CAU 92], Area 3 U-3ax/bl Subsidence Crater [CAU 110], and Area 23 Hazardous Waste Trenches [CAU 112]), and two currently require semi-annual post-closure inspections (Area 2 Bitcutter Containment [CAU 90] and Area 3 U-3fi Injection Well ([CAU 91]). VZM for the Area 3 U-3fi Injection Well and Area 23 Hazardous Waste Trenches is no longer conducted because the most recent monitoring results demonstrated continuing stable conditions at these sites.

The one site still requiring VZM is CAU 110, the Area 3 U-3ax/bl Subsidence Crater. At this site, post-closure inspections are performed quarterly and consist of visual observations to check that the cover is intact. The U-3ax/bl Subsidence Crater cover is designed to limit infiltration into the disposal unit and is monitored using TDR soil water content sensors buried at various depths within the waste cover to provide water content profile data. The soil water 
Table 9-4. Environmental restoration activities conducted in 2006

\begin{tabular}{|c|c|c|c|c|c|c|}
\hline CAU & CAU Description & $\begin{array}{l}\text { Number } \\
\text { of CASs }\end{array}$ & Milestone & $\begin{array}{l}\text { Due } \\
\text { Date }\end{array}$ & $\begin{array}{c}\text { Date } \\
\text { Submitted }\end{array}$ & $\begin{array}{c}\text { Date NDEP } \\
\text { Approved }\end{array}$ \\
\hline \multicolumn{7}{|c|}{ DOE Industrial Sites - Defense Project } \\
\hline 322 & Areas $1 \& 3$ Release Sites and Injection Wells & 3 & Closure Report to State & 09/30/06 & $06 / 26 / 06$ & 07/02/06 \\
\hline 530 & LANL Preshot Mud Pits & 54 & Closure Report to State & $07 / 31 / 06$ & 07/10/06 & $07 / 27 / 06$ \\
\hline 531 & LANL Postshot Mud Pits & 12 & Closure Report to State & 07/31/06 & 07/10/06 & 07/27/06 \\
\hline 532 & LLNL Preshot Mud Pits & 78 & Closure Report to State & $07 / 31 / 06$ & 07/10/06 & 07/27/06 \\
\hline 533 & LLNL Postshot Mud Pits & 69 & Closure Report to State & $07 / 31 / 06$ & 07/10/06 & $07 / 27 / 06$ \\
\hline 534 & Exploratory/Instrumentation Mud Pits & 40 & Closure Report to State & $07 / 31 / 06$ & 07/10/06 & 07/27/06 \\
\hline 535 & Mud Pits/Disposal Areas & 15 & Closure Report to State & 07/31/06 & 07/10/06 & 07/27/06 \\
\hline 540 & Spill Sites & 9 & Closure Report to State & $02 / 28 / 07$ & $10 / 19 / 06$ & $11 / 09 / 06$ \\
\hline 555 & Septic Systems & 5 & CAIP to State & $02 / 28 / 06$ & $12 / 27 / 05$ & 01/09/06 \\
\hline 565 & Stored Samples & 1 & CAIP to State & 09/30/06 & 08/30/06 & 09/07/06 \\
\hline \multicolumn{7}{|c|}{ Defense Threat Reduction Agency/DOE - Industrial Sites } \\
\hline 559 & T-Tunnel Compressor/Blower Pad & 1 & CADD to State & $11 / 30 / 06$ & $11 / 28 / 06$ & $12 / 21 / 06$ \\
\hline 559 & T-Tunnel Compressor/Blower Pad & 1 & Closure Report to State & $11 / 30 / 06$ & $11 / 28 / 06$ & $12 / 21 / 06$ \\
\hline \multicolumn{7}{|c|}{ DOE Industrial Sites - Environmental Restoration Project (ERP) } \\
\hline 5 & Landfills & 8 & Closure Report to State & $02 / 28 / 06$ & 02/08/06 & 03/07/06 \\
\hline 115 & Area 25 Test Cell A Facility & 4 & Closure Report to State & $03 / 31 / 06$ & 03/06/06 & 03/13/06 \\
\hline 116 & Area 25 Test Cell C Facility & 2 & SAFER Plan to State & 09/30/06 & $07 / 24 / 06$ & 08/11/06 \\
\hline 118 & Area 27 Super Kukla Facility & 1 & SAFER Plan Rev 1 to State & & $09 / 20 / 06$ & $09 / 21 / 06$ \\
\hline 118 & Area 27 Super Kukla Facility & 1 & SAFER Plan to State & 09/30/06 & 08/24/06 & 09/05/06 \\
\hline 139 & Waste Disposal Sites & 7 & CAIP to State & $05 / 31 / 06$ & 04/07/06 & 04/18/06 \\
\hline 145 & Wells and Storage Holes & 6 & CAP to State & $12 / 31 / 06$ & $11 / 16 / 06$ & $12 / 04 / 06$ \\
\hline 145 & Wells and Storage Holes & 6 & CADD to State & $05 / 31 / 06$ & $04 / 27 / 06$ & 05/04/06 \\
\hline 151 & Septic Systems and Discharge Area & 8 & CADD to State & $05 / 31 / 06$ & 05/10/06 & 06/09/06 \\
\hline 166 & Storage Yards and Contaminated Materials & 7 & CAIP to State & 07/31/06 & 06/16/06 & $06 / 26 / 06$ \\
\hline 168 & Area 25 \& 26 Contaminated Materials \& Waste Dumps & 12 & CADD Rev 2 to State & & $12 / 05 / 06$ & $12 / 21 / 06$ \\
\hline 168 & Area 25 \& 26 Contaminated Materials \& Waste Dumps & 12 & CAP Rev 1 to State & & $12 / 14 / 06$ & $12 / 28 / 06$ \\
\hline 177 & Mud Pits and Cellars & 12 & SAFER Plan to State & 07/31/06 & 06/12/06 & 06/29/06 \\
\hline 190 & Contaminated Waste Sites & 4 & CAIP to State & 01/31/07 & $12 / 11 / 06$ & $12 / 14 / 06$ \\
\hline 204 & Storage Bunkers & 6 & Closure Report to State & 05/01/06 & 04/04/06 & 04/17/06 \\
\hline 214 & Bunkers and Storage Areas & 9 & Closure Report to State & 09/30/06 & 09/13/06 & 09/18/06 \\
\hline 219 & Septic Systems and Injection Wells & 6 & Closure Report to State & 06/30/06 & $05 / 31 / 06$ & $06 / 15 / 06$ \\
\hline 219 & Septic Systems and Injection Wells & 6 & CADD to State & $06 / 30 / 06$ & $05 / 31 / 06$ & $06 / 15 / 06$ \\
\hline
\end{tabular}


Table 9-4. Environmental restoration activities conducted in 2006 (continued)

\begin{tabular}{|c|c|c|c|c|c|c|}
\hline CAU & CAU Description & $\begin{array}{l}\text { Number } \\
\text { of CASs }\end{array}$ & Milestone & $\begin{array}{l}\text { Due } \\
\text { Date }\end{array}$ & $\begin{array}{c}\text { Date } \\
\text { Submitted }\end{array}$ & $\begin{array}{c}\text { Date NDEP } \\
\text { Approved }\end{array}$ \\
\hline \multicolumn{7}{|c|}{ DOE Industrial Sites - ERP cont. } \\
\hline 224 & Decon Pad and Septic Systems & 9 & CAP to State & 08/30/06 & 08/02/06 & 08/08/06 \\
\hline 274 & Septic Systems & 5 & Closure Report to State & 09/30/06 & 09/20/06 & 09/21/06 \\
\hline 274 & Septic Systems & 5 & CADD to State & 09/30/06 & 09/20/06 & 09/21/06 \\
\hline 300 & Surface Release Areas & 7 & CAP to State & 08/31/06 & 08/02/06 & 08/08/06 \\
\hline 309 & Area 12 Muckpiles & 3 & CADD to State & 02/28/06 & $12 / 23 / 05$ & 01/10/06 \\
\hline 309 & Area 12 Muckpiles & 3 & Closure Report to State & $02 / 28 / 06$ & $12 / 23 / 05$ & 01/10/06 \\
\hline 408 & Bomblet Target Area (TTR) & 1 & SAFER Plan to State & $11 / 30 / 06$ & $10 / 31 / 06$ & $11 / 09 / 06$ \\
\hline 489 & WWII UXO Sites (TTR) & 3 & Closure Report to State & 09/30/06 & $06 / 14 / 06$ & $06 / 23 / 06$ \\
\hline 511 & Waste Dumps (Piles \& Debris) & 9 & CADD to State & $01 / 31 / 06$ & $12 / 12 / 05$ & 01/03/06 \\
\hline 511 & Waste Dumps (Piles \& Debris) & 9 & Closure Report to State & $01 / 31 / 06$ & $12 / 12 / 05$ & 01/03/06 \\
\hline 528 & Polychlorinated Biphenyls Contamination & 1 & Closure Report to State & $02 / 28 / 07$ & 09/26/06 & 10/17/06 \\
\hline 538 & Spill Sites & 7 & SAFER Plan to State & $04 / 30 / 06$ & $04 / 12 / 06$ & 05/04/06 \\
\hline 542 & Disposal Holes & 8 & CAIP to State & 06/30/06 & $05 / 26 / 06$ & 06/08/06 \\
\hline 543 & Liquid Disposal Units & 7 & CAP to State & $01 / 31 / 07$ & $10 / 05 / 06$ & $10 / 16 / 06$ \\
\hline 551 & Area 12 Muckpiles & 4 & CADD/Closure Report Rev. 1 to State & $11 / 30 / 06$ & 11/17/06 & $12 / 18 / 06$ \\
\hline 553 & Areas 19, 20 Mud Pits and Cellars & 4 & SAFER Plan to State & $12 / 08 / 06$ & $11 / 22 / 06$ & $12 / 06 / 06$ \\
\hline 97 & Yucca Flat/Climax Mine & DOE & $\begin{array}{l}\text { TA Sites } \\
\text { Submit Hydrostratigraphic Model \& } \\
\text { Alternatives for the Groundwater Flow \& } \\
\text { Contaminant Transport Model }\end{array}$ & 02/01/06 & $01 / 24 / 06$ & 03/16/06 \\
\hline \multicolumn{7}{|c|}{ Submit Phase I Hydrology Documentation } \\
\hline 97 & Yucca Flat/Climax Mine & 720 & Package & 07/01/06 & $06 / 22 / 06$ & 06/27/07 \\
\hline 98 & Frenchman Flat & 11 & Initiate Phase II Transport Modeling & 03/15/06 & 03/10/06 & 03/14/06 \\
\hline 98 & Frenchman Flat & 11 & Submit Phase II Flow Model Report & 05/31/06 & 05/03/06 & 05/08/06 \\
\hline 99 & Rainier/Shoshone & 66 & Complete Well Development and Testing & 04/01/06 & $03 / 22 / 06$ & 04/10/06 \\
\hline 99 & Rainier/Shoshone & 66 & Initiate Phase I Hydrostratigraphic Model & 06/01/06 & $06 / 01 / 06$ & $06 / 05 / 06$ \\
\hline 99 & Rainier/Shoshone & 66 & Draft Phase I Hydrostratigraphic Model & $12 / 01 / 06$ & $11 / 28 / 06$ & $11 / 29 / 06$ \\
\hline 101 & Central Pahute Mess & 64 & Submit Final Phase I Flow Model Report & 07/31/06 & 06/07/06 & $06 / 20 / 07$ \\
\hline 102 & Western Pahute Mess & 18 & Submit Final Phase I Flow Model Report & 07/31/06 & 06/07/06 & $06 / 20 / 07$ \\
\hline
\end{tabular}


content profile data are used to demonstrate whether the cover is performing as expected. An annual report of postclosure monitoring includes monthly precipitation data for the reporting period, an annual vegetation survey, and results of semi-annual subsidence surveys. The annual report is submitted to NDEP by the last day of August.

All required VZM and inspections of the applicable RCRA closed sites were conducted in 2006 as specified by RCRA permit or by each site's closure report. VZM results for the RCRA closure site CAU 110 indicated that surface water is not migrating into buried wastes. Annual reports were prepared for the 5 RCRA post closure sites and submitted to NDEP.

The sites at which physical inspections were conducted in 2006 are:

CAU 005 Landfills

CAU 90 Area 2 Bitcutter Containment

CAU 91 Area 3 U-3fi Injection Well

CAU 92 Area 6 Decon Pond Facility

CAU 110 Area 3 U-3ax/bl Subsidence Crater

CAU 112 Area 23 Hazardous Waste Trenches

CAU 140 Waste Dumps, Burn Pits, and Storage Area

CAU 143 Area 25 Contaminated Waste Dumps

CAU 165 Area 25 and 26 Dry Well and Washdown Areas

CAU 204 Storage Bunkers

CAU 254 Area 25 Reactor Maintenance, Assembly, and Disassembly Decontamination Facility

CAU 261 Area 25 Test Cell A Leachfield

CAU 262 Area 25 Septic Systems and UDP

CAU 271 Areas 25, 26, and 27 Septic Systems

CAU 322 Areas 1 and 3 release Sites and Injection Wells

CAU 333 U-3auS Disposal Site (not required until 2011)

CAU 335 Area 6 Injection Well and Drain Pit

CAU 339 Area 12 Fleet Operations Steam Cleaning Effluent

CAU 342 Mercury Fire Training Pit

CAU 357 Mud Pits and Waste Dump

CAU 400 Bomblet Pit and Five Points Landfill (TTR)

CAU 404 Roller Coaster Lagoons and Trench (TTR)

CAU 407 Roller Coaster RadSafe Area (TTR)

CAU 417 Central Nevada Test Area -Surface

CAU 423 Area 3 Underground Discharge Point, Building 0360 (TTR)

CAU 424 Area 3 Landfill Complexes (TTR)

CAU 426 Cactus Spring Waste Trenches (TTR)

CAU 427 Area 3 Septic Waste Systems 2, 6 (TTR)

CAU 453 Area 9 UXO Landfill (TTR)

CAU 487 Thunderwell Site (TTR)

CAU 529 Area 25 Contaminated Materials

CAU 552 Area 12 Muckpiles and Ponds

CAU 554 Area 23 Release Sites 


\subsection{Solid and Sanitary Waste Management}

\subsubsection{Landfills}

The NTS has three landfills for solid waste disposal that are regulated and permitted by the state of Nevada (see Table 2-11 for list of permits). No liquids, hazardous waste, or radioactive waste are accepted in these landfills. They include:

- Area 6 Hydrocarbon Disposal Site - accepts hydrocarbon-contaminated wastes, such as soil and absorbents.

- Area 9 U10c Solid Waste Disposal Site - designated for industrial waste such as construction and demolition debris.

- Area 23 Solid Waste Disposal Site - accepts municipal-type wastes such as food waste and office waste. Regulated asbestos-containing material is also permitted in a special section. The permit allows disposal of no more than an average of 20 tons/day at this site.

These landfills are designed, constructed, operated, maintained, and monitored in adherence to the requirements of their state-issued permits. The NDEP visually inspects the landfills and checks the records on an annual basis to ensure compliance with the permits.

The vadose zone is monitored at two of the permitted sanitary landfills: the Area 6 Hydrocarbon Disposal Site and the Area 9 U10c Solid Waste Disposal Site. VZM is performed in lieu of groundwater monitoring to demonstrate that contaminants from the landfills are not leaching into the groundwater. In previous years, semiannual reports containing VZM data, rainfall data, and conclusions were sent to the state of Nevada, as specified in the landfill permits. In July 2004, the state of Nevada granted a reduction in the frequency of VZM at these landfills. Monitoring now takes place annually instead of semiannually. VZM of the Area 6 and Area 9 landfills in 2006 indicated that there was no soil moisture migration and therefore no waste leachate migration to the water table.

The amount of waste disposed of in each solid waste landfill in 2006 is shown in Table 9-5. An average of 2.1 tons/day was disposed at the Area 23 landfill, well within permit limits. State inspections of the three permitted landfills were conducted in March 2006. No out-of-compliance issues were noted.

Table 9-5. Quantity of solid wastes disposed in NTS landfills in calendar year 2006

\begin{tabular}{|c|c|c|}
\hline $\begin{array}{c}\text { Area } 6 \text { Hydrocarbon } \\
\text { Disposal Site }\end{array}$ & $\begin{array}{c}\text { Metric Tons (Tons) of Waste } \\
\text { Area } 9 \text { U10c Solid Waste } \\
\text { Disposal Site }\end{array}$ & $\begin{array}{c}\text { Area } 23 \text { Solid Waste } \\
\text { Disposal Site }\end{array}$ \\
\hline $597(658)$ & $6,619(7,296)$ & $1,650(1,819)$ \\
\hline
\end{tabular}

\subsubsection{Sewage Lagoons}

The NTS also has two state-permitted sewage lagoons that were operated by NSTec Waste Management in 2006, as were the solid waste landfills. They are the Area 6 Yucca Lake and Area 23 Mercury lagoons. The operations and monitoring requirements for these sewage lagoons are specified by Nevada water pollution control regulations. Because of this, the discussion of their operations and compliance monitoring are presented in Section 4.2.3. 
THIS PAGE INTENTIONALLY LEFT BLANK 


\subsection{Hazardous Materials Control and Management}

Hazardous materials used or stored on the Nevada Test Site (NTS) are controlled and managed through the use of a Hazardous Substance Inventory database. The NTS Maintenance and Operating contractor and all other U.S. Department of Energy, National Nuclear Security Administration Nevada Site Office (NNSA/NSO) subcontractors utilize this database if they use or store hazardous materials. They are required to comply with the operational and reporting requirements of the Toxic Substances Control Act (TSCA); Federal Insecticide, Fungicide, and Rodenticide Act (FIFRA); the Emergency Planning and Community Right-to-Know Act (EPCRA); and the Nevada Chemical Catastrophe Act (see Section 2.5). Chemicals to be purchased are subject to a requisition compliance review process. Environmental Services personnel, with Bechtel Nevada (BN) (through June 30, 2006) and then with National Security Technologies, LLC (NSTec), reviewed each chemical purchase in 2006 to ensure that restricted chemicals were not purchased when less hazardous chemical substitutes were commercially available. Requirements and responsibilities for the use and management of hazardous/toxic chemicals were provided in company documents and were aimed at meeting the goals shown below. The reports or activities that are prepared or performed annually to document compliance with hazardous materials regulations are also listed below.

\begin{tabular}{|c|c|}
\hline $\begin{array}{c}\text { Hazardous Materials Control } \\
\text { and Management Goals }\end{array}$ & Compliance Activities/Reports \\
\hline $\begin{array}{l}\text { Minimize the adverse effects of improper } \\
\text { use, storage, or management of } \\
\text { hazardous/toxic chemicals }\end{array}$ & $\begin{array}{l}\text { Use of Hazardous Substance Inventory database } \\
\text { Annual TSCA report } \\
\text { FIFRA management assessments } \\
\text { Annual EPCRA Toxic Release Inventory (TRI) Report, } \\
\text { Form R }\end{array}$ \\
\hline $\begin{array}{l}\text { Ensure compliance with applicable } \\
\text { federal and state environmental } \\
\text { regulations related to hazardous materials }\end{array}$ & $\begin{array}{l}\text { Annual Nevada Combined Agency (NCA) Report } \\
\text { Nevada Division of Environmental Protection (NDEP)- } \\
\text { Chemical Accident Prevention Program Annual } \\
\text { Registration Form } \\
\text { Use of the electronic Hazardous Materials Notification } \\
\text { System (known as HAZTRAK) for tracking the } \\
\text { movements of such materials }\end{array}$ \\
\hline
\end{tabular}

\subsection{TSCA Program}

There are no known pieces of polychlorinated biphenyl (PCB)-containing electrical equipment (transformers, capacitors, or regulators) at the NTS; however, sometimes during demolition activities, old hydraulic systems are found to contain PCB liquids. The TSCA program consists mainly of properly characterizing, storing, and disposing of various $\mathrm{PCB}$ wastes generated through remediation activities and maintenance of fluorescent lights. The remediation waste is generated by BN/NSTec and Stoller-Navarro Joint Venture at Corrective Action Sites during environmental restoration activities (see Section 9.4) and during maintenance activities and building decontamination and decommissioning activities performed by BN/NSTec. These activities can generate PCB-contaminated fluids and bulk product waste containing PCBs.

Waste classified as bulk product waste generated on the NTS by remediation and site operations can be disposed of onsite in the U10c landfill with prior state of Nevada approval. PCB-containing light ballasts removed during normal maintenance can also go to an onsite landfill, but when remediation or upgrade activities generate several ballasts, 
these must be disposed of offsite at an approved PCB disposal facility. Soil and other materials contaminated with PCBs must also be sent offsite for disposal.

During 2006, 15 drums of PCB light ballasts were generated from demolition and renovation activities and sent offsite for disposal in four separate shipments. No onsite disposal of PBW containing PCBs occurred in 2006. When PCB equipment or PCB fluids are managed during a calendar year, NNSA/NSO has been submitting an annual report to the U.S. Environmental Protection Agency (EPA) by July 1 of the following year. In 2003, NNSA/NSO determined that annual reports were not required to be sent to regulators since the NTS is not considered a commercial storer or disposer of PCBs. On April 23, 2007, an Annual Report was generated for PCB management activities during calendar year 2006, and may again be sent to outside regulators.

There were no TSCA inspections by outside regulators performed at the NTS in 2006.

\subsection{FIFRA Program}

ES personnel performed the following oversight functions to ensure FIFRA compliance: (1) screened all purchase requisitions for restricted-use pesticides; (2) reviewed operating procedures for handling, storing and applying pesticide products; and (3) conducted facility inspections for unauthorized pesticide storage/use. On the NTS, pesticides are applied under the direction of a state of Nevada certified applicator. This service was provided by Solid Waste Operations (SWO). SWO maintained appropriate Commercial Category (Industrial) certifications for applying restricted-use pesticides, but only non-restricted pesticides were used. Pesticide applications in food service facilities are subcontracted to state-certified vendors.

SWO did not purchase any restricted-use pesticides during 2006. The SWO procedure for pesticide application was updated in 2006, and training is provided to affected personnel annually. Certifications were kept current in 2006 for Industrial Category application(s) of restricted-use pesticides. Facility inspections were conducted and indicated that there were no restricted-use pesticides being used or stored in violation of federal/state requirements.

\subsection{EPCRA Program}

In response to the EPCRA requirements, all chemicals that are purchased are entered into a hazardous substance inventory database and assigned specific hazard classifications (e.g., corrosive liquid, flammable, diesel fuel). Annually, this database is updated to show the maximum amounts of chemicals that were present in each building at the NTS, the Non-Proliferation Test and Evaluation Complex, the North Las Vegas Facility (NLVF) (see Section A.1.4), and the Remote Sensing Laboratory (RSL)-Nellis (see Section A.3.3). This information is then used to complete the Nevada Combined Agency (NCA) Report. This report satisfies EPCRA reporting requirements (Table 10-1). It provides information to the state of Nevada, community, and local emergency planning commissions on the maximum amount of any chemical, based on its hazard classification, present at any given time during the preceding year. This report also provides the commissions with new chemicals or chemical classes that were not previously onsite. The State Fire Marshall then issues permits to store hazardous chemicals on the NTS, as well as at the RSL-Nellis and the NLVF.

Table 10-1. EPCRA compliance reporting at the NTS in 2006

\begin{tabular}{|llr||}
\hline \multicolumn{1}{|c|}{ Section of the Act } & \multicolumn{1}{c|}{ Activity Regulated } & $\begin{array}{c}\text { Notification/Report Submitted per } \\
\text { Applicable Requirement }\end{array}$ \\
\hline Section 302-303 & $\begin{array}{l}\text { Planning Notification } \\
\text { Extremely Hazardous Substance } \\
\text { Section 304 }\end{array}$ & $\begin{array}{r}\text { NCA Report } \\
\text { Release Notification }\end{array}$ \\
Section 311-312 & $\begin{array}{l}\text { Material Safety Data Sheet/ } \\
\text { Chemical Inventory }\end{array}$ & NCA Report \\
Section 313 & TRI Reporting & TRI Report \\
\hline \hline
\end{tabular}


The 2006 chemical inventory for NTS facilities was updated and submitted to the state of Nevada in the NCA Report on February 22, 2007. No accidental or unplanned release of an extremely hazardous substance occurred on the NTS in 2006.

The hazardous substance inventory database is also used to complete the TRI Report, Form R. This report provides EPA and the State Emergency Response Commission information on any toxic chemical that enters the environment above a given threshold. It also provides these agencies with the amounts of toxic chemicals that are recycled.

NNSA/NSO submitted this report for calendar year 2006 to EPA on June 26, 2007. Lead was the only listed toxic chemical released into the NTS environment in 2006 that was reportable (Table 10-2). Lead that is either recovered during site remediation activities or is excess to NTS operational needs (e.g., lead bricks, lead shielding), is sent offsite for recycling or proper disposal. A total of 11,362 pounds was sent offsite for recycling and 21,430 pounds sent off for disposal.

Table 10-2. EPCRA reportable releases of toxic chemicals in 2006

\begin{tabular}{||clc||}
\hline Toxic Chemical & \multicolumn{1}{c|}{ Source } & Quantity (lbs) \\
\hline Lead - solid & $\begin{array}{l}\text { Ammunition - } \\
\text { Mercury Firing Range }\end{array}$ & $4,295.4$ \\
Lead - air release & $\begin{array}{l}\text { Ammunition - } \\
\text { Mercury Firing Range }\end{array}$ & 30 \\
Lead - air release & Solder & 12 \\
\hline
\end{tabular}

There were no EPCRA inspections by outside regulators performed at the NTS in 2006.

HAZTRAK is a tracking system that monitors hazardous materials while they are in transit. When a truck transporting hazardous material enters the NTS, all information concerning the load is entered into the tracking system. Once the delivery is complete, the information provided at the time of entry is removed from the tracking system.

\subsection{Nevada Chemical Catastrophe Prevention Act}

If EHSs are stored in quantities which exceed threshold quantities established by the NDEP, then NNSA/NSO submits a report notifying the state of Nevada. During 2006, no NTS facility stored EHSs in quantities which required state notification. Therefore, no Nevada Chemical Accident Prevention Program Report was prepared regarding calendar year 2006 NTS operations. 


\section{THIS PAGE INTENTIONALLY LEFT BLANK}




\subsection{Pollution Prevention and Waste Minimization}

The U.S. Department of Energy, National Nuclear Security Administration Nevada Site Office (NNSA/NSO) has pollution prevention and waste minimization (P2/WM) initiatives. These initiatives establish a process to reduce the volume and toxicity of waste generated by the NNSA/NSO on the Nevada Test Site (NTS) and its satellite facilities. They also ensure that proposed methods of treatment, storage, and disposal of waste minimize potential threats to human health and the environment. These initiatives also address the requirements of several federal and state regulations applicable to operations on the NTS (see Section 2.7). The following information provides an overview of the P2/WM goals, major accomplishments during the reporting year, a description of efforts undertaken by National Security Technologies, LLC (NSTec), during 2006 to reduce the volume and toxicity of waste generated by the NNSA/NSO.

\subsection{P2/WM Goals and Components}

It is the priority of NNSA/NSO to minimize the generation, release, and disposal of pollutants to the environment by implementing cost-effective P2 technologies, practices, and policies. A commitment to P2 minimizes the impact on the environment, improves the safety of operations, improves energy efficiency, and promotes the sustainable use of natural resources. This commitment includes providing adequate administrative and financial materials on a continuing basis to ensure goals are achieved. When economically feasible, source reduction is the preferred method of handling waste, followed by reuse and recycling, treatment, and as a last resort, landfill disposal.

Source Reduction - Source reduction is the minimization or elimination of waste before it is generated by a project or operation. Examples of source reduction include chemical substitution, process modification, and segregation. NNSA/NSO's Integrated Safety Management System requires that every project/operation address waste minimization issues during the planning phase and ensure that adequate funds are allocated to perform any identified waste minimization activities.

To minimize the generation of waste, project managers are required to incorporate waste minimization into the planning phase of their projects. Waste-generating processes must be assessed to determine if the waste can be economically reduced or eliminated. Waste minimization activities that are determined to be cost effective should be incorporated into the project plan and adequate funding allocated to ensure their implementation.

Recycling - For wastes that are generated, an aggressive recycling program is maintained. Items recycled through the NNSA/NSO recycling program in 2006 included paper, cardboard, aluminum cans, toner cartridges, inkjet cartridges, used oil, food waste from the cafeteria, plastic, scrap metal, rechargeable batteries, lead-acid batteries, fluorescent light bulbs, mercury lamps, metal hydride lamps, and sodium lamps.

An effective method for reuse is the coordination of the Material Exchange Program. Created in 1998, the Material Exchange Program diverts supplies, chemicals, and equipment from landfills. Unwanted chemicals, supplies, and equipment are made available through electronic mail or postings on the intranet Material Exchange Database so that individuals in need can obtain the items at no cost. These materials are destined for disposal, either as solid or hazardous waste, as a result of process modification, discontinued use, or shelf-life expiration. Rather than disposing of these items, the majority of them are provided to other employees for their intended purpose, thus avoiding disposal costs and costs for new purchases. If items are not placed with another user, they can be returned to the vendor for recycle/reuse, or given to other U.S. Department of Energy (DOE) sites, other government agencies, or local schools.

Affirmative Procurement - As required by Resource Conservation and Recovery Act (RCRA), Section 42 United States Code (USC) 6962, the NNSA/NSO maintains an Affirmative Procurement process that stimulates a market for recycled content products and closes the loop on recycling. RCRA section 42 USC 6962 requires the U.S.

Environmental Protection Agency (EPA) to develop a list of items containing recycled materials that should be purchased. The EPA is also required to determine what the minimum content of recycled material should be for each item. Once this EPA-designated list was developed, federal facilities were required to ensure that a process was in place for purchasing the EPA-designated items containing the minimum content of recycled materials. Executive Order 13101, Greening the Government through Waste Prevention, Recycling and Federal Acquisition, went one step further and 
requires federal facilities to ensure that 100 percent of purchases of items from the EPA-designated list contain recycled materials at the specified minimum content. Of the items NNSA/NSO currently purchases from the EPAdesignated list, about 73 percent of those purchases contain recycled materials.

Employee and Public Awareness - The NNSA/NSO P2 and WM initiatives also include an employee and public awareness program. Awareness of $\mathrm{P} 2 / \mathrm{WM}$ issues is accomplished by dissemination of articles through electronic mail, contractor and NNSA/NSO newsletters, the maintenance of a P2/WM intranet Web site, employee training courses, and participation at employee and community events. These activities are intended to increase awareness of $\mathrm{P} 2 / \mathrm{WM}$ and environmental issues and highlight the importance of $\mathrm{P} 2 / \mathrm{WM}$ for improving environmental conditions in the workplace and community.

\subsection{Major P2/WM Accomplishments and Awards}

\subsubsection{Accomplishments}

In 2006, the NSTec Maintenance Department bought three refrigerant recycling machines. Two machines are located at the NTS, one at the Mercury base camp and one at the Area 6 base camp. The third machine is located at the North Las Vegas Facility. Refrigerant from old air conditioning and refrigeration units cannot be released to the atmosphere and must be collected. Non-contaminated refrigerant is stored on site and reused when needed. In past years, contaminated refrigerant was sent off site to a local vendor for destruction. The refrigerant recycling machines send used, contaminated refrigerant through a series of replaceable filters and oil separators to remove impurities, cleaning the refrigerant to virgin refrigerant quality for reuse. These machines are capable of removing wax and sludge contaminates, acid in the system, and excessive oil contaminates. In 2006, NSTec recycled 0.6 metric tons (mtons) of refrigerant.

Per NSTec's Environmental Management System (EMS), the Material Exchange Program is continually striving for improvement. To improve employee usage of the program in 2006, NSTec focused on publishing articles about it in site and contractor newsletters. These articles were disseminated to employees from all organizations within NNSA/NSO to raise the level of awareness of the program and its website. The Material Exchange Program diverted 2.1 mtons of chemicals, office supplies, and equipment from solid and hazardous waste landfills in 2006 and a total of 190 mtons of usable materials from such landfills since the program's inception in 1998.

\subsubsection{Award-winning Accomplishments}

NNSA/NSO received four NNSA Pollution Prevention Awards for P2 activities in 2006. Two were Environmental Stewardship Awards (ESAs) and two were NNSA Best-In-Class Awards. The Big Explosive Experiment Facility (BEEF), operated by the Lawrence Livermore National Laboratory, won an ESA for incorporating P2/WM practices into the facility design and daily operating procedures. These practices reduced or eliminated waste or emissions and, in most instances, improved safety by reducing the risk of occupational exposure through the use of safer, less hazardous materials. By implementing these P2/WM practices, BEEF realized improved efficiency of programmatic operations as well as some cost savings.

The second ESA was awarded to NSTec's Information Services Personal Computer Leasing Group for developing an electronics stewardship program. Computer equipment contains many components that are toxic to the environment. Because of these hazardous components, they are considered hazardous waste at end-of-life and are banned from municipal solid waste landfills. NSTec developed an electronic stewardship program whereby over 90 percent of the company's computers are leased from Dell Corporation for three years. At end-of-life, hard drives are removed and the leased computers are returned to Dell to be refurbished and sold for reuse. NSTec-owned computers are sold at end-of-life to the public through auction via the Excess Equipment Program, usually to salvage companies that disassemble and recycle most of the parts. As part of the continuous improvement process through integration of NSTec's EMS, Information Services now orders Electronic Product Environmental Assessment Tool (EPEAT)registered computers from Dell whenever possible as computers are replaced. EPEAT-registered computers are considered "Green Computers" because they are manufactured with materials that are more easily recycled and less toxic to the environment. 
One NNSA Best-In-Class Award recognized the efforts of Stoller-Navarro Joint Venture (SNJV) for fully integrating EMS into their infrastructure and culture. In fiscal year 2006, SNJV instituted a core team concept, developed and provided Safety Leadership training, and developed an EMS. The EMS identified areas to improve the reduction of life-cycle cost and liability of mission-related activities by reducing the amount of hazardous and radioactive waste at the source of generation by more than 50 percent, reducing the amount of hazardous products procured by more than 10 percent, procuring products that are either less hazardous or non-hazardous than products SNJV used previously, and implementing innovative modifications in planning and performing work. By instituting the SNJV EMS, the NNSA/NSO enhanced workplace safety, reduced potentially hazardous and potentially radioactive waste streams by an estimated 11,167 cubic feet, and saved an estimated \$1.4 million in disposition costs over the life-cycle of the Environmental Restoration Project.

The second NNSA Best-In-Class Award recognized the efforts of the NSTec Advanced Monitoring Systems Initiative Program for developing a 'Universal' platform for the deployment of analytical sensors in the field for long-term monitoring of environmental contaminants. This work was done in conjunction with Burge Environmental in Tempe, Arizona. The sensor platform is an automated version of the EPA SW-846 Standard Test Method, capable of sampling, calibrating, analyzing, and performing quality-control checks. The 'Universal' platform allows for the use of a variety of different sensors, depending on the analyte of interest. The analysis can be completed at any time of the day or night, during any season, regardless of weather, at intervals of 15 minutes or greater. At the completion of each analysis, analytical results are sent via wireless modem to the operator's computer, eliminating the 6-week laboratory turn-around time. The system was developed to monitor hexavalent chromium contamination in salmon spawning gravel beds in the Columbia River in Washington. The system was first tested at the NTS and then on location at the Columbia River under a variety of temperature extremes and weather conditions. Results of analyses during precision testing compared very well with control samples sent to an analytical laboratory. System power is furnished by solar array, and the ability to operate this system remotely from an office reduces disturbance to the local flora in the field. Use of this system greatly reduces costs associated with sampling, transportation, shipment, and analysis of samples as well as worker exposure to hazardous chemicals. This system is currently proposed and under review for acceptance as an equivalent EPA standard test method. Although the automated method cannot yet be used for compliance, this sensor platform can be programmed to function as an alarm if analyte levels approach compliance levels, greatly minimizing the potential for hazardous contamination of the environment and reducing the risk of out-of-compliance fines.

\subsection{Waste Reductions}

P2/WM techniques and practices are implemented for all activities that may generate waste. These P2/WM activities result in reductions to the volume and/or toxicity of waste actually generated onsite. Table 11-1 compares the amounts of radioactive, hazardous, and solid wastes reduced in 2006 to prior years.

Table 11-1. Waste reduction through P2/WM activities by year

\begin{tabular}{|c|c|c|c|}
\hline $\begin{array}{c}\text { Calendar } \\
\text { Year }\end{array}$ & $\begin{array}{l}\text { Radioactive Waste } \\
\text { Reduced }\left(\mathrm{m}^{3}\right)^{(\text {)a }}\end{array}$ & $\begin{array}{l}\text { Hazardous Waste } \\
\text { Reduced (mtons) }\end{array}$ & $\begin{array}{c}\text { Solid Waste } \\
\text { Reduced (mtons) }\end{array}$ \\
\hline 2006 & 0 & 149 & 803 \\
\hline 2005 & 0 & 13,992 & 1,194 \\
\hline 2004 & 0 & 115 & 1,438 \\
\hline 2003 & 40.0 & 207 & 1,547 \\
\hline 2002 & 63.2 & 177 & 904 \\
\hline
\end{tabular}

(a) 1 cubic meter $\left(\mathrm{m}^{3}\right)=1.3$ cubic yards

(b) (b) 1 mton $=1.1$ ton 
Table 11-2 shows a summary of the waste reduction activities accomplished during 2006. An estimated 149-mtons reduction of hazardous waste (including RCRA, Toxic Substance Control Act, and state-regulated hazardous wastes) and an 803-mtons reduction of solid waste (sanitary waste) occurred in 2006, all from recycling and reuse.

Table 11-2. Waste reduction activities in 2006

\begin{tabular}{|c|c|}
\hline Activity & $\begin{array}{c}\text { Volume } \\
\text { Reduction } \\
\text { (mtons) }^{(a)}\end{array}$ \\
\hline \multicolumn{2}{|l|}{ Hazardous Waste } \\
\hline Bulk used oil was sent to an offsite vendor for recycling & 98.2 \\
\hline Lead acid batteries were shipped to an offsite vendor for recycling & 34.5 \\
\hline Computer equipment was returned to the vendor where it is refurbished and sold for reuse & 5.8 \\
\hline Lead scrap metal was sold for reuse/recycling & $5.2^{(b)}$ \\
\hline $\begin{array}{l}\text { Spent fluorescent light bulbs, mercury lamps, metal hydride lamps, and sodium lamps } \\
\text { were sent to an offsite vendor for recycling }\end{array}$ & 3.1 \\
\hline Rechargeable batteries were sent to an offsite vendor for recycling & 1.6 \\
\hline Lead tire weights were reused instead of being disposed as hazardous waste & 0.7 \\
\hline $\begin{array}{l}\text { Hazardous chemicals were relocated to new users through the Material Exchange } \\
\text { Program, diverting them from landfill disposal }\end{array}$ & 0.3 \\
\hline Total & $149.4^{(b)}$ \\
\hline \multicolumn{2}{|l|}{ Solid Waste } \\
\hline Scrap ferrous metal was sold to a vendor for recycling & 538.7 \\
\hline Mixed paper and cardboard was sent offsite for recycling & 154.4 \\
\hline $\begin{array}{l}\text { Food waste from the cafeterias was sent offsite to be reused as pig feed for a local pig } \\
\text { farmer }\end{array}$ & 67.0 \\
\hline $\begin{array}{l}\text { Shipping materials including pallets, styrofoam, bubble wrap, and shipping containers } \\
\text { were reused }\end{array}$ & 20.7 \\
\hline Scrap non-ferrous metal was sold to a vendor for recycling & 17.4 \\
\hline Spent toner cartridges were sent offsite for recycling & 2.6 \\
\hline $\begin{array}{l}\text { Non-hazardous chemicals, equipment, and supplies were relocated to new users through } \\
\text { the Material Exchange Program, diverting them from landfill disposal }\end{array}$ & 1.8 \\
\hline Aluminum cans were sent offsite for recycling & 0.4 \\
\hline Total & 803.0 \\
\hline
\end{tabular}

(a) 1 mton $=1.1$ ton

(b) The value reported to Nevada Division of Environmental Protection (NDEP) in the 2006 Annual Waste Minimization Summary Report for lead scrap metal was 3.2 mtons. The correct value of 5.2 mtons was verified after submittal of the report to NDEP. Therefore, the total volume reduction of hazardous waste in 2006 was 149.4 mtons, not 147.4 mtons as reported to NDEP.

By December 15, 2006, NSTec completed the 2006 fiscal year (October 1, 2005-September 31, 2006) Waste Generation and Pollution Prevention Progress Report for the NTS. This was done by entering the site's data, including annual recycling totals and waste minimization accomplishments, into the DOE Headquarters electronic database. NSTec also submitted to NDEP on February 23, 2007, a 2006 calendar year Waste Minimization Summary Report. 


\subsection{Historic Preservation and Cultural Resources Management}

The historic landscape of the Nevada Test Site (NTS) contains archaeological sites, buildings, structures, and places of importance to American Indians and others. These are referred to as "cultural resources." U.S. Department of Energy (DOE) Order 450.1, Environmental Protection Program, requires that NTS activities and programs comply with all applicable cultural resources regulations (see Section 2.8) and that such resources on the NTS be monitored. The Cultural Resources Management (CRM) program has been established and is implemented by the Desert Research Institute (DRI) on the NTS to meet this requirement. The CRM program is designed to meet the specific goals shown below.

\begin{tabular}{||l||}
\hline Cultural Resources Management Program Goals \\
\hline Ensure compliance with all regulations pertaining to cultural resources on the NTS (see Section 2.8) \\
Inventory and manage cultural resources on the NTS \\
Provide information that can be used to evaluate the potential impacts of proposed projects and programs to \\
cultural resources on the NTS and mitigate adverse effects \\
Curate archaeological collections in accordance with 36 Code of Federal Regulations (CFR) Part 79 \\
Conduct American Indian consultations related to places and items of importance to the Consolidated Group \\
of Tribal Organizations
\end{tabular}

In order to achieve the program goals and meet federal and state requirements, the CRM program is multifaceted and contains the following major components: (1) inventories and historical evaluations, (2) curation of archaeological collections, and (3) the American Indian Program. The guidance for the CRM program work is provided in the Cultural Resources Management Plan for the Nevada Test Site (Drollinger et al., 2002). Historic preservation personnel and archaeologists of DRI who meet the Secretary of the Interior standards conduct the work and the archaeological efforts are permitted under the Archeological Resources Protection Act (ARPA).

A brief description of the CRM program components and their 2006 accomplishments are provided in this chapter. The methods used to conduct inventories and historical evaluations in support of NTS operations were summarized in the 2003 NTS Environmental Report (DOE, 2004c). The reader is directed to a separate file called Nevada Test Site Description on the compact disc of this 2006 report. The Nevada Test Site Description contains a summary of the known human occupation and use of the NTS from the Paleo-Indian Period, about 12,000 years ago, until the mining and ranching period of the twentieth century, just before NTS lands were withdrawn for federal use.

\subsection{Cultural Resources Inventories, Historical Evaluations, and Associated Activities}

Cultural resources inventories are conducted at the NTS to meet the requirements of the National Historic Preservation Act (NHPA) and the ARPA. The inventories are completed prior to proposed projects that may disturb or otherwise alter the environment. The following information is maintained in databases: 
- Number of cultural resources inventories conducted

- Location of each inventory

- Number of acres surveyed at each project location

- Types of cultural resources identified at each project location

- Number of cultural resources determined eligible to the National Register of Historic Places (NRHP)

- Eligible properties avoided by project activities

- Cultural resources requiring mitigation to address an adverse effect

- Final report on results

\subsubsection{Cultural Resources Inventories}

In 2006, two cultural resources inventories were conducted for proposed projects: (1) the replacement of the existing Castle Rock Substation and the associated construction of a new powerline corridor to the substation, and (2) the Chicken Little Project. Both projects are in NTS Area 18. One isolated artifact was identified during the Castle Rock Substation inventory. During the Chicken Little survey, three prehistoric sites, two isolated features, and six isolated artifacts were recorded. None of the sites meet the criteria for eligibility of the NRHP.

\subsubsection{Evaluations of Historic Structures}

Three historical evaluations (U12b Tunnel, U12e Tunnel, and the Area 25 BREN Tower Complex) were undertaken in 2006 with the U12b Tunnel completed and the latter two in progress as of the end of 2006. The U12b Tunnel complex was utilized between 1957 and 1963. During this time, six underground nuclear tests and one high explosives test were conducted at the location. Fieldwork consisted of inventorying the portal areas and recording associated structures and features. During the inventory of the U12b Tunnel complex, 21 structures and 20 features were recorded (Jones et al., 2006). The U12b Tunnel complex is eligible to the NRHP because of its significance in the history of nuclear testing. The U12b Tunnel was specifically designed and constructed in 1957 to facilitate the Rainier Test which became the first fully contained underground nuclear explosion in the world. Seventeen of the recorded 21 structures and 12 of the 20 recorded features are contributing properties (Jones et al., 2006).

As summarized in Table 12-1, a total of 140.2 hectares (346.7 acres) was examined during cultural resources inventories and historical evaluations. No historic or prehistoric archaeological sites were studied for inclusion to the NRHP. The U12b Tunnel complex has been determined eligible to the NRHP.

Table 12-1. Summary data for cultural resources inventories and historical evaluations conducted in 2006

\begin{tabular}{|c|c|c|c|c|c|}
\hline \multirow{2}{*}{$\begin{array}{l}\text { Inventory/Historical } \\
\text { Evaluation }\end{array}$} & \multirow{2}{*}{$\begin{array}{c}\text { Prehistoric/Historic } \\
\text { Sites Found }\end{array}$} & \multirow{2}{*}{$\begin{array}{l}\text { Structures } \\
\text { Evaluated }\end{array}$} & \multirow{2}{*}{$\begin{array}{c}\text { Sites } \\
\text { Determined } \\
\text { NRHP Eligible }\end{array}$} & \multicolumn{2}{|c|}{ Area Surveyed } \\
\hline & & & & Acres & Hectares \\
\hline $\begin{array}{l}\text { Castle Rock Substation and } \\
\text { Powerline Corridor }\end{array}$ & 0 & 0 & 0 & 167 & 68 \\
\hline Chicken Little Project & 3 & 0 & 0 & 147 & 59 \\
\hline $\begin{array}{l}\text { Historical Evaluation of U12b } \\
\text { Tunnel Complex }\end{array}$ & 0 & 21 & 1 & 32.7 & 13.2 \\
\hline Totals & 3 & 21 & 1 & 346.7 & 140.2 \\
\hline
\end{tabular}




\subsubsection{Associated Cultural Resources Activities}

\subsubsection{Adverse Effect Assessments and Mitigation Activities}

One project was undertaken to mitigate potential adverse effects to the rock cabin near Tippipah Spring from the proposed Divine Strake test (Jones, 2006). The mitigation research was undertaken by DRI for the National Nuclear Security Administration Nevada Site Office (NNSA/NSO) to meet the NNSA/NSO's responsibilities under section 110 of the NHPA (Jones, 2006). The historic research consisted of in-depth document searches at local, state, and federal repositories, black-and-white photographic documentation of the cabin and development of a floor plan for the building.

\subsubsection{General Reconnaissance/Archival Research}

General reconnaissance and other activities were also conducted in 2006. There were four field projects and one archival research project. Two field projects monitored cultural resources sites because the NHPA requires federal agencies to identify and maintain the integrity of historic properties under their jurisdiction. Historic properties are cultural resources that have been determined eligible to the NRHP through consultation between the NNSA/NSO and the Nevada State Historic Preservation Office. The purpose of the monitoring program is to periodically document that the historic properties, traditional cultural properties, and American Indian sacred sites on the NTS retain their integrity and NRHP eligibility. Monitoring the condition of cultural resources is an integral part of the NNSA/NSO historic preservation program. The first monitoring project focused on 10 properties eligible to the NRHP. The sites monitored were temporary American Indian camps and lithic tool manufacturing areas. All of the sites were in a very good state of preservation. The second monitoring effort was conducted at Cane Spring. The other two field projects focused on obtaining photographic documentation of late twentieth century nuclear testing related structures.

One project required archival research but no fieldwork. This was in support of the proposed small arms range in Area 12 near Area 12 Camp. Later, the project was cancelled.

\subsubsection{Reports}

Three inventory reports (SR), one historical evaluation (HE), one letter report (LR), and one historical research report (HR) were completed and are listed in Table 12-2. Site location information is protected from public distribution and those reports containing such data are not available to the public. Technical reports can be obtained from the DOE's Office of Scientific and Technical Information at email address < $<$ http://www.osti.gov/bridge $>$.

The data on NTS archaeological activities also were provided to DOE Headquarters in the formal Archeology Questionnaire for transmittal to the Secretary of the Interior and, ultimately, to the U.S. Congress as part of the Secretary of the Interior's Annual Archeology Report to Congress.

Table 12-2. Reports prepared in 2006

\begin{tabular}{|c|c|c|}
\hline Project & Report No. & $\begin{array}{l}\text { Author(s) } \\
\text { (see References) }\end{array}$ \\
\hline Castle Rock Substation and a New PowerLine Corridor & SR050106-1 & Holz and Rager, 2006 \\
\hline Chicken Little Project & SR071006-1 & Holz, 2006a \\
\hline Fiscal Year 2006 Monitoring & SR102405-1 & Holz, 2006b \\
\hline Historical Evaluation of the U12b Tunnel & HE050106-1 & Jones et al., 2006 \\
\hline Underground Centrifuge & LR061206-1 & Beck and Holz, 2006 \\
\hline $\begin{array}{l}\text { Documentation for the mitigation of potential adverse effect to } \\
\text { the Rock Cabin near Tippipah Spring }\end{array}$ & HR040606-1 & Jones, 2006 \\
\hline
\end{tabular}




\subsection{Curation}

The NHPA requires that archaeological collections and associated records be maintained at professional standards; the specific requirements are delineated in 36 CFR Part 79, Curation of Federally-Owned and Administered Archeological Collections. Requirements for curation of the NTS archaeological collection include the following:

- Maintain a catalog of the items in the NTS collection

- Package the NTS collection in materials that meet archival standards (e.g., acid-free boxes)

- Store the NTS collection and records in a facility that is secure and has environmental controls

- Establish and follow curation procedures for the NTS collection and facility

- Comply with the Native American Graves Protection and Repatriation Act

In the 1990s, the NNSA/NSO completed the required inventory and summary of NTS cultural materials accessioned into the NTS Archaeological Collection and distributed the inventory list and summary to the tribes affiliated with the NTS and adjacent lands. Consultations followed and all artifacts the tribes requested were repatriated to them. This process was completed in 2002; it will be repeated for any new additions to the NTS collection in the future. Known locations of American Indian human remains at the NTS continued to be protected from NTS activities in 2006.

The NTS Archaeological Collection contains over 400,000 artifacts and is curated in accordance with 36 CFR Part 79. The curation procedures provide guidelines to follow in order to comply with 36 CFR Part 79 (Drollinger, 2004). Continuing in 2006 is the review of the documents in the curation archives. Currently the move of project files to the new fire proof cabinets in the archival records room has provided the opportunity to identify records for disposal, such as draft documents, out-of-date documents, non-project documents, or duplicate documents and records no longer pertinent to the cultural resources program. This effort is about 50 percent complete and is combined with a reorganization of the archives that also is in progress. Original copies of technical reports in standard file cabinets in the records room have also been transferred to the fire proof cabinets. Large maps, such as USGS topographic map records, and other similar size documents have been stored in the larger flat file cabinets in the records room (Drollinger, 2006).

In regard to the artifact collection, one change implemented in 2006 was to reorganize the collection by provenience, that is, according to site number. Previously, items were organized according to artifact types, such as chipped stone, ground stone, pottery, etc.; but now, these items have been grouped together whenever possible on the shelves according to their origin (Drollinger, 2005). This effort is 80 percent complete. Combined with the reorganization is the transfer of the artifacts from archival cardboard boxes to archival plastic carton boxes. This type of box will be more protective of the artifact collections in regard to accidents, such as water damage, and to nesting insects. They are also less likely to deteriorate due to handling and age. As part of the curation activities, assistance was provided to the Atomic Testing Museum for the loan of the McGuffin collection with the extension of the loan agreement for these artifacts and historic artifacts from ranching and mining sites from the NTS artifact collection.

\subsection{American Indian Program}

The NNSA/NSO has had an active American Indian Program since the late 1980s. The function of the program is to conduct consultations between NNSA/NSO and NTS-affiliated American Indian tribes. Such consultation occurs through the Consolidated Group of Tribes and Organizations (CGTO). The CGTO is comprised of 16 groups of Southern Paiute, Western Shoshone, and Owens Valley Paiute-Shoshone, along with the Las Vegas Indian Center, a Pan-Indian organization (Table 12-3). A history of this program is contained in American Indians and the Nevada Test Site, A Model of Research and Consultation (Stoffle et al., 2001). The goals of the program are to:

- Provide a forum of the CGTO to express and discuss issues of importance

- Provide the CGTO with opportunities to actively participate in decisions that involve places and locations that hold significance for them 
- Involve the CGTO in the curation and display of American Indian artifacts

- Enable the CGTO and its constituency to practice their religious and traditional activities

Table 12-3. Culturally affiliated tribes and organizations in the CGTO

\begin{tabular}{||ll||}
\hline Ethnic Group & Tribe/Band \\
\hline Southern Paiute & Chemehuevi Indian Tribe \\
& Colorado River Indian Tribes \\
& Kaibab Paiute Tribe \\
& Las Vegas Paiute Tribe \\
& Moapa Paiute Tribe \\
& Paiute Indian Tribe of Utah \\
& Pahrump Band of Paiutes \\
Western Shoshone & Duckwater Shoshone Tribe \\
& Ely Shoshone Tribe \\
& Timbisha Shoshone Tribe \\
& Yomba Shoshone Tribe \\
Owens Valley Paiute-Shoshone & Benton Paiute-Shoshone Tribe \\
& Big Pine Paiute Tribe \\
& Bishop Paiute Tribe \\
Pan-Indian Organization & Fort Independence Indian Tribe \\
& Lone Pine Paiute-Shoshone Tribe \\
& \\
\hline
\end{tabular}

In 2006, the CGTO tribal groups were consulted regarding the proposed Divine Strake high explosives test at the NTS. Also, work continued on the Atomic Testing Museum American Indian exhibit. In 2003, the CGTO established an Atomic Testing Museum subgroup to work with the museum on the content of an exhibit for the NTS American Indian history, culture, and views regarding the NTS landscape. In 2004, the subgroup, facilitated by NNSA/NSO, finalized the concept for the exhibit. In early 2005, recently made American Indian items that represent traditional life ways were loaned to the museum for the display with the subgroup completing the exhibit in time for the opening of the museum. In 2006, the American Indian History Timeline, created by the subgroup, was added to the museum display. 


\section{THIS PAGE INTENTIONALLY LEFT BLANK}




\subsection{Ecological Monitoring}

U.S. Department of Energy (DOE) Order 450.1 Environmental Protection Program requires ecological monitoring and biological compliance support for activities and programs conducted at the DOE facilities. The National Security Technologies, LLC (NSTec), Ecological Monitoring and Compliance Program (EMAC) provides this support for the Nevada Test Site (NTS). The major sub-programs and tasks within EMAC include: (1) the Desert Tortoise Compliance Program, (2) biological surveys at proposed construction sites, (3) monitoring important species and habitats, (4) the Habitat Restoration Program, (5) ecosystem mapping and data management, and (6) biological impact monitoring at the Non-Proliferation Test and Evaluation Complex (NPTEC). Brief descriptions of these program components and their 2006 accomplishments are provided in this chapter. More detailed information may be found in the most recent annual EMAC report (NSTec, 2007c) which is distributed to several state and federal natural

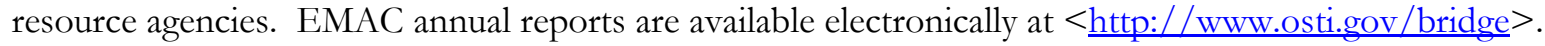

\section{Ecological Monitoring and Compliance Program Program Goals}

Ensure compliance with all state and federal regulations and stakeholder commitments pertaining to NTS flora, fauna, wetlands, and sensitive vegetation and wildlife habitats (see Section 2.9)

Delineate NTS ecosystems

Provide ecological information that can be used to evaluate the potential impacts of proposed projects and programs on NTS ecosystems and important plant and animal species

\subsection{Desert Tortoise Compliance Program}

The desert tortoise inhabits the southern one-third of the NTS at fairly low estimated densities (Figure 13-1). This species is listed as threatened under the Endangered Species Act. In December 1995, the U.S. Department of Energy, National Nuclear Security Administration (NNSA/NSO) completed consultation with the U.S. Fish and Wildlife Service (FWS) concerning the effects of NNSA/NSO activities on the desert tortoise, as described in the Final Environmental Impact Statement for the Nevada Test Site and Off-Site Locations in the State of Nevada (DOE, 1996a). A final Biological Opinion (Opinion) (FWS, 1996) was received from the FWS in August 1996. The Opinion concluded that the proposed activities on the NTS were not likely to jeopardize the continued existence of the Mojave population of the species and that no critical habitat would be destroyed or adversely modified. The Opinion established compliance limits for the numbers of accidentally injured and killed tortoises, captured and displaced tortoises, and acres of tortoise habitat that can be disturbed. All terms and conditions listed in the Opinion must be followed when activities are conducted within the range of the desert tortoise on the NTS. The Desert Tortoise Compliance Program was developed to implement the Opinion's terms and conditions, document compliance actions taken, and assist NNSA/NSO in FWS consultations.

In 2006, biologists conducted surveys for 21 projects that were within the distribution range of the desert tortoise (see Figure 13-2). All of the proposed projects were covered under the 1996 Opinion. No desert tortoises were accidentally injured or killed, nor were any found, captured, or displaced from project sites. One desert tortoise was accidentally killed along a paved road. One site-specific revegetation plan was submitted to the FWS as required by the desert tortoise habitat revegetation plan approved in 2004. Revegetation of habitat at the Bren Tower burn was completed in the spring of 2006. In the summer of 2006, NSTec biologists prepared a Biological Assessment of the security activities that were being conducted at the Device Assembly Facility (DAF). In late 2006, NNSA/NSO requested a Biological Opinion from the FWS regarding security operations at the DAF. 


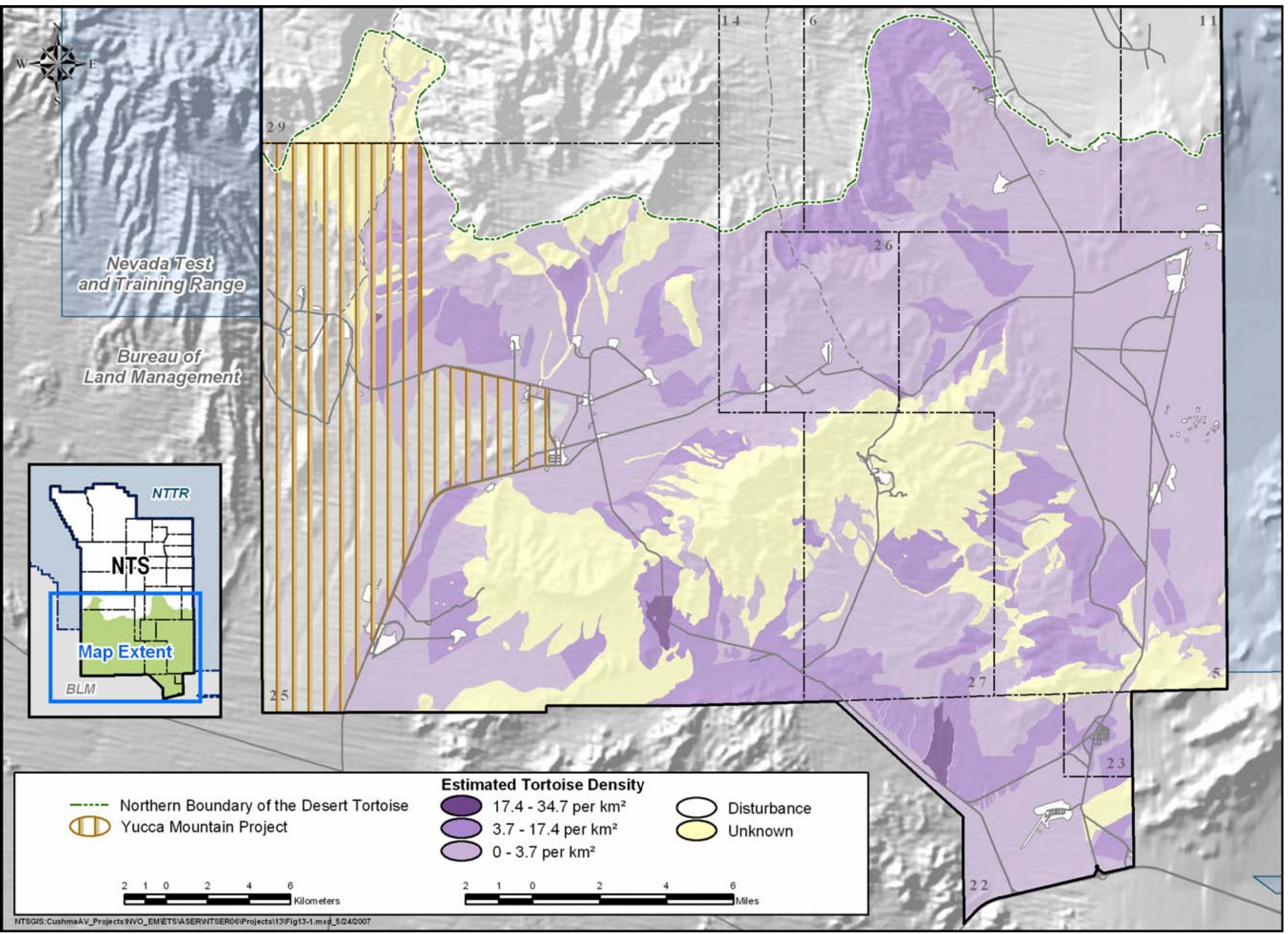


A cumulative total of 110.25 hectares (ha) (272.43 acres [ac]) of tortoise habitat on the NTS has been disturbed since the desert tortoise was listed as threatened in 1992. During 2006, none of the threshold levels for compliance measures established by the FWS were exceeded (Table 13-1). In January 2007, NNSA/NSO submitted a report to the FWS Southern Nevada Field Office that summarized tortoise compliance activities for the 1996 Opinion conducted on the NTS from January 1 through December 31, 2006.

Table 13-1. Compliance limits and status for NTS operations in tortoise habitat

\begin{tabular}{|c|c|c|}
\hline Compliance Measure & $\begin{array}{l}\text { Threshold } \\
\text { Value }\end{array}$ & $\begin{array}{c}2006 \\
\text { Value }\end{array}$ \\
\hline \multicolumn{3}{|l|}{1996 Opinion for NTS Programmatic Activities: } \\
\hline Number of tortoises accidentally injured or killed as a result of NTS activities per year & 3 & 0 \\
\hline Number of tortoises captured and displaced from NTS project sites per year & 10 & 0 \\
\hline $\begin{array}{l}\text { Number of tortoises taken in form of injury or mortality on paved roads on the NTS by } \\
\text { vehicles other than those in use during a project }\end{array}$ & Unlimited & 1 \\
\hline $\begin{array}{l}\text { Number of total ha (ac) of desert tortoise habitat disturbed during NTS project } \\
\text { construction since } 1992\end{array}$ & $1,220(3,015)$ & $110.25(272.43)$ \\
\hline
\end{tabular}

\subsection{Biological Surveys at Proposed Project Sites}

Biological surveys are performed at proposed project sites where land disturbance will occur. The goal is to minimize the adverse effects of land disturbance on important plant and animal species and their associated habitat, important biological resources (i.e., nest sites, active tortoise burrows), and wetlands. Biological surveys comply with the terms and conditions of the 1996 Opinion and with the mitigation measures specified in the Final Environmental Impact Statement for the Nevada Test Site and Off-Site Locations in the State of Nevada (DOE, 1996a) and its Record of Decision.

Species considered important include those protected or managed under state or federal regulations, plants listed on the Nevada Natural Heritage Program's (NNHP's) Nevada At-Risk Plant and Lichen Tracking List (called "sensitive" plants), animals listed on NNHP's Nevada At-Risk Animal Tracking List (called "sensitive" animals), and bats assigned a high or moderate risk assessment designation under The Revised Nevada Bat Conservation Plan (Bradley et al., 2005). The important species known to occur on the NTS include 44 plants, 1 mollusk, 2 reptiles, over 250 birds, and 26 mammals (Tables 13-2 and 13-3). All of these species are evaluated for their inclusion in long-term monitoring activities on the NTS. Important biological resources include such things as cover sites, nest or burrow sites, roost sites, wetlands, or water sources that are vital to important species. The biological survey parameters which are documented include:

- Number of biological surveys conducted

- Number of hectares/acres surveyed per proposed project

- Types and numbers of important species and biological resources found

- Mitigation recommendations and actions taken to protect species/resources

In 2006, surveys at 100 sites for 34 projects were conducted (Figure 13-2). The important species and biological resources found included: 2 inactive tortoise burrows, 2 western burrowing owls (Athene cunicularia hypugaea), several horses (Equus caballus), 2 active predator burrows, mature Joshua trees (Yucca brevifolia), yuccas and cacti, 1 barn owl (Tyto alba), 1 active great-horned owl (Bubo virginianus) nest (2 eggs), and 1 kestrel nest with four eggs in it. The greathorned owl nest with two eggs was monitored during work activity. At least one of the eggs hatched and the owls did not abandon the nest. With approval from the FWS, biologists removed the four kestrel eggs from their nest located in a crane that needed to be used. The four eggs were taken to Wild Wing Project, Inc., in Las Vegas and determined to be non-viable. For each project, NSTec provided a written summary report of all survey findings and mitigation recommendations. All flagged burrows were avoided during construction activities. 
Table 13-2. Important plants which are known to occur on or adjacent to the NTS

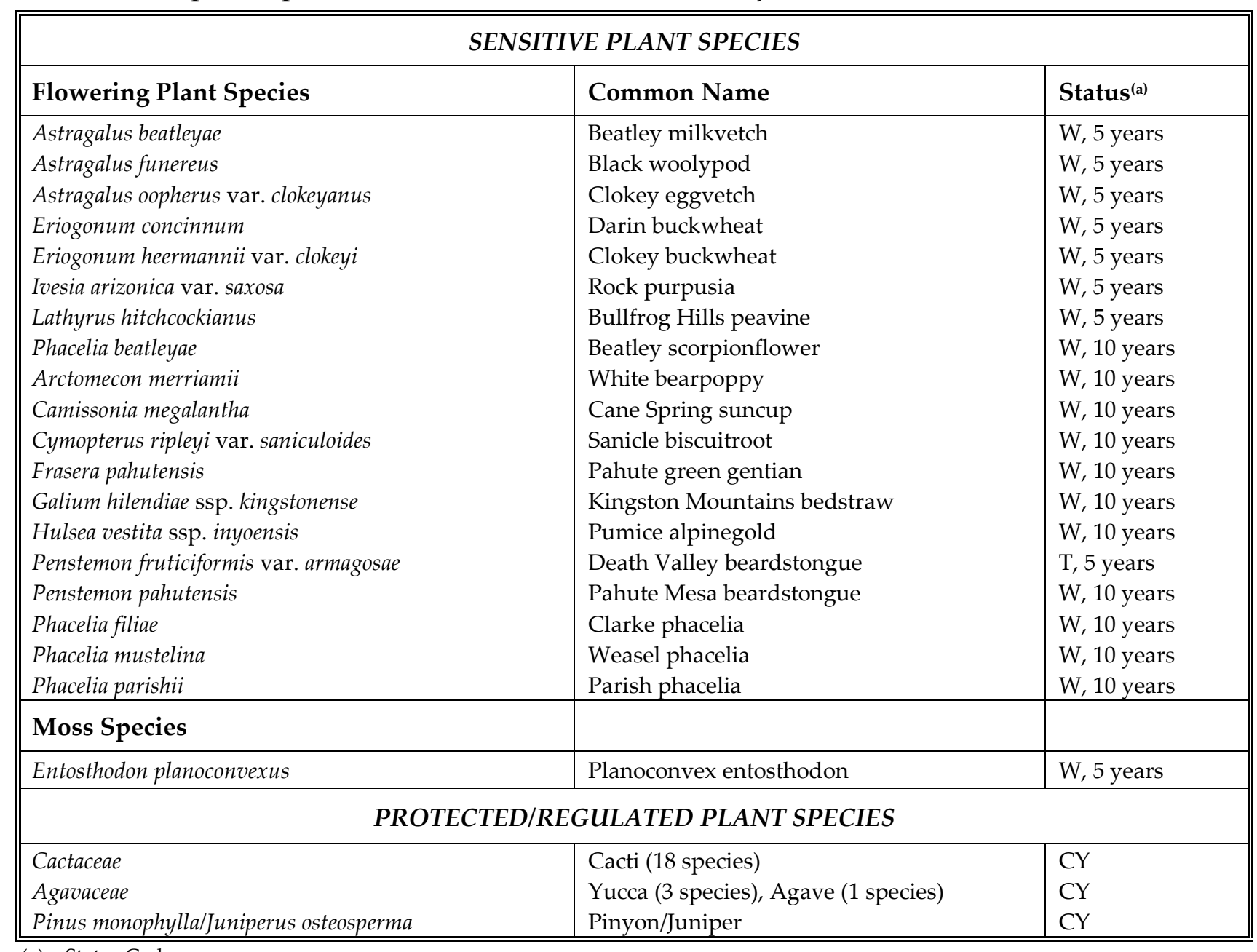

(a) Status Codes:

$\underline{\text { State of Nevada }}$

T - NNHP At Risk Plant and Lichen Taxa, Threatened: believed to meet the ESA definition of Threatened

W - NNHP At Risk Plant and Lichen Taxa, Watch-list species: potentially vulnerable to becoming Threatened or Endangered

CY - Protected as a cactus, yucca, or Christmas tree from unauthorized collection on public lands. Such plants are not protected from harm on private lands or on withdrawn public lands such as the NTS

Long-term Sensitive Plant Monitoring Status under EMAC

5 years - Monitor a minimum of once every 5 years

10 years - Monitor a minimum of once every 10 years 
Table 13-3. Important animals which are known to occur on or adjacent to the NTS

\begin{tabular}{|c|c|c|}
\hline Mollusk Species & Common Names & Status ${ }^{(a)}$ \\
\hline Pyrgulopsis turbatrix & Southeast Nevada springsnail & $\mathrm{S}, \mathrm{A}$ \\
\hline \multicolumn{3}{|l|}{ Reptile Species } \\
\hline $\begin{array}{l}\text { Eumeces gilberti rubricaudatus } \\
\text { Gopherus agassizii }\end{array}$ & $\begin{array}{l}\text { Western red-tailed skink } \\
\text { Desert tortoise }\end{array}$ & $\begin{array}{l}\text { S, E } \\
\text { LT, NPT, S, IA }\end{array}$ \\
\hline \multicolumn{3}{|l|}{ Bird Species(b) } \\
\hline $\begin{array}{l}\text { Accipiter gentilis } \\
\text { Alectoris chukar } \\
\text { Aquila chrysaetos } \\
\text { Athene cunicularia hypugaea } \\
\text { Buteo regalis } \\
\text { Buteo swainsoni } \\
\text { Callipepla gambelii } \\
\text { Charadrius montanus } \\
\text { Chlidonias niger } \\
\text { Coccyzus americanus } \\
\text { Falco peregrinus anatum } \\
\text { Gavia immer } \\
\text { Haliaeetus leucocephalus leucocephalus } \\
\text { Ixobrychus exillis hesperis } \\
\text { Lanius ludovicianus } \\
\text { Oreoscoptes montanus } \\
\text { Phainopepla nitens } \\
\text { Plegadis chihi } \\
\text { Spizella breweri }\end{array}$ & $\begin{array}{l}\text { Northern goshawk } \\
\text { Chukar } \\
\text { Golden eagle } \\
\text { Western burrowing owl } \\
\text { Ferruginous hawk } \\
\text { Swainson's hawk } \\
\text { Gambel's quail } \\
\text { Mountain plover } \\
\text { Black tern } \\
\text { Western yellow-billed cuckoo } \\
\text { American peregrine falcon } \\
\text { Common loon } \\
\text { Bald eagle } \\
\text { Western least bittern } \\
\text { Loggerhead shrike } \\
\text { Sage thrasher } \\
\text { Phainopepla } \\
\text { White-faced ibis } \\
\text { Brewer's sparrow }\end{array}$ & $\begin{array}{l}\text { NP, S, IA } \\
\text { G } \\
\text { EA, NP } \\
\text { NP, S, A } \\
\text { NP, S, IA } \\
\text { NP, S, IA } \\
\text { G } \\
\text { PT, NP } \\
\text { NP, S, IA } \\
\text { NP, S, IA } \\
<\text { LE, NPE, S, IA } \\
\text { NP, S, IA } \\
\text { LT-PD, EA, NPE, S, IA } \\
\text { NP, S, IA } \\
\text { NPS } \\
\text { NPS } \\
\text { NP, S, IA } \\
\text { NP, S, IA } \\
\text { NPS }\end{array}$ \\
\hline \multicolumn{3}{|l|}{ Mammal Species } \\
\hline $\begin{array}{l}\text { Antrozous pallidus } \\
\text { Antilocapra americana } \\
\text { Corynorhinus townsendii pallescens } \\
\text { Equus asinus } \\
\text { Equus caballus } \\
\text { Euderma maculatum } \\
\text { Felis concolor } \\
\text { Lasionycteris noctivagans } \\
\text { Lasiurus blossevillii } \\
\text { Lasiurus cinereus } \\
\text { Lynx rufus } \\
\text { Microdipodops megacephalus } \\
\text { Microdipodops pallidus } \\
\text { Myotis californicus }\end{array}$ & $\begin{array}{l}\text { Pallid bat } \\
\text { Pronghorn antelope } \\
\text { Townsend's big-eared bat } \\
\text { Burro } \\
\text { Horse } \\
\text { Spotted bat } \\
\text { Mountain lion } \\
\text { Silver-haired bat } \\
\text { Western red bat } \\
\text { Hoary bat } \\
\text { Bobcat } \\
\text { Dark kangaroo mouse } \\
\text { Pale kangaroo mouse } \\
\text { California myotis }\end{array}$ & $\begin{array}{l}\text { NP, M, A } \\
\text { G } \\
\text { NPS, S, H, A } \\
\text { HB } \\
\text { HB } \\
\text { NPT, S, M, A } \\
\text { G } \\
\text { M, A } \\
\text { NPS, S, H, A } \\
\text { M, A } \\
\text { F } \\
\text { NP } \\
\text { NP } \\
\text { S, M, A }\end{array}$ \\
\hline
\end{tabular}


Table 13-3. Important animals which are known to occur on or adjacent to the NTS (continued)

\begin{tabular}{||l|l|l||}
\hline Mammal Species (continued) & Common Name & Status $^{(\mathbf{a})}$ \\
\hline Myotis ciliolabrum & Small-footed myotis & $\mathrm{S}, \mathrm{M}, \mathrm{A}$ \\
Myotis evotis & Long-eared myotis & $\mathrm{M}, \mathrm{A}$ \\
Myotis thysanodes & Fringed myotis & $\mathrm{NP}, \mathrm{S}, \mathrm{H}, \mathrm{A}$ \\
Myotis yumanensis & Yuma myotis & $\mathrm{M}, \mathrm{A}$ \\
Ovis canadensis nelsoni & Desert bighorn sheep & $\mathrm{G}$ \\
Odocoileus hemionus & Mule deer & $\mathrm{G}$ \\
Pipistrellus hesperus & Western pipistrelle & $\mathrm{M}, \mathrm{A}$ \\
Sylvilagus audubonii & Audubon's cottontail & $\mathrm{G}$ \\
Sylvilagus nuttallii & Nuttall's cottontail & $\mathrm{G}$ \\
Tadarida brasiliensis & Brazilian free-tailed bat & $\mathrm{NP}$ \\
Urocyon cinereoargenteus & Gray fox & $\mathrm{F}$ \\
Vulpes velox macrotis & Kit fox & $\mathrm{F}$ \\
\hline
\end{tabular}

(a) Status Codes:

U. S. Fish and Wildlife Service, Endangered Species Act

$<$ LE - Former listed endangered species

LT - Listed Threatened

PD - Proposed for delisting

PT - Proposed for listing as Threatened

U.S. Department of Interior

EA - Protected under Bald and Golden Eagle Act

HB - Protected under Wild Free Roaming Horses and Burros Act

$\underline{\text { State of Nevada }}$

F - Regulated as fur-bearer species

G - Regulated as game species

NPE - Species protected as endangered under Nevada Administrative Code (NAC) 503

NPT - Species protected as threatened under NAC 503

NPS - Species protected as sensitive under NAC 503

NP - Species listed as protected under NAC 503

S - Listed on NNHP's Nevada At-Risk Animal Tracking List

$\underline{\text { Revised Nevada Bat Conservation Plan - Bat Species Risk Assessment Designations }}$

$\mathrm{H}$ - High: species imperiled or at high risk of imperilment and having the highest priority for funding, planning, and conservation actions

M - Moderate: species which warrant closer evaluation, more research, and conservation actions and lacking meaningful information to adequately assess species' status

Long-term Sensitive Animal Monitoring Status under EMAC

A - Active: currently included in long-term population monitoring activities

E - Evaluate: species for which more information on distribution, abundance, and susceptibilities to threats on the NTS must be gathered before deciding to include in long-term monitoring activities

IA - Inactive: not currently included in long-term population monitoring activities

(b) All bird species on the NTS are protected by the Migratory Bird Treaty Act except for the following five species: Gambel's quail, chukar, English house sparrow, rock dove, and European starling Also, the state of Nevada protects all birds that are protected by federal laws in addition to the species listed in this table. 


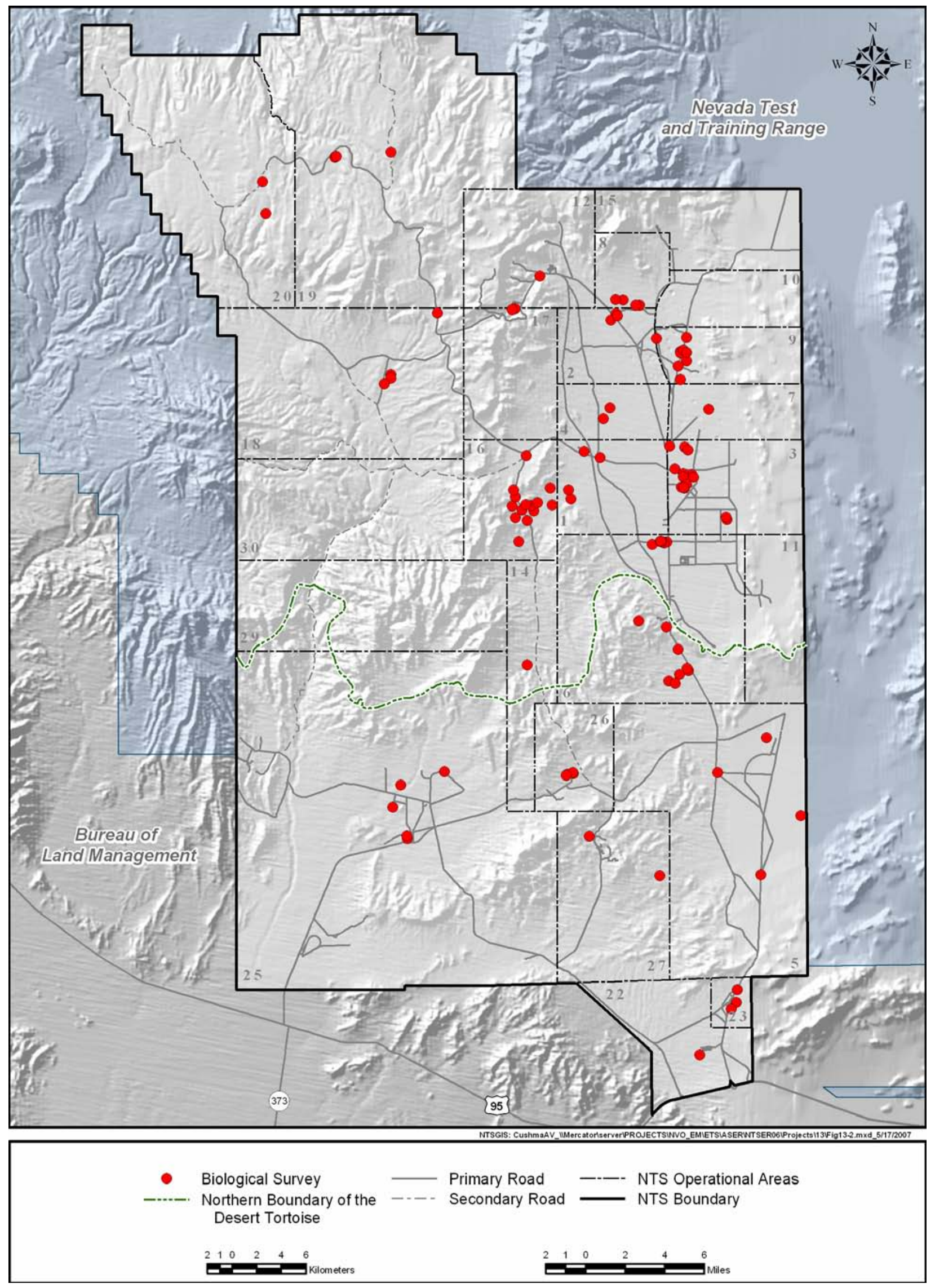

Figure 13-2. Location of biological surveys conducted on the NTS in 2006 


\subsection{Important Species and Habitat Monitoring}

Over the last three decades, NNSA/NSO has taken an active role in collecting or supporting the collection of information on the status of important plants and animals and their habitat on the NTS and has produced numerous documents reporting their occurrence, distribution, and susceptibility to threats on the NTS (see Ecology of the Nevada Test Site: An Annotated Bibliography [Wills and Ostler, 2001]). In 1998, NNSA/NSO prepared a Resource Management Plan (DOE, 1998). One of the many natural resources goals stated in the plan is to protect and conserve sensitive plant and animal species found on the NTS and to minimize cumulative impacts to those species as a result of NNSA/NSO activities. The EMAC goals of species and habitat monitoring on the NTS are to:

- Ensure that impacts caused directly by NTS projects can be detected, quantified, and managed so that a species' occurrence on the NTS is not threatened by such projects

- Ensure adherence to state and federal regulations aimed at protecting wild horses, migratory birds, wetlands, and wildlife habitat

Data collected for monitored species include:

- Distribution on the NTS

- Relative abundance, density, or population size on the NTS

- Susceptibility to threats from NTS projects
- Location of nest burrows, nests, or roost sites of sensitive animals

- Location of preferred habitats

- Incidence and cause of mortality

In 2006, the major accomplishments under this EMAC task are presented below. Detailed descriptions of these actions and results can be found in NSTec, 2007c.

\subsubsection{Sensitive Plants}

The list of sensitive plants for the NTS (see Table 13-2) was reviewed in 2006 and two plants were added: Penstemon fruticiformis var. amargosae (Death Valley beardtongue), which may occur along the southern boundary of the NTS, and Phacelia filiae (Clarke phacelia), a newly described species that occurs in Frenchman Flat and Rock Valley. One plant was removed from the list: Sclerocactus polyancistrus (redspined fishhook cactus), a cactus widespread throughout several western states. There are currently 19 vascular species and 1 non-vascular species on the list of NTS sensitive plants.

Field surveys for three species were conducted in 2006 which yielded new data. Populations of Frasera pahutensis and Hulsea vestita spp. inyoensis were inventoried, and detailed delineations of their population boundaries were updated. Surveys for potential habitat for Ivesia arizonica var. saxosa were conducted and a new population was found. Results of these surveys are summarized below.

Field surveys for three additional sensitive plants were conducted in 2006 but did not yield new data or the identification of new populations. The Mercury Ridge population of Eriogonum heermannii var. clokeyi was surveyed with the objective of making voucher collections, but because of poor growing conditions, no collections were made. Surveys of known populations of Cymopterus ripleyi var. ripleyi and C. ripleyi var. saniculoides, two species whose taxonomy has been in question for years, were conducted to correctly distinguish the collection sites of each species on the NTS. However, growing conditions were poor, and an insufficient number of plants were located. Surveys were conducted for Entosthodon planoconvexus, a bryophyte, to look for similar habitat and new plants in the immediate vicinity of the one previous collection site on the NTS. No similar habitat was found in the area.

\subsubsection{Frasera pahutensis}

F. pahutensis is known from two regions on the NTS: Pahute Mesa in Area 19 along the 19-01 Road (the type locality), and Rainier Mesa near Gold Meadows in Area 12 (Figure 13-3). The goal of monitoring in 2006 was to revisit populations along the 19-01 Road to better define population boundaries using more accurate Geographical Positioning System (GPS) units and to assess population status (density and vigor). A total of approximately 30 ha (73 ac) were surveyed at two locations adjacent to 19-01 Road in July. At each location, several hundred plants were 


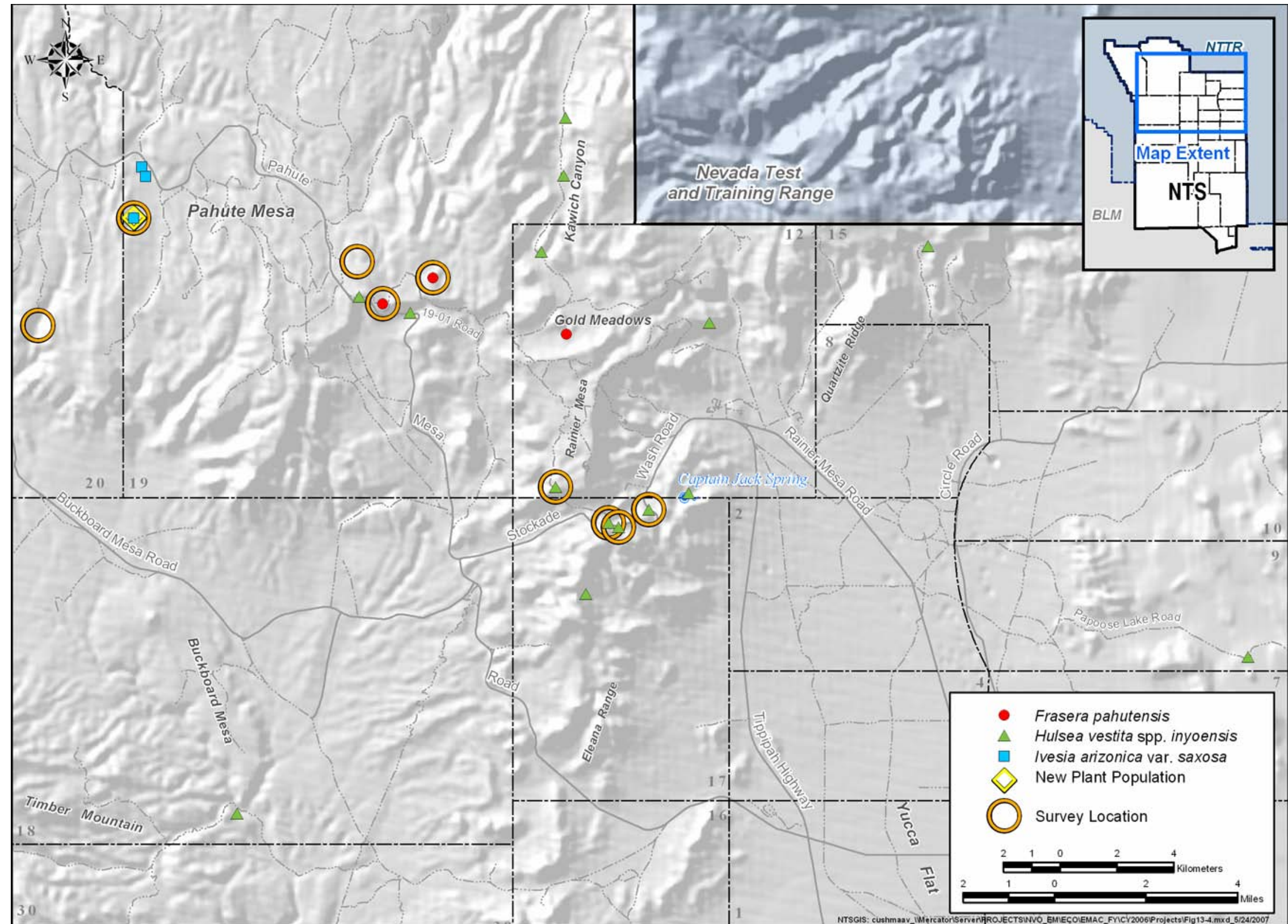

Figure 13-3. Location of sensitive plant populations monitored on the NTS in 2006 
counted. Based on the abundance of individual plants, their vigor, and the lack of any activities in the immediate vicinity, these two populations appear to be in good condition and there appears to be no impacts from NNSA/NSO activities. There appears to be an abundance of potential habitat for this species on the NTS and additional locations may be found in the future as remote locations are accessed and surveyed. The Gold Meadows population of F. pabutensis will be similarly surveyed in future years.

\subsubsection{Hulsea vestita spp. inyoensis}

Known NTS populations of $H$. vestita spp. inyoensis occur on road cuts along Holmes and Stockade Wash roads, the vicinity of Captain Jack Springs, the slopes of Rainier Mesa, north into Kawich Canyon and east along Papoose Lake Road (Figure 13-3). Surveys were conducted in June at the previously reported locations along Holmes and Stockade Wash roads. Plant population boundaries were recorded using GPS readings. Plant numbers were small and consisted of but a few plants along several road cuts. Plants were flowering (Figure 13-4) and showed no signs of threats either from NNSA/NSO activities in the area or from natural impacts such as pests, disease, or herbivory. Future surveys for this species will focus on the other known NTS population sites.

\subsubsection{Ivesia arizonica var. saxosa}

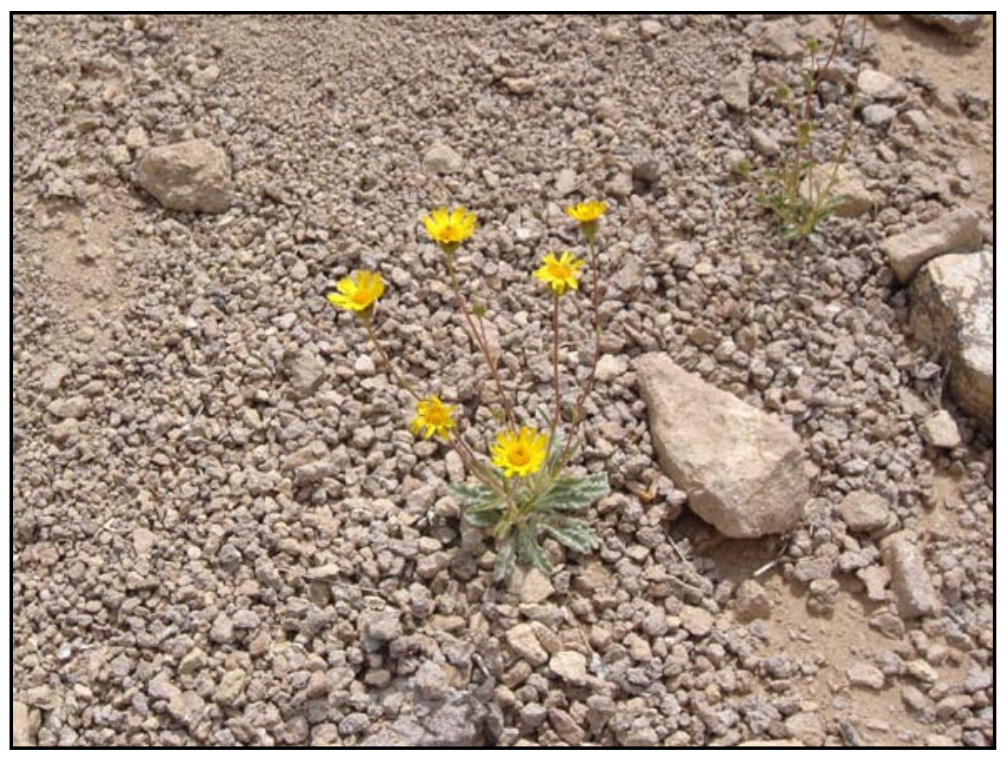

Figure 13-4. H. vestita spp. inyoensis on road cut along Stockade Wash Road (Photo by D. C. Anderson, June 2006)

I. arizonica var. saxosa is endemic to Nevada and is only known to occur on the NTS and in the Pahroc Mountains in Lincoln County. Before 2005, only one NTS population was known to occur in Columbine Canyon just off of Pahute Mesa Road (Figure 13-3). In 2005, an extension of this population was located about $100 \mathrm{~m}$ (328 ft) to the south, and then a second small population was found an additional 300 meters (m) (984 feet [ft]) south. The objective of the surveys in 2006 was to identify this species' potential habitat using aerial photographs and topographic maps and conduct field surveys in those areas to locate new populations. Two areas of potential habitat covering about 815 ha

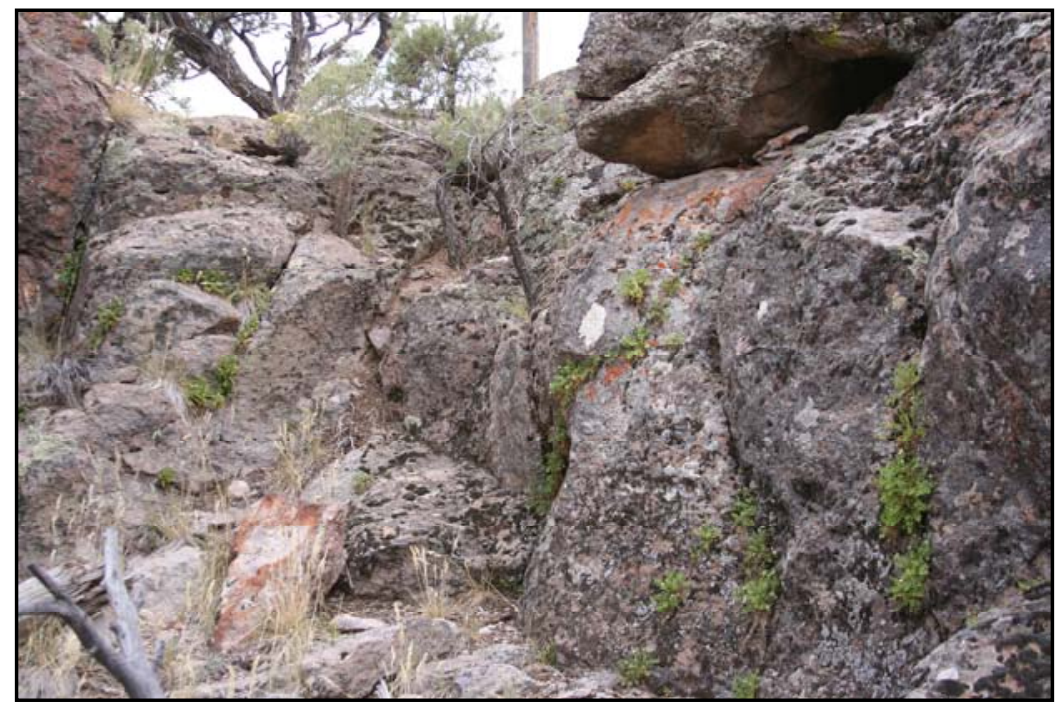

Figure 13-5. I. arizonica var. saxosa growing on north and west faces of large boulders on Pahute Mesa (Photo by W. K. Ostler, Iune 2006) $(2,024 \mathrm{ac})$ were identified to the south of the known locations and were surveyed. One was about 5 kilometers $(\mathrm{km})(3$ miles [mi]) to the south and west of Columbine Canyon and the other was $8 \mathrm{~km}(5 \mathrm{mi})$ east and south of Columbine Canyon. No new populations of I. arizonica var. saxosa were found. A third area of potential habitat covering almost $10 \mathrm{ha}(25 \mathrm{ac})$ about $2,000 \mathrm{~m}(6,561 \mathrm{ft})$ south of Columbine Canyon was also surveyed, and one new population was found (Figure 13-3). The population's habitat is on the westerly and northerly exposures of large boulders of Rainier Mesa tuff (Figure 13-5). Plants at this location were more abundant than at Columbine Canyon. Future monitoring efforts for this species may involve the establishment of permanent transects to monitor the density of plants over time. 


\subsubsection{Important Animals}

\subsubsection{Western Red-tailed Skink}

Surveys for the western red-tailed skink (Eumeces gilberti rubricaudatus) (Figure 13-6), an NNHP sensitive species, were conducted in 2006. A total of 9 skinks was captured over 6,092 trap days (1 skink/677 trap days) at 7 of 48 sampling sites (see Figure 13-8, following page). All skinks were captured in funnel traps set near rocks or vegetation. Figure 13-8 (following page) shows the current known distribution of this skink on the NTS where "Location" on the figure denotes a site where a skink was trapped either in 2006 ("New Location") or prior to 2006 ("Historic Location"). In 2006, over 500 other reptiles were observed or captured in the funnel traps at the 48 sampling sites. These other reptiles included 10 of 16 lizard species known to occur on the NTS and 11 of 17 snake species

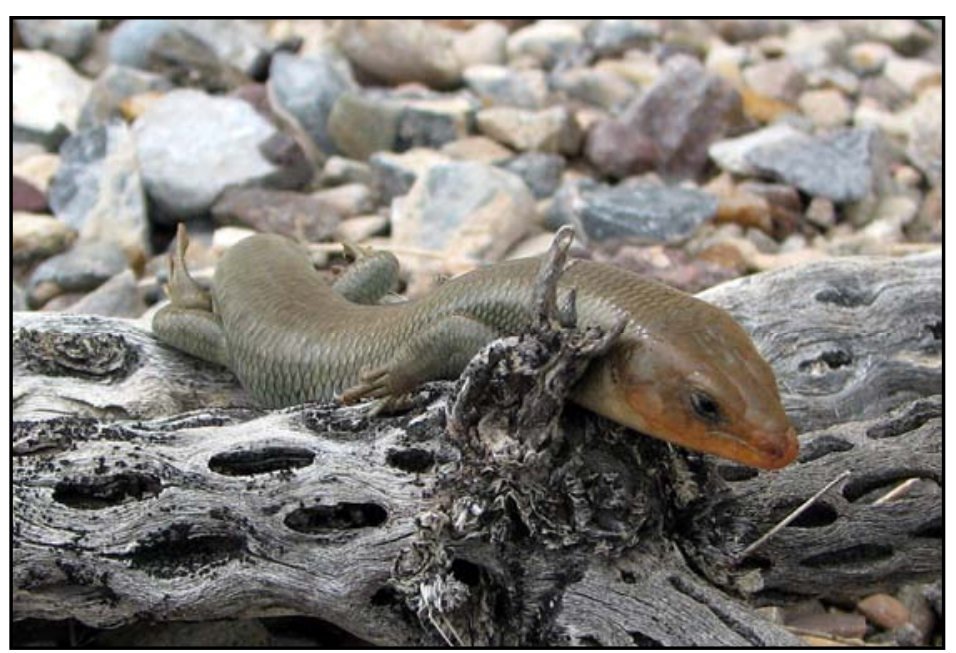

Figure 13-6. Western red-tailed skink captured at Twin Spring, Site 9 (Photo by D. B. Hall, May 11, 2006) known to occur on the NTS. Overall trap success was 8.8 percent (538 captures/6,092 trap days).

\subsubsection{Western Burrowing Owl}

Western burrowing owls (Athene cunicularia hypugaea) (Figure 13-7) were trapped on the NTS in 2006 as part of a collaborative effort with Dr. Courtney Conway to evaluate the genetic relatedness and migratory status of owls in western North America. Dr. Conway is funded by the Department of Defense Legacy Project. One adult female owl that was banded last year as a juvenile was captured again this year $5.3 \mathrm{~km}$ (3.29 mi) from her natal site.

Radioisotopic analysis of the feathers from this owl should provide information on where she spent the winter.

Trapping also contributes new information on the distribution of burrowing owls on the NTS. A total of 34 owls, including 16 adults and 18 juveniles, were captured. Additionally, six new burrow sites were found, including four burrows in the Mojave Desert ecoregion and two in the Great Basin Desert ecoregion.

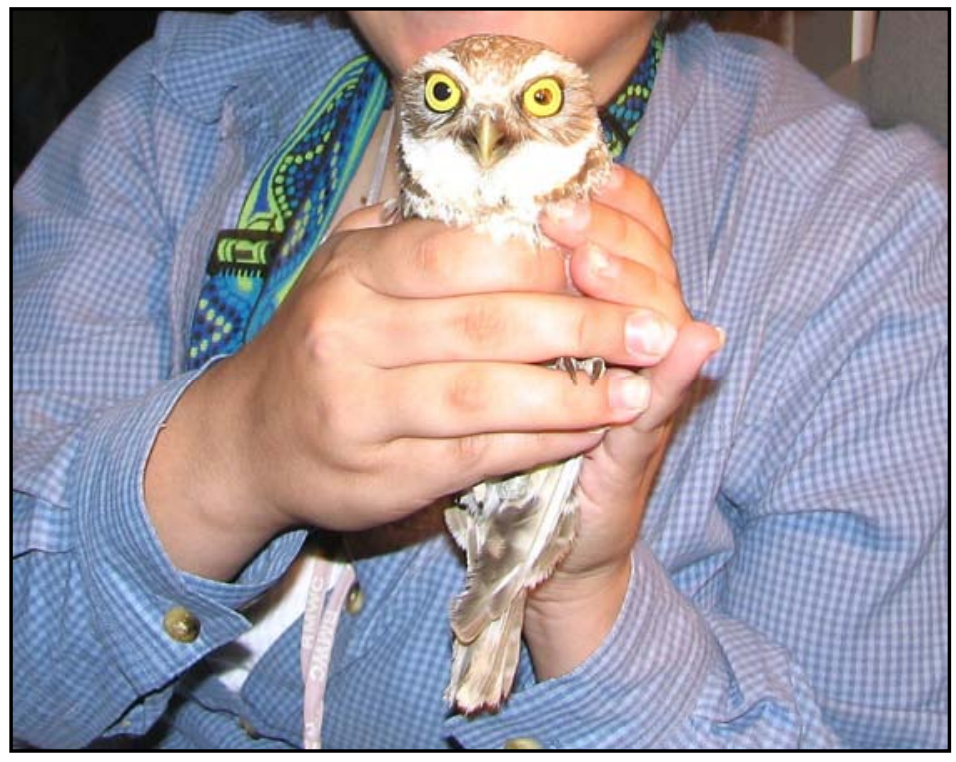

Figure 13-7. Captured western burrowing owl (Photo by D. B. Hall on June 6, 2006) A total of 132 burrowing owl locations (30 owl sightings and 102 burrow sites) are documented on the NTS (see Figure 13-9, page 13-13).

\subsubsection{Bird Monitoring and Mortality}

Several raptors occur on the NTS. Some are sensitive species and all are protected or regulated under the Migratory Bird Treaty Act or Nevada state law (see Table 13-3). Because these birds occupy the higher trophic levels of the food chain, they are regarded as indicators of ecosystem stability and health. Nine raptor species are known to breed on the NTS. No field surveys for active raptor nests were conducted in 2006, although this means of monitoring raptor breeding is conducted at least once every five years. 


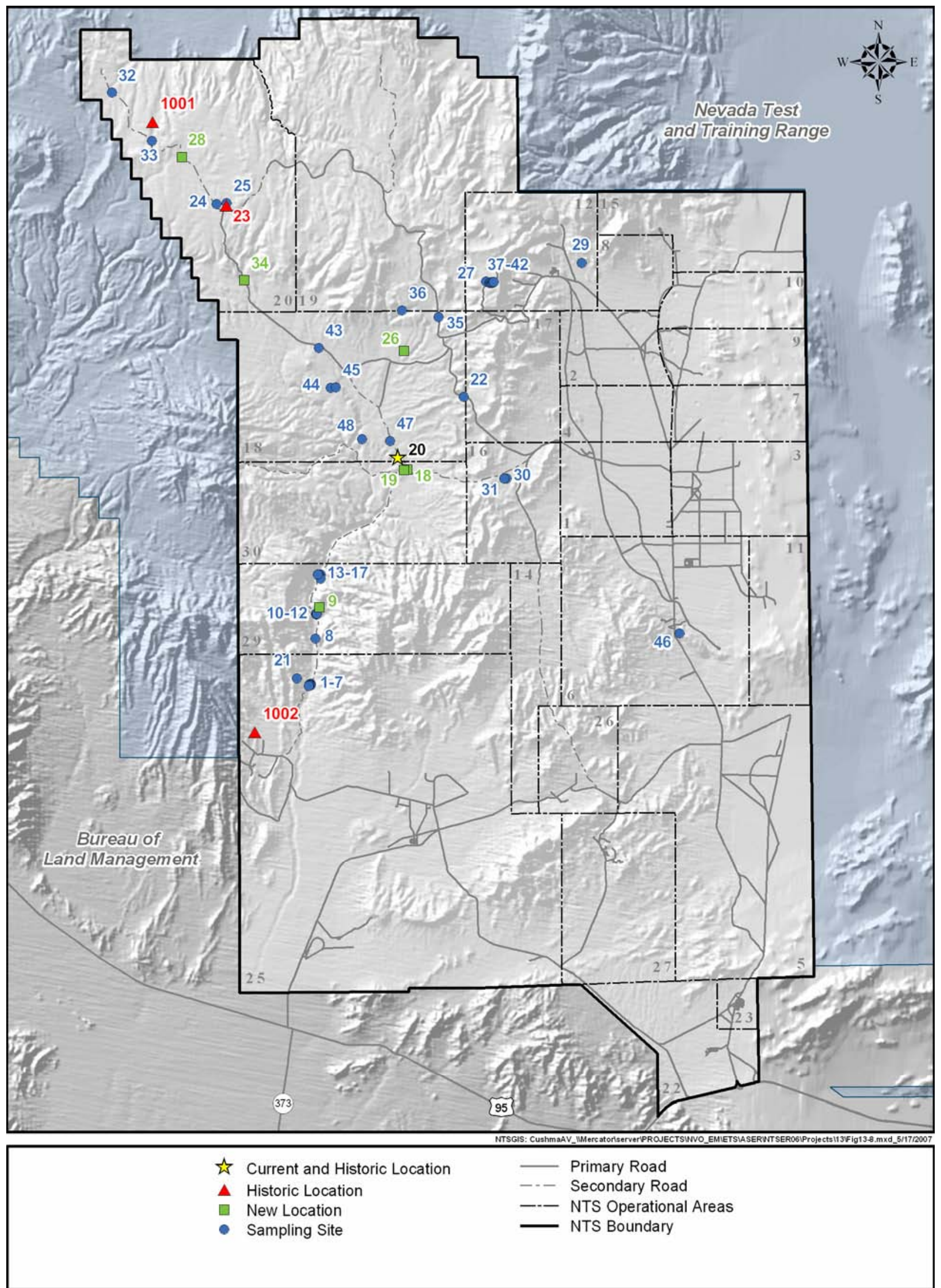

Figure 13-8. Locations where western red-tailed skinks have been trapped and sites sampled in 2006 


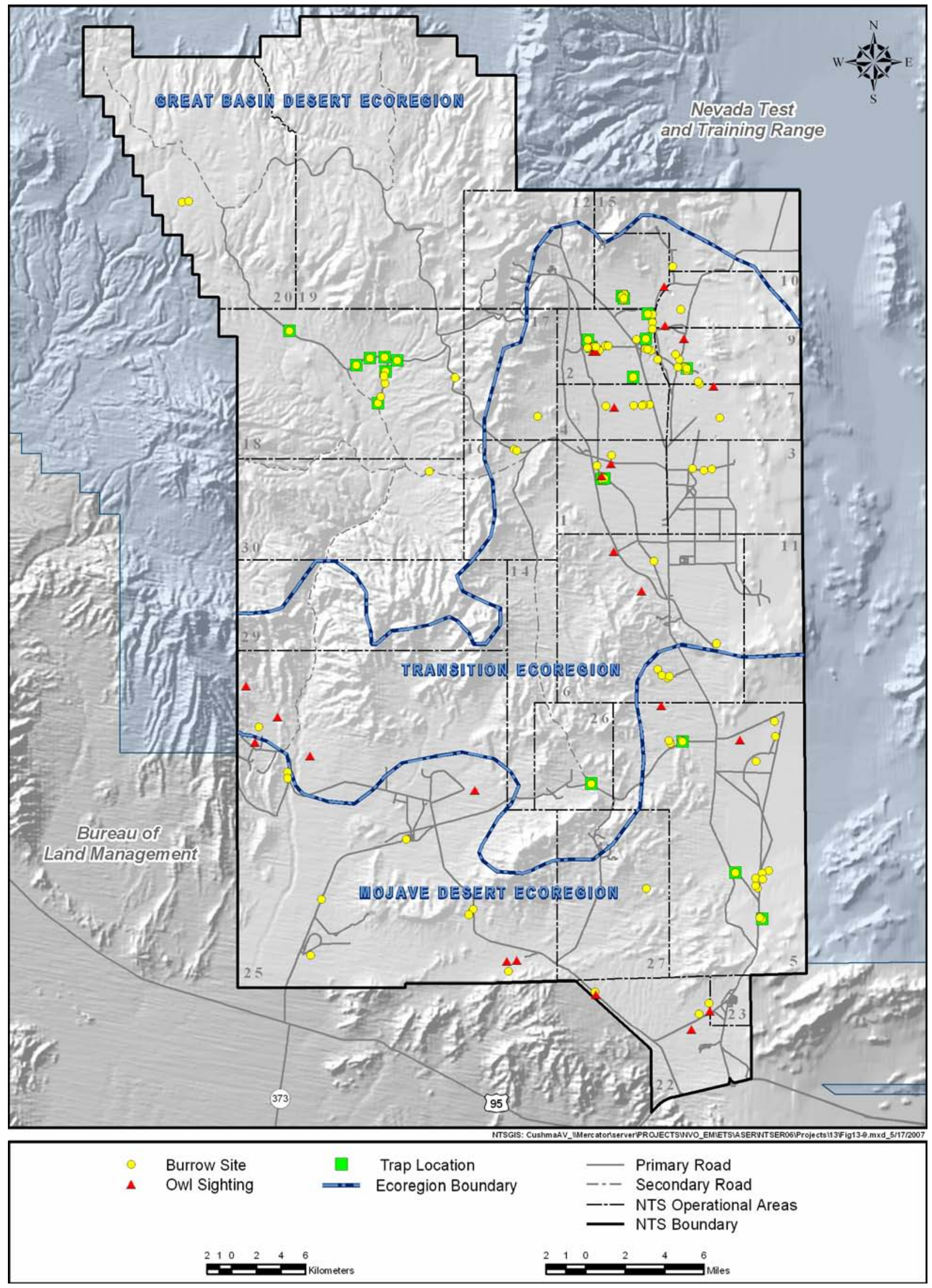

Figure 13-9. Known western burrowing owl distribution on the NTS and locations trapped in 2006 
Opportunistic sightings of raptors were common in 2006 and included red-tailed hawks (Buteo jamaicensis), turkey vultures (Cathartes aura), golden eagles (Aquila chrysaetos), American kestrels (Falco sparverius) and prairie falcons (Falco mexicanus). Many of these individuals are commonly seen perching on utility poles on Frenchman and Yucca flats. Barn owls (Tyto alba) nesting in buildings on the NTS were a common occurrence in 2006. Cooper's hawk (Accipter cooperii) and red-tailed hawks were observed around water sources near Rainier Mesa. A common black-hawk (Buteogallus anthracinus) was observed flying near the Mercury Highway on Yucca Flat (Area 4) on April 4, 2006, by a NSTec biologist. This species breeds in central and southern Arizona and New Mexico and has been observed as a rare species in southern Nevada. It is the first known record of this hawk for the NTS.

Bird mortality is recorded as a measure of potential impacts that NNSA/NSO activities may have on protected birds. Only 5 bird mortalities and 6 injured raptors were recorded in 2006. Two of the primary causes of bird mortality were road kill and electrocution (Table 13-4). Injured birds were captured and taken to the North Las Vegas Animal Hospital for examination, cared for by Wild Wing Project, Inc., and were then released into the wild. No feasible mitigation actions were identified in 2006 to reduce the incidence of bird mortality on the NTS. NTS activities appear to have a low impact on natural bird populations since the reported number of bird deaths related directly to NTS activities over the past 16 years is very low and the causes are varied (Figure 13-10).

Table 13-4. Records of bird mortality and injury on the NTS in 2006

\begin{tabular}{|c|c|c|c|c|}
\hline \multirow[t]{2}{*}{ Species } & \multicolumn{4}{|c|}{ Cause of Death } \\
\hline & Electrocution & Road Kill & Unknown & Injury ${ }^{(a)}$ \\
\hline Barn owl (Tyto alba) & & & & 3 \\
\hline Golden eagle (Aquila chrysaetos) & 2 & & & \\
\hline Long-eared owl (Asio otus) & & & 1 & \\
\hline Prairie falcon (Falco mexicanus) & & & & 1 \\
\hline Red-tailed hawk (Buteo jamaicensis) & & & & 2 \\
\hline Roadrunner (Geococcyx californianus) & & 1 & & \\
\hline Turkey vulture (Cathartes aura) & & 1 & & \\
\hline Total & 2 & 2 & 1 & 6 \\
\hline
\end{tabular}

(a) Taken to veterinary clinic for treatment, rehabilitated at Wild Wing Project, Inc., and released

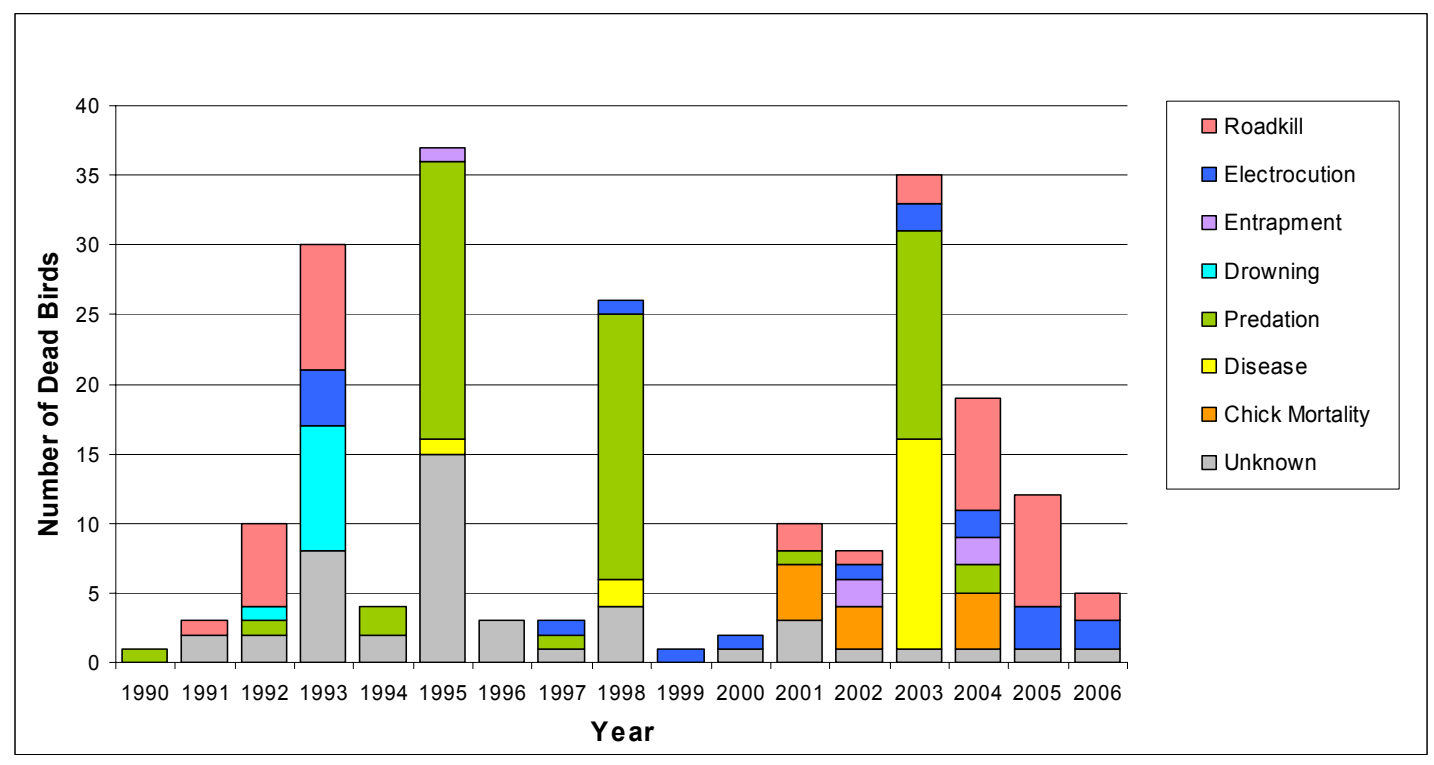

Figure 13-10. Number of bird deaths recorded on the NTS by year and cause 


\subsubsection{State-Protected Small Mammals}

Each year the NNHP Nevada At-Risk Animal Tracking List and the NAC 503 are reviewed to identify changes in the status of animals known to occur on the NTS. A noteworthy change in 2005 was the addition of the dark kangaroo mouse (Microdipodops megacephalus) and the pale kangaroo mouse (M. pallidus) to the list of Nevada Protected species under NAC 503. As a result, small mammal trapping was initiated in 2005 to help assess these species' distribution and abundance on the NTS. Small mammal trapping continued in 2006, however, neither of these two species were captured. A total of 2,965 animal captures representing 14 species was recorded in 7,488 trap nights at 23 sites.

\subsubsection{Sensitive Bats}

Monitoring sensitive bat species of the NTS (see Table 13-3) focused on sampling known maternity roosts to determine occupancy patterns and compare techniques for counting bats; conducting pre-closure surveys at $\mathrm{N}$ and T Tunnel complexes to determine if gating is necessary; passive acoustic monitoring of bat activity at Camp 17 Pond; and responding to numerous calls to remove bats, including a rabid bat, and documenting their roost sites. Maternity roosts occupied in previous years were occupied again this year by both Townsend's big-eared bat (Corynorbinus townsendir) and fringed myotis (Myotis thysanodes). Counts from the two types of cameras showed varying results. Counting bats was easier using the images from the NightSight ${ }^{\mathrm{TM}}$ camera than images from the Sony® nightshot camera. Two bat gates were installed in the $\mathrm{N}$ Tunnel Complex. These are the first bat gates to be installed on the NTS. Several thousand files containing bat vocalizations were recorded from Camp 17 Pond and are in the process of being analyzed. The first rabid bat on the NTS was collected, and 23 bats in or around buildings were found roosting (8 dead) on 19 occasions at 15 buildings. Ten bats were western pipistrelles (Pipistrellus hesperus), five were pallid bats (Antrozous pallidus), one was either California or small-footed myotis (Myotis spp.), and seven were unknown species.

\subsubsection{Wild Horses}

An annual horse census is conducted at the NTS by driving selected roads, and by using cameras to record individual markings of animals. Numbers have increased from a low of about 33 in 1999 to about 53 individuals in 2006 (Table 13-5). Moderate numbers of young horses have been recruited to the population during this period. Mountain lion predation pressure may be reduced on horses, allowing the increase numbers of young horses, because many more deer are now available as prey (see Section 13.3.2.7).

Table 13-5. Number of individual horses observed on the NTS by age class, gender, and year

\begin{tabular}{|c|c|c|c|c|c|c|c|c|c|c|c|c|c|c|c|c|}
\hline Age Class & \multicolumn{16}{|c|}{ Years } \\
\hline \multirow{8}{*}{$\begin{array}{l}\text { 2-Year Olds } \\
\text { 3-Year Olds } \\
\text { (>3-Year Olds) }\end{array}$} & \multicolumn{2}{|c|}{1999} & \multicolumn{2}{|c|}{2000} & \multicolumn{2}{|c|}{2001} & \multicolumn{2}{|c|}{2002} & \multicolumn{2}{|c|}{2003} & \multicolumn{2}{|c|}{2004} & \multicolumn{2}{|c|}{2005} & \multicolumn{2}{|c|}{2006} \\
\hline & \multicolumn{2}{|c|}{5} & \multicolumn{2}{|c|}{11} & \multicolumn{2}{|c|}{11} & \multicolumn{2}{|c|}{5} & \multicolumn{2}{|c|}{6} & \multicolumn{2}{|c|}{5} & \multicolumn{2}{|c|}{5} & \multicolumn{2}{|c|}{8} \\
\hline & \multicolumn{2}{|c|}{2} & & & \multicolumn{2}{|c|}{2} & & & \multicolumn{2}{|c|}{9 (a) } & & & \multicolumn{2}{|c|}{6} & \multicolumn{2}{|c|}{8} \\
\hline & \multicolumn{16}{|c|}{ Gender $^{(b)}$} \\
\hline & $\mathbf{M}$ & $\mathbf{F}$ & $\mathbf{M}$ & $\mathbf{F}$ & $\mathbf{M}$ & $\mathbf{F}$ & $\mathbf{M}$ & F & $\mathbf{M}$ & F & $\mathbf{M}$ & $\mathbf{F}$ & $\mathbf{M}$ & $\mathbf{F}$ & $\mathbf{M}$ & $\mathbf{F}$ \\
\hline & 0 & 0 & 2 (c) & 0 & 2 & 2 & 0 & 2 & 0 & 0 & 4 & 4 & 5 & 4 & 3 & 3 \\
\hline & 0 & 0 & 0 & 0 & 0 & 0 & 2 & 2 & 0 & 2 & 0 & 0 & 4 & 4 & 4 & 4 \\
\hline & & 20 & 13 & 21 & 11 & 20 & 8 & 19 & 8 & 20 & 6 & 21 & 5 & 21 & 7 & 24 \\
\hline $\begin{array}{r}\text { Total } \\
\text { (excludes foals } \\
\text { and dead horses) }\end{array}$ & \multicolumn{2}{|c|}{33} & \multicolumn{2}{|c|}{38} & \multicolumn{2}{|c|}{37} & \multicolumn{2}{|c|}{33} & \multicolumn{2}{|c|}{38} & \multicolumn{2}{|c|}{44} & \multicolumn{2}{|c|}{49} & \multicolumn{2}{|c|}{53} \\
\hline
\end{tabular}
(a) 1 of the 9 was found dead
(b) $\mathrm{M}=$ Male, $\mathrm{F}=$ Female
(c) These 2 were found dead 
During 2006, road surveys were conducted to monitor the size and location of the wild horse range on the NTS. Eight days of effort were expended for the road surveys. Horse sign data and horse use at natural and human-made water sources indicate that the 2006 horse range includes Gold Meadows, Yucca Flat, Eleana Range, southwest foothills of the Eleana Range, and the Echo Peak region of southeast Pahute Mesa. This range appears to be similar to previous years but possibly smaller due to less use of habitats east of the Eleana Range. In 2006, Camp 17 pond and Gold Meadows Spring continue to be important summer water sources for horses.

\subsubsection{Mule Deer}

Mule deer (Odocoileus hemionus) abundance has been measured on the NTS from 1989-1994, 1999-2000, and in 2006 by driving two standardized road courses at night with spotlights in the northern region of the NTS (77 km [47.8 mi] total length). A spotlighting session involved three consecutive nights of surveying. The number of deer per spotlighting session has increased greatly from 38-42 in 1999-2000 to 153-245 in 2006. Overall, this represents a 5-6 fold increase in deer counted on the NTS. Periodic surveys will continue to be conducted to see if deer numbers remain high.

\subsubsection{Mountain Lions}

Mountain lions (Puma concolor) prey on wild horses, deer, antelope, and even tortoises, and pose a potential threat to humans on the NTS. A collaborative effort continued in 2006 between Erin Boydston, a research scientist with the U.S. Geological Survey, and NSTec biologists to investigate mountain lion distribution and abundance. Remote, motion-activated cameras were were set up at 12 sites where mountain lions were likely to occur. Only one mountain lion was photographed, a female at Tub Spring in late March (Figure 13-11). At least 29 other species of mammals and birds were also detected with the greatest activity at water sources, particularly during the dry summer and fall months.

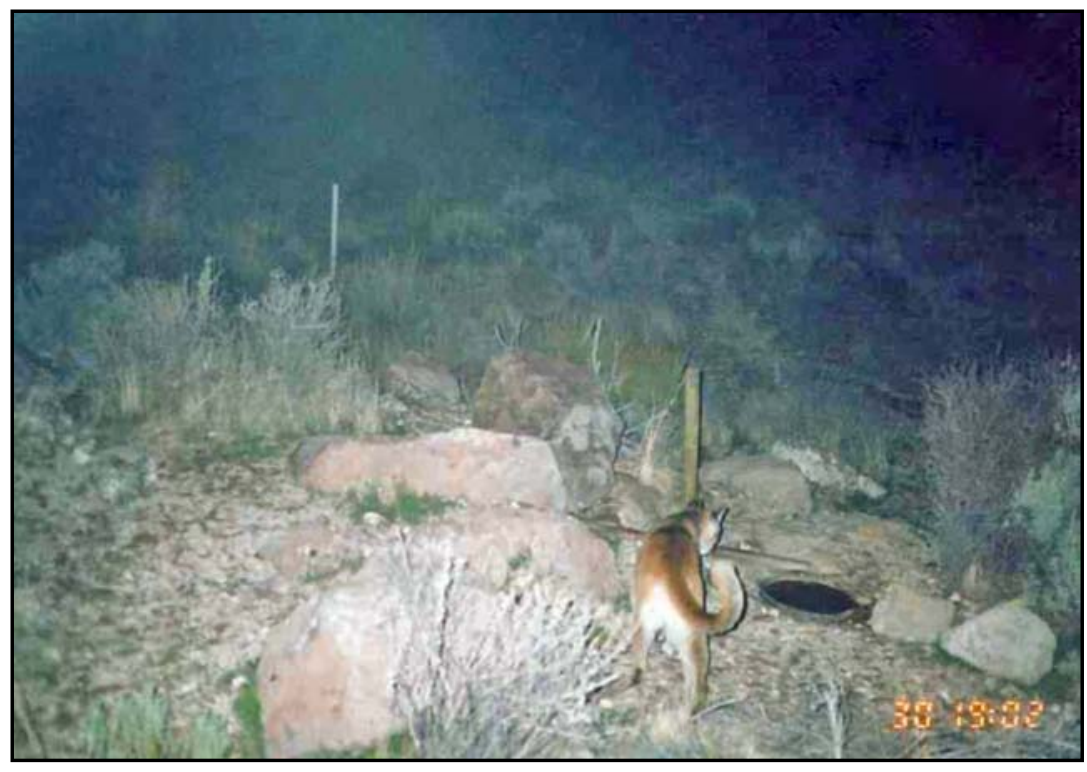

Figure 13-11. Mountain lion photographed at Tub Spring (Photo by remote camera, March 30, 2006)

\subsubsection{Natural and Man-Made Water Sources}

Natural wetlands (e.g., vegetated seeps and springs) and human-made water sources (e.g., sumps and sewage lagoons) provide unique habitats for vegetation and wildlife. NTS wetlands are monitored and are protected when feasible as unique and important habitats for plants and wildlife per the intent of EO 11990 Protection of Wetlands.

Characterization of these mesic habitats and periodic monitoring of their hydrologic and biotic parameters was started in 1997. Monitoring will help identify annual fluctuations and ranges in measured parameters that are natural versus those related to NNSA/NSO activities. Monitoring activities in 2006 included (1) documenting surface area, surface flow, observed disturbances, and wildlife use and mortality at 12 natural wetlands; and (2) documenting wildlife use and mortality observed at 38 plastic-lined sumps and 2 radioactive containment ponds. The surface areas (in square meters $\left.\left[\mathrm{m}^{2}\right]\right)$ and flow rates (in liters per minute $\left.[\mathrm{L} / \mathrm{min}]\right)$ were very small at the natural springs $\left(0-200 \mathrm{~m}^{2}\right.$ and $0-0.9 \mathrm{~L} / \mathrm{min}$ where flow was measurable, respectively). No wetlands were damaged by NTS activities. A dead deer was found in each of two plastic-lined sumps at ER-20-6, Sumps \#5 and \#6. Two sediment ramps were subsequently constructed in these two sumps to prevent future deer entrapment. These sumps will be monitored closely in 2007 to evaluate their effectiveness. Other detailed results of water source monitoring are reported in NSTec, 2007c. 


\subsubsection{West Nile Virus}

Within the important species and habitat monitoring subtask of EMAC, NSTec biologists work cooperatively with the Clark County Health District (CCHD) to determine if mosquitoes on the NTS carry the West Nile virus (WNV). This effort continued in 2006 for the third consecutive year. Mosquito traps were set up at eight NTS sites and were sampled 14 times. Mosquitoes were taken to CCHD personnel for species identification and WNV testing. A total of 111 individuals representing 6 species was captured and analyzed. Three species of mosquitoes were newly detected on the NTS in 2006. All specimens tested negative for WNV except for one Culiseta inornata from Well 3 Pond, and the test result is suspected to be false. This site will be sampled more intensively along with other sites in 2007 to confirm WNV presence on the NTS. The six injured raptors taken to the North Las Vegas Animal Hospital for treatment (see Section 13.3.2.3 above) were also tested for WNV. All raptors tested negative.

\subsection{Habitat Restoration Monitoring Program}

The native vegetation and wildlife habitat at disturbed NTS sites are sometimes restored by seeding and/or planting native plant species. This effort is called revegetation. NNSA/NSO evaluates revegetation as a potential method to stabilize soils at a site based on site size, future use, nature of soils, annual precipitation, slope, aspect, and site location (DOE, 1996a). Revegetation supports the intent of Executive Order 13112 Invasive Species, which is to prevent the introduction and spread of invasive (non-native) species and restore native species to disturbed sites. To date, the majority of NNSA/NSO projects for which revegetation has been pursued are wildland fire sites and abandoned industrial or nuclear test support sites that have been characterized and remediated under the Environmental Restoration (ER) Program. Also, the ER Program has funded revegetation of soil closure covers (or cover caps) to protect against soil erosion and water percolation into buried waste. In addition to conducting all seeding and planting, the Habitat Restoration Monitoring Program conducts short- and long-term monitoring of revegetated sites.

\subsubsection{Revegetated Project Sites}

In 2006, eight Corrective Action Units (CAUs) were monitored (Table 13-6). At each site, the plant density and the percent plant cover of each life form (i.e., shrub, grass, forb/annual) were measured and compared to the plant density and cover measured at adjacent undisturbed habitat to assess the success of revegetation efforts (Table 13-6).

Table 13-6. Comparison of plant density and cover at revegetated sites versus plant density and cover at their reference undisturbed sites as measured in 2006

\begin{tabular}{|c|c|c|c|c|c|c|c|c|c|}
\hline \multirow[b]{2}{*}{ CAU } & \multirow[b]{2}{*}{ Monitored Site } & \multicolumn{4}{|c|}{$\begin{array}{c}\text { Percent Plant Cover } \\
\text { Comparison (a) }\end{array}$} & \multicolumn{4}{|c|}{$\begin{array}{l}\text { Plant Density } \\
\text { Comparison (a) }\end{array}$} \\
\hline & & Shrub & Grass & $\begin{array}{c}\text { Forb/ } \\
\text { Annual }\end{array}$ & Total ${ }^{(b)}$ & Shrub & Grass & $\begin{array}{c}\text { Forb/ } \\
\text { Annual }\end{array}$ & Total \\
\hline 400 & Five Points Landfill & $\mathrm{H}$ & $\mathrm{L}$ & $\mathrm{H}$ & $\mathrm{H}$ & $\mathrm{H}$ & $\mathrm{L}$ & $\mathrm{H}$ & $\mathrm{H}$ \\
\hline 400 & Bomblet Pit & $\mathrm{H}$ & $\mathrm{L}$ & $=$ & $\mathrm{H}$ & $\mathrm{H}$ & $=$ & $\mathrm{L}$ & $\mathrm{H}$ \\
\hline 426 & Cactus Springs Waste Trenches Staging Area & $\mathrm{L}$ & $\mathrm{H}$ & $=$ & $\mathrm{H}$ & $\mathrm{L}$ & $\mathrm{H}$ & $\mathrm{H}$ & $\mathrm{H}$ \\
\hline 404 & Rollercoaster Sewage Lagoons Staging Area & $\mathrm{H}$ & $\mathrm{L}$ & $\mathrm{L}$ & $\mathrm{H}$ & $\mathrm{H}$ & $\mathrm{L}$ & $\mathrm{L}$ & $=$ \\
\hline 404 & Rollercoaster Sewage Lagoons Cover Cap & $\mathrm{H}$ & $\mathrm{H}$ & $\mathrm{L}$ & $\mathrm{H}$ & $\mathrm{H}$ & $\mathrm{H}$ & $\mathrm{L}$ & $\mathrm{H}$ \\
\hline 417 & Central Nevada Test Area Cover Cap & $\mathrm{L}$ & $\mathrm{H}$ & $=$ & $\mathrm{L}$ & $\mathrm{H}$ & $\mathrm{L}$ & $=$ & $\mathrm{H}$ \\
\hline NA & $\begin{array}{l}\text { U-3ax/bl Cover Cap } \\
\text { Area } 6 \text { Waterline - Tortoise Habitat } \\
\text { Restoration }\end{array}$ & \multicolumn{8}{|c|}{$\begin{array}{l}\text { No undisturbed reference site for comparison. Total plant cover was } 19.6 \% \text {, total } \\
\text { plant density was } 8.3 \text { plants } / \mathrm{m}^{2} \text {. } \\
\text { Seeded in the fall of } 2005 \text {. Subsequent lack of rain resulted in poor germination. } \\
\text { Site was visited but no monitoring data were collected. }\end{array}$} \\
\hline
\end{tabular}

(a) $\mathrm{H}$ - cover/density of revegetated site was higher than cover/density of its undisturbed reference site

L - cover/density of revegetated site was lower than cover/density of its undisturbed reference site

$=-$ cover/density of revegetated site was equal to cover/density of its undisturbed reference site

(b) All life forms combined 


\subsubsection{Wildland Fire Sites}

Several major fires on NTS in the past decade have impacted several thousand acres (see Section 13.5). Restoration efforts at these sites have been minimal. The Egg Point Fire in Area 12 that occurred in August 2002 impacted an area near several major facilities, and it was important that some action be taken to protect those facilities from the effects of the fire. In the fall of 2002, the burned areas were revegetated using a combination of seeding and transplanting. The site was monitored the first three years afterwards to evaluate transplant survival and seeding success. The site was not monitored in 2006, but will be in 2007 .

The Shoshone Mountain and Bren Tower fires occurred during the summer of 2005. Reseeding trials with native species were conducted in 2006 at these two sites. The objectives of the trials were to evaluate seeding rates, season of seeding, seed soaking, and harrowing for covering the seed. At the Shoshone Mountain site, germination and establishment of seeded species was very poor in 2006, and the density values were very low. The treatment that had the highest density of seeded species $\left(2.43\right.$ plants $/ \mathrm{m}^{2}$ ) was spring seeding (March). No germination occurred at the Bren Tower Fire so the plots were not sampled. They will be sampled in 2007 if adequate rainfall occurs.

\subsection{Wildland Fire Hazard Assessment}

DOE Order 450.1, Environmental Protection Program, requires protection of site resources from wildland and operational fires. In response to this Order, an annual vegetation survey to determine wildland fire hazards is conducted on the NTS each spring. Survey findings are submitted to the NTS Fire Marshal and also summarized in the annual EMAC report (NSTec, 2007c) along with a description of NTS wildland fires that occurred during the year.

An average of 11 wildland fires per year have occurred on the NTS since 1978, and the average aerial extent of each fire has been 96 ha $(23 \mathrm{ac})$. Based on the limited data set of the dates and number of historic NTS fires, the "fire season" on the NTS appears to be the months of June through August. Wildland fires do not occur randomly across the NTS. They occur more often in blackbrush vegetation types that have sufficient fuels (fine and woody) that are conducive to ignition and spread of wildland fires. Fine fuels refer to fine-textured fuels, typically invasive non-native and native grasses and forbs. Woody fuels refer mainly to shrubs. In 2006, there were 16 wildland fires and a total of 3,486 ha (8,615 ac) burned. The largest was located in Mid Valley (about 3,270 ha [8,000 ac]) (Figure 13-12).

The 2006 vegetation survey was conducted in April and May. A total of 211 sampling stations was visited to assess a fuel index (a rating from 0 to 10) for the risk of wildfires based on the presence of fine fuels and woody fuels combined. Mean precipitation in 2006 was about 20 percent above average (Table 13-7) at the 17 NTS rain gauges operated by the Air Resources Laboratory, Special Operations and Research Division (ARL/SORD)

(see Section 16.0). This contributed to an increase in the percent presence of invasive non-native grasses and forbs and therefore, a slight increase in fine fuels in 2006. Also, a substantial amount of fine fuels from 2005 still persisted. In 2006, the mean combined fuels index for all 211 sampling stations on the NTS was 5.26, compared to 5.64 and 4.88 in 2005 and 2004, respectively. The location of the sampling stations and their fuel index (i.e., sum of each site's fine fuel index and woody fuel index) for 2006 are shown in Figure 13-13.

Table 13-7. Precipitation history and presence of top species contributing to fine fuels

\begin{tabular}{|c|c|c|c|}
\hline & 2004 & 2005 & 2006 \\
\hline Mean Precipitation & \multicolumn{3}{|c|}{ Percent Above Average } \\
\hline (January - April, for 17 ARL/SORD rain guage stations) & 4 & 67 & 20 \\
\hline Invasive Introduced Species & \multicolumn{3}{|c|}{ Percent Presence } \\
\hline Bromus matridensis spp. rubens (red brome) & 51.7 & 64.4 & 67.8 \\
\hline Bromus tectorum (cheatgrass) & 40.3 & 54.0 & 60.7 \\
\hline Erodium cicutarium (redstem stork's bill) & 5.2 & 6.2 & 24.6 \\
\hline Schismus arabicus (Arabian schismus) & 4.7 & 2.8 & 5.2 \\
\hline \multicolumn{4}{|l|}{ Native Species } \\
\hline Amsinkia tessellata (bristly fiddleneck) & 34.0 & 62.0 & 16.1 \\
\hline Mentzelia albicaulis (whitestem blazingstar) & 49.8 & 8.1 & 0.0 \\
\hline Chaenactis fremontii (pincushion flower) & 27.0 & 8.0 & 0.0 \\
\hline
\end{tabular}




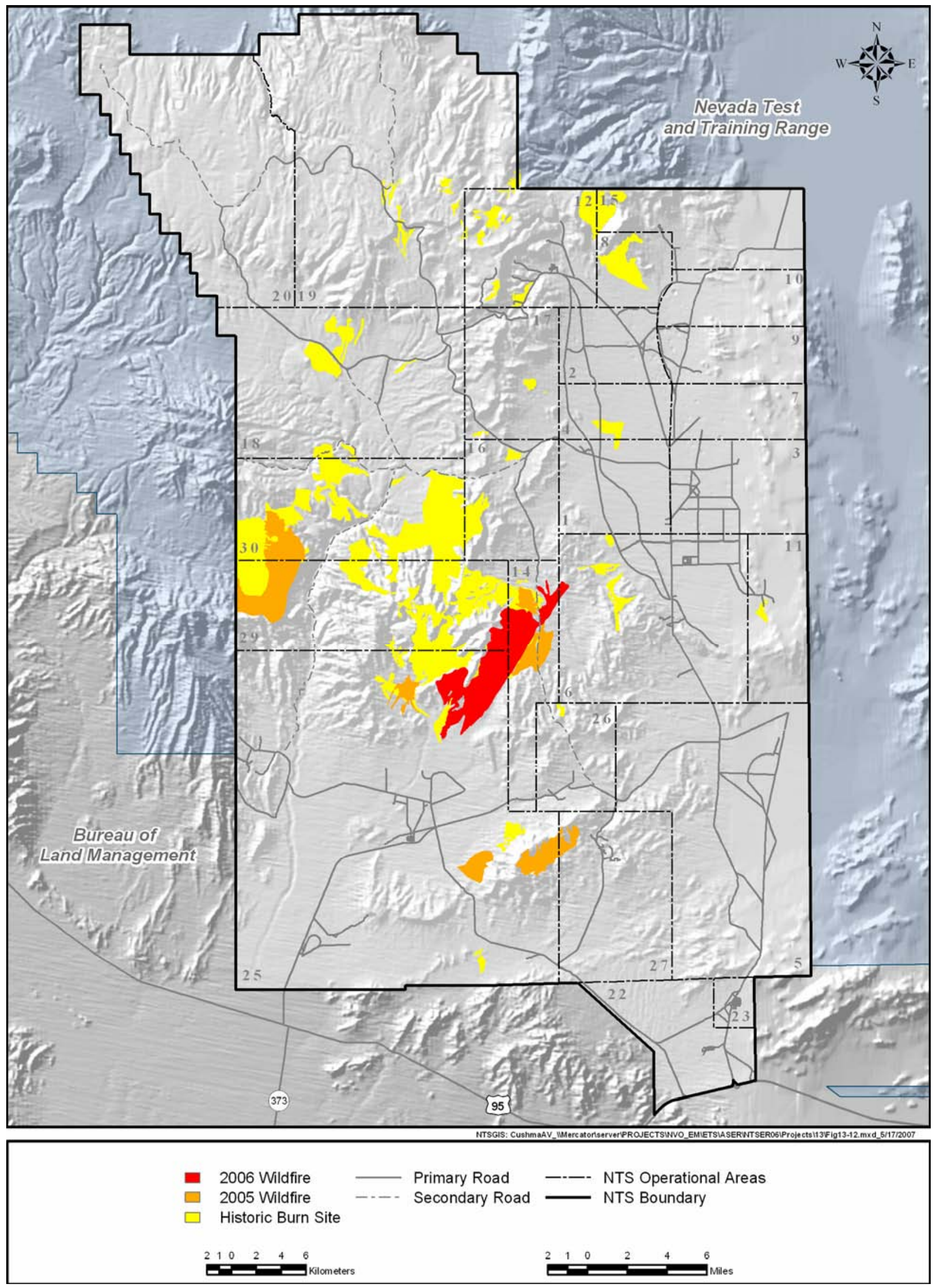

Figure 13-12. Location of wildland fires on the NTS 


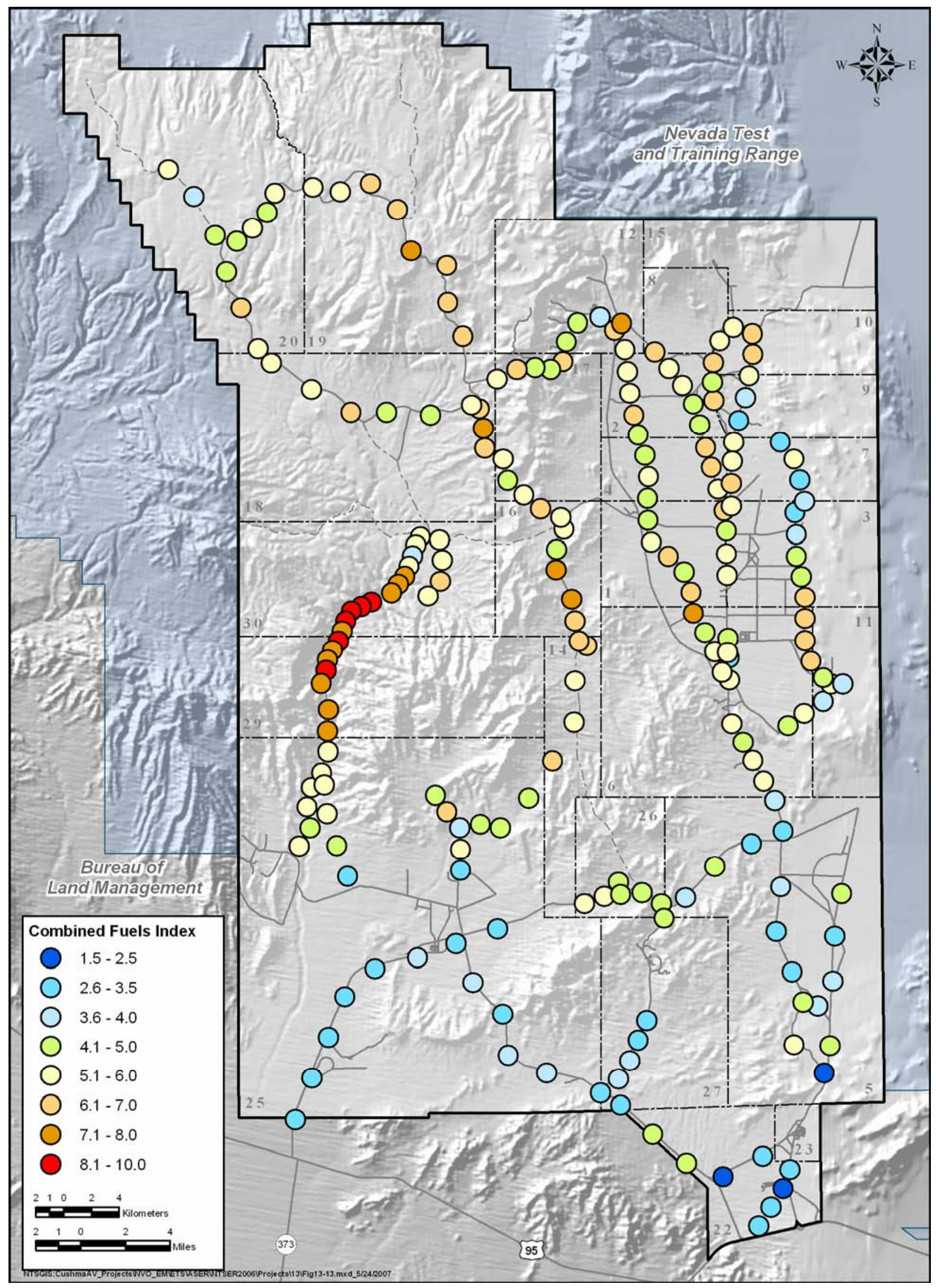

Figure 13-13. Index of combined fine and woody fuels at 211 survey stations on the NTS during 2006 


\subsection{Biological Monitoring of the NPTEC Complex}

Biological monitoring at NPTEC on the playa of Frenchman Lake in Area 5 will be performed as an EMAC task whenever there is a risk of significant exposure to downwind plants and animals from planned test releases of hazardous materials. The Desert National Wildlife Refuge (DNWR) lies just east of the NTS border, approximately $5 \mathrm{~km}(3 \mathrm{mi})$ downwind from the NPTEC. The National Wildlife Refuge Administration Act forbids the disturbance or injury of native vegetation and wildlife on any National Wildlife Refuge lands unless permitted by the Secretary of the Interior; the DNWR is administered within this System. Biological monitoring is conducted to verify that approved tests do not disperse toxic chemicals that could harm biota on DNWR. This is also a requirement of the facility's Programmatic Environmental Assessment (DOE, 2002c).

An unpublished document titled Biological Monitoring Plan for Hazardous Materials Testing at the Liquefied Gaseous Fuels Spill Test Facility on the Nevada Test Site, prepared in 1996 and updated in 2002, describes how field surveys will be conducted to meet the following two goals: (1) document significant impacts of chemical testing on plants and animals and (2) verify that NPTEC operations comply with the National Wildlife Refuge Administration Act (see Section 2.9). Monitoring will entail sampling established transects both downwind and upwind of the NPTEC. Since 1996, the majority of chemical releases being studied at the center have used such small quantities that downwind test-specific monitoring has not been necessary. The parameters to be measured whenever transects must be sampled will include:

- Number and type of dead animals observed

- Number and type of wildlife observed

- Presence of observed vegetation damage

In 2006, chemical release test plans for two activities on Frenchman Lake playa were reviewed. These tests were called Raven and Tarantula II. Because chemical releases for these tests were of such low volumes or low toxicity, there was no need to monitor downwind transects for biological impacts. Seasonal sampling of downwind and upwind transects near the NPTEC was conducted in 2006 to document baseline conditions of biota and any cumulative impacts over time of test center activities on biota downwind of the facility. The condition of plants and the presence of wildlife sign during the period of vegetative growth and following summer drought were noted. No differences in biota were noted along downwind (treatment) versus upwind (control) transects. These data are made available to neighboring land managers upon request. 


\section{THIS PAGE INTENTIONALLY LEFT BLANK}




\subsection{Underground Test Area Subproject}

The Underground Test Area (UGTA) Subproject is the largest project in the Environmental Restoration Program. It addresses groundwater contamination resulting from past underground nuclear testing conducted in shafts and tunnels on the Nevada Test Site (NTS). From 1951 to 1992 more than 800 underground nuclear tests were conducted at the NTS (U.S. Department of Energy, 2000a). Most of these tests were conducted hundreds of feet above groundwater; however, over 200 of the tests were within or near the water table. Underground testing was limited to specific areas of the NTS including Pahute Mesa, Rainier Mesa, Shoshone Mountain, Frenchman Flat, and Yucca Flat.

The UGTA Subproject collects data to define groundwater flow rates and direction to determine the nature and location of aquifers (geologic formations of permeable rock containing or conducting groundwater). In addition, project team members gather information regarding the hydrology and geology of the area under investigation. Data from these studies are used to produce hydrogeologic models that will be used to predict groundwater flow and contaminant transport. Numerous surface and subsurface investigations are ongoing to ensure that these issues are addressed.

Surface investigations include:

- Evaluating discharges from springs located downgradient of the NTS

- Assessing surface geology

Subsurface investigations include:

- Drilling deep wells to access groundwater hundreds to thousands of feet below the surface

- Sampling groundwater to test for radioactive contaminants

- Assessing NTS hydrology and subsurface geology to determine possible groundwater flow direction

\subsection{Aquifer Tests}

There were no aquifer/tracer testing activities conducted during 2006.

\subsection{Groundwater Sampling}

Well purging and sampling operations were conducted at three UGTA well sites: ER-12-4, U-12s and USGS HTH \#2. Groundwater samples were collected at all three of these sites. The results of sampling in 2006 are presented in Section 4.1.11 of this report along with all other radiological groundwater monitoring results.

\subsection{UGTA Subproject Modeling}

A regional three-dimensional computer groundwater model (International Technologies Corporation [IT], 1996) was developed in the initial stages of the UGTA project to identify any immediate risk and to provide a basis for developing more detailed models of specific nuclear testing areas designated as Corrective Action Units (CAUs). The CAU-specific models, of which four are planned, geographically cover the six former NTS underground nuclear testing areas (Figure 14-1). CAU-specific groundwater-flow and contaminant-transport models will be used to determine contaminant boundaries based on the extent of contaminant migration at specified regulatory limits. The models will also be used to refine a monitoring network to ensure public health and safety.

Construction of CAU-specific groundwater-flow and contaminant-transport models requires a hydrostratigraphic framework that depicts the character and extent of hydrostratigraphic units in three dimensions. To date, three hydrostratigraphic framework models, also referred to as Geologic models, have been built: Frenchman Flat 
(Bechtel Nevada [BN], 2005a), Pahute Mesa-Oasis Valley (BN, 2002) and Yucca Flat-Climax Mine (BN, 2006) models. A draft hydrostratigraphic framework model for the Rainier Mesa-Shoshone Mountain CAU was completed in 2006 and is scheduled to be finalized early in 2007.

Also in 2006, two UGTA CAU-scale flow models were completed. This work is documented in the following reports: Phase II Groundwater Flow Model of Corrective Action Unit 98: Frenchman Flat, Nye County, Nevada (Stoller-Navarro Joint Venture [SNJV], 2006a) and Groundwater Flow Model of Corrective Action Units 101 and 102: Central and Western Pabute Mesa, Nevada Test Site, Nye County, Nevada (SNJV, 2006b). 


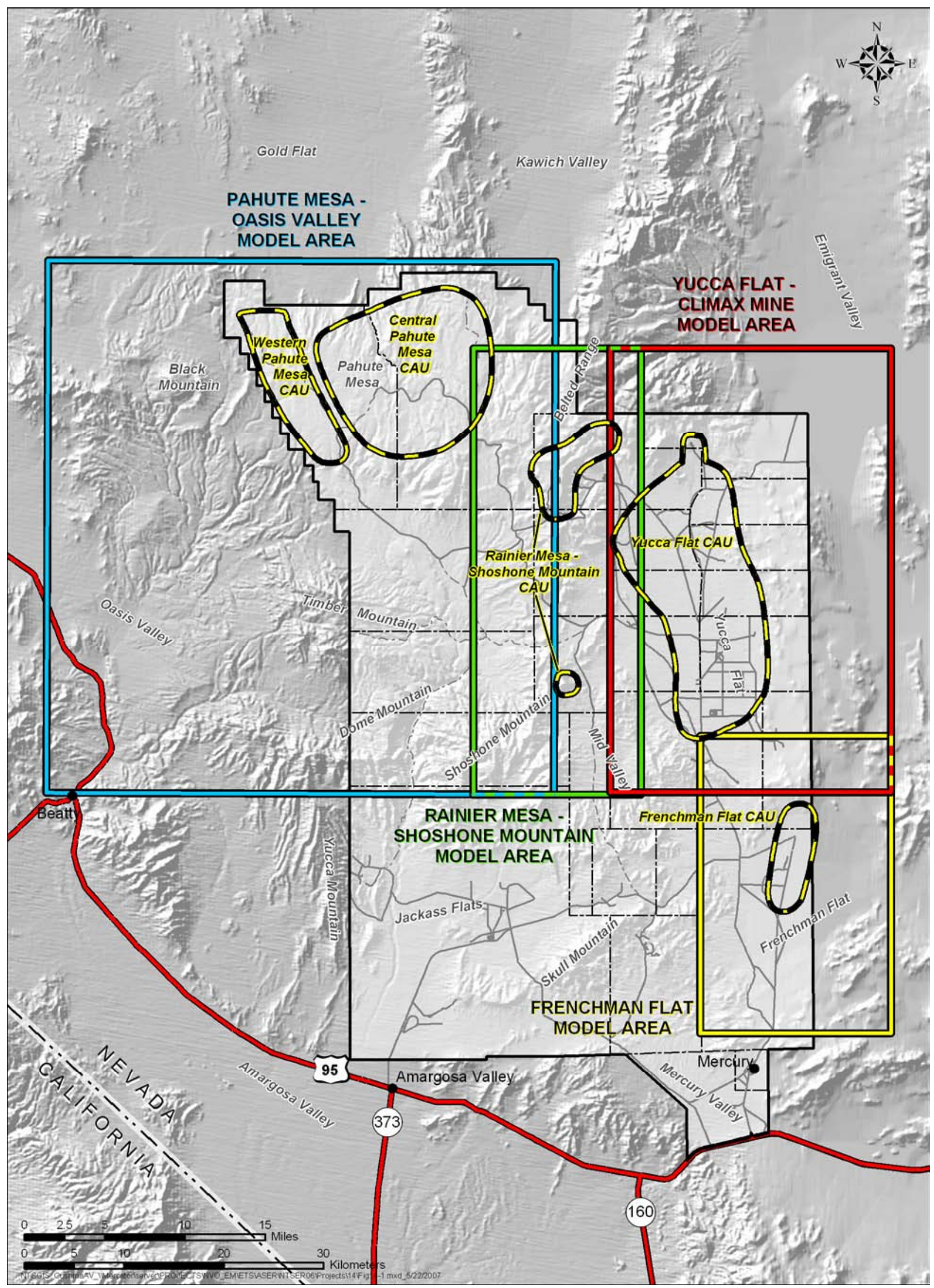

Figure 14-1. Location of UGTA Project model areas 


\section{THIS PAGE INTENTIONALLY LEFT BLANK}




\subsection{Hydrologic Resources Management Program}

The primary responsibility of the Hydrologic Resources Management Program (HRMP) is to provide the U.S. Department of Energy, National Nuclear Security Administration Nevada Site Office (NNSA/NSO) with hydrologic data and information on groundwater supplies to support ongoing and future activities at the Nevada Test Site (NTS). The main objective of this program is to provide a sound technical basis for NTS groundwater use decisions regarding the quality and quantity of water resources available on the NTS, and the potential impacts of large-scale water withdrawals from or near the groundwater basins of the NTS. Participants in the HRMP include Los Alamos National Laboratory, Lawrence Livermore National Laboratory, the U.S. Geological Survey (USGS), and the Desert Research Institute.

\subsection{Program Goals and Activities}

The goal of the HRMP is to support national security operations at the NTS by the investigation of site hydrology, radionuclide migration, and protection of NTS water resources. The HRMP meets this goal through long-term research activities including data collection, analysis, evaluation, modeling, equipment development, and documentation. These activities provide reliable information for decision-making on groundwater utilization, stewardship, and environmental protection. Research and technology development activities essential to the achievement of these goals are an integral part of the HRMP.

Results of program activities are available as technical reports and documents. Project participants also disseminate information and transfer technologies through publication in technical reports and peer-reviewed journals, presentations at professional meetings and symposia, and educational outreach activities.

\subsubsection{Hydrology and Radionuclide Investigations for Operations}

The HRMP assists NNSA/NSO in maintaining capabilities in hydrology and radiochemistry to support test readiness and science-based stockpile stewardship through applied field and laboratory studies of the occurrence, distribution, and movement of radionuclides in groundwater at the NTS. Scientific expertise is utilized in the assembly, analysis, and evaluation of data to produce hydrologic and radionuclide information products. State of Nevada regulations require NNSA/NSO to provide detailed information on hydrologic conditions of the NTS. At the request of NNSA/NSO management, the HRMP gathers, analyzes, and transfers science-based information to the state of Nevada and other external customers.

Hydrologic services, provided upon request to NNSA/NSO programs, include depth-to-groundwater estimates, water level measurements, containment evaluations, and determination of emplacement hole integrity. Technology development projects and research investigations are conducted to address gaps in the capabilities and knowledge required to support safe conduct of operations for stockpile stewardship, nuclear test readiness, and national security. Previous and current activities include:

- Determining the steady state and transient hydrologic conditions in the subsurface, such as the location of the groundwater table, perched water zones, and regions of enhanced permeability

- Using and developing state-of-the-art radiochemical instrumentation to analyze rock and water samples to assist in predicting the fate and transport of radioactive isotopes deposited from subsurface experiments

- Supporting the development of enhanced borehole radionuclide monitoring and sampling equipment capability

- Achieving a more fundamental understanding of chemical fractionation in underground nuclear tests through sample analysis and experimentation

- Investigating the subsurface geology and fracture propagation in the vicinity of underground nuclear tests for containment issues 
- Building public confidence by conducting public and government outreach and education programs on the hydrologic environment and the impact of nuclear testing on water resources at the NTS

- Investigating the free water and bound water relationships in rock samples from boreholes and cores

\subsubsection{Long-Term Groundwater Stewardship}

A major element of the HRMP mission is the protection and long-term stewardship of NTS groundwater resources. Numerous activities are conducted to accomplish this element. These include the following: monitoring of groundwater levels, quality and consumption; evaluation of monitoring well locations and conditions; and utilization of groundwater modeling to evaluate water resource availability and the impacts of potential groundwater withdrawals. HRMP supports the development and ongoing refinement of groundwater flow models for both the Death Valley Region (which includes the NTS) and for groundwater sub-basins which include portions of the NTS. Based upon hydrologic investigations and modeling, HRMP will evaluate proposed new groundwater withdrawals on and near the NTS for their potential impacts on NTS groundwater reserves, quality, flow paths, and radionuclide migration. The HRMP protects NTS groundwater by supporting a well installation and maintenance program which insures:

- Reliability of the potable water supply.

- Optimal location, design, and construction of new potable water wells.

- Long-term reliability of monitoring wells to supply representative water samples.

- Integrity of emplacement and groundwater boreholes.

The HRMP also provides assistance to NNSA/NSO regarding the impact of NTS water usage on offsite water supplies and springs, such as Devil's Hole. In addition, the HRMP assists in addressing compliance issues and is responsive to the needs of NNSA/NSO that result from state and federal regulations not within the purview of other programs or which may be well-addressed by the capabilities of the HRMP. For example, implementation of the Safe Drinking Water Act dictates substantial compliance efforts both on and outside the boundaries of the NTS, a process to which HRMP can provide valuable support.

HRMP also has a groundwater review and advice capability with a unique NTS perspective that is invaluable to NNSA/NSO. HRMP scientists conduct competent, informed, and independent reviews of NNSA/NSO groundwater-related program documents prior to their release to extensive regulatory and public scrutiny. This capability enhances both the protection of NTS groundwater resources and the accuracy and credibility of NNSA/NSO program documentation.

\subsection{HRMP Activities}

\subsubsection{USGS Activities}

The USGS Water Resources Discipline collects, compiles, stores, and reports hydrologic data used in determining the local and regional hydrogeologic conditions in and around the NTS for HRMP and for the Underground Test Area Project. Hydrologic data are collected quarterly or semi-annually from wells within two monitoring networks: an onsite and an offsite network (wells located on and off of the NTS).

By the end of 2006, the USGS monitored water levels in 181 wells. This included 95 wells on the NTS and 86 wells off the NTS. Also during 2006, annual temperature data were collected from wells at 1.5 and 16.8 meters (5 and 55 feet) below the water surface. All water-level and temperature data are posted on the USGS/NNSA Web site at $<$ http://nevada.usgs.gov/doe\%5Fnv/>. The water-level data are also published in the USGS Nevada Water Science Center Annual Water-Resources Data Report available at < $\underline{\text { http://nevada.usgs.gov/>. }}$.

Groundwater use from water-supply wells on the NTS is collected using flow meters which are read monthly by the NTS Maintenance and Operating subcontractor and then reported to the USGS Water Resources Discipline. The principal water supply wells monitored during 2006 included J-12 WW, J-13 WW, UE-16d WW, WW \#4, WW \#4A, WW 5B, WW 5C, WW 8, and WW C-1. The USGS compiles the annual water-use data and reports annual 
withdrawals in millions of gallons. Discharge data from these wells for 2006 have been compiled, processed, and

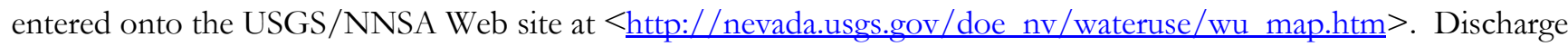
from these wells during 2006 was approximately 223 million gallons.

Water-use data is also published in the USGS Nevada Water Science Center Annual Water-Resources Data Report on a water-year calendar (October through September). The Water-Year 2006 report is available at

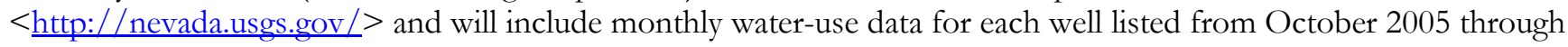
September 2006.

The USGS also continued to maintain and develop the Death Valley Regional Groundwater Flow System Model, manage the NTS well hydrologic and geologic information database, and characterize high-altitude precipitation environmental isotope parameters in cooperation with LLNL.

\subsubsection{DRI Activities}

DRI continued work on NTS sub-basin groundwater withdrawal impact modeling and development of a staged, portable, Bennett pump system and a delayed down-hole tritium monitor.

\subsubsection{LANL Activities}

LANL analyzed radionuclide speciation and transport parameters and characterized NTS groundwater parameters.

\subsubsection{LLNL Activities}

LLNL analyzed radionuclide speciation and transport parameters, and characterized high-altitude precipitation environmental isotope parameters in cooperation with USGS. 
THIS PAGE INTENTIONALLY LEFT BLANK 


\subsection{Meteorological Monitoring}

\subsection{Meteorological Monitoring Goals}

Meteorological and climatological data are collected on the Nevada Test Site (NTS) by the Air Resources Laboratory, Special Operations and Research Division (ARL/SORD). Data are collected through the Meteorological Data Acquisition (MEDA) system, a network of approximately 30 mobile meteorological towers located primarily on the NTS. The MEDA system became operational in 1981, replacing an older system. MEDA is used to measure, transmit, and display vital meteorological data to SORD meteorologists and U.S. Department of Energy, National Nuclear Security Administration Nevada Site Office (NNSA/NSO) customers. These data are used daily for operational support to a wide variety of projects on the NTS and form the climatological database for the NTS. The data are also used in safety analysis reports, emergency response activities, radioactive waste remediation projects, environmental reports, and consequence assessments. The NTS Site Description, Section 3 presents descriptive NTS climatological data collected by the MEDA system. The NTS Site Description is included as a separate file on the compact disc of this 2006 report for easy reference.

\subsection{MEDA Station Locations}

A standard MEDA unit consists of an enclosed trailer, a portable 10-meter (m) (32.8-feet [ft]) tower, an electric generator (when needed), a microprocessor, and a microwave radio transmitter (Figure 16-1). Locations of the MEDA stations are shown in Figure 16-2. All towers were sited according to standards set by the Federal Meteorological Handbook No. 1 (NOAA, 1995) and the World Meteorological Organization (WMO, 2002) so as not to be influenced by natural or man- made obstructions or by heat dissipation and generation systems. MEDA station locations are based on the following criteria:

(1) availability of power, (2) access by road,

(3) line-of-sight to a microwave repeater, and

(4) project support. A primary goal of the network is to provide details in the surface wind field for emergency response activities related to the transport and dispersion of hazardous materials. Another primary goal is to provide data used in computing off-site radiological dose estimates.

\subsection{MEDA Station Instrumentation}

MEDA station instrumentation is located on booms oriented into the prevailing wind direction and at a minimum distance of two tower widths from the tower.

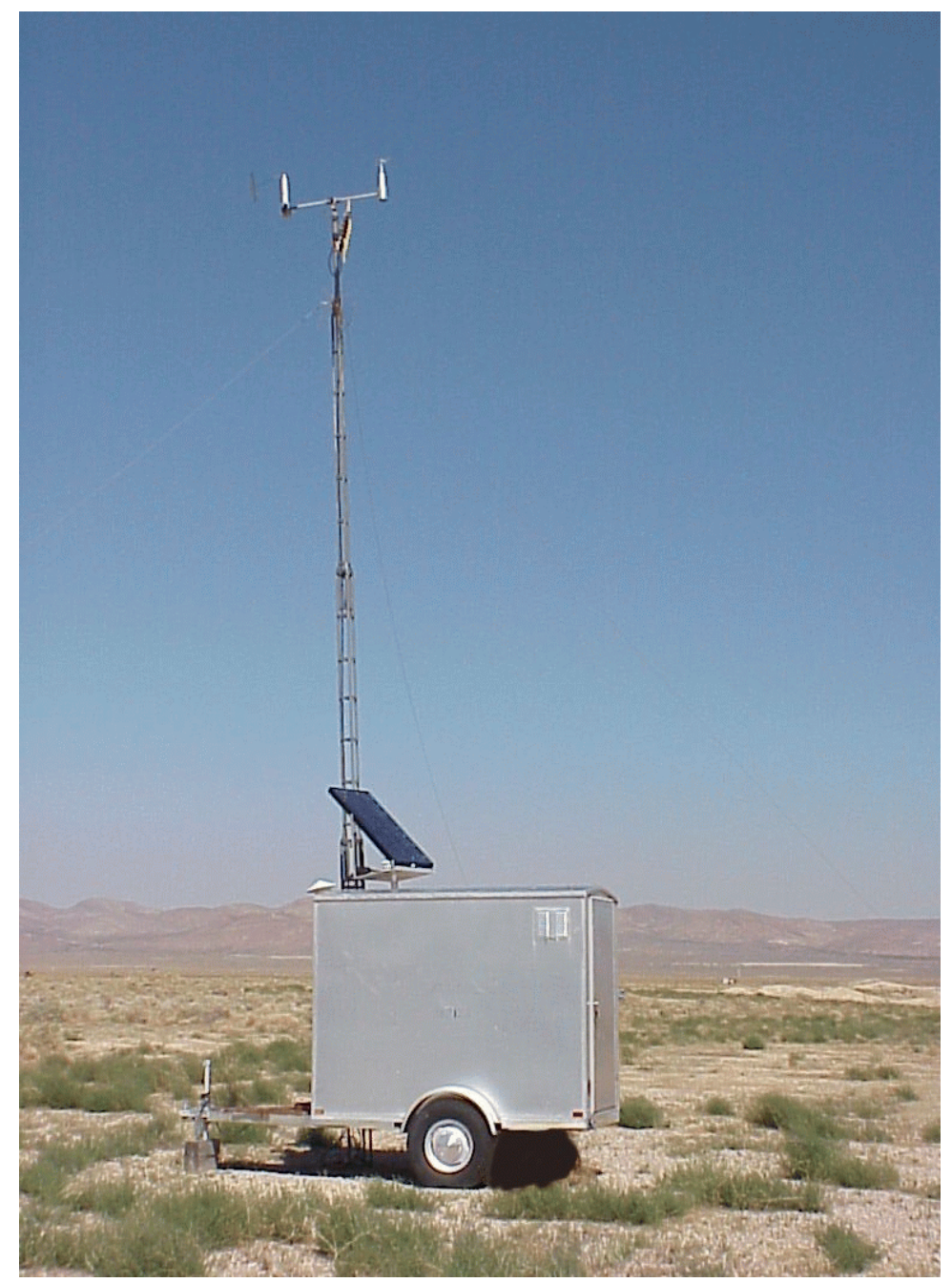

Figure 16-1. Example of a typical MEDA station with a 10-meter tower 


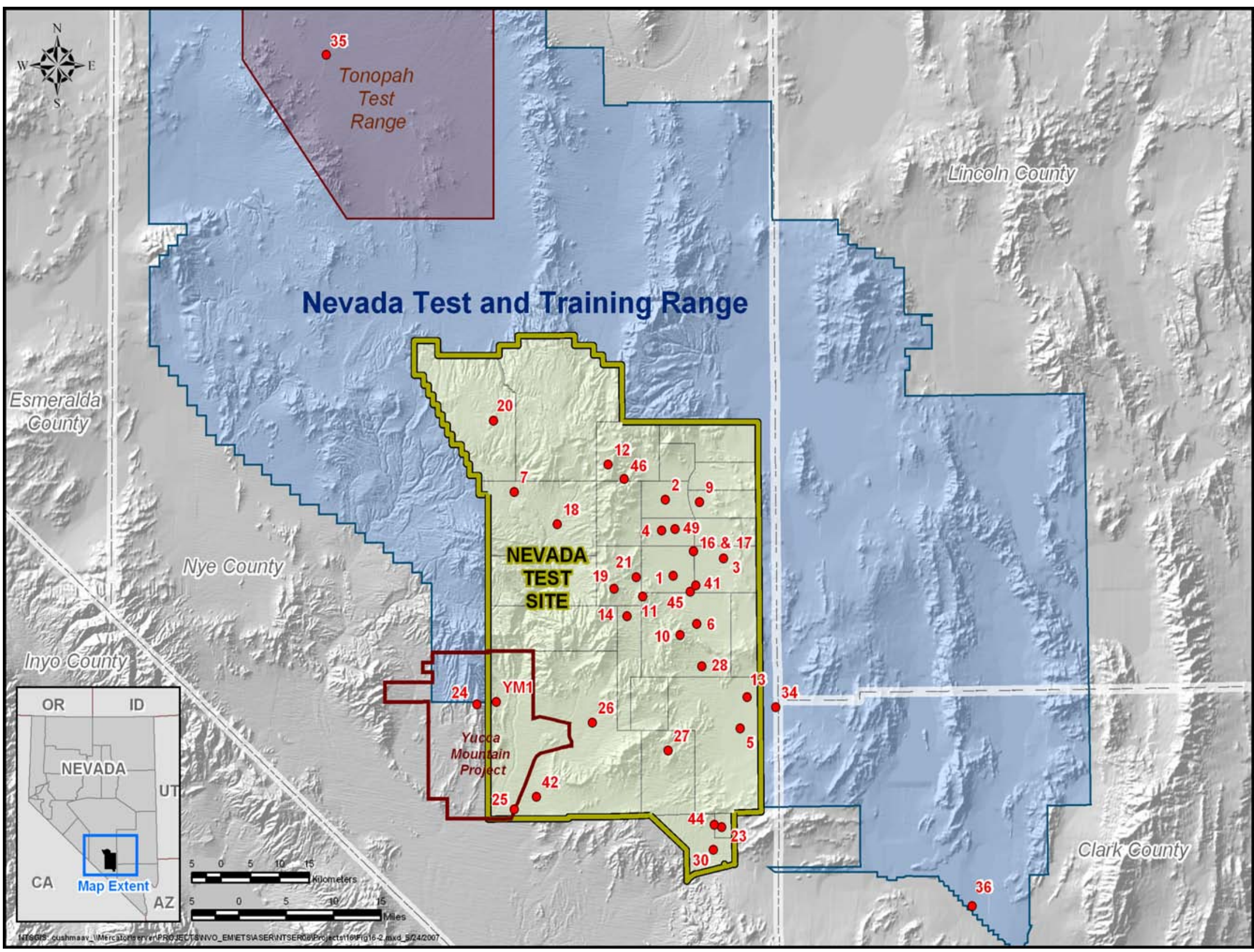


Wind direction and speed are measured at the $10-\mathrm{m}(32.8-\mathrm{ft})$ level, in accordance with the American National Standard for Determining Meteorological Information at Nuclear Facilities (American Nuclear Society, 2000) specifications. Ambient temperature, relative humidity, and atmospheric pressure measurements are taken at approximately the 2-m (6.6-ft) level so as to be within the surface boundary layer. Observations are collected and transmitted every 15 minutes on the quarter hours. Wind data are 5-minute averages of speed and direction. The peak wind speed is the fastest instantaneous gust measured within the 15-minute time interval. Temperature, relative humidity, and pressure are instantaneous measurements.

\subsection{Rain Gauge Network}

ARL/SORD also operates and maintains a climatological rain gauge network on the NTS. This network consists of 17 Belford Series 5-780 Universal Precipitation Gauges (Figure 16-3). These are strip chart recorders that are read at least every 30 days. Once read and checked, the data are entered into the SORD precipitation climatological database. Data are recorded as daily totals. Under special circumstances, 1- to 3-hour totals can be obtained.

\subsection{Data Access}

The meteorological parameters measured at each station are listed on the SORD Web site

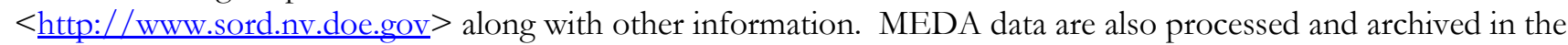
ARL/SORD climatological database. Climatological data summaries are posted on the ARL/SORD Web site under the Climate section. SORD meteorologists provide specially tailored climatological summaries by request through NNSA/NSO. For new NTS projects and facility modifications which may produce radiological emissions, wind data from the MEDA stations are used to calculate potential radiological doses to members of the public residing near the NTS (see Section 3.1.7). 


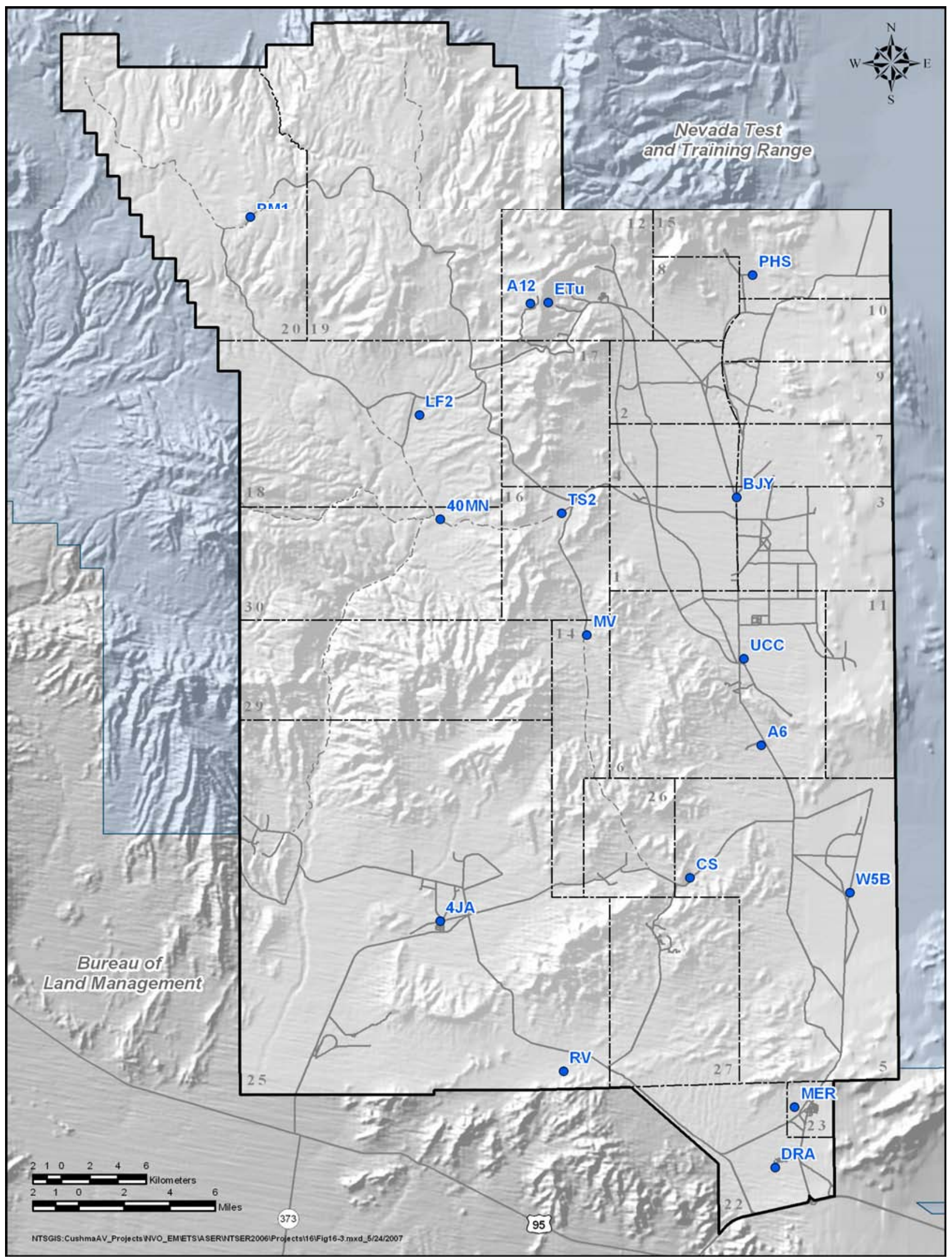

Figure 16-3. Climatological rain gauge network on the NTS 


\subsection{Integrated Safety Management System and Environmental Management System}

A plan to integrate environment, safety, and health (ES\&H) management programs at the Nevada Test Site (NTS) was developed and initiated at the NTS in 1996. The NTS Integrated Safety Management System (ISMS) is designed to ensure the systematic integration of ES\&H concerns into management and work practices so that missions are accomplished safely. The term safety is used synonymously with environment, safety, and health throughout the NTS ISMS implementation policies to encompass protection of the public, the workers, and the environment. The seven guiding principles of ISMS and the five core functions are shown below.

\begin{tabular}{|c|c|}
\hline Seven Guiding Principles & Five Core Functions \\
\hline $\begin{array}{l}\text { Line management is directly responsible for the protection of the public, } \\
\text { the workers, and the environment } \\
\text { Clear roles and responsibilities for ES\&H are established and maintained } \\
\text { Personnel competence is commensurate with their responsibilities } \\
\text { Resources are effectively allocated to address ES\&H, programmatic, and } \\
\text { operational considerations with balanced priorities } \\
\text { ES\&H standards and requirements are established that ensure adequate } \\
\text { protection of the employees, the public, and the environment } \\
\text { Administrative and engineering controls to prevent and mitigate ES\&H } \\
\text { hazards are tailored to the work being performed } \\
\text { Operations are authorized }\end{array}$ & $\begin{array}{l}\text { Define the scope of work } \\
\text { Identify and analyze the hazards } \\
\text { and environmental aspects } \\
\text { associated with the work } \\
\text { Develop and implement hazard } \\
\text { and aspect controls } \\
\text { Perform work within the } \\
\text { controls } \\
\text { Provide feedback on the } \\
\text { adequacy of the controls for } \\
\text { continuous improvement }\end{array}$ \\
\hline
\end{tabular}

The use of an ISMS helps ensure that (1) all levels of program organizations are accountable for environmental protection, (2) all projects are planned with ES\&H concerns in mind, and (3) continuous improvements in program implementation occur.

In 2000, Executive Order (EO) 13148, Greening of the Government Through Leadership in Environmental Management, was issued. It requires all federal agencies to adopt an environmental management system (EMS). An EMS is a business management practice that allows an organization to strategically address its ES\&H matters. EMSs are designed to incorporate concern for environmental performance throughout an organization, with the ultimate goal being continual reduction of the organization's impact on the environment. EMS implementation reflects accepted quality management principles based on the "Plan, Do, Check, Act" model, using a standard process to identify goals, implement them, determine progress, and make improvements to ensure continual improvement.

EO 13148 applies to most of the NNSA as well as to DOE and NNSA contractors. The U.S. Department of Energy (DOE) required contractors who operate DOE sites to develop an EMS and expected full integration of their EMS into their ISMS by December 31, 2005.

\subsection{Scope of Chapter}

This chapter, written in April 2007, reflects the status of EMS and ISMS in 2006 when Bechtel Nevada (BN) was the Management and Operating $(\mathrm{M \& O})$ contractor until June 30 and then when National Security Technologies, LLC (NSTec), became the new M\&O contractor on July 1. Work in previous years on the M\&O's EMS and ISMS integration can be found in the Nevada Test Site Environmental Report 2005 (DOE, 2006b). 
For 2006, an effort was made to include, within this chapter, the EMS status and activities of other National Nuclear Security Administration Nevada Site Office (NNSA/NSO) contractors involved in environmental work on the NTS. Stoller-Navarro Joint Venture (SNJV) is an NNSA/NSO contractor involved with site characterization and groundwater monitoring work at historic sites scheduled for cleanup or monitoring under the Federal Facility Agreement and Consent Order. In 2006, SNJV developed an EMS. The EMS identified areas to improve the reduction of life-cycle cost and liability of mission-related activities. Although the EMS elements presented below discuss predominantly the M\&O Contractor's status and activities, those of SNJV are also briefly discussed.

\subsection{Elements and Status of the NTS EMS}

The major event affecting the EMS program during 2006 was a commitment by NSTec, the new M\&O contractor, to pursue ISO 14001 Certification (ISO stands for the International Organization for Standardization). NSTec committed in their contract proposal to obtain the certification by June 30, 2009. An internal management assessment was performed in December 2006 to evaluate the current environmental program against the requirements of the ISO 14001:2004 Standard. The assessment showed that the current program is mature and effective, but improvements must be made in some of the elements to satisfy all the rigorous ISO 14001 requirements. In 2007, an Implementation Strategy will be developed to address the identified deficiencies, and an Implementation Working Group representing all operating parts of the company will be formed to direct the implementation strategy. The 2006 status and some of the intended NSTec future actions to meet the requirements of each ISO element are discussed in the subsections below.

At the end of 2005, SNJV senior staff reviewed their EMS to ensure compliance with the requirements of DOE Order 450.1A. In particular, its programmatic description, its inclusion into the SNJV ISMS, and its implementation through flow-down implementing procedures were reviewed. Areas for improvement were identified and approved by the SNJV Environment, Safety, Health and Quality (ESH\&Q) Project Manager. These areas are presented in some of the subsections below along with actions taken in 2006 to implement and improve the EMS.

\subsubsection{NTS Environmental Policy}

The previous BN Environmental Policy was adopted without revision by NSTec on July 1, 2006. It will be reviewed, updated, and made an NSTec policy in 2007. The policy is a statement of NSTec's intentions and principles regarding overall ES\&H performance. It provides a framework for planning and action. The new policy will be placed on the NSTec Internet home page, so it will be available to the public. The NSTec Environmental Policy contains the following key goals and commitments:

- Protect the environment by meeting all applicable DOE orders and federal, state, and local environmental laws and regulations

- Evaluate activities to identify potential environmental impacts, and then take mitigative actions to eliminate or minimize the hazards

- Establish objectives and targets in order to continually improve the environmental program

- Protect valued natural resources and support waste minimization and pollution prevention (P2) activities

- Communicate and instill an organizational commitment to environmental excellence in company activities

SNJV integrates the NSTec Environmental Policy throughout SNJV's processes. The integregation of the policy is documented in its Standards Based Management System which consists of program level documents. Such documents include the ISMS, Project Execution Plans, Subject Areas, and Implementing Procedures.

\subsubsection{Environmental Aspects}

When operations have an environmental aspect, NSTec implements the EMS to minimize or eliminate any potential impact. NSTec evaluates its operations by performing a Hazard Assessment, identifies the aspects of operations that can impact the environment, and determines which of those potential impacts are significant. The Hazard Assessment requires the activity manager to go through a series of questions that identify potential environmental 
impacts. The assessment also lists available mitigations, such as training and applicable procedures and guidance. The completed hazard assessment is then reviewed, and when approved by ES\&H, becomes part of the authorization basis for performing the work. National Environmental Policy Act (NEPA) documents, Health and Safety Plans, and Execution Plans also identify aspects that can have potential impacts. Each of these documents then requires that mitigative actions be identified to minimize the risk of adverse impacts. NSTec has determined that the following aspects of its operations have the potential to affect the environment:

- Waste generation and management

- Air quality

- Waste management

- Industrial chemical use

- NEPA compliance

- Drinking water quality

SNJV identified the environmental aspects of their work. These include:

- Waste generation

- Waste disposal

- Industrial chemical use and storage

- NEPA compliance

\subsubsection{Legal and Other Requirements}

To implement the compliance commitments of the NSTec Environmental Policy and to meet its legal requirements, NSTec has a procedure in place to review changes in federal, state, or local environmental regulations and to communicate those changes to affected staff. These regulatory changes frequently require amendments to operating permits, modifications to record keeping or hours of operation, revisions to procedures, and upgraded training. Execution plans identify requirements applicable to each NSTec managed facility, project, and work activity by referencing the NNSA/NSO Work Smart Standards that apply to that plan. Execution Plans are required to be reviewed annually and updated as necessary.

To ensure compliance with SNJV's EMS, SNJV included its requirements in all appropriate contracts. SNJV verified that the ISMS Clause was included in the Staff Augmentation contracts, the Drilling contract, and the Amchitka contract. It was also verified that the new Recycling contract included an expanded recycling stream (see Section 17.2.5 below). All contractors fulfilled their defined roles and responsibilities.

\subsubsection{Objectives, Targets, and Programs}

Objectives and targets are developed by NSTec on a fiscal year (FY) basis (October 1 through September 30) by prioritizing environmental aspects. Objectives to improve performance with respect to these aspects are then established. Finally, targets to meet the objectives are suggested. The potential objectives and targets are then presented to the Executive Safety Council for final selection and approval. NSTec also works with NNSA/NSO to clearly define expectations and performance measures. Objectives and targets, established in FY 2005 and implemented in FY 2006, are described in Table 17-1. Organizations within NSTec are assigned responsibility for targets, and develop action plans detailing how they will achieve their objectives and targets and commit the necessary resources to successfully implement them. The current procedure for objectives and targets is an Environmental Services (ES) Organizational Instruction. The procedure will be revised and upgraded to a Company Directive to document the responsibilities of all organizations involved in establishing, tracking and reporting progress on environmental targets. 


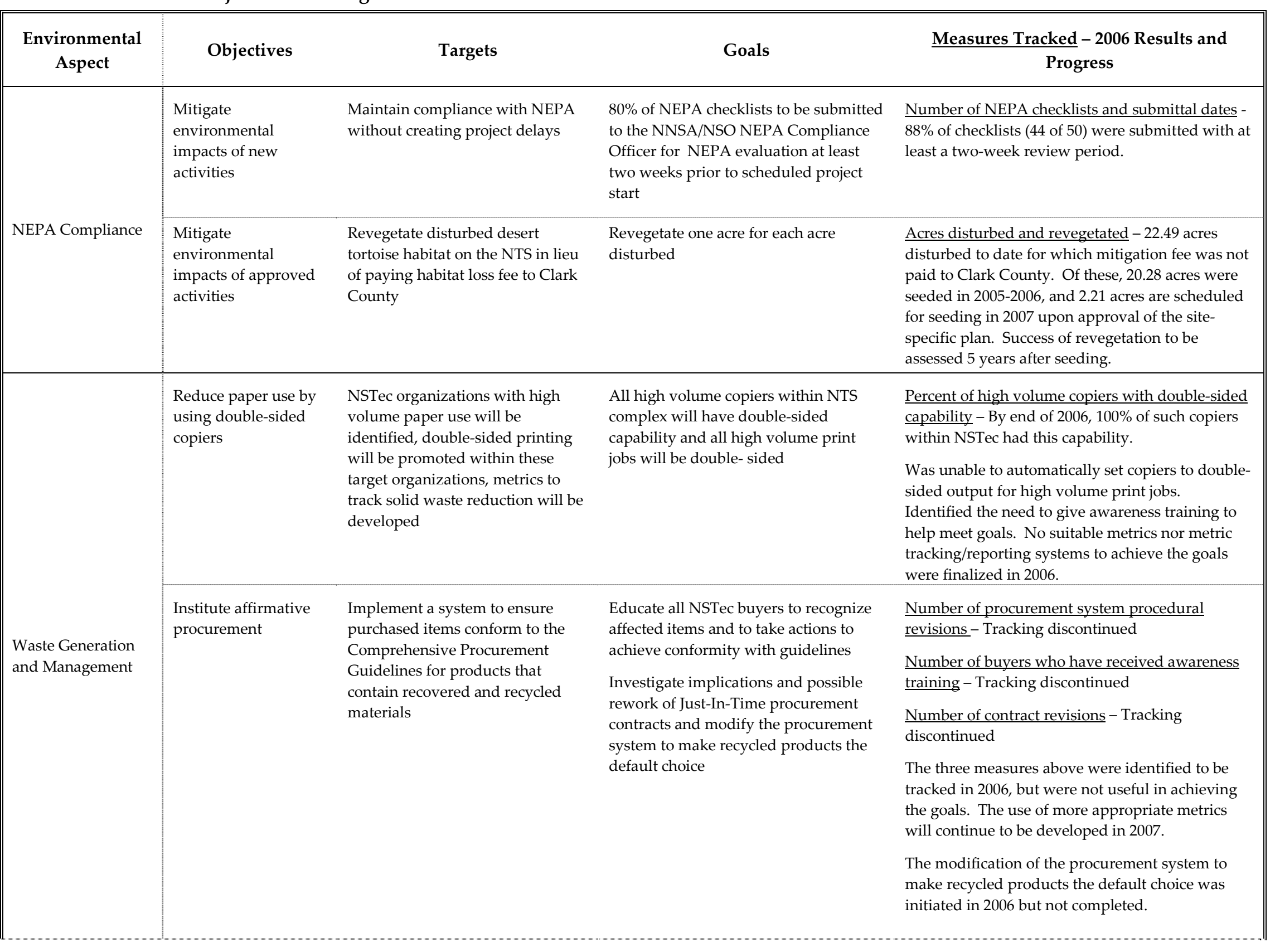


Table 17-1. 2006 EMS objectives and targets (continued)

\begin{tabular}{|c|c|c|c|c|}
\hline $\begin{array}{c}\text { Environmental } \\
\text { Aspect }\end{array}$ & Objectives & Targets & Goals & $\frac{\text { Measures Tracked }-2006 \text { Results and }}{\text { Progress }}$ \\
\hline \multirow[b]{2}{*}{$\begin{array}{l}\text { Industrial Chemical } \\
\text { Use }\end{array}$} & \multirow[b]{2}{*}{$\begin{array}{l}\text { Reduce chemical } \\
\text { waste }\end{array}$} & $\begin{array}{l}\text { Plan for implementing a chemical } \\
\text { pharmacy system for hazardous } \\
\text { materials }\end{array}$ & $\begin{array}{l}\text { Assess the hazardous materials } \\
\text { program } \\
\text { Develop plan for centralization of } \\
\text { system for purchasing chemicals }\end{array}$ & $\begin{array}{l}\text { No metric to be tracked was determined for } 2006 \text {. } \\
\text { The hazardous materials program was assessed in } \\
\text { 2006. The centralized purchasing system to be } \\
\text { used was identified, and it will be purchased in } \\
\text { 2007. A pilot project was started at the receiving } \\
\text { warehouse to bar code and track chemicals. }\end{array}$ \\
\hline & & $\begin{array}{l}\text { Enhance requisition compliance } \\
\text { reviews (RCRs) to identify } \\
\text { purchase requests for large } \\
\text { quantity chemical purchases to } \\
\text { avoid having excess chemicals at } \\
\text { end of project }\end{array}$ & $\begin{array}{l}\text { Train at least three ES personnel to } \\
\text { recognize large-quantity chemical } \\
\text { purchase requests and obtain } \\
\text { justification for purchase prior to } \\
\text { purchase approval } \\
\text { Reduce the volume of large quantity } \\
\text { chemicals purchased when not } \\
\text { justifiable }\end{array}$ & $\begin{array}{l}\text { Number of ES personnel trained - Four ES } \\
\text { personnel trained. } \\
\text { Percent of RCRs for large quantity chemical } \\
\text { purchase requests that received extra scrutiny - } \\
100 \% \text { of such purchase requests were reviewed, } \\
\text { justified, and approved. They represented only } \\
4 \% \text { of all chemical purchase requests. } \\
\text { Volume of chemicals that were not approved for } \\
\text { purchase - Zero. All purchase were justified and } \\
\text { approved. }\end{array}$ \\
\hline $\begin{array}{l}\text { Groundwater } \\
\text { Contamination }\end{array}$ & $\begin{array}{l}\text { Protect ground- } \\
\text { water quality }\end{array}$ & $\begin{array}{l}\text { Plug boreholes in accordance with } \\
\text { the Borehole Management Plan }\end{array}$ & Meet schedule in Plan & $\begin{array}{l}\text { Number of boreholes plugged - } 100 \text { boreholes were } \\
\text { scheduled for plugging, } 112 \text { were plugged. }\end{array}$ \\
\hline \multirow{3}{*}{$\begin{array}{l}\text { Natural Resource } \\
\text { Use }\end{array}$} & \multirow{3}{*}{$\begin{array}{l}\text { Reduce } \\
\text { consumption of } \\
\text { petroleum-based } \\
\text { fuels }\end{array}$} & $\begin{array}{l}\text { Increase the percentage of sedan/ } \\
\text { minivans/light duty trucks/ } \\
\text { minitrucks vs. sport utility } \\
\text { vehicles (SUVs) and large pickup } \\
\text { trucks used solely for people } \\
\text { transport }\end{array}$ & $\begin{array}{l}\text { Determine current use ratio of } \\
\text { sedan/minivan/light duty } \\
\text { truck/minitruck vs. SUV/large truck } \\
\text { and increase the ratio by } 20 \%\end{array}$ & $\begin{array}{l}\text { Ratio of sedans/minivans/light duty trucks/ } \\
\text { minitrucks vs. SUVs/large trucks rented from Fleet } \\
\underline{\text { Services - Discontinued tracking. This metric did }} \\
\text { not provide the information needed to determine if } \\
\text { goal is reached. Will work to identify more } \\
\text { suitable metric and metric tracking/reporting } \\
\text { system in } 2007 .\end{array}$ \\
\hline & & $\begin{array}{l}\text { Promote increased use of } \\
\text { alternative fuels }\end{array}$ & $\begin{array}{l}\text { Decrease use of petroleum-based fuels } \\
\text { by } 20 \% \text { by end of } 2006 \text { using } 1^{\text {st }} \text { Quarter } \\
\text { FY06 as baseline }\end{array}$ & $\begin{array}{l}\text { Percent decrease in gallons of gasoline used in } \\
\text { government vehicles within Fleet Services - } \\
11 \% \text { decrease by } 4^{\text {th }} \text { Quarter FY06. }\end{array}$ \\
\hline & & $\begin{array}{l}\text { Purchase vehicles that accept } \\
\text { alternative fuels }\end{array}$ & $\begin{array}{l}75 \% \text { of new vehicles ordered must } \\
\text { accept alternative fuel }\end{array}$ & $\begin{array}{l}\text { Percentage of new vehicles received that accept } \\
\text { alternative fuels - } 99 \% \text { of new vehicles received } \\
\text { (98/99) accept alternative fuel. }\end{array}$ \\
\hline $\begin{array}{l}\text { Liquid Effluents and } \\
\text { Disposal Systems }\end{array}$ & $\begin{array}{l}\text { Manage North Las } \\
\text { Vegas Facility } \\
\text { (NLVF) pumped } \\
\text { groundwater }\end{array}$ & $\begin{array}{l}\text { Develop a system to collect and } \\
\text { manage NLVF groundwater after } \\
\text { pumping }\end{array}$ & $\begin{array}{l}\text { Use } 50 \% \text { of groundwater for beneficial } \\
\text { use such as irrigation }\end{array}$ & $\begin{array}{l}\text { Percent of groundwater volume pumped that is } \\
\text { beneficially used onsite - } 100 \% \text { of the water was } \\
\text { reused for dust suppression in } 2006 \text {. }\end{array}$ \\
\hline
\end{tabular}


Several environmental management programs exist throughout NSTec. These programs are discussed in sequential sections of this report:

- Environmental Compliance - Section 2.0

- Air Quality Protection - Section 3.0

- Groundwater Protection - Section 4.0

- Routine Radiological Environmental Monitoring - Sections 3.1, 4.1, 5.0, 7.0, and 8.0

- Waste Management and Environmental Restoration - Section 9.0

- Hazardous Materials Control and Management - Section 10.0

- Pollution Prevention and Waste Minimization - Section 11.0

- Historic Preservation and Cultural Resources Management - Section 12.0

- Ecological Monitoring - Section 13.0

- Underground Test Area Project - Section 14.0

- Hydrologic Resources Management Program - Section 15.0

- Meteorological Monitoring - Section 16.0

Throughout 2006, SNJV identified, reviewed, and updated measurable environmental goals, objectives, and targets. Between 80 and 100 percent of the identified targets were on schedule. The goal and targets and the dates by which they were met, or the 2006 results obtained while working towards them, include:

- Establish and document internal P2 goals (including recycling activities training) - completed February 28; SNJV Program Manager approved SNJV Pollution Prevention (P2) Goals on February 16

- Address and document what SNJV does, or plans to do, to conserve energy - completed February 28

- Revise NEPA guidance to address SNJV responsibilities - completed February 28

- Revise SNJV investigation-derived waste procedure to include segregation and screening of investigationderived waste and disposition of waste - competed March 4

- Complete Environmental Compliance Improvement Plan, Initiative A -- Evaluation of the SNJV Environmental Management System (EMS) - March 31.

- Replace gasoline-only vehicles with Alternative Fuel Vehicles - replaced 60 percent of the current fleet; scheduled to replace 100 percent in 2007.

- Enhance solid waste recycling processes - selected a new paper recycling service in May, expanded recycle streams to include 3-ring binders, glass, plastic, books, magazines, newspaper, and cardboard in August.

- Update SNJV Purchase Requisition Form (SN-178) - September 5. Included a "Green" check box on form that, when selected, indicates an environmentally-preferable purchase of products, supplies, or services.

\subsubsection{Resources, Roles, Responsibilities, and Authorities}

All employees at NSTec have specific roles and responsibilities in key areas, including environmental protection. Employee-stop-work authority applies to potential environmental issues as well as health and safety problems. Job-specific environmental training is identified for workers and included on their company-required training matrix. ES technical support personnel assist the line organizations with developing and meeting their environmental responsibilities.

\subsubsection{Competence, Training, and Awareness}

Extensive training on NSTec's EMS requirements has been provided to staff whose responsibilities include environmental protection. The training program includes general environmental awareness for all employees, regulatory compliance training for selected staff, and specific courses for managers, internal assessors, and operations personnel whose work can impact the environment. Training and awareness specific to the ISO 14001 Standard will be conducted in 2007 at all worker and management levels. 
SNJV established environmental training procedures to identify individual competence and responsibility requirements. Training was offered, conducted, recorded, and tracked within the company. Training requirements were monitored, revised, and refresher training was offered to maintain competence, as appropriate. The 2006 training activities performed by SNJV included:

- Updated slide presentation of Waste Awareness Training - February 8

- EMS System Awareness Training received by all personnel - February 15

- New Employee Orientation and EMS Training - June 16

- Added P2 to the SNJV All-Hands Meeting

\subsubsection{Communication}

NSTec communicates environmental issues to employees through e-mails, articles in newsletters, safety meetings, new-hire orientations, job hazard analyses, pre-task briefings, and company procedures. NSTec assists NNSA/NSO in soliciting input from interested external parties such as community members, activists, civic organizations, Indian tribes, elected officials, and regulators. This is accomplished primarily through Community Advisory Board (CAB) meetings. The $\mathrm{CAB}$ is comprised of $10-15$ volunteer Nevada citizens who represent rural and urban areas. $\mathrm{CAB}$ meetings occur monthly and focus on the Environmental Management program and projects onsite. Environmental Management also sponsors a Speakers Bureau which provides representatives a chance to give presentations to schools, groups, or organizations and sponsors community exhibits and displays for communicating NTS environmental issues and interacting one-on-one with the public. All external communications are coordinated through NNSA/NSO.

\subsubsection{Documentation}

NSTec has comprehensive environmental documents as part of the EMS which detail information on regulatory requirements, site-wide operating procedures, and work control procedures on how to control processes and perform work in a way that protects the environment. The current "Environmental Management System Description" will be updated in 2007 to incorporate the program improvements being made in pursuit of ISO Certification.

In 2006, SNJV identified, re-evaluated, and updated (added/deleted/modified) selected environmental documents and work procedures as appropriate. The following documents were all issued and implemented in 2006:

- NEPA Subject Area - issued March 14

- Waste Minimization Procedure - issued March 16

- Affirmative Procurement Procedure - issued March 16

- Waste Characterization Subject Area - issued June 16

\subsubsection{Control of Documents}

The NSTec document control system ensures effective management of procedures and other requirements documents. When facilities require additional procedures to control their work, document control protocols are implemented to ensure that workers have access to the most current versions of procedures. Documents of longterm NNSA/NSO or NSTec interest are archived, and are destroyed according to federal laws.

\subsubsection{Operational Control}

Operations are evaluated through Hazard Assessments for the adequacy of current controls to prevent or minimize impacts to the environment. Task-specific procedures or work plans are developed when needed. Additional administrative or engineered controls are identified, and plans for upgrades and improvements are developed and implemented. Assessments are currently being performed to make sure that all environmental issues identified in 
upper-tier documents like Hazard Analyses are rolled down to the work level plans. Lessons learned and critiques are incorporated into work processes to continually improve environmental performance.

SNJV performs management assessments to ensure that significant environmental aspects identified under the EMS are being addressed consistent with identified goals, objectives, and targets. Management assessments are tracked within SNJV's Assessment \& Condition Tracking System. In 2006, the following assessments were performed and entered into the tracking system:

- Pollution Prevention Assessments - completed July 28, 2006

- Reduce, Reuse, Recycle Assessments - completed July 28 and August 15, 2006

- Energy Efficiency Assessments - completed August 1 and August 17, 2006

- Training Assessments - completed August 15, 2006

\subsubsection{Emergency Preparedness and Response}

NSTec has an emergency preparedness and response program and specialized onsite staff to provide timely response to hazardous materials releases or other environmental emergencies. This program includes procedures for preventing, as well as responding to, emergencies. Agreements are in place with outside emergency response agencies to support non-NTS facilities.

\subsubsection{Monitoring and Measurement}

NSTec has an extensive network of environmental compliance programs with defined monitoring, surveillance, and compliance and performance measures tracking (see Section 2.0, Compliance Summary). These programs help ensure the effectiveness of controls, adherence to regulatory requirements, and timely identification and implementation of corrective measures for all work performed by NSTec for NNSA/NSO. In addition to the monitoring programs, an oversight program called the Community Environmental Monitoring Program, established by NNSA/NSO, monitors air and groundwater within communities adjacent to the NTS. Onsite and offsite monitoring and surveillance results are reported to regulatory agencies and are summarized annually in this report, the Nevada Test Site Environmental Report. Many of these monitoring activities are required by state or federal environmental operating permits. In addition, NSTec tracks and trends its progress and performance in achieving environmental objectives and performance measures which are not strictly compliance-driven (see Table 17-1).

\subsubsection{Evaluation of Compliance}

NSTec has procedures for periodically evaluating its compliance with relevant environmental regulations. Line managers and facility managers periodically inspect their operations and facilities. NSTec ES and NNSA/NSO personnel also perform regulatory assessments in a particular topical area to verify the compliance status of multiple organizations, or a comprehensive assessment of a particular organization. Lastly, external regulatory agencies and/or technical experts frequently conduct independent audits of compliance.

\subsubsection{Nonconformity and Corrective and Preventive Actions}

NSTec continues to improve processes that identify and correct problems. Lessons Learned and Root Cause Analyses are used in an attempt to prevent recurrences of environmental problems and promote continual improvement. Any deficiencies resulting from incidents or assessments are entered into an electronic Web-based system, where corrective actions are identified and tracked until completed.

\subsubsection{Control of Records}

EMS-related records, including audit and training records, are maintained according to federal standards to ensure integrity, facilitate retrieval, and protect them from loss. 


\subsubsection{Internal Audit}

NSTec has used internal staff and subcontractors to identify the EMS elements that are fully implemented and those that still require strengthening. This is an ongoing activity intended to continually improve the environmental program. In addition, compliance with regulatory requirements is verified through routine inspections, operational evaluations, and periodic audits.

SNJV established EMS audit/evaluation procedures and an internal audit was conducted in 2006. It identified nonconformities that were addressed, corrected, or are in the process of being corrected.

\subsubsection{Management Review}

The NSTec Senior Manager for ESH\&Q will ensure periodic review of the EMS to ensure its continuing suitability, adequacy, and effectiveness. The review process will be scheduled in the NSTec ESH\&Q Execution Plan and documented. The results of these internal audits will be reported to the Executive Leadership Council to prioritize improvement initiatives.

SNJV will ensure periodic EMS reviews at the senior management level. During FY 2006, SNJV conducted a Senior Leadership review of the EMS and top management responded to recommendations for continual improvement. The following list includes actions performed by senior SNJV management as a result of their reviews:

- Implemented the ISMSs flow-down of P2 activities into SNJV's EMS program and Program Manager approved P2 goals by February 14

- Program Manager recommended energy efficient lighting to the landlord

- Program Manager participated in the New-Hire Orientation and EMS video 
THIS PAGE INTENTIONALLY LEFT BLANK 


\subsection{Compliance Quality Assurance}

The National Security Technologies, LLC (NSTec), Quality Assurance Program (QAP) establishes the requirements to comply with the quality requirements of the contract's Work Smart Standards, namely: (1) Title 10 Code of Federal Regulations (CFR) 830, Subpart A, Quality Assurance Requirements; (2) U.S. Department of Energy (DOE) Order 414.1C, Quality Assurance; and (3) other relevant requirements documents for the operation, process, or program to which they apply. The ten criteria established in 10 CFR 830 Subpart A and DOE Order 414.1C that are required as part of a quality program are shown in the box below. The NSTec QAP requires a graded approach to quality for determining the level of rigor that effectively provides assurance of performance and conformance to requirements.

The Data Quality Objectives (DQO) process developed by the U.S. Environmental Protection Agency (EPA) is generally used to provide the quality assurance (QA) structure for designing, implementing, and improving upon environmental monitoring efforts when environmental sampling and analysis are involved. Sampling and Analysis Plans are developed prior to performing an activity to ensure complete understanding of the data use objectives. Personnel are trained and qualified in accordance with company and task-specific requirements. Access to sampling locations is coordinated with operations conducting work at or having authority over those locations in order to de-conflict activities and communicate hazards to better ensure successful execution of the work and the safety and health of sampling personnel. Sample collection

\section{Required Criteria of a Quality Program}

- Quality assurance program

- Personnel training and qualification

- Quality improvement process

- Documents and records

- Established work processes

- Established standards for design and verification

- Established procurement requirements

- Inspection and acceptance testing

- Management assessment

- Independent assessment activities adhere to organization instructions and/or procedures that are designed to ensure that samples are representative and data are reliable and defensible. Sample shipments onsite and to offsite laboratories are conducted in accordance with the U.S. Department of Transportation and International Air Transport Association regulations, as applicable. Quality Control (QC) in the analytical laboratories is maintained through adherence to standard operating procedures that are based on methodologies developed by nationally-recognized organizations such as the EPA, DOE, and American Standard for Testing and Materials International. Key quality-affecting procedural areas cover sample collection, preparation, instrument calibration, instrument performance checking, testing for precision and accuracy, and laboratory data review. NSTec data users perform review as required by the project-specific objectives before the data are used to support decision making.

The key elements of environmental monitoring process work flow are listed below. Each of these elements is designed to ensure the applicable QA requirements are implemented. A discussion of these elements follows.

- A Sampling and Analysis Plan (SAP) is developed using the EPA DQO process to ensure clear goals and objectives are established for the environmental monitoring activity. The SAP is implemented in accordance with EPA, DOE, and other requirements addressing environmental, safety, and health concerns.

- Environmental Sampling is performed in accordance with the SAP and site work controls to ensure defensibility of the resulting data products and protection of the workers and the environment.

- Laboratory Analyses are performed to ensure that the resultant data meet DOE, NSTec, and regulatory-defined requirements.

- Data Review is done to ensure that the SAP DQOs have been met, and thereby determine whether the data are suitable for their intended purpose.

- Assessments are employed to ensure that monitoring operations are conducted accordingly and that analytical data quality requirements are met in order to identify nonconforming items, investigate causal factors, implement corrective actions, and monitor for corrective action effectiveness. 


\subsection{Sampling and Analysis Plan}

Most environmental monitoring is specifically mandated to demonstrate compliance with a variety of requirements including federal and state regulations, and DOE orders and standards. Developing the SAP with a DQO approach ensures those requirements are considered in the planning stage. The following statistical concepts and controls are vital in designing and evaluating the system design and implementation.

\subsubsection{Precision}

Precision is the degree to which a set of observations or measurements of the same property, obtained under similar conditions, conform to themselves; a data quality indicator. Precision is usually expressed as standard deviation, variance or range, in either absolute or relative terms (DOE, 2006c).

Practically, precision is determined by comparing the results obtained from performing analyses on split or duplicate samples taken at the same time from the same location, and maintaining sampling and analytical conditions as nearly identical as possible.

\subsubsection{Accuracy}

Accuracy refers to the degree of agreement between an observed value and an accepted reference value. Accuracy includes a combination of random error (precision) and systematic error (bias) components that are due to sampling and analytical operations; a data quality indicator (DOE, 2006c).

Accuracy related to the overall monitoring effort is evaluated by analyzing field sample results to determine whether the data points fall within acceptable statistical trends. Accuracy related to laboratory operations is monitored by performing measurements and evaluating results of control samples containing known quantities of the analytes of interest.

\subsubsection{Representativeness}

Representativeness is the degree to which a measurement is truly representative of the sampled medium (i.e., the degree to which measured analytical concentrations represent the concentrations in the medium being sampled) (Stanley and Verner, 1985).

At each sampling point in the sampling and analysis process, subsamples of the medium of interest are obtained. The challenge is to ensure that each subsampling maintains the character of the larger sampled population. From a field sample collection standpoint, representativeness is managed through sampling plan design and execution. Representativeness related to laboratory operations concerns the ability to appropriately subsample and characterize for analytes of interest. For example, in order to ensure representative characterization of a heterogeneous matrix (soil, sludge, solids, etc.), the sampling and/or analysis process should evaluate whether homogenization or segregation should be employed prior to sampling or analysis. Water samples are generally considered homogeneous unless observation suggests otherwise. Field sample duplicate analyses are additional controls allowing evaluation of representativeness and heterogeneity.

\subsubsection{Comparability}

Comparability refers to "the confidence with which one data set can be compared to another" (Stanley and Verner, 1985). Comparability from an overall monitoring perspective is ensured by consistent execution of the sampling design concerning sample collection and handling, laboratory analyses, and data review. This is ensured through adherence to established procedures and standardized methodologies. 


\subsection{Environmental Sampling}

Environmental samples are collected in support of various environmental programs. Each program executes the field sampling activities in accordance with the SAP to ensure usability and defensibility of the resulting data. The key elements supporting the quality and defensibility of the sampling process and products include:

- Training and qualification

- Procedures and methods

- Field documentation

- Inspection and Acceptance testing

\subsubsection{Training and Qualification}

The environmental programs ensure that personnel are properly trained and qualified prior to doing the work. In addition to procedure-specific and task-specific qualifications for performing work, training addresses environment, safety, and health aspects to ensure protection of the workers, the public, and the environment. Recurrent training is also conducted if necessary to maintain proficiency.

\subsubsection{Procedures and Methods}

Sampling is conducted in accordance with established procedures to ensure consistent execution and continuous comparability of the environmental data. The methods to be used for sample analyses are also consulted in order to ensure that viable samples are obtained.

\subsubsection{Field Documentation}

Field documentation is generated for each sample collection activity, and may include chain of custody, sampling procedures, analytical methods, equipment and data logs, maps, Material Safety Data Sheets, and other materials needed to support the safe and successful execution and defense of the sampling effort. Chain of custody practices are employed from point of generation through disposal (cradle-to-grave) and are critical to defensibility of the decisions made as a result of the sampling and analysis. Sampling data and documentation are stored and archived in a manner that they are readily retrievable in the event they are needed at a later date. In many cases, these data may be managed in electronic data management systems for more convenient management of the data. Routine assessments or surveillances are performed to ensure that sampling activities are performed in accordance with applicable requirements. Deficiencies are noted, causal factors are determined, corrective actions are implemented, and followup assessments are performed to ensure effective resolution. This managed approach to sampling ensures the quality and defensibility of the decisions made on the resulting analytical data.

\subsubsection{Inspection and Acceptance Testing}

Sample collection data are reviewed for appropriateness, accuracy and fit with historical measurements. In the case of groundwater sampling, real-time field measurements may be monitored during purging to determine when parameters have stabilized, thereby indicating that the purge water is generally representative of the aquifer and sampling may begin. After a sampling activity is complete, data are reviewed to ensure the samples were collected in accordance with the SAP. Samples are further inspected to ensure the integrity has not been compromised, either physically (leaks, tears, breakage, custody seals) or administratively (labeled incorrectly) and that they are valid for supporting the intended analyses. If concerns are raised at any point during collection, the data user, in consideration of data usability, is consulted for direction on proceeding or canceling the subsequent analyses. 


\subsection{Laboratory Analyses}

Samples are transported to a laboratory for characterization. Several NSTec organizations maintain measurement capabilities which are generally considered "screening" operations, and may be used to support planning or preliminary decision-making activities. However, unless specifically authorized by the National Nuclear Security Administration Nevada Site Office or the regulator, all data used for reporting purposes are generated by a DOE and NSTec-qualified laboratory which have been obtained through subcontracts. Ensuring the quality of procured laboratory services is accomplished through focus on three specific areas: (1) procurement, (2) initial and continuing assessment, and (3) data evaluation.

\subsubsection{Procurement}

Laboratory services are procured through a request for proposal (RFP) and formal bid process, and are awarded on a "best value" basis. The RFP requires that a prospective vendor submit an in-depth proposal, which includes:

- A Laboratory Quality Assurance Plan and/or Manual describing the laboratory's policies and approach to the implementation of quality assurance requirements for ensuring the generation of data of a known quality

- An Environment, Safety and Health Plan

- A Waste Management Plan

- All procedures pertinent to subcontract scope

- Examples of deliverables, both hardcopy and electronic

- Proficiency testing results from previous year participation in recognized proficiency testing programs

- Resumes of those conducting the work

- A description of the facility or its design, and instrumentation and capabilities

- Licenses, accreditations and certifications

- Audits performed within the last year by the DOE Consolidated Audit Program (DOECAP), other DOE sites, or other audits covering comparable scope and acceptable to NSTec

- Past performance surveys

- Pricing

Proposal evaluations are conducted and scored as explained to proposers in the RFP. A procurement representative evaluates pricing separately from the technical evaluation. The NSTec technical evaluation team does not receive pricing information. Rather, it bases its evaluation solely on technical capability. The results of the technical evaluation are then compiled with those of the pricing evaluation to ensure a "best-value" award is achieved.

\subsubsection{Initial and Continuing Assessment}

An initial assessment is made during the RFP process above, including a pre-award audit. If an acceptable audit has not been performed within the past year, NSTec will consider performing an audit (or participating in a DOECAP audit) of those laboratories awarded the contract. NSTec will not initiate work with a laboratory without authorized approval of those NSTec personnel responsible for ensuring vendor acceptability.

A continuing assessment consists of the ongoing monitoring of a laboratory's performance against contract terms and conditions, of which the technical specifications are a part. Tasks supporting continuing assessment are:

- Conducting regular audits or participating in evaluation of DOECAP audit products

- Monitoring for continued successful participation in proficiency testing programs such as:

- National Institute of Standards and Technology Radiochemistry Intercomparison Program

- Studies that support certification by the state of Nevada or appropriate regulatory authority for analyses performed in support of compliance monitoring

- Monitoring of the laboratory's adherence to the quality assurance requirements 


\subsubsection{Data Evaluation}

Data products are continuously evaluated for compliance with contract terms and specifications. This primarily involves review of the data against the specified analytical method to determine the laboratory's ability to adhere to the quality assurance and quality control requirements as well as an evaluation of the data against the DQOs. This activity is discussed in further detail in Section 18.4. Any discrepancies are documented and resolved with the laboratory, and continuous assessment tracks the recurrence and efficacy of corrective actions.

\subsection{Data Review}

A systematic approach to thoroughly evaluating the data products generated from an environmental monitoring effort is essential for understanding and sustaining the quality of data collected under the program. This allows the programs to determine whether the DQOs established in the planning phase were achieved and whether the monitoring design performed as intended or requires review.

Because decisions are based on environmental data, and the effectiveness of operations is measured at least in part by environmental data, reliable, accurate and defensible records are essential. Detailed records that must be kept include temporal, spatial, numerical, geotechnical, chemical, and radiological data, and all sampling, analytical and data review procedures used. Failure to maintain these records in a secure but accessible form may result in exposure to legal challenges and the inability to respond to demands or requests from regulators and other interested organizations.

An electronic data management system is a key tool used by many programs for achieving standardization and integrity in managing environmental data. The primary objective is to store and manage in an easily and efficiently retrievable form unclassified environmental data that are directly or indirectly tied to monitoring events. This may include information on monitoring system construction (groundwater wells, ambient air monitoring), analytical, geotechnical, and field parameters at the Nevada Test Site. Database integrity and security are enforced through the assignment of role memberships and the provision of available menu items.

\subsubsection{Data Verification}

Data verification is defined as a subcontract compliance and completeness review to ensure that all laboratory data and sample documentation are present and complete. Additional critical sampling and analysis process information is also reviewed at this stage, which may include, but is not limited to, sample preservation and temperature, defensible chain-of-custody documentation and integrity, and analytical hold-time compliance. Data verification also ensures that electronic data products correctly represent the sampling and/or analyses performed and includes evaluation of quality control sample results.

\subsubsection{Data Validation}

Data validation supplements verification and is a more thorough process of analytical data review to better determine if the data meet the analytical and project requirements. Data validation ensures that the reported results correctly represent the sampling and analyses performed, determines the validity of the reported results, and assigns data qualifiers (or "flags"), if required.

\subsubsection{Data Quality Assessment (DQA)}

DQA is a scientific and statistical evaluation to determine if the data obtained from environmental operations are of the right type, quality, and quantity to support their intended use. The DQA includes reviewing data for accuracy, representativeness, and fit with historical measurements, to ensure that the data will support their intended uses. 


\subsection{Assessments}

The overall effectiveness of the environmental program is determined through routine surveillance and assessments of work execution as well as review of the program requirements. Deficiencies are identified, causal factors are investigated, corrective actions are developed and implemented, and follow-on monitoring is performed to ensure effective resolution. The assessments discussed below are broken down into general programmatic and focused measurement data areas.

\subsubsection{Programmatic}

Assessments and audits under this category include evaluations of the work planning, execution, and performance activities. Personnel independent of the work activity perform the assessments to evaluate compliance with established requirements and report on the identified deficiencies. Organizations responsible for the activity are required to develop and implement corrective actions, with the concurrence of the deficiency originator or recognized subject matter expert. NSTec maintains the companywide issues tracking system (called CaWeb) to manage assessments, findings, and corrective actions.

\subsubsection{Measurement Data}

This type of assessment includes routine evaluation of data generated from analyses of QC samples. QC sample data monitor the analytical control on a given batch of samples and are indicators over time of potential biases in laboratory performance. Discussion of the 2006 results for field duplicates, laboratory control samples, blank analysis, and inter-laboratory comparison studies are provided and summary tables are included below.

\subsubsection{Field Duplicates}

Samples obtained at approximately the same locations and times as initial samples are termed field duplicates and are used to evaluate measurement precision of the analyte of interest in the sampled environment. The relative error ratio (RER) is the standardized absolute difference between the sample and corresponding field duplicate and incorporates the analytical uncertainty of the measurements into the precision calculation. The radiological measurement RER data were determined and are presented in Table 18-1. The average absolute relative percent differences (RPDs) for measurements above their MDCs are also provided in Table 18-1. (For thermoluminescent dosimeter [TLD] data, all measurements are included in the average RPD calculation.) Nonradiological data are not reported with an associated uncertainty, and therefore, an RER cannot be determined. 
Table 18-1. Summary of field duplicate samples for compliance monitoring in 2006

\begin{tabular}{|c|c|c|c|c|c|}
\hline Analysis & Matrix & $\begin{array}{l}\text { Number of } \\
\text { Samples } \\
\text { Reported }^{(a)} \\
\end{array}$ & $\begin{array}{c}\text { Number of } \\
\text { Samples } \\
\text { Reported above } \\
\text { MDC }^{(b)} \\
\end{array}$ & $\begin{array}{l}\text { Average Absolute } \\
\text { RPD of those } \\
\text { above MDC (\%)(c) }\end{array}$ & $\begin{array}{c}\text { Average } \\
\text { Absolute } \\
\text { RER }^{(d)} \\
\end{array}$ \\
\hline Gross Alpha & Air & 100 & 16 & 20.6 & 0.7 \\
\hline Gross Beta & Air & 100 & 100 & 8.6 & 0.7 \\
\hline${ }^{241} \mathrm{Am}$ & Air & 24 & 3 & 70.3 & 1.0 \\
\hline${ }^{7} \mathrm{Be}^{(\mathrm{e})}$ & Air & 24 & 23 & 14.3 & 2.5 \\
\hline${ }^{40} \mathrm{~K}^{(\mathrm{e})}$ & Air & 18 & 3 & 45.8 & 1.2 \\
\hline${ }^{238} \mathrm{Pu}$ & Air & 24 & 0 & NA & 0.6 \\
\hline${ }^{239+240} \mathrm{Pu}$ & Air & 22 & 5 & 87.7 & 1.5 \\
\hline Tritium & Air & 43 & 21 & 13.1 & 1.1 \\
\hline${ }^{241} \mathrm{Am}$ & Soil & 1 & 1 & 66.0 & 4.0 \\
\hline${ }^{238} \mathrm{Pu}$ & Soil & 1 & 1 & 46.2 & 3.2 \\
\hline${ }^{239+240} \mathrm{Pu}$ & Soil & 1 & 1 & 12.7 & 1.1 \\
\hline${ }^{90} \mathrm{Sr}$ & Soil & 1 & 1 & 4.6 & 0.2 \\
\hline${ }^{241} \mathrm{Am}$ & Water & 1 & 1 & 5.0 & 0.2 \\
\hline Gross Alpha & Water & 10 & 7 & 11.7 & 0.9 \\
\hline Gross Beta & Water & 10 & 8 & 15.3 & 1.6 \\
\hline${ }^{238} \mathrm{Pu}$ & Water & 1 & 1 & 18.2 & 1.0 \\
\hline${ }^{239+240} \mathrm{Pu}$ & Water & 1 & 1 & 4.5 & 0.3 \\
\hline${ }^{90} \mathrm{Sr}$ & Water & 1 & 1 & 8.1 & 0.2 \\
\hline Tritium & Water & 34 & 3 & 8.8 & 0.5 \\
\hline TLDs & $\begin{array}{c}\text { Ambient } \\
\text { Radiation }\end{array}$ & 400 & NA & 2.5 & 0.5 \\
\hline
\end{tabular}

(a) Represents the number of field duplicates reported for the purpose of monitoring precision. If an associated field sample was not processed, the field duplicate was not included in this table.

(b) Represents the number of field duplicate - field sample result sets reported above the MDC. The MDC does not apply to TLD measurements. If either the field samples or its duplicate was reported below MDC, the precision was not determined.

(c) Reflects the average absolute RPD calculated as follows:

$$
\text { Absolute } R P D=\frac{|D-S|}{(D+S) / 2} X 100
$$

$$
\text { Where: } \quad \begin{aligned}
& S=\text { Sample result } \\
& D=\text { Duplicate result }
\end{aligned}
$$

(d) Relative error ratio (RER) determined by the following equation is used to determine whether a sample result and the associated field duplicate result differ significantly when compared to their respective one sigma uncertainties. The RER is calculated for all sample and field duplicate pairs reported without regard to the MDC.

$$
\begin{array}{ll}
\text { Absolute } & R E R=\frac{|S-D|}{\sqrt{\left(T P U_{S}\right)^{2}+\left(T P U_{D}\right)^{2}}} \\
\text { Where: } \quad & \begin{array}{l}
S=\text { Sample result } \\
\mathrm{D}=\text { Duplicate result } \\
\text { TPUS }=1 \text { sigma total propagated uncertainty of the field sample } \\
\text { TPUD }=1 \text { sigma total propagated uncertainty of the field duplicate }
\end{array}
\end{array}
$$

(e) ${ }^{7} \mathrm{Be}$ and ${ }^{40} \mathrm{~K}$ are naturally occurring analytes included in the gamma for quality assessment of the analyses. 


\subsubsection{Laboratory Control Samples (LCSs)}

An LCS is a sample matrix, free from the analytes of interest, spiked with verified known amounts of analytes or a material containing known and verified amounts of analytes. It is generally used to establish intra-laboratory or analyst-specific precision and bias or to assess the performance of all or a portion of the measurement system (DOE, 2006c).

The results are calculated as a percentage of the true value, and must fall within established control limits (or percentage range) to be considered acceptable. If the LCS recovery falls outside control limits, evaluation for potential sample data bias is necessary. The numbers of 2006 LCSs analyzed and within control limits are summarized in Table 18-2.

Table 18-2. Summary of LCSs for 2006

\begin{tabular}{|c|c|c|c|c|}
\hline Analysis & Matrix & $\begin{array}{l}\text { Number of LCS } \\
\text { Results Reported }\end{array}$ & $\begin{array}{c}\text { Number Within } \\
\text { Control Limits }\end{array}$ & $\begin{array}{c}\text { Control Limits } \\
(\%)\end{array}$ \\
\hline \multicolumn{5}{|c|}{ Radiological Analyses } \\
\hline${ }^{239+240} \mathrm{Pu}$ & Air & 40 & 40 & $70-130$ \\
\hline${ }^{241} \mathrm{Am}$ & Air & 37 & 37 & $70-130$ \\
\hline${ }^{137} \mathrm{Cs}$ & Air & 31 & 31 & $70-130$ \\
\hline${ }^{60} \mathrm{Co}$ & Air & 31 & 31 & $70-130$ \\
\hline Tritium & Air & 56 & 55 & $70-130$ \\
\hline Gross Alpha & Water & 16 & 16 & $70-130$ \\
\hline Gross Beta & Water & 16 & 16 & $70-130$ \\
\hline${ }^{239+240} \mathrm{Pu}$ & Water & 16 & 16 & $70-130$ \\
\hline Tritium & Water & 42 & 42 & $70-130$ \\
\hline${ }^{90} \mathrm{Sr}$ & Water & 11 & 11 & $70-130$ \\
\hline${ }^{241} \mathrm{Am}$ & Water & 2 & 1 & $70-130$ \\
\hline${ }^{137} \mathrm{Cs}$ & Water & 14 & 14 & $70-130$ \\
\hline${ }^{60} \mathrm{Co}$ & Water & 14 & 14 & $70-130$ \\
\hline${ }^{90} \mathrm{Sr}$ & Soil & 7 & 7 & $70-130$ \\
\hline${ }^{239+240} \mathrm{Pu}$ & Soil & 12 & 12 & $70-130$ \\
\hline${ }^{241} \mathrm{Am}$ & Soil & 13 & 13 & $70-130$ \\
\hline${ }^{60} \mathrm{Co}$ & Soil & 12 & 12 & $70-130$ \\
\hline${ }^{137} \mathrm{Cs}$ & Soil & 12 & 12 & $70-130$ \\
\hline \multicolumn{5}{|c|}{ Nonradiological Analyses } \\
\hline Metals & Water & 170 & 170 & $80-120$ \\
\hline Volatiles & Water & 273 & 271 & $70-130$ \\
\hline Semi Volatiles & Water & 78 & 76 & Laboratory specific \\
\hline Miscellaneous & Water & 227 & 222 & $80-120$ \\
\hline Metals & Soil & 25 & 25 & $75-125$ \\
\hline Volatiles & Soil & 10 & 10 & $70-130$ \\
\hline Semi Volatiles & Soil & 46 & 44 & Laboratory specific \\
\hline
\end{tabular}

\subsubsection{Blank Analysis}

In general terms, a blank is a sample that has not been exposed to the analyzed sample stream in order to monitor contamination during sampling, transport, storage or analysis. The blank is subjected to the usual analytical and measurement process to establish a zero baseline or background value and is sometimes used to adjust or correct routine analytical results (DOE, 2006c).

Laboratory method blank data are summarized in Table 18-3. A method blank is a sample of a matrix similar to the batch of associated samples (when available) that is free from the analytes of interest and is processed simultaneously 
with and under the same conditions as samples through all steps of the analytical procedures, and in which no target analytes or interferences are present at concentrations that impact the analytical results for sample analyses (DOE, 2006c).

Table 18-3. Summary of laboratory blank samples for 2006

\begin{tabular}{|c|c|c|c|}
\hline Analysis & Matrix & $\begin{array}{l}\text { Number of Blank } \\
\text { Results Reported }\end{array}$ & $\begin{array}{l}\text { Number Within } \\
\text { Control Limits }\end{array}$ \\
\hline \multicolumn{4}{|c|}{ Radiological Analyses } \\
\hline${ }^{239+240} \mathrm{Pu}$ & Air & 26 & 21 \\
\hline${ }^{137} \mathrm{Cs}$ & Air & 31 & 31 \\
\hline${ }^{241} \mathrm{Am}$ & Air & 23 & 20 \\
\hline Tritium & Air & 57 & 54 \\
\hline${ }^{7} \mathrm{Be}$ & Air & 31 & 31 \\
\hline${ }^{238} \mathrm{Pu}$ & Air & 26 & 26 \\
\hline Gross Alpha & Water & 16 & 15 \\
\hline Gross Beta & Water & 16 & 16 \\
\hline${ }^{60} \mathrm{Co}$ & Water & 14 & 14 \\
\hline${ }^{239+240} \mathrm{Pu}$ & Water & 10 & 9 \\
\hline Tritium & Water & 42 & 40 \\
\hline${ }^{90} \mathrm{Sr}$ & Water & 6 & 5 \\
\hline${ }^{241} \mathrm{Am}$ & Water & 1 & 0 \\
\hline${ }^{238} \mathrm{Pu}$ & Water & 10 & 10 \\
\hline${ }^{238} \mathrm{Pu}$ & Soil & 12 & 12 \\
\hline${ }^{241} \mathrm{Am}$ & Soil & 13 & 13 \\
\hline${ }^{90} \mathrm{Sr}$ & Soil & 7 & 7 \\
\hline${ }^{239+240} \mathrm{Pu}$ & Soil & 12 & 12 \\
\hline \multirow[t]{2}{*}{${ }^{60} \mathrm{Co}$} & Soil & 12 & 12 \\
\hline & \multicolumn{2}{|c|}{ Nonradiological Analyses } & $\begin{array}{l}\text { Number of Results } \\
<\text { Reporting Limit }\end{array}$ \\
\hline Metals & Water & 185 & 163 \\
\hline Volatiles & Water & 269 & 265 \\
\hline Semi Volatiles & Water & 81 & 81 \\
\hline Miscellaneous & Water & 168 & 166 \\
\hline Metals & Soil & 56 & 54 \\
\hline Volatiles & Soil & 20 & 20 \\
\hline Semi Volatiles & Soil & 60 & 60 \\
\hline
\end{tabular}

(a) Indicates the numbers of results reported less than the MDC (radiochemistry) or the reporting limit (non-radiochemistry)

\subsubsection{Proficiency Testing Program Participation}

Laboratories are required to participate in Proficiency Testing Programs. Laboratory performance supports decisions on work distribution and may also be a basis for state certifications. Table 18-4 presents the 2006 results for the Mixed Analyte Performance Evaluation Program (MAPEP) conducted by the Radiological and Environmental Sciences Laboratory of the Idaho National Engineering and Environmental Laboratory. 
Table 18-4. Summary of 2006 radiological MAPEP reports

\begin{tabular}{||lccc||}
\hline Analysis & Matrix & $\begin{array}{c}\text { Number of } \\
\text { Results Reported }\end{array}$ & $\begin{array}{c}\text { Number Within } \\
\text { Control Limits(a) }\end{array}$ \\
\hline Gross Alpha & Filter & 4 & 4 \\
Gross Beta & Filter & 4 & 4 \\
${ }^{60} \mathrm{Co}$ & Filter & 6 & 6 \\
${ }^{137} \mathrm{Cs}$ & Filter & 6 & 6 \\
${ }^{241} \mathrm{Am}$ & Filter & 6 & 6 \\
${ }^{239+240} \mathrm{Pu}$ & Filter & 6 & 6 \\
Gross Alpha & Water & 6 & 6 \\
Gross Beta & Water & 6 & 6 \\
${ }^{60} \mathrm{Co}$ & Water & 6 & 6 \\
${ }^{137} \mathrm{Cs}$ & Water & 6 & 6 \\
${ }^{241} \mathrm{Am}$ & Water & 6 & 6 \\
${ }^{239+240} \mathrm{Pu}$ & Water & 6 & 6 \\
${ }^{90} \mathrm{Sr}$ & Water & 6 & 6 \\
${ }^{\mathrm{Tritium}}$ & Water & 6 & 6 \\
${ }^{60} \mathrm{Co}$ & Vegetation & 6 & 6 \\
${ }^{137} \mathrm{Cs}$ & Vegetation & 6 & 5 \\
${ }^{241} \mathrm{Am}$ & Vegetation & 6 & 4 \\
${ }^{239+240} \mathrm{Pu}$ & Vegetation & 5 & 3 \\
${ }^{90} \mathrm{Sr}$ & Vegetation & 6 & 6 \\
${ }^{60} \mathrm{Co}$ & Soil & 6 & 5 \\
${ }^{137} \mathrm{Cs}$ & Soil & 6 & 6 \\
${ }^{241} \mathrm{Am}$ & Soil & 6 & 6 \\
${ }^{239+240} \mathrm{Pu}$ & Soil & 6 & 6 \\
${ }^{90} \mathrm{Sr}$ & Soil & 6 & 5 \\
\hline \hline
\end{tabular}

(a) Control limits are determined by the individual inter-laboratory comparison study

Table 18-5 shows the summary of inter-laboratory comparison sample results for the NSTec Radiological Health Dosimetry Group. This internal evaluation was based on National Voluntary Laboratory Accreditation Program (NVLAP) criteria. The Dosimetry Group participated in the Battelle Pacific Northwest National Laboratory performance evaluation study program during the course of the year. The Dosimetry Group performed very well during the year by passing 36 out of 36 TLDs analyzed.

Table 18-5. Summary of inter-laboratory comparison TLD samples for the subcontract dosimetry group in 2006

\begin{tabular}{||lccc||}
\hline Analysis & Matrix & $\begin{array}{c}\text { Number of } \\
\text { Results Reported }\end{array}$ & $\begin{array}{c}\text { Number Within } \\
\text { Control Limits }\end{array}$ \\
\hline \hline TLD & Ambient Radiation & 36 & 36 \\
\hline
\end{tabular}

(a) Based upon NVLAP criteria; absolute value of the bias plus one standard deviation $<0.3$ 


\subsection{Oversight Quality Assurance Program for the Community Environmental Monitoring Program}

The Community Environmental Monitoring Program (CEMP) Quality Assurance Program Plan (QAPP) was followed for the collection and analysis of radiological air and water data presented in Section 6.0 of this report. The CEMP QAPP ensures compliance with U.S. Department of Energy (DOE) Order 414.1A, Quality Assurance which implements a quality management system ensuring the generation and use of quality data. This QAPP addresses the following items previously defined in Section 18.0:

- Data Quality Objectives (DQOs)

- Sampling plan development appropriate to satisfy the DQOs

- Environmental health and safety

- Sampling plan execution

- Sample analyses

- Data review

- Continuous improvement

\subsection{Data Quality Objectives}

The DQO process is a strategic planning approach that is used to plan data collection activities. It provides a systematic process for defining the criteria that a data collection design should satisfy. These criteria include when and where samples should be collected, how many samples to collect, and the tolerable level of decision errors for the study. DQOs are unique to the specific data collection or monitoring activity, and are further explained in Appendices A through E of the Routine Radiological Environmental Monitoring Plan (DOE, 2003b).

\subsection{Measurement Quality Objectives (MQOs)}

The MQOs are basically equivalent to DQOs for analytical processes. The MQOs provide direction to the laboratory concerning performance objectives or requirements for specific method performance characteristics. Default MQOs are established in the subcontract, but may be altered in order to satisfy changes in the DQOs. The MQOs for the CEMP project are described in terms of precision, accuracy, representativeness, completeness, and comparability requirements. These terms are defined and discussed in Section 18.1 for onsite activities.

\subsection{Sampling Quality Assurance Program}

Quality Assurance (QA) in field operations for the CEMP includes sampling assessments, surveillances, and oversight of the following supporting elements:

- The sampling plan, data quality objectives, and field data sheets accompanying the sample package

- Database support for field and laboratory results, including systems for long-term storage and retrieval

- A training program to ensure that qualified personnel are available to perform required tasks

Sample packages include the following items:

- Station manager checklist confirming all observable information pertinent to sample collection

- An Air Surveillance Network Sample Data Form documenting air sampler parameters, collection dates and times, and total sample volumes collected

- Chains-of-custody forms 
This managed approach to sampling ensures that the sampling is traceable and enhances the value of the final data available to the project manager. The sample package also ensures that the station manager Community Environmental Monitor (CEM) (see Section 6.0 for description of CEMs) has followed proper procedures for sample collection. The CEMP Project Manager or QA Officer routinely performs assessments of the station managers and field monitors to ensure that standard operating procedures and sampling protocol are being followed properly.

Data obtained in the course of executing field operations are entered in the documentation accompanying the sample package during sample collection and in the CEMP database along with analytical results upon their receipt and evaluation.

Completed sample packages are kept as hard copy in file archives. Analytical reports are kept as hard copy in file archives as well as compact disk-read only memory by calendar year. Analytical reports and databases are protected and maintained in accordance with the Desert Research Institute's (DRI's) Computer Protection Program.

\subsection{Laboratory QA Oversight}

CEMP ensures that DOE Order 414.1A, Quality Assurance, requirements are met with respect to laboratory services through review of the vendor laboratory policies formalized in a Laboratory Quality Assurance Plan (LQAP). CEMP is assured of obtaining quality data from laboratory services through a multifaceted approach involving specific procurement protocols, the conduct of quality assessments, and requirements for selected laboratories to have an acceptable QA program. These elements are discussed below.

\subsubsection{Procurement}

Laboratory services are procured through subcontracts. The subcontract establishes the technical specifications required of the laboratory and provides the basis for determining compliance with those requirements and evaluating overall performance. The subcontract is awarded on a "best value" basis as determined by pre-award audits. The prospective vendor is required to provide a review package to CEMP that includes the following items:

- All procedures pertinent to subcontract scope

- Enironment, Safety, and Health Plan

- LQAP

- Example deliverables (hard copy and/or electronic)

- Proficiency testing (PT) results from the previous year from recognized PT programs

- Resumes

- Facility design/description

- Accreditations and certifications

- Licenses

- Audits performed by an acceptable DOE program covering comparable scope

- Past performance surveys

- Pricing

CEMP evaluates the review package in terms of technical capability. Vendor selection is based solely on these capabilities and not biased by pricing.

\subsubsection{Initial and Continuing Assessment}

An initial assessment of a laboratory is managed through the procurement process above, including a pre-award audit. Pre-award audits are conducted by CEMP (usually by the CEMP QA Officer). In no instance shall CEMP initiate work with a laboratory without approval of the CEMP Program Manager. 
A continuing assessment of a selected laboratory involves ongoing monitoring of a laboratory's performance against the contract terms and conditions, of which technical specifications are a part. Tasks supporting continuing assessment are:

- Tracking schedule compliance

- Review of analytical data deliverables

- Monitoring of the laboratory's adherence to the LQAP

- Conducting regular audits

- Monitoring for continued successful participation in approved PT programs

\subsubsection{Laboratory QA Program}

The laboratory policies and approach to the implementation of DOE Order 414.1A must be verified in a LQAP prepared by the laboratory. The elements of a LQAP required for the CEMP are similar to those required by National Security Technologies, LLC for onsite monitoring, and are described in Section 18.3.3.

\subsection{Data Review}

Essential components of process-based QA are data checks, verification, validation, and data quality assessment to evaluate data quality and usability.

Data Checks - Data checks are conducted to ensure accuracy and consistency of field data collection operations prior to and upon data entry into CEMP databases and data management systems.

Data Verification - Data verification is defined as a subcontract compliance and completeness review to ensure that all laboratory data and sample documentation are present and complete. Sample preservation, chain-of-custody, and other field sampling documentation shall be reviewed during the verification process. Data verification ensures that the reported results entered in CEMP databases correctly represent the sampling and/or analyses performed and includes evaluation of quality control (QC) sample results.

Data Validation - Data validation is the process of reviewing a body of analytical data to determine if it meets the data quality criteria defined in operating instructions (OIs). Data validation ensures that the reported results correctly represent the sampling and/or analyses performed, determines the validity of the reported results, and assigns data qualifiers (or "flags"), if required. The process of data validation consists of:

- Evaluating the quality of the data to ensure that all project requirements are met

- Determining the impact on data quality of those requirements if they are not met

- Verifying compliance with QA requirements

- Checking QC values against defined limits

- Appling qualifiers to analytical results in the CEMP databases for the purposes of defining the limitations in the use of the reviewed data

OIs. procedures, applicable project specific work plans, field sampling plans, QAPPs, analytical method references, and laboratory statements of work may all be used in the process of data validation. Documentation of data validation includes checklists, qualifier assignments, and summary forms.

Data Quality Assessment - Data Quality Assessment (DQA) is the scientific evaluation of data to determine if the data obtained from environmental data operations are of the right type, quality, and quantity to support their intended use. DQA review is a systematic review against pre-established criteria to verify that the data are valid for their intended use. 


\subsection{QA Program Assessments}

The overall effectiveness of the QA program is determined through management and independent assessment as defined in the CEMP QAPP. These assessments evaluate the plan execution work-flow (sampling plan development and execution, chain-of-custody, sample receiving, shipping, subcontract laboratory analytical activities, and data review) as well as program requirements as it pertains to the organization.

\subsection{Sample QA Results}

QA procedures were performed by the CEMP, including the laboratories responsible for sample analyses. These assessments ensure that sample collection procedures, analytical techniques, and data provided by the subcontracted laboratories comply with CEMP requirements. Data were provided by Severn Trent Laboratories (gross alpha/beta and gamma spectroscopy data), Global Dosimetry Solutions (thermoluminescent dosimeter [TLD] data), and DRI (tritium data). A brief discussion of the 2006 results for field duplicates, laboratory control samples, blank analysis, and inter-laboratory comparison studies is provided along with summary tables within this section. The 2006 CEMP radiological air and water monitoring data are presented in Section 6.0.

\subsubsection{Field Duplicates (Precision)}

A field duplicate is a sample collected, handled, and analyzed following the same procedures as the primary sample. The Relative Percent Difference (RPD) between the field duplicate result and the corresponding field sample result is a measure of the variability in the process caused by the sampling uncertainty (matrix heterogeneity, collection variables, etc.) and measurement uncertainty (field and laboratory) used to arrive at a final result. The average absolute RPD, expressed as a percentage, was determined for the calendar year 2006 samples and is listed in Table 19-1. An RPD of zero indicates a perfect duplication of results of the duplicate pair, whereas an RPD greater than 100 percent generally indicates that a duplicate pair falls beyond QA requirements and are not considered valid for use in data interpretation. These samples are further evaluated to determine the reason for QA failure and if any corrective actions are required. Overall, the RPD values for all analyses indicate very good results, with only two alpha duplicate exceeding an RPD of 100 percent.

Table 19-1. Summary of field duplicate samples for oversight monitoring in 2006

\begin{tabular}{||lcccc||}
\hline Analysis & Matrix & $\begin{array}{c}\text { Number of } \\
\text { Samples } \\
\text { Reported }^{(a)}\end{array}$ & $\begin{array}{c}\text { Number of } \\
\text { Samples } \\
\text { Reported } \\
\text { above MDC }\end{array}$ & $\begin{array}{c}\text { (b) } \\
\text { Average Absolute } \\
\text { RPD of those } \\
\text { above MDC (\%)(c) }\end{array}$ \\
\hline Gross Alpha & Air & 153 & 145 & 26.1 \\
Gross Beta & Air & 153 & 153 & 8.5 \\
Gamma - Beryllium-7 & Air & 12 & 9 & 26.1 \\
Tritium & Water & 4 & 1 & 19.9 \\
TLDs & Ambient & 12 & 12 & 4.5 \\
& Radiation & & & \\
\hline
\end{tabular}

(a) Represents the number of field duplicates reported for the purpose of monitoring precision. If an associated field sample was not processed, the field duplicate was not included in this table.

(b) Represents the number of field duplicate - field sample result sets reported above the minimum detectable concentration (MDC) (MDC is not applicable for TLDs). If either the field sample or its duplicate was reported below the detection limit, the precision was not determined.

(c) Reflects the average absolute RPD calculated for those field duplicates reported above the MDC. The absolute RPD calculation is as follows:
Absolute $R P D=\frac{|F D-F S|}{(F D+F S) / 2} X \quad 100 \%$
Where: $\quad F D=$ Field duplicate result
FS $=$ Field sample result 


\subsubsection{Laboratory Control Samples (LCSs) (Accuracy)}

Laboratory control samples (a.k.a. matrix spikes) are performed by the subcontract laboratory to evaluate analytical accuracy, which is the degree of agreement of a measured value with the true or expected value. Samples of known concentration are analyzed using the same methods as employed for the project samples. The results are determined as the measured value divided by the true value, expressed as a percent. To be considered valid, the results must fall within established control limits (or percentage range) for further analyses to be performed. The LCS results obtained for 2006 are summarized in Table 19-2. The LCS results were satisfactory with only 2 percent of the alpha control samples falling outside of control parameters for the air sample matrix.

Table 19-2. Summary of laboratory control samples (LCS) for oversight monitoring in 2006

\begin{tabular}{||cccc||}
\hline Analysis & Matrix & $\begin{array}{c}\text { Number of LCS } \\
\text { Results Reported }\end{array}$ & $\begin{array}{c}\text { Number Within } \\
\text { Control Limits }\end{array}$ \\
\hline Gross Alpha & Air & 106 & 104 \\
Gross Beta & Air & 106 & 106 \\
Gamma & Air & 8 & 8 \\
Tritium & Water & 13 & 13 \\
\hline \hline
\end{tabular}

(a) Control limits are as follows: 80 to 120 percent for gross alpha, 80 to 120 percent for gross beta, 80 to 114 percent for gamma $\left({ }^{137} \mathrm{Cs},{ }^{60} \mathrm{Co},{ }^{241} \mathrm{Am}\right), 80$ to 120 percent for tritium.

\subsubsection{Blank Analysis}

Laboratory blank sample analyses are essentially the opposite of control samples discussed in Section 19.7.2. These samples do not contain any of the analyte of interest. Results of these analyses are expected to be 'zero,' or more accurately, below the MDC of a specific procedure. Blank analysis and control samples are used to evaluate overall laboratory procedures, including sample preparation and instrument performance. The laboratory blank sample results obtained for 2006 are summarized in Table 19-3. The laboratory blank results were satisfactory with less than 5 percent of the alpha and beta blank samples outside of control parameters for the air sample matrix.

Table 19-3. Summary of laboratory blank samples for oversight monitoring in 2006

\begin{tabular}{||lccc||}
\hline \hline Analysis & Matrix & $\begin{array}{c}\text { Number of Blank } \\
\text { Results Reported }\end{array}$ & $\begin{array}{c}\text { Number Within } \\
\text { Control Limits(a) }\end{array}$ \\
\hline Gross Alpha & Air & 106 & 100 \\
Gross Beta & Air & 106 & 101 \\
Gamma & Air & 8 & 8 \\
Tritium & Water & 4 & 4 \\
\hline
\end{tabular}

(a) Control limit is less than the MDC.

\subsubsection{Inter-laboratory Comparison Studies}

Inter-laboratory comparison studies are conducted by the subcontracted laboratories to evaluate their performance relative to other laboratories providing the same service. These types of samples are commonly known as 'blind' samples, in which the expected values are known only to the program conducting the study. The analyses are evaluated and, if found satisfactory, the laboratory is certified that its procedures produce reliable results. The 
inter-laboratory comparison sample results obtained for 2006 are summarized in Tables 19-4 and 19-5. Note: the DRI tritium laboratory did not participate in any of these programs.

Table 19-4 shows the summary of inter-laboratory comparison sample results for the Subcontract Radiochemistry Laboratory. The Laboratory participated in the Quality Assurance Program administered by the Environmental Measurements Laboratory (EML) and the Mixed Analyte Performance Evaluation Program (MAPEP) for gross alpha, gross beta, and gamma analyses. The subcontractor performed very well during the year by passing all of the parameters analyzed.

Table 19-5 shows the summary of the in-house performance evaluation results conducted by the Subcontract Dosimetry Group. This internal evaluation was based on National Voluntary Laboratory Accreditation Program (NVLAP) criteria and was performed biannually. The Dosimetry Group performed very well during the year passing 20 out of 20 TLDs analyzed.

Table 19-4. Summary of inter-laboratory comparison samples of the subcontract radiochemistry laboratory for oversight monitoring in 2006

\begin{tabular}{||lccc||}
\hline \hline Analysis & Matrix & $\begin{array}{c}\text { Number of } \\
\text { Results Reported }\end{array}$ & $\begin{array}{c}\text { Number Within } \\
\text { Control Limits }\end{array}$ \\
\hline Gross Alpha & \multicolumn{3}{c||}{ MAPEP and EML Results } \\
Gross Beta & Air & 2 & 2 \\
Gamma & Air & 2 & 2 \\
\hline
\end{tabular}

(a) Control limits are determined by the individual inter-laboratory comparison study.

Table 19-5. Summary of inter-laboratory comparison TLD samples of the subcontract dosimetry group for oversight monitoring in 2006

\begin{tabular}{||l|c|c|c||}
\hline Analysis & Matrix & $\begin{array}{c}\text { Number of } \\
\text { Results Reported }\end{array}$ & $\begin{array}{c}\text { Number Within } \\
\text { Control Limits }\end{array}$ \\
\hline TLDs & Ambient Radiation & 20 & 20 \\
\hline \hline
\end{tabular}

(a) Based upon NVLAP criteria; absolute value of the bias plus one standard deviation $<0.3$. 


\section{Appendix A}

Nevada Test Site Satellite Facilities 
THIS PAGE INTENTIONALLY LEFT BLANK 


\section{Appendix A: Nevada Test Site Satellite Facilities}

This appendix provides a general description of the three Nevada Test Site (NTS) satellite facilities in Nevada which support work on the NTS and all environmental monitoring and compliance activities conducted in 2006 related to these facilities. The NTS and these facilities are managed by the U.S. Department of Energy, National Nuclear Security Administration Nevada Site Office (NNSA/NSO). They include the North Las Vegas Facility (NLVF), Cheyenne Las Vegas Facility (CLVF), and Remote Sensing Laboratory (RSL)-Nellis. They are all located in Clark County (Figure A-1).

\section{A.1 North Las Vegas Facility}

The NLVF is a fenced complex comprised of 31 buildings which houses much of the NTS project management, diagnostic development and testing, design, engineering, and procurement. The 80 -acre facility is located along Losee Road, a short distance west of Interstate 15 (Figure A-1). The facility is buffered on the north, south, and east by general industrial zoning. The western border separates the property from fully developed, single-family residential-zoned property. The NLVF is a controlled-access facility.

Environmental compliance and monitoring activities associated with this facility in 2006 included the maintenance of three wastewater permits, one National Pollution Discharge Elimination System (NPDES) permit, one air quality operating permit, one hazardous materials permit (Table A-1), and the monitoring of tritium in air and ambient gamma-emissions to comply with radiation protection regulations.

Table A-1. Environmental permits for NLVF in 2006

\begin{tabular}{||llcc||}
\hline Permit Number & Description & Expiration Date & Reporting \\
\hline Wastewater Discharge & & & \\
VEH-112 & NLVF Wastewater Contribution Permit & December 31, 2006 & Annually \\
TNEV2006369 & NLVF Temporary Authorization to Discharge & June 6, 2006 & Monthly \\
TNEV2006445 & NLVF Temporary Authorization to Discharge & December 6, 2006 & Monthly \\
NV0023507 & NLVF NPDES Permit & November 2, 2011 & Quarterly \\
Air Quality & & & \\
Facility 657, Mod. 2 & Clark County Authority to Construct/ & None & March \\
Hazardous Materials & Operating Permit for a Testing Laboratory & & \\
2287-5144 & NLVF Hazardous Materials Permit & February 28, 2007 & Annually \\
\hline
\end{tabular}

\section{A.1.1 Compliance with Water Permits}

Wastewater permits in 2006 for NLVF included: (1) a Class II Wastewater Contribution Permit with the City of North Las Vegas (CNLV) for sewer discharges, and (2) two temporary discharge permits to support groundwater characterization and dewatering issued by the Nevada Division of Environmental Protection (NDEP), and (3) one NPDES Discharge permit issued by the U.S. Environmental Protection Agency (EPA).

Discharges of sewage and industrial wastewater from NLVF are required to meet permit limits set by the CNLV. These limits support the permit limits for the Publicly Owned Treatment Works (POTW) operated by the City of Las Vegas. Regulations for wastewater discharges are codified in the municipal codes for both cities. Groundwater discharges are state-regulated by the NDEP and are used onsite for dust suppression and landscape irrigation. 


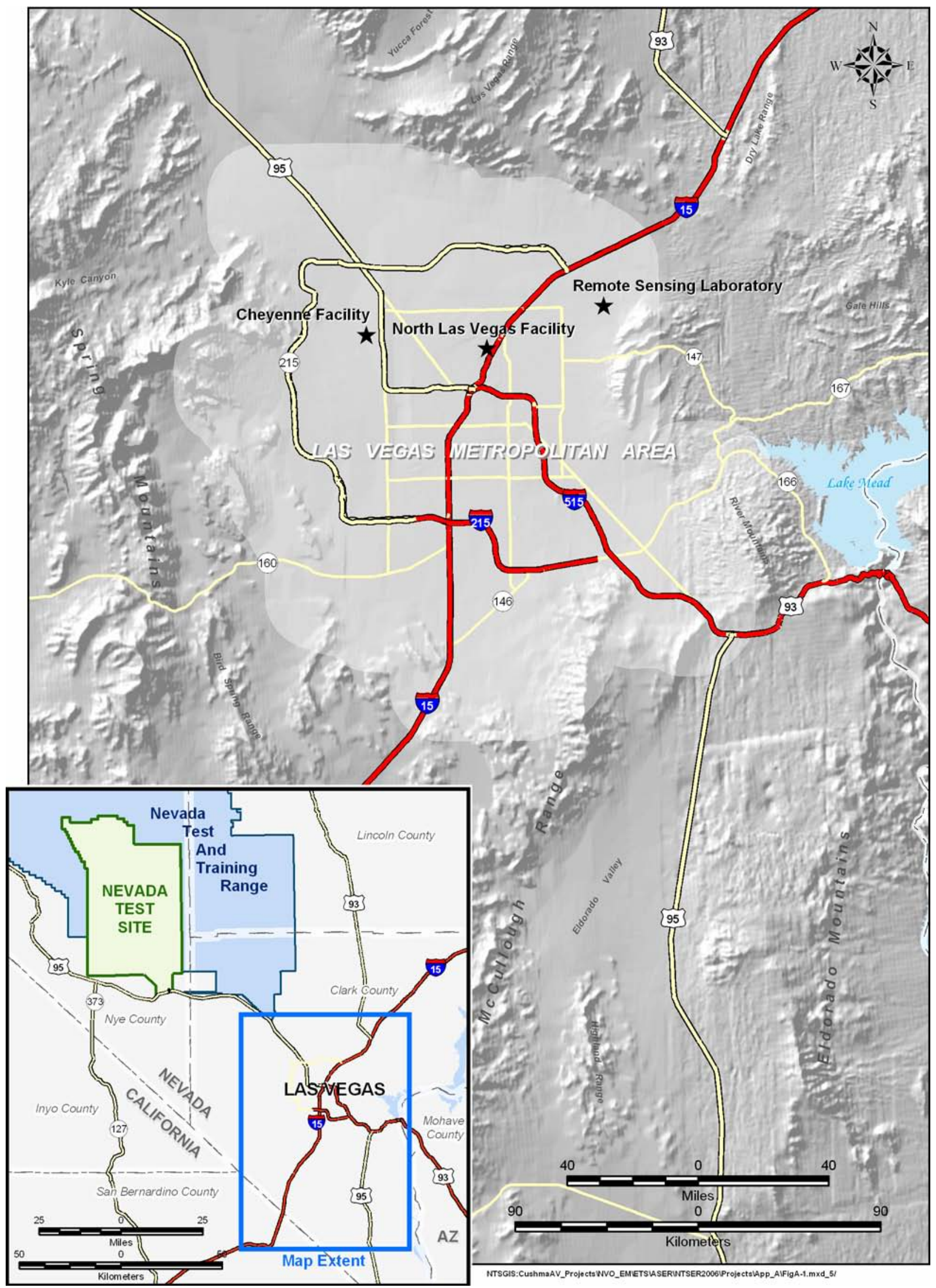

Figure A-1. Location of NTS satellite facilities 


\section{A.1.1.1 Wastewater Contribution Permit VEH-112}

This permit specifies concentration limits for contaminants in domestic and industrial wastewater discharges. Self-monitoring and reporting of the levels of non-radiological contaminants in sewage and industrial outfalls is conducted. In 2006, contaminant concentrations (in milligrams per liter [mg/L]) were below established permit limits (Table A-2) in all water samples from NLVF outfalls and all sludge and liquid samples from NLVF sand/oil interceptors except for total dissolved solids (TDS) samples collected from Outfalls B and C2. In response to these exceedances, National Security Technologies, LLC (NSTec), wrote a Salinity Control Plan (SCP) discussing steps taken to reduce the TDS levels. The SCP was submitted to CNLV within the required timeframe and additional samples were collected and the results were reported. CNLV conducted an annual inspection on November 14, 2006, that resulted in no findings or corrective actions. In compliance with this permit, a report summarizing wastewater monitoring was generated for NLVF operations and was submitted on October 18, 2006 to CNLV. The report is titled Self-Monitoring Report for the National Nuclear Security Administration's North Las Vegas Facility: Permit VEH-112.

Table A-2. Results of 2006 monitoring at NLVF for Wastewater Contribution Permit VEH-112

\begin{tabular}{||lcccc||}
\hline \multicolumn{1}{|c}{ Contaminant } & $\begin{array}{c}\text { Permit Limit } \\
(\mathbf{m g} / \mathbf{L})\end{array}$ & $\begin{array}{c}\text { Outfall A } \\
(\mathbf{m g} / \mathbf{L})\end{array}$ & $\begin{array}{c}\text { Outfall B } \\
(\mathbf{m g} / \mathbf{L})\end{array}$ & $\begin{array}{c}\text { Outfall C2 } \\
(\mathbf{m g} / \mathbf{L})\end{array}$ \\
\hline Ammonia & 61 & 7.6 & 20.7 & 10.0 \\
Barium & 13.1 & 0.162 & 0.216 & 0.211 \\
BOD & 600 & 28 & 140 & 37 \\
Cadmium & 0.15 & $<0.0004$ & $<0.0004$ & $<0.0004$ \\
Chromium (hexavalent) & 0.10 & $<0.01$ & $<0.01$ & $<0.01$ \\
Chromium (total) & 5.60 & 0.0013 & 0.00089 & 0.0187 \\
Copper & 0.60 & 0.0849 & 0.184 & 0.0515 \\
Cyanide (total) & 19.9 & $<0.005$ & $<0.005$ & $<0.005$ \\
Lead & 0.20 & $<0.0029$ & $<0.0029$ & 0.0066 \\
Nickel & 1.10 & 0.0043 & 0.0035 & 0.0121 \\
Oil \& Grease (animal or vegetable) & 250 & 5.9 & 3.6 & 1.8 \\
pH (Standard Units) & $5.0-11.0$ & 8.15 & 8.14 & 7.83 \\
Phenols & 33.6 & $<0.02$ & $<0.02$ & $<0.02$ \\
Phosphorus (total) & 14.0 & 2.3 & 5.1 & 1.9 \\
Silver & 2.70 & $<0.0008$ & $<0.0008$ & $<0.0008$ \\
TDS (total dissolved solids) & 1200 & 1020 & 1,320 & 4,760 \\
TSS (total suspended solids) & 750 & 48.6 & 182 & 25.3 \\
Zinc & 8.20 & 0.182 & 0.261 & 0.0673 \\
\hline Yellow & & & \\
\hline
\end{tabular}

Yellow-shaded results are any which are equal to or greater than the permit limit.

\section{A.1.1.2 National Pollution Discharge Elimination System Permits TNEV2006369, TNEV2006445, and NV0023507}

Temporary and Final NPDES/State Pollutant Discharge Elimination System (SPDES) permits covered the groundwater characterization study and remedial dewatering operation conducted in 2006 at the NLVF (see Section A.1.2 below). Each temporary permit was valid for a period of six months. In November 2006, the EPA awarded the NLVF a final NPDES Discharge Permit, NV0023507, which will expire in 2011. NNSA/NSO is authorized to discharge water from dewatering operations to the groundwater of the State via percolation and to the Las Vegas Wash via the CNLV storm drain system. Onsite discharge may continue for irrigation of landscape and for dust suppression. Water produced from the dewatering wells may also be used for purposes that do not require a groundwater discharge or an NPDES permit (e.g., evaporative cooling). The volume of water pumped is reported quarterly to the state per the requirements of the permit (Table A-3). 
Table A-3. NPDES/SPDES Noncompliances

\begin{tabular}{|c|c|c|c|c|c|c|c|c|}
\hline Permit Type & Outfall & Parameter & $\begin{array}{c}\text { Number } \\
\text { of Permit } \\
\text { Exceedances }\end{array}$ & $\begin{array}{c}\text { Number of } \\
\text { Samples } \\
\text { Taken }\end{array}$ & $\begin{array}{c}\text { Number of } \\
\text { Compliant } \\
\text { Samples }\end{array}$ & $\begin{array}{c}\text { Percent } \\
\text { Compliance }\end{array}$ & $\begin{array}{c}\text { Date(s) } \\
\text { Exceeded }\end{array}$ & $\begin{array}{c}\text { Description/ } \\
\text { Solution }\end{array}$ \\
\hline $\begin{array}{c}\text { TNEV } \\
2006369 \\
2006445\end{array}$ & 001 & $\begin{array}{l}\text { Discharge } \\
\text { volume }\end{array}$ & NA & 12 (1/month) & 12 & 100 & NA & NA \\
\hline
\end{tabular}

NA $=$ not applicable

Note: These permits only allow onsite discharge of groundwater.

\section{A.1.2 Groundwater Control Study and Dewatering Operations}

During 2006, the groundwater control study and dewatering operation at the NLVF added three new wells and deactivated one well that was producing poorly. A total of four dewatering wells are now active, producing about 9,275 liters (L) (2,450 gallons [gal]) per day. The project, in general, has transitioned from initial groundwater investigations and characterization phases to a long-term/permanent dewatering operational mode. As mentioned above, the project also transitioned from short-term (six month), renewable temporary discharge permits to a longterm (five year) NPDES permit that allows for discharge into the CNLV storm water drainage system. Routine water chemistry monitoring indicates that the quality of the water pumped continues to meet the Safe Drinking Water Standards.

Work performed in 2006 is summarized here following a review of the rising groundwater situation and past efforts to understand and remediate the problem. More information regarding this project, including maps, figures, and data is reported in previous annual reports (e.g., Bechtel Nevada [BN], 2003; 2004; 2005b; NSTec, 2006).

\section{A.1.2.1 Background}

Rising groundwater below Building A-1 at the NLVF intruded into the elevator pit in 1999. Between November 1999 and January 2001, the water level in a well installed in the basement of Building A-1 rose at a rate of 0.61 meters (m) (2 feet [ft]) per year (BN, 2001), and slowed to less than $0.3 \mathrm{~m} \mathrm{(1.0} \mathrm{ft)} \mathrm{per} \mathrm{year} \mathrm{by} \mathrm{the} \mathrm{end} \mathrm{of} 2003$ (BN, 2003). Sealing of the elevator pit and interim pumping at the nearby basement sump slowed the encroaching water. However, if the water level is not lowered, it could jeopardize the integrity of the deep-footed infrastructure (e.g., elevator pits, utility trenches, foundation footers, etc.). Subsequent groundwater studies have guided the current dewatering initiative. These hydrogeologic investigations and initial dewatering efforts were reported in the 2004 and 2005 NTS environmental reports (U.S. Department of Energy [DOE], 2005a and 2006, respectively).

In 2002 and 2003, BN conducted a groundwater control study. This comprehensive investigation included the installation of 25 wells, soil and water sampling, hydrologic testing, and rudimentary modeling (BN, 2003). The study indicated a complex hydrogeologic setting and implicated multiple factors for the rise of the water table. The preliminary geologic interpretation of borehole data indicates that these fine-grained sediments represent a lowenergy, mid-valley alluvial and fluvial environment. Individual lithologic units of sand, silt, and clay are complexly interbedded and several normal faults have been mapped in the vicinity.

The near-surface (unconfined) water table at the NLVF was encountered in the depth range of 3.8 to $14.9 \mathrm{~m}$ (12.6 to $49 \mathrm{ft})$. Artesian water flow of 3.0 to 7.6 liters per minute $(\mathrm{Lpm})(0.8$ to 2 gallons per minute [gpm]) was encountered at two wells.

Water chemistry reveals that this water is not related to the near surface "nuisance water" commonly supplied by excessive irrigation, but is from a deeper alluvial aquifer. The hydrogeologic setting suggests that the source of this rising groundwater is water flowing upward along local faults from deeper confined aquifer(s). This condition is considered a long-term adjustment that can be attributed to a combination of causes, including a seasonal water injection program conducted by the Southern Nevada Water Authority and shifting of regional pumping centers away from the vicinity of NLVF. 
On May, 18, 2004, two shallow hydrologic characterization wells, proximal to Building A-1, NLVF-12S and NLVF-13S (Figure A-2), were converted into dewatering wells to remediate the rising groundwater below Building A-1. The objective of this dewatering effort was to lower the water level $1.2 \mathrm{~m}$ (4 ft) (or $1 \mathrm{ft}$ below the lowest building footing) within two years.

The water level at the A-1 Basement Sump well showed a steady decrease due to pumping at Wells NLVF-12S and NLVF-13S up to about December 20, 2004. After this date, the water level at the A-1 Basement Sump well began to rise, possibly due to recharge associated with the higher than normal precipitation for the July 2003 to April 2005 period (http://www.wrcc.dri.edu). It is interesting to note that the static water level at a majority of the NLVF monitoring wells has been gradually rising since the network was installed.

Plans to add at least two new wells to the remedial dewatering system and the resumption of pumping at the Building A-1 Basement Sump well were initiated in April 2005. While waiting for an appropriate long-term discharge permit, interim onsite water disposal methods were put in place. They included dust suppression, landscape irrigation, and evaporation of the Building A-1 Basement Sump well water. Since data gathered to date suggest that groundwater pumping may need to be continued indefinitely, permanent options for onsite use or disposal of pumped groundwater were investigated (BN, 2005c).

Based on recommendations using data collected from the NLVF Groundwater Control Program (BN, 2003; 2004; 2005b), three shallow dewatering wells were drilled in July and August, 2005. The new wells, NLVF-15, NLVF-16, and NLVF-17, are located along the north side of Building A-1 (Figure A-2). They were drilled with a 34.3-centimeter (cm) $\left(13 \frac{1}{2}\right.$-inch [in.]) auger bit to a total depth of between 15.2 to $16.8 \mathrm{~m}(50$ to $55 \mathrm{ft})$ and completed with 10.2-cm (4-in.) inside diameter polyvinyl chloride casing. All three wells have a single $9.1-\mathrm{m}(30-\mathrm{ft})$ long slotted section and are completed in the same shallow, clayey, sandy-silty aquifer as the two existing dewatering wells, NLVF-12S and NLVF-13S. Preliminary results from short-term step drawdown aquifer tests conducted in the three new wells suggested that discharge rates from 2.6 to $3.8 \mathrm{Lpm}(0.7$ to $1.0 \mathrm{gpm})$ might be sustained. BN and then NSTec Construction personnel performed the drilling and well construction activities. BN and then NSTec Geotechnical Sciences personnel conducted geologic and hydrologic data collection and analysis.

\section{A.1.2.2 Dewatering System Development}

Activities at the NLVF in 2006 focused on wellhead construction, pump installation, and completion of the discharge water collection and plumbing system. Subsurface vaults with traffic-rated covers were installed at each wellhead in 2006 (Figure A-3). Submersible pumps were installed in April and June, 2006. The new pumping wells installed in fiscal year (FY) 2005 (see Figure A-2) were brought on-line sequentially as construction efforts progressed. On June 22, 2006, Well NLVF-12S was shut down. Its pump rate was only $0.95 \mathrm{Lpm}(0.25 \mathrm{gpm})$ and was contributing little to the overall dewatering effort. Well NLVF-13s was connected on July 25, 2006 to the discharge accumulation plumbing system mounted on the exterior wall of Building A-1 (see Figure A-3). Water from Well NLVF-13S is now directed into a 10,500 gal (39,747 L) storage tank (Figure A-4), along with the discharged waters from Wells NLVF15, NLVF-16, and NLVF-17. Water in the storage tank can be transferred to a tanker truck for dust suppression and landscape irrigation (permit “Outfall 001"), or pumped directly into the CNLV storm water sewer system (permit “Outfall 002").

By August 2006, all on-line wells were operational and pumping rates were adjusted to maximize output. Recent pumping rates are $3.18 \mathrm{Lpm}(0.70 \mathrm{gpm})$ at NLVF-13S, $1.59 \mathrm{Lpm}(0.35 \mathrm{gpm})$ at NLVF-15, $1.82 \mathrm{Lpm}(0.40 \mathrm{gpm})$ at NLVF-16, and 2.95 Lpm (0.65 gpm) at NLVF-17.

A state-required Operations and Maintenance Manual for the NLVF groundwater dewatering system was completed in late 2006 (NSTec, 2006). This manual provides direction for the operation and maintenance of the dewatering wells and distribution network and facilitates compliance with the final NPDES permit. Topics addressed include roles and responsibilities, monitoring, reporting, records management, health and safety, and training.

Future project work plans include the installation of a permanent water distribution system. The long-range plan is to use the pumped water onsite for landscape irrigation, dust control, and possibly in existing cooling towers. 

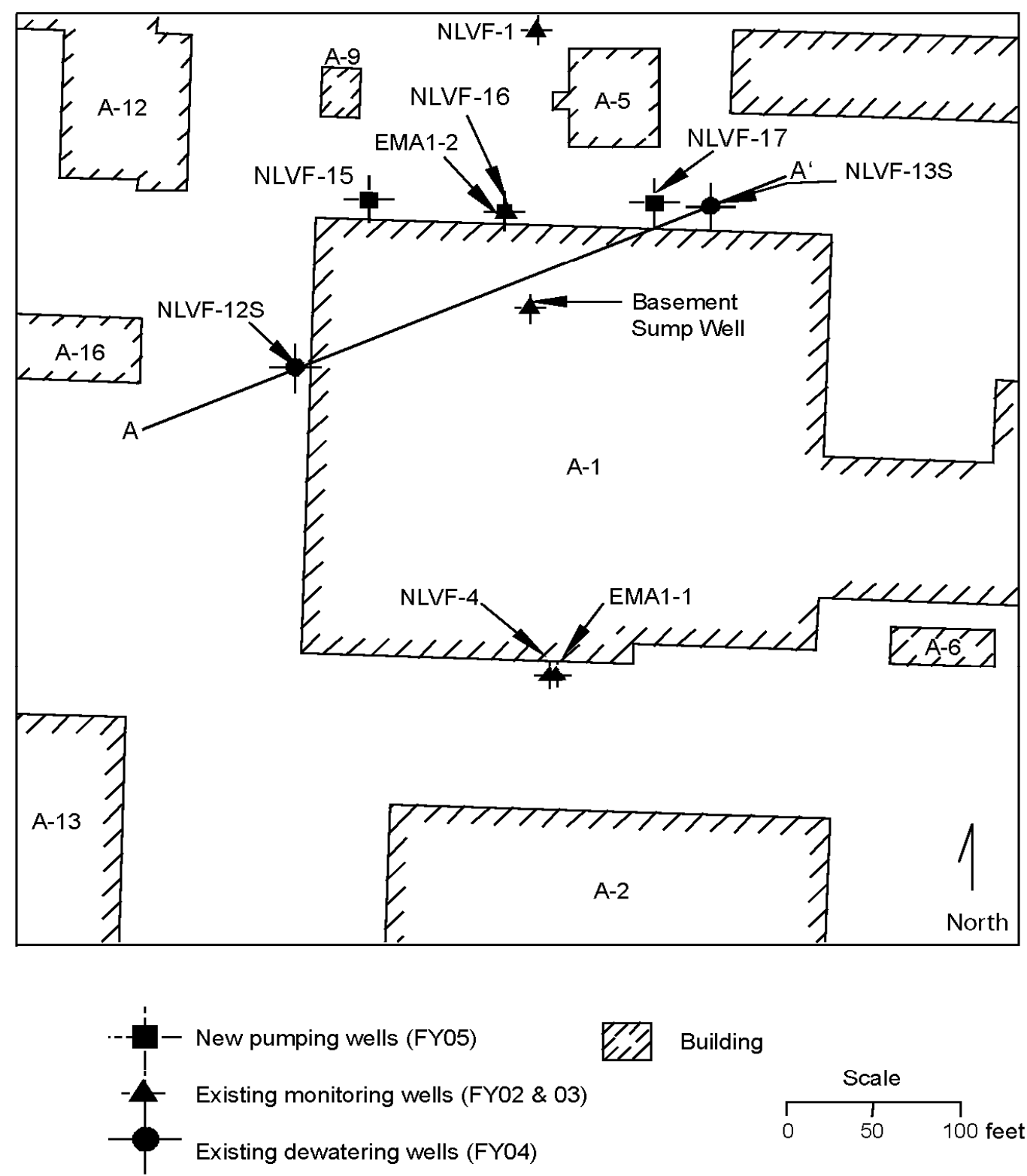

Building

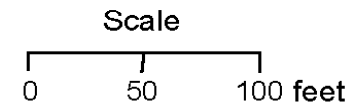

Figure A-2. Location of existing and new dewatering wells around Building A-1 


\section{A.1.2.3 Groundwater Monitoring}

Groundwater monitoring includes taking periodic water-level measurements at all accessible NLVF wells (including continuous measurements at the A-1 Basement Sump well), measuring the total volume of discharged groundwater, and conducting groundwater chemistry analyses quarterly and annually for the active dewatering wells. Under the temporary permits, composite water samples were collected periodically from selected dewatering wells and analyzed for tritium and for the standard field parameters of $\mathrm{pH}$, conductivity, temperature, and turbidity. The sample results were not required to be reported to the State, but were reported in previous NTS annual environmental reports (e.g., DOE, 2006b).

Under the final NDEPS permit, water samples will be collected periodically from the 10,500 gal storage tank and analyzed for a number of parameters as specified in Table A-4. Compliance sampling for this final NPDES permit begins in January 2007, and the first sampling results are due to NDEP at the end of the first quarter of 2007. Quarterly sampling will then be required for the duration of the NPDES permit. Additionally, the NPDES permit requires a very comprehensive analysis to be conducted bi-annually. The standardized list of analytes, presented as Appendix A of the NPDES permit, includes 46 base neutral extractables (e.g., dichlorobenzene, naphalene. diethylphthalate), 12 acid extractables (e.g., chlorophenol), 28 volatile organics (e.g., benzene, trichloro-ethene, carbon tetrachloride, toluene), 25 pesticides (e.g., Aldrin,

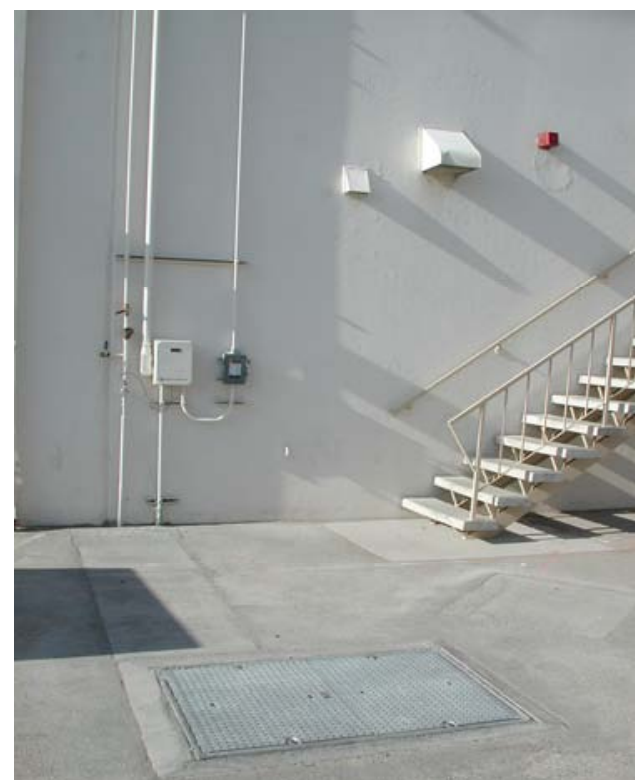

Figure A-3. Well NLVF-17 vicinity showing concrete pull box installed to ground level, completed utility trench from wellhead to Building A-1, wallmounted control box, and piping of the accumulation system.

(Photo by S. L. Drellack, August 9, 2006)

Chlordane, Endosulfan), dioxin, 13 metals (e.g., arsenic, lead, mercury), cyanide, and asbestos.

Though not required, water samples were collected in September 2006 from the storage tank and analyzed for metals, total dissolved solids (TDS), tritium, volatile organics, and $\mathrm{pH}$. These results were used to compare regulatory permit limits of these parameters with their levels in groundwater from the dewatering well system. All of the parameters analyzed in the September 2006 water samples from the 10,500 gal storage tank were either non-detectable or below permit limits (Table A-4).

The pumping rate at the dewatering wells varies from $3.2 \mathrm{Lpm}(0.85 \mathrm{gpm})$ at NLVF-13S to $1.5 \mathrm{Lpm}$ (0.4 gpm) at NLVF-16. The average combined discharge from all four dewatering wells is about $277,440 \mathrm{~L}(73,300 \mathrm{gal})$ per month. The total quantity of water produced/discharged was reported quarterly to the NDEP, Bureau of Water Pollution Control in Carson City, Nevada. Groundwater monitoring data are reported in the 2006 dewatering initiative report (NSTec, 2006) and are used to help

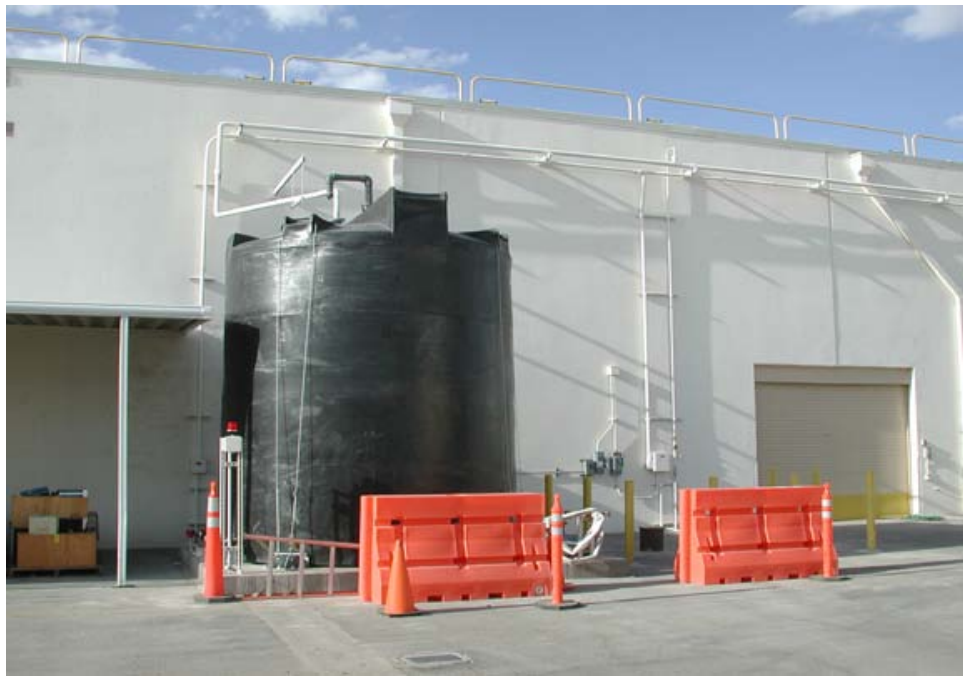

Figure A-4. Storage tank used to hold discharge water from the active dewatering wells on the north side of Building A-1. (Photo by S. L. Drellack, August 9, 2006)

characterize the groundwater. The presence or absence of particular constituents, or overall chemical signature, could suggest or confirm source(s) of the rising near-surface groundwater. In 2006, all sampled well waters met the Safe Drinking Water Standards (Table A-4). These analyses were as expected and compare well with previous sampling events. Water monitoring data are maintained in the Bechtel Environmental Integrated Data Management System database. 
Table A-4. NPDES Permit NV0023507 monitoring requirements and 2006 preliminary sampling results

\begin{tabular}{|c|c|c|c|c|}
\hline \multirow[b]{2}{*}{ Parameter } & \multirow{2}{*}{$\begin{array}{c}\text { Permit Discharge } \\
\text { Limits/Requirements }\end{array}$} & \multirow{2}{*}{$\begin{array}{c}\text { Sample } \\
\text { Results } \\
9 / 19 / 2006\end{array}$} & \multicolumn{2}{|c|}{ Monitoring Requirements } \\
\hline & & & $\begin{array}{c}\text { Sample } \\
\text { Frequency }\end{array}$ & $\begin{array}{c}\text { Sample } \\
\text { Type }\end{array}$ \\
\hline Daily Maximum Flow (MGD) (a) & 0.005184 & 0.002473 & Continuous & Flow Meter \\
\hline $\begin{array}{l}\text { Total Petroleum Hydrocarbons } \\
(\mathrm{mg} / \mathrm{L})\end{array}$ & 1.0 & $\mathrm{ND}^{(\mathrm{b})}$ & $\begin{array}{c}\text { Annually } \\
\left(4^{\text {th }} \text { Quarter }\right)\end{array}$ & Discrete \\
\hline Total Suspended Solids (mg/L) & 135 & ND & Quarterly & Discrete \\
\hline Total Dissolved Solids (mg/L) & 1900 & 582 & Quarterly & Discrete \\
\hline Total Inorganic Nitrogen as N (mg/L) & 20.0 & 1.1 & Quarterly & Discrete \\
\hline pH (S.U.) & $6.5-9.0$ & 8.47 & Quarterly & Discrete \\
\hline Tritium (pCi/L) & 20,000 & ND & $\begin{array}{c}\text { Annually } \\
\left(4^{\text {th }} \text { Quarter }\right)\end{array}$ & Discrete \\
\hline Metals (mg/L): & & & Bi-Annually & Discrete \\
\hline Ag & 0.05 & ND & & \\
\hline As & $\mathrm{MR}^{(\mathrm{c})}$ & 0.0129 & & \\
\hline $\mathrm{Be}$ & MR & 0.00016 & & \\
\hline Cd & 0.01 & 0.0013 & & \\
\hline $\mathrm{Cr}$ & 0.05 & ND & & \\
\hline $\mathrm{Cu}$ & 1.0 & 0.101 & & \\
\hline $\mathrm{Hg}$ & 0.002 & ND & & \\
\hline $\mathbf{N i}$ & MR & 0.0039 & & \\
\hline $\mathbf{P b}$ & 0.05 & 0.0019 & & \\
\hline $\mathrm{Sb}$ & MR & ND & & \\
\hline Se & MR & 0.0063 & & \\
\hline Th & MR & ND & & \\
\hline Zn & 5.0 & 0.0156 & & \\
\hline Permit Appendix A Analytes (mg/L): & & & Bi-Annually & Discrete \\
\hline Volatile Organics & MR & ND & & \\
\hline Pesticides/PCBs & MR & ND & & \\
\hline Acid Extractables & MR & ND & & \\
\hline Base Neutral Extractables & MR & ND & & \\
\hline Dioxins & $\mathrm{MR}$ & ND & & \\
\hline Asbestos & MR & ND & & \\
\hline
\end{tabular}

(a) $\mathrm{MGD}=$ million gallons per day

(b) $\mathrm{ND}=$ not detected

(c) $\mathrm{MR}=$ monitor and report

\section{A.1.2.4 Building A-1 Sump Well}

During 2001, a sump well was installed in the basement of Building A-1 and used in remediation operations. The discharge water was disposed of at the NTS. The sump well was turned off after the remedial operations were completed. However, beginning in early 2003, the sump well has been used intermittently to help control the encroaching water below Building A-1. Because this water contains some residual tritium $(1,900 \mathrm{pCi} / \mathrm{L}$, or about one 
tenth of the Safe Drinking Water Act limits of 20,000 pCi/L), it is kept separate with its own disposal process. The discharge is transported to the NTS during the winter, but during the warm months, the discharge is evaporated with an exterior array of evaporative units on the north side of Building A-1. In 2006, about 37,854 to 60,566 L (10,000 to $16,000 \mathrm{gal})$ were transported monthly to the NTS for disposal during the winter and about 30,283 to 94,635 L (8,000 to 25,000 gal) were evaporated at the NLVF during the summer months.

\section{A.1.3 Compliance with Air Quality Permits}

Sources of air pollutants at the NLVF are regulated by the Facility 657 Authority to Construct/Operating Permit for the emission of criteria pollutants (see Glossary, Appendix B) and hazardous air pollutants (HAPs). They include sulfur dioxide $\left(\mathrm{SO}_{2}\right)$, nitrogen oxide $(\mathrm{NO})$, carbon monoxide $(\mathrm{CO})$, particulate matter $(\mathrm{PM})$, volatile organic compounds (VOCs), and any of 189 defined HAPs. The regulated sources of emissions at the NLVF include an aluminum sander, an abrasive blaster, emergency generators, and a spray paint booth. There are no monitoring requirements associated with the permit. An application to modify the Facility 657 permit by adding three new diesel generators was submitted to Clark County at the end of 2006. The Clark County Department of Air Quality and Environmental Management (DAQEM) requires submittal of an annual emissions inventory. The emissions inventory for 2006 was submitted to DAQEM on March 21, 2007. The estimated quantities of criteria air pollutants and HAPs emitted in 2006 are shown in Table A-5.

Table A-5. Tons of criteria air pollutant and HAPs emissions estimated for NLVF in 2006

\begin{tabular}{|c|c|c|c|c|c|}
\hline \multicolumn{5}{|c|}{ Criteria Pollutant (Tons/yr) } & \multirow{2}{*}{$\begin{array}{c}\text { HAPs } \\
\text { (Tons/yr) }\end{array}$} \\
\hline $\mathrm{CO}$ & $\mathrm{NO}_{x}$ & PM10 $^{(b)}$ & $\mathrm{SO}_{2}$ & VOC & \\
\hline 0.056 & 0.237 & 0.022 & 0.016 & 0.019 & 0.001 \\
\hline \multicolumn{6}{|c|}{ Total Emissions $=0.351$} \\
\hline
\end{tabular}

(a) 1 ton equals 0.91 metric tons

(b) Particulate matter equal to or less than 10 microns in diameter

\section{A.1.4 Compliance with Hazardous Materials Regulations}

In 2006, the chemical inventory at NLVF was updated and submitted to the state in the Nevada Combined Agency (NCA) Report on February 22, 2006, as per the requirements of the Hazardous Materials Permit 2287-5144 (see Section 2.5, Emergency Planning and Community Right-to-Know Act for description of content, purpose, and federal regulatory driver behind the NCA Report). No accidental or unplanned release of an extremely hazardous substance (EHS) occurred at NLVF in 2006. Also, no annual usage quantities of toxic chemicals kept at NLVF exceeded specified thresholds (see Section 2.5 concerning Toxic Chemical Release Inventory, Form R).

\section{A.1.5 Compliance with Radiation Protection Regulations}

\section{A.1.5.1 National Emission Standards for Hazardous Air Pollutants (NESHAP)}

The Clean Air Act, Title 40 Code of Federal Regulations (CFR) 61, Subpart H (NESHAP) requires managers of DOE facilities to perform an assessment of all radionuclide air emissions caused by their operations and to estimate the radiation dose that a member of the public could receive from them. NESHAP establishes a dose limit for the general public to be no greater than 10 millirems per year (mrem/yr). Building A-1's basement was contaminated with tritium in 1995 when a container of tritium foils was opened, emitting about 1 Curie of tritium (DOE, 1996b). Complete cleanup of the tritium was unsuccessful due to the tritium being absorbed into the building materials. This has resulted in a continuous but decreasing release of tritium into the basement air space, which is ventilated to the outdoors. Since 1995, a dose assessment has been performed every year for this building. One air sample was 
collected from the basement in 2006 (from September 12 to September 19). As in previous years, the calculated radiation dose to the nearest member of the general public, located $100 \mathrm{~m}$ northwest of the building vent pipe, was less than $0.002 \mathrm{mrem} / \mathrm{yr}$.

\section{A.1.5.2 DOE Order 5400.5}

DOE Order 5400.5, Radiation Protection of the Public and the Environment, specifies that the radiological dose to a member of the public from radiation from all pathways must not exceed the $100 \mathrm{mrem} / \mathrm{yr}$ as a result of DOE activities. This dose limit does not include the dose contribution from natural background radiation. The facilities at NLVF which use radioactive sources or where radiation-producing operations are conducted which have the potential to expose the general population or non-project personnel to direct radiation are the Atlas A-1 Source Range Laboratory and the Building C-3 High Intensity Source Building. NSTec's Environmental Technical Services (ETS) conducts direct radiation monitoring at the site. ETS utilizes thermoluminescent dosimeters (TLDs) to monitor external gamma radiation exposure near the boundaries of these NLVF facilities. The methods of TLD use and data analyses are described in Section 5.0 of this report.

In 2006, radiation exposure was measured at two locations along the perimeter fence and at one control location. Annual exposure rates estimated from measurements at those NLVF locations are summarized in Table A-6. These exposures include contributions from background radiation and were all less than $100 \mathrm{mrem} / \mathrm{yr}$.

Table A-6. Results of 2006 direct radiation exposure monitoring at NLVF

\begin{tabular}{||lccccc||}
\hline & & \multicolumn{4}{c||}{ Gamma Exposure (milliroentgens per year [mR/yr]) } \\
\cline { 3 - 6 } \multicolumn{1}{c}{ Location } & $\begin{array}{c}\text { Number of } \\
\text { Samples }\end{array}$ & Mean & Median & Minimum & Maximum \\
\hline Control & 4 & 70 & 69 & 64 & 78 \\
North Fence of Building A-1 & 4 & 64 & 63 & 61 & 69 \\
North Fence of Building C-3 & 4 & 64 & 64 & 60 & 69 \\
\hline \hline
\end{tabular}

\section{A.2 Cheyenne Las Vegas Facility}

The CLVF is located at the Flynn Gallagher Corporate Center on West Cheyenne Avenue in northwest Las Vegas. It is comprised of five buildings which house engineering, procurement, and administrative functions. Access to the facility requires proper identification, badging, and a security access card. Facility and infrastructure maintenance is provided by the facility owner. No environmental monitoring or compliance activities are conducted at or for this facility.

\section{A.3 Remote Sensing Laboratory-Nellis}

RSL-Nellis is approximately 13.7 kilometers $(\mathrm{km})$ (8.5 miles [mi]) northeast of the Las Vegas city center, and approximately $11.3 \mathrm{~km}(7 \mathrm{mi})$ northeast of NLVF. It occupies six facilities on approximately 14 secured hectares (35 acres) at the Nellis Air Force Base. The six NNSA/NSO facilities were constructed on property owned by the U.S. Air Force (USAF). There is a Memorandum of Agreement between the USAF and the NNSA/NSO whereby the land belongs to the USAF, but is under lease to the NNSA/NSO for 25 years (as of 1989) with an option for a 25-year extension. The facilities are owned by NNSA/NSO. RSL-Nellis provides emergency response resources for weapons-of-mass-destruction incidents. The laboratory also designs and field tests counter-terrorism/intelligence technologies and has the capability to assess environmental and facility conditions using complex radiation measurements and multi-spectral imaging technologies.

Environmental compliance and monitoring activities at RSL-Nellis in 2006 included maintenance of a wastewater contribution permit, an air quality permit, and a hazardous materials permit (Table A-7). Sealed radiation sources are used for calibration at RSL-Nellis, but the public has no access to any area which may have elevated gamma radiation 
emitted by the sources. Therefore, no environmental TLD monitoring is conducted. However, dosimetry monitoring to ensure protection of personnel who work within the facility is performed.

Table A-7. Environmental permits for RSL-Nellis in 2006

\begin{tabular}{|c|c|c|c|}
\hline Permit Number & Description & Expiration Date & Reporting \\
\hline \multicolumn{4}{|l|}{ Wastewater Discharge } \\
\hline CCWRD-080 & Industrial Wastewater Discharge Permit & June 30, 2007 & $\begin{array}{c}\text { March, May, } \\
\text { September, December }\end{array}$ \\
\hline \multicolumn{4}{|l|}{ Air Quality } \\
\hline Facility 348, Mod. 2 & $\begin{array}{l}\text { Clark County Authority to } \\
\text { Construct/Operating Permit for a } \\
\text { Testing Laboratory }\end{array}$ & None & March \\
\hline \multicolumn{4}{|l|}{ Hazardous Materials } \\
\hline $2287-5145$ & RSL-Nellis Hazardous Materials Permit & February 28, 2007 & Annually \\
\hline \multicolumn{4}{|l|}{ Waste Management } \\
\hline U1576-33N-01 & $\begin{array}{l}\text { RSL-Nellis Waste Management Permit- } \\
\text { Underground Storage Tank }\end{array}$ & December 31, 2006 & None \\
\hline
\end{tabular}

\section{A.3.1 Compliance with Wastewater Contribution Permit CCWRD-080}

Discharges of wastewater from RSL-Nellis are required to meet permit limits set by the Clark County Water Reclamation District (CCWRD). These limits support the permit limits for the POTW operated by Clark County. The wastewater permit for this facility requires quarterly monitoring and reporting. Table A- 8 presents the mean concentration of outfall measurements collected once per quarter in 2006. All contaminants in the outfall samples were below permit limits. Quarterly reports were submitted on March 6, May 11, August 8, and December 11, 2006, to the CCWRD. The CCWRD also conducted two inspections of RSL-Nellis in 2006. The inspections resulted in no findings or corrective actions for the facility.

Table A-8. Mean concentration of outfall measurements at RSL-Nellis in 2006

\begin{tabular}{|c|c|c|}
\hline Contaminant/Measure & Permit Limit & Outfall \\
\hline & \multicolumn{2}{|c|}{$\mathrm{mg} / \mathrm{L}$} \\
\hline Ammonia & $\mathrm{NL}^{(a)}$ & 11.08 \\
\hline Cadmium & 0.35 & 0.0010 \\
\hline Chromium (Total) & 1.7 & 0.0029 \\
\hline Copper & 3.36 & 0.304 \\
\hline Cyanide (Total) & 1 & 0.0816 \\
\hline Lead & 0.99 & 0.0038 \\
\hline Nickel & 10.08 & 0.0072 \\
\hline Phosphorus & NL & 3.21 \\
\hline Silver & 6.3 & 0.0081 \\
\hline TDS & NL & 1,293 \\
\hline TSS & NL & 162.28 \\
\hline \multirow[t]{2}{*}{ Zinc } & 23.06 & 0.612 \\
\hline & \multicolumn{2}{|c|}{ Standard Units } \\
\hline \multirow[t]{2}{*}{$\mathrm{pH}$} & $5.0-11.0$ & $5.0-11.0$ \\
\hline & \multicolumn{2}{|c|}{ Degrees Fahrenheit } \\
\hline Temperature & 140 & 140 \\
\hline
\end{tabular}

(a) No limit listed on permit 


\section{A.3.2 Compliance with Air Quality Permits}

Sources of air pollutants at RSL-Nellis are regulated by the Facility 348 Authority to Construct/Operating Permit for the emission of criteria pollutants and HAPs (see Glossary, Appendix B). The regulated sources include boilers, water heaters, emergency generators, a spray paint booth, and a vapor degreaser. There are no monitoring requirements associated with the permit. In mid 2006, a permit modification application was submitted to the DAQEM to remove a boiler and large water heater, replacing the latter with two smaller water heaters, and increasing the testing and maintenance hours for two permitted emergency generators. The modified permit was issued in January 2007. The DAQEM requires submittal of the annual emissions inventory. The estimated quantities of criteria air pollutants and HAPs emitted at RSL-Nellis in 2006 are presented in Table A-9. Natural gas consumption is also reported as per the requirements of the consolidated air permit issued for RSL-Nellis. The emissions inventory for 2006 was submitted to DAQEM on March 21, 2007.

Table A-9. Summary of air emissions for RSL-Nellis in 2006

\begin{tabular}{|c|c|c|c|c|c|c|}
\hline \multicolumn{5}{|c|}{ Criteria Pollutant (Tons/yr)(a) } & \multirow{2}{*}{$\begin{array}{c}\text { HAPs } \\
\text { (Tons/yr) }\end{array}$} & \multirow{2}{*}{$\begin{array}{c}\text { Natural Gas } \\
\text { Consumption }\left(\mathrm{ft}^{3}\right) \\
\end{array}$} \\
\hline $\mathrm{CO}$ & $\mathrm{NO}_{x}$ & PM10 $^{(\mathrm{b})}$ & $\mathrm{SO}_{2}$ & VOC & & \\
\hline 0.0637 & 0.261 & 0.013 & 0.010 & 0.032 & 0.003 & $3,213,100$ \\
\hline \multicolumn{6}{|c|}{ Total Emissions of Pollutants $=0.383$} & \\
\hline
\end{tabular}

(a) 1 ton equals 0.91 metric tons

(b) Particulate matter equal to or less than 10 microns in diameter

(c) Cubic feet

\section{A.3.3 Compliance with Hazardous Materials Regulations}

In 2006, the chemical inventory at RSL-Nellis was updated and submitted to the state in the NCA Report on February 23, 2007, as per the requirements of the Hazardous Materials Permit 2287-5145 (see Section 2.5 of this report for description of content, purpose, and federal regulatory driver behind the NCA Report). No accidental or unplanned release of an EHS occurred at RSL-Nellis in 2006. Also, no annual usage quantities of toxic chemicals kept at RSL-Nellis exceeded specified thresholds (see Section 2.5 concerning Toxic Chemical Release Inventory, Form R).

\section{A.3.4 Compliance with Waste Management Regulations}

The underground storage tank program at RSL-Nellis consists of two active permitted tanks (gasoline/diesel fuel), one inactive tank (empty used oil tank), one deferred tank (as per 40 Code of Federal Regulations 280.10(d)) for emergency power generation, and three unregulated tanks. The permitted and deferred tanks are located at Building 2211. The fuel tanks were retrofitted with spill/overflow protection in 1998. They are inspected annually by the Southern Nevada Health District. No deficiencies were noted during the 2006 health district's inspection at RSLNellis. 


\section{Appendix B: Glossary of Terms}

A Absorbed dose: the amount of energy imparted to matter by ionizing radiation per unit mass of irradiated material, in which the absorbed dose is expressed in units of rad or gray (1 rad equals 0.01 gray).

Accuracy: the closeness of the result of a measurement to the true value of the quantity measured.

Action level: defined by regulatory agencies, the level of pollutants which, if exceeded, requires regulatory action.

Aerosol: a gaseous suspension of very small particles of liquid or solid.

Alluvium: a sediment deposited by flowing water.

Alpha particle: a positively charged particle emitted from the nucleus of an atom, having mass and charge equal to those of a helium nucleus (two protons and two neutrons), usually emitted by transuranic elements.

Ambient air: the surrounding atmosphere, usually the outside air, as it exists around people, plants, and structures; not considered in monitoring purposes when immediately adjacent to emission sources.

Analyte: the specific component measured in a chemical analysis.

Anion: a negatively charged ion, such as $\mathrm{Cl}^{-}$.

Aquifer: a saturated layer of rock or soil below the ground surface that can supply usable quantities of ground water to wells and springs, and be a source of water for domestic, agricultural, and industrial uses.

Aquitard: a low-permeability geologic formation that bounds an aquifer.

Atom: the smallest particle of an element capable of entering into a chemical reaction.

B Background: as used in this report, background is the term for the amounts of chemical constituents or radioactivity in the environment which are not caused by Nevada Test Site operations.

Becquerel (Bq): the Système International d'Unités unit of activity of a radionuclide, equal to the activity of a radionuclide having one spontaneous nuclear transition per second.

Beta particle: a negatively charged particle emitted from the nucleus of an atom, having charge, mass, and other properties of an electron, emitted from fission products such as ${ }^{137} \mathrm{Cs}$.

Biochemical (biological) oxygen demand (BOD): a measure of the amount of dissolved oxygen that microorganisms need to break down organic matter in water; used as an indicator of water quality.

C CAP88-PC: a computer code required by the U.S. Environmental Protection Agency for modeling air emissions of radionuclides.

Chain-of-custody: a method for documenting the history and possession of a sample from the time of its collection through its analysis and data reporting to its final disposition.

Code of Federal Regulations (CFR): a codification of all regulations promulgated by federal government agencies.

Collective population dose: the sum of the total effective dose equivalents of all individuals within a defined population. The unit of collective population dose is person-rem or person-sievert. Collective population dose may also be referred to as "collective effective dose equivalent" or simply "population dose." 
Committed dose equivalent: the dose equivalent to a tissue or organ over a 50-year period after an intake of a radionuclide into the body. Committed dose equivalent is expressed in units of rem or sievert.

Committed effective dose equivalent: the sum of the committed dose equivalents to various tissues in the body, each multiplied by an appropriate weighting factor representing the relative vulnerability of different parts of the body to radiation. Committed effective dose equivalent is expressed in units of rem or sievert.

Compliance Level (CL): stands for the Clean Air Act National Emission Standards for Hazardous Air Pollutants Concentration Level for Environmental Compliance. The CL value represents the annual average concentration which would result in a dose of 10 millirem per year, which is the federal dose limit to the public from all radioactive air emissions.

Cosmic radiation: radiation with very high energies originating outside the earth's atmosphere; it is one source contributing to natural background radiation.

Criteria pollutants: those air pollutants designated by the U.S. Environmental Protection Agency as potentially harmful and for which National Ambient Air Quality Standards under the Clean Air Act have been established to protect the public health and welfare. These pollutants include sulfur dioxide $\left(\mathrm{SO}_{2}\right)$, nitrogen oxides $\left(\mathrm{NO}_{\mathrm{x}}\right)$, carbon monoxide (CO), ozone, lead, and particulate matter equal to or less than 10 microns in diameter (PM10). The state of Nevada, through an air quality permit, establishes emission limits on the Nevada Test Site for $\mathrm{SO}_{2}$, $\mathrm{NO}_{\mathrm{x}}, \mathrm{CO}, \mathrm{PM10}$, and volatile organic compounds (VOCs). Ozone is not regulated by the permit as an emission as it is formed in part from $\mathrm{NO}_{\mathrm{X}}$ and VOCs. Lead is considered a hazardous air pollutant (HAP) as well as a criteria pollutant, and lead emissions on the Nevada Test Site are reported as part of the total HAP emissions. Lead emissions above a specified threshold are also reported under Section 313 of the Emergency Planning and Community Right-to-Know Act.

Curie (Ci): a unit of measurement of radioactivity, defined as the amount of radioactive material in which the decay rate is $3.7 \times 10^{10}$ disintegrations per second or $2.22 \times 10^{12}$ disintegrations per minute; one $\mathrm{Ci}$ is approximately equal to the decay rate of one gram of pure radium.

D Daughter nuclide: a nuclide formed by the radioactive decay of another nuclide, which is called the parent.

Decision level: the counts of radioactivity (or concentration level of a radionuclide) in a sample that must be exceeded before there is a specified level of confidence (typically 95 or 99 percent) that the sample contains radioactive material above the background; also known as the Critical Level $\left(\mathrm{L}_{\mathrm{C}}\right)$.

Depleted uranium: uranium having a lower proportion of the isotope ${ }^{235} \mathrm{U}$ than is found in naturally-occurring uranium. The masses of the three uranium isotopes with atomic weights 238, 235, and 234 occur in depleted uranium in the weight-percentages 99.8, 0.2, and $5 \times 10^{-4}$, respectively; see Table 3-7 and related discussion.

Derived Concentration Guide (DCG): concentrations of radionuclides in water and air that could be continuously consumed or inhaled for one year and not exceed the U.S. Department of Energy primary radiation dose limit to the public of 100 millirem per year effective dose equivalent.

Dose: the energy imparted to matter by ionizing radiation; the unit of absorbed dose is the rad, equal to 0.01 joules per kilogram for irradiated material in any medium.

Dose commitment: the dose that an organ or tissue would receive during a specified period of time (typically 50 or 70 years) as a result of one year's intake of one or more radionuclides.

Dose equivalent: the product of absorbed dose in rad (or gray) in tissue and a quality factor representing the relative damage caused to living tissue by different kinds of radiation, and perhaps other modifying factors representing the distribution of radiation, etc., expressed in units of rem or sievert.

Dosimeter: a portable detection device for measuring the total accumulated exposure to ionizing radiation. 
Dosimetry: the theory and application of the principles and techniques of measuring and recording radiation doses.

Downgradient: in the direction of groundwater flow from a designated area; analogous to downstream.

E Effective dose equivalent (EDE): an estimate of the total risk of potential effects from radiation exposure; it is the summation of the products of the dose equivalent and weighting factor for each tissue. The weighting factor is the decimal fraction of the risk arising from irradiation of a selected tissue to the total risk when the whole body is irradiated uniformly to the same dose equivalent. These factors permit dose equivalents from non-uniform exposure of the body to be expressed in terms of an EDE that is numerically equal to the dose from a uniform exposure of the whole body that entails the same risk as the internal exposure. The EDE includes the committed effective dose equivalent from internal deposition of radionuclides and the EDE caused by penetrating radiation from sources external to the body, and is expressed in units of rem or sievert.

Effluent: used in this report to refer to a liquid discharged to the environment.

Emission: used in this report to refer to a vapor, gas, airborne particulate, or radiation discharged to the environment via the air.

Environmental Impact Statement (EIS): a detailed report, required by the National Environmental Policy Act, on the environmental impacts from a federally-approved or funded project. An EIS must be prepared by a federal agency when a "major" federal action that will have "significant" environmental impacts is planned.

F Federal facility: a facility that is owned or operated by the federal government, subject to the same requirements as other responsible parties when placed on the Superfund National Priorities List.

Federal Facility Agreement (FFA): a negotiated agreement that specifies required actions at a federal facility as agreed upon by various agencies (e.g., U.S. Environmental Protection Agency, U.S. Department of Energy, U.S. Department of Defense).

Federal Register: a document published daily by the federal government containing notification of government agency actions, including notification of U.S. Environmental Protection Agency and U.S. Department of Energy decisions concerning permit applications and rule-making.

Fiscal year: the National Nuclear Security Agency Nevada Site Office's fiscal year is from October 1 through September 30.

G Gamma ray: high-energy, short-wavelength, electromagnetic radiation emitted from the nucleus of an atom, frequently accompanying the emission of alpha or beta particles.

Gray (Gy): the Système International d'Unités unit of measure for absorbed dose; the quantity of energy imparted by ionizing radiation to a unit mass of matter, such as tissue. One gray equals 100 rads, or 1 joule per kilogram.

Gross alpha: the measure of radioactivity caused by all radionuclides present in a sample which emit alpha particles. Gross alpha measurements reflect alpha activity from all sources, including those that occur naturally. Gross measurements are used as a method to screen samples for relative levels of radioactivity.

Gross beta: the measure of radioactivity caused by all radionuclides present in a sample which emit beta particles. Gross beta measurements reflect beta activity from all sources, including those that occur naturally. Gross measurements are used as a method to screen samples for relative levels of radioactivity.

Groundwater: all subsurface water. 
H Half-life: the time required for one-half the radioactive atoms in a given amount of material to decay; for example, after one half-life, half of the atoms will have decayed; after two half-lives, three-fourths; after three half-lives, seven-eighths; and so on, exponentially.

Hazardous waste: hazardous wastes exhibit any of the following characteristics: ignitability, corrosivity, reactivity, or Extraction Procedure toxicity (yielding excessive levels of toxic constituents in a leaching test), but other wastes that do not necessarily exhibit these characteristics have been determined to be hazardous by the U.S. Environmental Protection Agency (EPA). Although the legal definition of hazardous waste is complex, according to EPA, the term generally refers to any waste that, if managed improperly, could pose a threat to human health and the environment.

High-efficiency particulate air filter (HEPA): a throwaway, extended-media, dry-type filter used to capture particulates in an air stream; HEPA collection efficiencies are at least 99.97 percent for 0.3 -micrometer diameter particles.

Hydraulic gradient: in an aquifer, the rate of change of total head (water-level elevation) per unit distance of flow at a given point and in a given direction.

Hydrology: the science dealing with the properties, distribution, and circulation of natural water systems.

I Inorganic compounds: compounds that either do not contain carbon or do not contain hydrogen along with carbon, including metals, salts, various carbon oxides (e.g., carbon monoxide and carbon dioxide), and cyanide.

In situ: in the natural or original position. Generally refers to measurements taken in the environment or to the treatment of contaminated areas in place without excavation or removal.

Instrument detection limit (IDL): the lowest concentration that can be detected by an instrument without correction for the effects of sample matrix or method-specific parameters such as sample preparation. IDLs are explicitly determined and generally defined as three times the standard deviation of the mean noise level. This represents 99 percent confidence that the signal is not random noise.

Interim status: a legal classification allowing hazardous waste incinerators or other hazardous waste management facilities to operate while EPA considers their permit applications, provided that they were under construction or in operation by November 19, 1980, and can meet other interim status requirements.

Isotopes: forms of an element having the same number of protons in their nuclei, but differing numbers of neutrons.

L Less than detection limits: a phrase indicating that a chemical constituent or radionuclide was either not present in a sample, or is present in such a small concentration that it cannot be measured as significantly different from zero by a laboratory's analytical procedure and, therefore, is not identified at the lowest level of sensitivity.

Low-level radioactive waste (LLW): waste defined by U.S. Department of Energy Order 5820.2A, which contains transuranic nuclide concentrations less than 100 nanocuries per gram.

Lower limit of detection: the smallest concentration or amount of analyte that can be detected in a sample at a 95-percent confidence level.

Lysimeter: an instrument for measuring the water percolating through soils and determining the dissolved materials.

M Maximally exposed individual (MEI): a hypothetical member of the public at a fixed location who, over an entire year, receives the maximum effective dose equivalent (summed over all pathways) from a given source of radionuclide releases to air. Generally, the MEI is different for each source at a site.

Maximum contaminant level (MCL): the highest level of a contaminant in drinking water that is allowed by U.S. Environmental Protection Agency regulation. 
Minimum detectable concentration (MDC): also known as the lower limit of detection, the smallest amount of radioactive material in a sample that can be quantitatively distinguished from background radiation in the sample with 95 percent confidence.

Metric units: metric units, U.S. customary units, and their respective equivalents are shown in Table C-6. Except for temperature for which specific equations apply, U.S. customary units can be determined from metric units by multiplying the metric units by the U.S. customary equivalent. Similarly, metric units can be determined from U.S. customary equivalent units by multiplying the U.S. customary units by the metric equivalent.

Mixed waste (MW): waste that has the properties of both hazardous and radioactive waste.

N National Emission Standards for Hazardous Air Pollutants (NESHAPs): standards found in the Clean Air Act that set limits for hazardous air pollutants.

National Pollutant Discharge Elimination System (NPDES): a federal regulation under the Clean Water Act that requires permits for discharges into surface waterways.

Non-point source: any nonconfined area from which pollutants are discharged into a body of water (e.g., agricultural runoff, construction runoff, and parking lot drainage), or into air (e.g., a pile of uranium tailings).

O Offsite: for effluent releases or in the nuclear testing area, any place outside the Nevada Test Site and adjacent Nevada Test and Training Range.

Onsite: for effluent releases or in the nuclear testing area, any place inside the Nevada Test Site and adjacent Nevada Test and Training Range.

P Part B Permit: the second, narrative section submitted by generators in the Resource Conservation and Recovery Act permitting process that covers in detail the procedures followed at a facility to protect human health and the environment.

Parts per billion (ppb): a unit of measure for the concentration of a substance in its surrounding medium; for example, one billion grams of water containing one gram of salt has a salt concentration of $1 \mathrm{ppb}$.

Parts per million (ppm): a unit of measure for the concentration of a substance in its surrounding medium; for example, one million grams of water containing one gram of salt has a salt concentration of $1 \mathrm{ppm}$.

Perched aquifer: an aquifer that is separated from another water-bearing stratum by an impermeable layer.

Performance standards (incinerators): specific regulatory requirements established by the U.S. Environmental Protection Agency limiting the concentrations of designated organic compounds, particulate matter, and hydrogen chloride in incinerator emissions.

pH: a measure of hydrogen ion concentration in an aqueous solution. Acidic solutions have a $\mathrm{pH}$ from 0 to 7 ; basic solutions have a $\mathrm{pH}$ greater than 7; and neutral solutions have a $\mathrm{pH}$ of 7.

Pliocene: a geological epoch of the Tertiary period, starting about 12 million years ago.

PM-10: a fine particulate matter with an aerodynamic diameter equal to or less than 10 microns.

Point source: any confined and discrete conveyance (e.g., pipe, ditch, well, or stack).

Q Quality assurance (QA): a system of activities whose purpose is to provide the assurance that standards of quality are attained with a stated level of confidence.

Quality control (QC): procedures used to verify that prescribed standards of performance are attained. 
Quality factor: the factor by which the absorbed dose ( $\mathrm{rad}$ ) is multiplied to obtain a quantity that expresses (on a common scale for all ionizing radiation) the biological damage to exposed persons, usually used because some types of radiation, such as alpha particles, are biologically more damaging than others. Quality factors for alpha, beta, and gamma radiation are in the ratio 20:1:1.

Quaternary: the geologic era encompassing the last 2-3 million years.

R Rad: the unit of absorbed dose and the quantity of energy imparted by ionizing radiation to a unit mass of matter such as tissue; equal to 0.01 joule per kilogram, or 0.01 gray.

Radioactive decay: the spontaneous transformation of one radionuclide into a different nuclide (which may or may not be radioactive), or de-excitation to a lower energy state of the nucleus by emission of nuclear radiation, primarily alpha or beta particles, or gamma rays (photons).

Radioactivity: the spontaneous emission of nuclear radiation, generally alpha or beta particles, or gamma rays, from the nucleus of an unstable isotope.

Radionuclide: an unstable nuclide. See nuclide and radioactivity.

Rem: a unit of radiation dose equivalent and effective dose equivalent describing the effectiveness of a type of radiation to produce biological effects; coined from the phrase "roentgen equivalent man," and the product of the absorbed dose $(\mathrm{rad})$, a quality factor $(\mathrm{Q})$, a distribution factor, and other necessary modifying factors. One rem equals 0.01 sievert.

Risk assessment: the use of established methods to measure the risks posed by an activity or exposure by evaluating the relationship between exposure to radioactive substances and the subsequent occurrence of health effects and the likelihood for that exposure to occur.

Roentgen (R): a unit of measurement used to express radiation exposure in terms of the amount of ionization produced in a volume of air.

S Sanitary waste: most simply, waste generated by routine operations that is not regulated as hazardous or radioactive by state or federal agencies.

Saturated zone: a subsurface zone below which all rock pore-space is filled with water; also called the phreatic zone.

Sensitivity: the capability of methodology or instrumentation to discriminate between samples having differing concentrations or containing varying amounts of analyte.

Sievert (Sv): the Système International d'Unités unit of radiation dose equivalent and effective dose equivalent, that is the product of the absorbed dose (gray), quality factor $(\mathrm{Q})$, distribution factor, and other necessary modifying factors; $1 \mathrm{~Sv}$ equals 100 rem.

Source term: the amount of a specific pollutant emitted or discharged to a particular medium, such as the air or water, from a particular source.

Specific conductance: the measure of the ability of a material to conduct electricity; also called conductivity.

Subcritical experiment: an experiment using high explosives and nuclear weapon materials (including special nuclear materials like plutonium) to gain data used to maintain the nuclear stockpile without conducting nuclear explosions banned by the Comprehensive Test Ban Treaty.

Système International d'Unités (SI): an international system of physical units which include meter (length), kilogram (mass), kelvin (temperature), becquerel (radioactivity), gray (radioactive dose), and sievert (dose equivalent). 
T Thermoluminescent dosimeter (TLD): a device used to measure external beta or gamma radiation levels, and which contains a material that, after exposure to beta or gamma radiation, emits light when processed and heated.

Total dissolved solids (TDS): the portion of solid material in a waste stream that is dissolved and passed through a filter.

Total organic carbon (TOC): the sum of the organic material present in a sample.

Total organic halides (TOX): the sum of the organic halides present in a sample.

Total suspended solids (TSS): the total mass of particulate matter per unit volume suspended in water and wastewater discharges that is large enough to be collected by a 0.45 micron filter.

Transpiration: a process by which water is transferred from the soil to the air by plants that take the water up through their roots and release it through their leaves and other aboveground tissue.

Tritium: a radioactive isotope of hydrogen, containing one proton and two neutrons in its nucleus, which decays at a half-life of 12.3 years by emitting a low-energy beta particle.

Transuranic waste (TRU): material contaminated with alpha-emitting transuranium nuclides which have an atomic number greater than 92 (e.g., ${ }^{239} \mathrm{Pu}$ ), half-lives longer than 20 years, and are present in concentrations greater than $100 \mathrm{nCi} / \mathrm{g}$ of waste.

U Uncertainty: the parameter associated with a sample measurement that characterizes the range of the measurement that could reasonably be attributed to the sample. Used in this report, the uncertainty value is established at \pm 2 standard deviations.

Unsaturated zone: that portion of the subsurface in which the pores are only partially filled with water and the direction of water flow is vertical; is also referred to as the vadose zone.

V Vadose zone: the partially saturated or unsaturated region above the water table that does not yield water to wells.

Volatile organic compound (VOC): liquid or solid organic compounds that have a high vapor pressure at normal pressures and temperatures and thus tend to spontaneously pass into the vapor state.

W Waste accumulation area (WAA): an officially designated area that meets current environmental standards and guidelines for temporary (less than 90 days) storage of hazardous waste before off-site disposal.

Wastewater treatment system: a collection of treatment processes and facilities designed and built to reduce the amount of suspended solids, bacteria, oxygen-demanding materials, and chemical constituents in wastewater.

Water table: the water-level surface below the ground at which the unsaturated zone ends and the saturated zone begins, and the level to which a well that is screened in the unconfined aquifer would fill with water.

Weighting factor: a tissue-specific value used to calculate dose equivalents which represents the fraction of the total health risk resulting from uniform, whole-body irradiation that could be contributed to that particular tissue. The weighting factors used in this report are recommended by the International Commission on Radiological Protection.

Wind rose: a diagram that shows the frequency and intensity of wind from different directions at a specific location. 
THIS PAGE INTENTIONALLY LEFT BLANK 


\section{Appendix C: Acronyms and Abbreviations}

ac

AEA

AEC

ALARA

${ }^{241} \mathrm{Am}$

ARL

ARPA

ASN

ATM

BCG

$\mathrm{Be}$

BEEF

BFF

bgs

BHPS

BLM

$\mathrm{BN}$

BOD

BREN

$\mathrm{Bq}$

$\mathrm{Bq} / \mathrm{m}^{3}$

${ }^{\circ} \mathrm{C}$

ca.

CA

CAA

$\mathrm{CAB}$

CADD

CAI

CAIP

CAP

CAPP

CAP88-PC

CAS

CAU

CCHD

CCWRD

CEDE $\operatorname{acre}(\mathrm{s})$

Atomic Energy Act

Atomic Energy Commission

as low as reasonably achievable

americium-241

Air Resources Laboratory

Archeological Resources Protection Act

Air Surveillance Network

Atomic Testing Museum

Biota Concentration Guide

beryllium

Big Explosives Experimental Facility

Bureau of Federal Facilities

below ground surface

Bureau of Health Protection Services

Bureau of Land Management

Bechtel Nevada

biological oxygen demand

Bare Reactor Experiment Nevada

Becquerel

Becquerels per cubic meter

degree(s) Celsius

circa, meaning "approximately"

composite analysis

Clean Air Act

Community Advisory Board

Corrective Action Decision Document

corrective action investigation

Corrective Action Investigation Plan

Corrective Action Plan

Chemical Accident Prevention Program

Clean Air Package 1988

Corrective Action Site

Corrective Action Unit

Clark County Health District

Clark County Water Reclamation District

committed effective dose equivalent 


\begin{tabular}{|c|c|}
\hline CEM & Community Environmental Monitor \\
\hline CEMP & Community Environmental Monitoring Program \\
\hline CERCLA & Comprehensive Environmental Response, Compensation, and Liability Act \\
\hline CFR & Code of Federal Regulations \\
\hline CGTO & Consolidated Group of Tribes and Organizations \\
\hline $\mathrm{Ci}$ & curie(s) \\
\hline $\mathrm{Ci} / \mathrm{yr}$ & curie(s) per year \\
\hline CL & $\begin{array}{l}\text { Compliance Level (used in text for the Clean Air Act National Emission Standards for Hazardous } \\
\text { Pollutants Concentration Level for Environmental Compliance) }\end{array}$ \\
\hline CLVF & Cheyenne Las Vegas Facility \\
\hline $\mathrm{cm}$ & centimeter(s) \\
\hline CNLV & City of North Las Vegas \\
\hline Co & cobalt \\
\hline $\mathrm{CO}$ & carbon monoxide \\
\hline $\mathrm{CP}$ & Control Point \\
\hline cpm & counts per minute \\
\hline CRM & Cultural Resources Management \\
\hline Cs & cesium \\
\hline CWA & Clean Water Act \\
\hline $\mathrm{CX}$ & categorical exclusion \\
\hline $\mathrm{CY}$ & calendar year \\
\hline $\mathrm{d}$ & $\operatorname{day}(\mathrm{s})$ \\
\hline DAF & Device Assembly Facility \\
\hline DAQEM & Department of Air Quality and Environmental Management (Clark County) \\
\hline DAS & Disposal Authorization Statement \\
\hline DCG & Derived Concentration Guide \\
\hline $\mathrm{D} \& \mathrm{D}$ & deactivation and disposal \\
\hline DNWR & Desert National Wildlife Refuge \\
\hline DoD & U.S. Department of Defense \\
\hline DOE & U.S. Department of Energy \\
\hline DOECAP & U.S. Department of Energy Consolidated Audit Program \\
\hline $\mathrm{DOE} / \mathrm{HQ}$ & U.S. Department of Energy Headquarters \\
\hline $\mathrm{dpm} / 100 \mathrm{~cm}^{2}$ & disintegrations per minute per 100 square centimeters \\
\hline DQA & Data Quality Assessment \\
\hline DQO & Data Quality Objectives \\
\hline DRI & Desert Research Institute \\
\hline DTRA & Defense Threat Reduction Agency \\
\hline EA & Environmental Assessment \\
\hline EDE & effective dose equivalent \\
\hline EHS & extremely hazardous substance \\
\hline
\end{tabular}


EIS Environmental Impact Statement

EMAC Ecological Monitoring and Compliance

EML Environmental Measurements Laboratory

EMS Environmental Management System

EO Executive Order

EODU Explosive Ordnance Disposal Unit

EPA U.S. Environmental Protection Agency

EPCRA Emergency Reporting and Community Right-to-Know Act

EPEAT Electronic Product Environmental Assessment Tool

ER Environmental Restoration

ES Environmental Services

ES\&H Environment, Safety, and Health

ESA Endangered Species Act

ESH\&Q Environment, Safety, Health, and Quality

ETS Environmental Technical Services

${ }^{\circ} \mathrm{F} \quad$ degree(s) Fahrenheit

FD field duplicate

FFACO Federal Facility Agreement and Consent Order

FFCA Federal Facility Compliance Act

FIFRA Federal Insecticide, Fungicide, and Rodenticide Act

$\mathrm{ft} \quad$ foot or feet

$\mathrm{ft}^{2} \quad$ square feet

$\mathrm{ft}^{3} \quad$ cubic feet

$\mathrm{ft}^{3} / \mathrm{hr} \quad$ cubic feet per hour

FWS U.S. Fish and Wildlife Service

FY fiscal year

g $\quad \operatorname{gram}(\mathrm{s})$

gal gallon(s)

$\mathrm{gal} / \mathrm{d} \quad$ gallon(s) per day

GCD Greater Confinement Disposal

GIS Geographic Information System

gpm gallon(s) per minute

GPS global positioning satellite

Gy $\quad$ gray(s)

Gy/d gray(s) per day

ha hectare(s)

${ }^{3} \mathrm{H} \quad$ tritium

HAP hazardous air pollutant

HC hard copy

HENRE High-Energy Neutron Reactions Experiment 
HEPA high-efficiency particulate air

HRMP Hydrologic Resources Management Program

HTO tritiated water

HW hazardous waste

HWAA hazardous waste accumulation area

HWSU hazardous waste storage unit

ICMP Integrated Closure and Monitoring Plan

IDL instrument detection limit

IL investigation level

in. inch(es)

INL Idaho National Laboratory

ISMS Integrated Safety Management System

ISO International Organization for Standardization

IT International Technology Corporation

JASPER Joint Actinide Shock Physics Experimental Research

$\mathrm{K} \quad$ potassium

$\mathrm{kg} \quad$ kilogram(s)

$\mathrm{kg} / \mathrm{d} \quad$ kilogram(s) per day

$\mathrm{km} \quad$ kilometer(s)

$\mathrm{km}^{2} \quad$ square kilometer(s)

$\mathrm{kmh} \quad$ kilometer(s) per hour

L $\quad$ liter(s)

L/d liter(s) per day

LANL Los Alamos National Laboratory

lb pound(s)

LC Critical Level (synonymous with Decision Level)

LCA lower carbonate aquifer

LCS laboratory control sample

L/d liter(s) per day

LLMW low-level mixed waste

LLNL Lawrence Livermore National Laboratory

LLW low-level radioactive waste

$\mathrm{L} / \mathrm{min} \quad$ liter(s) per minute

$\log \quad$ logarithmic

lpm liter(s) per minute

LQAP Laboratory Quality Assurance Plan

$\mu \mathrm{Bq} / \mathrm{m}^{3} \quad$ microbecquerel(s) per cubic meter

$\mu \mathrm{Ci} / \mathrm{mL} \quad$ microcurie(s) per milliliter

$\mu \mathrm{g} / \mathrm{L} \quad$ microgram(s) per liter

$\mu \mathrm{R} / \mathrm{hr} \quad$ microroentgens per hour 
$\mathrm{m}$

$\mathrm{m}^{2}$

$\mathrm{m}^{3}$

MAPEP

MBTA

MCL

MDC

MEDA

MEI

$\mathrm{mGy} / \mathrm{d}$

$\mathrm{mg} / \mathrm{L}$

$\mathrm{mi}$

$\mathrm{mi}^{2}$

$\mathrm{mm}$

$\mathrm{mmhos} / \mathrm{cm}$

$\mathrm{M} \& \mathrm{O}$

MQO

$\mathrm{mR}$

$\mathrm{mR} / \mathrm{d}$

$\mathrm{mR} / \mathrm{yr}$

mrad

$\mathrm{mrad} / \mathrm{yr}$

mrem

mrem/yr

MSA

MSDS

$\mathrm{mSv}$

$\mathrm{mSv} / \mathrm{yr}$

mton

MW

NAAQS

NAC

NAGPRA

NCA

NCRP

NDEP

$\mathrm{NDOA}$

NDWS

NEPA

NESHAP meter(s)

square meter(s)

cubic meter(s)

Mixed Analyte Performance Evaluation Program

Migratory Bird Treaty Act

maximum contaminant level

minimum detectable concentration

meteorological data acquisition

maximally exposed individual

milligray(s) per day

milligram(s) per liter

mile(s)

square mile(s)

millimeter(s)

millimhos per centimeter

Management and Operating

Measurement Quality Objectives

milliroentgen(s)

milliroentgen(s) per day

milliroentgen(s) per year

milliard(s)

milliard(s) per year

millirem(s)

millirem(s) per year

Management Self-Assessments

Material Safety Data Sheet

millisievert(s)

millisievert(s) per day

metric ton(s)

mixed waste

National Ambient Air Quality Standards

Nevada Administrative Code

Native American Graves Protection and Repatriation Act

Nevada Combined Agency

National Council on Radiation Protection

Nevada Division of Environmental Protection

Nevada Department of Agriculture

Nevada Drinking Water Standards

National Environmental Policy Act

National Emission Standards for Hazardous Air Pollutants 
NHPA National Historic Preservation Act

NLV North Las Vegas

NLVF North Las Vegas Facility

NNHP Nevada Natural Heritage Program

NNSA/NSO U.S. Department of Energy, National Nuclear Security Administration Nevada Site Office

NOx nitrous oxides

NPDES National Pollution Discharge Elimination System

NPTEC Non-Proliferation Test and Evaluation Complex

NRC Nuclear Regulatory Commission

NRHP National Register of Historic Places

NRS Nevada Revised Statues

NSPS New Source Performance Standards

NSTec National Security Technologies, LLC

NTS Nevada Test Site

NTSER Nevada Test Site Environmental Report

NTTR Nevada Test and Training Range

NVLAP National Voluntary Laboratory Accreditation Program

ODS Ozone-depleting substance

OI

$\mathrm{OZ}$

operating instruction (DRI) or organization instruction (NSTec)

$\mathrm{p}$ once(s)

page

P03U Pit 3 Mixed Waste Disposal Unit

P06U An Area 5 Asbestiform Low-Level Solid Waste Disposal Unit

P2 pollution prevention

P2/WM pollution prevention/waste minimization

PA Performance Assessment

PAAA Price-Anderson Amendments Act

$\mathrm{Pb} \quad$ lead

PCB polychlorinated biphenyl

$\mathrm{pCi} \quad$ picocurie(s)

$\mathrm{pCi} / \mathrm{g} \quad$ picocurie(s) per gram

$\mathrm{pCi} / \mathrm{L} \quad$ picocurie(s) per liter

$\mathrm{pCi} / \mathrm{mL} \quad$ picocurie(s) per milliliter

PHS Public Health Service

PI prediction interval

PIC pressurized ion chamber

PM particulate matter

PM10 particulate matter equal to or less than 10 microns in diameter

POTW Publicly-Owned Treatment Works

pp pages 


\begin{tabular}{|c|c|}
\hline $\mathrm{ppb}$ & part(s) per billion \\
\hline ppm & part(s) per million \\
\hline PST & Pacific Standard Time \\
\hline PT & proficiency testing \\
\hline PTE & potential to emit \\
\hline $\mathrm{Pu}$ & plutonium \\
\hline PWS & public water systems \\
\hline QA & quality assurance \\
\hline QAP & Quality Assurance Program \\
\hline QAPP & Quality Assurance Program Plan \\
\hline QA/QC & quality assurance and quality control \\
\hline QC & quality control \\
\hline $\mathrm{R}$ & roentgen $(\mathrm{s})$ \\
\hline $\mathrm{rad}$ & radiation absorbed dose (a unit of measure) \\
\hline $\mathrm{rad} / \mathrm{d}$ & $\operatorname{rad}(\mathrm{s})$ per day \\
\hline Rad/NucCTEC & Radiological/Nuclear Countermeasures Test and Evaluation Complex \\
\hline RCD & Radiological Control Department \\
\hline RCR & requisition compliance reviews \\
\hline RCRA & Resource Conservation and Recovery Act \\
\hline rem & roentgen equivalent man (a unit of measure) \\
\hline RER & Relative Error Ratio \\
\hline RFP & request for proposal \\
\hline RPD & relative percent difference \\
\hline RREMP & Routine Radiological Environmental Monitoring Plan \\
\hline RSL & Remote Sensing Laboratory \\
\hline RWMC & Radioactive Waste Management Complex \\
\hline RWMS & Radioactive Waste Management Site \\
\hline SA & Supplement Analysis \\
\hline SAFER & Streamlined Approach for Environmental Restoration \\
\hline SAP & Sampling and Analysis Plan \\
\hline SARA & Superfund Amendments and Reauthorization Act \\
\hline SC & specific conductance \\
\hline SCP & Salinity Control Plan \\
\hline SD & standard deviation \\
\hline SDWA & Safe Drinking Water Act \\
\hline SE & standard error of the mean \\
\hline SHPO & Nevada State Historic Preservation Office \\
\hline SI & International System of Units \\
\hline SNL & Sandia National Laboratories \\
\hline SNJV & Stoller-Navarro Joint Venture \\
\hline
\end{tabular}




\begin{tabular}{|c|c|}
\hline SORD & Special Operations and Research Division \\
\hline $\mathrm{SO}_{2}$ & sulfur dioxide \\
\hline SSC & structures, systems, and components \\
\hline STL & Special Technologies Laboratory \\
\hline STP & standard temperature and pressure \\
\hline S.U. & standard unit(s) (for measuring $\mathrm{pH}$ ) \\
\hline SUV & sport utility vehicle \\
\hline Sv & sievert(s) \\
\hline SWL & static water level \\
\hline SWO & Solid Waste Operations \\
\hline TaDD & Tactical Demilitarization Development Project \\
\hline ТCP & thermocouple psychrometer \\
\hline TDR & time-domain reflectometry \\
\hline TDS & total dissolved solids \\
\hline TLD & thermoluminescent dosimeter \\
\hline TOC & total organic carbon \\
\hline TOX & total organic halides \\
\hline ТPCB & Transuranic Pad Cover Building \\
\hline TRI & Toxic Release Inventory \\
\hline TRU & transuranic \\
\hline TSCA & Toxic Substances Control Act \\
\hline TSS & total suspended solids \\
\hline TTR & Tonopah Test Range \\
\hline UGTA & Underground Test Area \\
\hline U.S. & United States \\
\hline USACE & U.S. Army Corps of Engineers \\
\hline USAF & U.S. Air Force \\
\hline USC & United States Code \\
\hline USGS & U.S. Geological Survey \\
\hline UST & underground storage tank \\
\hline VOC & volatile organic compounds \\
\hline VZM & vadose zone monitoring \\
\hline WEF & Waste Examination Facility \\
\hline WGS & Waste Generation Services \\
\hline WIPP & Waste Isolation Pilot Plant \\
\hline WM & waste minimization \\
\hline WMO & World Meteorological Organization \\
\hline WSI & Wackenhut Services, Inc. \\
\hline WSS & Work Smart Standards \\
\hline WNV & West Nile virus \\
\hline
\end{tabular}




$\begin{array}{ll}\text { WW } & \text { water well } \\ \text { yd } & \text { yard(s) } \\ \text { yd }^{3} & \text { cubic yard(s) } \\ \text { YMP } & \text { Yucca Mountain Project } \\ \text { yr } & \text { year(s) }\end{array}$




\section{THIS PAGE INTENTIONALLY LEFT BLANK}




\section{References}

American Nuclear Society, 2000: American National Standard for Determining Meteorological Information at Nuclear Facilities, ANSI/ANS-3.11-2000, American Nuclear Society, 555 North Kensington Avenue, La Grange Park, IL.

Arizona Department of Economic Security, 2007. July 1, 2006 Population Estimates for Arizona's Counties, Incorporated Places and Balance of County Areas, from Internet URL:

http://www.workforce.az.gov/admin/uploadedPublications/1943 EEC05.pdf, as accessed on 5/17/2007.

Bechtel Nevada, 2001. Groundwater Control Study, North Las Vegas Facility, Bechtel Nevada Project Report, March 2001.

Bechtel Nevada, 2002. A Hydrostratigraphic Framework Model of the Pabute Mesa - Oasis Valley Area, Nye County, Nevada, DOE/NV/11718-646. Las Vegas, NV.

Bechtel Nevada, 2003. Summary Report for the U.S. Department of Energy National Nuclear Security Administration Nevada Site Office FY02/FY03 Groundwater Control Study at the North Las Vegas Facility, September 2003, prepared by the Bechtel Nevada Geotechnical Sciences Group.

Bechtel Nevada, 2004. Summary Report for the U.S. Department of Energy National Nuclear Security Administration Nevada Site Office Groundwater Control at Building A-1 North Las Vegas Facility. Las Vegas, NV.

Bechtel Nevada, 2005a. A Hydrostratigraphic Framework Model and Alternatives for the Groundwater Flow and Contaminant Transport Model of Corrective Action Unit 98: Frenchman Flat, Clark, Lincoln and Nye Counties, Nevada. DOE/NV/11718--1064. Las Vegas, NV.

Bechtel Nevada, 2005b. FY 2005 Mid-Year Status Report for the U.S. Department of Energy National Nuclear Security Administration Nevada Site Office Groundwater Control at Building A-1 North Las Vegas Facility. Las Vegas, NV.

Bechtel Nevada, 2005c. North Las Vegas (NLV) Ground Water Control System Plan. August 15, 2005, Revision 0. Las Vegas, NV.

Bechtel Nevada. 2006. A Hydrostratigraphic Framework Model and Alternatives for the Groundwater Flow and Contaminant Transport Model of Corrective Action Unit 97: Yucca Flat-Climax Mine, Lincoln and Nye Counties, Nevada. DOE/NV/11718—1119. Las Vegas, NV.

Beck, C. and B. A. Holz, 2006. Historical Assessment Statement for CAU 190, CAS11-02-01, Underground Centrifuge Area 6, Nevada Test Site, Nye County Nevada. Desert Research Institute Letter Report No. LR061206-1, Las Vegas.

BEIR III, 1980. The Effects on Populations of Exposure to Low Levels of Ionizing Radiation: 1980, Committee on the Biological Effects of Ionizing Radiation III, National Academy Press, Washington, D.C.

BHPS, see Nevada State Health Division, Bureau of Health Protection Services.

BN, see Bechtel Nevada.

Bowen, S. M., D. L. Finnegan, J. L. Thompson, C. M. Miller, P. L. Baca, L. F. Olivas, C. G. Geoffrion, D. K. Smith, W. Goishi, B. K. Esser, J. W. Meadows, N. Namboodiri, J. F. Wild, 2001. Nevada Test Site Radionuclide Inventory, 1951-1992. LA-13859-MS, Los Alamos National Laboratory, Los Alamos, NM.

Bradley, P. V., J. J. O’Farrell, J. A. Williams, and J. E. Newmark (Editors), 2005. The Revised Nevada Bat Conservation Plan. Nevada Bat Working Group, Reno, NV. 209 pp.

Brikowski, T. H., J. B. Chapman, B. F. Lyles, and S. Hokett, 1993. Origin of Elevated Water Levels Encountered in Pabute Mesa Emplacement Boreholes: Preliminary Investigations, Desert Research Institute Publication No. 45123, Las Vegas, NV. 
Carlson, K. A., 2000. DOE Nevada Operations Office (DOE/NV) National Environmental Policy Act (NEPA) Compliance Program, Letter to Bechtel Nevada Distribution, February 25, 2000. U.S. Department of Energy, National Nuclear Security Administration Nevada Operations Office, Las Vegas, NV.

Defense Threat Reduction Agency, 2006. Water Pollution Control Permit NEV 96021, Quarterly Monitoring Report and Annual Summary Report for E Tunnel Waste Water Disposal System. Fourth Quarter Calendar Year 2006 Report. Defense Threat Reduction Agency, Mercury, NV.

Desotell, L. T., D. B. Hudson, V. Yucel, and J. T. Carilli, 2006. Use of Long-term Lysimeter Data in Support of Shallow Land Waste Disposal Cover Design. Proceedings of the Waste Management '06 Conference, Tucson, AZ, February 26 to March 2, 2006.

DOE, see U.S. Department of Energy.

Drollinger, H., 2004. Curation Compliance Annual Progress Report. Desert Research Institute Short Report No. SR120704-1, Las Vegas, NV.

Drollinger, H., 2005. Curation Compliance Annual Progress Report. Desert Research Institute Short Report No. SR091905-1, Las Vegas, NV.

Drollinger, H., 2006. Curation Compliance Annual Progress Report. Desert Research Institute Letter Report No. LR092606-1, Las Vegas, NV.

Drollinger, H., C. M. Beck, and R. Furlow, 2002. Cultural Resources Management Plan for the Nevada Test Site. Desert Research Institute, Las Vegas, NV.

DTRA, see Defense Threat Reduction Agency.

FWS, see U.S. Fish and Wildlife Service.

Grossman, R. F. 2006. National Emission Standards for Hazardous Air Pollutants, Calendar Year 2005.

DOE/NV/11718-1235. U.S. Department of Energy, National Nuclear Security Administration Nevada Site Office, Las Vegas, NV.

Hardcastle, J., 2007. 2006 Estimates by County. Prepared by Nevada State Demographer's Office for Nevada Department of Taxation, Nevada Small Business Development Center, from Internet URL: $<$ http://www.nsbdc.org/what/data statistics/demographer/pubs/pop increase/>, as accessed on $5 / 17 / 2007$.

Holz, B. A., 2006a. A Class III Cultural Resources Inventory of the Proposed Chicken Little Project, Area 18, Nevada Test Site, Nye County, Nevada. Cultural Resources Inventory Short Report No. SR071006-1, Las Vegas, NV.

Holz, B. A, 2006b. Fiscal Year 2006 Cultural Resources Site Monitoring Short Report for the Nevada Test Site, Nye County, Nevada. Desert Research Institute Monitoring Report No. MR0192405-1, Las Vegas, NV.

Holz, B. A. and H. B. Rager, 2006. A Class III Cultural Resources Inventory of the Proposed Replacement of the Castle Rock Substation and New Powerline Corridor, Area 18, Nevada Test Site, Nye County Nevada. Cultural Resources Inventory Short Report No. SR050106-1, Las Vegas, NV.

Hunter, R. B., and R. R. Kinnison, 1998. Tritium in Vegetation on the Nevada Test Site, United States Department of Energy, December 1998, In: Nevada Test Site Routine Radiological Environmental Monitoring Plan, Appendices, DOE/NV/11718--244. Bechtel NV, Las Vegas, NV.

International Technology Corporation, 1996. Regional Geologic Model Data Documentation Package (Phase I, Data Analysis Documentation, Volume I, Parts 1 and 2), ITLV/10972-181, Las Vegas, NV. 
International Technology Corporation, 1997. Groundwater Flow Model Documentation Package (Phase I, Data Analysis Documentation, Volume VI), prepared for the U.S. Department of Energy, Nevada Operations Office, Las Vegas, NV.

IT, see International Technology Corporation.

Jones, R. C., 2006. Historical Evaluation of U12b Tunnel Complex in Area 12, Nevada Test Site, Nye County, Nevada. Historical Evaluation Short Report No. SR050106-1, Las Vegas, NV.

Jones, R. C., T. F. Bullard, and C. M. Beck, 2006. Architectural and Historic Documentation for the Mitigation of Potential Adverse Effects to the Rock Cabin Near Tippipah Spring, Area 16, Nevada Test Site, Nye County, Nevada. Historical Research Report No. HR040606-1, Las Vegas, NV.

Kelly, I. T., and C. S. Fowler, 1986. Southern Paiute. In Great Basin, edited by W. L. d'Azevedo, pp. 135-148. Handbook of North American Indians, Volume 11, Smithsonian Institution, Washington, D.C.

Lyles, B. F., 1990. Tritium Variations in Groundwater on the Nevada Test Site, Desert Research Report 45086, DOE/NV/10384--380.

McArthur, R. D., 1991. Radionuclides in Surface Soil at the Nevada Test Site. DOE/NV/10845-02, Water Resources Center Publication \#45077, Desert Research Institute, Las Vegas, NV.

McArthur, R. D., and J. F. Kordas, 1985. Radionuclide Inventory and Distribution Program: Report \#2, Areas 2 and 4, DOE/NV/10162-20, Desert Research Institute, Water Resources Center Publication 45-41, Las Vegas, NV.

NCRP, see National Council on Radiation Protection.

National Council on Radiation Protection, 1996. A Guide for Uncertainty Analysis in Dose and Risk. Assessments Related to Environmental Contamination, NCRP Commentary No. 14, Bethesda, MD.

National Oceanic and Atmospheric Administration, 1995. Surface Weather Observations and Reports, FCM-H1-1995, U.S. Department of Commerce, Washington, D.C.

National Security Technologies, LLC, 2006. U.S. Department of Energy National Nuclear Security Administration Nevada Site Office Groundwater Control at Building A-1, North Las Vegas Facility Enhanced Dewatering Initiative. Las Vegas, NV.

National Security Technologies, LLC, 2007a. Nevada Test Site 2006 Data Report: Groundwater Monitoring Program Area 5 Radioactive Waste Management Site, DOE/NV/25946--138, NSTec, Las Vegas, NV, February 2007.

National Security Technologies, LLC, 2007b. Nevada Test Site 2006, Waste Management Monitoring Report, Area 3 and Area 5 Radioactive Waste Management Sites. DOE/NV/25946--225, NSTec, Las Vegas, NV.

National Security Technologies, LLC, 2007c. Ecological Monitoring and Compliance Program 2006 Report, DOE/NV/25946--174, March 2007, Las Vegas, NV.

Nevada State Health Division, Bureau of Health Protection Services, 2006a. State of Nevada Report HDAIP 27, Sanford Cohen \& Associates ID 6614, Las Vegas, NV.

Nevada State Health Division, Bureau of Health Protection Services, 2006b. State of Nevada Report HDAIP 28, Sanford Cohen \& Associates ID 6730, Las Vegas, NV.

Nevada State Health Division, Bureau of Health Protection Services, 2006c. State of Nevada Report HDAIP 29, Sanford Cohen \& Associates ID 7124, 7125, and 7200, Las Vegas, NV.

NOAA, see National Oceanic and Atmospheric Administration.

NRC, see U.S. Nuclear Regulatory Commission. 
NSTec, see National Security Technologies, LLC.

PHS, see U.S. Public Health Service.

Shleien, B. (ed.). 1992. The Health Physics and Radiological Health Handbook, Revised Edition. Scinta, Inc., Silver Spring, MD.

Smith, D. K., 1993. A Review of Literature Pertaining to the Leaching and Sorption of Radionuclides Associated with Nuclear Explosive Melt Glasses, UCRL-ID-113370, Lawrence Livermore National Laboratory, Livermore, CA.

Smith, D. K., 2001. Unclassified Radiologic Source Term for Nevada Test Site Areas 19 and 20, UCRL-ID-141706 Lawrence Livermore National Laboratory, Livermore, CA.

Smith, D. K., B. K. Esser, and J. L. Thompson, 1995. Uncertainties Associated with the Definition of a Hydrologic Source Term for the Nevada Test Site. Lawerence Livermore National Laboratory, UCRL-ID-120322.

Smith, D. K., S. B. Kersting, J. M. Keneally, T. P. Rose, G. B. Hudson, and G. F. Eaton, 1999. Radionuclide Migration Studies: FY 1998 Progress Report, Lawrence Livermore National Laboratory, Livermore, CA.

SNJV, see Stoller-Navarro Joint Venture.

Stanley, T. W., and S. S. Verner, 1985. The U.S. Environmental Protection Agency's Quality Assurance Program, in J. K. Taylor and T. W. Stanley (eds.), Quality Assurance for Environmental Measurements, ASTM STP-867, Philadelphia, PA.

Stoffle, R. W., M. N. Zedeno, and D. B. Halmo, 2001. American Indians and the Nevada Test Site, A Model of Research and Consultation. U.S. Government Printing Office, Washington, D.C.

Stoller-Navarro Joint Venture, 2006a. Phase II Groundwater Flow Model of Corrective Action Unit 98: Frenchman Flat, Nye County, Nevada. S-N/99205--074. Las Vegas, NV.

Stoller-Navarro Joint Venture, 2006b. Groundwater Flow Model of Corrective Action Units 101 and 102: Central and Western Pabute Mesa, Nevada Test Site, Nye County, Nevada. S-N/99205--076. Las Vegas, NV.

U.S. Department of Energy, 1988. Internal Dose Conversion Factors for Calculation of Dose to the Public, DOE/EH-0071. U.S. Department of Energy. Washington, D.C.

U.S. Department of Energy, 1992. Summary of the Nevada Applied Ecology Group and Correlative Programs, DOE/NV--357, Nevada Operations Office, Las Vegas, NV.

U.S. Department of Energy, 1996a. Final Environmental Impact Statement for the Nevada Test Site and Off-Site Locations in the State of Nevada, Volume 1, Chapters 1-9, DOE/EIS--0243, Las Vegas, NV, August 1996.

U.S. Department of Energy, 1996b. National Emission Standards for Hazardous Air Pollutants Submittal - 1995, DOE/NV/11718--032, Nevada Operations Office, Las Vegas, NV.

U.S. Department of Energy, 1998. Nevada Test Site Resource Management Plan, DOE/NV--518, December 1998. Nevada Operations Office, Las Vegas, NV.

U.S. Department of Energy, 2000a. United States Nuclear Tests, July 1945 through September 1992, DOE/NV--209, Rev. 15, Nevada Operations Office, Las Vegas, NV.

U.S. Department of Energy, 2000b. NV/YMP Radiological Control Manual, DOE/NV/11718--079, Rev. 4, Nevada Operations Office, Las Vegas, NV.

U.S. Department of Energy, 2001. Radioactive Waste Management Manual, DOE M 435.1-1, Washington, D.C. 
U.S. Department of Energy, 2002a. A Graded Approach for Evaluating Radiation Doses to Aquatic and Terrestrial Biota, DOE-STD-1153-2002, Washington, D.C.

U.S. Department of Energy, 2002b. Final Environmental Impact Statement for the Proposed Relocation of Technical Area 18 Capabilities and Materials at the Los Alamos National Laboratory, DOE/EIS-0319, Washington D.C.

U.S. Department of Energy, 2002c. Environmental Assessment for Hazardous Materials Testing at the Hazardous Materials Spill Center, Nevada Test Site, DOE/EA-0864, Nevada Operations Office, Las Vegas, NV.

U.S. Department of Energy, 2002d. Nevada Test Site Annual Site Environmental Report for Calendar Year 2001, DOE/NV/11718--747, Bechtel Nevada, Las Vegas, NV.

U.S. Department of Energy, 2003a. Routine Radiological Environmental Monitoring Plan, DOE/NV/11718--804, Bechtel Nevada, Las Vegas, NV.

U.S. Department of Energy, 2003b. Nevada Test Site Annual Site Environmental Report for Calendar Year 2002, DOE/NV/11718--842, Bechtel Nevada, Las Vegas, NV.

U.S. Department of Energy, 2004a. Final Environmental Assessment for Activities Using Biological Simulants and Releases of Chemicals at the Nevada Test Site, DOE/EA-1494, Nevada Site Office, Las Vegas, NV.

U.S. Department of Energy, 2004b. Environmental Assessment for the Radiological/Nuclear Countermeasures Test and Evaluation Complex, DOE/EA-1499, Nevada Site Office, Las Vegas, NV.

U.S. Department of Energy, 2004c. Nevada Test Site Environmental Report 2003, DOE/NV/11718--971, Bechtel Nevada, Las Vegas, NV.

U.S. Department of Energy, 2004d, E-mail from Gustavo Vazquez, DOE/EH-41, to Bruce W. Hurley, NNSA/NVO, dated April 1, 2004.

U.S. Department of Energy, 2004e. Users Guide, Version 1; RESRAD-BIOTA: A Tool for Implementing A Graded Approach To Biota Dose Evaluation. DOE/EH-0676 [also Interagency Steering Committee on Radiation Standards (ISCORS) Technical Report 2004-02], Washington D.C.

U.S. Department of Energy, 2005a. Nevada Test Site Environmental Report 2004, DOE/NV/11718--1080, Bechtel Nevada, Las Vegas, NV.

U.S. Department of Energy, 2005b. Environmental Assessment for Large-Scale, Open-Air Explosive Detonation DIVINE STRAKE at the Nevada Test Site, DOE/EA-1550, Nevada Site Office, Las Vegas, NV.

U.S. Department of Energy, 2006a. Environmental Assessment for Large-Scale, Open-Air Explosive Detonation DIVINE STRAKE at the Nevada Test Site - Revised Environmental Assessment, DOE/EA-1550, Nevada Site Office, Las Vegas, NV.

U.S. Department of Energy, 2006b. Nevada Test Site Environmental Report 2005, DOE/NV/11718--1214 and DOE/NV/25946-007, Bechtel Nevada and National Security Technologies, LLC, Las Vegas, NV.

U.S. Department of Energy, 2006c. Quality Systems for Analytical Services, Revision 2.2, October 2006.

U.S. Department of Energy, 2007. Annual Transportation Report for Radioactive waste Shipments to and from the Nevada Test Site - Fiscal Year 2006, DOE/NV--1187, Nevada Site Office, Las Vegas, NV.

U.S. Fish and Wildlife Service, 1996. Final Programmatic Biological Opinion for Nevada Test Site Activities,

File No. 1-5-96-F-33, August 22, 1996, Reno, NV. 
U.S. Nuclear Regulatory Commission, 1983. Radiological Assessment. Report NUREG/CR-3332, J. E. Till and H. R. Meyer, Editors, Office of Nuclear Reactor Regulation, Washington, D.C.

U.S. Public Health Service, 1963. Project SEDAN, Final Off-Site Report, AEC Report PNE-200F, Offsite Radiological Safety Organization, Las Vegas, NV.

Utah's Associations of Government and Governor's Office of Planning and Budget, Demographic and Economic Analysis, 2000. Population Projections for Utah's Cities \& Unincorporated Areas 2000 - 2030, from Internet URL: $<$ http://governor.utah.gov/dea/Publications/2000FinalPublish.pdf>, as accessed on 5/17/2007.

Warren, R. W., and R. F. Grossman, 2007. National Emissioni Standards for Hazardous Air Pollutants, Calendar Year 2006. DOE/NV/25946--171, U.S. Department of Energy, National Nuclear Security Administration Nevada Site Office, Las Vegas, NV.

Wills, C. A., and W. K. Ostler, 2001. Ecology of the Nevada Test Site: An Annotated Bibliography, with Narrative Summary, Keyword Index, and Species List. DOE/NV/11718--594, Bechtel Nevada, Ecological Services, Las Vegas, NV.

WMO, see World Meteorological Organization.

World Meteorological Organization, 2002. Manual on the Global Observing System, Vol. 1, WMO No. 55, Secretariat of the World Meteorological Organization, Geneva, Switzerland. 


\section{Distribution List}

All individuals in this list will be mailed a compact disc of this report and a hard copy (HC) of the abbreviated Nevada Test Site Environmental Report Summary 2006. One or more HCs of this report will be mailed to only those individuals specified.

\section{$\underline{\text { DOE and NNSA Headquarters }}$}

J. A. Rispoli, Assistant Secretary for Environmental Management (EM-1/Forrestal Building), U.S. Department of Energy, 1000 Independence Avenue SW, Washington, D.C. 20585 (1 HC)

F. Marcinowski, Deputy Assistant Secretary for Regulatory Compliance (EM-10/Forrestal Building), U.S. Department of Energy, 1000 Independence Avenue SW, Washington, D.C. 20585

M. A. Gilbertson, Deputy Assistant Secretary for Engineering and Technology (EM-20/Forrestal Building), U.S. Department of Energy, 1000 Independence Avenue SW, Washington, D.C. 20585

M. W. Frei, Deputy Assistant Secretary for Planning and Budget (EM-30/Forrestal Building), U.S. Department of Energy, 1000 Independence Avenue SW, Washington, D.C. 20585

J. J. Fiore, Deputy Assistant Secretary for Human Capital and Business Services (EM-40/Forrestal Building), U.S. Department of Energy, 1000 Independence Avenue SW, Washington, D.C. 20585

G. S. Podonsky, Director, Office of Health, Safety and Security (HS-1/Forrestal Building), U.S. Department of Energy, 1000 Independence Avenue SW, Washington, D.C. 20585 (2 HC)

P. R. Worthington, Director, Office of Health and Safety (HS-10/Forrestal Building), U.S. Department of Energy, 1000 Independence Avenue SW, Washington, D.C. 20585 (1 HC)

A. C. Lawrence, Director, Office of Nuclear Safety and Environment (HS-20/Forrestal Building), U.S. Department of Energy, 1000 Independence Avenue SW, Washington, D.C. 20585 (1 HC)

Director, Office of Corporate Safety Analysis (HS-30/270 Corporate Square Building), U.S. Department of Energy, 1000 Independence Avenue SW, Washington, D.C. 20585-0270 (1 HC)

R. L. Natoli, Office of Analysis (HS-32/Forrestal Building), U.S. Department of Energy, 1000 Independence Avenue SW, Washington, D.C. 20585 (3 HCs)

B. A. Peterson, Director, Office of Independent Oversight (HS-60/Forrestal Building), U.S. Department of Energy, 1000 Independence Avenue SW, Washington, D.C. 20585 (1 HC)

Administrator, National Nuclear Security Administration (NA-1/Forrestal Building), U.S. Department of Energy, 1000 Independence Avenue SW, Washington, D.C. 20585 (1 HC)

W. C. Ostendorff, Principal Deputy Administrator for National Nuclear Security Administration (NA-2/Forrestal Building), U.S. Department of Energy, 1000 Independence Avenue SW, Washington, D.C. 20585

T. P. D’Agostino, Deputy Administrator for Defense Programs (NA-10/Forrestal Building), U.S. Department of Energy, 1000 Independence Avenue SW, Washington, D.C. 20585

D. H. Crandall, Assistant Deputy Administrator for Research Development and Simulation (NA-11/Forrestal Building), U.S. Department of Energy, 1000 Independence Avenue SW, Washington, D.C. 20585

M. J. Schoenbauer, Assistant Deputy Administrator for Military Application and Stockpile Op (NA-12 /Forrestal Building), U.S. Department of Energy, Forrestal, 1000 Independence Avenue SW, Washington, D.C. 20585 
T. P. D’Agostino, Assistant Deputy Administrator for Program Integration (NA-13/Forrestal Building), U.S. Department of Energy, 1000 Independence Avenue SW, Washington, D.C. 20585

D. P. Wade, Director, Office of Programming, Budgeting and Execution (NA-133/Forrestal Building), U.S. Department of Energy, 1000 Independence Avenue SW, Washington, D.C. 20585

E. F. Sproat, Director, Office of Civilian Radioactive Waste Management (RW-1/Forrestal Building), U.S. Department of Energy, 1000 Independence Avenue SW, Washington, D.C. 20585

R. L. Orbach, Under Secretary for Science, Office of Science (SC-1/Forrestal Building), U.S. Department of Energy, 1000 Independence Avenue SW, Washington, D.C. 20585 (1 HC)

Associate Director, Office of Safety, Security and Infrastructure (SC-31/Germantown Building), U.S. Department of Energy, 1000 Independence Avenue SW, Washington, D.C. 20585-1290

\section{$\underline{\text { DOE }}$}

W. J. Arthur, Deputy Director, Office of Repository Development, U.S. Department of Energy, 1551 Hillshire Drive, Las Vegas, NV 89134

\section{NNSA/NSO}

G. L. Talbot, Manager, Nevada Site Office, U.S. Department of Energy, National Nuclear Security Administration, P.O. Box 98518, Las Vegas, NV 89193-8518, M/S 505 (1 HC)

R. T. Brock, Acting Deputy Manager, Nevada Site Office, U.S. Department of Energy, National Nuclear Security Administration, P.O. Box 98518, Las Vegas, NV 89193-8518, M/S 505 (1 HC)

S. A. Hejazi, Site Counsel, Nevada Site Office, U.S. Department of Energy, National Nuclear Security Administration, P.O. Box 98518, Las Vegas, NV 89193-8518, M/S 505 (1 HC)

K. M. Lynn, Acting Assistant Manager for Business and Contract Management, Nevada Site Office, U.S. Department of Energy, National Nuclear Security Administration, P.O. Box 98518, Las Vegas, NV 89193-8518, M/S 505

D. J. Morgan, Program Manager, Office of Public Affairs, Nevada Site Office, U.S. Department of Energy, National Nuclear Security Administration, P.O. Box 98518, Las Vegas, NV 89193-8518, M/S 505 (1 HC)

K. J. Rohrer, Office of Public Affairs, Nevada Site Office, U.S. Department of Energy, National Nuclear Security Administration, P.O. Box 98518, Las Vegas, NV 89193-8518, M/S 505 (1 HC)

S. A. Mellington, Assistant Manager for Environmental Management, Nevada Site Office, U.S. Department of Energy, National Nuclear Security Administration, P.O. Box 98518, Las Vegas, NV 89193-8518, M/S 505

J. L. Appenzeller-Wing, Deputy Assistant Manager for Environmental Management, Nevada Site Office, U.S. Department of Energy, National Nuclear Security Administration, P.O. Box 98518, Las Vegas, NV 89193-8518, M/S 505

D. D. Monette, Assistant Manager for National Security, Nevada Site Office, U.S. Department of Energy, National Nuclear Security Administration, P.O. Box 98518, Las Vegas, NV 89193-8518, M/S 505

L. M. Tomlinson, Acting Assistant Manager for Site Operations, NNSA/NSO, Nevada Site Office, U.S. Department of Energy, National Nuclear Security Administration, P.O. Box 98518, Las Vegas, NV 89193-8518, M/S 505

R. L. Phifer, Jr., Assistant Manager for Safeguards and Security, Nevada Site Office, U.S. Department of Energy, National Nuclear Security Administration, P.O. Box 98518, Las Vegas, NV 89193-8518, M/S 505 
K. A. Hoar, Environmental Protection Team Leader, Nevada Site Office, U.S. Department of Energy, National Nuclear Security Administration, P.O. Box 98518, Las Vegas, NV 89193-8518, M/S 505 (1 HC)

L. M. Cohn, Environmental Protection Team, Nevada Site Office, U.S. Department of Energy, National Nuclear Security Administration, P.O. Box 98518, Las Vegas, NV 89193-8518, M/S 505 (1 HC)

B. W. Hurley, Environmental Protection Team, Nevada Site Office, U.S. Department of Energy, National Nuclear Security Administration, P.O. Box 98518, Las Vegas, NV 89193-8518, M/S 505 (1 HC)

M. G. Skougard, Environmental Protection Team, Nevada Site Office, U.S. Department of Energy, National Nuclear Security Administration, P.O. Box 98518, Las Vegas, NV 89193-8518, M/S 505 (1 HC)

\section{$\underline{\text { EPA }}$}

K. Bellamy, Waste Management Division, EPA, Region IX, 75 Hawthorne Street, San Francisco, CA 94105

Director, Air Division, Region IX, U.S. Environmental Protection Agency, 75 Hawthorne Street, San Francisco, CA 94105 (1 HC)

Deputy Director, Radiation \& Indoor Environments National Laboratory, U.S. Environmental Protection Agency, P.O. Box 98517, Las Vegas, NV 89198-8517, M/S 513

Director, Radiation \& Indoor Environments National Laboratory, U.S. Environmental Protection Agency, P.O. Box 98517, Las Vegas, NV 89198-8517, M/S 513

Director, Center for Environmental Restoration, Monitoring, and Emergency Response, U.S. Environmental Protection Agency, P.O. Box 98517, Las Vegas, NV 89198-8517, M/S 513

E. Thorton-Jones, EPA, Office of Radiation and Indoor Air, Radiation Protection Division, Center for Waste Management, 1200 Pennsylvania Avenue, MC 6608J, Washington, D.C. 20460

\section{$\underline{\text { LANL }}$}

J. M. Dewart, Los Alamos National Laboratory, P.O. Box 1663, Los Alamos, NM 87545, M/S J978 (1 HC)

C. F. Eberhart, Los Alamos National Laboratory, P.O. Box 1663, Los Alamos, NM 87545, M/S F670

\section{$\underline{\text { LLNL }}$}

M. J. Dunning, Lawrence Livermore National Laboratory, L-149, Livermore, CA 94551 (1 HC)

J. M. Haeberlin, Lawrence Livermore National Laboratory, P.O. Box 45, Mercury, NV 89023, M/S 777

R. C. Higgs, Lawrence Livermore National Laboratory, P.O. Box 45, Mercury, NV 89023, M/S 777

\section{$\underline{\text { SNL }}$}

D. R. Bozman, Sandia National Laboratories, P.O. Box 238, Mercury, NV 89023, M/S NTS944

S. E. Lacy, Sandia National Laboratories, P.O. Box 5800, Albuquerque, NM 87185-0184 (1 HC)

J. H. Metcalf, Sandia National Laboratories, P.O. Box 238, Mercury, NV 89023, M/S NTS944

R. A. Smith, Sandia National Laboratories, P.O. Box 871, Tonopah, NV 89049

D. D. Thomson, Sandia National Laboratories, P.O. Box 238, Mercury, NV 89023, M/S NTS944 


\section{$\underline{\text { DTRA }}$}

T. Lantow, Defense Threat Reduction Agency, P.O. Box 208, Las Vegas, NV 89023, M/S NTS645

D. Loewer, Chief, Defense Threat Reduction Agency, P.O. Box 208, Las Vegas, NV 89023, M/S NTS645

\section{State of Nevada}

M. Elges, Nevada Division of Environmental Protection, 901 South Stewart Street Suite 4001, Carson City, NV 89701

D. Elle, Nevada Division of Environmental Protection, 171 E. Flamingo Rd., Suite 121-A, Las Vegas, NV 89119 $(1 \mathrm{HC})$

T. Murphy, Nevada Division of Environmental Protection, 171 E. Flamingo Rd., Suite 121-A, Las Vegas, NV 89119

G. Raab, Nevada Division of Environmental Protection, 171 E. Flamingo Rd., Suite 121-A, Las Vegas, NV 89119

S. Marshall, Bureau of Health Protection Services, 1179 Fairview Drive, Carson, City, NV 89701-5405 (1 HC)

K. K. Beckley, Supervisor, Radiological Health Section, Bureau of Health Protection Services, 4150 Technology Way Ste. 300, Carson City, NV 89706 (1 HC)

M. Stafford, Nevada State Clearinghouse, Capitol Complex, 209 E. Musser St., Carson City, NV 89710

\section{State Departments of Environment and Health}

Dr. D. Blodgett, Southwest Utah Public Health Department, 260 East DL Sargent Dr., Cedar City, UT 84720

Director, Bureau of Radiation and Occupational Health, 288 N. 1460 West, P.O. Box 16690, Salt Lake City, UT 84116-0690

Director, Division of Air Quality, State Department of Health, 150 N. 1950 West, Salt Lake City, UT 84116

Director, Environmental Improvement Division, Department of Health and Environment, 1190 Saint Francis Drive, Santa Fe, NM 87503

Director, Radiation and Hazardous Waste Control Division, Department of Health, 4210 E. 11 th Avenue, Denver, CO 80220

Director Santa Barbara Health Care Services, 315 Camino Del Remedio, Santa Barbara, CA 93110

\section{$\underline{\text { DRI }}$}

C. Beck, Desert Research Institute, 755 E. Flamingo Road, Las Vegas, NV 89119, M/S 433 (1 HC)

S. Campbell, Desert Research Institute, 755 E. Flamingo Road, Las Vegas, NV 89119, M/S 433 (1 HC)

D. Donithan, Desert Research Institute, 755 E. Flamingo Road, Las Vegas, NV 89119, M/S 433 (1 HC)

H. Drollinger, Desert Research Institute, 755 E. Flamingo Road, Las Vegas, NV 89119, M/S 433 (1 HC)

K. Giles, Desert Research Institute, 755 E. Flamingo Road, Las Vegas, NV 89119, M/S 433 (1 HC)

W. Hartwell, Desert Research Institute, 755 E. Flamingo Road, Las Vegas, NV 89119, M/S 433 (1 HC)

B. Holz, Desert Research Institute, 755 E. Flamingo Road, Las Vegas, NV 89119, M/S 433 (1 HC)

R. Jones, Desert Research Institute, 755 E. Flamingo Road, Las Vegas, NV 89119, M/S 433 
L. Karr, Desert Research Institute, 755 E. Flamingo Road, Las Vegas, NV 89119, M/S 433 (1 HC)

B. Kennedy, Desert Research Institute, 755 E. Flamingo Road, Las Vegas, NV 89119, M/S 433

C. Martin, Desert Research Institute, 755 E. Flamingo Road, Las Vegas, NV 89119, M/S 433 (1HC)

G. McCurdy, 2215 Raggio Parkway, Reno, NV 89512 (1 HC)

A. Russell, Desert Research Institute, 755 E. Flamingo Road, Las Vegas, NV 89119, M/S 433

C. Russell, Desert Research Institute, 755 E. Flamingo Road, Las Vegas, NV 89119, M/S 433 (1 HC)

C. Shadel, Desert Research Institute, 755 E. Flamingo Road, Las Vegas, NV 89119, M/S 433 (1 HC)

D. Shafer, Desert Research Institute, 755 E. Flamingo Road, Las Vegas, NV 89119, M/S 433 (1 HC)

\section{$\underline{\text { NSTec }}$}

E. C. Calman, Environmental Services, National Security Technologies, LLC, P.O. Box 98521, Las Vegas NV 89193-8521, M/S NTS327

J. A. Ciucci, Director, Environmental Management, National Security Technologies, LLC, P.O. Box 98521, Las Vegas, NV 89193-8521, M/S NSF082 (1 HC)

D. K. Clark, Low-Level Waste Operations, National Security Technologies, LLC, P.O. Box 98521, Las Vegas, NV 89193-8521, M/S NTS403

E. L. Cox, Jr., Emergency Planning and Preparedness, National Security Technologies, LLC, P.O. Box 98521, Las Vegas, NV 89193-8521, M/S NTS 780

A. V. Cushman, Geographic Information Services, National Security Technologies, LLC, P.O. Box 98521, Las Vegas, NV 89193-8521, M/S NTS780

S. L. Drellack, Science and Technology, National Security Technologies, LLC, P.O. Box 98521, Las Vegas, NV 89193-8521, M/S NLV082

J. J. Dugas, BN, Environmental Technical Services, National Security Technologies, LLC, P.O. Box 98521, Las Vegas, NV 89193-8521, M/S NTS273

A. L. Gile, Contractor Assurance, National Security Technologies, LLC, P.O. Box 98521, Las Vegas, NV 89193-8521, M/S NSF118

P. D. Greger, Environmental Technical Services, National Security Technologies, LLC, P.O. Box 98521, Las Vegas, NV 89193-8521, M/S NTS260

G. R. Griess, Manager, Environment, Safety, Health and Quality, National Security Technologies, LLC, P.O. Box 98521, Las Vegas, NV 89193-8521, M/S NTS327 (1 HC)

R. F. Grossman, Environmental Technical Services, National Security Technologies, LLC, P.O. Box 98521, Las Vegas, NV 89193-8521, M/S NTS273 (1 HC)

D. L. Gustafson, Science and Technology, National Security Technologies, LLC, P.O. Box 98521, Las Vegas, NV 89193-8521, M/S NTS416

D. J. Hansen, Environmental Technical Services, National Security Technologies, LLC, P.O. Box 98521, Las Vegas, NV 89193-8521, M/S NTS260 
M. A. Hayes, Environmental Services, National Security Technologies, LLC, P.O. Box 98521, Las Vegas, NV 89193-8521, M/S NTS327

O. L. Haworth, Environmental Services, National Security Technologies, LLC, P.O. Box 98521, Las Vegas, NV 89193-8521, M/S NTS327

J. M. Holden, Technical Facilities Operation, National Security Technologies, LLC, P.O. Box 98521, Las Vegas, NV 89193-8521, M/S NTS401

B. C. Hopkins, Waste Facilities and Operations, National Security Technologies, LLC, P.O. Box 98521, Las Vegas, NV 89193-8521, M/S NTS304

D. B. Hudson, Environmental Technical Services, National Security Technologies, LLC, P.O. Box 98521, Las Vegas, NV 89193-8521, M/S NTS273 (1 HC)

A. J. Karns, Environmental Services, National Security Technologies, LLC, P.O. Box 98521, Las Vegas NV 89193-8521, M/S NSF083

C. F. Lohrstorfer, Environmental Technical Services, National Security Technologies, LLC, P.O. Box 98521, Las Vegas, NV 89193-8521, M/S NTS273 (1 HC)

D. A. Nichols, Defense and Civil Projects, National Security Technologies, LLC, P.O. Box 98521, Las Vegas, NV 89193-8521, M/S NLV103

P. K. Ortego, Environmental Management, National Security Technologies, LLC, P.O. Box 98521, Las Vegas, NV 89193-8521, M/S NSF082

W. K. Ostler, Environmental Technical Services, National Security Technologies, LLC, P.O. Box 98521, Las Vegas, NV 89193-8521, M/S NTS260 (1 HC)

H. A. Perry, Solid Waste Operations, National Security Technologies, LLC, P.O. Box 98521, Las Vegas, NV 89193-8521, M/S NTS110

P. M. Radack, Environmental Services, National Security Technologies, LLC, P.O. Box 98521, Las Vegas, NV 89193-8521, M/S NTS327 (1 HC)

S. E. Rawlinson, Environmental Management, National Security Technologies, LLC, P.O. Box 98521, Las Vegas NV 89193-8521, M/S NTS416

T. J. Redding, Environmental Technical Services, National Security Technologies, LLC, P.O. Box 98521, Las Vegas, NV 89193-8521, M/S NTS273 (1 HC)

G. Richardson, Environmental Restoration, National Security Technologies, LLC, P.O. Box 98521, Las Vegas, NV 89193-8521, M/S NTS306

J. L. Smith, Environmental Management, National Security Technologies, LLC, P.O. Box 98521, Las Vegas, NV 89193-8521, M/S NTS306

C. Soong, Environmental Services, National Security Technologies, LLC, P.O. Box 98521, Las Vegas, NV 89193-8521, M/S NTS327

J. L. VanDeroef, Environmental Services, National Security Technologies, LLC, P.O. Box 98521, Las Vegas, NV 89193-8521, M/S NTS327

T. H. Wallace, Environmental Services, National Security Technologies, LLC, P.O. Box 98521, Las Vegas, NV 89193-8521, M/S NTS327 
R. W. Warren, Environmental Technical Services, National Security Technologies, LLC, P.O. Box 98521, Las Vegas, NV 89193-8521, M/S NTS273 (1 HC)

C. A. Wills, Environmental Technical Services, National Security Technologies, LLC, P.O. Box 98521, Las Vegas, NV 89193-8521, M/S NTS260 (1 HC)

S. M. Younger, President and General Manager, National Security Technologies, LLC, P.O. Box 98521, Las Vegas, NV 89193-8521, M/S NLV001 (1 HC)

\section{$\underline{\text { PAI }}$}

S. Gordon, Professional Analysis, Inc., 537 E. Brooks Ave, North Las Vegas, NV 89030, M/S 422

\section{$\underline{\text { SNJV }}$}

W. Bliss, Stoller-Navarro Joint Venture, P.O. 98518, Las Vegas, NV 89193, M/S 505

T. Y. Brown, Stoller-Navarro Joint Venture, 7710 West Cheyenne Ave., Building 3, Las Vegas, NV 89129, M/S 505

C. F. Dinsman, Stoller-Navarro Joint Venture, 7710 West Cheyenne Ave., Building 3, Las Vegas, NV 89129, M/S 505

J. M. Fowler, Stoller-Navarro Joint Venture, 7710 West Cheyenne Ave., Building 3, Las Vegas, NV 89129, M/S CF438 (1 HC)

P. K. Matthews, Stoller-Navarro Joint Venture, 7710 West Cheyenne Ave., Building 3, Las Vegas, NV 89129, M/S CF439 (1 HC)

D. Schrock, Stoller-Navarro Joint Venture, 7710 West Cheyenne Ave., Building 3, Las Vegas, NV 89129, M/S 505

D. Taylor, Stoller-Navarro Joint Venture, 7710 West Cheyenne Ave., Building 3, Las Vegas, NV 89129, M/S 505

\section{$\underline{\text { ARL-SORD }}$}

D. Randerson, Director, Air Resources Laboratory, Special Operations and Research Division, P.O. Box 94227, Las Vegas, NV 89193, M/S NSF516 (1 HC)

\section{$\underline{\text { CEMP }}$}

J. Randall Allen, P.O. Box 93, Panaca, NV 89042 (1 HC)

K. Allisen-Medlin, HCR 61, Box 30, Alamo, NV 89001-9706 (1 HC)

M. Anderson, 1151 “A” Avenue N, P.O. Box 869, Beatty, NV 89003

M. D. Baldwin, 1646 North 175 West, Cedar City, UT 84720

B. L. Benson, 606 Lake Superior Lane, Boulder City, NV 89005-1057

N. J. Bowler, P.O. Box 368, Logandale, NV 89021

B. W. Brown, P.O. Box 61, Shoshone, CA 92384

R. Clifford, Jr., P.O. Box 206, Tonopah, NV 89040 (1 HC)

C. Crookshanks, P.O. Box 150464, Ely, NV 89315

D. M. Curry, 8207 Burnt Sienna, Las Vegas, NV 89123 
N. Darby, 1111 Avenue M, Ely, NV 89301

M. DeLee, P.O. Box 96, Amargosa Valley, NV 89020

B. P. DeWyze, P.O. Box 295, Delta, UT 84624

P. Donohue, P.O. Box 291, Pioche, NV 89043

J. and S. Fallini, HC 76, P.O. Box 1100, Tonopah, NV 89040 (1 HC)

K. G. Gary, BarBQ Ranch, Box 1, Amargosa Valley, NV 89020

M. L. Gay, P.O. Box 369, Milford, UT 84751

L. B. Goins, 2440 South River Plate Drive, Pahrump, NV 89048

C. S. Graf, P.O. Box 385, Alamo, NV 89001 (1 HC)

L. L. Hafen, 1009 Providence Lane, Boulder City, NV 89005

C. M. Hardy, P.O. Box 299, Alamo, NV 89001

L. Hatthorn, 1182 Pebble Beach Drive, Mesquite, NV 89027-2554

G. F. Hein, 612 Largo Azul Avenue, Henderson, NV 89015

M. Heizer, Garden Valley, P.O. Box 33, Hiko, NV 89017 (1 HC)

M. Herndon, 8104 Squaw Springs Lane, Las Vegas, NV 89131

J. M. Hopkin, P.O. Box 597, Indian Springs, NV 89018 (1 HC)

R. Hopkins, P.O. Box 3516, Pahrump, NV 89041

M. E. Howard, P.O. Box 935, Tonopah, NV 89049

D. E. Jenson, 2982 South 300 East, Box 25, Milford, UT 84751

R. A. Johnson, P.O. Box 626, Beatty, NV 89003 (1 HC)

R. Johnson, P.O. Box 332, Goldfield, NV 89013

V. G. Johnson, P.O. Box 765, Indian Springs, NV 89018

T. S. Judd, 850 North 500 West, Delta, UT 84624

G. Leggio, 5177 South 5200 West, Cedar City, UT 84720

J. C. Lisle, P.O. Box 357, Beatty, NV 89003

L. Martin, 1200 Avenue H, Ely, NV 89301

K. F. McFate, P.O. Box 373, 470 W. Raleigh Lane, Indian Springs, NV 89018

S. and G. Medlin, HCR 61, Box 30, Alamo, NV 89001 (1 HC)

J. Mike, 153 Second Street, Duckwater, NV 89134

R. Mike, 161 Second Street, Duckwater, NV 89314 
S. Mortensen, 143 S. Main, St. George, UT 84770

J. W. Nelson, P.O. Box 232, Logandale, NV 89021

D. Newman, 141 Sunbow, Cedar City, UT 84720

J. L. Odegard, 630 Tomahawk Court, Pahrump, NV 89060 (1 HC)

D. J. Peltz, 10194 Eden Falls Lane, Las Vegas, NV 89123

B. H. Perkins, P.O. Box 495, Caliente, NV 89008

T. C. Sauvageau, P.O. Box 1674, Tonopah, NV 89049

GN\&M Sharp, Nyala Ranch, HC 76, Box 900, Tonopah, NV 89040 (1 HC)

J. Skullestad, P.O. Box 593 Goldfield, NV 89013 (1 HC)

A. P. Smith, P.O. Box 101 Caliente, NV 89008

K. Smith, P.O. Box 114, Shoshone, CA 92384

G. V. Sorensen, 421 Circle Way Drive, Cedar City, UT 84720 (1 HC)

D. Sullivan, P.O. Box 182, Alamo, NV 89001 (1 HC)

R. Taylor, 1239 Cedar Knolls South, Cedar City, UT 84720-3626 (1 HC)

J. Terrell, P.O. Box 454, Goldfield, NV 89013 (1 HC)

H. Uhalde, Uhalde Ranch, P.O. Box 88, Ely, NV 89301

C. Vogel, 107 Navajo Street, Mesquite, NV 89027

C. Walker, 903 Coyote Way, Dammeron Valley, UT 84738

G. Williams, HCR 61, Box 24, Alamo, NV 89001 (1 HC)

\section{$\underline{\text { Libraries }}$}

Alamo Branch Library, P.O. Box 239, Alamo, NV 89001 (1 HC)

Amargosa Valley Library District, HCR 69, P.O. Box 401-T, Amargosa Valley, NV 89020 (1 HC)

Beatty Library District, P.O. Box 129, Beatty, NV 89003 (1 HC)

Boulder City Library, 701 Adams Blvd., Boulder City, NV 89005 (1 HC)

Caliente Branch Library, P.O. Box 306, Caliente, NV 89009 (1 HC)

Cedar City Public Library, 303 N 100 E Cedar City, UT 84720-2610 (1 HC)

Delta City Library, 76 N. 200 W. Delta, UT 84624-9440 (1 HC)

Goldfield Public Library, P.O. Box 430, Goldfield, NV 89013 (1 HC)

Henderson District Public Library, 280 Water Street, Henderson, NV 89015 (1 HC)

Indian Springs Library, P.O. Box 629, Indian Springs, NV 89018 (1 HC) 
Lincoln County Library, P.O. Box 330, Pioche, NV 89043 (1 HC)

Milford Public Library, P.O. Box 579, Milford, UT 84751-0579 (1 HC)

Moapa Valley Library, P.O. Box 397, Overton, NV 89040 (1 HC)

Office of Scientific and Technical Information, Technical Center, U.S. Department of Energy, P.O. Box 62, Oak Ridge, TN 37831 (1 electronic copy)

Pahrump Library District, 2101 E. Calvada Boulevard, Pahrump, NV 89048 (1 HC)

Public Reading Facility, Nuclear Testing Archive, Nevada Site Office, U.S. Department of Energy, National Nuclear Security Administration P.O. Box 98521 Las Vegas, NV 89193-8521, M/S 400 (1 HC)

Technical Library, Nevada Site Office, U.S. Department of Energy, National Nuclear Security Administration, P.O. Box 98518, Las Vegas, NV 89193, M/S 505 (1 HC)

Tonopah Library District, P.O. Box 449, Tonopah, NV 89049 (1 HC)

UNLV Library Government Documents, University of Nevada-Las Vegas, P.O. Box 457013, Las Vegas, NV 89154-7013 (1 HC)

A. Huckle, Business \& Government Information Center/322, University of Nevada Libraries, 1664 North Virginia Street, Reno, NV 89557-0044 (1 HC)

Washington County Library, 50 S. Main Street, St George, UT 84770-3490 (1 HC)

White Pine County Library, 950 Campton Street, Ely, NV 89301 (1 HC)

\section{$\underline{\text { Miscellaneous }}$}

Community Advisory Board for Nevada Test Site Programs, c/o Navarro Engineering, 2721 Losee Rd, Suite D, North Las Vegas, NV 89030 (5 HCs)

R. Birger, Project Leader, Desert National Wildlife Refuge Complex, 4701 N. Torrey Pines Dr., Las Vegas, NV 89130

A. Choephel, Nuclear Waste Repository Project Office, P.O. Box 1767, Tonopah, NV 89049

L. Coch, Dyncorp, P.O. Box 569, Indian Springs, NV 89018

C. B. Davis, EnviroStat, 3468 Misty Court, Las Vegas, NV 89120

S. Deandi, Western Governmental Association, 223 Old P.O. Road, Boulder, CO 80302

J. R. Dyer, Yucca Mountain Site Characterization Office, 1551 Hillshire Dr., Suite A, Las Vegas, NV 89134

M. Estrada, 4370 N. Washington Blvd., Suite 223, Nellis AFB, NV 89191

D. Finerfrock, Director, Division of Radiation Control, Department of Environmental Quality, 168 North 1950 West, P. O. Box. 144850, Salt Lake City, UT 84114-4850

P. Fledderman, Washington Savannah River Co., Bldg. 735-B, Aiken SC 29802

V. Gabbard, Tonopah Test Range, P.O. Box 871, Tonopah, NV 89049

N. W. Golchert, Argonne National Laboratory, 9700 South Cass Avenue, Argonne, IL 60439

R. P. Graves, U.S. Geological Survey, 160 N. Stephanie St., Henderson, NV 89074-8829 
B. Jonker, DOE Idaho Operations Office, 1955 Fremont Ave., Mailstop 1216, Idaho Falls, ID 83401

W. Mackie, Program Manager, Nuclear Waste Transportation Western Governors' Association, 1515 Cleveland Place, Suite 200, Denver, CO 80202-5114

R. Martin, Superintendent, Death Valley National Monument, P.O. Box 579, Death Valley, CA 92328

Mason and Hanger, Environmental Protection Department, Silas-Mason Co., Inc., Pantex Plant, P.O. Box 30020, Amarillo, TX 79177

J. Palma, Bureau of Land Management, Las Vegas Manager, 4701 North Torrey Pines Drive Las Vegas, NV 89130

M. Morse, Bureau of Land Management Las Vegas Field Office, 4701 N. Torrey Pines Dr., Las Vegas, NV 89130

D. and N. Spicer, P.O. Box 897, Beatty, NV 89003

D. Swanson, Nye County Nuclear Waste Repository Project Office, 1210 E. Basin Road, Suite \#6, Pahrump, NV 89048

B. Swedock, Tetra Tech, Inc., 5205 Leesburg Pike, Suite 1400, Falls Church, VA 22041

B. K. Thompson, National Nuclear Security Administration Program Manager, U.S. Geological Survey, 160 N. Stephanie St., Henderson, NV 89074 
THIS PAGE INTENTIONALLY LEFT BLANK 


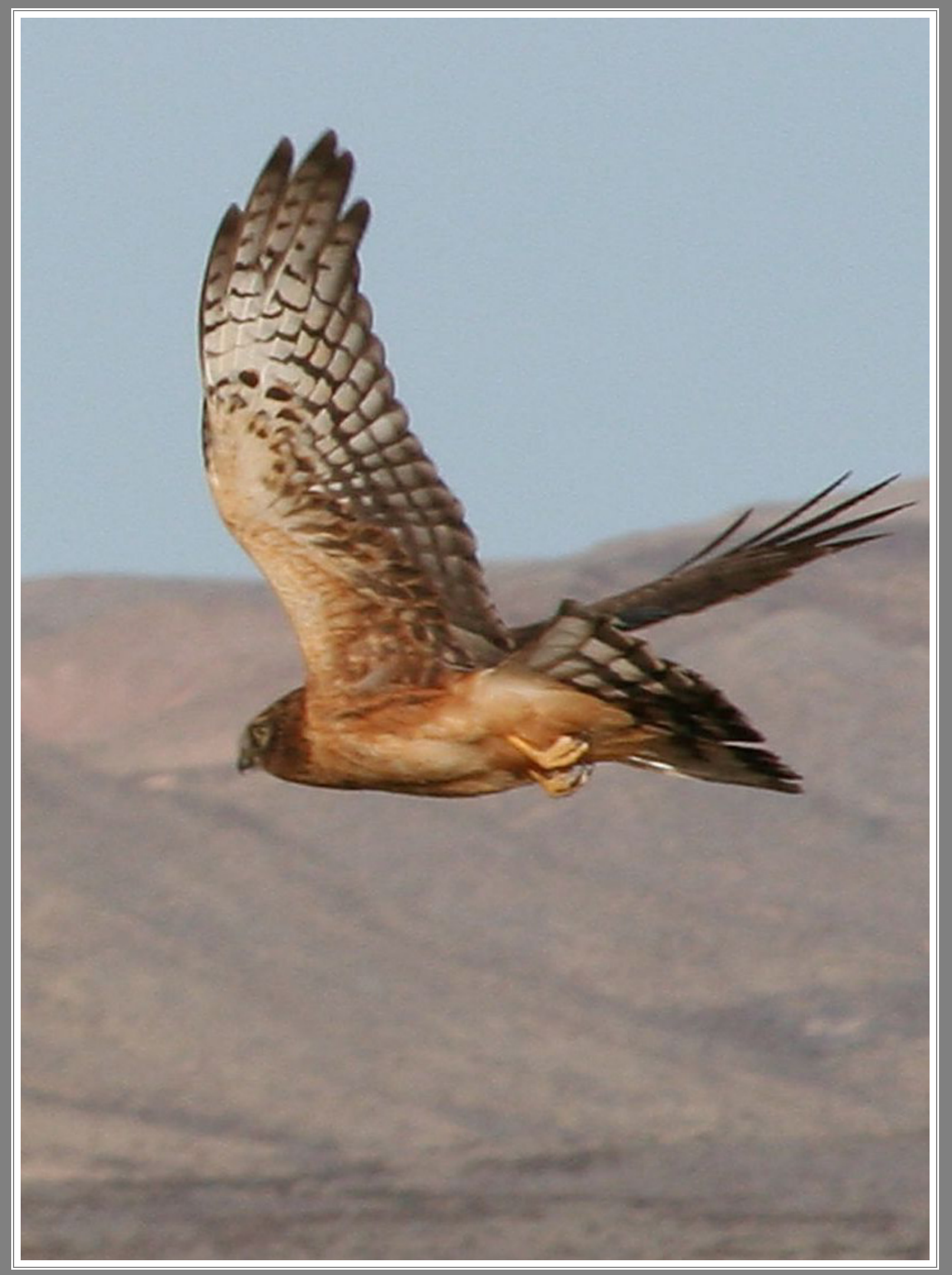

